\title{
((ख)
}

AUTARQUIA ASSOCIADA À UNIVERSIDADE DE SÃO PAULO

DESENVOLVIMENTO E VALIDAÇÃO DE METODOLOGIA SPE-LC-MS/MS PARA A DETERMINACÃO DE FÁRMACOS E DROGA DE ABUSO NAS ÁGUAS DA REPRESA GUARAPIRANGA-SÃO PAULO/SP, BRASIL

Helena Miho Shihomatsu

Tese apresentada como parte dos requisitos para obtenção do Grau de Doutor em Ciências na Área de Tecnologia Nuclear - Materiais

Orientadora:

Profa. Dra. Maria Aparecida Faustino Pires 


\title{
INSTITUTO DE PESQUISAS ENERGÉTICAS E NUCLEARES
}

Autarquia associada à Universidade de São Paulo

\section{DESENVOLVIMENTO E VALIDAÇÃO DE METODOLOGIA SPE-LC-MS/MS PARA A DETERMINACÃO DE FÁRMACOS E DROGA DE ABUSO NAS ÁGUAS DA REPRESA GUARAPIRANGA-SÃO PAULO/SP, BRASIL}

\author{
Helena Miho Shihomatsu
}

Tese apresentada como parte dos requisitos para obtenção do Grau de Doutor em Ciências na Área de Tecnologia Nuclear - Materiais

Orientadora:

Profa. Dra. Maria Aparecida Faustino Pires 


\section{DEDICATÓRIA}

Zlos meus pais Hiroko e Junzo (in memorium) pelo exemplo de vida e aos amores da minha vida Paulo, Xárcio, Fernando (in memorium) e André. 


\section{AGRADECIMENTOS}

À Profa. Dra. Maria Aparecida Faustino Pires pela oportunidade, confiança, orientação, incentivo e amizade.

Ao Instituto de Pesquisas Energéticas e Nucleares, IPEN/CNEN, ao Centro de Química e Meio Ambiente, CQMA, e ao Centro de Espectrometria de Massas Aplicada, CEMSA, pela oportunidade e disponibilização da infraestrutura para a realização deste trabalho.

À FAPESP - Fundação de Amparo a Pesquisa do Estado de São Paulo, pelo apoio financeiro concedido ao projeto de pesquisa que este trabalho está inserido (FAPESP n० 2009/53898-9). Assim, o agradecimento também é estendido ao Prof. Dr. Carlos Eduardo de Mattos Bicudo e a Profa. Dra. Denise de Mattos Bicudo do Instituto de Botânica, coordenadores do projeto juntamente com a Profa. Dra. Maria Aparecida Faustino Pires do IPEN. Agradecimento especial a Sabesp - Companhia de Saneamento Básico do Estado de São Paulo pela parceria e o auxílio nas coletas das amostras de água e apoio logístico de campo.

Ao CNPq, projeto de pesquisa $n^{0} 310214 / 2013-0$ (Avanços no controle da qualidade de reservatórios: uso de multitraçadores de alterações ambientais) pelo apoio concedido.

A Dra. Marycel Elena Barbosa Cotrim, Dra. Elâine Arantes Jardim Martins e Dr. Hélio Akira Furusawa pela colaboração nos estudos estatísticos dos dados, revisões e discussões técnicas;

Ao Daniel Temponi Lebre e Renato Lahos pela paciência e dedicação nos ensinamentos técnicos instrumentais e incentivos

Ao Dr. Hélio Ferreto pela ajuda na formatação final do trabalho. 
Ao Alexandre Scuotto, Caroline Lima de Oliveira, Juliana Otomo, Justine de Oliveira, Dra. Nilce Ortiz, Lucilena Rebelo Monteiro e Dra. Ana Copat pela amizade, carinho e incentivos.

Aos amigos da vida profissional que hoje fazem parte da minha vida pessoal, por ensinarem, além da química, a importância de se ter amigos para dividir os momentos tanto de alegrias como difícies: Elisa Kayo Shibuya, Irene Tomiyoshi Bona, Marcos Antônio Hortellani, Maurício Hiromitu Kakazu, Mônica Campos e Dr. Sundaram Sankara Subba lyer.

Um agradecimento especial aos meus pais que me ensinaram a valorizar os pequenos detalhes do dia-a-dia, meus irmãos Kiyoshi e Akira (in memorium) a quem tenho carinho muito especial, ao Paulo pelo amor, companheirismo, paciência, dedicação e respeito, aos nossos filhos, Márcio e André e noras Renata e Midori que me ensinaram a me tornar uma pessoa melhor.

A todos aqueles que, direta ou indiretamente, contribuíram para a realização deste trabalho.

Muito Obrigada! 


\section{EPÍGRAFE}

'É triste pensar que a natureza fala e o gênero humano não a ouve."

Victor Hugo 


\title{
DESENVOLVIMENTO E VALIDAÇÃO DE METODOLOGIA SPE-LC-MS/MS PARA A DETERMINACÃO DE FÁRMACOS E DROGA DE ABUSO NAS ÁGUAS DA REPRESA GUARAPIRANGA- SÃO PAULO/SP, BRASIL
}

\author{
Helena Miho Shihomatsu
}

\begin{abstract}
RESUMO
Este estudo apresenta o desenvolvimento da metodologia de extração em fase sólida e separação em cromatográfica líquida acoplada a espectrometria de massas em sequencia, SPE-LC-MS/MS, para a determinação de 21 (vinte e um) fármacos pertencentes a diferentes classes terapeuticas, 1 (uma) droga de abuso e seu principal metabólito, em amostras de água superficial. A separação cromatográfica foi otimizada estudando o desempenho de fases estacionárias e fases móvies. A quantificação dos compostos selecionados foi realizada com a ionização por eletronebulização ("electrospray ionization"- ESI) e o espectrômetro de massas operando no modo de Monitoramento de Múltiplas Reações ("Multiplas Reaction Monitoring"- MRM). A validação da metodologia proposta foi realizada utilizando os parâmetros de seletividade, efeito de matriz, faixa de trabalho, linearidade, limites de detecção (LD) e quantificação (LQ), precisão, exatidão, recuperação e robustez. A validação da metodologia permitiu a sua aplicação na avaliação da distribuição dos 23 compostos selecionados, nas águas da represa Guarapiranga, um dos principais sistemas produtor de água potável da Região Metropolitana de São Paulo (RMSP). A presença desses poluentes nos ambientes aquáticos é proveniente da liberação direta do esgoto urbano das habitações do seu entorno, como consequência do precário sistema de saneamento básico. As águas da represa Guarapiranga foram avaliadas em 14 (quatorze) locais estrategicamente escolhidos e amostradas durante 3 (três) campanhas de coleta de amostra (agosto de 2011, setembro de 2012 e abril de 2013). Nessas amostras foram quantificados acetaminofeno (9,6 - $\left.254 \mathrm{ng} \mathrm{L}^{-1}\right)$, atenolol $\left(8,5\right.$ - $\left.177 \mathrm{ng} \mathrm{L}^{-1}\right)$, benzoilegonina $\left(7,9\right.$ - $\left.139 \mathrm{ng} \mathrm{L}^{-1}\right)$, cafeína $\left(27\right.$ - $\left.27386 \mathrm{ng} \mathrm{L^{-1 }}\right)$, carbamazepina $\left(12-358 \mathrm{ng} \mathrm{L}^{-1}\right)$, clortalidona
\end{abstract}


$\left(9,4-35 \mathrm{ng} \mathrm{L}^{-1}\right)$, cocaína $\left(12,8-2650 \mathrm{ng} \mathrm{L}^{-1}\right)$, diclofenaco $\left(8-35 \mathrm{ng} \mathrm{L}^{-1}\right)$, enalapril (20 ng L-1), losartana $\left(6,7-114 \mathrm{ng} \mathrm{L}^{-1}\right)$ e valsartana $\left(9,7-47 \mathrm{ng} \mathrm{L^{-1 }}\right)$. $\mathrm{O}$

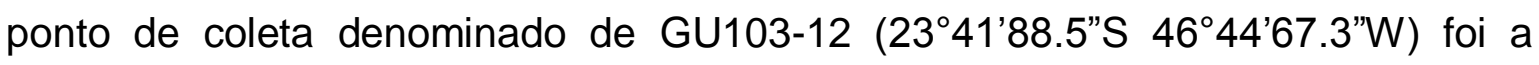
região que apresentou os valores mais elevados quanto ao nível de concentração dos compostos avaliados e ao índice de risco integrado de poluição química aquática ("Integrated Risk Index of Chemical Aquatic Pollution - IRICAP"). O estudo também foi realizado em amostras de água de reservatórios das Unidades de Gerenciamento de Recursos Hídricos (UGRHI) 5 e 6 do Estado de São Paulo. Os resultados demonstraram que o uso e a ocupação do solo influenciam diretamente na qualidade da água dos reservatórios, evidenciando a necessidade de implementar melhorias no sistema de coleta de esgoto e de ocupação irregular para evitar a contaminação e o descarte inadequado em ambientes aquáticos. 


\title{
DEVELOPMENT AND VALIDATION OF METHODOLOGY SPE-LC-MS/MS FOR PHARMACEUTICALS AND ILLICIT DRUG DETERMINATION IN THE WATERS OF GUARAPIRANGA DAM - SAO PAULO/SP, BRAZIL
}

\author{
Helena Miho Shihomatsu
}

\begin{abstract}
This study presents the development of the methodology of solid phase extraction and liquid chromatography - tandem mass spectrometry, SPE-LC-MS/MS, for the determination of 21 (twenty one) pharmaceuticals belonging to different therapeutic groups, 1 (one) illicit drug and its major metabolite, in surface water samples. The chromatographic separation was optimized by studying the performance of different stationary and mobile phases. Quantitation of selected compounds was performed by electrospray ionization (ESI) and the mass spectrometer operating in a multiple reaction monitoring (MRM) mode. The validation of the proposed methodology was performed using the parameters of selectivity, matrix effect, dynamic range, linearity, limit of detection (LOD), limit of quantification (LOQ), precision, accuracy, recovery and robustness. The validation of methodology allowed to apply the methodology in the evaluation of the distribution of the 23 (twenty one) selected compounds, in Guarapiranga Dam waters, an of the major producer system of drinking water of the Metropolitan Region of São Paulo (MRSP). The presence of these pollutants in aquatic environments is from the direct release of urban sewage from the homes of your surroundings, as a result of poor sanitation system. The waters of Guarapiranga dam were evaluated in 14 (fourteen) locations strategically chosen and sampled in 3 (three) campaigns of sample collection (August 2011, September 2012 and April 2013). In these samples were quantified acetaminophen (9.6 - $\left.254 \mathrm{ng} \mathrm{L}^{-1}\right)$, atenolol (8.5 - $\left.177 n g L^{-1}\right)$, benzoylegonine (7.9 - $\left.139 n g L^{-1}\right)$, caffeine $\left(27\right.$ - $\left.27386 n g L^{-1}\right)$ carbamazepine $\left(12\right.$ - $\left.358 \mathrm{ng} \mathrm{L^{-1 }}\right)$, chlorthalidone $\left(9.4\right.$ - $\left.35 \mathrm{ng} \mathrm{L}^{-1}\right)$, cocaine (12.8 - $\left.2560 \mathrm{ng} \mathrm{L}^{-1}\right)$, diclofenac $\left(8\right.$ - $\left.36 \mathrm{ng} \mathrm{L^{-1 }}\right)$, enalapril $\left(20 \mathrm{ng} \mathrm{L}^{-1}\right)$, losartan

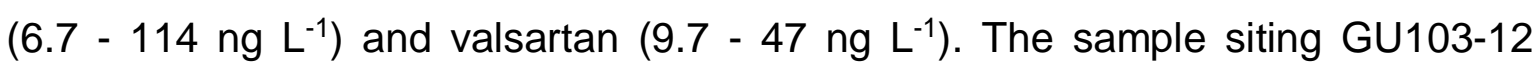


( $\left.23^{\circ} 41^{\prime} 88.5^{\prime \prime} \mathrm{S} 46^{\circ} 44^{\prime} 67.3^{\prime \prime} \mathrm{W}\right)$ was the region with the highest values in the level of concentration of the target compounds and the integrated risk index of chemical aquatic pollution (IRICAP). The study was also conducted on water samples from reservoirs of the UGRHI (Unit of Water Resources Management) 5 and 6, State 0 São Paulo. The results showed that the use and occupation of land directly influence the reservoir water quality highlighting the need to implement improvements in sewage collection system and illegal occupation to prevent contamination and the improper disposal in aquatic environments. 


\section{Sumário}

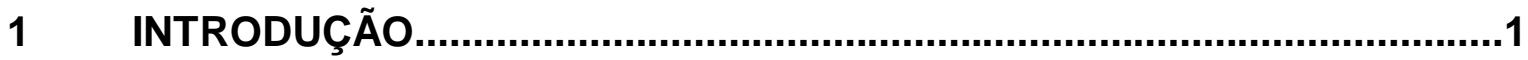

2 OBJETIVOS E RELEVÂNCIA DO TRABALHO......................................

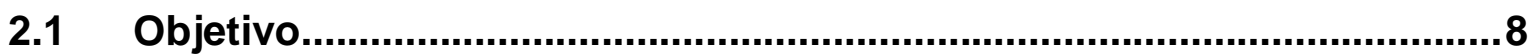

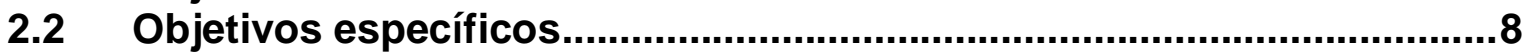

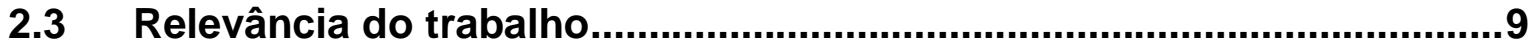

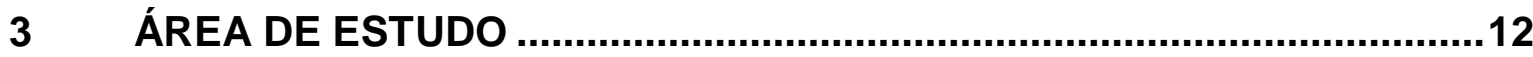

3.1 Represa Guarapiranga......................................................................12

3.1.1 Ocupação do entorno da Represa Guarapiranga.....................................16

3.1.2 Saneamento básico na Bacia da Guarapiranga......................................18

3.2 Represas das UGRHI 5 e 6 do Estado de São Paulo.............................19

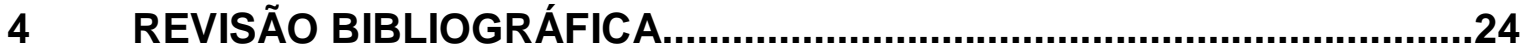

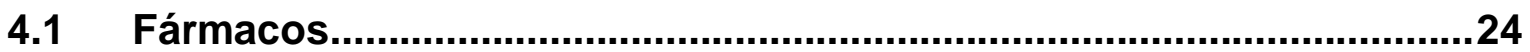

4.2 Destinos dos fármacos no meio ambiente .........................................30

4.3 Ocorrência dos fármacos no meio ambiente .......................................33

4.4 Toxicidade em ambiente aquático ……............................................44

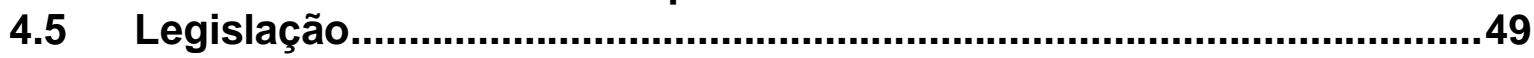

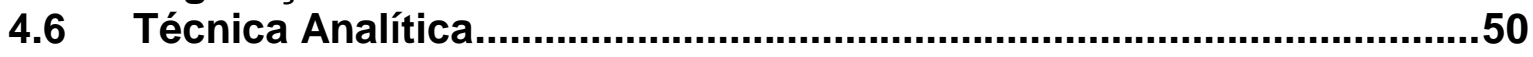

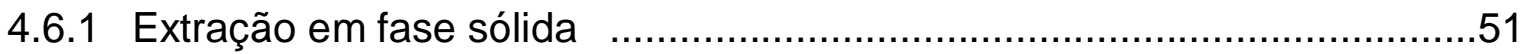

4.6.2 Cromatografia líquida acoplada à espectrometria de massas sequencial,

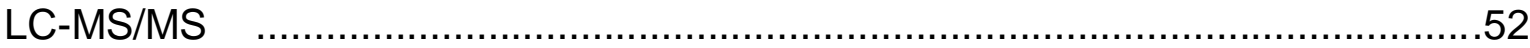

4.7 Validação da metodologia .............................................................58

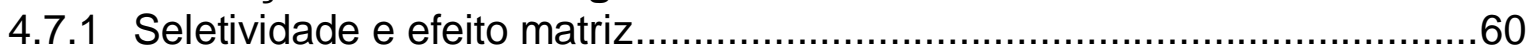

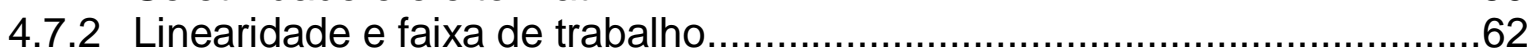

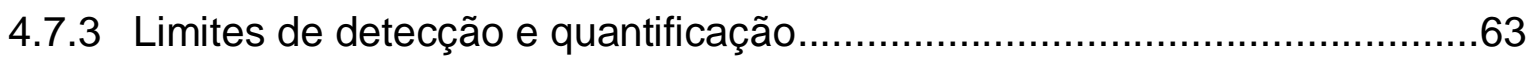

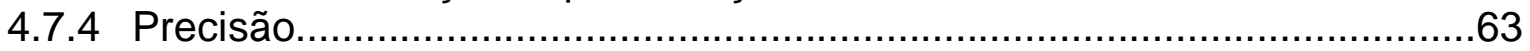

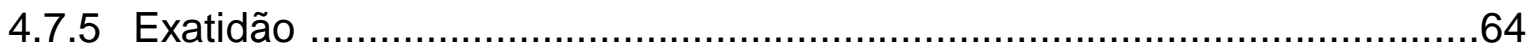

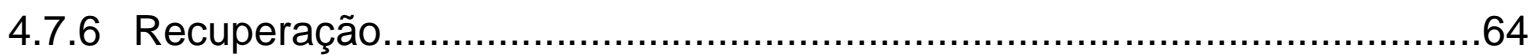

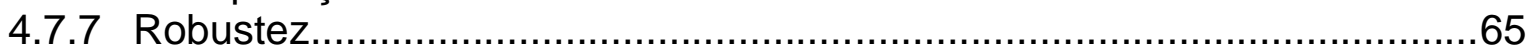

4.8 Incerteza nas medições analíticas.......................................................65

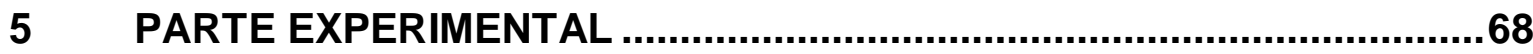

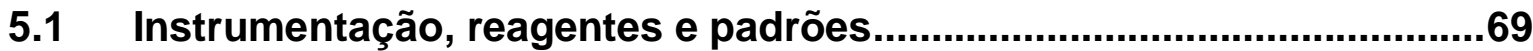

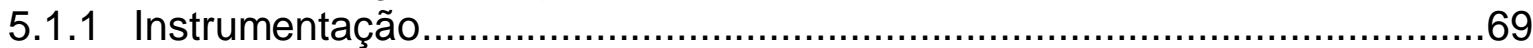

5.1.2 Reagentes e Padrões.................................................................

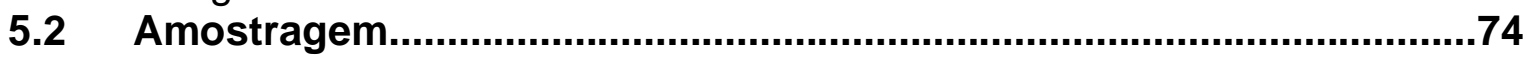

5.3 Preparação das soluções de calibração mista de padrões das curvas

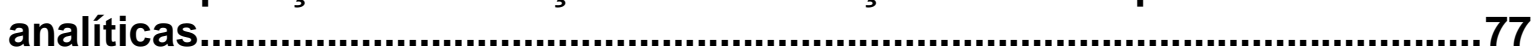

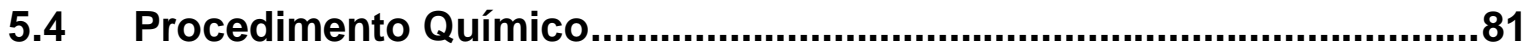

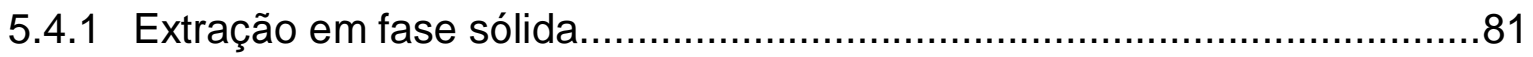

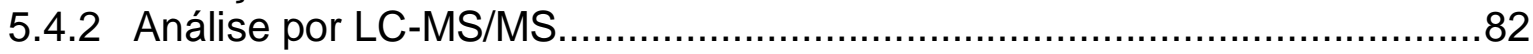

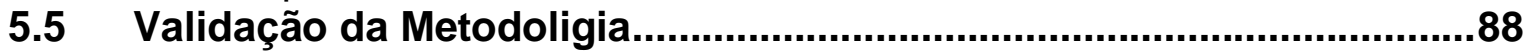

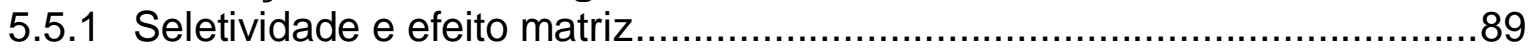




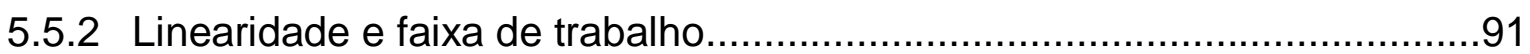

5.5.3 Limite de detecção (LD) e quantificação (LQ) .......................................92

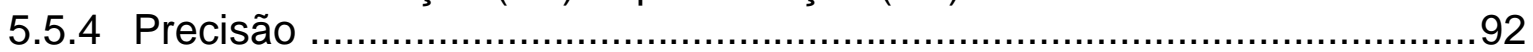

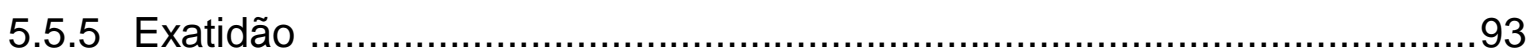

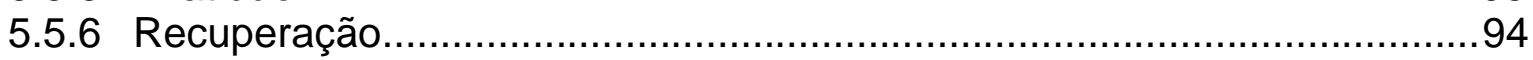

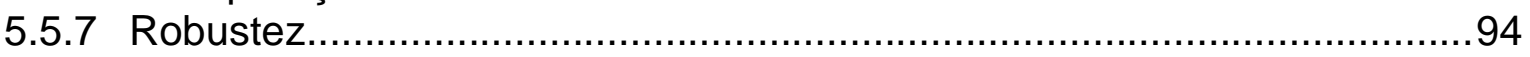

5.6 Incerteza nas medições químicas........................................................95

5.6.1 Incertezas associada à concentração do composto $\left(\mathrm{C}_{0}\right)$ na alíquota analisada.

5.6.2 Incerteza associada à recuperação do método...................................100

5.6.3 Incerteza associada ao volume final e inicial da amostra.........................100

5.6.4 Incerteza combinada e expandida do método.........................................101

6 RESULTADOS E DISCUSSÃO ............................................................102

6.1 Procedimento analítico........................................................................102

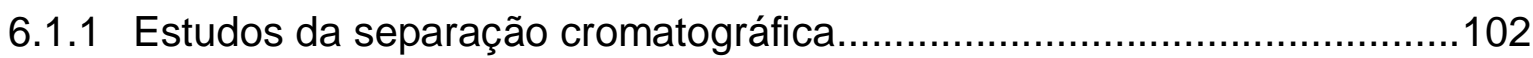

6.2 Validação da Metodologia..................................................................105

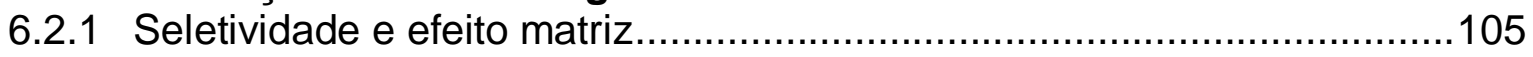

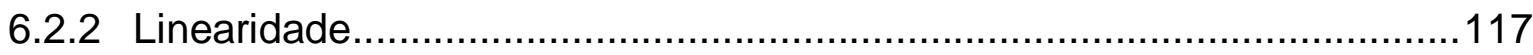

6.2.3 Limites de detecção (LD) e quantificação (LQ) ..................................126

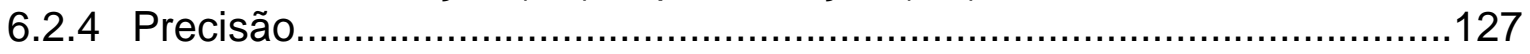

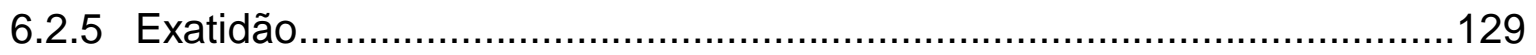

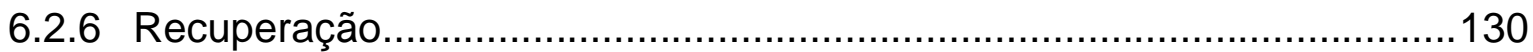

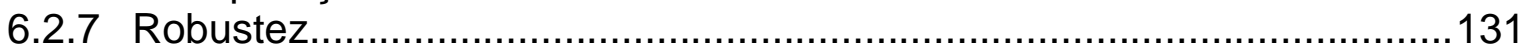

6.3 Incerteza nas medições químicas.....................................................142

6.4 Aplicação da metodologia nas águas da Represa Guarapiranga......144

6.4.1 Avaliação de risco integrado (IRICAP) nas águas da Represa Guarapiranga............................................................................... 176

6.5 Aplicação da metodologia nas águas das represas das UGRHI 5 e 6 do Estado de São Paulo.....................................................................................179

7 CONCLUSÃO ................................................................................. 184

8 CONSIDERAÇÕES GERAIS ......................................................... 187

APÊNDICE A...........................................................................................188

APÊNDICE B........................................................................................ 192

APÊNDICE C..........................................................................................200

APENDICE D.................................................................................................203

REFEÊNCIAS BIBLIOGRÁFICAS ............................................................207 


\section{LISTA DE FIGURAS}

FIGURA 1. Localização da Represa Guarapiranga, com os municípios em seu entorno, na Região Metropolitana de São Paulo (adaptação de SÃO PAULO (2008))

FIGURA 2. Participação (\%) dos municípios na área da Bacia da Guarapiranga.

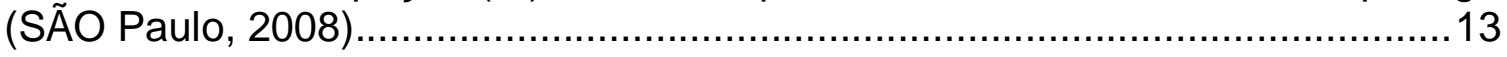

FIGURA 3. Represa Guarapiranga e seus tributários....................................14

FIGURA 4. Represa Guarapiranga com áreas mais preservadas (A) e com alta densidade urbana (B).... 18

FIGURA 5. Mapa do Estado de São Paulo com as 22 UGRHI com destaque para as 5 e 6 , onde se encontram as represas estudadas (MATSUMURATUNDISI \& TUNDISI, 2011). 20

FIGURA 6. Localização das Represas Ribeirão do Pinhal, Salto Grande, Atibainha e Cachoeira na UGRHI 5. Adaptação de SILVA et al. (2007). 21

FIGURA 7. Localização da Represa Paiva Castro, Tanque Grande e Cabuçu na

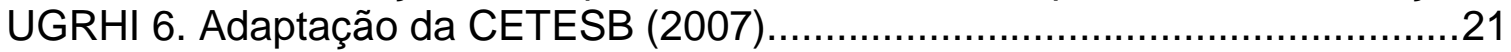

FIGURA 8. Represas do Sistema Cantareira...............................................22

FIGURA 9. As principais vias de administração e eliminação de fármacos (RANG, et al., 1997). Vias de administração: $1=$ oral ou retal; $2=$ =ndovenosa; $3=$ percutânea; 4 =intramuscular; $5=$ =inalação; $6=$ intratecal. Vias de eliminação: $7=$ urina; $8=$ ar expirado; $9=$ =leite e suor; $10=$ fezes.

FIGURA 10. Representação dos caminhos percorridos pelos fármacos para se tornar disponível no organismo (MODA, 2007).

FIGURA 11. Principais rotas de entrada dos fármacos no ambiente aquático. (Adaptação de BILA \& DEZOTTI (2003)).

FIGURA 12. Presença das classes terapêuticas (\%) mais relevantes em termos de contaminação ambientais (SANTOS, et al., 2010).

FIGURA 13. Modelo de ionização por eletronebulização: (A) modelo do resíduo carregado - CRM, e (B) modelo da dessorção de íons - IDM (SOUZA, 2008)...56

FIGURA 14. Esquema de funcionamento do analisador triploquadrupolo (SOUZA, 2008) 57

FIGURA 15. Fluxograma das etapas envolvidas no procedimento desenvolvido para análise dos compostos de interesse por HPLC-MS/MS, nas amostras de águas superficiais. 68

FIGURA 16. Sistema de extração em fase sólida 69

FIGURA 17. Estrutura Química dos compostos em estudo (DRUGBANK). .73 
FIGURA 18. Localização dos pontos de coleta das amostras de água na represa Guarapiranga e seus tributários. .75

FIGURA 19. Garrafa de Van Dorn horizontal, em PVC, para coleta de amostra.

FIGURA 20. Esquema do sistema de ionização por eletronebulização acoplado ao espectrômetro triploquadrupolo. (MARTINS JUNIOR, et al., 2006). 85

FIGURA 21. Diagrama de causa e efeito das fontes de incertezas associadas nas determinações das concentrações dos compostos por LC-MS/MS .96

FIGURA 22. Intensidade (contagem/s) dos compostos em estudo obtida na separação cromatográfica com as colunas Allura PFP Propyl e Zobax Eclipse XDB-C18. Análises realizadas nos modos de ESI(+) e ESI(-) e com injeção de 10 $\mu \mathrm{L}$ da solução mista de padrões $\left(50 \mathrm{ng} \mathrm{mL}^{-1}\right)$ 102

FIGURA 23. Largura dos picos dos compostos em estudo obtida na separação cromatográfica com as colunas Allura PFP Propyl e Zobax Eclipse XDB-C18. Análises realizadas nos modos $\mathrm{ESI}(+)$ e ESI(-) e com injeção de $10 \mu \mathrm{L}$ da solução mista de padrões $\left(50 \mathrm{ng} \mathrm{mL}^{-1}\right)$.

FIGURA 24. Área do pico dos compostos em estudo na separação cromatográfica utilizando diferentes fases móveis: (a) Fase A: água $+0,1 \%$ de ácido fórmico/Fase B: ACN; (b) Fase A: água + $1 \%$ de $A C N+0,1 \%$ de ácido fórmico $+2 \mathrm{mM}$ de acetato de amônio/Fase $\mathrm{B}$ : $\mathrm{ACN}+1 \%$ de água $+0,1 \%$ de ácido fórmico $+2 \mathrm{mM}$ de acetato de amônio; (c) Fase A: água $+1 \%$ de $\mathrm{ACN}+$ $0,1 \%$ de ácido fórmico $+2 \mathrm{mM}$ de acetato de amônio/Fase B: ACN. Análises realizadas no modo $\mathrm{ESI}(+)$ e com injeção de $10 \mu \mathrm{L}$ da solução mista de padrões (50 $\mathrm{ng} \mathrm{mL}^{-1}$ ). 104

FIGURA 25. Área do pico da clortalidona na separação cromatográfica utilizando duas fases móveis: (d) Fase A: água $+5 \mathrm{mM}$ de acetato de amônio/Fase B: ACN; (e) Fase A: água $+1 \%$ de $\mathrm{ACN}+0,1 \%$ de ácido fórmico $+2 \mathrm{mM}$ de acetato de amônio/Fase B: ACN $+1 \%$ de água $+0,1 \%$ de ácido fórmico $+2 \mathrm{mM}$ de acetato de amônio. Análises realizadas no modo ESI(-) e com injeção de $10 \mu \mathrm{L}$ da solução mista de padrões (50 $\mathrm{ng} \mathrm{mL}^{-1}$ )

FIGURA 26. Cromatograma da solução de calibração (P3) para os compostos em estudo analisados no LC-ESI(+)-MS/MS no modo MRM. 106

FIGURA 27. Cromatograma de uma amostra analisada no LC-ESI(-)-MS/MS no modo MRM.

FIGURA 28. Estudo do efeito da matriz na quantificação do acetaminofeno, atenolol, benzoilecgonina, bromazepam, cafeína e carbamazepina, utilizando padronização externa. 114

FIGURA 29. Estudo do efeito da matriz na quantificação da ciproterona, citalopram, clonazepam, clopidogrel, clortalidona, cocaína, diclofenaco, enalapril, loratadina e losartana, utilizando padronização externa. 
FIGURA 30. Estudo do efeito da matriz na quantificação da midazolam, orfenadrina, paroxetina, propranolol, rosuvastatina, sildenafila e valsartana utilizando padronização externa.

FIGURA 31. Gráficos de resíduo absoluto e normalizado para acetaminofeno. Atenolol, benzoilecgonina, bromazepam, cafeína e carbamazepina nas soluções de calibração com matriz.

FIGURA 32. Gráficos de resíduo absoluto e normalizado para ciproterona, citalopram, clonazepam, clopidogrel, clortalidona e cocaína nas soluções de calibração com matriz.

FIGURA 33. Gráficos de resíduo absoluto e normalizado para diclofenaco, enalapril, loratadina, losartana, midazolam e orfenadrina nas soluções de calibração com matriz. 124

FIGURA 34. Gráficos de resíduo absoluto e normalizado para paroxetina, propranolol, rosuvastatina, sildenafila e valsartana nas soluções de calibração com matriz. 125

FIGURA 35. Efeitos dos parâmetros selecionados para avaliar a robustez do método na quantificação do acetaminofeno, atenolol, benzoilecgonina, bromazepam, cafeína, carbamazepina, ciproterona e citalopram, em amostra com adição de solução mista de padrões 132

FIGURA 36. Efeitos dos parâmetros selecionados para avaliar a robustez do método de quantificação do clonazepam, clopidogrel, clortalidona, cocaína, diclofenaco, enalapril, loratadina e losartana, em amostra com adição de solução mistura de padrões. 133

FIGURA 37. Efeitos dos parâmetros selecionados para avaliar a robustez do método de quantificação do midazolam, orfenadrina, paroxetina, propranolol, rosuvastatina, sildenafila e valsartana, em amostra com adição de solução mista de padrões 134

FIGURA 38. Gráficos de rankit para acetaminofeno, atenolol, benzoilecgonina, bromazepam, cafeína, carbamazepina, ciproterona e citalopram nas amostras com adição de solução mista de padrões. 136

FIGURA 39. Gráficos de rankit para clonazepam, clopidogrel, clortalidona, cocaína, diclofenaco, enalapril, loratadina e losartana nas amostras com adição de solução mista de padrões.

FIGURA 40. Gráficos de rankit para midazolam, orfenadrina, paroxetina, propranolol, rosuvastatina, sildenafila e valsartana nas amostras com adição de solução mista de padrões. 138

FIGURA 41. Gráficos de probabilidade normal para acetaminofeno, atenolol, benzoilecgonina, bromazepam, cafeína, carbamazepina, ciproterona, e citalopram nas amostras com adição de solução mista de padrões.

FIGURA 42. Gráficos de probabilidade normal para clonazepam, clopidogrel, clortalidona, cocaína, diclofenaco, enalapril, loratadina e losartana nas amostras com adição de solução mista de padrões 
FIGURA 43. Gráficos de probabilidade normal para midazolam, orfenadrina, paroxetina, propranolol, rosuvastatina, sildenafila e valsartana nas amostras com adição de solução mista de padrões.

141

FIGURA 44. Contribuição das incertezas combinadas envolvidas na determinação da concentração do acetaminofeno, atenolol, benzoilecgonina, bromazepam, cafeína, carbamazepina, clortalidona, cocaína e diclofenaco pelo método desenvolvido. 143

FIGURA 45. Contribuição das incertezas combinadas envolvidas na determinação da concentração do enalapril, losartana e valsartana pelo método desenvolvido 144

FIGURA 46. Visualização gráfica da frequência de detecção dos compostos de interesse nas amostras de água da represa Guarapiranga. 149

FIGURA 47. Distribuição do acetaminofeno nas águas da represa Guarapiranga durante as coletas realizadas em ago./2011, set./2012 e abr./2013. 150

FIGURA 48. Distribuição do atenolol nas águas da represa Guarapiranga durante as coletas realizadas em ago./2011, set./2012 e abr./2013. 150

FIGURA 49. Distribuição do benzoilecgonina nas águas da represa Guarapiranga durante as coletas realizadas em ago./2011, set./2012 e abr./2013. 151

FIGURA 50. Distribuição da cafeína nas águas da represa Guarapiranga durante as coletas realizadas em ago./2011, set./2012 e abr./2013. 151

FIGURA 51. Distribuição da carbamazepina nas águas da represa Guarapiranga durante as coletas realizadas em ago./2011, set./2012 e abr./2013. 152

FIGURA 52. Distribuição da clortalidona nas águas da represa Guarapiranga durante as coletas realizadas em ago./2011, set./2012 e abr./2013. .152

FIGURA 53. Distribuição da cocaína nas águas da represa Guarapiranga durante as coletas realizadas em ago./2011, set./2012 e abr./2013. 153

FIGURA 54. Distribuição da losartana nas águas da represa Guarapiranga durante as coletas realizadas em ago./2011, set./2012 e abr./2013. 153

FIGURA 55. Pluviometria histórica média do mês e volume armazenado até o dia da coleta na represa Guarapiranga (SABESP). 154

FIGURA 56. Ocorrência da cafeína (A) e carbamazepina (B) em ago./2011, set./2012 e abr./2013 nas águas da represa Guarapiranga. 156

FIGURA 57. Perfil de ocorrência do atenolol (A) e losartana (B) nas águas da represa Guarapiranga coletadas em ago./2011; set./2012 e abr./2013............160

FIGURA 58. Perfil de ocorrência da valsartana nas águas da represa Guarapiranga coletada em ago./2011; set./2012 e abr./2013..........................162

FIGURA 59. Perfil de ocorrência da clortalidona nas águas da represa Guarapiranga coletada em ago./2011; set./2012 e abr./2013.........................164

FIGURA 60. Perfil de ocorrência do acetaminofeno (A) e diclofenaco (B) nas águas da represa Guarapiranga coletadas em ago./2011; set./2012 e abr./2013. 166 
FIGURA 61. Perfil de ocorrência da cocaína (A) e benzoilecgonina (B) nas águas da represa Guarapiranga coletadas em ago./2011; set./2012 e abr./2013........169

FIGURA 62. Dendograma da distribuição do atenolol nas águas da represa Guarapiranga coletadas em ago./2011, set./2012 e abr./2013...

FIGURA 63. Dendograma da distribuição da cocaína nas águas da represa Guarapiranga coletadas em ago./2011, set./2012 e abr./2013.

FIGURA 64. Imagem fotográfica da região de coleta G103-12 mostrando a ocupação e a rede de contenção de lixo (Foto de Shihomatsu, H. M. em 4/abril/2013). 173

FIGURA 65. Imagem fotográfica da região de coleta GU107-06 (A) e GU108-07 (B) (Foto de Shihomatsu, H. M. em 4/abril/2013). 174

FIGURA 66. Imagem fotográfica da região de coleta GU100-01 (A) e GU100-02 (B) (Foto de Shihomatsu, H. M. em 4/abril/2013). 175

FIGURA 67. Dendograma da distribuição do acetaminofeno, atenolol, cocaína, cafeína, carbamazepina, clortalidona e benzoilecgonina nas águas da represa Guarapiranga coletadas em ago./2011, set./2012 e abr./2013. 176

FIGURA 68. Índice de riscos integrado da poluição química aquática ao longo da represa Guarapiranga durante as coletas de ago./2011, set./2012 e abr./2013. 178

FIGURA 69. Ocorrência de atenolol, benzoilecgonina, cafeína, carbamazepina, clortalidona, cocaína, losartana e valsartana nas águas das represas: Cachoeira (CA), Paiva Castro (PC), Ribeirão do Pinhal (RP), Atibainha (AT), Salto Grande (SG), Cabuçu (CB) e Tanque Grande (TG). 181

FIGURA 70. Reservatório de Salto Grande com ocupação predominantemente urbana na margem esquerda e agrícola na margem direita. (https://www.google.com.br/maps/@-22.7290256,- 


\section{LISTA DE TABELAS}

TABELA 1. Dados dos municípios integrantes da Bacia Hidrográfica do Guarapiranga (SÃO PAULO, 2008)........................................................13

TABELA 2. População por município residente na Bacia da Guarapiranga, em 2000 (SÃO PAULO, 2008).......................................................................17

TABELA 3. Índice de tratamento de esgotos dos municípios na Bacia Hidrográfica da Guarapiranga (SNSA, 2013) ..............................................19

TABELA 4. Localização das represas Cabuçu, Tanque Grande, Paiva Castro, Cachoeira, Atibainha, Salto Grande e Ribeirão do Pinhal.................................20

TABELA 5. Ocorrência de anti-inflamatórios não esteroides (acetaminofeno) em água superficial, afluente e efluente de ETE........................................................

TABELA 6. Ocorrência de anti-inflamatórios não esteroides (diclofenaco) em águas superficiais, afluente e efluente de ETE..................................................3

TABELA 7. Ocorrência de anticonvulsivante (carbamazepina) em águas superficiais, afluente e efluente de ETE

TABELA 8. Ocorrência de antidepressivo (paroxetina e citalopram) e estimulante (cafeína) em águas superficiais, afluente e efluente de ETE. 39

TABELA 9. Ocorrência de $\beta$-bloqueador (atenolol) em águas superficiais, afluente e efluente de ETE. .40

TABELA 10. Ocorrência de $\beta$-bloqueador (propranolol) e anti-hipertensivo (enalapril) em águas superficiais, afluente e efluente de ETE. 41

TABELA 11. Ocorrência de droga de abuso e metabólito (cocaína e benzoilecgonina) em águas superficiais e afluente/efluente de ETE.

TABELA 12. Definição dos dados obtidos nos ensaios de toxicidade aguda e crônica (COSTA, et al., 2008)...

TABELA 13. Estudo de toxicidade para anti-inflamatório (acetaminofeno e diclofenaco) encontrado na literatura.

TABELA 14. Estudo de toxicidade para anticonvulsivante (carbamazepina), antidepressivo (paroxetina), estimulante (cafeína), $\beta$-bloqueador (propranolol) e anti-hipertensivo (atenolol) encontrado na literatura

TABELA 15. Características dos compostos selecionados para estudo (DRUGBANK). .72

TABELA 16. Coordenadas geográficas dos pontos de coleta das amostras de água da Represa Guarapiranga. .74

TABELA 17. Cronograma e a coordenada geográfica do local de coleta das amostras de água das represas: Paiva Castro, Ribeirão do Pinhal, Salto Grande, Atibainha, Cachoeira, Tanque Grande e Cabuçu. 
TABELA 18. Concentrações das soluções de calibração das curvas analíticas com solvente e com matriz.

TABELA 19. Gradientes "1 e 2" de eluição utilizados na separação cromatográfica das colunas Allura PFP Propyl e Zorbax Eclise XDBC18, respectivamente......83

TABELA 20. Parâmetros dependentes dos compostos otimizados para detecção

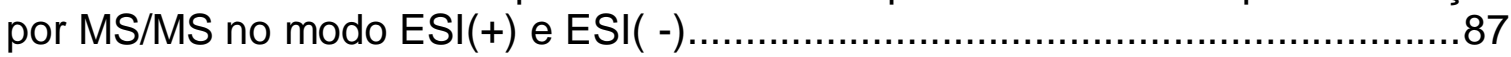

TABELA 21. Parâmetros selecionados para estudo da robustez..........................94

TABELA 22. Combinação fatorial para o estudo da robustez, segundo Youden..95

TABELA 23. Condições cromatográficas estabelecidas para a separação simultânea dos compostos selecionados para estudo......................................105

TABELA 24. Pontos de identificação (PI) adotados para a confirmação da presença dos compostos de interesse.........................................................108

TABELA 25. Valores de $F_{\text {calc }}$ e $t_{\text {calc }}$ do acetaminofeno, atenolol, benzoilecgonina e bromazepam para o estudo da seletividade com a solução de calibração com solvente e com matriz considerando $\mathrm{F}_{\mathrm{tab}(6,95 \%)}=4,28$ e $\mathrm{t}_{\mathrm{tab}(12,95 \%)}=2,179$. 109

TABELA 26. Valores de $F_{\text {calc }}$ e $t_{c a l c}$ da cafeína carbamazpina, ciproterona, citalopram e clonazepam para o estudo da seletividade com a solução de

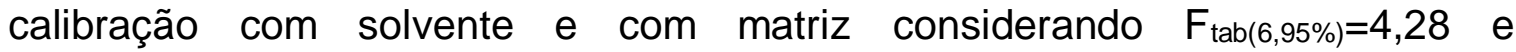
$t_{\text {tab }(12,95 \%)}=2,179$...

TABELA 27. Valores de $F_{\text {calc }}$ e $t_{\text {calc }}$ do clopidogrel, clortalidona, cocaína, diclofenaco e enalapril para o estudo da seletividade com a solução de calibração com solvente e com matriz considerando $F_{\text {tab(6,95\%) }}=4,28$ e $t_{\text {tab }(12,95 \%)}=2,179$. 111

TABELA 28. Valores de $F_{\text {calc }}$ e tcalc da loratadina, losartana, midazolam, orfenadrina e paroxetina para o estudo da seletividade com a solução de calibração com solvente e com matriz considerando $F_{\operatorname{tab}(6,95 \%)}=4,28$ e $t_{\text {tab }(12,95 \%)}=2,179$. 112

TABELA 29. Valores de $F_{\text {calc }}$ e $t_{\text {calc }}$ do propranolol, rosuvastatina, sildenafila e valsartana para o estudo da seletividade com a solução de calibração com solvente e com matriz considerando $\mathrm{F}_{\mathrm{tab}(6,95 \%)}=4,28$ e $\mathrm{t}_{\mathrm{tab}(12,95 \%)}=2,179$. 113

TABELA 30. Faixa de trabalho, equação da reta e coeficiente de determinação $\left(r^{2}\right)$ para os compostos de estudo obtidos das 8 (oito) soluções de calibração com matriz. .118

TABELA 31. Valores de tcalc para a análise de resíduo das soluções de calibração com matriz do acetaminofeno, atenolol, benzoilecgonina, bromazepam, cafeína,

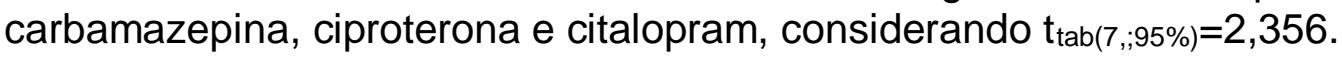
119

TABELA 32. Valores de $t_{c a l c}$ para a análise de resíduo das soluções de calibração com matriz da clonazepam, clopidogrel, clortalidona, cocaína, diclofenaco, enalapril, Ioratadina, losartana, midazolam, orfenadrina, paroxetina e propranolol considerando $t_{\text {tab }(7,95 \%)}=2,356$. 
TABELA 33. Valores de tcalc para a análise de resíduo das soluções de calibração com matriz da rosuvastatina, sildenafila e valsartana considerando $\operatorname{tab}(7,95 \%)=2,356$.

TABELA 34. Limites de detecção (LD) e quantificação (LQ) do método com matriz. 126

TABELA 35. Coeficiente de variação (CV\%), limites de repetibilidade $(r)$ e reprodutibilidade $(R)$ e seus respectivos desvios padrão $\left(S_{r}\right.$ e $\left.S_{R}\right)$ obtidos em três níveis de concentrações da curva analítica com matriz para os compostos em estudo.

TABELA 36. Valores de $Z$ obtidos para os 23 compostos nas soluções de calibração com matriz. 129

TABELA 37. Recuperação, referente à média de 3 ensaios, em 3 níveis de concentrações dos 23 compostos selecionados 130

TABELA 38. Concentração, incertezas expandidas e as contribuições das grandezas de entrada envolvidas na quantificação dos compostos desse estudo. 142

TABELA 39. Concentração média de 3 extrações e o valor da incerteza associada dos compostos detectados nas amostras coletadas da Represa Guarapiranga em Agosto de 2011 146

TABELA 40. Concentração média de 3 extrações mais o valor da incerteza associada dos compostos detectados nas amostras coletadas da Represa Guarapiranga em setembro de 2012. 147

TABELA 41. Concentração média de 3 extrações mais o valor da incerteza associada dos compostos detectados nas amostras coletadas da Represa Guarapiranga em abril de 2013 148

TABELA 42. Índice integrado de risco de poluição química aquática (IRICAP) nos locais de coletas das amostragens de ago./2011, set./2012 e abr./2013 177

TABELA 43. Valores de fármacos em $\mathrm{ng} \mathrm{L}^{-1}$ encontrados nas represas Cachoeira (CA), Paiva Castro (PC), Ribeirão do Pinhal (RP), Atibainha (AT), Salto Grande (SG), Cabuçu (CB) e Tanque Grande (TG). 180 


\section{LISTA DE ABREVIATURAS}

ADP Difosfato de Adenosina

AINE Anti-inflamatório não esteroide

ACE Enzima Conversora de Angiotensina

ACN Acetronitrila

API Atmospheric Pressure Ionization (Ionização a Pressão Atmosférica)

CAS Chemical Abstract Service

CETESB Companhia Ambiental do Estado de São Paulo

CONAMA Conselho Nacional do Meio Ambiente

DDT Dicloro-difenil-tricloroetano

ESI Electrospray Ionization (Ionização por eletronebulização)

ETA Estação de Tratamento de Água

ETA-ABV Estação de Tratamento de Água-Alta da Boa Vista

ETE Estação de Tratamento de Esgoto

GABA Ácido Gama-aminobutírico

GC Gas Chromatography (Cromatografia Gasosa)

GC-ECD Gas Chromatography-Electron Capture Detector (Cromatografia Gasosa com Detector de Captura de Elétrons)

GC-FID Gas Chromatography-Flame Ionization Detector (Cromatografia Gasosa com Detector de Ionização de Chama)

GC/MS Gas Chromatography with Mass Spectrometry (Cromatografia gasosa acoplada à espectrometria de massas)

GMPc Deguanosina Monofosfato cíclico

$\mathrm{H}_{2} \mathrm{O}$ Água

HPLC-UV Cromatografia Líquida de Alta Eficiência com detecção Ultravioleta IBGE Instituto Brasileiro de Geografia e Estatística

INMETRO Instituto Nacional de Metrologia, Normalização e Qualidade Industrial IPEN Instituto de Pesquisas Energéticas e Nucleares

ISO International Organization for Standardization (Organização Internacional para Padronização)

IRICAP Integrated Risk Index of Chemical Aquatic Pollution 
LC-MS/MS Liquid Chromatography-tandem Mass Spectrometry (Cromatografia líquida e espectrometria de massas em sequência)

LD Limite de detecção

LDL Lipoproteína de baixa densidade

LQ Limite de quantificação

ME Margin of error (margem de erro)

MeOH Metanol

MRM Multiple Reaction Monitoring (Monitoramento de múltiplas reações)

MS Mass Spectrometry (Espectrometria de massas)

Pa Pascal

RMSP Região Metropolitana de São Paulo

SABESP Companhia de Saneamento Básico do Estado de São Paulo

SCAN Varredura de uma faixa determinada de íons

SIM Select ion monitoring (Monitoramento seletivo de íons)

SME Simultaneous margin of error (Margem simultânea de erro)

SNC Sistema Nervoso Central

SPE Solid phase extraction (extração em fase sólida)

SPME Solid phase micro extraction (micro extração em fase sólida)

SRS Serotonina

UGRHI Unidade de Gerenciamento de Recursos Hídricos

USEPA United States Environmental Protection Agency (Agência de Proteção Ambiental dos Estados Unidos) 


\section{INTRODUÇÃO}

A água é um recurso natural essencial para o abastecimento público e industrial, assim como, para a irrigação agrícola, produção de energia elétrica, preservação da vida aquática e atividades de lazer/recreação. Sem água não há vida.

A manutenção da qualidade da água é uma preocupação mundial do século XXI. De toda água existente no nosso planeta aproximadamente $3 \%$ é de água doce e, o fato de a maior parte da água doce se apresentar em forma de gelo ou neve permanente, apenas $0,01 \%$ do total de água do planeta está disponível para consumo humano. Nos grandes centros urbanos, a dinâmica social impõe um quadro complexo de disputa pela água, que por consequência do mau uso e gestão inadequada, a oferta da água tem se tornado cada vez mais limitada (RIBEIRO, 2011)

O avanço industrial e tecnológico, observado nas últimas décadas, propiciou o desenvolvimento de produtos químicos inovadores para atender a sociedade cada vez mais exigente. Como consequência, a presença dessas substâncias no ambiente aquático tem sido cada vez mais frequente, inclusive, em águas para abastecimento público e industrial, sugerindo risco iminente à saúde humana e ambiental (KOLPIN, et al., 2002).

Todo esse cenário foi agravado pela ausência de tecnologia de tratamento de efluente diferenciado, técnicas analíticas sensíveis e de regulamentação que estabelece os padrões de descarte de efluentes industriais, domésticos e das estações de tratamento de esgoto (ETE's).

O interesse pelas questões ambientais tem aumentado gradativamente nestas últimas décadas, em decorrência de acidentes com produtos químicos, 
com repercussão mundial. Vários exemplos podem ser citados, dentre os quais o uso indiscriminado do DDT (diclorodifeniltricloroetano) durante os anos 40. Esse produto altamente bioacumulável, apesar de suas vantagens contra doenças e pragas, pode ter sido o principal causador do declínio populacional de algumas espécies de pássaros; muitas delas pertencentes ao topo da cadeia alimentar, como o falcão peregrino e a águia calva, animais símbolos dos EUA (SOLOMOSNS, 1968).

Atualmente, mais de 100 mil substâncias químicas diferentes são utilizadas e, a previsão em 2020, segundo o Programa das Nações Unidas para o Meio Ambiente é de que o consumo em países em desenvolvimento pode chegar a um terço do consumo mundial (PNUMA, 2014). Uma parcela pequena dessas substâncias utilizadas é produzida em grande quantidade (acima de $500 \mathrm{mil} \mathrm{kg}$ ), sendo que menos de $45 \%$ destas substâncias são submetidas a testes toxicológicos básicos e, apenas 10\% estudadas quanto aos seus efeitos tóxicos sobre organismos em desenvolvimento (MELLO-DA-SILVA \& FRUCHTENGARTEN, 2005). O ritmo crescente da produção e do uso global de substâncias químicas tem produzido um aumento rápido na geração de resíduos perigosos, com potencial de oferecer riscos ao ambiente e a saúde humana (PNUMA, 2014).

$\mathrm{Na}$ literatura são encontrados estudos que relatam a presença de algumas destas substâncias emergentes em efluentes de ETE's, em águas residuais e águas superficiais de várias partes do mundo, como: Estados Unidos (KOLPIN, et al., 2002; WANG, et al., 2011; KLOSTERHAUS, et al., 2013), Europa (BARREK, et al., 2009; LOSS, et al., 2009; LOSS, et al., 2010), Reino Unido (ROBERTS\&THOMAS, 2006), Ásia (YOON, et al., 2010), Canadá (WINKLER, et al., 2001) e Brasil (BILA \& DEZOTTI, 2003; ALMEIDA \& WEBER, 2005; MELLODA-SILVA \& FRUCHTENGARTEN, 2005; SODRÉ, et al., 2007). De acordo com os autores, a presença dessas substâncias em águas superficiais é proveniente do descarte de esgoto doméstico e industrial, assim como de efluentes de ETE's com tratamento convencional, que não são projetados para remover esses contaminantes. Nesses estudos, a presença de diferentes categorias terapêuticas 
de fármacos foi detectada como: antibióticos, hormônios, anestésicos, antiinflamatório, antilipêmicos, meio de contraste de raios-X, entre outros.

No ano de 2010, o Brasil ocupou o $7^{\circ}$ lugar no faturamento mundial da Indústria Química, com US\$130 bilhões, atrás da China, Estados Unidos, Japão, Alemanha, Coréia e França (FIGUEREDO, 2012). Em 2013, o faturamento líquido da indústria química brasileira foi de US\$162,3 bilhões, tendo os produtos farmacêuticos em $2^{\circ}$ lugar com $26,5 \%$ do faturamento total, perdendo apenas para os produtos químicos de uso industrial (72,2\%) (ABQUIM, 2013).

Fármacos podem ser definidos como substâncias químicas conhecidas, de estrutura química definida e usadas para prevenir, diagnosticar e tratar doenças tanto na medicina humana como veterinária. Os fármacos são substâncias desenvolvidas para desempenhar um efeito biológico, com propriedades lipofílicas, capazes de passar por membranas e persistirem para não se tornarem inativos, antes de obter o efeito desejado (ALMEIDA \& WEBER, 2005; FENT, et al., 2006). De acordo com Mulroy (2001), 50\% a 90\% dos medicamentos consumidos são excretados na sua forma ativa ou metabolizada pela urina e fezes.

O desenvolvimento de bactérias resistentes aos antibióticos e os efeitos adversos no sistema reprodutivo de peixes, como resposta à presença de estrogênios esteroides no ambiente aquático, são amplamente discutidos na literatura (KÓLAR, et al., 2001; RODGERS-GRAY, et al., 2001; RUSSEL, 2003). Entretanto, os efeitos ecotoxicológicos de produtos farmacêuticos utilizados na medicina humana e veterinária são pouco conhecidos e uma das razões para essa falta de dados é que, até há pouco tempo, não eram vistos como compostos potencialmente tóxicos ao meio ambiente e também pela baixa disponibilidade de métodos analíticos capazes de detectar concentrações na faixa de $\mu \mathrm{g} \mathrm{L}^{-1}$ a ng L L

Segundo Gros et al. (2006), a presença de fármacos em baixas concentrações não deve ser menosprezada, pois a entrada contínua no meio aquático, a longo prazo pode provocar o efeito cumulativo e acarretar reações 
adversas tanto nos seres humanos como nos organismos não alvos. De acordo com Fent et al. (2006), os efeitos da mistura complexa de fármacos, no ambiente, provavelmente seguem o conceito de adição de concentração, assim, a toxicidade total é o resultado da soma individual de cada composto, que podem interferir no crescimento, na reprodução, na fertilidade e causar alterações no comportamento dos seres vivos.

A oferta de saneamento básico é fundamental para a qualidade de vida, pois sua ausência acarreta poluição dos recursos hídricos, trazendo prejuízo à saúde da população, principalmente o aumento da mortalidade infantil. No Brasil, o percentual de esgoto tratado em relação ao coletado, passou de $8,7 \%$ em 1995 para 61,6\% em 2005, atingindo 66,2\% em 2008. Em 2008, as regiões com maiores percentuais de tratamento foram Centro-Oeste $(88,9 \%)$ e Sul $(78,8 \%)$. O Sudeste embora considerado a região mais populosa do Brasil, tratava, em 2008 , apenas $58,5 \%$ dos esgotos coletados. Os valores apresentados se referem ao percentual de esgoto tratado em relação ao coletado, portanto, alguns dos elevados índices podem decorrer apenas da baixa coleta de esgotos (IBGE, 2012).

Atualmente, ainda se constata que grande parte do esgoto coletado continua sendo lançado nas águas superficiais, muitas vezes sem tratamento. No Brasil, a preocupação com as questões ambientais é relativamente recente e para auxiliar as autoridades competentes na tomada de decisões ainda é necessário um maior número de estudos para estabelecer um perfil de contaminação preciso, bem como, estudos conclusivos sobre toxicidade crônica devido à exposição de fármacos e seus metabólitos, em longo prazo, na fauna e flora (SANTOS, et al., 2010).

O órgão responsável pela formulação de resoluções normativas para a gestão ambiental, que estabelece os padrões de qualidade de água no Brasil, é o Conselho Nacional do Meio Ambiente (CONAMA) e a resolução, em vigor, que aborda esse tema é a CONAMA no 357/2005, acrescida da CONAMA 430/2011. Na última revisão desta resolução foram incluídas importantes modificações, entre 
elas, a exigência da realização de ensaios ecotoxicológicos no controle de efluentes líquidos, entretanto sem o estabelecimento de um nível de concentração máximo permissível dos resíduos de produtos farmacêuticos e de uso pessoal nos ambientes aquáticos (BRASIL, 2005; BRASIL, 2011). Fato semelhante ocorre com a legislação de padrão de potabilidade, quanto aos níveis máximos permitidos para a água distribuída, Portaria 2.914 do Ministério da Saúde, atualmente em revisão.

A Região Metropolitana de São Paulo (RMSP), maior metrópole da América do Sul com 20.284.891 milhões de habitantes em 2014 (SEADE, 2014), concentra o mais importante polo financeiro, industrial e comercial do Brasil. Atualmente, enfrenta o desafio de melhorar os padrões de prestação de serviços em um contexto de severas limitações físicas. As áreas de mananciais $(52 \%$ da área da RMSP, incluindo 25 municípios) têm sofrido intensos processos de degradação ambiental apresentando eutrofização, assoreamento e toxicidade (WHATELY \& CUNHA, 2006). O uso e ocupação do entorno das áreas de mananciais, assim como as previsões oriundas de estudos de variações climáticas, sugerem conforme declarado por TUNDSI (2008) que em um período relativamente curto, o sistema de produção de água para a RMSP tornar-se-á insuficiente, com qualidade de água cada vez inferior. Parte dessa previsão tornou realidade, quando uma parcela significativa da água disponibilizada à população da RMSP, em termos de abastecimento público, passou a ser proveniente de outra bacia hidrográfica, como exemplo a bacia do rio Piracicaba (TUNDISI, 2008).

A RMSP, em 2014, está enfrentando a pior escassez de água dos últimos 80 anos. O nível dos principais reservatórios, responsáveis pelo abastecimento da população da RMSP como a do sistema Cantareira (11,3\%), Alto do Tietê $(8,3 \%)$ e Guarapiranga (36,4\%) estão registrando queda dia a dia (G1.GLOBO, 2014). Além da escassez de água, a população de RMSP está sendo ameaçada com a piora da qualidade da água, principalmente com relação aos micro poluentes não legislados como os produtos farmacêuticos, produtos de higiene pessoal e interferentes endócrinos. 
Durante muitos anos, a análise de microcontaminates orgânicos foi realizada por cromatografia líquida de alta eficiência com detecção ultravioleta (HPLC-UV) e cromatografia gasosa acoplada a detetores de captura de elétrons (GC-ECD), ionização de chama (GC-FID) e espectrometria de massas (GC-MS). Entretanto, após a introdução da ionização em pressão atmosférica e a ionização "electrospray" (ESI), a cromatografia líquida com detecção por espectrometria de massas (LC-MS/MS) tornou-se a técnica mais aplicada nas análises de produtos farmacêuticos em amostras ambientalmente complexas. A determinação de resíduos de fármacos empregando a técnica analítica LC-MS/MS apresenta vantagens como versatilidade, especificidade e seletividade (GROS, et al., 2006). Além disso, permite a utilização de uma etapa simplificada de pré-tratamento da amostra, para determinar maior número de compostos polares e produtos de transformação sem derivatização, que necessita de mais tempo de execução e fornece resultados muitas vezes irreprodutíveis (DIAZ-CRUZ \& BARCELÓ, 2005; IBANEZ, et al., 2005; RICHARDSON \& TERNES, 2005).

Embora, a técnica de LC-MS/MS seja altamente sensível, o procedimento de pré-concentração auxilia na redução dos valores de limite de detecção, permitindo que os contaminantes emergentes, especialmente os produtos farmacêuticos, presentes no ambiente sejam determinados na concentração de ng L-1 a $\mu g \mathrm{~L}^{-1}$.

Atualmente, a maioria dos procedimentos analíticos de determinação de fármacos em amostras ambientais emprega a extração em fase sólida (SPE). Este procedimento permite que seja realizada a extração simultânea de vários compostos em apenas uma etapa, fornecendo também a pré-concentração e remoção de contamintes interferentes da matriz (RODRIGUEZ-MOZAZ, et al., 2007). Para esta finalidade, os cartuchos de SPE escolhidos são os que têm a capacidade de extrair compostos ácidos, básicos e neutros em um amplo intervalo de pH (HILTON \& THOMAS, 2003; BARREK, et al., 2009). Os cartuchos com estas características são constituídos de uma combinação de polímeros lipofílico e hidrofílico (GROS, et al., 2006). 
No presente estudo foi desenvolvida e validada uma metodologia utilizando a SPE-LC-MS/MS para a determinação de 21 (vinte e um) fármacos, 1 (uma) droga de abuso e seu principal metabólito, presentes em amostras de água superficial. Os compostos estudados foram selecionados de acordo com o consumo e venda divulgada pelo IMS Health, empresa multinacional, que fornece informações de venda e serviços de consultoria para as indústrias farmacêuticas, assim como pelos trabalhos divulgados na literatura.

Estudaram-se os fármacos pertencem às classes terapêuticas de antiinflamatório não esteroide, AINE (acetaminofeno, diclofenaco e orfenadrina), $\beta$ bloqueador (atenolol e propranolol), anti-hipertensivo (enalapril, losartana e valsartana), antidepressivo (citalopram e paroxetina), ansiolítico (bromazepam e midazolam), antiplaquetário (clopidogrel), diurético (clortalidona), anticolesterêmico (rosuvastatina), anticonvulsivante (carbamazepina e clonazepam), anti-histamínico (loratadina), estimulante (cafeína), droga de abuso/metabólito (cocaína/benzoilecgonina), estimulante sexual (sildenafila) e anticoncepcional (ciproterona).

Demonstrou-se a confiabilidade dos dados por meio de indicadores de validação como a seletividade, efeito matriz, faixa de trabalho, precisão, exatidão, limite de detecção, limite de quantificação, recuperação, robustez e estimar a incerteza envolvida em todo o processo analítico.

A metodologia desenvolvida foi utilizada para verificar a ocorrência e a distribuição dos 23 (vinte e três) compostos nas águas da represa Guarapiranga, considerada a segunda maior represa destinada ao abastecimento público da Região Metropolitana de São Paulo (RMSP). Como também, na avaliação da distribuição dos 23 (vinte e três) compostos nas águas de represas do Estado de São Paulo, especificamente pertencentes à Unidade de Gerenciamento de Recursos Hídrico (UGRHI) 5 - Salto Grande, Ribeirão do Pinhal, Cachoeira e Atibainha - e UGRHI 6 - Paiva Castro, Cabuçu e Tanque Grande. 


\section{OBJETIVOS E RELEVÂNCIA DO TRABALHO}

\subsection{Objetivo}

O objetivo principal deste trabalho foi desenvolver e validar a metodologia de extração em fase sólida seguida da cromatografia líquida e espectrometria de massas em sequência (SPE-LC-MS/MS) para avaliar a ocorrência e a distribuição de 21(vinte e um) fármacos, 1 (uma) droga de abuso e seu principal metabólito, nas águas da represa Guarapiranga, São Paulo, SP, Brasil.

\subsection{Objetivos específicos}

Desenvolver e otimizar o procedimento de extração em fase sólido (SPE) para extrair, concentrar e purificar 23 (vinte e três) compostos pertencentes a diferentes classe terapêuticas:

- anti-inflamatório não esteroide, AINE (acetaminofeno, diclofenaco e orfenadrina),

- $\quad \beta$-bloqueador (atenolol e propranolol)

- anti-hipertensivo (enalapril, losartana e valsartana),

- antidepressivo (citalopram e paroxetina),

- $\quad$ ansiolítico (bromazepam e midazolam),

- antiplaquetário (clopidogrel),

- diurético (clortalidona),

- anticolesterêmico (rosuvastatina),

- anticonvulsivante (carbamazepina e clonazepam),

- anti-histamínico (loratadina),

- estimulante (cafeína),

- droga de abuso/metabólito (cocaína/benzoilecgonina),

- estimulante sexual (sildenafila) e

- anticoncepcional (ciproterona). 
Desenvolver e otimizar o método analítico de cromatografia líquida com a espectrometria de massas em sequência para análise simultânea dos 23 compostos acima citados;

Demonstrar a confiabilidade dos resultados obtidos aplicando os indicadores de validação como a seletividade, efeito matriz, faixa de trabalho, limite de detecção, limite de quantificação, precisão, exatidão, recuperação, robustez e incerteza combinada e expandida;

Aplicar a metodologia desenvolvida e validada para quantificar os compostos, acima citados, para avaliar a sua distribuição nas amostras de águas provenientes da represa Guarapiranga;

Avaliar o risco à exposição integrada de mistura de poluentes orgânicos detectados nas águas da represa Guarapiranga;

Avaliar a ocorrência dos 23 (vinte e três) compostos nas águas das represas do Estado de São Paulo, pertencentes à UGHI 5 e 6: Cachoeira, Atibainha, Paiva Castro, Salto Grande, Ribeirão do Pinhal, Cabuçu e Tanque Grande;

\subsection{Relevância do trabalho}

Um dos desafios do século XXI é a manutenção da qualidade da água doce destinada ao abastecimento público. A atual crise hídrica agravada pelas mudanças climáticas e a falta de chuva, é um somatório resultante da diminuição da oferta em função do aumento demográfico exponencial, dos usos múltiplos, da perda de seus mecanismos de retenção, bem como da degradação crescente dos ambientes aquáticos.

Na Região Metropolitana de São Paulo (RMSP), a maior cidade da América do Sul, com aproximadamente 20 milhões de habitantes (IBGE, 2010), a disponibilidade hídrica é de $200 \mathrm{~m}$ /habitante/ano (SABESP), valor este considerado aproximadamente sete vezes menor que o valor crítico estabelecido pela Organização das Nações Unidas (ONU) (1500 m³/habitante/ano). Além da baixa disponibilidade natural, as águas dos mananciais utilizadas como água de 
abastecimento estão sendo poluídas pelo descarte direto de esgoto doméstico e industrial, resultante do uso e ocupação irregular do entorno do manancial.

A represa Guarapiranga é considerada o segundo mais importante manancial da RMSP e responsável pelo fornecimento de $14 \mathrm{mil}$ litros/segundos de água, para abastecer aproximadamente 4 milhões de habitantes (RICHTER, et al., 2007). Com a atual crise hídrica (2014 e 2015), a represa Guarapiranga passou a ser o principal manancial da RMSP passando a produzir 15 mil litros/segundos e abastecer mais 1,3 milhões de pessoas dos bairros das zonas Oeste e Sul da capital: Aclimação, Alto de Pinheiros, Brooklin, Itaim-Bibi, Saúde e Vila Mariana, para impedir o colapso do Sistema Cantareira, antes considerado o principal sistema produtora de água potável da RMSP (VEJA/SP, 2014). As águas das 7 (sete) represas da UGRHI 5 e 6 são também destinadas para produção de água potável e abastecimento da população de cidades próximas.

O levantamento de dados ambientais sobre o comportamento e distribuição de fármacos em reservatórios pertencentes ao segundo mais importante reservatório de abastecimento urbano da RMSP e, aos outros 7 reservatórios da UGRHI 5 e 6 é inédito.

O estudo é de grande importância para o diagnóstico ambiental de reservatórios e para o fornecimento de dados básicos visando à revisão das normas sobre a qualidade de recursos hídricos. Assim, pretende-se contribuir na formação de banco de dados de contaminantes emergente orgânicos presentes em águas de reservatórios, uma vez que essas informações são escassas na literatura.

A metodologia analítica de SPE-LC-MS/MS desenvolvida é altamente seletiva, específica, versátil e indicada para análise qualitativa e quantitativa de compostos orgânicos, presentes na faixa de concentração de ng L-1 a $\mu \mathrm{g} \mathrm{L}^{-1}$, em amostras ambientais complexas. 
Adicionalmente, o estudo pretende contribuir ao projeto temático "Reconstrução paleolimnológica da Represa Guarapiranga e diagnóstico da qualidade atual da água e dos sedimentos de mananciais da RMSP com vistas ao gerenciamento do abastecimento", FAPESP 2009/53898-9, sob a coordenação geral do Prof. Dr. Carlos Eduardo de Mattos Bicudo do Instituto de Botânica com participação do Instituto de Pesquisas Energéticas e Nucleares (IPEN-CNEN/SP) sob a coordenação da Profa. Dra. Maria Aparecida Faustino Pires. O projeto visa reconstituir o histórico de eutrofização e impactos antropogênicos da represa, identificando os principais fatores desencadeadores do cenário atual, o qual conta com apoio da Sabesp no que se refere à logística de campo e fornecimento de dados secundários. 


\section{3 ÁREA DE ESTUDO}

\subsection{Represa Guarapiranga}

A represa Guarapiranga localiza-se na porção sudoeste da RMSP, nas coordenadas $23^{\circ} 43^{\prime} 15.8^{\prime \prime} S$ e $46^{\circ} 43^{\prime} 59.8^{\prime \prime} \mathrm{W}$ e na UGRHI 6. Ela está totalmente inserida no Estado de São Paulo tendo em seu entorno, parte dos municípios de São Paulo e Embu, a quase totalidade do território de Itapecerica da Serra e Embu-Guaçu, além de porções relativamente pouco extensas e habitadas dos municípios de Juquitiba, São Lourenço da Serra e Cotia (FIG. 1).

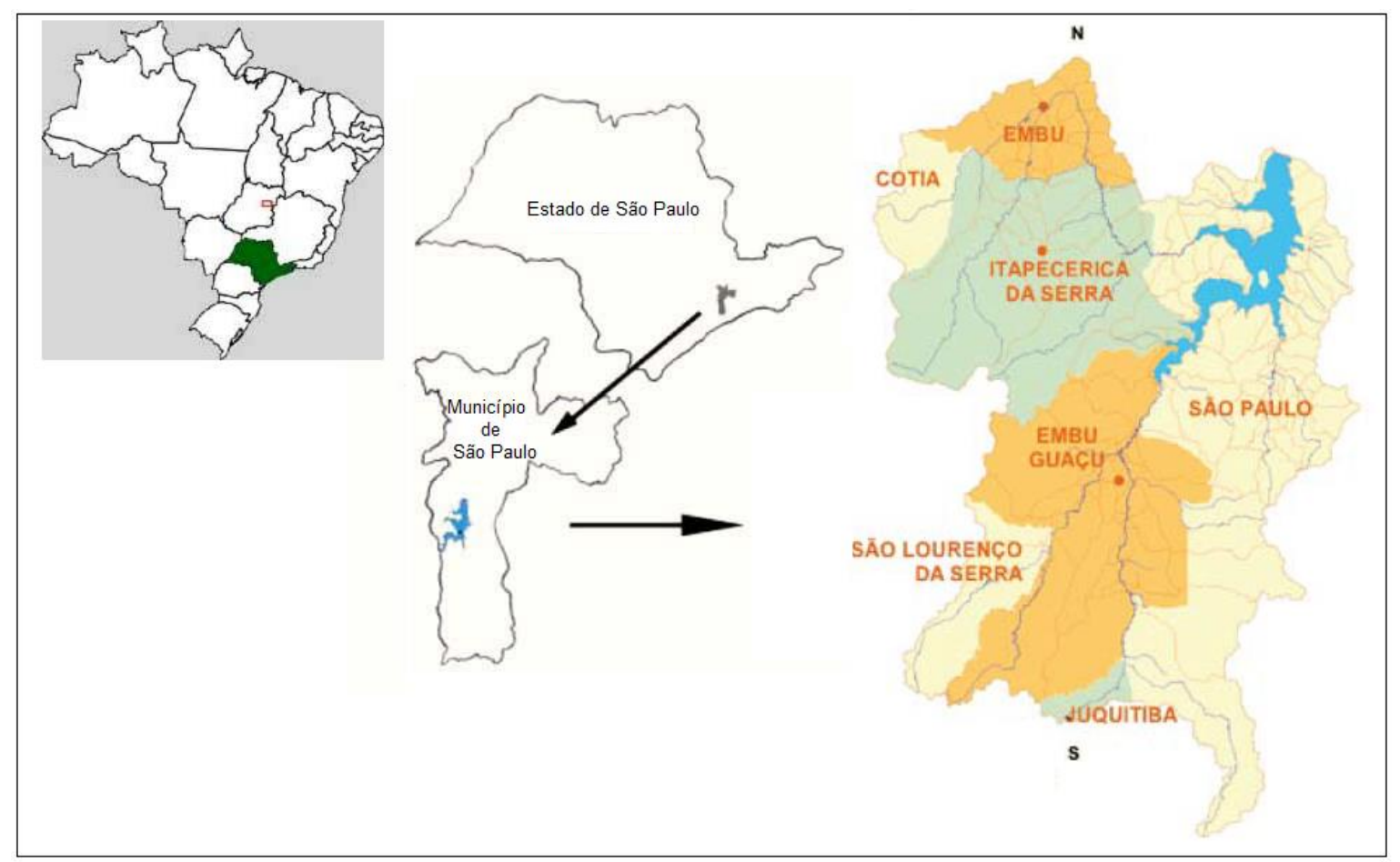

FIGURA 1. Localização da Represa Guarapiranga, com os municípios em seu entorno, na Região Metropolitana de São Paulo (adaptação de SÃO PAULO (2008)).

A participação dos municípios, em números, na Bacia Hidrográfica do Guarapiranga é apresentada na TAB. 1, e a representação gráfica dessa participação na FIG. 2. 
TABELA 1. Dados dos municípios integrantes da Bacia Hidrográfica do Guarapiranga (SÃO PAULO, 2008).

\begin{tabular}{lcccc}
\hline \multicolumn{1}{c}{ Município } & \multicolumn{2}{c}{ Área Total Área na Bacia } & $\begin{array}{c}\text { \% da área do município } \\
\text { na bacia em relação } \\
\left(\mathrm{km}^{2}\right)\end{array}$ & $\begin{array}{c}\text { \% da área do município } \\
\text { na bacia em relação }\end{array}$ \\
\hline São Paulo & $1.522,99$ & 233,02 & 15,3 & 36,5 \\
São Lourenço & 186,71 & 33,07 & 17,7 & 5,2 \\
Juquitiba & 521,6 & 7,81 & 1,5 & 1,2 \\
Itapecerica da Serra & 151,8 & 145,88 & 96,1 & 22,8 \\
Embu-Gauçu & 155,4 & 155,04 & 99,8 & 24,3 \\
Embu & 70,8 & 40,71 & 57,5 & 6,4 \\
Cotia & 325,9 & 22,28 & 6,8 & 3,5 \\
\hline
\end{tabular}

(1) Área total da Bacia da Guarapiranga $=639 \mathrm{~km}^{2}$.

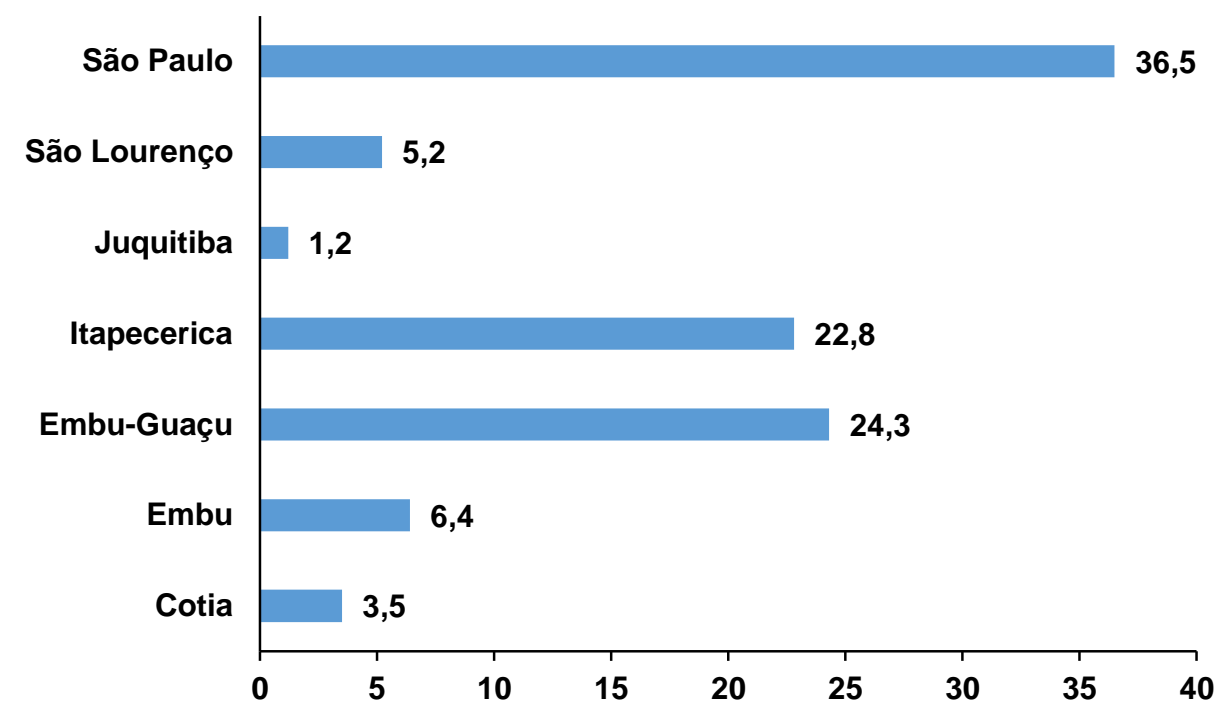

FIGURA 2. Participação (\%) dos municípios na área da Bacia da Guarapiranga. (SÃO Paulo, 2008).

A represa Guarapiranga apresenta área de drenagem de $639 \mathrm{~km}^{2}$, perímetro de $85 \mathrm{~km}$, área de $34 \mathrm{~km}^{2}$, tempo de retenção da água de 185 dias, profundidades média e máxima de 5,7 m e 13,0 m, respectivamente, (BEYRUTH, 2000; CARVALHO, 2003; ANDRADE, 2005) e volume total de $194 \times 10^{6} \mathrm{~m}^{3}$ (MOZETO, et al., 2001).

Os principais tributários, que alimentam o reservatório são os rios Parelheiros, localizado na margem direita, Embu-Guaçu e Embu-Mirim, na margem esquerda (FIG. 3). Alguns ribeirões e córregos que convergem para a 
represa também se destacam como, por exemplo, Rio Bonito, Rio das Pedras, córregos São José e Tanquinho, na margem direita, e rios Guavirutuba, Itupú e Córrego Mombaça, na margem esquerda (MATEUS, 2006). Além disso, conta com a transposição de água do rio Capivari para o rio Embu-Guaçu e a reversão das águas do braço Taquacetuba, da Represa Billings, para o rio Parelheiros.

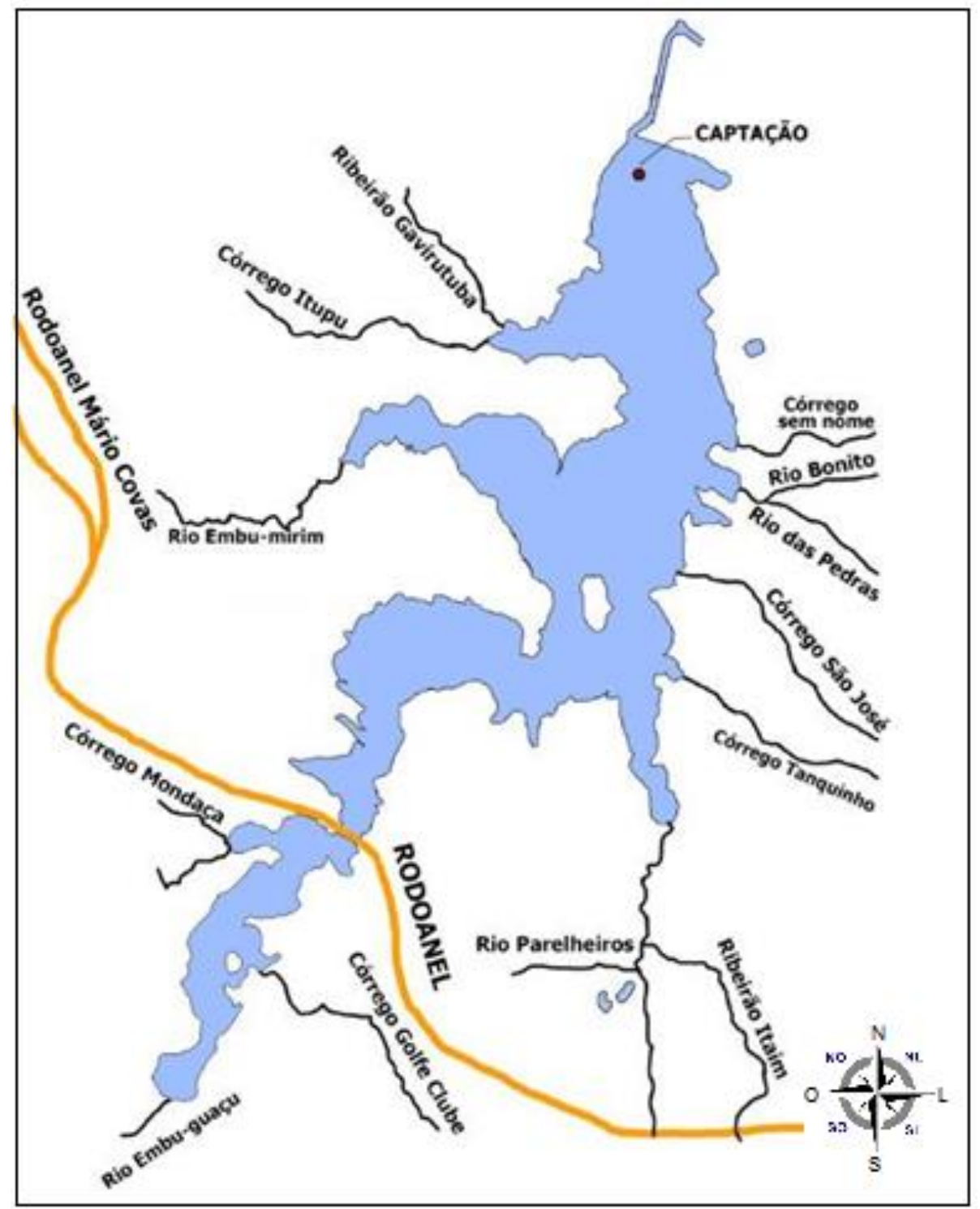

FIGURA 3. Represa Guarapiranga e seus tributários.

A represa foi construída no início do século XX, entre 1906 a 1909, pela empresa canadense "The São Paulo Tramway, Light \& Power Co", visando atender à crescente demanda energética do Estado de São Paulo. A água da represa era enviada para o rio Pinheiros com o objetivo de regularizar a vazão do 
rio Tietê, durante os períodos de estiagem, para movimentar as turbinas da Usina de Santana de Parnaíba, atual Usina Edgard de Souza (PMSP, 2000). Este processo perdurou de 1909 a 1928.

A partir de 1929, a represa tornou-se a principal fonte de água para abastecimento público da cidade de São Paulo, com fornecimento de 86,4 milhões de litro de água por dia (vazão média de $1 \mathrm{~m}^{3} \mathrm{~s}^{-1}$ ) para a Estação de Tratamento de Água Theodoro Augusto Ramos (MATEUS, 2006).

Em 1958, com a construção da Estação de Tratamento de água do Alto de Boa Vista (ETA - ABV), a represa teve a sua capacidade ampliada para $9,5 \mathrm{~m}^{3} \mathrm{~s}^{-1}$. Para esta finalidade foram construídas duas transposições de água de outras bacias, gerenciadas pela Companhia de Saneamento Básico do Estado de São Paulo (SABESP), para os tributários que alimentam a represa Guarapiranga. A primeira e mais antiga, é a reversão do Rio Capivari para o Rio Embu-Guaçu (cerca de $1.000 \mathrm{~L} \mathrm{~s}^{-1}$ ). A segunda, em funcionamento desde 2000, consiste na reversão das águas do braço Taquacetuba, da Represa Billings, para o Rio

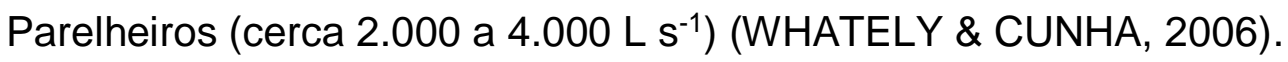

Em 1998, a ETA Theodoro Augusto Ramos foi desativada e a ETAABV ficou responsável pela captação das águas da represa Guarapiranga, pelos processos de tratamento da água bruta, assim como, pelo fornecimento de água tratada aos reservatórios de distribuição. São contempladas cerca de 4 (quatro) milhões de pessoas, ou seja, 20\% da população da RMSP, sendo 95\% dos moradores das regiões de Santo Amaro, Morumbi, Pinheiros, Butantã e $5 \%$ da região de Taboão da Serra (WHATELY \& CUNHA, 2006; MATEUS, 2006; MATSUZAKI, 2007).

No entanto, a partir de fevereiro de 2014 a represa Guarapiranga passou a ser responsável pelo abastecimento de 4 para 4,9 milhões de moradores nas zonas sul e sudeste da capital paulista, antes atendida pelo maior sistema de abastecimento de água da RMSP, o Cantareira. O aumento do número de pessoas atendidas pela represa Guarapiranga foi devido às baixas 
sucessivas do nível de água do sistema Cantareira provocada pela grande estiagem nos meses do verão de 2013/2014, na região sudeste do Brasil (LEITE, 2014). A continuidade da crise hídrica até os últimos meses de 2014 tornou necessário que a represa Guarapiranga fosse responsável pelo abastecimento de 4,9 para 5,3 milhões de pessoas (VEJA/SP, 2014).

\subsubsection{Ocupação do entorno da Represa Guarapiranga}

A ocupação do entorno da represa Guarapiranga teve início na década de 20, com formação de chácaras, residências, marinas, clubes e instalações religiosas devido às belas paisagens favorecendo atividades de laser.

A partir da década de 40, o crescimento populacional da cidade de São Paulo fez com que a população, sem condições econômicas para habitar áreas nobres e centrais, buscasse habitações com preços mais acessíveis encontradas somente em locais mais distantes. Como consequência, na década de 70, em regiões definidas como áreas de proteção ambiental, a desordem se instalou com formação de núcleos urbanos precários caracterizados por lotes menores, densidades populacionais maiores e sem infraestrutura.

A Lei de Proteção aos Mananciais (Lei $\left.n^{\circ} 1.172 / 1976\right)$ foi criada para controlar os assentamentos irregulares e, juntamente com outras normas jurídicas, disciplinar o uso e a ocupação do solo. Entretanto, ela não foi suficiente para conter a degradação dos mananciais da RMSP, sendo que no período de 1980 e 1991, a população residente na Bacia da Guarapiranga teve um aumento de $65 \%$.

No início de 2006, foi aprovada a Lei Específica da Área de Proteção e Recuperação da Guarapiranga, lei n 12.233/2006 (APRM-G), definindo a área na Bacia Hidrográfica do Guarapiranga a ser protegida e recuperada. Com a nova lei, a Guarapiranga ficou situada na Unidade de Gerenciamento de Recursos Hídricos (UGRHI) do Alto Tietê, com gestão descentralizada, integrada e de responsabilidade compartilhada entre estado, municípios e sociedade civil (WHATELY \& CUNHA, 2006). No entanto, nenhuma mudança esperada no 
quadro de ocupação destas áreas e o desejado isolamento dos corpos d'água foram observados, uma vez que continuaram sendo os locais preferidos para os assentamentos.

Em 2000, a população residente por município na Bacia Guarapiranga era de 754.443 habitantes, das quais $67,5 \%$ referem-se à população do município de São Paulo presente com 3 (três) subprefeituras - Capela do Socorro, M'Boi Mirim e Parelheiros (TAB. 2). Em 2007, esta população foi estimada em aproximadamente 800.000 pessoas, demonstrando o aumento da população nas vizinhanças da represa, que está ocorrendo principalmente como loteamento irregular com infraestrutura de saneamento precário (SÃO PAULO, 2008).

TABELA 2. População por município residente na Bacia da Guarapiranga, em 2000 (SÃO PAULO, 2008).

\begin{tabular}{lcc}
\hline Municípios/Subprefeituras & Habitantes & $\%$ \\
\hline Cotia & 1.915 & 0,2 \\
Embu & 58.595 & 7,6 \\
Embu-Guaçu & 56.916 & 7,4 \\
Itapecerica da Serra & 129.685 & 16,9 \\
Juquitiba & 1.439 & 0,2 \\
São Lourenço da Serra & 472 & 0,1 \\
São Paulo & 517.788 & 67,5 \\
Capela do Socorro & 232.945 & 30,4 \\
M'Boi Mirim & 208.650 & 27,2 \\
Parelheiros & 76.193 & 9,9 \\
\hline Total na Bacia & $\mathbf{7 6 6 . 8 1 0}$ & $\mathbf{1 0 0 , 0}$ \\
\hline
\end{tabular}

Atualmente, a represa Guarapiranga encontra-se ocupada no seu entorno por uma diversidade de tipos e usos. Na FIG. 4 podem-se observar áreas mais preservadas (A) e área de ocupação urbana (B). O uso antrópico inclui atividades agrícolas, industrial, mineração, reflorestamento, solo exposto e lazer, enquanto $\mathrm{O}$ uso urbano compreende áreas com ocupação urbana de média a alta densidade, ocupação dispersa e condomínios (WHATELY \& CUNHA, 2006). 


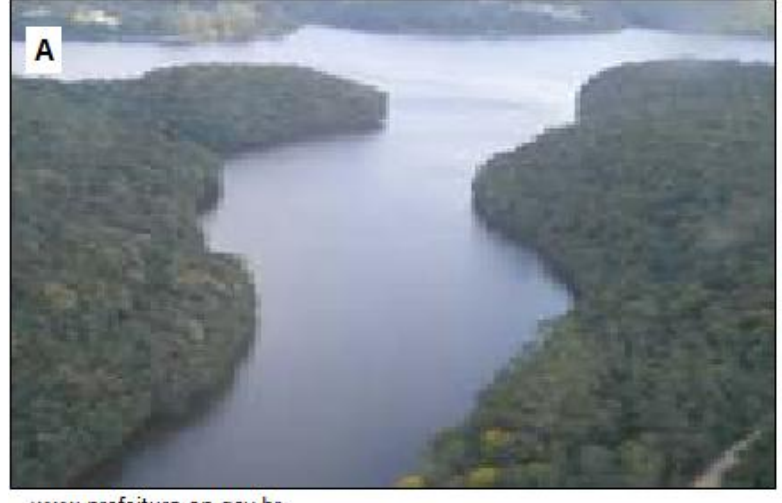

www. prefeitura.sp.gov.br

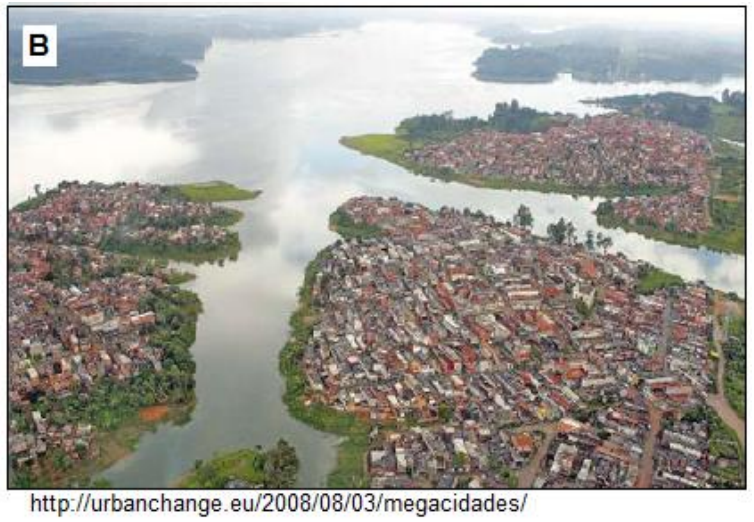

FIGURA 4. Represa Guarapiranga com áreas mais preservadas $(A)$ e com alta densidade urbana $(B)$.

\subsubsection{Saneamento básico na Bacia da Guarapiranga}

A urbanização da área de mananciais aliada à ausência de infraestrutura adequada de coleta e tratamento de esgotos e efluentes urbanos tem provocado grande impacto ambiental na qualidade da água da Guarapiranga usada para abastecimento público. SILVA (2008) estima que o efluente de origem doméstico corresponda a cerca de $80 \%$ da poluição transportada para 0 reservatório, sem considerar as deficiências nos sistemas de drenagem, cuja consequência é a erosão e o carreamento de sedimentos e resíduos sólidos que causam o assoreamento dos córregos contribuintes e consequentemente da própria represa.

O diagnóstico do esgotamento sanitário de 2.925 municípios, que correspondem a 86,6\% da população urbana do país (SNSA, 2013), demonstra que, do esgoto gerado pelos municípios do entorno da represa Guarapiranga (TAB. 3) em média $29,6 \%$ é atendido pela rede pública, sendo o menor índice para Itapecerica da Serra (8,9\%) e o maior para São Paulo (50,3\%). Para EmbuGuaçu, Juquitiba e São Lourenço da Serra todo o esgoto coletado é tratado, enquanto nos demais municípios são tratados em média $56,1 \%$ do esgoto coletado. As informações do diagnóstico revelaram também que mais da metade do esgoto gerado é despejado diretamente na represa e aproximadamente a metade do esgoto coletado pela rede pública e encaminhado para as Estações de Tratamento de Esgoto (ETEs) não é tratado, sendo apenas afastado e lançado in natura em corpos d'agua. 
TABELA 3. Índice de tratamento de esgotos dos municípios na Bacia Hidrográfica da Guarapiranga (SNSA, 2013).

\begin{tabular}{lcc}
\hline \multirow{2}{*}{ MUNICíPIO } & \multicolumn{2}{c}{ Indice de Tratamento de } \\
& \multicolumn{2}{c}{ Esgoto } \\
\cline { 2 - 3 } & $\begin{array}{c}\text { Esgoto } \\
\text { Coletado }\end{array}$ & $\begin{array}{c}\text { Esgoto } \\
\text { Gerado }\end{array}$ \\
\cline { 2 - 3 } & $\%$ & $\%$ \\
\hline Cotia & 43,0 & 13,1 \\
Embu & 55,0 & 28,7 \\
Embu-Guaçu & 100,0 & 37,1 \\
Itapecerica da serra & 57,0 & 8,9 \\
Juquitiba & 100,0 & 22,5 \\
São Lourenço da serra & 100,0 & 46,7 \\
São Paulo & 69,4 & 50,3 \\
\hline
\end{tabular}

A deficiência de rede de coleta, afastamento e tratamento de esgoto na região do entorno da represa Guarapiranga constituem na principal causa da degradação e diminuição da qualidade da água de um dos principais produtores de água potável de boa parte da população da RMSP (WHATELY \& CUNHA, 2006).

\subsection{Represas das UGRHI 5 e 6 do Estado de São Paulo}

Este trabalho apresenta também uma avaliação, quanto à presença dos 23 poluentes, das águas das represas Cabuçu, Tanque Grande, Paiva Castro, Cachoeira, Atibainha, Salto Grande e Ribeirão do Pinhal. A TAB. 4 apresenta a UGRHI (Unidade de Gerenciamento de Recursos Hídricos), a região e o município onde estão inseridas essas represas. 
TABELA 4. Localização das represas Cabuçu, Tanque Grande, Paiva Castro, Cachoeira, Atibainha, Salto Grande e Ribeirão do Pinhal.

\begin{tabular}{cccc}
\hline UGRHI & Represa & Região na RMSP & Município \\
\hline 5 & Cachoeira & Norte & Piracaia \\
$\begin{array}{c}\text { (Piracicaba, } \\
\text { Capivari e } \\
\text { Jundiai) }\end{array}$ & Atibainha & Norte & Nazaré Paulista \\
& Salto Grande & Norte & Americana \\
& Ribeirão do Pinhal & Norte & Limeira \\
6 & Cabuçu & Norte & Guarulhos \\
(Alto Tietê) & Tanque Grande & Norte & Guarulhos \\
& Paiva Castro & Norte & Mairiporã e Juqueri \\
\hline
\end{tabular}

A FIG. 5 mostra o mapa do Estado de São Paulo com as 22 UGRHI com destaque para as UGRHI 5 e 6 , onde se encontram as represas estudadas.

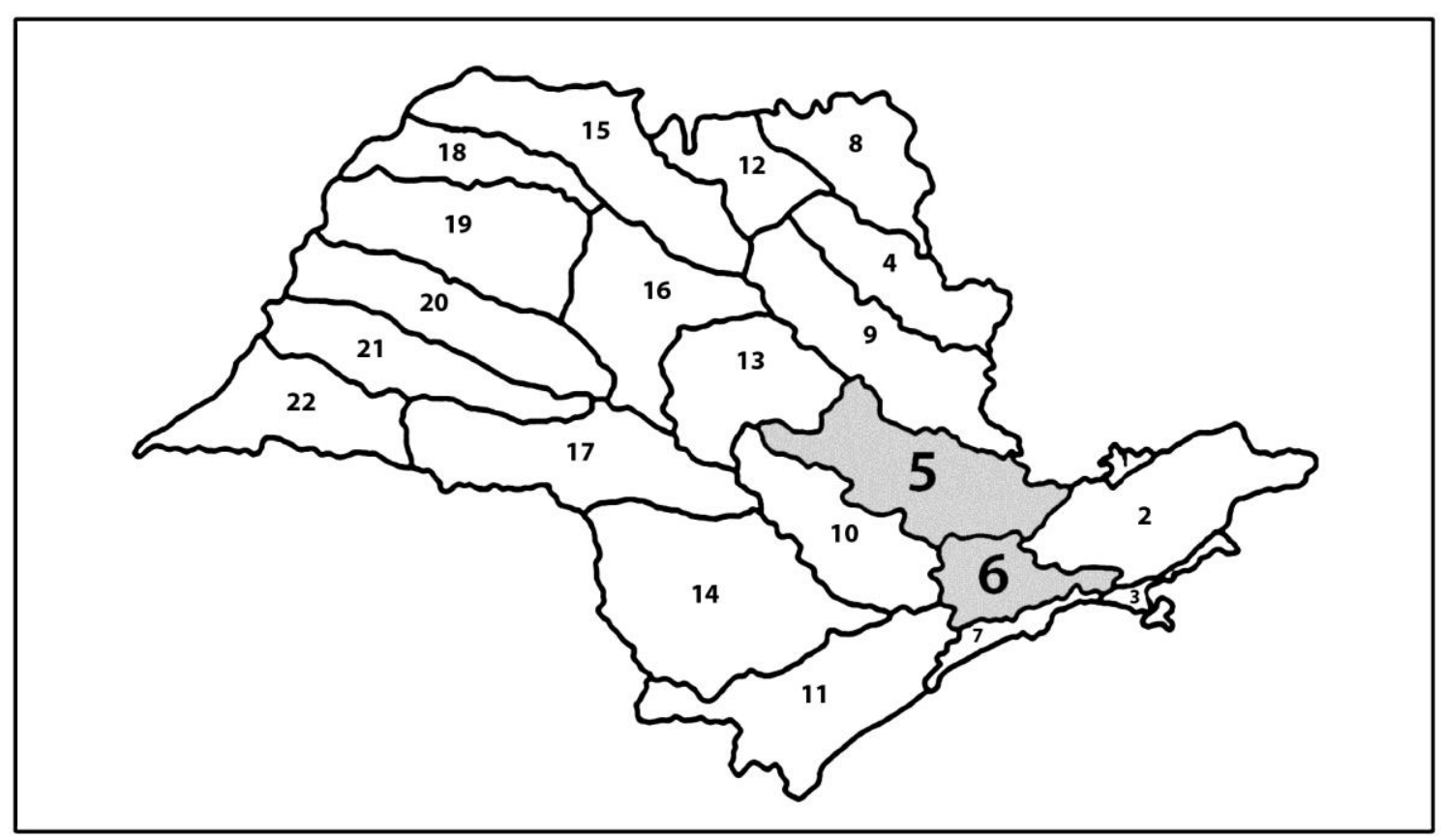

FIGURA 5. Mapa do Estado de São Paulo com as 22 UGRHI com destaque para as 5 e 6 , onde se encontram as represas estudadas (MATSUMURA-TUNDISI \& TUNDISI, 2011).

A localização das represas Cachoeira (Rio Cachoeira), Atibainha (Rio Atibainha), Salto Grande (Rio Atibaia) e Ribeirão do Pinhal na UGRHI 5 é 
mostrada na FIG. 6, enquanto que a localização das represas Paiva Castro, Cabuçu e Tanque Grande na UGRHI 6 é mostrada na FIG. 7.

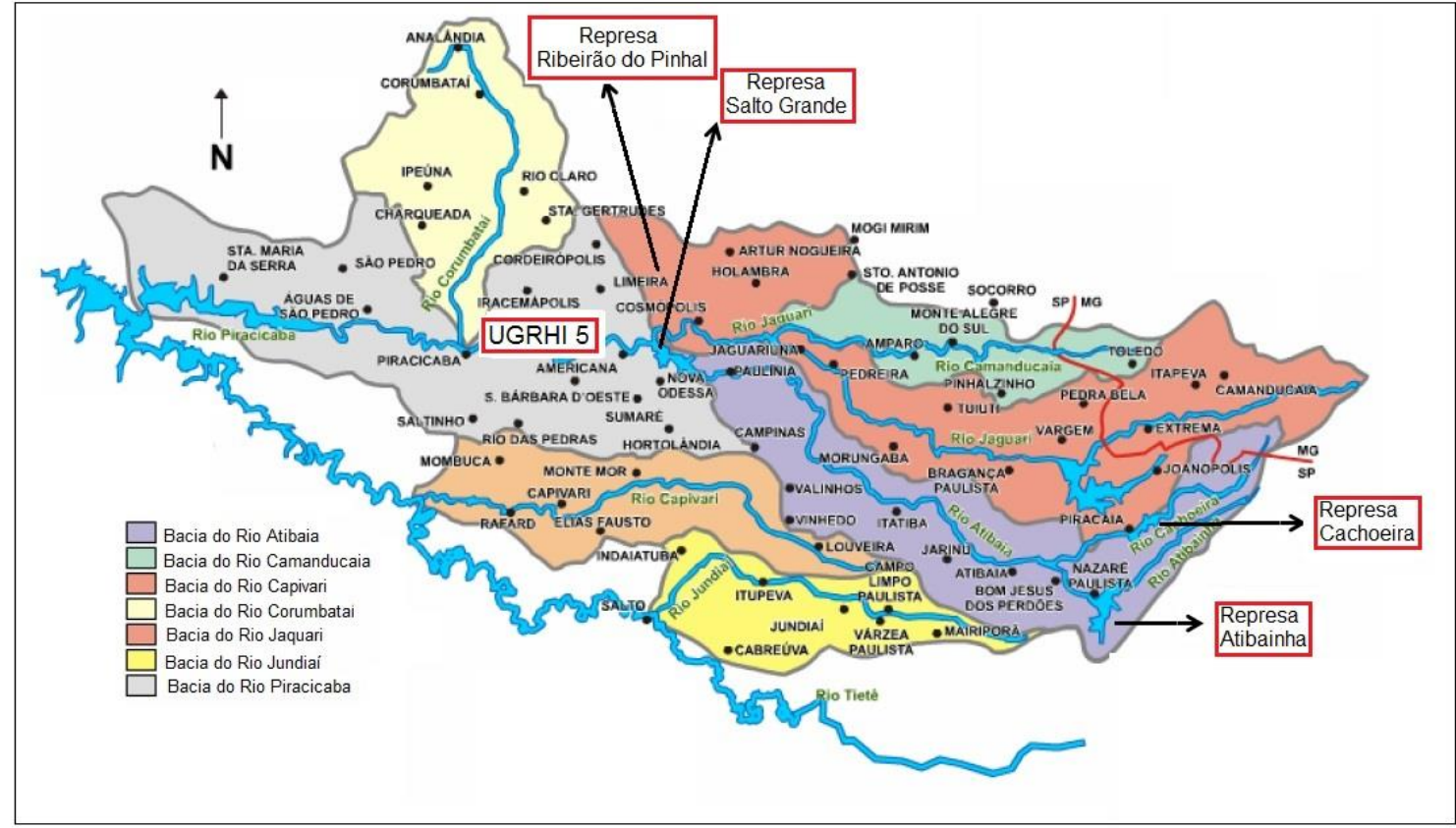

FIGURA 6. Localização das Represas Ribeirão do Pinhal, Salto Grande, Atibainha e Cachoeira na UGRHI 5. Adaptação de SILVA et al. (2007).

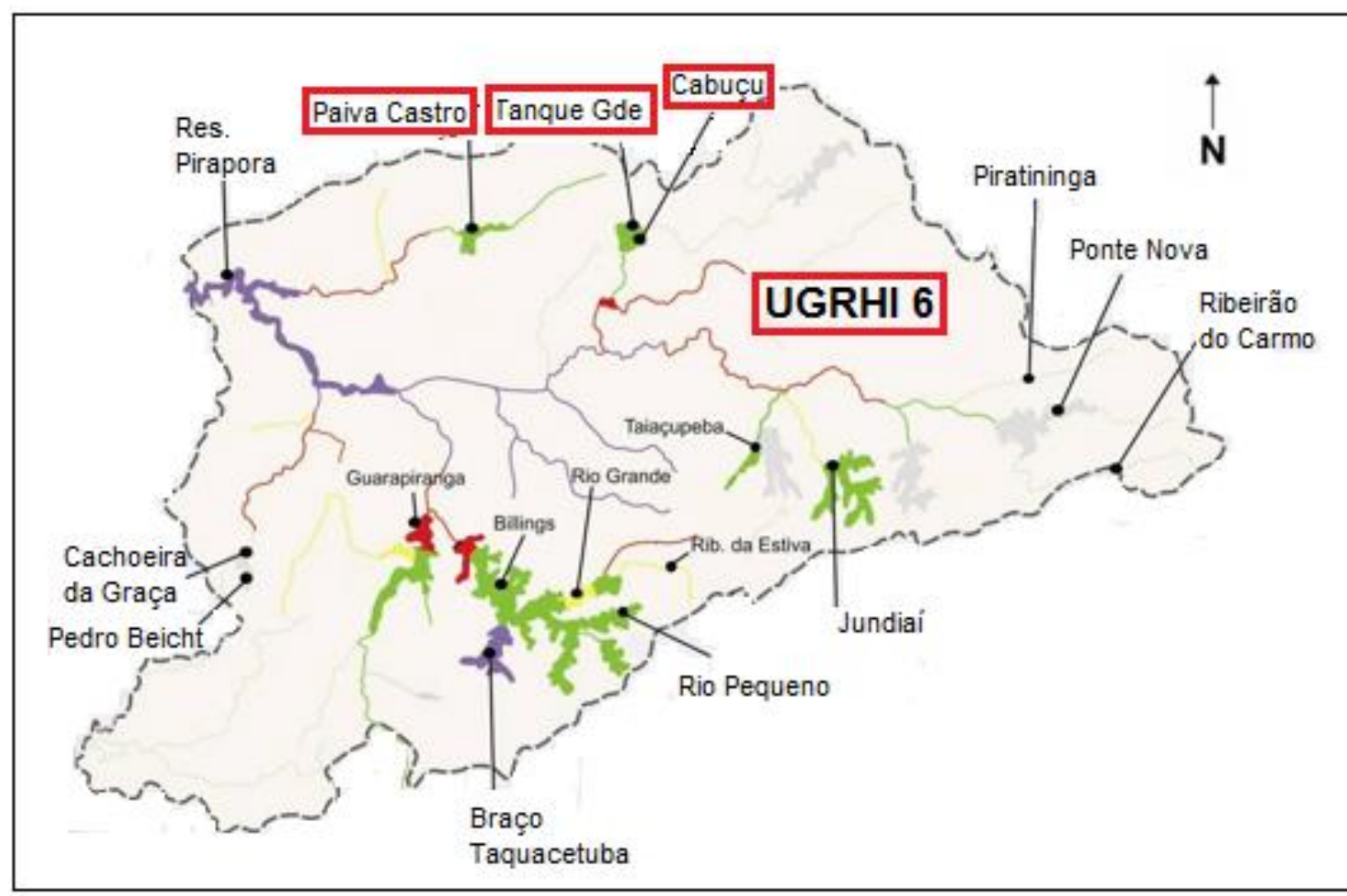

FIGURA 7. Localização da Represa Paiva Castro, Tanque Grande e Cabuçu na UGRHI 6. Adaptação da CETESB (2007) 
As represas: Cachoeira, Atibainha e Paiva Castro fazem parte do Sistema Produtor Cantareira, o principal sistema de abastecimento da população da RMSP (FIG. 8).

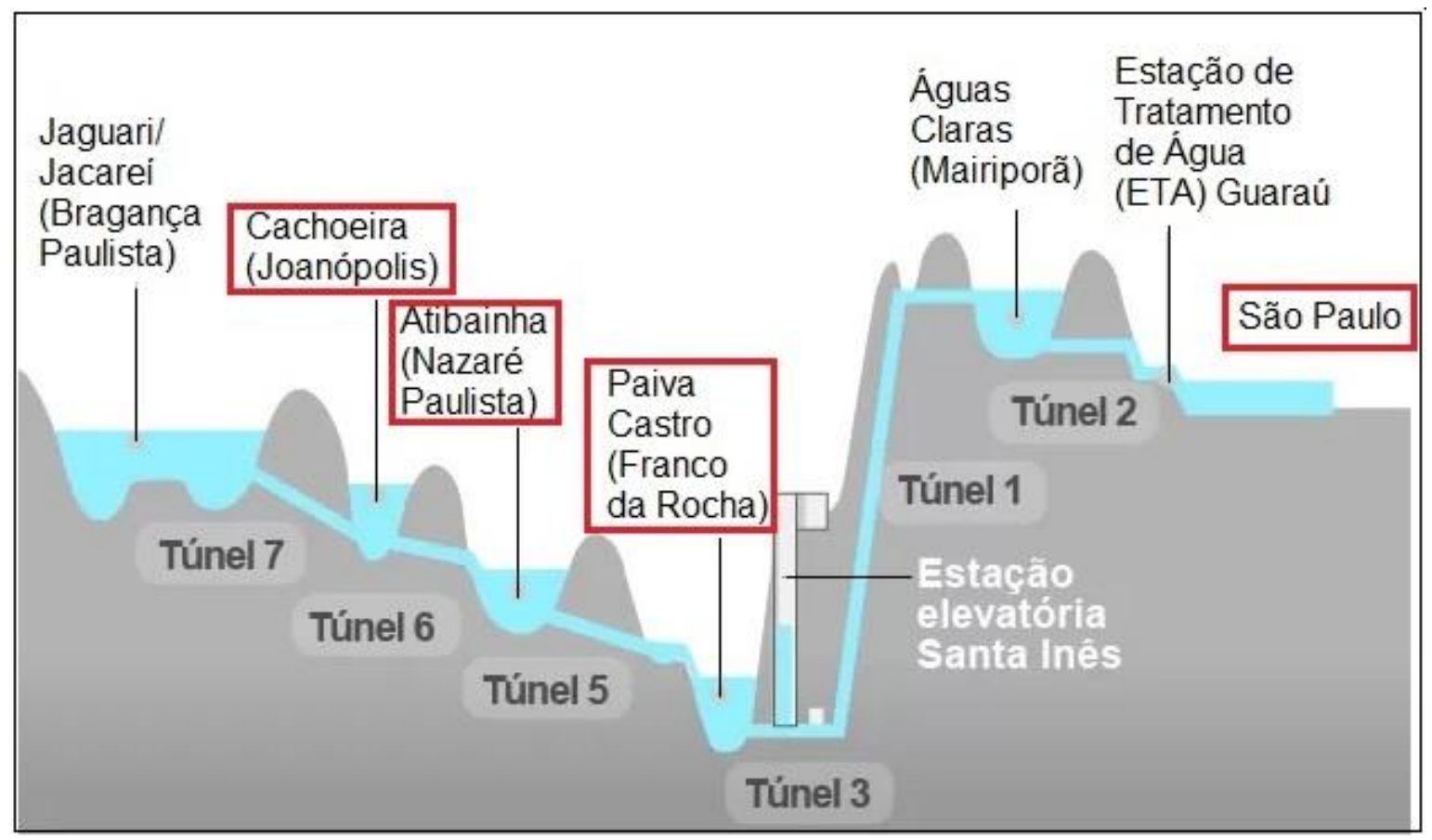

http://g1.globo.com/sao-paulo/noticia/2015/01/represa-cheia-no-cantareira-leva-boato-sobre-atual-nivel-do-sistema.html FIGURA 8. Represas do Sistema Cantareira.

A represa Cachoeira entrou em operação em novembro de 1974 e contribui com 5 mil L/s para o sistema Cantareira. Ela está localizada no município de Piracaia, que possui uma área total de 39.174,3 hectares, onde 26.876,7 hectares $(68,6 \%)$ estão inseridos no sistema Cantareira, o qual corresponde a 11,8\% do sistema (WHATELY \& CUNHA, 2007). A represa Atibainha entrou em operação em fevereiro de 1975 e contribui com 4 mil L/s para o sistema Cantareira. Ela está localizada no município de Nazaré Paulista, que possui uma área total de $32.243,3$ hectares, onde $25.281,0$ hectares $(78,4 \%)$ estão inseridos no sistema Cantareira, o qual corresponde a $11,1 \%$ do sistema (WHATELY \& CUNHA, 2007). A represa Paiva Castro entrou em operação em maio de 1973. Situado no município de Mairiporã, o reservatório do Rio Juquery, chamado de Paiva Castro, contribui com 2 mil L/s. O município de Mairiporã possui uma área total de $32.032,6$ hectares, onde $25.854,7$ hectares $(80,7 \%)$ estão inseridos no 
sistema Cantareira, o qual corresponde a $11,3 \%$ do sistema (WHATELY \& CUNHA, 2007).

A represa Ribeirão do Pinhal juntamente com o rio Jaguari faz parte do sistema de abastecimento do município de Limeira, SP, para atender aproximadamente 260.000 pessoas (LIMEIRA, 2015).

As represas Cabuçu e Tanque Grande são importantes mananciais para o abastecimento o município de Guarulhos, que vem sofrendo significativa pressão da expansão imobiliária e do desenvolvimento das atividades econômicas rurais (ANDRADE, 2009).

A represa Salto Grande, localizado no município de Americana, SP, foi formada, nos anos entre 1940 e 1949, com o represamento das águas do rio Atibaia para instalação de uma usina hidrelétrica. Além da geração de energia elétrica, a água do reservatório é utilizada para irrigação, piscicultura e a recreação, sendo que durante as décadas de 70 e 80 o reservatório foi considerado um polo turístico para a população local e de outras regiões. 


\section{REVISÃO BIBLIOGRÁFICA}

\subsection{Fármacos}

Fármacos são substâncias normalmente de baixo peso molecular com estrutura química definida e dotada de propriedades farmacológicas, que utilizadas como princípios ativos farmacêuticos e convertidas em medicamentos finais são usadas para prevenir, diagnosticar e tratar doenças tanto na medicina humana como na veterinária. Nesse sentido, são desenvolvidas para serem persistentes, isto é, não perder a sua atividade biológica até alcançar o efeito esperado (ALMEIDA \& WEBER, 2005; FENT, et al., 2006). Na FIG. 9 são apresentadas as principais vias de administração e eliminação de fármacos no organismo.

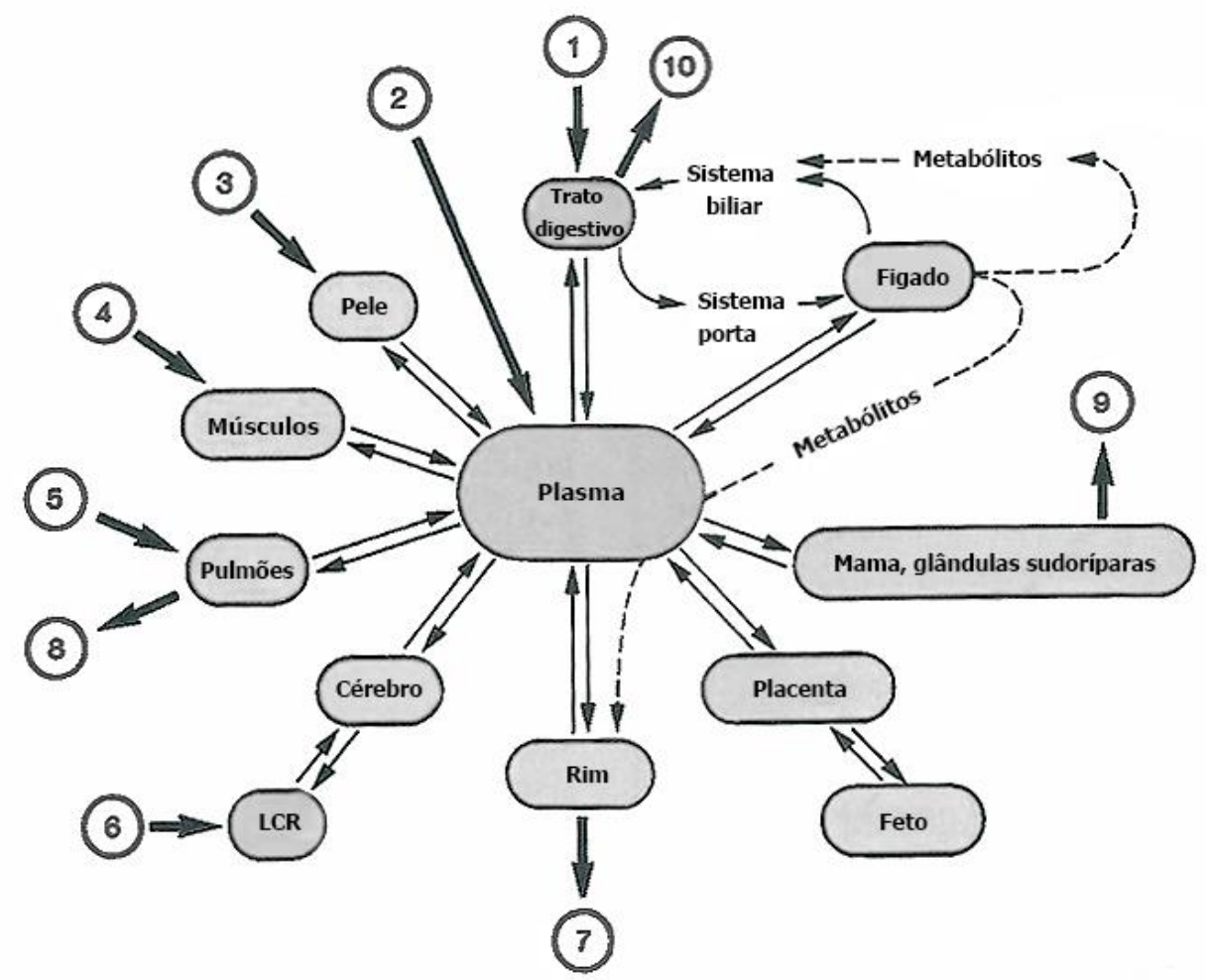

FIGURA 9. As principais vias de administração e eliminação de fármacos (RANG, et al., 1997). Vias de administração: 1=oral ou retal; 2=endovenosa; 3=percutânea; $\quad 4$ =intramuscular; $5=$ =inalação; 6=intratecal. Vias de eliminação: 7=urina; 8=ar expirado; 9=leite e suor; $10=$ fezes. 
Os fármacos, após a administração, são submetidos aos processos de absorção, distribuição, metabolização parcial e excreção (ADME). Assim, os fármacos administrados pela via mais comum, a oral, devem apresentar alguma lipossolubilidade ou solubilidade em lipídeos para atravessar a primeira barreira, as membranas celulares, cuja estrutura química é lipoprotéica, assim como, alguma hidrossolubilidade ou solubilidade em água para ter boa circulação na corrente sanguínea (RANG, et al., 1997). O efeito farmacológico desejado somente é alcançado quando o fármaco sobrevive às enzimas metabólicas, presentes no intestino, corrente sanguínea e principalmente no fígado (FIG. 10).

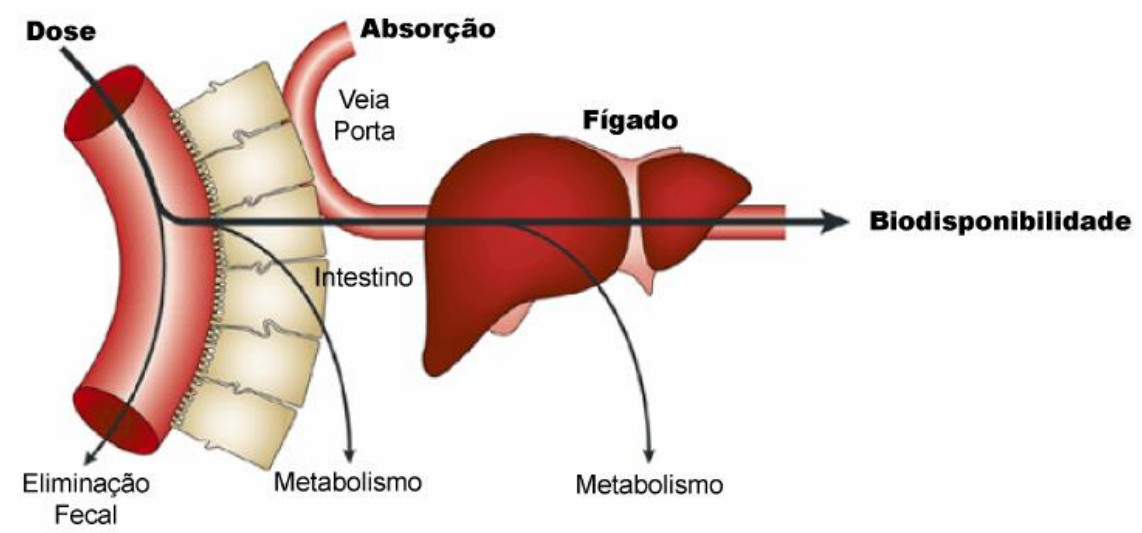

FIGURA 10. Representação dos caminhos percorridos pelos fármacos para se tornar disponível no organismo (MODA, 2007)

Os fármacos e seus metabólitos transformados em compostos mais polares, para facilitar a sua excreção, são eliminados principalmente pelos rins (PATRICK, 2001). Os rins filtram o sangue removendo os resíduos químicos, que posteriormente são eliminados pela urina. Alguns fármacos podem ser desviados da corrente sanguínea através do ducto biliar para o intestino e eliminados nas fezes, viabilizando a presença de uma quantidade significativa de resíduos químicos no esgoto doméstico.

Conforme JJEMBA (2006), os fármacos ao entrar no meio ambiente também são submetidos aos processos de distribuição, absorção, metabolismo (biodegradação) e mobilidade (equivalente à excreção nos organismos vivos). $\mathrm{A}$ 
diferença aparente é que ao serem eliminados do corpo, os fármacos deixam o corpo ao passo que, no meio ambiente, eles se deslocam de um local para outro. Nesse deslocamento, os fármacos podem sofrer interferência de fatores químicos e físicos, no ambiente, tais como a absorção, $\mathrm{pH}$, presença de metais pesados e a permeabilidade do solo. No organismo, a excreção ocorre depois que o fármaco e os metabólitos são submetidos a uma série de membranas com potencial de permeabilidade e retenção variada. Do mesmo modo, o metabolismo de fármacos no organismo resulta na degradação do composto em metabólitos e, no ambiente são os processos químicos e biológicos que podem ocasionar a degradação do fármaco.

Os fármacos podem ser classificados de acordo com os efeitos farmacológicos, o processo bioquímico, o tipo de estrutura ou a molécula alvo onde deve ocorrer a interação (PATRICK, 2001).

As classes terapêuticas dos compostos estudados, neste trabalho, serão descritas a seguir.

Os AINEs são drogas que impedem ou amenizam a inflamação (ação anti-inflamatória), dor (ação analgésica) e febre (ação antipirética) provocada por uma infecção ou lesão dos tecidos. Esses efeitos são alcançados com a inibição de modo reversível ou irreversível em uma ou nas duas isoformas da enzima cicloxigenase (COX-1 e COX-2) e, portanto, inibição da síntese de diferentes prostaglandinas do ácido araquidônico (FENT, et al., 2006). A inibição da COX-2 está relacionada com a ação anti-inflamatória e a inibição da COX-1, relacionada com os efeitos indesejados (RANG, et al., 1997). Nem todos os AINEs apresentam ações analgésicas, antipirética e anti-inflamatória, como por exemplo, a acetaminofeno, não apresenta a ação anti-inflamatória e o diclofenaco e a orfenadrina, a ação antipirética (RANG, et al., 1997).

$\beta$-bloqueador é uma classe terapêutica que apresenta como mecanismo de ação, o bloqueio dos receptores beta adrenergéticos $\left(\beta_{1}, \beta_{2}\right.$ e $\left.\beta_{3}\right)$ para impedir que a neurotransmissão chegue à célula, como por exemplo, dos 
vasos sanguíneos, coração ou rins. Os principais efeitos da ativação do receptor $\beta_{1}$ : são o aumento da frequência e da força cardíaca e relaxamento da musculatura lisa gastrointestinal, enquanto que do receptor $\beta_{2}$ são: bronco dilatação, vasodilatação, relaxamento da musculatura lisa visceral, glicogenólise hepática e tremor muscular e, no receptor $\beta_{3}$ é a lipólise (RANG, et al., 1997). Assim, esta classe terapêutica possui diversas indicações terapêuticas, mas é particularmente indicada como antiarrítmico e anti-hipertensivo, na proteção cardíaca após enfarte do miocárdio. $\mathrm{O}$ atenolol e o propranolol fazem parte dessa classe terapêutica.

Os anti-hipertensivos são utilizados no tratamento da hipertensão. A hipertensão ou pressão alta é uma doença cardiovascular crônica, a qual sem tratamento há risco do paciente ser acometido por trombose coronariana, acidentes vasculares cerebrais e insuficiência renal. Esses medicamentos atuam na resistência da circulação periférica e/ou na insuficiência cardíaca inibindo a contratilidade do miocárdio ou reduzindo a pressão do ventrículo do coração. Os medicamentos são classificados de acordo com o local de ação, como por exemplo, o enalapril, losartana e valsartana são vasodilatadores de ação indireta, que atua na inibição da enzima conversora de angiotensina, ACE, para diminuir a vasoconstrição e a secreção de aldosterona no córtex adrenal, que pode ocasionar a retenção de sódio e água (RANG, et al., 1997).

O antidepressivo, ansiolítico e anticonvulsivante são medicamentos com princípio ativo psicotrópico que atuam no sistema nervoso central, SNC, para regular a neurotransmissão cerebral envolvida na comunicação dos neurônios e associada na regulação do humor, emoções, sono e apetite. Os principais neurotransmissores são a serotonina, noradrenalina, dopamina, ácido gamaaminobutírico, GABA. Os antidepressivos, citalopram e paroxetina, pesquisados nesse trabalho, pertencem à classe dos inibidores seletivos da receptação de serotonina, ISRS, que agem impedindo a retirada da serotonina da fenda sináptica, local onde este neurotransmissor exerce suas ações, para permitir a serotonina permanecer disponível por mais tempo, causando melhora no humor dos pacientes. Os ansiolíticos, bromazepam e midazolam atuam nos receptores 
de GABA aumentando a permeabilidade neuronal aos íons cloretos e consequentemente potencializando os efeitos sedativos e ansiolíticos (RANG, et al., 1997).

A carbamazepina é um importante fármaco empregado no tratamento de uma grande variedade de distúrbios como a epilepsia e esquizofrenia e, também um dos fármacos mais frequentemente detectado no ambiente aquático (PETROVIC, et al., 2005). O anticonvulsivante é utilizado na prevenção e no tratamento das crises convulsivas e epiléticas, neuralgias e também no tratamento de transtorno de humor. A carbamazepina atua, no nível celular, sobre os canais de sódio, responsável pelo transporte da corrente para dentro da célula e que ocasiona a geração de um potencial de ação, bloqueando a excitabilidade da célula (RANG, et al., 1997). O clonazepam apresenta um mecanismo de ação semelhante ao bromazepam e o midazolam e, por apresentar o efeito sedativo pronunciado é usado na terapia de manutenção anticonvulsivante (RANG, et al., 1997).

O antiplaquetário, clopidogrel, é um medicamento usado na terapia tromboembólica para evitar a ativação e agregação das plaquetas e formação de trombo dentro do vaso sanguíneo ou do coração (RANG, et al., 1997). O clopidogrel atua bloqueando de modo irreversível o receptor de difosfato de adenosina (ADP), que bloqueia o componente P2Y12 do receptor de ADP e inibe a ativação e agregação plaquetária (SMS, 2007).

Os diuréticos são medicamentos usados no tratamento da hipertensão arterial, insuficiência renal, cardíaca ou cirrose hepática. A clortalidona atua sobre o rim aumentando o fluxo urinário e eliminação de eletrólito como o sódio e o cloro (RANG, et al., 1997).

Os reguladores lipídicos são medicamentos para reduzir a concentração excessiva de umas das classes importantes de lipoproteínas, conhecida como lipoproteína de baixa densidade (LDL). Assim como outras estatinas, a rosuvastatina atua como inibidor competitivo da enzima HMG-CoA 
redutas (3-hidroxi-3-trimetilglutaril-CoA redutase) para reduzir a produção do colesterol sanguíneo (RANG, et al., 1997).

Os anti-histamínicos são medicamentos indicados para tratamentos inflamatórios e alérgicos. A loratadina é um antagonista dos receptores $\mathrm{H} 1$ (antihistamínico $\mathrm{H} 1$ ) e inibe a contração induzida pela histamina na musculatura lisa dos brônquios, intestino e útero sem ação sedativa (RANG, et al., 1997).

A cafeína é um alcaloide encontrado em várias plantas como café, cacau, chá, guaraná e, presente nos refrigerantes e diversos medicamentos. A cafeína tem efeito importante sobre o estado de alerta e podendo apresentar aumento nos níveis de atividades motoras e cognitivas (FREDHOLM, et al., 1999). Em níveis de ingestão associados com o consumo de café, a cafeína bloqueia os receptores de adenosina presente no tecido nervoso para manter o estado de excitação e melhorar a capacidade física e mental (HIGDON \& FREI, 2006). Os resultados de estudos epidemiológicos sugerem que o consumo de café pode ajudar a prevenir várias doenças crônicas, incluindo diabetes mellitus tipo 2, doença de Parkinson e doença hepática (cirrose e carcinoma hepatocelular). O consumo de café está associado ao aumento de risco de várias doenças cardiovasculares, incluindo pressão arterial e níveis plasmáticos de homocisteína. Entretanto, para os adultos que consomem quantidades moderadas de café (3-4 xícaras/d equivalente a 300-400 mg/d de cafeína), há pouca evidência de riscos à saúde e alguma evidência de benefícios para a saúde (HIGDON \& FREI, 2006).

A cocaína é extraída de uma planta chamada Erytroxylon coca ou simplesmente coca e usada por suas propriedades estimulantes, que provoca euforia, atividade motora aumentada e um exagero do prazer. Ela é um psicotrópico e atua no SNC inibindo a receptação das catecolaminas pelos terminais nervosos noradrenérgicos e aumenta os efeitos da atividade nervosa simpática (RANG, et al., 1997). As complicações mais frequentes associadas ao uso crônico da cocaína são os cardiovasculares incluindo distúrbios no ritmo cardíaco e ataques do coração, assim como a disfunção respiratória que podem 
levar a morte. Segundo a Secretaria Nacional de Políticas sobre Drogas (SENAD, 2009), a cocaína é considerada uma droga de abuso e seu consumo tem resultado em graves consequências socioeconômicas a população. A cocaína apresenta meia vida relativamente curta (30 min.), assim a verificação de exposição à droga é monitorada pela presença de seu principal metabólito a benzoilecgonina.

A sildenafila transformada no princípio ativo sob a forma de citrato de sildenafila é um medicamento indicado para o tratamento da disfunção erétil, isto é, incapacidade de obter ou manter uma rigidez do pênis suficiente para um desempenho sexual. Atua no sistema nervoso parassimpático causando a liberação de óxido nitroso (NO) no corpo cavernoso, principal estrutura erétil do pênis. O NO se liga aos receptores da enzima guanilato ciclase o que resulta em níveis aumentados da deguanosina monofosfato cíclico (GMPc), induzindo ao relaxamento da musculatura lisa do corpo cavernoso e a dilatação das artérias resultando em um influxo maior de sangue e, consequentemente favorecendo a ereção.

Ciproterona é um produto sintético que apresenta estrutura semelhante às dos hormônios naturais. O acetato de ciproterona possui ação antiandrogênico e algumas propriedades progestogênicas. Inibe os hormônios masculinos e, portanto é indicada para o tratamento de crescimento intenso de pelos na mulher em locais usuais ao homem (hirsutismo), calvície masculina grave, formas graves de acne e seborreia e no tratamento do carcinoma de próstata.

\subsection{Destinos dos fármacos no meio ambiente}

Os fármacos e seus metabólitos entram no ambiente aquático após a aplicação e/ou produção. Entre a variedade de fontes pode-se citar o efluente doméstico ou urbano, efluente industrial, derramamento acidental, enchentes, atividades de mineração e agrícolas, entre outras.

O caminho a ser percorrido pelos fármacos e seus metabólitos no ambiente é dependente das suas propriedades físico-químicas, como solubilidade 
na água, pressão de vapor e polaridade (FARRÉ, et al., 2008). A FIG. 11 sugere os possíveis caminhos percorridos pelos fármacos para alcançarem o ambiente aquático.

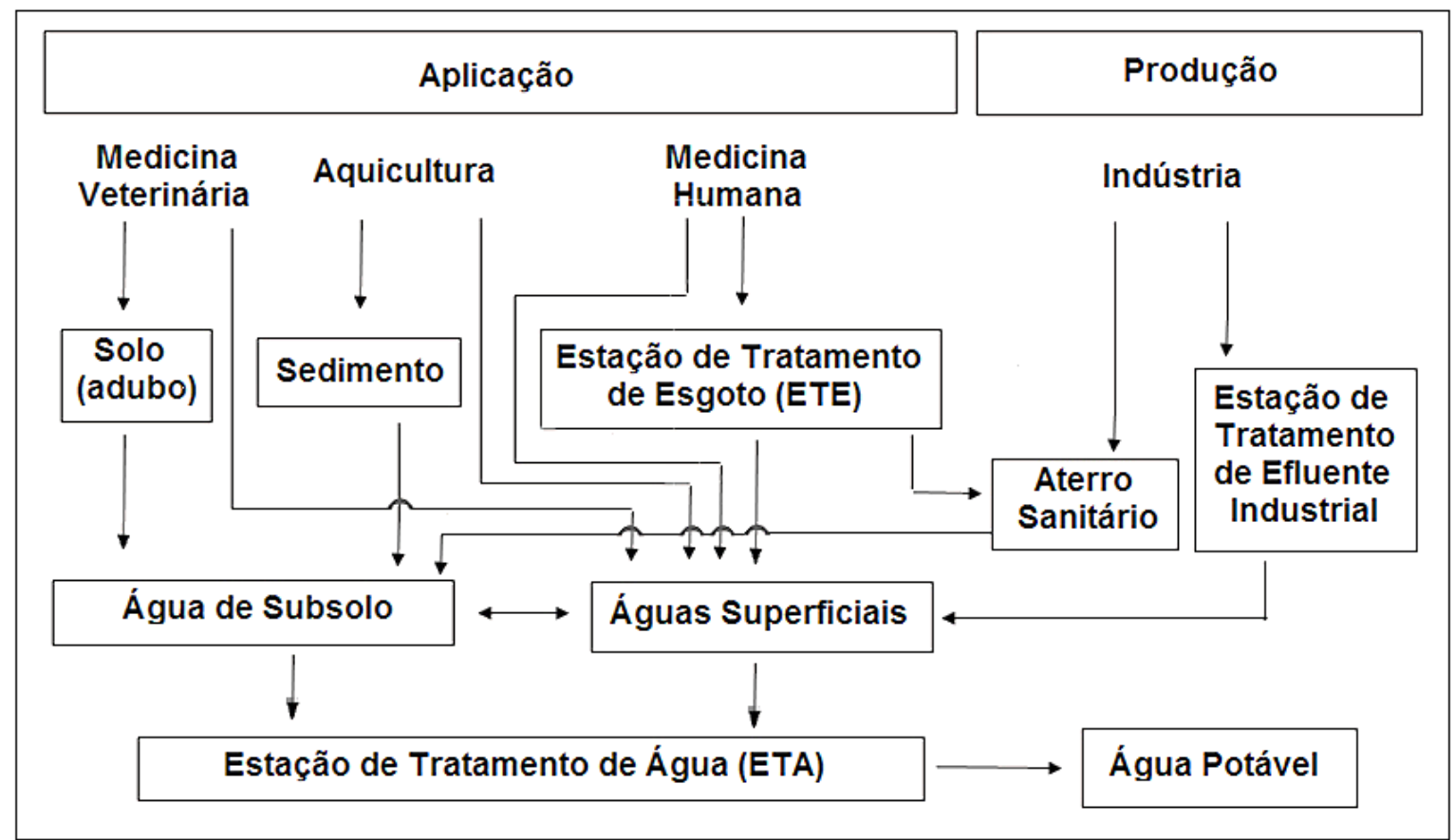

FIGURA 11. Principais rotas de entrada dos fármacos no ambiente aquático. (Adaptação de BILA \& DEZOTTI (2003)).

O principal caminho de entrada dos fármacos no ambiente aquático é durante a sua aplicação na medicina humana. Após a sua administração, os fármacos são excretados na sua forma ativa e ou como metabólitos pela urina e fezes. O esgoto doméstico gerado é coletado por sistema de redes coletoras de esgoto e encaminhado à Estação de Tratamento de Esgoto (ETE), onde são removidos em conjunto com outros constituintes orgânicos e inorgânicos contidos nas águas residuais. No entanto, alguns destes compostos farmacêuticos, presentes em concentração no nível de traço $\left(n \mathrm{n} \mathrm{L}^{-1}\right)$, não são totalmente removidos durante o tratamento e estão sendo detectados nos efluentes das ETEs e nas águas superficiais de vários países (TAB. 5 a11).

Uma vez presente no ambiente aquático, os fármacos ainda são submetidos a processos de biodegradação e degradação química e fotoquímica, que podem contribuir na sua eliminação, mesmo assim, estudos tem detectado a 
presença de fármacos até em água potável (BENOTTI, et al., 2009; WANG, et al., 2011).

Além disso, é importante destacar que a capacidade de operação das ETEs, muitas vezes, é também responsável por uma porção significativa do esgoto coletado ser lançado diretamente no ambiente aquático sem tratamento adequado, assim como, os esgotos das pequenas comunidades de baixa renda sem aporte de recursos financeiros para o tratamento de águas residuais.

No Brasil, por exemplo, apenas metade dos municípios brasileiros apresenta sistema de coleta de esgoto, tendo ainda grande parte desse esgoto coletado, aproximadamente $70 \%$ para a maioria dos Estados brasileiros, lançados diretamente no ambiente aquático sem nenhum tratamento (GUERRA, 2011).

Os fármacos podem também estar presentes no ambiente aquático, embora em menor quantidade, pelo descarte de medicamentos fora de uso e do prazo de validade.

Os fármacos utilizados na medicina veterinária podem entrar no ambiente aquático quando as fezes do animal contendo os contaminantes orgânicos são utilizadas como adubo na agricultura, permitindo assim o transporte dos fármacos para a água de subsolo por escoamento ou lixiviação do solo.

$\mathrm{Na}$ aquicultura, os fármacos são administrados diretamente no ambiente aquático, levando à contaminação também do sedimento e consequentemente da água de subsolo.

A presença de fármaco no ambiente aquático pode ser proveniente também de esgotos hospitalares e industriais sem tratamento adequado, bem como pelo destino final dos resíduos sólidos. O aterro sanitário controlado é a destinação final mais adequada para os resíduos sólidos, entretanto, no Brasil apenas 33\% dos municípios adotam esta medida (GUERRA, 2011). A grande maioria dos municípios brasileiros destinam os resíduos sólidos em lixões sem 
contenção do chorume, material com alta carga poluidora, que por lixiviação ou drenagem podem ocasionar a contaminação da água subterrânea, assim como do solo devido à sorção do fármaco no solo. Com a implantação da Política Nacional de Resíduos Sólidos, esses descartes e consequentemente as contaminações poderão ser minimizadas.

As classes terapêuticas mais relevantes e com maior frequência de detecção nas amostras ambientais estão apresentadas na FIG. 12.

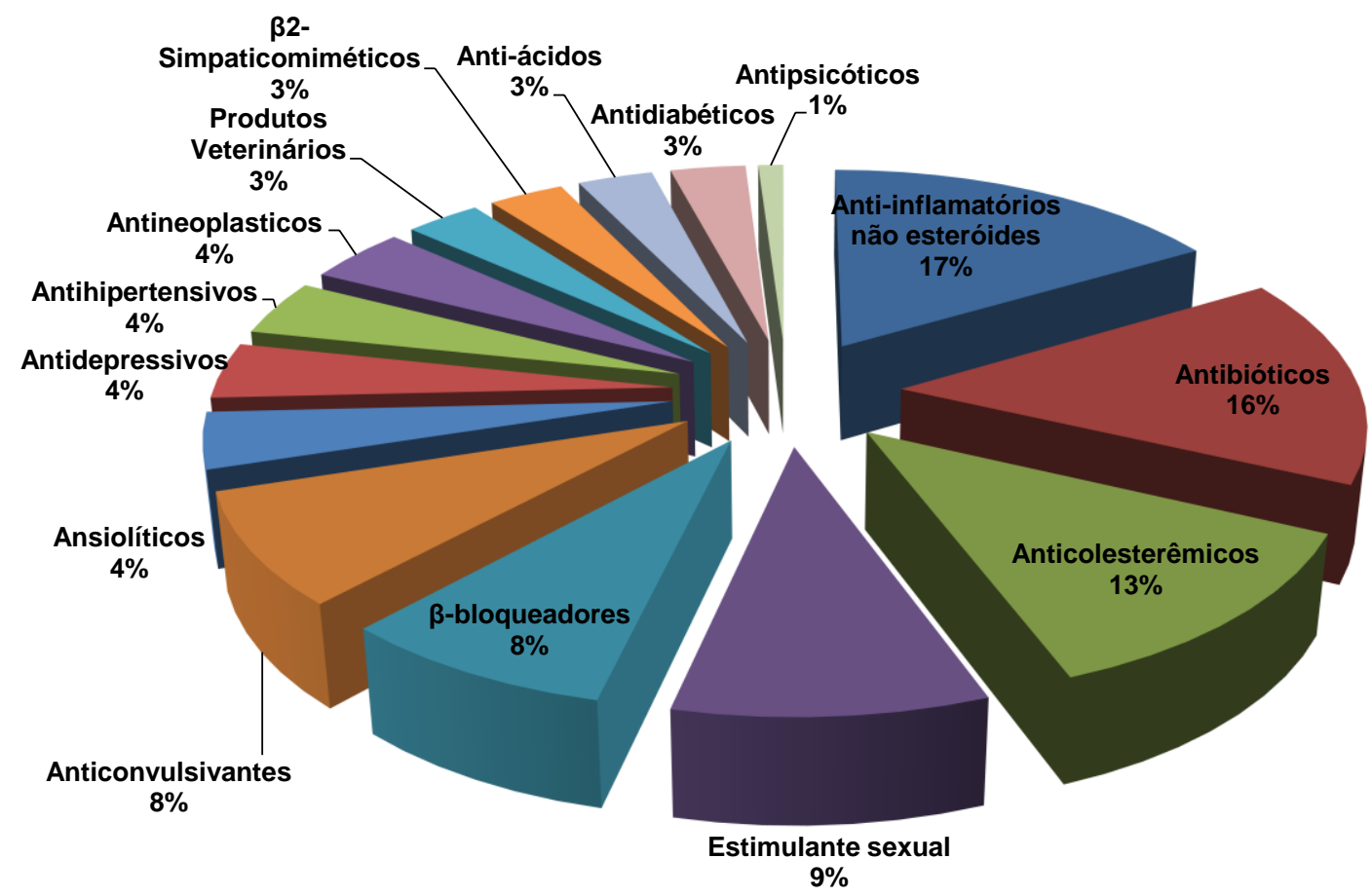

FIGURA 12. Presença das classes terapêuticas (\%) mais relevantes em termos de contaminação ambientais (SANTOS, et al., 2010)

\subsection{Ocorrência dos fármacos no meio ambiente}

A importância em diagnosticar e monitorar a presença de poluentes no ambiente deve-se principalmente a acidentes de repercussão mundial como: o uso indiscriminado do pesticida DDT (dicloro-difenil-tricloroetano) e seus derivados, que provocaram alterações hormonais, doenças e mortes na população de aves nos Estados Unidos por atuarem como um hormônio mimetizando o estrógeno, como o dietilestilbestrol interferindo, no metabolismo da testosterona e da tireoide (COLBORN, et al., 1997); no Japão o lançamento 
industrial de mercúrio, em 1956, que causou a doença de "Minamata" na população ao consumir organismos aquáticos com mercúrio bioacumulado; bem como o lançamento industrial de grande quantidade de cádmio, que ocasionou a doença "Itai itai" resultando em aproximadamente 100 mortes em 1965. Na índia e Paquistão, em 2004, o declínio da população de abutre por insuficiência renal e gota visceral, que se alimentavam de gados domésticos, foi correlacionada com a utilização de diclofenaco na medicina veterinária (FENT, et al., 2006).

Fármacos são desenvolvidos para desempenhar uma atividade biológica específica em humanos e animais, com objetivo de proporcionar um benefício à saúde. Segundo a previsão da empresa que audita o mercado farmacêutico mundial (IMS Health), o Brasil, em 2015, ocupará a $6^{\circ}$ posição de faturamento mundial. A crescente utilização de produtos farmacêuticos tanto na medicina humana quanto na veterinária se tornou uma questão relevante na área da pesquisa ambiental, uma vez que os fármacos de diferentes classes terapêuticas estão sendo detectados, em ambientes aquáticos de inúmeros países.

LÓPEZ-SERNA et al. (2011) detectaram, no Rio Ebro, Espanha, acetaminofeno, atenolol, carbamazepina, diclofenaco, enalapril e propranolol na concentração máxima de 384,$5 ; 1238 ; 8,97 ; 34,39 ; 0,99$ e 39,17 ng L-1, respectivamente. Nos tributários do Rio Ebro também foram encontrados acetaminofeno, atenolol, carbamazepina, diazepam, diclofenaco, paroxetina, e propranolol na concentração máxima de 872,5; 11021; 53,80; 2,68; 153,9; 225,0 e $14,17 \mathrm{ng} \mathrm{L}^{-1}$, respectivamente, constatando que as concentrações foram maiores do que no Rio Ebro, e com detecção da paroxetina e o diazepam, ausentes no Rio Ebro.

Pailler et al. (2009), estudou a distribuição de fármacos, pertencentes a 4 classes terapêuticas utilizados na medicina humana e veterinária (sulfonamidas, tetracilinas, analgésicos e hormônios), nas águas do Rio Alzette em Luxemburgo, incluindo Rio Mess (tributário do Rio Alzette) e em afluente e efluente da ETE de aproximadamente 300.000 habitantes. O resultado das amostras de afluentes e 
efluentes da ETE demonstrou uma eficiência de remoção de $90 \%, 75 \%$, 70\% e $15 \%$ para o ibuprofeno, sufametoxazol, tetraciclina e $\beta$-estradiol, respectivamente, enquanto que não foi observada nenhuma remoção para o diclofenaco. Diclofenaco foi observado no efluente com concentração acima de 55 ng L-1. Os compostos com maior frequência de determinação foram os analgésicos ibuprofeno (9-3080 $\mathrm{ng} \mathrm{L}^{-1}$ ) e diclofenaco (1-380 $\mathrm{ng} \mathrm{L}^{-1}$ ). $\beta$-estradiol foi detectado em concentração relativamente alta $\left(35 \mathrm{ng} \mathrm{L}^{-1}\right)$ ao considerar o possível efeito de interferente endócrino em animais.

Nas TAB. 5 e 6 são apresentadas algumas ocorrências de fármacos pertencentes à classe terapêutica de anti-inflamatório: acetaminofeno e diclofenaco, respetivamente; na TAB. 7 é o anticonvulsivante carbamazepina; na TAB. 8, os antidepressivos paroxetina e citalopram e o estimulante cafeína; na TAB. 9 o $\beta$-bloqueador atenolol; na TAB. 10 o $\beta$-bloqueador propranolol e o antihipertensivo enalapril; e na TAB. 11 a droga de abuso cocaína e seu principal metabólito benzoilecgonina em águas superficiais e em afluente e efluente de Estação de Tratamento de Esgoto (ETE) de vários países. Embora a literatura apresente a detecção de uma grande diversidade de fármacos, as tabelas mostram apenas os compostos estudados neste trabalho. 
TABELA 5. Ocorrência de anti-inflamatórios não esteroides (acetaminofeno) em água superficial, afluente e efluente de ETE.

\begin{tabular}{|c|c|c|c|c|c|}
\hline \multirow[b]{2}{*}{ Composto } & \multirow[b]{2}{*}{ País } & \multirow{2}{*}{$\begin{array}{c}\text { Água } \\
\text { Superficial } \\
\mathrm{ng} \mathrm{L}^{-1}\end{array}$} & \multicolumn{2}{|c|}{ ETE } & \multirow[b]{2}{*}{ Referência } \\
\hline & & & $\begin{array}{c}\text { Afluente } \\
\qquad \mathrm{ng} \mathrm{L}^{-1}\end{array}$ & $\begin{array}{c}\text { Efluente } \\
\text { phg } \mathrm{L}^{-1}-1\end{array}$ & \\
\hline \multirow[t]{13}{*}{ Acetaminofeno } & Alemanha (Gottingen) & $1992 \pm 198$ & - & - & (NÓDLER, et al., 2010) \\
\hline & Alemanha & - & - & 6000 & (TERNES, 1998) \\
\hline & Brasil (Represa Billings) & $0,3-10,3$ & - & - & (ALMEIDA \& WEBER, 2005) \\
\hline & Brasil (Campinas) & 840 & - & - & (SODRÉ, et al., 2007) \\
\hline & Espanha (Almeria) & - & $29000-246000$ & $<32-4300$ & (GÓMEZ, et al., 2007) \\
\hline & Espanha (Catalonia) & $<2-243$ & $4160-18681$ & $<7-1060$ & (GROS, et al., 2009; 2012) \\
\hline & Espanha ( Catalonia) & $282,4-499,4$ & - & - & (LÓPEZ-SERNA, et al., 2011) \\
\hline & Espanha (Madri) & $188-2813$ & - & - & (VALCÁRCEL, et al., 2011) \\
\hline & EUA & 10000 & - & - & (KOLPIN, et al., 2002) \\
\hline & França (Rio Allier) & 200 & - & - & (CELLE-JEANTON, et al., 2014) \\
\hline & Inglaterra (Rio Tyne) & $<20$ & $5529-69570$ & $<20$ & (ROBERTS\&THOMAS, 2006) \\
\hline & Malásia & 10 & - & 70 & (AL-ODAINI, et al., 2010) \\
\hline & Reino Unido & $<50$ & - & $<50$ & (HILTON \& THOMAS, 2003) \\
\hline
\end{tabular}


TABELA 6. Ocorrência de anti-inflamatórios não esteroides (diclofenaco) em águas superficiais, afluente e efluente de ETE.

\begin{tabular}{|c|c|c|c|c|c|}
\hline Composto & País & $\begin{array}{c}\text { Água } \\
\text { Superficial } \\
\text { ng L }^{-1}\end{array}$ & \multicolumn{2}{|c|}{ ETE } & Referência \\
\hline \multirow[t]{12}{*}{ Diclofenaco } & Alemanha (Luxemburgo) & $1-55$ & 15738,00 & $1-78$ & (PAILLER, et al., 2009) \\
\hline & Alemanha (Rio Leine, Göttingen) & $156 \pm 6,0$ & - & $1429 \pm 89$ & (NÓDLER, et al., 2010) \\
\hline & Alemanha (Rio Elbe, Hamburgo) & $26-67$ & - & - & (WEIGEL, et al., 2004) \\
\hline & China (Taiwan) & - & $3-437$ & 4-101 & (LIN, et al., 2009) \\
\hline & China (Beijing) & - & 318 & 204 & (SUI, et al., 2010) \\
\hline & Coreia do Sul (Rio Han) & $0,87-30$ & - & $21-98$ & (YOON, et al., 2010) \\
\hline & Espanha (Almeria) & - & $200-3600$ & $140-2200$ & (GÓMEZ, et al., 2007) \\
\hline & Europa & $7-247$ & - & - & (LOSS, et al., 2009; 2010) \\
\hline & Inglaterra (ETE de Howdon) & $<8$ & $901-1036$ & $261-598$ & (ROBERTS\&THOMAS, 2006) \\
\hline & Malásia & 1711 & - & 21711 & (AL-ODAINI, et al., 2010) \\
\hline & Reino Unido & $<20-91$ & - & $350-460$ & (HILTON \& THOMAS, 2003) \\
\hline & Suécia (ETE Kälby, Rio Höje) & - & 160 & 120 & (BENDZ, et al., 2005) \\
\hline
\end{tabular}


TABELA 7. Ocorrência de anticonvulsivante (carbamazepina) em águas superficiais, afluente e efluente de ETE.

\begin{tabular}{|c|c|c|c|c|c|}
\hline \multirow[b]{2}{*}{ Composto } & \multirow[b]{2}{*}{ País } & \multirow{2}{*}{$\begin{array}{c}\text { Água } \\
\text { Superficial } \\
\text { ng L-1 }\end{array}$} & \multicolumn{2}{|c|}{ ETE } & \multirow[b]{2}{*}{ Referência } \\
\hline & & & $\begin{array}{c}\text { Afluente } \\
\text { ng L-1 }\end{array}$ & $\begin{array}{c}\text { Efluente } \\
\text { ng L-1 }\end{array}$ & \\
\hline \multirow[t]{16}{*}{ Carbamazepina } & Alemanha & 1101 & - & 6300 & (TERNES, 1998) \\
\hline & Alemanha (Rio Leine, Göttingen) & $265 \pm 10$ & - & $1429 \pm 46$ & (NÓDLER, et al., 2010) \\
\hline & China (Taiwan) & - & $82-357$ & $93-214$ & (LIN, et al., 2009) \\
\hline & China (Beijing) & - & 113 & 108 & (SUI, et al., 2010) \\
\hline & Coreia do Sul (ETE, Rio Han) & $8,4-68$ & - & $56-160$ & (YOON, et al., 2010 \\
\hline & Espanha (Almeria) & - & $120-310$ & $110-230$ & (GÓMEZ, et al., 2007) \\
\hline & Espanha (Catalonia) & $1-60$ & $37-277$ & $8-277$ & (GROS, et al., 2009; 2012 \\
\hline & Espanha (Catalonia) & $6,93-29,12$ & - & - & (LÓPEZ-SERNA, et al., 2011) \\
\hline & EUA (Rio Colorado, Texas) & $<0,50-5,1$ & - & 170 & (TRENHOLM, et al., 2009) \\
\hline & EUA & $<0,7$ & $300-1300$ & $300-340$ & (ANUMOL, et al., 2015) \\
\hline & Europa & $66-11561$ & - & - & (LOSS, et al., 2009; 2010) \\
\hline & Finlândia & $<1,4-66$ & $290-400$ & $380-470$ & (VIENO, et al., 2006) \\
\hline & França (Rio Allier) & 5,8 & - & - & (CELLE-JEANTON, et al., 2014) \\
\hline & Itália & - & - & $33-1318$ & (CASTIGLIONE, et al., 2005) \\
\hline & Romenia (Rio Somes) & $30-75,1$ & $30-75,1$ & - & (MOLDOVAN, 2006) \\
\hline & Suécia (ETE Kälby, Rio Höje) & - & - & 1180 & (BENDZ, et al., 2005) \\
\hline
\end{tabular}


TABELA 8. Ocorrência de antidepressivo (paroxetina e citalopram) e estimulante (cafeína) em águas superficiais, afluente e efluente de ETE.

\begin{tabular}{|c|c|c|c|c|c|}
\hline \multirow[b]{2}{*}{ Composto } & \multirow[b]{2}{*}{ País } & \multirow{2}{*}{$\begin{array}{c}\text { Água } \\
\text { Superficial } \\
n g L^{-1}\end{array}$} & \multicolumn{2}{|c|}{ ETE } & \multirow[b]{2}{*}{ Referência } \\
\hline & & & $\begin{array}{c}\text { Afluente } \\
n g L^{-1}\end{array}$ & $\begin{array}{c}\text { Efluente } \\
n g L^{-1}\end{array}$ & \\
\hline \multirow[t]{3}{*}{ Paroxetina } & Canadá & $1,3-3,0$ & $4,6-5,3$ & $4,3-5,2$ & (LAJEUNESSE, et al., 2008) \\
\hline & Espanha (Catalonia) & $<\mathrm{LQM}^{*}-212,5$ & - & - & (LÓPEZ-SERNA, et al., 2011) \\
\hline & Noruega & - & $0,6-12,3$ & $0,5-11,7$ & (VASSKOG, et al., 2006) \\
\hline \multirow[t]{3}{*}{ Citalopram } & Alemanha (Göttingen) & $54 \pm 4,7$ & - & $431 \pm 41$ & (NÓDLER, et al., 2010) \\
\hline & Canadá & $3,4-11,5$ & $52,2-52,7$ & $46,8-57,8$ & (LAJEUNESSE, et al., 2008) \\
\hline & Noruega & & $13-612$ & $9,2-382$ & (VASSKOG, et al., 2006) \\
\hline \multirow[t]{13}{*}{ Cafeína } & Alemanha (Göttingen) & $101 \pm 8,7$ & - & - & (NÓDLER, et al., 2010) \\
\hline & Brasil (Represa Billings) & $0,35-28,3$ & - & - & (ALMEIDA \& WEBER, 2005) \\
\hline & Brasil (Campinas) & $1950-41700$ & - & - & (SODRÉ, et al., 2007) \\
\hline & China (Taiwan) & - & $5173-17500$ & $19-727$ & (LIN, et al., 2009) \\
\hline & China (Beijing) & - & $3400-6600$ & 155 & (SUI, et al., 2010) \\
\hline & Coreia do Sul (Rio Han) & $50-59$ & - & $38-250$ & (YOON, et al., 2010) \\
\hline & Espanha (Almeria) & - & $52000-192000$ & $1400-44000$ & (GÓMEZ, et al., 2007) \\
\hline & Espanha (Almeria) & $475-515$ & $18305-96154$ & $1207-532000$ & (BUENO, et al., 2011) \\
\hline & EUA & 6000 & - & - & (KOLPIN, et al., 2002) \\
\hline & Europa & $1467-39813$ & - & - & (LOSS, et al., 2009; 2010) \\
\hline & França (Rio Allier) & 81 & - & - & (CELLE-JEANTON, et al., 2014) \\
\hline & Portugal & $<100-9000$ & - & $170-920$ & (SILVA, et al., 2014) \\
\hline & Suécia (ETE Kälby, Rio Höje) & - & 3690 & 220 & (BENDZ, et al., 2005) \\
\hline
\end{tabular}

* LQM=limite de quantificação do método 
TABELA 9. Ocorrência de $\beta$-bloqueador (atenolol) em águas superficiais, afluente e efluente de ETE.

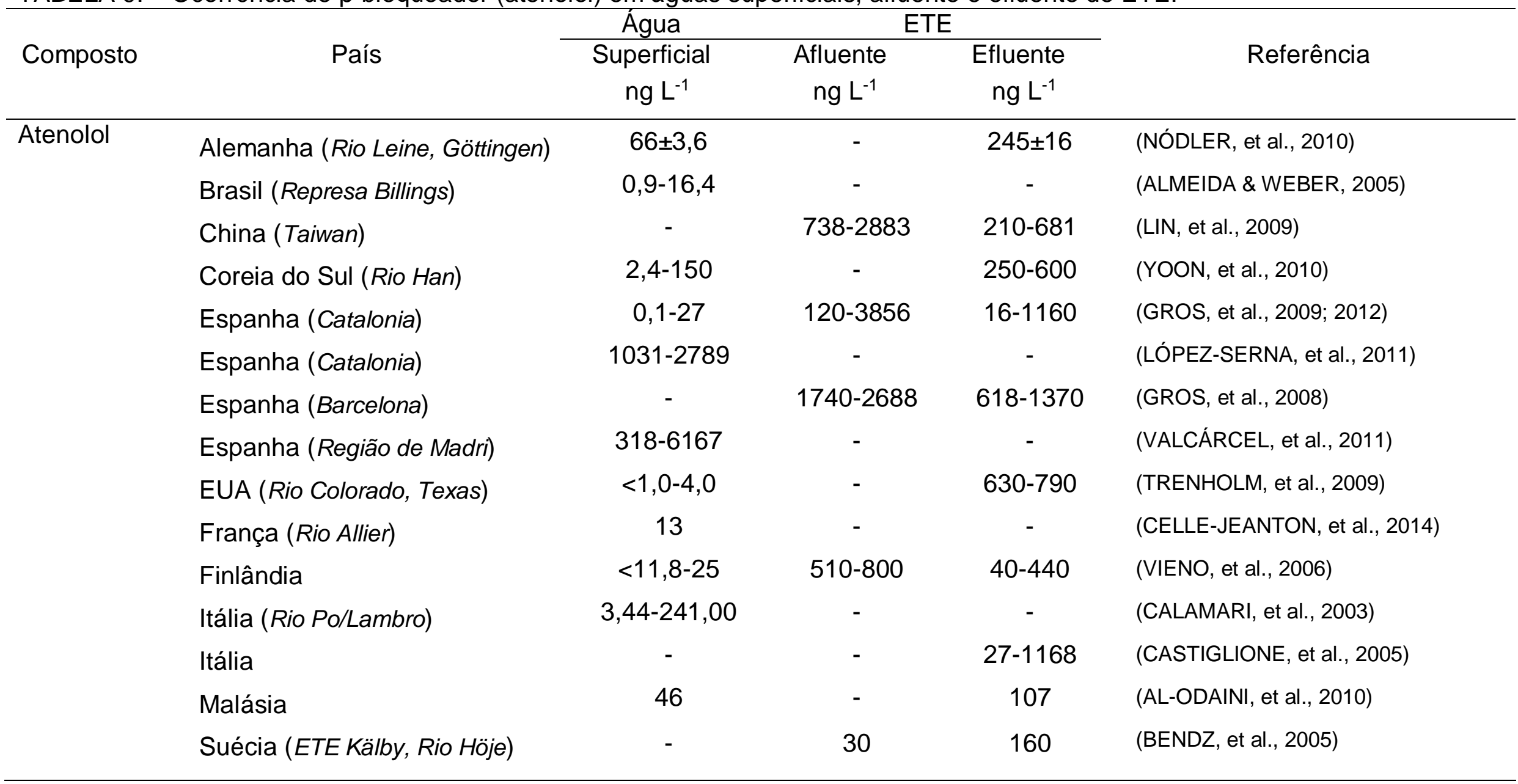


TABELA 10. Ocorrência de $\beta$-bloqueador (propranolol) e anti-hipertensivo (enalapril) em águas superficiais, afluente e efluente de ETE.

\begin{tabular}{|c|c|c|c|c|c|}
\hline Composto & País & $\begin{array}{c}\text { Água } \\
\text { Superficial } \\
\text { ng L-1 }\end{array}$ & \multicolumn{2}{|c|}{ ETE } & Referência \\
\hline \multirow[t]{6}{*}{ Propranolol } & Alemanha & 590 & - & 290 & (TERNES, 1998) \\
\hline & Espanha (Catalonia) & $<0,6-12$ & $<1-172$ & $<2-130$ & (GROS, et al., 2009; 2012) \\
\hline & Espanha (Catalonia) & $9,64-39,17$ & - & - & (LÓPEZ-SERNA, et al., 2011) \\
\hline & Espanha (Barcelona) & - & $74-144$ & $87-136$ & (GROS, et al., 2008) \\
\hline & Inglaterra (ETE de Howdon) & $35-107$ & $60-119$ & $195-373$ & (ROBERTS\&THOMAS, 2006) \\
\hline & EUA & $<1,3$ & $19-460$ & $<1,6-11$ & (ANUMOL, et al., 2015) \\
\hline \multirow[t]{3}{*}{ Enalapril } & Espanha (Catalonia) & $<0,3$ & $293-1268$ & $<0,7-1041$ & (GROS, et al., 2009) \\
\hline & Espanha (Catalonia) & $0,70-4,18$ & - & - & (LÓPEZ-SERNA, et al., 2011) \\
\hline & Itália (Rio Po/Lambro) & $0,05-0,54$ & - & - & (CALAMARI, et al., 2003) \\
\hline
\end{tabular}


TABELA 11. Ocorrência de droga de abuso e metabólito (cocaína e benzoilecgonina) em águas superficiais e afluente/efluente de ETE.

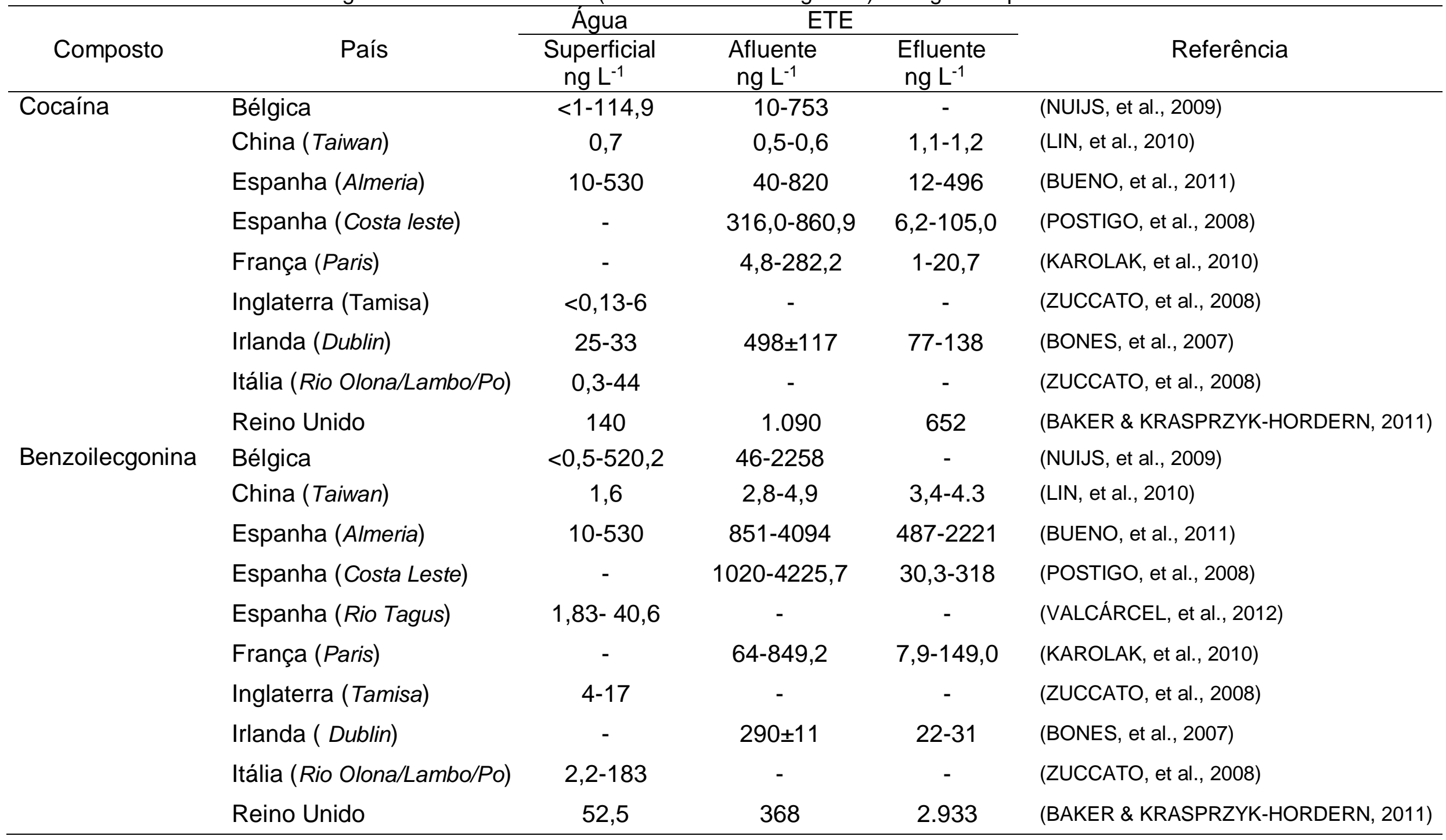


Os estudos citados nas TAB. 5 a 11 utilizaram no procedimento de preparação das amostras, a extração em fase sólida ("Solid Phase Extraction" SPE) para extrair os fármacos da matriz, concentrar e purificar. A separação cromatográfica dos fármacos foi realizada, na grande maioria dos estudos, por cromatografia líquida acoplada a espectrometria de massas sequencial, LCMS/MS ("Liquid Chromatography tandem Mass Spectrometry”). As exceções foram nos estudos de SODRÉ et al. (2007) que utilizaram a cromatografia líquida de alta eficiência ("Performance Liquid Chromatography", HPLC) acoplado ao detector UV com arranjo de fotodiodos ("UV/diode array detector", UV/DAD) e detector de fluorescência molecular ("Fluorescence detector", FL) para avaliar a concentração dos interferentes endócrinos e produtos farmacêuticos. Enquanto que, STUMPF et al. (1999), WEIZEL et al. (2004), MOLDOVAN (2006) e GÓMEZ et al. (2007) utilizaram a cromatografia gasosa acoplada a espectrometria de massas ("Gas Chromatography-Mass Spectrometry", GC-MS) para a separação cromatográfica e detecção dos fármacos. SUI et al. (2010) e LOPEZ-SERNA et al. (2011) utilizaram a cromatografia líquida de ultra eficiência e a espectrometria de massas em sequência (Ultra Performance Liquid Chromatography tandem Mass Spectrometry", UPLC-MS/MS) para separar e detectar os fármacos em seus estudos, enquanto que SILVA et al. (2014) quantificou a cafeína por ensaios de imunoabsorção enzimática ("enzyme-linked immunosorbent assay", ELISA).

A presença de fármacos também foi observada em outros compartimentos do ambiente aquático. Gomez et al. (2006) identificaram e determinaram, nos efluentes do Hospital em Almería, província do sudeste da Espanha na costa mediterrânea, os fármacos acetaminofeno $\left(0,5-29 \mu \mathrm{g} \mathrm{L}^{-1}\right)$,

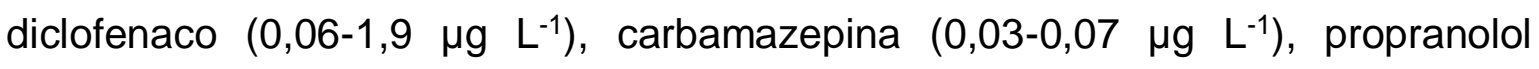
(0,2-6,5 $\left.\mu \mathrm{g} \mathrm{L}^{-1}\right)$ e atenolol (0,1-122 $\left.\mu \mathrm{g} \mathrm{L}^{-1}\right)$, utilizando a extração em fase sólida (SPE) e cromatografia líquida e espectrometria de massas em sequência (SPELC-MS/MS). Com essas altas concentrações de fármacos encontradas, os autores destacam a necessidade de um tratamento preliminar do efluente hospitalar, antes de serem liberados no sistema de coleta de esgoto urbano, por representar uma fonte significativa de contaminação de fármaco no ambiente aquático. 
Fármacos também foram detectados nas águas de mar. NODLER et al. (2010) detectaram nas águas do mar Báltico, Ahlbeck, Usedom, Alemanha, a cafeína $\left(58 \pm 5,4 \mathrm{ng} \mathrm{L}^{-1}\right)$, carbamazepina $\left(26 \pm 1,6 \mathrm{ng} \mathrm{L}^{-1}\right)$ e loratadina $\left(4 \pm 4,0 \mathrm{ng} \mathrm{L}^{-1}\right)$ utilizando a SPE-LC-MS/MS. WU et al. (2010) também analisaram 6 amostras de água do mar de estuário e detectaram o diclofenaco na faixa de 4 - 38 ng L L-1.

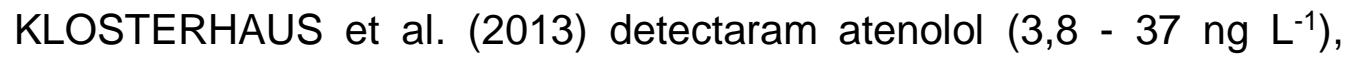
benzoilecgonina $(2,8$ - 7,2 ng L L-1), cafeína (15 - 40,8 ng L-1) e carbamazepina (5,2 - 4,2 ng L-1) em 100\% das amostras de água coletadas da Baia de São Francisco, CA, EUA, um estuário urbano que recebe descarga direta de mais de 40 (quarenta) emissários de águas residuais municipais e industriais.

\subsection{Toxicidade em ambiente aquático}

Os fármacos liberados, na sua forma ativa, agrupados ou metabolizados, no ambiente aquático, podem desempenhar as mesmas atividades biológicas, para qual ele foi desenvolvido em muitos organismos não alvos com vias metabólicas semelhantes aos humanos e animais, em tecidos, células ou biomoléculas (FENT, et al., 2006). A entrada contínua de uma mistura complexa de fármacos provenientes de efluentes de ETE e descarga direta no ambiente aquático é uma preocupação para a comunidade científica, por representar uma ameaça potencial para a saúde pública. Apesar disso, os dados de toxicidade ambiental de fármacos são escassos na literatura atual.

Os testes de toxicidade devem incluir ensaios laboratoriais realizados em condições específicas e controlados para avaliar o potencial de uma substância, de efluentes industriais ou de ETE e de amostras ambientais, em causar um efeito danoso a um organismo vivo (COSTA, et al., 2008). Nesses ensaios são avaliados os efeitos agudo e crônico provocados nos organismos teste como as algas, crustáceos, peixes e bactérias.

No teste de toxicidade aguda é estimada a dose ou a concentração de um agente tóxico em que uma resposta específica e mensurável, como a mortalidade e a imobilidade, é produzida no organismo teste ou na população, durante um período de tempo relativamente curto de 24 a 96 horas 
(ZACATO\&BERTOLETTI, 2008). No teste de toxicidade crônica, os organismos testes são expostos a agentes tóxicos, durante um tempo prolongado, para avaliar os efeitos na reprodução, desenvolvimento de ovos, crescimento e maturação dos organismos testes (COSTA, et al., 2008). Os dados normalmente obtidos nos ensaios de toxicidade aguda são expressos como $\mathrm{DL}_{50}, \mathrm{CL}_{50}$ e $\mathrm{CE}_{50}$, enquanto que nos ensaios de toxicidade crônica são CENO e CEO. A definição desses termos é apresentada na TAB. 12.

TABELA 12. Definição dos dados obtidos nos ensaios de toxicidade aguda e crônica (COSTA, et al., 2008).

\begin{tabular}{|c|c|c|}
\hline Parâmetro & Definição & $\begin{array}{l}\text { Tempo de } \\
\text { exposição }\end{array}$ \\
\hline \multirow[t]{2}{*}{$\mathrm{DL}_{50}$} & Dose Letal Média: & \\
\hline & $\begin{array}{l}\text { Dose de amostra que causa mortalidade de } 50 \% \text { dos organismos } \\
\text { no tempo de exposição e condições do teste. }\end{array}$ & 24 a 96 horas \\
\hline \multirow[t]{2}{*}{$\mathrm{CL}_{50}$} & Concentração Letal Média: & \\
\hline & $\begin{array}{l}\text { Concentração de amostra que causa mortalidade de } 50 \% \text { dos } \\
\text { organismos no tempo de exposição e condições do teste. }\end{array}$ & 24 a 96 horas \\
\hline \multirow[t]{2}{*}{$\mathrm{CE}_{50}$} & Concentração Efetiva Média: & \\
\hline & $\begin{array}{l}\text { Concentração de amostra que causa um efeito agudo (imobilidade, } \\
\text { por exemplo) a } 50 \% \text { dos organismos no tempo de exposição e nas } \\
\text { condições do teste. }\end{array}$ & 24 a 96 horas \\
\hline \multirow[t]{2}{*}{ CENO } & Concentração de Efeito Não Observado: & \\
\hline & $\begin{array}{l}\text { Maior concentração de agente tóxico que não causa efeito deletério } \\
\text { estatisticamente significativo nos organismos no tempo de exposição } \\
\text { e nas condições do teste. }\end{array}$ & 7 dias \\
\hline CEO & $\begin{array}{l}\text { Concentração de Efeito Observado: } \\
\text { Menor concentração de agente tóxico que causa efeito deletário } \\
\text { estatisticamente significativo nos organismos no tempo de exposição } \\
\text { e nas condiçoes do teste. }\end{array}$ & 7 dias \\
\hline
\end{tabular}

Protocolos padronizados de testes de toxicidade são disponibilizados por órgãos como a Environment Canada, United State Environmental Protection (USEPA), American Society for Testing and Materials (ASTM), Association of Analytical Communities (AOAC) e International Organization for Standardization (ISO). No Brasil, os protocolos padronizados são disponibilizados pela Associação Brasileira de Normas Técnicas (ABNT) e a Companhia de Tecnologia de Saneamento Ambiental do Estado de São Paulo (CETESB). 
Nas TAB. 13 e 14, são apresentados alguns estudos de toxicidade para os anti-inflamatórios não esteroides (acetaminofeno e diclofenaco), $\quad \beta$ bloqueadores (atenolol e propranolol), estimulante (cafeína) e antiepiléptico (carbamazepina) encontrados na literatura.

TABELA 13. Estudo de toxicidade para anti-inflamatório (acetaminofeno e diclofenaco) encontrado na literatura.

\begin{tabular}{|c|c|c|c|}
\hline Composto & $\begin{array}{c}\text { Organismo } \\
\text { Teste } \\
\end{array}$ & $\begin{array}{l}\text { Parâmetro } \\
\text { Toxicológico }\end{array}$ & $\begin{array}{c}\text { Ecotoxicidade } \\
\left(\mathrm{mg} \mathrm{L}^{-1}\right)\end{array}$ \\
\hline \multicolumn{4}{|l|}{ Anti-inflamatório } \\
\hline \multirow[t]{3}{*}{ Acetaminofeno } & Bactéria (Vibrio Fischeri) & $\mathrm{CE}_{50}(5 \mathrm{~min})$. & $549,7^{1}$ \\
\hline & Crustáceo (D. magma) & $\mathrm{CE}_{50}(48$ h. $)$ & $30,1^{1}$ \\
\hline & Peixe (Oryzias latipes) & $\mathrm{CE}_{50}(48$ h. $)$ & $>160^{1}$ \\
\hline \multirow[t]{17}{*}{ Diclofenaco } & Alga (D. subspictus) & $\mathrm{CE}_{50}($ taxa cresc. -3 d.) & $72^{2}$ \\
\hline & Alga (Lemna minor) & $\mathrm{CE}_{50}($ taxa cresc. -3 d.) & $7,5^{2}$ \\
\hline & Alga (S. Constatum) & $\mathrm{CL}_{50}$ & $5,0^{3}$ \\
\hline & Crustáceo (D. magma) & $\mathrm{CE}_{50}($ Imob.-48 h. $)$ & $68^{2}$ \\
\hline & Crustáceo (D. magma) & $\mathrm{CE}_{50}(21 d)$. & $28,1^{4}$ \\
\hline & Crustáceo (D. magma) & $\mathrm{CL}_{50}(21 d)$. & $56,6^{4}$ \\
\hline & Crustáceos ( Tisbe Battagliai) & $\mathrm{CL}_{50}$ & $15,8^{3}$ \\
\hline & Crustáceo (D. magma) & CEO (21d.) & $32^{4}$ \\
\hline & Crustáceo (D. magma) & CENO (21 d.) & $10^{4}$ \\
\hline & Bactéria (Vibrio Fischeri) & $\mathrm{CE}_{50}$ & $27,8^{3}$ \\
\hline & Peixe (Danio rerio) & $\mathrm{CE}_{50}(72 h)$. & $5,3^{5}$ \\
\hline & Peixe (Danio rerio) & $\mathrm{CL}_{50}(72 h)$. & $7,8^{5}$ \\
\hline & Peixe (O. mykiss) & CEO (Citop. do fígado-21 d.) & $1^{6}$ \\
\hline & Peixe (O. mykiss) & CEO (Citop. do rins-21 d.) & $1^{6}$ \\
\hline & Peixe (O. mykiss) & CEO (Citop. das guelras-21 d.) & $1^{6}$ \\
\hline & Peixe (Salmo t. f. fario) & CENO (Alt. Histopatológica-21 d.) & $0,5^{7}$ \\
\hline & Peixe (Danio rerio) & CENO (72 h.) & $1,5^{5}$ \\
\hline
\end{tabular}


TABELA 14. Estudo de toxicidade para anticonvulsivante (carbamazepina), antidepressivo (paroxetina), estimulante (cafeína), $\beta$-bloqueador (propranolol) e anti-hipertensivo (atenolol) encontrado na literatura.

\begin{tabular}{|c|c|c|c|}
\hline Composto & $\begin{array}{c}\text { Organismo } \\
\text { Teste } \\
\end{array}$ & $\begin{array}{l}\text { Parâmetro } \\
\text { Toxicológico } \\
\end{array}$ & $\begin{array}{c}\text { Ecotoxicidade } \\
\left(\mathrm{mg} \mathrm{L}^{-1}\right)\end{array}$ \\
\hline \multicolumn{4}{|l|}{ Anticonvulsivante } \\
\hline \multirow[t]{11}{*}{ Carbamazepina } & Alga (D. subspictus) & $\mathrm{CE}_{50}($ taxa cresc. $-3 d)$. & $74^{1}$ \\
\hline & Alga (Lemna minor) & $\mathrm{CE}_{50}($ taxa cresc. $-7 d)$ & $25,5^{1}$ \\
\hline & Crustáceo (D. magma) & $\mathrm{CE}_{50}($ Imob. -48 h. $)$ & $>100^{1}$ \\
\hline & Bactéria (Vibrio Fischeri) & $\mathrm{CE}_{50}(5 \mathrm{~min})$. & $52,5^{2}$ \\
\hline & Crustáceo (D. magma) & $\mathrm{CE}_{50}(48$ h.) & $>100^{2}$ \\
\hline & Peixe (Oryzias latipes) & $\mathrm{CE}_{50}(48$ h.) & $35,4^{2}$ \\
\hline & Peixe (Danio rerio) & $\mathrm{CE}_{50}(72 h)$. & $86,5^{3}$ \\
\hline & Peixe (Danio rerio) & $\mathrm{CL}_{50}(72$ h.) & $\geq 245^{3}$ \\
\hline & Peixe (Danio rerio) & CENO (72 h.) & $30,6^{3}$ \\
\hline & Invertebrado $(H$. attenuata $)$ & $\mathrm{CE}_{50}$ (alt. Morfolog.-96 h.) & $15,52^{4}$ \\
\hline & Invertebrado ( $H$. attenuata) & $\mathrm{CL}_{50}(96$ h.) & $29,4^{4}$ \\
\hline \multicolumn{4}{|l|}{ Antidepressivo } \\
\hline $\begin{array}{l}\text { Paroxetina } \\
\text { Estimulante }\end{array}$ & Crustáceo (D. magma) & $\mathrm{CE}_{50}(\operatorname{Imob.}-48$ h. $)$ & $2,5^{5}$ \\
\hline $\begin{array}{l}\text { Cafeína } \\
\beta \text {-Bloqueador }\end{array}$ & Invertebrado ( $H$. attenuata) & $\mathrm{CL}_{50}$ (96 h.) & $>100^{4}$ \\
\hline \multirow[t]{6}{*}{ Propranolol } & Alga (D. subspictus) & $\mathrm{CE}_{50}($ taxa cresc. $-3 d)$. & $5,8^{1}$ \\
\hline & Alga (Lemna minor) & $\mathrm{CE}_{50}($ taxa cresc. $-7 d)$. & $114^{1}$ \\
\hline & Crustáceo (D. magma) & $\mathrm{CE}_{50}(\operatorname{Imob})$. & $7,5^{1}$ \\
\hline & Peixe (Oryzias latipes) & $\mathrm{CL}_{50}(96$ h.) & $11,40^{2}$ \\
\hline & Peixe ( $P$. promelas) & CEO (Reprod.-21d.) & $1,0^{6}$ \\
\hline & Peixe (P. promelas) & CENO (Reprod.-21 d.) & $0,1^{6}$ \\
\hline \multicolumn{4}{|l|}{ Antihipertensivo } \\
\hline \multirow[t]{5}{*}{ Atenolol } & Alga (D. subspictus) & $\mathrm{CE}_{50}($ Imob.-7d.) & $620^{7}$ \\
\hline & Crustáceo (D. magma) & $\mathrm{CE}_{50}($ Imob.-48 h.) & $313^{7}$ \\
\hline & Peixe (Oryzias latipes) & $\mathrm{CL}_{50}(96$ h.) & $>100^{2}$ \\
\hline & Peixe (P. promelas) & CEO (Reprod.-21 d.) & $>10^{8}$ \\
\hline & Peixe (P. promelas) & CENO (Reprod.-21 d.) & $10^{8}$ \\
\hline
\end{tabular}

1 (CLEUVERS, 2003); ${ }^{2}$ (KIM, et al., 2007); ${ }^{3}$ (BRANDHOF\&MONTFORTS, 2010); 4 (QUINN, et al., 2008); ${ }^{5}$ (CUNNINGHAM, et al., 2004); ${ }^{6}$ (GILTROW, et al., 2009); ${ }^{7}$ (CLEUVERS, 2005); ${ }^{8}$ (WINTER, et al., 2008). 
Para a avaliação da toxicidade de um poluente é recomendado à realização do ensaio com vários organismos testes, uma vez que, o teste em um único organismo teste pode fornecer informações imprecisas sobre a toxicidade dos poluentes (SCHMIDT, et al., 2011). A evidência dessa necessidade é a diferença na sensibilidade dos organismos teste, nos ensaios de toxicidade aguda de um mesmo fármaco.

Diclofenaco é o fármaco com menor resposta nos ensaios de toxicidade. Nos estudos de TRIEBSKORN et al. (2007) o diclofenaco, induziu lesão renal, bioacumulação do fármaco no fígado e nas guelras musculares em peixes, na faixa de concentração ambiental $\left(\mu g \mathrm{~L}^{-1}\right)$. Nessas condições, possivelmente pode ocasionar um comprometimento na saúde da população de peixes (HOEGER, et al., 2005)

Carbamazepina e diclofenaco induziram vários efeitos (mortalidade embrionária, gastrulação, formação somito, pigmentação, movimento e separação de calda, batimentos cardíacos, malformação da cabeça, otólitos e coração, escoliose, deformidade de gema e sucesso de eclosão) em 72 horas em $50 \%$ da população de peixes na concentração de $86,5 \mathrm{mg} \mathrm{L}^{-1}$ e $5,3 \mathrm{mg} \mathrm{L}^{-1}$, respectivamente (BRANDHOF\&MONTFORTS, 2010).

Resultados de testes de toxicidade aguda são geralmente encontrados na literatura na faixa de $\mathrm{mg} \mathrm{L}^{-1}$, podendo ser interpretada por reguladores como a ausência de ameaça para o ambiente, uma vez que dificilmente um fármaco será encontrado nesta faixa de concentração no ambiente (FENT, et al., 2006). Entretanto, com a aplicação do fator de avaliação para corrigir as incertezas de risco, as concentrações de alguns fármacos, como o diclofenaco, fica apenas uma ordem de grandeza maior que a concentração encontrada no ambiente $\left(\mu \mathrm{g} \mathrm{L}^{-1}\right)$ (SCHMIDT, et al., 2011). Além disso, estes compostos são encontrados, no ambiente aquático, em mistura complexa podendo provocar efeitos adversos nos organismos aquáticos, devido à exposição contínua durante período longo, que muitas vezes se estende por todo o seu ciclo de vida. 


\subsection{Legislação}

A legislação atual, sobre contaminação ambiental por produtos farmacêuticos ainda apresenta lacunas, provavelmente pela indisponibilidade de dados para estabelecer um perfil de contaminação preciso, assim como de estudos de toxicidade crônica para avaliar os riscos de exposição, em longo prazo, de fármacos e seus metabólitos, na fauna e flora (SANTOS, et al., 2010)

Para a Comissão Europeia (Europa) e o FDA ("Food and Drug Administration"- Estados Unidos), a avaliação do risco de impacto ambiental é um pré-requisito para obter a autorização de comercialização de produtos farmacêuticos. Neste contexto, a EMEA ("European Agency for the Evaluation of Medical Products") estabeleceu diretrizes para avaliar o risco de impacto ambiental de medicamentos veterinários (EMEA, 1998) e humanos (EMEA, 2006). No entanto, a avaliação do destino e efeitos dos fármacos utilizados na medicina humana, na fauna e flora é exigida se a concentração ambiental prevista em água de superfície for igual ou superior a $0,01 \mu \mathrm{g} \mathrm{L}^{-1}$ (EMEA, 2006). Enquanto que a FDA exige uma avaliação ambiental somente se a concentração ambiental estimada do produto farmacêutico, no ponto de entrada, for superior a $1 \mathrm{\mu g} \mathrm{L}^{-1}$ (FDA, 1998).

No Brasil, o Conselho Nacional do Meio Ambiente (CONAMA) é o órgão responsável pela regulação das questões ambientais e por meio da Resolução n 357 de 17 de março de 2005, acrescida pelas alterações parciais e complementações apresentadas na Resolução n430, de 13 em maio de 2011, dispõe a classificação e diretrizes ambientais para o enquadramento dos corpos de água superficiais e estabelecido às condições e padrões de lançamento de efluentes (BRASIL, 2005; BRASIL, 2011). Conforme esta resolução, os efluentes não devem apresentar potencial para gerar efeitos tóxicos aos organismos aquáticos no corpo receptor. Os critérios de ecotoxicidade devem ser baseados em resultados de ensaios ecotoxicológicos aceitos pelo órgão ambiental, realizados no efluente, utilizando organismos aquáticos de pelo menos dois níveis tróficos diferentes. Na ausência de critérios de ecotoxicidade estabelecidos, a avaliação do efeito tóxico do efluente no corpo receptor, deve obedecer às seguintes diretrizes: 
a) para efluentes lançados em corpos receptores de água destinados ao abastecimento para consumo humano após tratamento simplificado (Classe 1) e convencional (Classe 2), a Concentração do Efluente no Corpo Receptor (CECR) deve ser menor ou igual à Concentração de Efeito Não Observado (CENO) de pelo menos dois organismos de níveis tróficos diferentes;

b) para efluentes lançados em corpos receptores de água destinada ao consumo humano após tratamento convencional e avançado (Classe 3), a Concentração do Efluente no Corpo Receptor (CECR) deve ser menor ou igual à concentração que não causa efeito agudo aos organismos aquáticos de pelo menos dois organismos de níveis tróficos diferentes.

\subsection{Técnica Analítica}

Neste trabalho, as técnicas analíticas são citadas com as abreviações em inglês para facilitar o entendimento por ser a forma mais conhecida.

A cromatografia líquida com detecção por espectrometria de massas em sequência (LC-MS/MS) avançou, nestas últimas décadas, tanto tecnologicamente como analiticamente. Atualmente, ela é amplamente aplicada nas análises qualitativa e quantitativa de inúmeros fármacos, presentes em concentrações na ordem de $\mathrm{ng} \mathrm{L}^{-1}$ a $\mathrm{g} \mathrm{L} \mathrm{L}^{-1}$, em amostras ambientais complexas e de águas residuais, devido a sua seletividade, especificidade e versatilidade (PETROVIC, et al., 2005; GROS, et al., 2006).

O bom desempenho de uma técnica analítica depende em grande parte do método de tratamento da amostra adotado, que ocupa mais que $75 \%$ do tempo do método (PETROVIC, et al., 2010). A grande maioria das metodologias analíticas realiza a extração simultânea de vários compostos alvos em uma única etapa de extração, usando a extração em fase sólida ("Solid Phase Extraction", SPE) (GÓMEZ, , et al., 2006).

A seguir são apresentadas discussões sobre o método de SPE e a técnica de LC-MS/MS utilizadas neste trabalho. 


\subsubsection{Extração em fase sólida}

A SPE é uma técnica rápida e sensível de separação líquido-sólido utilizado para extrair, concentrar e purificar os analitos semivoláteis e não voláteis presentes em amostras complexas, com base nos mecanismos de separação da cromatografia líquida de baixa pressão (JARDIM, 2010; SOUZA, 2011). Os principais mecanismos de retenção dos analitos de interesse na fase sólida (material sorvente) são adsorção, partição (fase normal e fase reversa), troca iônica e exclusão, podendo envolver interações não polares, polares e iônicas (SANTOS NETO, 2007; JARDIM, 2010).

A SPE emprega cartuchos, discos, bandejas perfuradas, colunas, ponteiras e formas miniaturizadas recheada com material sorvente (SANTOS NETO, 2007). O formato de SPE mais utilizado é o de cartucho, que consiste de um recipiente na forma de uma seringa de polipropileno, preenchido com cerca de 50 a $500 \mathrm{mg}$ de material sorvente, de 40 a $60 \mu \mathrm{m}$ de tamanho de partícula (QUEIROZ, 2011).

A escolha do material sorvente depende do analito de interesse e segue normalmente os mesmos critérios de seleção usados na escolha da fase estacionária da cromatografia líquida. Nesse critério de seleção são considerados: a estrutura química do analito, as propriedades do material sorvente e a composição da matriz da amostra (JARDIM, 2010). Atualmente, o mercado disponibiliza cartuchos de SPE com uma variedade de materiais sorventes de vasta gama de seletividade para atender uma gama de aplicações (RODRIGUEZMOZAZ, et al., 2007). Entre eles, os cartuchos mais utilizados para extrair e concentrar fármacos são o C18, HLB Oasis ${ }^{\circledR}$ e mais recentemente o Strata ${ }^{T M} X$. O material sorvente do primeiro cartucho é uma cadeia alifática de 18 carbonos em suporte de sílica, enquanto que nos outros dois é um copolímero com capacidade de adsorção de compostos lipofílico e hidrofílico simultaneamente, que permite a extração de compostos ácido, neutro e básico em um intervalo amplo de $\mathrm{pH}$, isentando a necessidade de ajuste do $\mathrm{pH}$ da amostra (GROS, et al., 2006). 
A extração simultânea e análise de diversos grupos de compostos com diferentes propriedades físico-químicas requerem um estudo de seleção dos parâmetros experimentais da extração, separação cromatográfica e detecção por espectrometria de massas, que muitas vezes são favoráveis para um composto e não para outros (PETROVIC, et al., 2010). No entanto, esse método possibilita obter, em uma única análise, resultados de múltiplos fármacos com menor gasto de solvente e tempo de análise. Além disso, esses resultados fornecem um conhecimento mais amplo da ocorrência dos contaminantes no ambiente aquático e podem auxiliar nos estudos de sua remoção, partição e destino final (PETROVIC, et al., 2010)

As principais etapas da extração em fase sólida compreendem: 1ativação e condicionamento dos sítios ativos do material sorvente; 2-percolação da amostra; 3-lavagem ou eliminação de interferentes; e 4-eluição dos compostos de interesse (LANÇAS, 2004). Na etapa 3 são removidas as impurezas ionizáveis presentes na matriz, como matéria orgânica, sais, contaminantes não alvo, que podem interferir no processo de ionização e aumentar o efeito matriz (JELIC, et al., 2009)

\subsubsection{Cromatografia líquida acoplada à espectrometria de massas sequencial, LC-MS/MS}

A cromatografia líquida e a espectrometria de massas são técnicas analíticas bem estabelecidas. Neste trabalho, a cromatografia líquida e a espectrometria são citadas como LC e MS, respectivamente.

A cromatografia líquida de alta eficiência ("High Performance Liquid Chromatography", HPLC") permite a separação de compostos de interesse presentes em uma mistura complexa para sua identificação e quantificação. Nesta técnica, a identificação do composto de interesse é baseada na comparação dos tempos de retenção do composto na amostra desconhecida com o do material de referência, determinada em condições experimentais idênticas (ARDREY, 2003). Entretanto, existem muitos compostos com tempo de retenção, dentro do limite do erro experimental, que não se pode afirmar com certeza absoluta, que o composto desconhecido é o mesmo do material de referência. Como também, 
nem sempre é possível obter uma separação completa de todos os compostos de uma mistura, impossibilitando uma determinação quantitativa precisa e exata do composto de interesse. Por outro lado, a espectrometria de massas por meio da aceleração da forma iônica em um campo elétrico e/ou magnético e separação pela razão $\mathrm{m} / \mathrm{z}$ (massa carga) apresenta a capacidade de identificar a forma iônica com alto grau de confiança, uma vez que, para muitos compostos, os espectros de massas obtidos por MS são específicos. A espectrometria de massas possibilita também a fragmentação da forma iônica, que permite a elucidação da sua estrutura (SOUZA, 2008).

A combinação da capacidade de separação da cromatografia e a de identificação da espectrometria massas resulta em identificação definitiva e na determinação quantitativa de compostos. A identificação é obtida mesmo para os compostos com baixa resolução cromatográfica, pois são diferenciados pela relação massa/carga $(\mathrm{m} / \mathrm{z})$.

O acoplamento das duas técnicas só foi possível após o desenvolvimento de interfaces que permitiram solucionar as incompatibilidades relacionadas à vazão do eluente do sistema cromatográfico e a entrada de amostra (fonte de ionização) no espectrômetro de massas. As vazões dos sistemas cromatográficos são da ordem de $1,0 \mathrm{~mL} \min ^{-1}$ e as fontes de ionização dos espectrômetros de massas operam em alto vácuo, cerca de $1,3 \times 10^{-4} \mathrm{~Pa}$ (ARDREY, 2003; CHIARADIA, et al., 2008). Além disso, os compostos separados por LC são relativamente pouco voláteis e/ou sensíveis à temperatura, que impossibilitam utilização dos métodos de ionização comumente aplicados na Cromatografia gasosa ("Gas Chromatography", GC), como a ionização por impacto de elétrons, ("electron ionization”, El) e ionização química, ("Chemical Ionization", Cl).

A evolução dos métodos de ionização à pressão atmosférica (“Atmospheric Pressure Ionization”, API), nos anos 80, possibilitou a união da LC com a MS. Os principais métodos de API são: a ionização por eletronebulização ("electrospray ionization”, ESI), ionização química à pressão atmosférica 
(“Atmospheric Pressure Chemical Ionization”, APCI) e a fotoionização à pressão atmosférica ("Atmospheric Pressure Photoionization”, APFI).

A ESI é a fonte de ionização mais amplamente utilizada na interface entre a LC e MS. Na ESI são gerados íons de baixa energia, que resultam em espectros de massas com sinais intensos relativos às moléculas protonadas ou desprotonadas com pouca ou nenhuma informação sobre a fragmentação dos íons, e, portanto, recomendada para as análises de compostos polares e termicamente lábeis, tais como produtos farmacêuticos (ARDREY, 2003; ALODAINI, et al., 2010). Com o desenvolvimento de técnicas de fragmentação induzidas, surgiu a espectrometria de massas em "tandem" ou sequencial (MS/MS).

Atualmente, os espectrômetros de massas combinam vários analisadores de massas em sequência e as configurações mais utilizadas são o triplo quadrupolo ( $Q q Q$ ), quadrupolo analisador de tempo de voo ("Quadrupole Time-of-Flight Analyzer, Q - TFA"), aprisionadores de íons (“Ion Trap, IT") e mais recentemente, o triplo quadrupolo aprisionador de íons linear, QqLIT ("Quadrupole Linear Ion Trap").

Os detectores normalmente utilizados são o copo de Faraday ("Faraday cup"), multiplicadores de elétrons ("Electro Multiplier - EM") e multiplicadores de fótons (SOUZA, 2008).

Nesse trabalho foram utilizados a fonte de ESI, analisador QqLIT e o detector multiplicador de elétrons e são detalhados a seguir.

\subsubsection{Ionização por Eletronebulização, ESI}

A ESI foi sugerida como um possível método de ionização por DOLE (1968), nos seus estudos de transferência de macromoléculas, existentes em uma solução, para a fase gasosa. Entretanto, a aplicabilidade da fonte de ESI como um método de ionização branda foi demonstrada somente por YAMASHITA e FENN (1984). Atualmente, essa fonte é amplamente aplicada na investigação de 
mais de $90 \%$ dos compostos orgânicos, em pesquisas de produtos farmacêuticos (PRAMANIK, et al., 2008)

O processo de ESI ocorre quando o eluato do HPLC, contendo um solvente volátil e os analitos de interesse, é conduzido para um fino capilar de aço inoxidável (50 a $100 \mu \mathrm{m}$ de diâmetro interno) com um potencial elétrico elevado (3-5 kV) aplicado na saída do capilar. O processo de ionização compreende as etapas de formação de gotículas, carregamento das gotículas, dessolvatação das gotículas e formação dos íons do analito. A ESI pode ser comparada a uma célula eletrolítica de dois eletrodos, onde os eletrodos são o capilar metálico e o contra eletrodo, apesar de somente o capilar estar em contato com a solução. Assim, quando um potencial, por exemplo, positivo é aplicado na solução ocorre uma separação de cargas e os íons positivos tendem a se direcionar para uma região menos positiva, isto é, ao contra eletrodo. Com isso, há formação, na ponta do capilar, de uma gota contendo íons positivos dos analitos e dos solventes. No entanto, à medida que aumenta a densidade de carga na gota, o potencial elétrico entre o capilar e o contra eletrodo aumenta e a forma da gota assume a forma de um cone denominado cone de Taylor (YAMASHITA \& FENN, 1984). O cone de Taylor foi descrito por Geoffrey Ingram Taylor, em 1964. A gota na forma de cone é liberada do capilar, na forma de um aerossol, no momento em que a densidade de carga na superfície da gota e o aumento da repulsão entre os íons superam a tensão superficial da gota. Para melhorar a eficiência do aerossol é introduzido um fluxo de gás inerte (normalmente nitrogênio), fluindo externamente ao capilar, em temperaturas elevadas $\left(150-200^{\circ} \mathrm{C}\right)$ para a evaporação do excesso do solvente. Isto faz com que as cargas ali contidas passem a ter maior proximidade, e consequentemente maior repulsão eletrostática provocando ruptura da gota com consequente formação de outras gotas ainda menores, conhecido como fissão Coulômbica (repulsão eletrostática). Este processo depende do campo elétrico, da tensão superficial da gota do solvente e da condutividade do solvente (MORAES \& LAGO, 2003)

O processo de ESI, até este momento, está bem entendido, entretanto ainda não se sabe exatamente como o íon é gerado na fase gasosa. Existe ainda muita discussão quanto ao modelo exato de formação de íons na fase gasosa, 
mas são propostos dois modelos, que podem estar ocorrendo tanto separadamente como simultaneamente. O primeiro é o modelo do resíduo carregado ("Charged-Residue Model", CRM) proposto por Dole, em 1968, que acontece quando a fissão Coulômbica é repetida até que o solvente seja evaporado por completo, restando apenas os íons dos analitos (FIG. 12). O segundo é o modelo da dessorção de íons ("Ion-Desorption Model”, IDM) proposto por IRIBANI \& THOMSON (1976), que se aplica quando a evaporação resulta em gotas com determinado raio, onde a densidade elétrica nas suas superfícies é grande o suficiente para expulsar os analitos diretamente para a fase gasosa (NIESSEN, 2006) (FIG. 13).

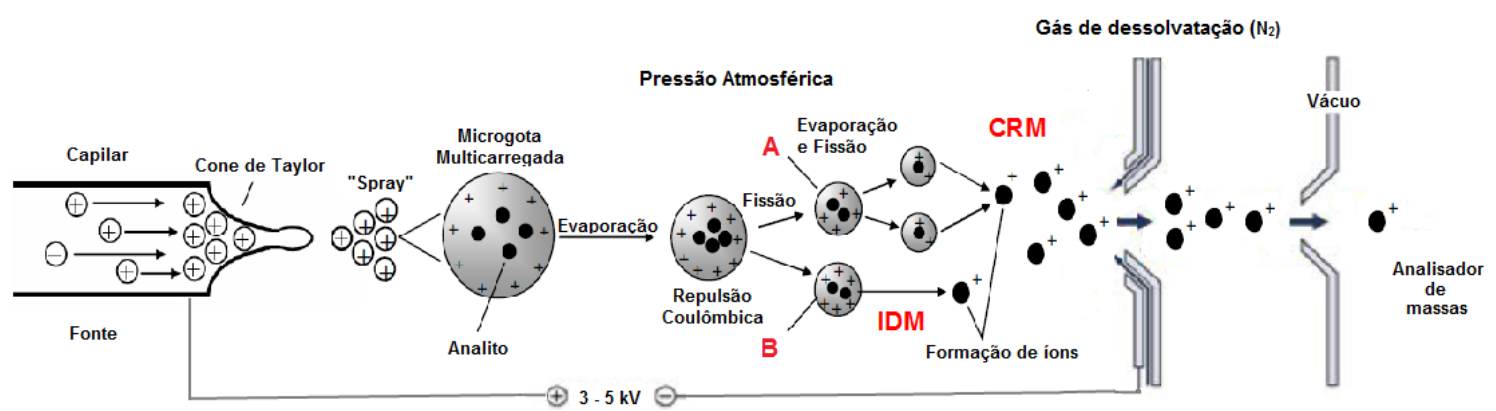

FIGURA 13. Modelo de ionização por eletronebulização: (A) modelo do resíduo carregado - CRM, e (B) modelo da dessorção de íons - IDM (SOUZA, 2008).

Os íons gerados na fonte de ionização são direcionados da região de pressão atmosférica para a de alto vácuo por meio de uma interface, cuja função é transferir os íons para os analisadores de massas, restringindo a passagem de solventes, interferentes, ar e umidade para garantir o ótimo funcionamento do sistema.

\subsubsection{Analisador de massas triploquadrupolo aprisionadores linear de íons (QqAIL)}

O analisador quadrupolar consiste de quatro hastes dispostas em paralelo e equidistante. Os pares formados pelas hastes opostas são conectados eletricamente e uma voltagem tanto de radiofrequência (RF) quanto de corrente contínua específica, aplicada entre elas, permite a passagem de íons com uma determinada razão m/z descrevendo uma trajetória estável (ARDREY, 2003). 
O analisador de massas triploquadrupolo é composto por três quadrupolos em série. O primeiro (Q1) e o terceiro (Q3) quadrupolos selecionam os íons precursores (íon de interesse) e produtos (fragmentos), respectivamente, definindo uma transição $\mathrm{m} / \mathrm{z}$ específica. O segundo (Q2) quadrupolo funciona como uma cela de colisão, onde os íons precursores selecionados, de acordo com as razões $\mathrm{m} / \mathrm{z}$, no primeiro quadrupolo são fragmentados por dissociação induzida por colisão ("Collision-Induced Dissociation", CID), após colisão com um gás inerte, sob uma energia específica (MARTINS JUNIOR, et al., 2006). Na FIG. 14 é apresentado o esquema de funcionamento do analisador triploquadrupolo.

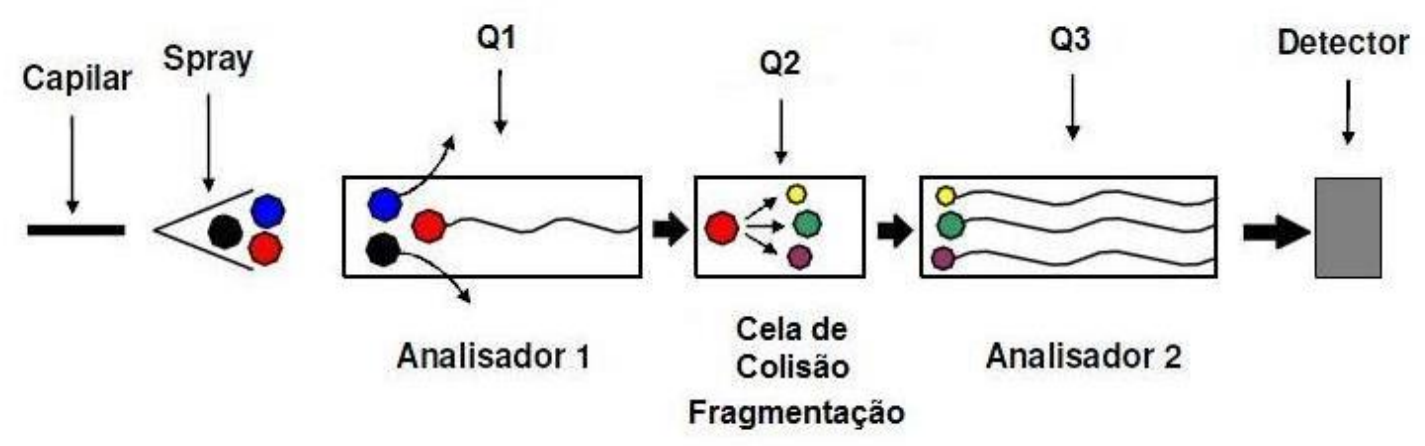

FIGURA 14. Esquema de funcionamento do analisador triploquadrupolo (SOUZA, 2008).

O analisador de massas triploquadrupolo aprisionadores de íons linear (QqAIL) pode utilizar o terceiro quadrupolo (Q3) para aprisionar íons com uma determinada razão $\mathrm{m} / \mathrm{z}$ com aplicação de uma voltagem de RF específica. A variação da voltagem de RF de forma sistemática torna os íons aprisionados, de determinada razão $\mathrm{m} / \mathrm{z}$, instáveis e os liberam para serem detectados (ARDREY, 2003).

Os espectrômetros de massas tipo triploquadrupolo podem operar em modo MS ou MS/MS. Para as análises quantitativas deste estudo, o espectrômetro de massas operou no modo de monitoramento de reações múltiplas ("Multiple Reaction Monitoring", MRM). Este modo de aquisição foi escolhido, uma vez que no modo de MRM, um determinado íon precursor é 
monitorado juntamente com os seus íons produtos de maior intensidade, sendo o íon produto mais intenso utilizado para a quantificação e o segundo mais intenso para a confirmação. Este modo de aquisição agrega à técnica de LC-MS/MS maior seletividade e especificidade nas análises quantitativas.

\subsubsection{Detector multiplicador de elétrons}

O detector multiplicador de elétrons (“Electron Multiplier”, EM) consiste em direcionar os íons provenientes do analisador para uma placa metálica (dínodo - liga de $\mathrm{Cu}-\mathrm{Be}$ ) que apresenta facilidade em perder elétrons quando atingidos por um íon. Os elétrons removidos são acelerados através de um potencial elétrico em direção de um segundo dínodo. Supondo que cada colisão de íon provoca a remoção de 10 elétrons, no segundo dínodo, cada um destes elétrons provoca a remoção de mais 10 elétrons, em tal situação, a chegada de apenas um íon causa a remoção de $10 \times 10=10^{2}=100$ elétrons que são direcionados para o segundo dínodo, resultando em uma amplificação de 100.

Multiplicadores de elétrons comerciais rotineiramente têm 10, 11 ou 12 dínodos, disponibilizando amplificações de $10^{6}$. O fluxo final de elétrons fornece uma corrente elétrica que pode ser ainda amplificado eletronicamente e convertido em sinal gráfico, isto é, a intensidade ou abundância do íon produto convertido em um espectro de massas.

Esses multiplicadores trabalham em baixa pressão e fornecem sistemas de detecção de íons altamente sensíveis e robustos por depender apenas de potenciais elétricos para funcionar. Eventualmente, a sensibilidade dos multiplicadores pode ser prejudicada pela contaminação da superfície causada pela instabilidade do vácuo e do impacto de íons nas superfícies dos dínodos.

\subsection{Validação da metodologia}

Validar um método analítico consiste em assegurar que as medições químicas obtidas por este método são confiáveis, inequívocas e podem ser utilizadas com segurança na interpretação das amostras em estudo. Com esta finalidade, as características de desempenho do método analítico devem ser submetidas a um conjunto de verificações e seus resultados documentados para 
comprovar, a nível internacional, a sua comparabilidade, rastreabilidade e confiabilidade (RIBANI, et al., 2004; PASCHOAL, et al., 2008).

Agências reguladoras, nacionais e internacionais, com poder de avaliar a competência de laboratórios, disponibilizam guias de orientação, para elaborar um processo de validação com evidências objetivas de que o método e o sistema utilizados são adequados para a aplicação proposta (RIBANI, et al., 2004; SILVA, 2011).

As diferenças nas definições de alguns parâmetros de validação levaram a organização do ICH (“International Conference on Harmonization") a normatizar um guia sobre validação de método analítico para aplicações farmacêuticas. Atualmente, este guia também está sendo utilizado em outras áreas. Participaram desta conferência, os representantes das indústrias e agências reguladoras FDA dos Estados Unidos ("Food and Drug Agency"), MHLW do Japão ("Ministry of Health, Labor and Welfare") e EMEA da União Europeia (“European Medicine Agency”). $\mathrm{Na}$ área da química ambiental, a EPA (“Environmental Protection Agency") publica os métodos padrões para análises de contaminantes com orientações para validação de métodos analíticos em questão (RIBEIRO, et al., 2008).

No Brasil, as agências reguladoras para verificar a competência de laboratórios de ensaios químicos são a Agência Nacional de Vigilância Sanitária (ANVISA) e Instituto Nacional de Metrologia, Normalização e Qualidade Industrial (INMETRO). Para tanto, a ANVISA disponibiliza a Resolução ANVISA RE n 899, de 29/05/2003 (ANVISA, 2003), com poder de lei, e o INMETRO o guia INMETRO DOQ-CGCRE-008, de março/2003 e as revisões de junho/2007, fevereiro/2010 e julho/2011 como uma orientação (INMETRO, 2003; 2007; 2011).

A identificação e a quantificação de resíduos de produtos farmacêuticos em ambientes aquáticos, nas últimas duas décadas, têm sido cada vez mais frequentes (TAB. 5 a 11). Dados analíticos não confiáveis podem conduzir a interpretações errôneas e tomadas de decisão desastrosas. Portanto, a validação de método analítico é importante para se obter uma caracterização 
correta dos possíveis efeitos ecotoxicológicos desses compostos na saúde humana, como também nos organismos não alvo.

O estabelecimento do procedimento de validação é um desafio na rotina de um laboratório devido às restrições de tempo, custo e instrumental. A validação de um método pode ser realizada utilizando os parâmetros de seletividade, efeito matriz, faixa de trabalho, linearidade, limite de detecção (LD), limite de quantificação (LQ), precisão, exatidão, recuperação e robustez, seguindo os guias de orientação disponibilizados pelo INMETRO (2003; 2007; 2010; 2011).

\subsubsection{Seletividade e efeito matriz}

O método seletivo é capaz de fornecer resultados de vários compostos e garantir que os resultados apresentados são exclusivos de cada camposto, mesmo em amostras complexas contendo interferentes, enquanto o método específico é capaz de fornecer resultado inequívoco de um único composto (INMETRO, 2007; PASCHOAL, et al., 2008). Esses dois termos, seletividade e especificidade, têm sido frequentemente utilizados como sinônimos e gerado confusão. Conforme Paschoal, et al. (2008) para os métodos cromatográficos o termo seletividade é o mais indicado por fornecer resultados de várias substâncias.

Para a identificação e quantificação de resíduos e contaminantes orgânicos em amostras de alimentos realizadas por LC-MS/MS, a decisão da Comissão Europeia 2002/657/EC (EUROPEAN COMMISSION, 2002) recomenda a utilização do sistema de pontos de identificação (PI). O sistema compreende a identificação para cada composto, o íon precursor e 2 (dois) íons produtos mais intensos. Este modo de aquisição confere a LC-MSMS alta seletividade por gerar um método confirmatório onde o íon mais intenso é utilizado para quantificação e o segundo mais intenso para identificação.

Atualmente este guia é também amplamente aplicado em matrizes ambientais. Alguns autores (GARCIA-GALÁN, et al., 2010; PETROVIC, et al., 2010; GROS, et al., 2012), recomendam também que a intensidade relativa dos 
íons produtos, em questão, não apesente variação maior que 20\% e o tempo de retenção maior que $2 \%$, quando comparados com os do padrão de referência.

A LC-MS/MS com ionização a pressão atmosférica (API - “Atmospheric Pressure Ionization") permite a ionização suave de uma gama grande de compostos, inclusive dos componentes coextraídos da matriz. Portanto, esta característica responsável pelo crescente sucesso das análises por LC/MS dos últimos 15 anos, também apresenta o efeito matriz como uma de suas limitações.

O efeito matriz é o aumento ou supressão de sinal de um analito na amostra quando comparada com o sinal do analito na solução padrão em solvente (VAN DE STEENE \& LAMBERT, 2008). Esse efeito é atribuído aos componentes residuais da matriz (matéria orgânica natural, sais, contaminantes não alvos, etc.) que coeluem com o analito alvo e interferem no processo de ionização. Esses componentes podem afetar a reprodutibilidade e a exatidão do procedimento utilizado, comprometendo ou levando a resultados imprecisos (BENIJTS, et al., 2004; JELIC, et al., 2009; QUEIROZ, 2011). Portanto, a validação do método também deve levar em consideração o efeito matriz para garantir a confiabilidade dos resultados obtidos.

O efeito matriz pode ser compensado com a utilização de padrão interno. Os padrões internos ideais são os isotopicamente marcados, entretanto, padrões marcados nem sempre estão disponíveis para todos os analitos em estudo, provavelmente pela dificuldade de serem sintetizados e/ou pelo custo elevado (QUEIROZ, 2011). Além disso, a análise quantitativa de vários compostos em amostra ambiental requer a adição de elevado número de padrão interno para diminuir o efeito matriz, o que resulta em um aumento no tempo de processamento da amostra e prejuízo na resolução dos picos cromatográficos (VAN DE STEENE \& LAMBERT, 2008).

Outra estratégia para compensar o efeito matriz é a diminuição do fluxo de entrada na fonte ESI, que apesar de não mudar a razão de analito e impureza coeluída da matriz, há uma redução significativa na quantidade de material orgânico a ser ionizado, que diminui a competição entre os analitos alvos e as 
impurezas coeluídas da amostra, na ESI, durante o processo de dessolvatação e ionização. Entretanto para taxas de fluxo baixas é necessária uma fonte de ESI nano (KLOEPFER, et al., 2005).

Embora estas abordagens possam compensar o efeito matriz e proporcionar resultado quantitativamente preciso não se pode evitar a perda de sensibilidade que é acompanhada por supressão de sinais e a variabilidade na sensibilidade do método, que pode ocorrer entre uma série de amostras. Resultado quantitativamente preciso só pode ser conseguido com processo eficiente de eliminação de interferências da matriz antes da análise por LC-ESIMS/MS (KLOEPFER, et al., 2005).

\subsubsection{Linearidade e faixa de trabalho}

Um método analítico é considerado linear quando as medições químicas geradas são diretamente proporcionais à concentração do analito, em uma determinada faixa de concentração (INMETRO, 2007).

Essa relação pode ser expressa por uma equação de regressão linear, método de mínimos quadrados, chamada curva analítica. A estimativa do coeficiente da curva analítica deve ser definida por no mínimo 5 (cinco) níveis de concentraçào do analito em estudo (THOMPSOM, et al., 2002). A equação é dada por:

$$
y=a x+b
$$

Equação 1

Onde:

$y=$ sinal resposta obtido, variável dependente;

$\mathrm{x}$ = concentração do composto, variável independente;

$a$ = coeficiente angular - inclinação da curva analítica em relação aos eixos;

$b=$ coeficiente linear - intersecção da curva aos eixos.

A partir dessa equação também é possível calcular o coeficiente de determinação, $r^{2}$, que permite estimar a qualidade da curva analítica. $O$ ajuste ideal do conjunto dos dados experimentais é obtido quando o valor de $r^{2}$ é mais próximo possível de 1,0 (GONSCHOROWSKI, 2013). 
Entretanto, nem sempre a obtenção de valor de $\mathrm{r}^{2}$ próximo de 1 significa um ajuste linear. Para garantir a linearidade da curva analítica faz-se necessário a análise cuidadosa do gráfico dos resíduos do sinal analítico e a aplicação de testes para determinar a faixa na qual a curva analítica apresenta um comportamento linear (RIBEIRO, et al., 2008).

\subsubsection{Limites de detecção e quantificação}

Os limites de detecção (LD) e de quantificação (LQ) estão relacionados com a sensibilidade do método.

O LD é a menor quantidade ou concentração do analítico de interesse na amostra que pode ser distinguido do zero ou sinal ruído. Esse parâmetro é importante na validação de métodos onde os analitos de interesse estão presentes em baixos níveis, análise de traços (THOMPSOM, et al., 2002). Segundo o INMETRO (2003), o LD instrumental é dado pela concentração do analito que produz um sinal de 3 a 5 vezes maior que a razão sinal/ruído do equipamento, enquanto que o LD é dado pela menor concentração de um analito, na amostra, medida e declarada com 95 ou $99 \%$ de confiança de que a concentração do analito é maior que zero.

O LQ é a menor concentração do analito de interesse na amostra que pode ser quantificada com precisão e exatidão aceitáveis sob as condições experimentais estabelecidas (RIBEIRO, et al., 2008). Segundo o INMETRO (2003), o LQ é dado pelo valor da média da menor concentração da curva analítica mais 5, 6 ou 10 desvios padrão.

\subsubsection{Precisão}

Precisão de um método analítico é o grau de concordância das medições químicas de ensaios independentes obtidas para mesma amostra, amostras semelhantes ou padrões, em condições estabelecidas (SOUZA, 2011; OLIVEIRA, 2012).

A precisão pode ser expressa pela repetibilidade e a reprodutibilidade, como também pelo desvio padrão relativo ou coeficiente de variação $(\mathrm{CV})$, sendo 
aceito valor de até $20 \%$ para análise de traço ou impurezas (HORWITZ \& ALBERT, 2006).

A repetibilidade pode ser determinada para as medições químicas de um analito realizadas por um mesmo analista, em um mesmo laboratório e na mesma instrumentação. INMETRO (2010) aconselha calcular o limite de repetitividade $(r)$ para verificar se a dispersão obtida entre as análises realizadas nas condições especificadas é significativa.

A reprodutibilidade poder ser determinada para as medições químicas de um analito realizadas em condições variadas de medição: mudança de operador, local, equipamentos, entre outros (RIBANI, et al., 2004). INMETRO (2010) e ANVISA (2003) aconselham calcular o limite de reprodutibilidade (R) para verificar se a dispersão obtida entre as análises realizadas nas condições especificadas é significativa.

\subsubsection{Exatidão}

A exatidão de um método analítico é definida como a concordância entre a medição química obtida e o valor de referência considerado verdadeiro (INMETRO, 2003; RIBEIRO, et al., 2008).

A avaliação da exatidão do método pode ser realizada com aplicação da metodologia proposta em materiais de referência, pela comparação de resultados obtidos por outro laboratório (programa interlaboratorial) e com os resultados dos ensaios de recuperação (INMETRO, 2011).

Um dos critérios de avaliação dos processos utilizados para investigar a exatidão é o índice z (z-score), que é usado para tomada de decisão se o resultado é satisfatório $(z \leq 2)$, questionável $(2 \leq z \leq 3)$ e insatisfatório $(z \geq 3)$ (INMETRO, 2011).

\subsubsection{Recuperação}

A recuperação do composto no método pode ser estimada pela quantificação do composto na amostra, após a adição do padrão ou material de 
referência em quantidade conhecida e submissão da amostra a todas as etapas do método proposto (GONSCHOROWSKI, 2013). INMETRO (2011) recomenda a adição do padrão na amostra, em pelo menos 3 (três) diferentes concentrações:

A limitação do procedimento de recuperação é a de que o composto adicionado, muitas vezes não está na mesma forma do composto na amostra. Composto adicionado em uma forma mais facilmente detectável pode fornecer medições químicas maiores ou menores, que podem resultar em valores de recuperação incorretos (INMETRO, 2003).

\subsubsection{Robustez}

Um método é robusto quando a exatidão e precisão permanecem praticamente inalteradas, frente a pequenas variações dos parâmetros analíticos do método estudado (INMETRO, 2007; RIBEIRO, et al., 2008).

O INMETRO (2007) recomenda o teste de Youden tanto para avaliar a robustez de um método, como também apresentar a magnitude da influência de cada uma das variações no resultado final. Este teste é um método multivariado, que utiliza um planejamento fracionário saturado para estudar a influência de vários fatores simultaneamente. Para tanto, 7 (sete) parâmetros de maior relevância ao método são selecionados e agrupados em 8 (oito) ensaios, com uma combinação fatorial, para avaliar a influência das variações impostas ao método.

\subsection{Incerteza nas medições analíticas}

A incerteza de medição é definida no Vocabulário Internacional de Metrologia (INMETRO, 2009) como "Parâmetro não negativo que caracteriza a dispersão dos valores atribuídos a um mensurando, com base nas informações utilizadas".

Com a exigência formal em demonstrar a qualidade das medições químicas de métodos normalizados ou desenvolvidos no próprio laboratório, tornou-se essencial também demonstrar, que esses resultados são rastreáveis a uma referência definida, como a unidade do Sistema Internacional de Medidas 
(SI), um material de referência ou quando aplicável, um método definido ou empírico. Para auxiliar todo esse processo, a estimativa da incerteza do resultado das medições químicas foi introduzida para fornecer maior confiança na validade do resultado, avaliando a variabilidade do resultado analítico (EURACHEM/CITAC, 2002; 2012).

A incerteza da medição, em geral, é proveniente de muitas fontes, tais como: definição incompleta, amostragem, efeito matriz e interferências, condições ambientais, incertezas de massas e equipamentos volumétricos, valores de referência, entre outras (EURACHEM/CITAC, 2002; OTOMO, 2010).

Para simplificar a identificação das fontes de incertezas mais relevantes em uma medição analítica, recomenda-se a utilização do Diagrama de Causa e Efeito (Ishikawa ou Espinha de peixe) (EURACHEM/CITAC, 2002; 2012). Esse método possibilita agrupar todas as incertezas envolvidas no processo, de modo simplificado, evitando que as contribuições sejam duplicadas (SOUZA, 2011).

As contribuições das fontes de incerteza ou componentes de incerteza podem ser agrupadas de acordo com o método de avaliação. O método de avaliação tipo A inclui os componentes da incerteza caracterizados por desvios padrão experimentais, proveniente da distribuição estatística de uma série de observações. O método de avaliação do tipo B inclui os componentes de incerteza caracterizados por desvios padrão proveniente de distribuição de probabilidades assumidas, tais como: dados fornecidos, por exemplo, por certificados de calibração de equipamentos e certificados de materiais de referência. Nessas condições, os componentes de incerteza são conhecidos como incerteza padronizada (EURACHEM/CITAC, 2002; 2012; OLIVEIRA, 2012).

A combinação de todas as incertezas padronizadas, independentemente de como foram avaliadas, resulta na incerteza padronizada combinada ou incerteza total, $u_{c}(y)$, para um resultado $y$ de uma medição. Além disso, na química analítica também deve ser estimado, com alto nível de confiança, o intervalo dentro do qual pode estar o valor do mensurando (resultado 
y). Este intervalo é conhecido como incerteza expandida, $U$, e é calculada multiplicando a incerteza padronizada combinada por um fator de abrangência $k$, relacionado ao nível de confiança desejado. Para um nível de confiança aproximado de 90\% adotou-se k=2 (EURACHEM/CITAC, 2002; SOUZA, 2011; EURACHEM/CITAC, 2012). 


\section{PARTE EXPERIMENTAL}

A quantificação por SPE-LC-ESI-MS/MS dos compostos de interesse compreende basicamente as etapas apresentadas no fluxograma da FIG. 15.

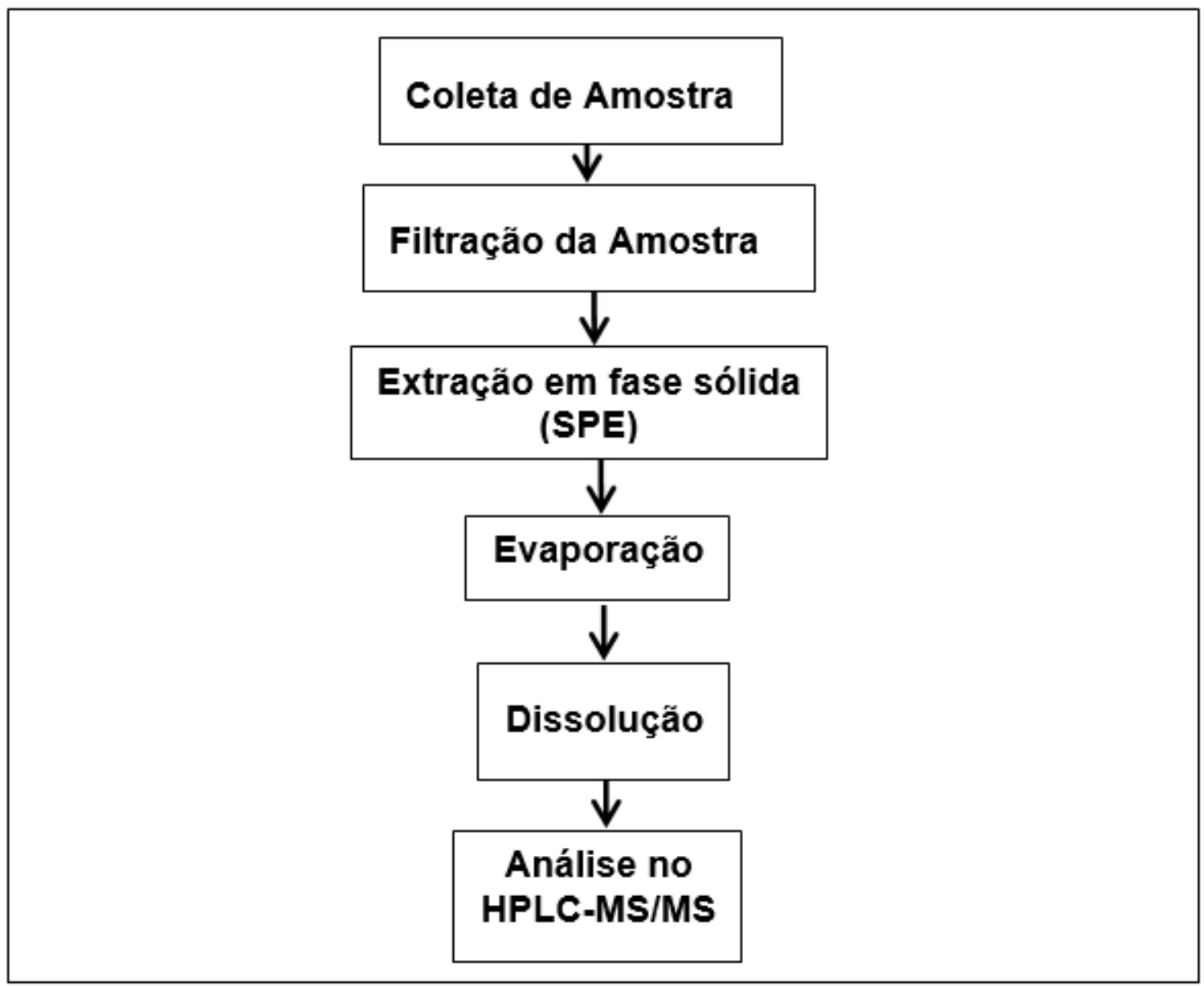

FIGURA 15. Fluxograma das etapas envolvidas no procedimento desenvolvido para análise dos compostos de interesse por HPLC-MS/MS, nas amostras de águas superficiais.

A seguir, serão descritas a instrumentação; reagentes e soluções utilizados no procedimento químico; a amostragem; os estudos de otimização do procedimento químico para a quantificação dos compostos selecionados em águas superficiais; os ensaios para a validação da metodologia; e a estimativa da incerteza do método analítico desenvolvido.

Antes de iniciar a etapa analítica, todas as vidrarias, inclusive os frascos de coleta, foram lavadas com detergente, enxaguadas em água corrente e 
após secos foram imersos, durante 6 horas, na solução mista de ácido nítrico e ácido sulfúrico P.A. (1:1, v/v). Em seguida, as vidrarias foram enxaguadas 10 vezes em água purificada no sistema de osmose reversa e 10 vezes na água de baixa condutância (19 M $\Omega$ ).

\subsection{Instrumentação, reagentes e padrões}

\subsubsection{Instrumentação}

Os compostos de interesse presentes nas amostras de água da represa Guarapiranga foram extraídos, concentrados e purificados utilizando o sistema de extração em fase sólida, desenvolvido nos laboratórios do CQMA (FIG. 16). Nesse procedimento foi utilizado o cartucho de extração em fase sólida (SPE) StrataX®, Phenomenex (Phenomenex, Inc. Torrance, CA USA), de $3 \mathrm{~mL}$ com $200 \mathrm{mg}$ de material polimérico.

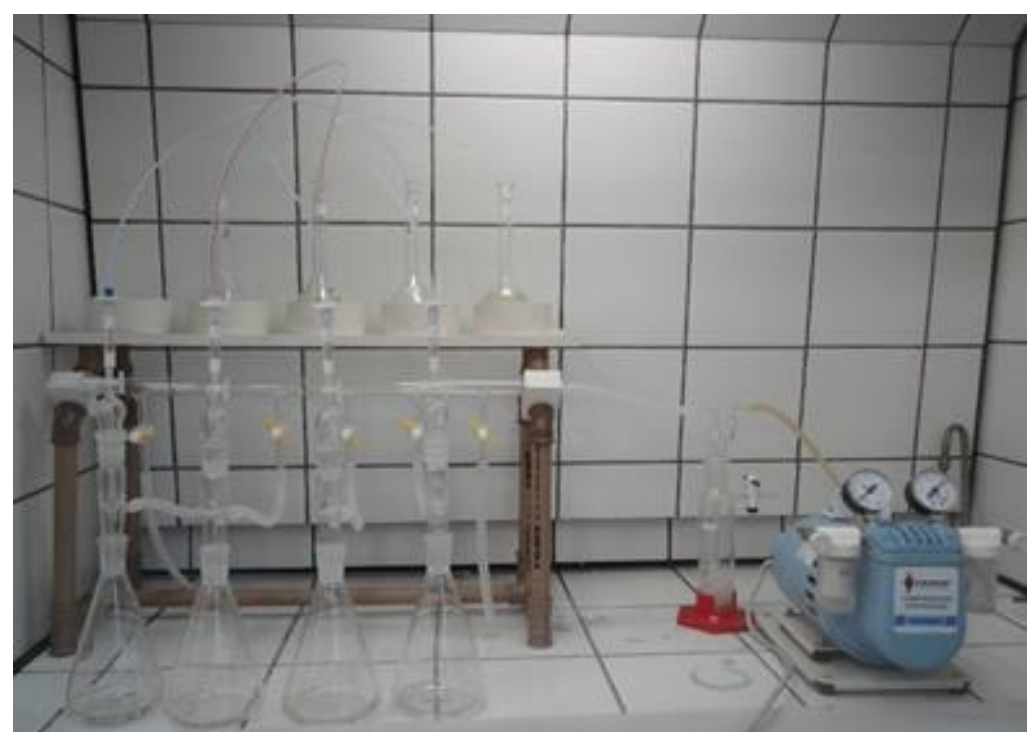

FIGURA 16. Sistema de extração em fase sólida.

A separação cromatográfica dos compostos de interesse foi realizada no o sistema de HPLC da Agilent (Agilent Technologies, Waldbronn, AL) composto de bomba quaternária, desgaseificador (modelo 1260); forno de coluna e injetor automático (modelo 1290), empregando uma coluna de fase reversa Eclipse ${ }^{\circledR}$ XDB-C18, 4,6x50mm, 1,8 $\mu \mathrm{m}$ da Agilent (USA).

A detecção e a quantificação dos compostos de interesse foi realizado no espectrômetro de massas sequencial híbrido, ion trap 3200 QTRAPTM (AB 
Sciex, Toronto, CA), com fonte de ionização Turbo $\mathrm{V}^{\mathrm{TM}}$, atuando no modo de ionização TurbolonSpray ${ }^{\circledR}$ (“electrospray”- ESI) e acoplado ao sistema de cromatografia líquida. O espectrômetro de massas também é equipado com bomba de infusão Harvard Apparatus (Holliston, MA, EUA) e programa de aquisição e tratamento de dados Analyst ${ }^{\circledR}$ versão 1.5.2.

A preparação das amostras envolveu outros equipamentos como:

- Sistema de filtração a vácuo, Millipore, conectado a bomba compressor/aspirador, modelo 089 cal, FANEM, utilizando as membranas de nitrocelulose de 0,45 $\mu \mathrm{m}$ da Sartorius Stedim Biotech (Alemanha), para a filtração das amostras de água;

- Sistema de purificação de água por Osmose reversa, ELIX 3, Millipore, para obtenção de água utilizada na descontaminação dos materiais usados no procedimento;

- Sistema de purificação de água de baixa condutância (19 $\mathrm{M} \Omega$ ), EasyPure, da Barnstead, para obtenção de água $\left(\mathrm{H}_{2} \mathrm{O}\right)$ utilizada na etapa final de descontaminação de materiais e na preparação e diluição de reagentes e soluções de todo o procedimento;

- Balança analítica, Sartorius, modelo MSX, faixa: 0,001 a 220g;

- Evaporador marca Techne;

- Agitador vortex, marca Vixar.

\subsubsection{Reagentes e Padrões}

Os reagentes e os padrões utilizados no procedimento foram:

- Solução ácida para descontaminação de vidrarias: ácido nítrico P.A. e ácido sulfúrico P.A. (1:1, v/v), ambos da Merck;

- Solventes orgânicos utilizados na extração em fase sólida de grau HPLC e na análise por LC-MS/MS de grau LCMS da J. T. Baker: acetonitrila $\left(\mathrm{CH}_{3} \mathrm{CN}, \mathrm{ACN}\right)$, metanol $\left(\mathrm{CH}_{3} \mathrm{OH}, \mathrm{MeOH}\right)$ e isopropanol $\left(\mathrm{C}_{3} \mathrm{H}_{8} \mathrm{O}\right)$;

- Aditivos das fases móveis: ácido fórmico grau LC-MS (Sigma-Aldrich) e acetato de amônio P.A. (Merck, Darmstadt, AL); 
- Padrão analítico de acetaminofeno, atenolol, bromazepam, cafeína, carbamazepina, ciproterona, clonazepam, clopidogrel, diclofenaco, enalapril, loratadina, losartana, midazolam orfenadrina, propranolol, sildenafila, e valsartana (Sigma-Aldrich);

- Padrão analítico de cocaína (982 $\left.\mu \mathrm{g} \mathrm{mL}^{-1}\right)$ e benzoilecgonina $\left(101 \mu \mathrm{g} \mathrm{mL}^{-1}\right)$ (Cerillant);

- Medicamentos de referência com princípio ativo de citalopram (Alcytam®, Torrent do Brasil Ltda.), Clortalidona (Higroton®, Novarts) e rosuvastatina (Crestor®, AstraZeneca);

- Medicamento genérico de paroxetina (Meddley).

A TAB. 15 e a FIG. 17 apresentam a característica e a estrutura dos compostos selecionados para estudo, respectivamente. 
TABELA 15. Características dos compostos selecionados para estudo (DRUGBANK).

\begin{tabular}{|c|c|c|c|c|c|c|c|c|}
\hline \multirow{3}{*}{$\begin{array}{c}\text { Classe } \\
\text { Terapêutica }\end{array}$} & \multirow{3}{*}{ Composto } & \multirow{3}{*}{ CAS N ${ }^{\circ}$} & \multirow{3}{*}{ Fórmula } & \multirow{3}{*}{$\begin{array}{c}\text { Peso Molecula } \\
\qquad\left(\mathrm{g} \mathrm{mol}^{-1}\right)\end{array}$} & \multicolumn{4}{|c|}{ Propriedades Previstas } \\
\hline & & & & & \multirow{2}{*}{$\begin{array}{c}\text { solubilidade } \\
\text { em água }\left(\mathrm{g} \mathrm{L}^{-1}\right)\end{array}$} & \multirow{2}{*}{$\log P$} & \multicolumn{2}{|c|}{ pka } \\
\hline & & & & & & & ácido & base \\
\hline \multirow{2}{*}{ Ansiolítico } & Bromazepam & $1812-30-2$ & $\mathrm{C} 14 \mathrm{H} 10 \mathrm{BrN} 3 \mathrm{O}$ & 316,153 & 0,0399 & 2,09 e 2,54 & 12,24 & 2,68 \\
\hline & Midazolam & $59467-70-8$ & C18H13CIFN3 & 325,767 & 0,00987 & 3.33 e 3.89 & n.i. & 6,57 \\
\hline Anticolesterémico & Rosuvastatina & $287714-41-4$ & $\mathrm{C} 22 \mathrm{H} 28 \mathrm{FN} 3 \mathrm{O} 6 \mathrm{~S}$ & 481,538 & 0,0886 & 1,47 e 1,92 & 4,00 & $-2,80$ \\
\hline Anticoncepcional & Ciproterona & $427-51-0$ & $\mathrm{C} 24 \mathrm{H} 29 \mathrm{ClO} 4$ & 416,938 & 0,00152 & 3,64 e 3,81 & 17,83 & $-5,60$ \\
\hline \multirow{2}{*}{ Anticonvulsivante } & Carbamazepina & $298-46-4$ & $\mathrm{C} 15 \mathrm{H} 12 \mathrm{~N} 2 \mathrm{O}$ & 236,2686 & 0,152 & 2,1 e 2,77 & 15,96 & $-3,80$ \\
\hline & Clonazepam & $1622-61-3$ & $\mathrm{C} 15 \mathrm{H} 10 \mathrm{CIN} 3 \mathrm{O} 3$ & 315,711 & 0,0106 & 2,75 e 3,15 & 11,89 & 1,86 \\
\hline \multirow{2}{*}{ Antidepressivo } & Citalopram & 5972 & $\mathrm{C} 2 \mathrm{OH} 21 \mathrm{FN} 2 \mathrm{O}$ & 324 & 0,00588 & 3,58 e 3,76 & n.i. & 9,78 \\
\hline & Paroxetina & 6186 & O3 & 325 & 853 & 3,1 e 3,15 & n.i. & 9,77 \\
\hline \multirow[t]{2}{*}{ Antiplaquetário } & Clopidogrel & $113665-84-2$ & C16H16CINO2S & 321,822 & 0,0118 & 3,84 e 4,03 & n.i. & 5,14 \\
\hline & Enalapril & 75847-73-3 & C2OH28N2O5 & 376,4 & 0,213 & $0,1930,59$ & 3,67 & 5,20 \\
\hline \multirow[t]{2}{*}{ Anti-hipertensivo } & Losartana & $114798-26-4$ & $\mathrm{C} 22 \mathrm{H} 23 \mathrm{CIN} 6 \mathrm{O}$ & 422,011 & 0,0047 & 4,5 e 5,08 & 7,40 & 4,12 \\
\hline & Valsartana & $137862-53-4$ & $\mathrm{C} 24 \mathrm{H} 29 \mathrm{~N} 5 \mathrm{O} 3$ & 435,5188 & 0,0234 & 3,68 e 5,27 & 4,37 & $-0,11$ \\
\hline Anti-histamínico & Loratadina & $79794-75-5$ & $\mathrm{C} 22 \mathrm{H} 23 \mathrm{CIN} 2 \mathrm{O} 2$ & 382,883 & 0,0134 & 4,55 e 4,8 & n.i. & 4,33 \\
\hline \multirow{3}{*}{ Anti-inflamatório } & Acetan & 103 & $\mathrm{C} 8 \mathrm{H}$ & 151 & 4,15 & 0,51 e 0,91 & 9,46 & $-4,40$ \\
\hline & Diclofenaco & $15307-86-5$ & $\mathrm{C} 14 \mathrm{H} 11 \mathrm{Cl} 2 \mathrm{NO} 2$ & 296,149 & 0,00447 & 4,26 e 4,98 & 4,00 & $-2,10$ \\
\hline & Orfenadrina & 83-98-7 & $\mathrm{C} 18 \mathrm{H} 23 \mathrm{NO}$ & 269,3813 & 0,03 & 3,5 e 4,17 & n.i. & 8,87 \\
\hline \multirow{2}{*}{$\beta$-bloqueador } & Atenolol & $29122-68-7$ & $\mathrm{C} 14 \mathrm{H} 22 \mathrm{~N} 2 \mathrm{O} 3$ & 266,3361 & 0,42 & 0,43 e 0,57 & 14,08 & 9,67 \\
\hline & Propranolol & 525 & & & 0,0794 & 2,58 e 3,03 & 14,09 & 9,67 \\
\hline ulante & Cafeína & $58-08-2$ & $\mathrm{C} 8 \mathrm{H} 10 \mathrm{~N} 4 \mathrm{O} 2$ & 1.941 .906 & 11 & $(-0,55$ e $-0,24)$ & n.i. & $-0,92$ \\
\hline \multirow{2}{*}{$\begin{array}{l}\text { Estimulante sexual } \\
\text { Diurético }\end{array}$} & Sildenafil & 139755-83-2 & $\mathrm{C} 22 \mathrm{H} 30 \mathrm{~N} 6 \mathrm{O} 4 \mathrm{~S}$ & 474,576 & 0,433 & 1,65 e 2,35 & 7,27 & 5,97 \\
\hline & Clortalidona & $77-36-1$ & $\mathrm{C} 14 \mathrm{H} 11 \mathrm{CIN} 2 \mathrm{O} 4 \mathrm{~S}$ & 338,766 & 0,0528 & 1,27 e 1,6 & 8,58 & $-2,60$ \\
\hline \multirow{2}{*}{$\begin{array}{l}\text { Dorga de abuso } \\
\text { Metabólito }\end{array}$} & Cocaína & $50-36-2$ & $\mathrm{C} 17 \mathrm{H} 21 \mathrm{NO} 4$ & 303,3529 & 5,03 & 1,97 e 2,28 & n.i. & 8,85 \\
\hline & Benzoilecgonina & 519-09-5 & $\mathrm{C} 16 \mathrm{H} 19 \mathrm{NO} 4$ & 289,3264 & 3,82 & $(-0,59$ e 1,71$)$ & 3,15 & 9,54 \\
\hline
\end{tabular}




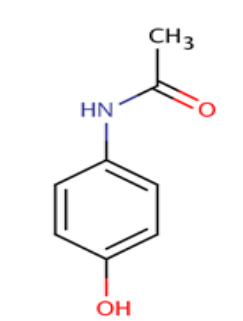

Acetaminofeno

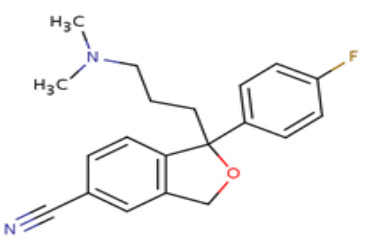

Citalopram

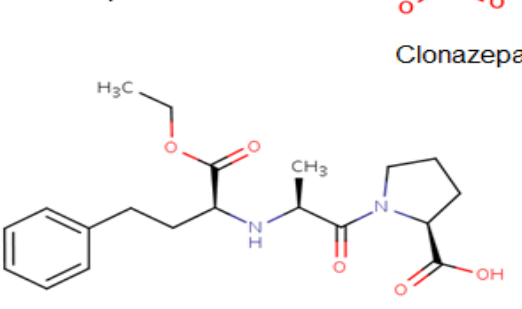

Enalapril

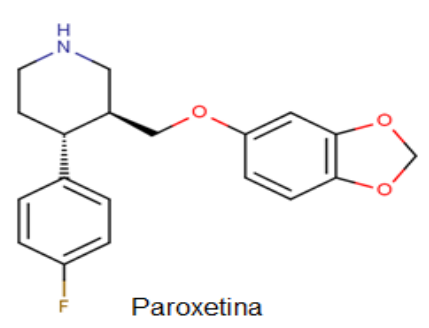

Paroxetina

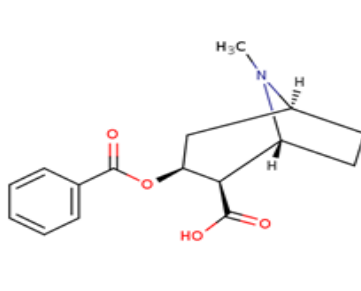

Benzoilecgonia

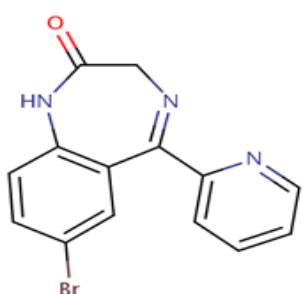<smiles>Cn1c(=O)c2c(ncn2C)n(C)c1=O</smiles><smiles>NC(=O)N1c2ccccc2C=Cc2ccccc21</smiles>

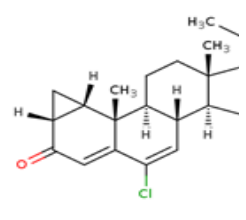

Bromazepam

Cafeina

Carbamazepina

Citrato de Ciprc
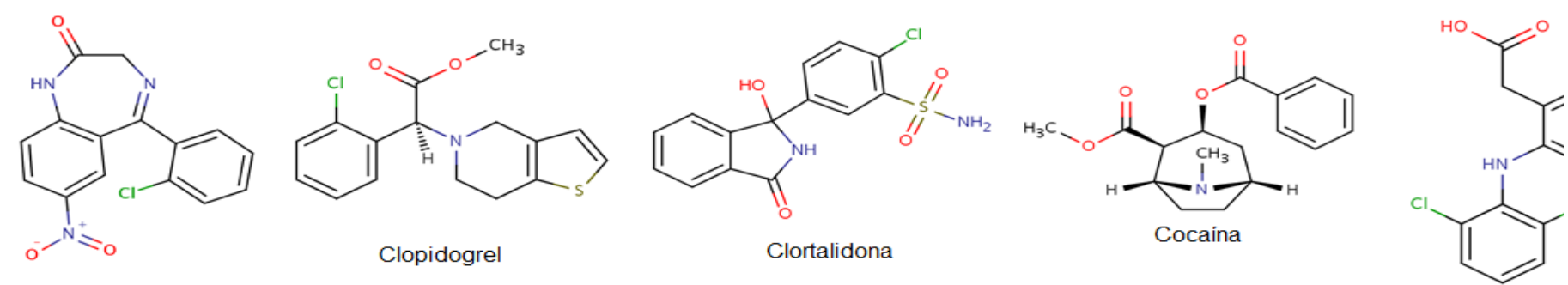

Diclofenac
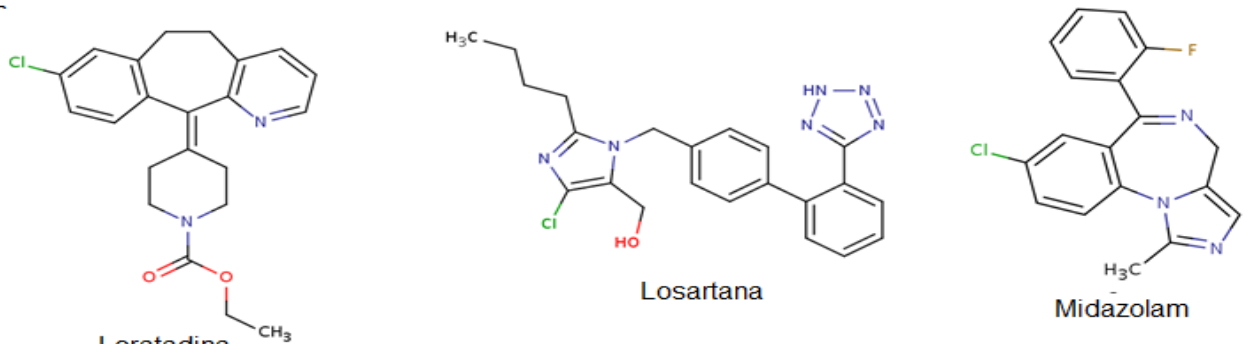

Midázolam
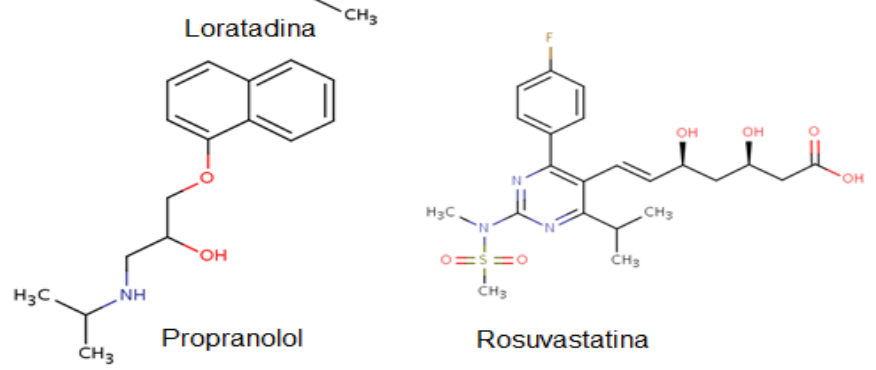

Rosuvastatina

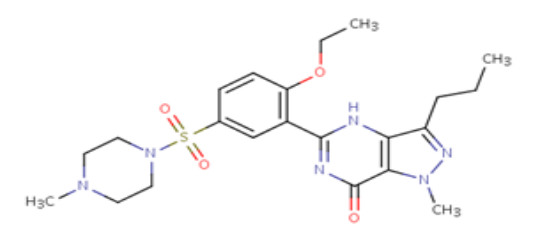

Sildenafila

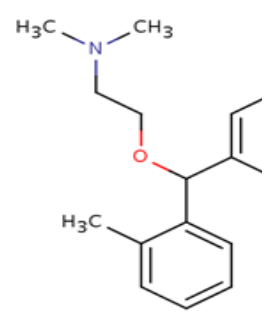

Orfenadrina

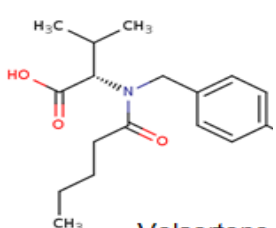

Valsartana

FIGURA 17. Estrutura Química dos compostos em estudo (DRUGBANK) 


\subsection{Amostragem}

Os locais de coleta das amostras de água da represa Guarapiranga foram selecionados visando avaliar a influência dos tributários considerados mais importantes e, conhecer a influência das sub-bacias na qualidade da água da represa. Esta seleção foi realizada com a participação dos representantes do Centro de Integração e Gerenciamento de Informações da Coordenadoria de Planejamento Ambiental da Secretaria do Meio Ambiente (SMA), Instituo de Pesquisas Energéticas e Nucleares (IPEN) e do Instituto de Botânica. Selecionaram-se 14 (quatorze) locais, sendo que 3 (três) são pontos de monitoramento da SABESP. As coordenadas geográficas e as profundidades dos pontos de amostragem são apresentadas na TAB.16 e podem ser visualizadas na FIG.18, juntamente com os principais tributários.

TABELA 16. Coordenadas geográficas dos pontos de coleta das amostras de água da Represa Guarapiranga.

\begin{tabular}{lccccc}
\hline Local de & \multicolumn{3}{c}{ Coordenada Geográfica } & \multicolumn{3}{c}{ Profundidade durante as amostragem (m) } \\
\cline { 2 - 6 } Amostragem & S & w & ago/11 & set/12 & abr/2013 \\
\hline GU000-01 & $23^{\circ} 46^{\prime} 49.6^{\prime \prime}$ & $46^{\circ} 47^{\prime} 22.0^{\prime \prime}$ & 0,5 & 2,6 & 3 \\
GU000-02 & $23^{\circ} 45^{\prime} 29.5^{\prime \prime}$ & $46^{\circ} 46^{\prime} 18.7^{\prime \prime}$ & 2,59 & 3,35 & 4,5 \\
GU-000-03 & $23^{\circ} 44^{\prime} 52.2^{\prime \prime}$ & $46^{\circ} 46^{\prime} 13.6^{\prime \prime}$ & 3 & 4 & 4 \\
GU106-04 & $23^{\circ} 44^{\prime} 44.6^{\prime \prime}$ & $46^{\circ} 45^{\prime} 25.8^{\prime \prime}$ & 5 & 5,5 & 6 \\
GU000-05 & $23^{\circ} 44^{\prime} 57.5^{\prime \prime}$ & $46^{\circ} 44^{\prime} 24.2^{\prime \prime}$ & 6,2 & 5 & 7 \\
*GU107-06 & $23^{\circ} 45^{\prime} 01.2^{\prime \prime}$ & $46^{\circ} 43^{\prime} 61.5^{\prime \prime}$ & 2,8 & 4 & 4 \\
GU108-07 & $23^{\circ} 43^{\prime} 64.7^{\prime \prime}$ & $46^{\circ} 43^{\prime} 42.3^{\prime \prime}$ & 2,2 & 4,9 & 3,5 \\
GU000-08 & $23^{\circ} 42^{\prime} 96.9^{\prime \prime}$ & $46^{\circ} 43^{\prime} 61.2^{\prime \prime}$ & 5 & 8 & 9 \\
GU109-09 & $23^{\circ} 43^{\prime} 04.6^{\prime \prime}$ & $46^{\circ} 43^{\prime} 34.0^{\prime \prime}$ & 7,5 & 4 & 6 \\
*GU105-10 & $23^{\circ} 42^{\prime} 89.9^{\prime \prime}$ & $46^{\circ} 44^{\prime} 68.7^{\prime \prime}$ & 4,97 & 8 & 9 \\
GU108-11 & $23^{\circ} 42^{\prime} 53.4^{\prime \prime}$ & $46^{\circ} 43^{\prime} 44.9^{\prime \prime}$ & 9 & 9,6 & 5 \\
GU103-12 & $23^{\circ} 41^{\prime} 88.5^{\prime \prime}$ & $46^{\circ} 44^{\prime} 67.3^{\prime \prime}$ & 3 & 3,9 & 4 \\
GU102-13 & $23^{\circ} 41^{\prime} 58.0^{\prime \prime}$ & $46^{\circ} 43^{\prime} 57.3^{\prime \prime}$ & 9,3 & 9,9 & 10 \\
*GU000-14 & $23^{\circ} 4078.2^{\prime \prime}$ & $46^{\circ} 43^{\prime} 55.9^{\prime \prime}$ & 8,7 & 8,85 & 10 \\
\hline
\end{tabular}

${ }^{*}$ Pontos de monitoramento da SABESP. 


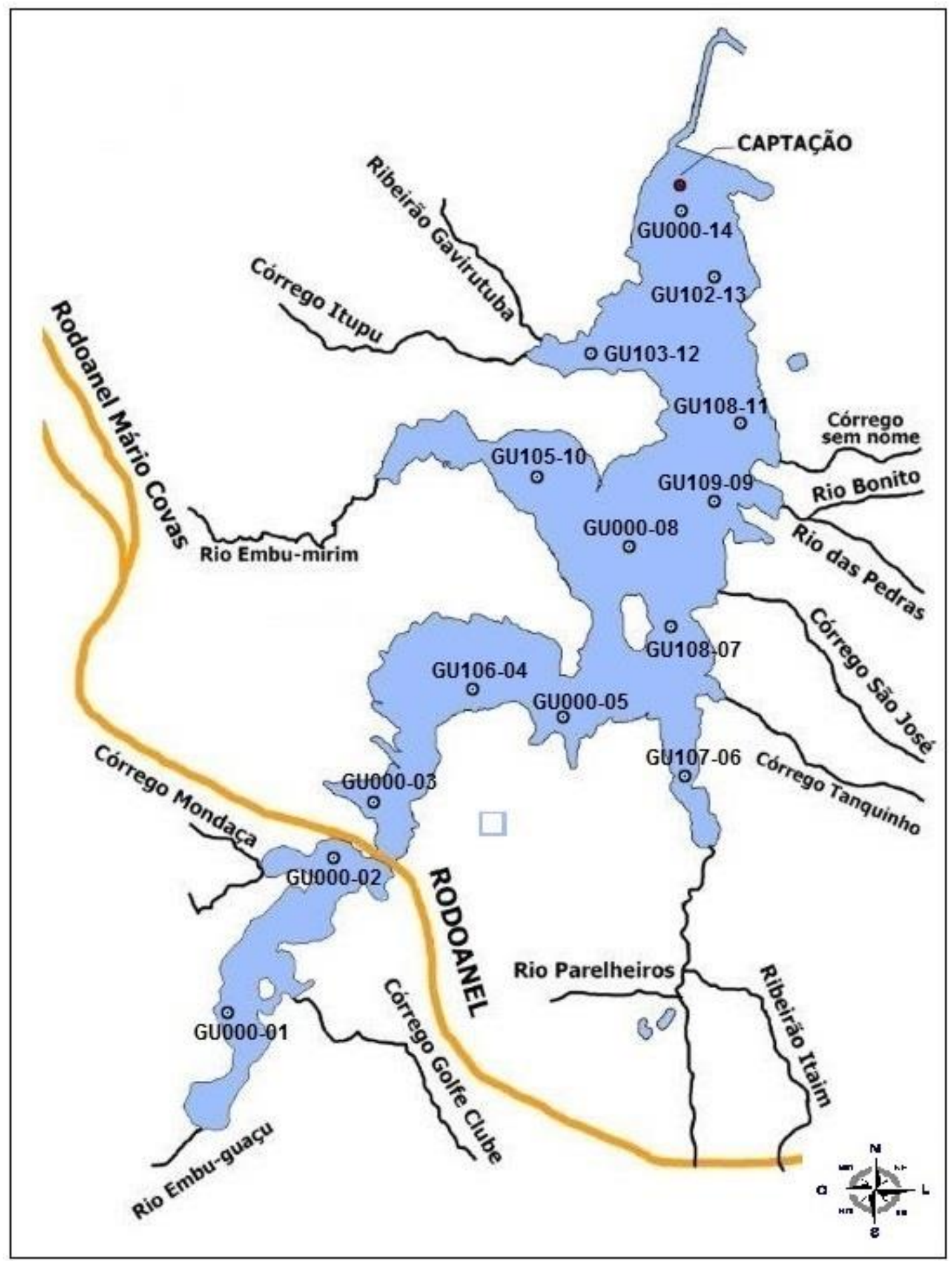

FIGURA 18. Localização dos pontos de coleta das amostras de água na represa Guarapiranga e seus tributários.

Nesse trabalho, os locais de coleta foram escolhidos estrategicamente para avaliar a contribuição dos tributários na contaminação das águas da Represa Guarapiranga. GU000-01 foi escolhido por receber as águas do rio Embu-Guaçu, o maior dos tributários, que drena uma área de 272 km², abrangendo o município 
de Embu-Guaçu e o extremo sul dos municípios de São Paulo e Itapecerica da Serra, além de uma pequena parcela de Juquitiba e São Lourenço da Serra. GU000-02 recebe as águas do córrego Mombaça; GU107-06 recebe as águas do rio Parelheiros que recebe a reversão das águas do braço Taquacetuba, da Represa Billings; em GU108-07 as águas do córrego Tanquinho e São José; em GU109-09 as águas dos rios das Pedras e Bonito; em GU105-10 as águas do rio Embu-Mirim e em GU103-12 as águas do córrego Itupu e ribeirão Guavirutuba.

As amostras de água da Represa Guarapiranga foram coletadas nos dias 02, 03, 04 e 29 de agosto de 2011; 11 de setembro de 2012 e 04 de abril de 2013. A amostragem do dia 4 foi interrompida e finalizada no dia 29 de agosto/2011, devido aos fortes ventos e chuvas que inviabilizaram a navegação da equipe com segurança. A amostragem de 2013, inicialmente programada para final de março, foi realizada em abril devido também aos fortes ventos e chuva.

As amostras de águas das represas: Cachoeira (CA), Atibainha (AT), Salto Grande (SG), Ribeirão do Pinhal (RP), Cabuçu (CB), Tanque Grande (TG) e Paiva Castro (PC) foram coletadas segundo o cronograma e as coordenadas geográficas apresentados na TAB. 17.

TABELA 17. Cronograma e a coordenada geográfica do local de coleta das amostras de água das represas: Paiva Castro, Ribeirão do Pinhal, Salto Grande, Atibainha, Cachoeira, Tanque Grande e Cabuçu.

\begin{tabular}{|c|c|c|c|c|}
\hline \multirow{2}{*}{ Represa } & \multirow{2}{*}{ Amostragem } & \multicolumn{2}{|c|}{ Coordenada Geográfica } & \multirow{2}{*}{$\begin{array}{c}\text { Data da } \\
\text { Coleta } \\
\end{array}$} \\
\hline & & $S$ & 0 & \\
\hline \multirow{2}{*}{ Paiva Castro } & PC2 & $23^{\circ} 19^{\prime} 43^{\prime \prime}$ & $46^{\circ} 38^{\prime} 11^{\prime \prime}$ & \multirow{2}{*}{$19 / 07 / 2013$} \\
\hline & PC4 & $23^{\circ} 19^{\prime} 49^{\prime \prime}$ & $46^{\circ} 40^{\prime} 37^{\prime \prime}$ & \\
\hline Ribeirão do Pinhal & RP3 & $22^{\circ} 39^{\prime} 35^{\prime \prime}$ & $47^{\circ} 16^{\prime} 47^{\prime \prime}$ & $23 / 07 / 2013$ \\
\hline \multirow[t]{2}{*}{ Salto Grande } & SG1 & $22^{\circ} 43^{\prime} 43^{\prime \prime}$ & $47^{\circ} 13^{\prime} 56^{\prime \prime}$ & \multirow{2}{*}{$23 / 07 / 2013$} \\
\hline & SG3 & $22^{\circ} 43^{\prime} 05^{\prime \prime}$ & $47^{\circ} 16^{\prime} 02^{\prime \prime}$ & \\
\hline \multirow[t]{2}{*}{ Atibainha } & AT3 & $23^{\circ} 11^{\prime} 12^{\prime \prime}$ & $46^{\circ} 22^{\prime} 51^{\prime \prime}$ & \multirow{2}{*}{$25 / 07 / 2013$} \\
\hline & AT6 & $23^{\circ} 10^{\prime} 46^{\prime \prime}$ & $46^{\circ} 21^{\prime} 25^{\prime \prime}$ & \\
\hline \multirow{2}{*}{ Cachoeira } & CA3 & $23^{\circ} 01^{\prime} 56^{\prime \prime}$ & $46^{\circ} 17^{\prime} 20^{\prime \prime}$ & \multirow{2}{*}{$26 / 07 / 2013$} \\
\hline & CA4 & $23^{\circ} 03^{\prime} 00^{\prime \prime}$ & $46^{\circ} 19^{\prime} 07^{\prime \prime}$ & \\
\hline Tanque Grande & TG1 & $23^{\circ} 22^{\prime} 27^{\prime \prime}$ & $46^{\circ} 27^{\prime} 36^{\prime \prime}$ & $22 / 08 / 2013$ \\
\hline Cabuçu & CB1 & $23^{\circ} 20^{\prime} 03^{\prime \prime}$ & $46^{\circ} 39^{\prime} 36^{\prime \prime}$ & $23 / 08 / 2013$ \\
\hline
\end{tabular}


As amostras de água superficial foram coletadas com garrafa de van Dorn horizontal, em PVC, (FIG. 19) e transferidas para frascos de vidro âmbar de 4 (quatro) litros, que foram selados com folha de alumínio e tampa de rosca. Os frascos de coleta foram previamente lavados e descontaminados. As amostras foram transportadas, para o laboratório, em caixas de isopor com gelo $\left( \pm 6^{\circ} \mathrm{C}\right)$. No laboratório, as amostras foram filtradas, em até 2 dias, com membranas de 0,45 $\mu \mathrm{m}$ para remoção de sólidos em suspensão e conservadas sob refrigeração. A extração, concentração e purificação dos fármacos de interesse foram realizadas em até 7 (sete) dias após a filtração (USEPA, 2007).

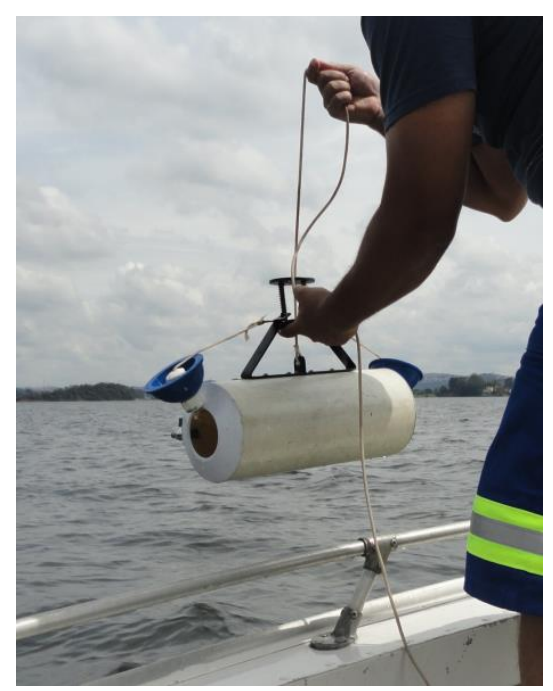

FIGURA 19. Garrafa de Van Dorn horizontal, em PVC, para coleta de amostra.

\subsection{Preparação das soluções de calibração mista de padrões das curvas analíticas}

Com a indisponibilidade de um padrão de referência com matriz similar às amostras desse estudo, foram preparadas duas curvas analíticas - curva analítica com solvente e curva analítica com matriz - para avaliar os parâmetros de validação da metodologia proposta e definir a curva analítica a ser utilizada na quantificação dos fármacos. As curvas analíticas foram construídas com 8 (oito) soluções de calibração com concentrações crescentes.

Inicialmente, preparou-se solução estoque individual de padrões, seguida da preparação das soluções de trabalho mista de padrões. Com diluições 
sucessivas das soluções de trabalho mista de padrões foram obtidas as soluções de calibração utilizadas para a construção da curva analítica.

As soluções estoque individuais de padrões foram preparadas em balão volumétrico de $10 \mathrm{~mL}$, devidamente calibrados, a partir de uma massa conhecida dos padrões analíticos de acetaminofeno, atenolol, bromazepam, cafeína, carbamazepina, ciproterona, clonazepam, clopidogrel, diclofenaco, enalapril, loratadina, losartana, midazolam, orfenadrina, propranolol e sildenafila, para obter uma concentração final de aproximadamente $200 \mu \mathrm{g} \mathrm{mL}^{-1}$.

A concentração do citalopram, clortalidona, paroxetina, rosuvastatina e valsartana presente como princípio ativo nos medicamentos de referência e genérico foi calculada com base na massa média de 10 comprimidos. Os comprimidos foram triturados em almofariz de porcelana e tomada uma massa conhecida do comporto para obter uma solução de concentração aproximada de $200 \mu \mathrm{g} \mathrm{mL}^{-1}$ em balão volumétrico de $10 \mathrm{~mL}$, devidamente calibrados.

Os padrões de acetaminofeno, atenolol, bromazepam, carbamazepina, ciproterona, citalopram, clonazepam, clortalidona, diclofenaco, enalapril, loratadina, midazolam, paroxetina e valsartana foram dissolvidos em solução de $\mathrm{MeOH} / \mathrm{H}_{2} \mathrm{O}(1: 1, v / v)$, enquanto os padrões de cafeína, clopidogrel, losartana, orfenadrina, propranolol, sildenafila e rosuvastatina dissolvidos em solução de $\mathrm{ACN} / \mathrm{H}_{2} \mathrm{O}(1: 1, \mathrm{v} / \mathrm{v})$.

Os padrões de benzoilecgonina e cocaína foram adquiridos em soluções de concentração 101 e $982 \mu \mathrm{g} \mathrm{mL}$, respectivamente. Para estes compostos foram preparadas soluções estoque individual tomando alíquotas das soluções dos padrões adquiridos e completando o volume a $2 \mathrm{~mL}$, utilizando micropipeta calibrada, com solução de $\mathrm{MeOH} / \mathrm{ACN} / \mathrm{H}_{2} \mathrm{O}(50: 25: 25$, v/v/v) para o benzoilecgonina e de $\mathrm{ACN} / \mathrm{H}_{2} \mathrm{O}(1: 1, \mathrm{v} / \mathrm{v})$ para a cocaína. A concentração das soluções estoque individual obtida foi de $50 \mu \mathrm{g} \mathrm{mL}^{-1}$ para benzoilecgonina e cocaína. 
Prepararam-se 3 (três) soluções de trabalho mista de padrões, em $\mathrm{ACN} / \mathrm{H}_{2} \mathrm{O}(1: 1, \mathrm{v} / \mathrm{v})$, de acordo com o intervalo de concentração esperado. Os diferentes intervalos de concentração nas curvas analítica são atribuídos ao processo de ionização dos compostos na interface do HPLC e o espectrômetro de massas.

A TAB. 18 apresenta a concentração das 8 (oito) soluções de calibração dos compostos estudados, preparados a partir das diluições sucessivas das soluções de trabalho mista de padrões, e que foram utilizadas para a construção das curvas analíticas com solvente e com matriz. As soluções preparadas foram armazenadas sob-refrigeração. 
TABELA 18. Concentrações das soluções de calibração das curvas analíticas com solvente e com matriz.

\begin{tabular}{lcccccccc}
\hline Composto & \multicolumn{7}{c}{ Concentração $\left(\mathrm{ng} \mathrm{mL}^{-1}\right)$} \\
\cline { 2 - 9 } & $\mathrm{P} 1$ & $\mathrm{P} 2$ & $\mathrm{P} 3$ & $\mathrm{P} 4$ & $\mathrm{P} 5$ & $\mathrm{P} 6$ & $\mathrm{P} 7$ & $\mathrm{P} 8$ \\
\hline Acetaminofeno & 5,01 & 15,00 & 50,01 & 70,07 & 100,02 & 140,03 & 170,14 & 199,55 \\
Atenolol & 5,02 & 15,03 & 50,09 & 70,17 & 100,17 & 140,24 & 170,40 & 199,85 \\
Benzoilecgonina & 5,01 & 15,00 & 50,00 & 70,05 & 100,00 & 140,00 & 170,10 & 199,50 \\
Bromazepam & 20,04 & 40,08 & 72,15 & 100,21 & 120,25 & 152,31 & 180,37 & 200,41 \\
Cafeína & 5,00 & 19,90 & 49,64 & 99,18 & 198,56 & 297,84 & 396,13 & 496,80 \\
Carbamazepina & 5,01 & 10,02 & 18,04 & 25,06 & 30,07 & 38,09 & 45,10 & 50,11 \\
Ciproterona & 5,01 & 10,01 & 18,02 & 25,03 & 30,03 & 38,04 & 45,05 & 50,05 \\
Citalopram & 5,00 & 10,01 & 18,01 & 25,02 & 30,02 & 38,02 & 45,03 & 50,03 \\
Clonazepam & 10,00 & 20,00 & 36,00 & 50,00 & 60,00 & 76,00 & 90,00 & 100,00 \\
Clopidogrel & 0,20 & 0,40 & 0,72 & 1,00 & 1,20 & 1,52 & 1,80 & 2,00 \\
Clortalidona & 5,00 & 10,00 & 18,01 & 25,01 & 30,01 & 38,01 & 45,02 & 50,02 \\
Cocaína & 5,04 & 20,04 & 50,00 & 99,90 & 200,00 & 300,00 & 399,00 & 500,40 \\
Diclofenaco & 5,00 & 10,00 & 17,99 & 24,99 & 29,99 & 37,99 & 44,98 & 49,98 \\
Enalapril & 5,01 & 10,02 & 18,03 & 25,04 & 30,05 & 38,06 & 45,07 & 50,08 \\
Loratadina & 10,02 & 20,05 & 36,09 & 50,12 & 60,15 & 76,19 & 90,22 & 100,25 \\
Losartana & 5,02 & 15,03 & 50,09 & 70,18 & 100,19 & 140,26 & 170,42 & 199,87 \\
Midazolam & 5,00 & 10,01 & 18,01 & 25,02 & 30,02 & 38,02 & 45,03 & 50,03 \\
Orfenadrina & 5,01 & 14,99 & 49,98 & 70,02 & 99,96 & 139,94 & 170,03 & 199,42 \\
Paroxetina & 20,00 & 39,99 & 71,99 & 99,99 & 119,98 & 151,98 & 179,97 & 199,97 \\
Propranolol & 5,00 & 10,00 & 17,99 & 24,99 & 29,99 & 37,99 & 44,98 & 49,98 \\
Rosuvastatina & 5,00 & 10,00 & 18,01 & 25,01 & 30,01 & 38,01 & 45,01 & 50,01 \\
Sildenafila & 30,00 & 60,00 & 107,99 & 149,99 & 179,99 & 227,98 & 269,98 & 299,98 \\
Valsartana & 5,00 & 10,00 & 18,00 & 25,00 & 29,99 & 37,99 & 44,99 & 49,99 \\
\hline
\end{tabular}

As soluções de calibração com matriz foram preparadas com os extratos de 4 (quatro) extrações em fase sólida de $250 \mathrm{~mL}$ de água cada, da represa Guarapiranga, seguindo o procedimento descrito em 5.4.1. A água coletada no ponto GU106-04 foi escolhida, para preparar as soluções de calibração da curva analítica com matriz, por apresentar menor número de fármacos de interesse e em concentrações mais baixas. Isto foi constatado nos ensaios preliminares realizados com a coleta de março de 2011. As soluções eluídas das 4 (quatro) extrações foram coletadas no mesmo recipiente e divididas em 9 partes iguais, sendo uma para a determinação do branco da matriz e as demais para a adição das soluções de calibração apresentadas na TAB. 18. 
Todas as soluções de calibração das curvas analíticas foram evaporadas até a secura e retomadas em $\mathrm{ACN}: \mathrm{H}_{2} \mathrm{O}(5: 95 ; \mathrm{v} / \mathrm{v})$.

\subsection{Procedimento Químico}

Para a determinação e quantificação dos compostos de interesse, as amostras de água da Represa Guarapiranga foram submetidas aos processos de extração em fase sólida, separação cromatográfica por HPLC acoplada à espectrometria de massas em sequência (MS/MS). A execução e otimização de cada etapa estão descritos nos ítens a seguir.

\subsubsection{Extração em fase sólida}

O procedimento de extração com o cartucho de SPE Strata ${ }^{\mathrm{TM}} X$ foi baseado no trabalho de BARREK et al. (2009) com algumas modificações. O procedimento otimizado consiste nas seguintes etapas:

a) Condicionamento do cartucho Strata ${ }^{\mathrm{TM}} X(3 \mathrm{~mL}, 200 \mathrm{mg})$ com:

- $3 \mathrm{~mL}$ de ACN, deixando a solução em contato com o material adsorvente do cartucho durante 2 minutos, para ativação;

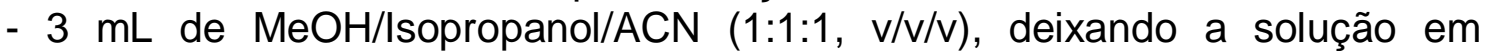
contato com o material adsorvente do cartucho durante 2 minutos; e

- $4 \mathrm{~mL}$ de água, deixando a solução em contato com o material adsorvente do cartucho durante 2 minutos.

b) Percolação de $250 \mathrm{~mL}$ da amostra com vazão de aproximadamente $5 \mathrm{~mL} \mathrm{~min}{ }^{-1}$,

c) Lavagem com $3 \mathrm{~mL}$ de água para eliminar impurezas.

d) Passagem de ar, durante 10 minutos, para eliminar água do cartucho.

e) Eluição com:

- $3 \mathrm{~mL}$ de MeOHI/Isopropanol/ACN (1:1:1, v/v/v), deixando a solução em contato com o material adsorvente do cartucho, durante 2 minutos, e

- $3 \mathrm{~mL}$ de ACN deixando a solução em contato com o material adsorvente do cartucho durante 2 minutos.

Os extratos foram evaporados, até a secura, em fluxo de ar e retomados com $250 \mu \mathrm{L}$ de $\mathrm{H}_{2} \mathrm{O}: \mathrm{ACN}$ (95:5; v/v), no dia da análise por LC-MS/MS. 


\subsubsection{Análise por LC-MS/MS}

\subsubsection{Separação cromatográfica}

A separação completa de todos os compostos alvos não é primordial para o método analítico com detecção por MS/MS, entretanto, busca-se sempre uma separação com melhor resolução para diminuir o efeito matriz. A redução do efeito matriz diminui a supressão ou aumento do sinal do analito provocado pela presença de impurezas da matriz (GROS, et al., 2008).

Os métodos analíticos de multi resíduos utilizam preferencialmente colunas mais curtas nas separações cromatográficas, para diminuir o tempo de análise e consequentemente a geração de rejeito orgânico (GROS, et al., 2006).

Na separação cromatográfica, fases móveis como a $\mathrm{ACN}, \mathrm{MeOH}$ ou a mistura de ambos solventes são utilizadas para diminuir o tempo de retenção e melhorar a resolução dos compostos alvos.

Sacher et al. (2001) recomendam também a utilização de ácidos e tampão, como modificadores de fases móveis, para obter uma retenção eficiênte do composto na coluna e melhorar a sensibilidade de detecção por MS. Os modificadores mais utilizados são os ácidos fórmico e acético e tampões de acetato de amônio e formiato de amônio.

O estudo da separação cromatográfica foi iniciado com a comparação do desempenho das colunas Allura PFP Propyl de dimensões $50 \times 2,1 \mathrm{~mm}$, com partícula de 5 $\mu \mathrm{m}$, Restek e Zorbax Eclipse XDB-C18 de dimensões 4,6x50 mm, com partícula de 1,8 $\mu \mathrm{m}$, Agilent. Para cada coluna foi utilizado um gradiente de eluição específico.

A separação cromatográfica na coluna Allura PFP Propyl foi baseada no procedimento iMethod ${ }^{\mathrm{TM}}$ Test for Cliquid $^{\circledR}$ Software, da Applied Biosystems. Utilizou-se como fase móvel $\underline{A}: \mathrm{H}_{2} \mathrm{O}+2 \mathrm{mM}$ de formiato de amonio $+0,2 \%$ de ácido fórmico e fase móvel $\underline{B}$ : $A C N+2 \mathrm{mM}$ de formiato de amônio $+0,2 \%$ de 
ácido fórmico. O gradiente de eluição utilizado foi o Gradiente_1 apresentado na TAB. 19 com a temperatura na coluna de $40^{\circ} \mathrm{C}$.

A separação cromatográfica na coluna Zorbax Eclipse XDB-C18 foi realizada com a fase móvel $\underline{A}: \mathrm{H}_{2} \mathrm{O}+1 \%$ de $\mathrm{ACN}+0,1 \%$ de ácido fórmico $+2 \mathrm{mM}$ de acetato de amônio e fase móvel $\underline{B}$ : $\mathrm{ACN}+1 \%$ de $\mathrm{H}_{2} \mathrm{O}+0,1 \%$ de ácido fórmico + $2 \mathrm{mM}$ de acetato de amônio. O gradiente de eluição utilizado foi o Gradiente_2 apresentado na TAB. $19 \mathrm{com}$ a temperatura na colluna de $25^{\circ} \mathrm{C}$.

As análises, com as colunas acima citadas, foram realizadas com injeção de $10 \mu \mathrm{L}$ da solução mista de padrões, com $50 \mathrm{ng} \mathrm{mL} \mathrm{L}^{-1}$ dos compostos alvos.

TABELA 19. Gradientes "1 e 2" de eluição utilizados na separação cromatográfica das colunas Allura PFP Propyl e Zorbax Eclise XDBC18, respectivamente.

\begin{tabular}{ccccc}
\hline \multicolumn{5}{c}{ Gradiente_1 } \\
\hline Etapas & $\begin{array}{c}\text { Tempo } \\
(\text { min. })\end{array}$ & $\begin{array}{c}\text { Vazão } \\
\left(\mu \mathrm{L} \mathrm{mim}^{-1}\right)\end{array}$ & $\%$ A & $\% \mathrm{~B}$ \\
\hline 1 & 0 & 500 & 90 & 10 \\
2 & 10 & 1000 & 10 & 90 \\
3 & 15 & 1000 & 10 & 90 \\
4 & 15,5 & 500 & 90 & 10 \\
5 & 17,5 & 500 & 90 & 10 \\
\hline \multicolumn{5}{c}{ Gradiente_2 } \\
\hline Etapas & Tempo & Vazão & $\%$ & $\% \mathrm{~B}$ \\
\hline 1 & 1 & 700 & 95 & 5 \\
3 & 0,5 & 700 & 95 & 5 \\
4 & 5 & 700 & 5 & 95 \\
5 & 6 & 700 & 5 & 95 \\
6 & 6,1 & 700 & 95 & 5 \\
7 & 8 & 700 & 95 & 5 \\
\hline
\end{tabular}


A comparação do desempenho das duas colunas mostrou que a coluna Zorbax Eclipse XDB-C18 resultou em picos mais estreitos, com maior intensidade (contagem/s.) e tempo de análise menor. Com isso, decidiu-se pela utilização da coluna Zorbax Eclipse XDB-C18 em todas as análises deste trabalho.

Com a coluna definida, o ensaio seguinte foi realizado para escolher a fase móvel. As fases móveis estudadas estão relacionadas a seguir:

Para as análises no modo electrospray positivo (ESI+) foram:

a) Fase $\mathrm{A}: \mathrm{H}_{2} \mathrm{O}+0,1 \%$ de ácido fórmico.

Fase B: ACN.

b) Fase $\mathrm{A}: \mathrm{H}_{2} \mathrm{O}+1 \%$ de $\mathrm{ACN}+0,1 \%$ de ácido fórmico $+2 \mathrm{mM}$ de Acetato de Amônio.

Fase $\mathrm{B}: \mathrm{ACN}+1 \%$ de $\mathrm{H}_{2} \mathrm{O}+0,1 \%$ de ácido fórmico $+2 \mathrm{mM}$ de Acetato de Amônio, e

c) Fase $\mathrm{A}: \mathrm{H}_{2} \mathrm{O}+0,1 \%$ de ácido fórmico $+2 \mathrm{mM}$ de Acetato de Amônio.

Fase B: ACN.

Para as análises no modo electrospray negativo (ESI-) foram:

d) Fase $\mathrm{A}: \mathrm{H}_{2} \mathrm{O}+5 \mathrm{mM}$ de Acetato de Amônio.

Fase B: ACN.

e) Fase $\mathrm{A}: \mathrm{H}_{2} \mathrm{O}+1 \%$ de $\mathrm{ACN}+0,1 \%$ de ácido fórmico $+2 \mathrm{mM}$ de Acetato de Amônio.

Fase $\mathrm{B}: \mathrm{ACN}+1 \%$ de $\mathrm{H}_{2} \mathrm{O}+0,1 \%$ de ácido fórmico $+2 \mathrm{mM}$ de Acetato de Amônio.

Em todos os ensaios foram injetadas $10 \mu \mathrm{L}$ da solução mista de padrões com $200 \mathrm{ng} \mathrm{mL}^{-1}$ dos compostos alvos e utilizado o gradiente de eluição 2 (TAB. 19).

\subsubsection{Espectrometria de massas (MS/MS)}

A FIG. 20 apresenta o esquema do sistema de ESI-MS/MS utilizado na detecção e quantificação dos compostos de interesse. 


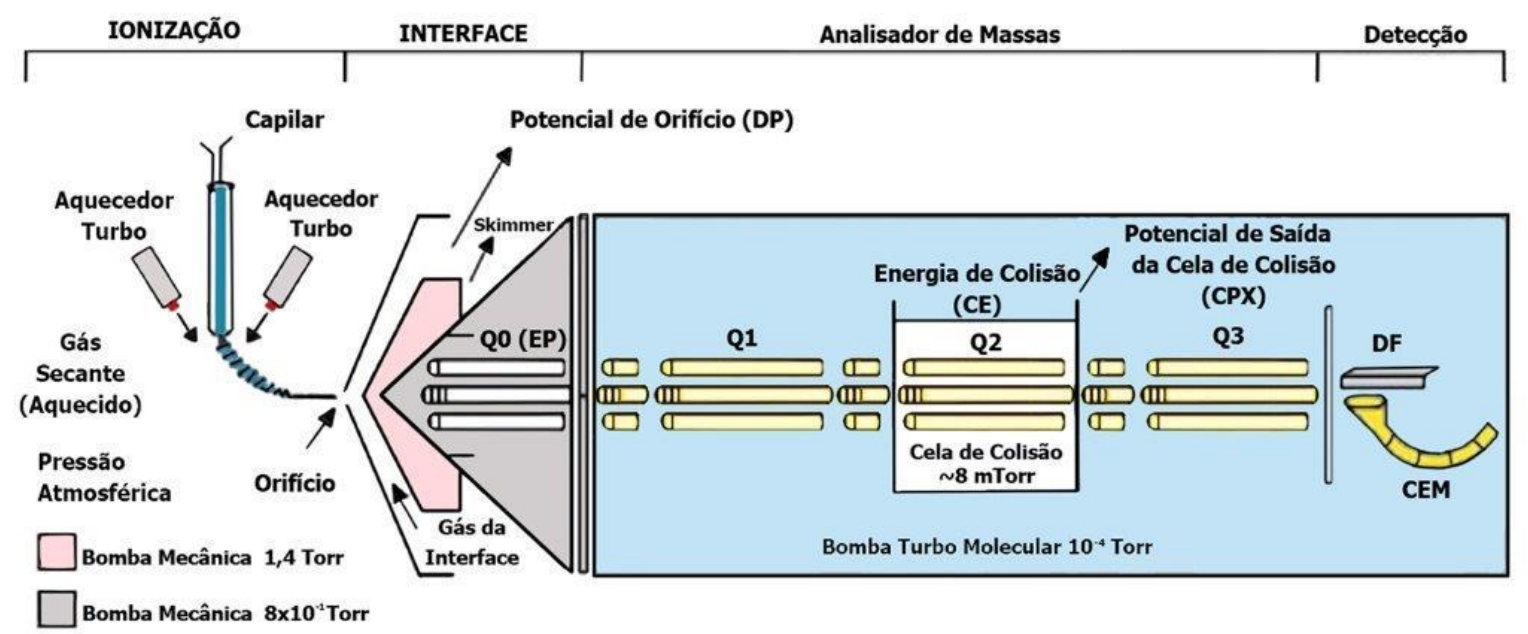

FIGURA 20. Esquema do sistema de ionização por eletronebulização acoplado ao espectrômetro triploquadrupolo. (MARTINS JUNIOR, et al., 2006)

A análise foi realizada no modo de MRM, onde os analisadores de massas Q1 (primeiro quadrupolo) e Q3 (terceiro quadrupolo) selecionam os íons precursores e produtos, respectivamente, definindo uma transição de $\mathrm{m} / \mathrm{z}$ específica. Os íons produtos são formados no Q2 (segundo quadrupolo), que atua como cela de colisão fragmentando os íons precursores, selecionados em Q1, por dissociação induzida por colisão (CID) com gás inerte sob uma energia específica.

A análise no modo MRM permite selecionar dois íons produtos mais intensos para cada íon precursor, sendo o primeiro íon produto mais intenso utilizado para a quantificação e, o segundo íon produto mais intenso para a confirmação do composto, conferindo desse modo um método confirmatório. Apresenta-se um exemplo no Apêndice A.

A escolha dos íons produtos para cada íon precursor e a otimização dos parâmetros de detecção dependentes dos compostos foram realizadas no modo de fluxo contínuo (infusão), $10 \mu \mathrm{L} \mathrm{mL}^{-1}$, das soluções individual de padrões (1 a $2 \mu \mathrm{g} \mathrm{mL}^{-1}$ ) no espectrômetro de massas.

Os parâmetros de detecção e dependente de cada composto analisado foram otimizados para obter a máxima eficiência de transmissão de sinal no modo 
de operação MRM. Esses parâmetros aplicados para o íon precursor e seus íons produtos podem ser visualizados na FIG. 19 e são:

- Potencial de Orifício (“Declustering Potential”, DP): é a diferença de potencial em volts (V) aplicada entre o orifício (orifice plate) e a superfície do cone (skimmer), região de interface entre a área de pressão atmosférica e sob vácuo a ser percorrida pelo íon formado a pressão atmosférica. Esse potencial direciona ou focaliza os íons precursores, previamente formados na fonte de íons a pressão atmosférica, para o quadrupolo de focalização (Q0). O potencial ideal deve minimizar a camada de solvatação dos íons, que resulta na diminuição da linha de base ou ruído de detecção, assim como, proporcionar uma eficiência de sinal de alta transmissão sem resultar na fragmentação das moléculas, fenômeno conhecido como "ion source fragmentation".

- Potencial de entrada ("Entrance Potential", EP): é a diferença de potencial em volts (V) aplicada entre o skimmer e o quadrupolo Q0, responsável por direcionar e focalizar os íons precursores para dentro da região de alto vácuo do filtro de massas (Q1).

- Potencial de entrada da cela de colisão ("Collision Cell Entrance Potential" CEP.): potencial em volts (V) aplicado na entrada da cela de colisão para focalizar os íons precursores direcionando para o segundo quadrupolo (Q2).

- Energia de colisão (“Collision Energy”, CE): é a energia em elétron volt (eV), que o íon precursor recebe quando entra na cela de colisão (Q2) para fragmentar ao colidir com moléculas de gás (nitrogênio, argônio, hélio). Nessa cela ocorre o processo de fragmentação controlada conhecida como CID (Collision Induced Dissociation).

- Potencial de saída da cela de colisão ("Collision Exit Potencial”, CXP): potencial em volts (V) aplicado na saída da cela de colisão para focalizar os íons fragmentados (íons produtos) direcionando para o terceiro quadrupolo (Q3). 
Os valores dos parâmetros dependentes dos compostos de interesse otimizados no espectrômetro de massas estão apresentados na TAB. 20.

TABELA 20. Parâmetros dependentes dos compostos otimizados para detecção por MS/MS no modo ESI(+) e ESI( -).

\begin{tabular}{|c|c|c|c|c|c|c|c|}
\hline \multirow{2}{*}{ Composto } & \multirow{2}{*}{ Q1 } & \multirow{2}{*}{ Q3 } & $\mathrm{DP}$ & $\mathrm{EP}$ & CEP & $\mathrm{CE}$ & $\mathrm{CXP}$ \\
\hline & & & $(V)$ & $(\mathrm{V})$ & $(\mathrm{V})$ & $(\mathrm{V})$ & (V) \\
\hline \multirow{2}{*}{ Acetaminofeno } & \multirow{2}{*}{152,1} & 109,9 & 26 & 9 & 12 & 19 & 4 \\
\hline & & 93,1 & 26 & 9 & 12 & 29 & 4 \\
\hline \multirow{2}{*}{ Atenolol } & \multirow{2}{*}{267,3} & 145,2 & 41 & 8 & 20 & 37 & 4 \\
\hline & & 190,3 & 41 & 8 & 20 & 25 & 4 \\
\hline \multirow{2}{*}{ Benzoilec gonina } & \multirow{2}{*}{290,2} & 168,2 & 31 & 3,5 & 14 & 25 & 4 \\
\hline & & 105,1 & 31 & 3,5 & 14 & 37 & 4 \\
\hline \multirow{2}{*}{ Bromazepam } & \multirow{2}{*}{316} & 182,2 & 51 & 3 & 14 & 41 & 4 \\
\hline & & 209,2 & 51 & 3 & 14 & 33 & 4 \\
\hline \multirow{2}{*}{ Cafeína } & \multirow{2}{*}{195,2} & 138,3 & 26 & 9 & 12 & 19 & 4 \\
\hline & & 110,1 & 26 & 9 & 12 & 29 & 4 \\
\hline \multirow{2}{*}{ Carbamazepina } & \multirow{2}{*}{237,1} & 194,2 & 36 & 9,5 & 16 & 43 & 4 \\
\hline & & 179,1 & 36 & 9,5 & 16 & 25 & 4 \\
\hline \multirow{2}{*}{ Citalpram } & \multirow{2}{*}{325,2} & 109,2 & 41 & 6 & 24 & 37 & 4 \\
\hline & & 262,1 & 41 & 6 & 24 & 25 & 4 \\
\hline \multirow{2}{*}{ Clonazepam } & \multirow{2}{*}{316,1} & 270,0 & 51 & 7,5 & 16 & 31 & 4 \\
\hline & & 214,2 & 51 & 7,5 & 16 & 47 & 4 \\
\hline \multirow{2}{*}{ Clopidogrel } & \multirow{2}{*}{322,2} & 212,2 & 31 & 9,5 & 18 & 23 & 4 \\
\hline & & 155,0 & 31 & 9,5 & 18 & 51 & 4 \\
\hline \multirow{2}{*}{ Clortalidona } & \multirow{2}{*}{336,94} & 189,9 & -35 & $-4,5$ & -14 & -22 & -2 \\
\hline & & 146,2 & -35 & $-4,5$ & -14 & -28 & -2 \\
\hline Cocaína & & 182,2 & 36 & 4 & 14 & 27 & 4 \\
\hline cocalna & 304,2 & 105,1 & 36 & 4 & 14 & 39 & 4 \\
\hline Diclofenaco & 2961 & 214,1 & 21 & 6,5 & 14 & 39 & 4 \\
\hline & 290,1 & 250,0 & 21 & 6,5 & 14 & 25 & 4 \\
\hline & 3773 & 234,2 & 36 & 6,5 & 16 & 27 & 4 \\
\hline EMalapm & 377,3 & 303,2 & 36 & 6,5 & 16 & 25 & 4 \\
\hline & 383.3 & 337,3 & 41 & 7,5 & 16 & 33 & 6 \\
\hline Loratadına & 383,3 & 267,1 & 41 & 7,5 & 16 & 41 & 4 \\
\hline Losartana & 4232 & 207,2 & 21 & 6 & 18 & 31 & 4 \\
\hline Losantana & 423,2 & 405,2 & 21 & 6 & 18 & 17 & 6 \\
\hline Midazolam & 3261 & 291,2 & 51 & 7,5 & 12 & 33 & 4 \\
\hline IVIUdzOIdII & $3<0,1$ & 249,1 & 51 & 7,5 & 12 & 44 & 4 \\
\hline Paroxetina & 3302 & 192,2 & 41 & 8,5 & 14 & 27 & 4 \\
\hline & 330,2 & 135,1 & 41 & 8,5 & 14 & 54 & 4 \\
\hline Propranolol & 2602 & 116,0 & 41 & 2,5 & 20 & 23 & 4 \\
\hline rToplanotol & 200,2 & 183,0 & 41 & 2,5 & 20 & 23 & 4 \\
\hline Rosuvastatina & 4822 & 258,2 & 61 & 6,5 & 20 & 41 & 4 \\
\hline Rosuvastauna & 402,2 & 270,2 & 61 & 6,5 & 20 & 47 & 4 \\
\hline Sildenafil & 4753 & 100,0 & 51 & 8,5 & 22 & 37 & 4 \\
\hline shuenail & 475,3 & 283,2 & 51 & 8,5 & 22 & 47 & 4 \\
\hline Valsartana & 4363 & 235,1 & 21 & 12 & 22 & 25 & 4 \\
\hline 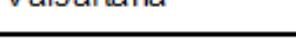 & 400,0 & 207,1 & 21 & 12 & 22 & 33 & 4 \\
\hline
\end{tabular}

Q1 (Primeiro quadrupolo); Q3 (Terceiro quadrupolo); DP (Declustering Potential); EP (Entrance Potential); CEP (Collision Cell Entrance Potential); CE (Collision Energy); CXP (Collision Exit Potential) Modo ESI - utilizou o Scheduled MRM ${ }^{T M}$ Algorithm para otimizar o dwell time Modo ESI - utilizou 100 ms de Dwell Time

Collision Gas Dissociation $\left(N_{2}\right)=8$ a.u 
Os parâmetros dependentes da fonte de ionização otimizados para as análises tanto no modo de $\mathrm{ESI}(+)$ como $\mathrm{ESI}(-)$ foram: 20 a.u. de gás da interface ("Curtain Gas"), $650{ }^{\circ} \mathrm{C}$ de temperatura da fonte ("Source Temperature"), 45 a.u. de gás 1 nebulizador ("Gas 1 nebulizer"), 65 a.u. de gás 2 aquecimento ("Gas 2 Heater") e 8 a.u. de gás $\left(\mathrm{N}_{2}\right)$ de colisão para dissociação ("Collision Gas Dissociation $\mathrm{N}_{2}$ "). As voltagens da ESI ("Ion Spray Voltage") utilizadas nas análises foram de 5500V e -4500V nos modos de ESI(+) e ESI(-), respectivamente.

Outro parâmetro também importante é o tempo de aquisição (dwell time) das transições, selecionadas no modo MRM, durante cada ciclo.

Para obter um pico cromatográfico com resolução adequada e melhor fator de resposta das medições, o tempo de aquisição das transições no modo MRM com ESI(+) foi monitorado com o recurso "Schedule MRM TM" Algorithm do programa de aquisição de dados Analyst ${ }^{\circledR}$ versão 1.5. Este recurso é especialmente importante quando se monitora um grande número de transições por permitr a otimização automática dos tempos do ciclo e aquisição para as condições de sensibilidade, exatidão e reprodutibilidade mais elevadas.

No modo MRM com ESI(-) foi monitorado apenas um composto e foi utilizados 100 milisegundos de tempo de aquisição.

A fonte de ionização quimica a pressão atmosférica (APCI) também foi estudada, entretanto para a maioria dos compostos de interesse, a sensibilidade foi aproximadamente 10 vezes menor que na ionização por electrospray (ESI).

\subsection{Validação da Metodoligia}

A validação da metodologia proposta foi realizada utilizando-se os parâmetros de: seletividade, efeito matriz, faixa de trabalho, linearidade, limite de detecção (LD), limite de quantificação (LQ), precisão, exatidão, recuperação e robustez. 
A avaliação dos parâmetros de validação foi realizada com as áreas dos picos dos compostos de interesse obtidas das soluções de calibração, das curvas analíticas com solvente e com matriz. O número de solução de calibração em cada curva foi 8 (oito) e cada uma analisada sete vezes para permitir o uso adequado dos testes estatísticos e proporcionar uma comparação válida. Os cálculos estatísticos foram realizados na planilha Excel, elaborada por FURUSAWA (2007), seguindo as orientações dos documentos do INMETRO (2003) e suas revisões INMETRO (2007), INMETRO (2010) e INMETRO (2011).

\subsubsection{Seletividade e efeito matriz}

A seletividade foi avaliada seguindo a orientação da Comissão Européia (EUROPEAN COMMISSION, 2002), isto é, adotando o sistema de PI. Utilizaram-se também os critérios de que a intensidade relativa e o tempo de retenção dos íons produtos na amostra não apresente variação superior a $20 \%$ e $2 \%$, respectivamente, quando comparados com os do padrão de referência.

$\mathrm{Na}$ ausência do íon precursor na amostra, utilizou-se a área do íon precursor na solução mista de padrões preparada com matriz e na concentração de $50 \mathrm{ng} \mathrm{mL}^{-1}$ dos compostos de interesse.

O estudo do efeito matriz foi realizado com os valores das áreas dos picos dos compostos de interesse obtidos nas análises das 8 (oito) soluções de calibração da curva analítica com solvente e com matriz. Inicialmente esses valores foram submetidos ao teste $F$-Snedecor, para avaliar a homogeneidade das variâncias nas medidas e depois ao teste t-Student para estudar a significância da diferença das médias (INMETRO, 2007; OTOMO, 2010).

Os valores de $\mathrm{F}$ foram calculados pela equação:

$$
\mathrm{F}=\frac{\mathrm{S}_{1}^{2}}{\mathrm{~S}_{2}^{2}}
$$


Onde: $\mathrm{S}_{1}{ }^{2}$ e $\mathrm{S}_{2}{ }^{2}$ são as variâncias das áreas das 7 (sete) análises de cada solução de calibração da curva analítica com matriz e com solvente, com a maior variância no numerador.

Os valores de $F$ calculado $\left(F_{\text {calc }}\right)$ pela Eq. 2 foram comparados com 0 valor de $F$ tabelado $\left(F_{\text {tab }}\right)$. Neste estudo, o valor de $F_{\text {tab }}$ é 4,28 (6 graus de liberdade (n-1) e 95\% de nível de confiança). Onde n é o número de medidas.

Quando o valor de $F_{\text {calc }}$ é menor que o valor de $F_{\text {tab, conclui-se que a }}$ matriz não tem efeito sobre a precisão do método na faixa de concentração estudada. A matriz exerce um efeito significativo sobre a precisão do método, quando o valor de $F_{\text {calc }}$ é maior que o valor de $F_{t a b}$.

Os valores de t foram calculados pela equação:

$$
\mathrm{t}_{\text {calc }}=\frac{\left|\overline{\mathrm{x}_{1}}-\overline{\mathrm{x}}_{2}\right|}{\sqrt{S^{2}\left(\frac{1}{n_{1}}+\frac{1}{n_{2}}\right)}}
$$

Onde: $\quad \overline{\mathrm{x}}_{1}$ e $\overline{\mathrm{x}}_{2}$ são as médias das áreas obtidas nas 7 (sete) análises de cada solução de calibração com matriz e com solvente na mesma faixa de concentrações;

$\mathrm{n}_{1}$ e $\mathrm{n}_{2}=$ número de análise para cada solução de calibração com matriz e com solvente.

$\mathrm{O}$ teste $\mathrm{t}$, como o teste $\mathrm{F}$, consiste em comparar os valores de $t_{\text {calc }}$ obtidos pela Eq. 2 com o valor de $t$ tabelado ( $\left.t_{t a b}\right)$. $O$ valor de $t_{t a b}$ depende do resultado do teste $\mathrm{F}$ para definir o grau de liberdade.

Para valor de $F_{\text {calc }}$ menor que $F_{\text {tab }}$ foi considerado o grau de liberdade dado por $\left(n_{1}+n_{2}-2\right)$. Nesse trabalho, o valor de $t_{\text {tab }}$ foi de 2,179 (12 graus de liberdade e $95 \%$ de nível de confiança). 
Para valor de $F_{\text {calc }}$ maior que $F_{\text {tab, }}$ o grau de liberdade foi calculado por:

$$
v=\frac{\left(\frac{s_{1}^{2}}{n_{1}}+\frac{s_{2}^{2}}{n_{2}}\right)^{2}}{\frac{\left(\frac{s_{1}^{2}}{n_{1}}\right)^{2}}{n_{1}+1}+\frac{\left(\frac{s_{2}^{2}}{n_{2}}\right)^{2}}{n_{2}+1}}-2
$$

Equação 4

Nesse trabalho, o valor $t_{\text {tab }}$ foi de 2,571 (6,2 graus de liberdade e $95 \%$ de confiança).

De maneira semelhante ao teste $F$, para valores de $t_{c a l c}<t_{t a b}$ a matriz não tem efeito significativo sobre a precisão do método na faixa de concentração em estudo, enquanto que para valores de $t_{c a l c}>t_{t a b}$, a matriz exerce efeito sobre os resultados obtidos.

\subsubsection{Linearidade e faixa de trabalho}

A faixa linear de trabalho para cada composto foi avaliada através dos respectivos coeficientes de determinação $\left(r^{2}\right)$ das curvas analíticas preparadas com solvente e com matriz. Um valor de $\mathrm{r}^{2}$ superior 0,90 é recomendado para que a curva analítica possa ser utilizada na quantificação (INMETRO, 2003).

Para verificar se todos os pontos utilizados estão dentro da faixa linear de trabalho, realizou-se a análise de resíduos através do teste $t$-Student, gráfico de resíduos e da probabilidade normalizada. $O$ vaor de t foi calculado por:

$$
t_{\text {calculado }}=\frac{\text { resíduo }}{s_{r} / \sqrt{n}}
$$

Onde: $\quad$ resíduo $=\left|x_{\text {nominal }}-x_{\text {obtido }}\right|$;

$s_{r}=$ desvio padrão dos resíduos;

$n$ = número de soluções de calibração na curva analítica. 
O valor de ttab foi obtido da tabela de distribuição de Student considerando (n-1) graus de liberdade e 95\% de nível de confiança. Onde n é o número de soluções de calibração na curva analítica. Nesse trabalho, o tab foi de 2,365 (7 graus de liberdade e 95\% de confiança).

Para valor de $t_{c a l c} \leq t_{t a b}$, o valor foi considerado pertencente à curva e a faixa de trabalho em estudo, linear.

\subsubsection{Limite de detecção (LD) e quantificação (LQ)}

Os cálculos dos limites de detecção (LD) e quantificação (LQ) foram obtidas das 7 (sete) medidas da solução de calibração, de menor concentração do composto, da curva analítica com matriz (INMETRO, 2003).

A equação utilizada para calcular o LD foi:

$$
\boldsymbol{L D}=\boldsymbol{t}_{(\boldsymbol{n}-1,1-\propto)} \cdot(\boldsymbol{s}) \quad \text { Equação } 6
$$

Onde: $\quad t=2,447$ (6 gruas de liberdade ( $\mathrm{n}-1)$ e $95 \%$ de confiança);

$s=$ desvio padrão das 7 (sete) medidas da solução de calibração de menor concentração do composto.

O limite de quantificação (LQ) do método foi calculado por:

$$
L Q=X+5 s
$$

Equação 7

Onde: $\quad X=$ média dos valores das 7 (sete) medidas da solução de calibração da curva analítica com menor concentração;

$s=$ desvio padrão das 7 (sete) medidas da solução calibração de menor concentração do composto.

\subsubsection{Precisão}

A precisão do método foi avaliada por meio dos valores de coeficiente de variação $(C V)$, limite de repetibilidade $(r)$ e limite de reprodutibilidade $(R)$ das 7 (sete) medidas nas soluções de calibração, em 3 (três) níveis de concentrações dos compostos (baixo, médio e alto), das curvas analíticas com matriz. As equações utilizadas foram: 


$$
\begin{array}{ll}
C V(\%)=\frac{s}{X} \cdot 100 & \text { Equação } 8 \\
r=2,8 \cdot S_{r} & \text { Equação } 9 \\
R=2,8 \cdot \sqrt{S_{r}{ }^{2}} & \text { Equação } 10
\end{array}
$$

Onde: $\quad s=$ desvio padrão das 7 (sete) medidas das soluções de calibração nos 3 (três) níveis de concentrações dos compostos;

$X=$ média dos valores das 7 (sete) medidas das soluções de calibração nos 3 (três) níveis de concentrações dos compostos;

$S_{r}=$ desvio padrão das replicatas utilizadas no ensaio da repetibilidade;

$\mathrm{S}_{\mathrm{r}}^{2}=$ variância das replicatas utilizadas no ensaio de reprodutibilidade.

\subsubsection{Exatidão}

A exatidão do método foi verificada com a aplicação do índice $Z$ (Z-score), seguindo a orientação do INMETRO (2003; 2011).

A equação utilizada para calcular o valor de $Z$ foi:

$$
Z=\frac{\left(X_{l a b}-X_{v}\right)}{s}
$$

Equação 11

Onde: $\quad \mathrm{X}_{\mathrm{lab}}=$ valor obtido experimentalmente ou a média dos valores;

$\mathrm{X}_{\mathrm{V}}=$ valor aceito como verdadeiro;

$\mathrm{s}=$ desvio padrão do conjunto de valores em questão

O valor de $Z$ foi avaliado pelo seguinte critério:

$\mathrm{Z} \leq 2$ = resultado satisfatório;

$2<Z \leq 3$ = resultado questionável;

Z > 3 = resultado insatisfatório. 


\subsubsection{Recuperação}

O ensaio de recuperação consistiu em adicionar uma alíquota conhecida da solução de calibração na amostra coletada (GU106-04), para obter no volume final de $250 \mathrm{~mL}$, concentrações dos compostos em estudo no nível de ng $\mathrm{L}^{-1}$. A seguir, submeter a amostra ao procedimento descrito no item $5.4 \mathrm{e}$ determinar a concentração para confrontar com o valor esperado.

A recuperação foi avaliada em 3 (três) níveis de concentrações com cada nível em triplicata. Assim, alíquotas das soluções de calibração P2, P4 e P7 (TAB. 18) foram adicionadas na amostra de agua da represa, para obter no final do procedimento, na solução de analise, valores de concentrações: próximo ao primeiro, médio e último ponto da curva analítica.

A recuperação percentual dos compostos foi calculada por:

$$
\% \text { Recuperação }=\frac{\text { valor obtido }}{\text { valor adicionado }} \times 100
$$

Equação 12

\subsubsection{Robustez}

A robustez do método foi estudada com a aplicação do teste de Youden (VANDER HEYDEN, et al., 2001), que consiste na seleção de 7 (sete) parâmetros de influência significativa sobre o método e planejamento dos ensaios de acordo com uma combinação fatorial, que resultam em 8 ensaios distintos.

Os parâmetros selecionados e seus respectivos valores para o ensaio da robustez, deste trabalho, são apresentados na TAB. 21.

TABELA 21. Parâmetros selecionados para estudo da robustez.

\begin{tabular}{lcc}
\hline \multicolumn{1}{c}{ Parâmetro } & \multicolumn{2}{c}{ Valor } \\
\cline { 2 - 3 } & Nominal & Variação \\
\hline Lavagem-SPE & $3 \mathrm{~mL}$ & $0 \mathrm{~mL}$ \\
Volume de eluição -SPE & $6 \mathrm{~mL}$ & $4 \mathrm{~mL}$ \\
Vazão - HPLC & $700 \mu \mathrm{L}$ & $710 \mu \mathrm{L}$ \\
Temperatura - coluna & $25^{\circ} \mathrm{C}$ & $27^{\circ} \mathrm{C}$ \\
Volume de injeção & $10 \mu \mathrm{L}$ & $15 \mu \mathrm{L}$ \\
Posição da Sonda & 1 & 0 \\
Temperatura de ionização & $650^{\circ} \mathrm{C}$ & $630^{\circ} \mathrm{C}$ \\
\hline
\end{tabular}


Na TAB. 22 é apresentada a combinação fatorial em que os ensaios da robustez foram realizados. Nesta combinação, as letras maiúsculas representam o valor nominal dos parâmetros e as letras minúsculas as suas respectivas variações.

TABELA 22. Combinação fatorial para o estudo da robustez, segundo Youden.

\begin{tabular}{|c|c|c|c|c|c|c|c|c|}
\hline \multirow{2}{*}{$\begin{array}{l}\text { Valor do } \\
\text { Parâmetro }\end{array}$} & \multicolumn{8}{|c|}{ Combinação Ensaiada } \\
\hline & 1 & 2 & 3 & 4 & 5 & 6 & 7 & 8 \\
\hline A ou a & $\bar{A}$ & $\bar{A}$ & $\bar{A}$ & $\bar{A}$ & $a$ & $a$ & $\bar{a}$ & $a$ \\
\hline B ou b & B & B & $b$ & $b$ & $\mathrm{~B}$ & B & $b$ & $b$ \\
\hline C ou c & C & c & $\mathrm{C}$ & c & $\mathrm{C}$ & c & C & c \\
\hline D oud & D & D & $d$ & d & $d$ & d & D & $\mathrm{D}$ \\
\hline E oue & $E$ & e & $E$ & e & e & $E$ & e & $E$ \\
\hline F ouf & $\mathrm{F}$ & $f$ & $f$ & $\mathrm{~F}$ & $\mathrm{~F}$ & $f$ & $f$ & $\mathrm{~F}$ \\
\hline Goug & G & $g$ & $g$ & G & $g$ & G & G & $g$ \\
\hline Resultado & $\mathrm{s}$ & $\mathrm{t}$ & $\mathrm{u}$ & $\mathrm{v}$ & w & $x$ & $y$ & $z$ \\
\hline
\end{tabular}

O cálculo do efeito de um parâmetro com a sua variação foi calculado por:

Exemplo: $\quad$ Efeito de $\mathrm{C} / \mathrm{c}=(\mathrm{s}+\mathrm{u}+\mathrm{w}+\mathrm{y}) / 4-(\mathrm{t}+\mathrm{v}+\mathrm{x}+\mathrm{z}) / 4$

$O$ estudo da robustez foi realizado com a amostra coletada no ponto GU106-04 adicionado da solução de calibração P4 (TAB. 18). Os 8 (oito) ensaios foram submetidos a todo o procedimento descrito em 5.4, obedecendo as mudanças nas variáveis acima descrito.

As médias das triplicatas de cada ensaio foram avaliadas utilizando-se os cálculos da planilha elaborada por FURUSAWA (2007) e também adotada por (BRITO, 2009; OTOMO, 2010; SOUZA, 2011; OLIVEIRA, 2012) para avaliar a robustez do método e indicar a magnitude da influência de cada fator nos resultados finais.

\subsection{Incerteza nas medições químicas}

Os cálculos da estimativa das incertezas nas concentrações dos compostos quantificados (grandezas de saída), nas amostras de água da 
Represa Guarapiranga foram baseados nas orientações do Guia EURACHEM (2002; 2012)

As grandezas de saída foram determinadas por LC-MS/MS seguindo o procedimento da FIG. 14 e calculadas pela Eq. 13, que apresenta a sua relação com as grandezas de entrada (fontes de incertezas).

$$
C_{F}=C_{0} \frac{V_{f}}{V_{i} \times R} \times 1000
$$

Equação 13

Onde: $\quad C_{F}=$ concentração do composto na amostra em $n g \mathrm{~L}^{-1}$,

$\mathrm{C}_{0}=$ concentração do composto na alíquota analisada em $\mathrm{ng} \mathrm{L}^{-1}$,

$V_{f=}$ volume final da solução de análise em $\mathrm{mL}$,

$V_{i}=$ volume inicial da amostra em $\mathrm{mL}$.

As fontes de incertezas (grandezas de entrada) são a concentração do composto na alíquota analisada, a curva analítica, a recuperação, o volume final e inicial da amostra e, foram identificadas pelo diagrama de causa e efeito apresentado na FIG. 21.

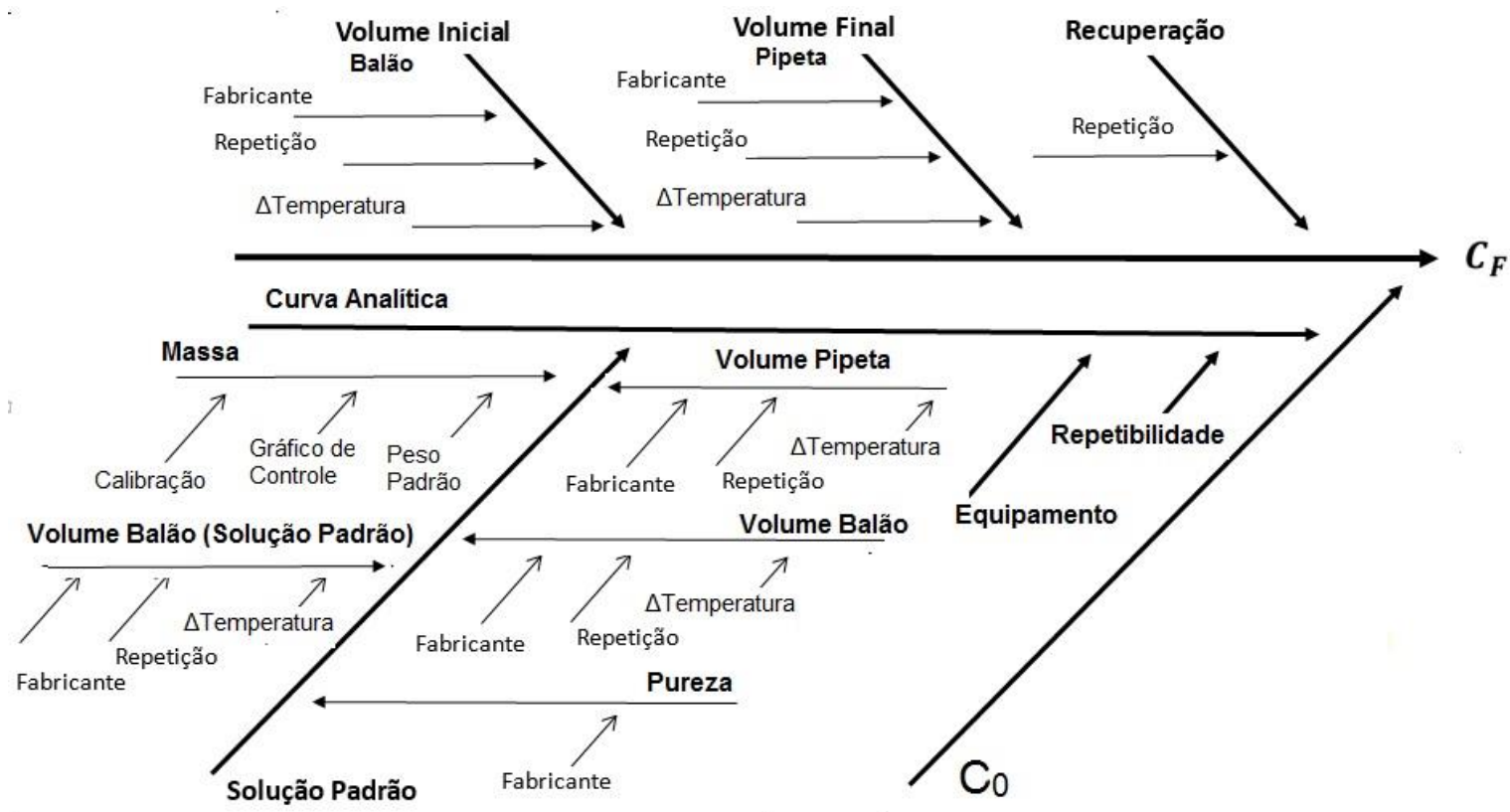

FIGURA 21. Diagrama de causa e efeito das fontes de incertezas associadas nas determinações das concentrações dos compostos por LC-MS/MS. 


\subsubsection{Incertezas associada à concentração do composto $\left(C_{0}\right)$ na alíquota analisada}

Nesta etapa, as grandezas de entrada foram associadas à preparação da solução estoque individual de padrões, solução de trabalho mista de padrões , às sucessivas diluições para a obtenção das soluções de calibração e às respectivas áreas obtidas como resposta do equipamento.

Todas as amostras foram preparadas em triplicatas e cada preparação analisada 3 (três) vez. As solução de calibração, da curva analítica, foram também analisadas 3 (três) vezes.

A incerteza da concentração do composto na alíquota analisada foi calculada pela Eq. 14.

$$
u\left(C_{0}\right)=\frac{S}{B_{1}} \sqrt{\frac{1}{n}+\frac{1}{m}+\frac{\left(C_{0}-\bar{c}\right)^{2}}{Q_{x x}}} \quad \text { Equação } 14
$$

Onde: $\quad u\left(C_{0}\right)=$ incerteza associada à determinação da concentração do composto na alíquota analisada;

$B_{1}=$ coeficiente angular da função calibração;

$n=$ número de medições para determinar $C_{0}$;

$m=$ número total de medições das curvas analíticas;

$C_{0}=$ concentração do composto na alíquota analisada $\left(\mu \mathrm{g} \mathrm{mL}^{-1}\right)$;

$S=$ desvio padrão residual, dada por:

$$
S=\sqrt{\sum_{j=1}^{m} \frac{\left(A_{j}-\left(B_{0}+B_{1} C_{1}\right)\right)^{2}}{m-2}}
$$

Onde: $A_{j}=$ área do composto em cada solução de calibração da curva analítica;

$B_{0}=$ coeficiente linear da função calibração;

$C_{1}=$ concentração real do composto em cada solução de calibração da curva analítica;

$Q_{x x}=$ somatória dada por: 


$$
Q_{x x}=\sum_{i=1}^{m}\left(C_{j}-\bar{c}\right)^{2}
$$

Equação 16

Onde: $\quad C_{j}=$ concentração medida do composto em cada solução de calibração da curva analítica, e

$\bar{c}=$ valor médio da concentração do composto nas soluções de calibração.

\subsubsection{Incerteza associada à curva analítica}

As soluções de calibração foram preparadas a partir de diluições sucessivas das soluções de trabalho mista de padrões, que por sua vez foram preparadas a partir das soluções estoque individual de padrões.

\subsection{Incerteza combinada da preparação da solução estoque Individual} do padrão

As fontes de incertezas envolvidas na preparação das soluções estoque individual de padrões estão relacionadas na Eq. 17, conforme o diagrama da FIG. 20.

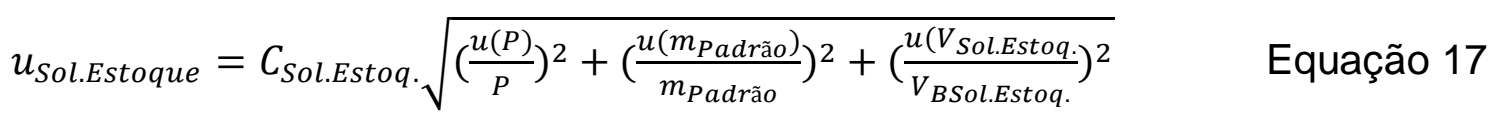

Onde: $\quad C_{\text {Sol.Estoq. }}=$ concentração calculada da solução estoque individual do padrão; $u(P)=$ incerteza da pureza do padrão fornecida pelo fabricante; $P=$ pureza do padrão; $u\left(m_{\text {Padão }}\right)=$ Incerteza associada à massa do padrão; $m_{P}=$ massa do padrão; $u\left(V_{\text {Sol.Estoq. }}\right)=$ incerteza do volume final da solução estoque individual do padrão;

$V_{\text {Sol.Estoq. }}=$ volume final da solução estoque individual do padrão.

$\mathrm{Na}$ estimativa da incerteza associada à massa do padrão foram consideradas as incertezas da repetitividade $(\mu($ repe $))$, do peso padrão (u(PesoPadrão)) e da balança (u(Calib.Balança)), calculada pela Eq. 18.

$$
u\left(m_{\text {Padrão }}\right)=\sqrt{(u(\text { repe }))^{2}+(u(\text { PesoPadrão }))^{2}+(u(\text { Calib.Balança }))^{2}} \quad \text { Equação } 18
$$


$\mathrm{Na}$ estimativa da incerteza associada ao volume do balão volumétrico foram consideradas as incertezas informadas pelo fabricante $(u(f a b)$.$) , repetições$ $(u($ repe $))$, variação de temperatura $(u(\Delta T))$ e coeficiente de dilatação do vidro (u(Coef.Dil.)), calculada pela Eq. 19.

$u\left(V_{\text {Sol.Estoq. }}\right)=\sqrt{\left(u(f a b .)^{2}+(u(\text { repe }))^{2}+(u(\Delta T))^{2}+\left(u(\text { Coef.Dil. })^{2}\right.\right.} \quad$ Equação 19

\subsection{Incerteza combinada da preparação da solução de trabalho mista de padrões}

As fontes de incertezas envolvidas na preparação das soluções de trabalho mista de padrões estão relacionadas na Eq. 20.

$u_{\text {Sol.Trab. }}=C_{\text {Sol.Trab. }} \sqrt{\left(\frac{u\left(V_{\text {Sol.Estoq. }}\right)}{V_{\text {Sol.Estoq }}}\right)^{2}+\left(\frac{u\left(V_{\text {Sol.Trab. }}\right)}{V_{\text {Sol.Trab. }}}\right)^{2}+\left(\frac{u\left(C_{\text {Sol.Estoq. }}\right)}{C_{\text {Sol.Estoq. }}}\right)^{2}} \quad$ Equação 20

Onde: $\quad u\left(V_{\text {Sol.Estoq. }}\right)=$ incerteza do volume pipetado da solução estoque individual do padrão;

$V_{\text {Sol.Estoq. }}=$ volume pipetado da solução estoque individual do padrão;

$u\left(V_{\text {Sol.Trab. }}\right)=$ incerteza do volume final da solução de trabalho mista de padrões;

$V_{\text {Sol.Trab. }}=$ volume final da solução de trabalho mista de padrões,

$u\left(C_{\text {Sol.Estoq. }}\right)=$ incerteza da preparação da solução estoque individual do padrão;

$c_{\text {Sol.Estoq. }}=$ concentração da solução estoque individual do padrão;

$C_{\text {Sol.Trab. }}=$ concentração da solução de trabalho mista de padrões, calculada por:

$$
C_{\text {Sol.Trab.. }}=C_{\text {Sol.Estoq. }} \frac{V_{\text {Sol.Estoq. }}}{V_{\text {Sol.Trab. }}}
$$

Nos cálculos de $u\left(V_{\text {Sol.Estoq. }}\right)$ e $u\left(V_{\text {Sol.Trab. }}\right)$ foram considerados a informação do fabricante, variação da temperatura e coeficiente de dilatação, conforme Eq. 19. 


\subsubsection{Incerteza associada à resposta do equipamento}

A incerteza da repetitividade de injeção foi calculada pela Eq. 22.

$$
u\left(A_{\text {obtida }}\right)=\frac{s}{\sqrt{n}}
$$

Onde: $\quad S=$ desvio padrão das medições;

$n=$ número de injeções realizadas.

\subsubsection{Incerteza associada à recuperação do método}

A incerteza associada à recuperação do fármaco $(\mu(R))$ no procedimento proposto foi calculada pela Eq. 23

$$
u(R)=R \sqrt{\left(\frac{u\left(C_{\text {Real }}\right)}{C_{\text {Real }}}\right)^{2}+\left(\frac{u\left(C_{\text {obtida }}\right)}{C_{\text {obtida }}}\right)^{2}}
$$

Onde: $\quad R=$ valor da recuperação do composto obtido,

$u\left(C_{\text {Real }}\right)=$ incerteza da concentração do composto na solução padrão do composto adicionada,

$C_{\text {Real }}=$ concentração real do composto adicionada,

$C_{\text {obtida }}=$ concentração do composto obtida,

$u\left(C_{\text {obtida }}\right)=$ incerteza da concentração do composto obtida, e calculada por:

$$
u\left(C_{\text {obtida }}\right)=\frac{S_{r e c}}{\sqrt{n}}
$$

Onde: $\quad S_{\text {rec }}=$ desvio padrão dos ensaios de recuperação do composto, $n=$ número de ensaios de recuperação realizado.

\subsubsection{Incerteza associada ao volume final e inicial da amostra}

O volume inicial de amostra, medido em balão volumétrico, foi de $250 \mathrm{~mL}$ e o volume final para análise, medido com micropipeta, foi de $0,25 \mathrm{~mL}$. Assim, a incerteza associada ao volume inicial $\left(u\left(V_{i}\right)\right)$ e ao volume final $\left(u\left(V_{f}\right)\right)$ foram calculadas conforme a Eq. 19. 


\subsubsection{Incerteza combinada e expandida do método}

Neste trabalho, a relação entre as grandezas de saída $\left(C_{F}\right)$ e as grandezas de entrada (fontes de incertezas) é apresentada na Equação 13. Portanto, a incerteza combinada das $\left(C_{F}\right)$ foi estimada pela Eq. 25.

$$
u\left(C_{F}\right)=C_{F} \sqrt{\left(\frac{u\left(C_{0}\right)}{C_{0}}\right)^{2}+\left(\frac{u\left(V_{f}\right)}{V_{f}}\right)^{2}+\left(\frac{u\left(V_{i}\right)}{V_{i}}\right)^{2}+\left(\frac{u(R)}{R}\right)^{2}} \quad \text { Equação } 25
$$

A incerteza expandida do método $(U)$ foi obtida multiplicando-se a incerteza combinada da concentração do composto $\left(u\left(C_{F}\right)\right)$ por um fator de abrangência (k). Neste trabalho, foi admitido um nível de confiança de $90 \%$ e um valor de k igual a 2. Assim, a incerteza expandida foi calculada pela Eq. 26.

$$
U=u\left(C_{F}\right) \times 2 \quad \text { Equação } 26
$$

Portanto, a concentração dos compostos com a incerteza associada ( $k=2,90 \%$ de confiança) foi dada por:

$$
C_{F}=(X \pm U) \quad \mathrm{ng} \mathrm{mL}^{-1} \quad(\mathrm{k}=2) \quad \text { Equação } 27
$$




\section{RESULTADOS E DISCUSSÃO}

\subsection{Procedimento analítico.}

\subsubsection{Estudos da separação cromatográfica.}

O desempenho das colunas Zorbax Eclipse XDB-C18, Agilent e Allura PFP Propyl foram avaliados quanto à intensidade (contagem/s) e largura dos picos dos compostos em estudo, conforme descrito em 5.4.2.1. A intensidade e a largura obtidas para os picos dos compostos em estudo são mostrados nas FIG. 22 e 23 , repectivamente.

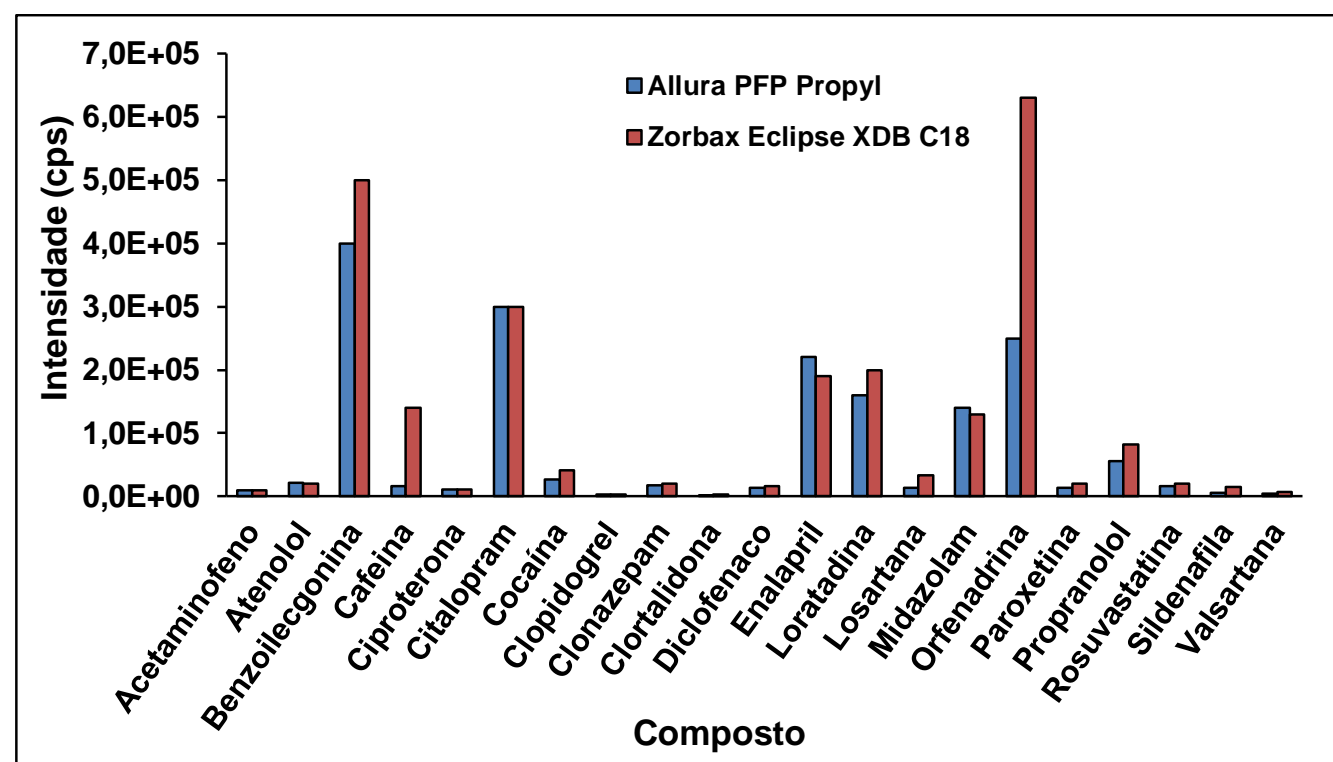

FIGURA 22. Intensidade (contagem/s) dos compostos em estudo obtida na separação cromatográfica com as colunas Allura PFP Propyl e Zobax Eclipse XDB-C18. Análises realizadas nos modos de ESI(+) e ESI(-) e com injeção de $10 \mu \mathrm{L}$ da solução mista de padrões $\left(50 \mathrm{ng} \mathrm{mL}^{-1}\right)$. 


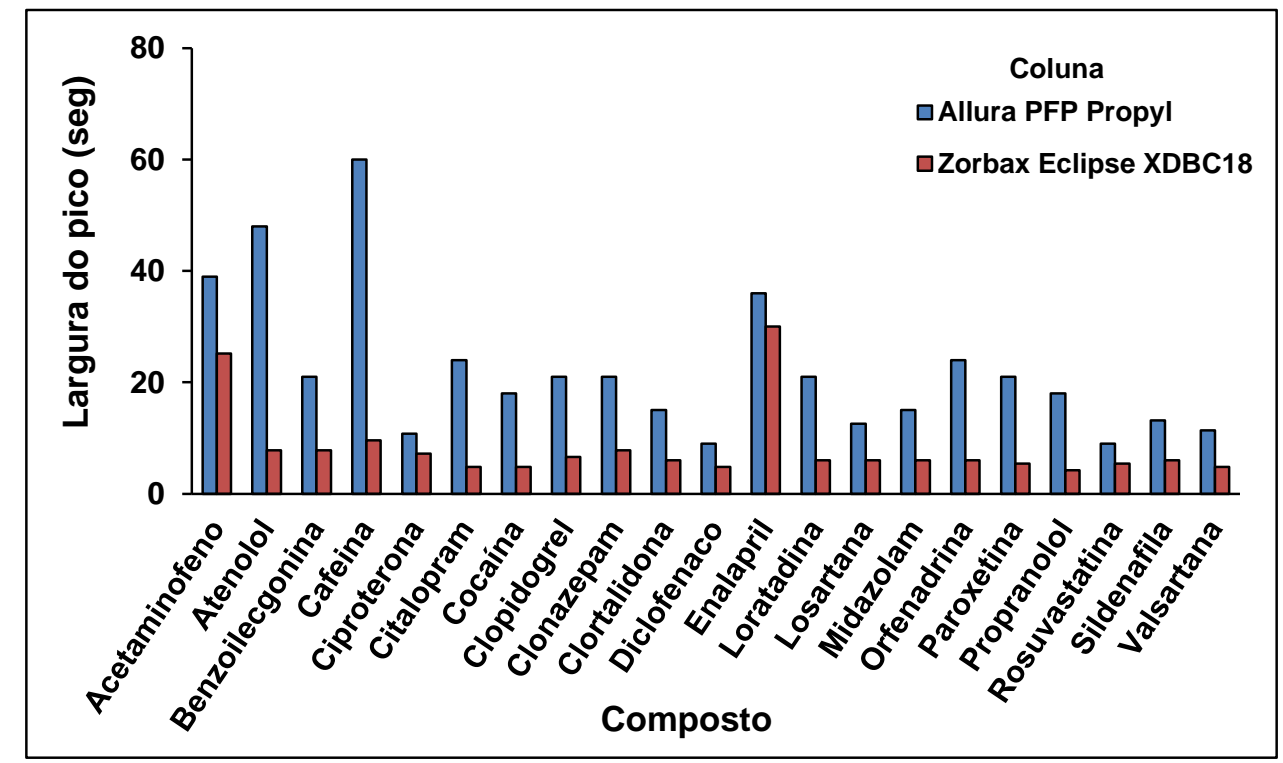

FIGURA 23. Largura dos picos dos compostos em estudo obtida na separação cromatográfica com as colunas Allura PFP Propyl e Zobax Eclipse XDB-C18. Análises realizadas nos modos ESI(+) e ESI(-) e com injeção de $10 \mu \mathrm{L}$ da solução mista de padrões $\left(50 \mathrm{ng} \mathrm{mL}^{-1}\right)$.

Os ensaios demonstraram que a análise com a coluna Zorbax Eclipse XDB-C18 forneceu 59\% e 100\% de picos mais intensos (FIG. 22) e mais estreitos (FIG. 23), respectivamente, para os compostos detectados. O tempo de análise foi também menor com a coluna Zorbax Eclipse XDB-C18 (8 minutos), quando comparada com a coluna Allura PFP Propyl (17,7 minutos). Com esses resultados, a coluna Zorbax Eclipse XDB-C18 foi selecionada para a separação cromatográfica desse trabalho.

A separação cromatográfica também foi ensaiada para verificar as fases móveis mais adequadas para a quantificação dos compostos selecionados. Os ensaios foram realizados com fonte de ESI(+), (FIG. 24), e ESI(-), (FIG. 25). Detalhes do ensaio estão descritos no ítem 5.4.2.1 desse trabalho. 


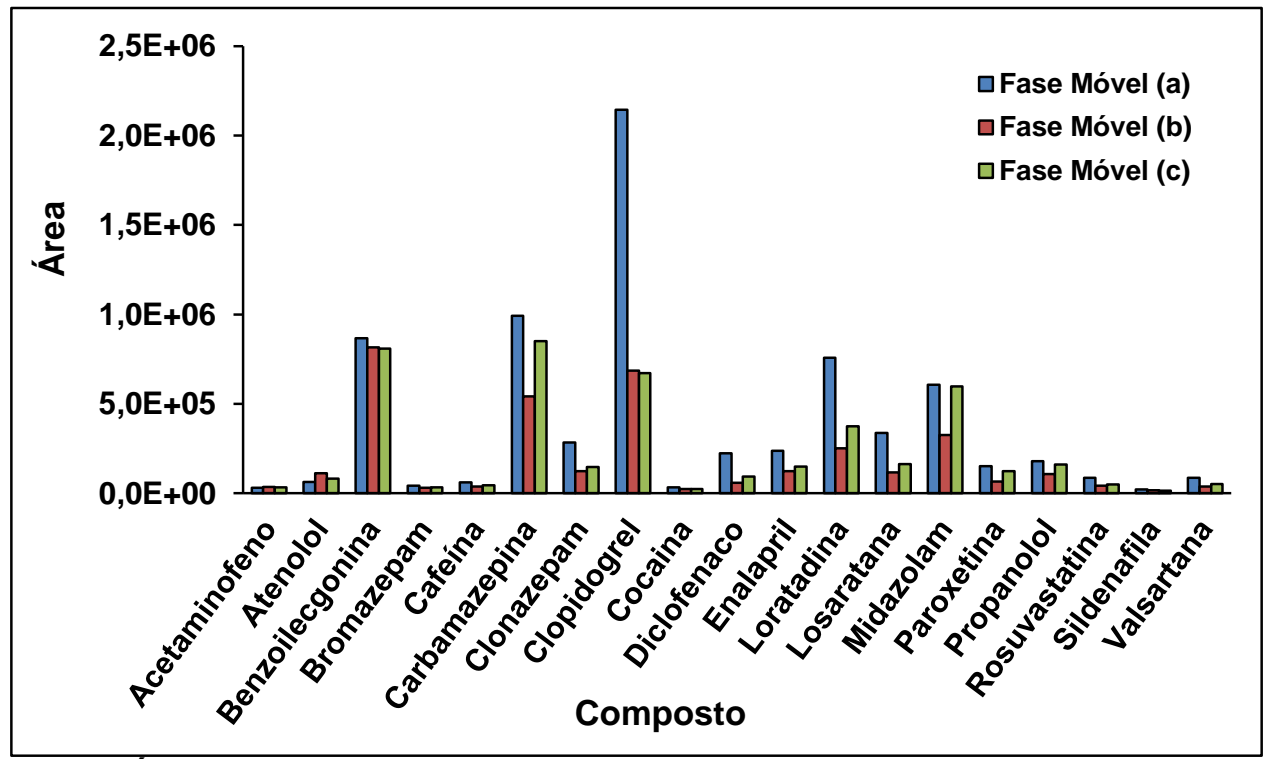

FIGURA 24. Área do pico dos compostos em estudo na separação cromatográfica utilizando diferentes fases móveis: (a) Fase A: água + $0,1 \%$ de ácido fórmico/Fase B: ACN; (b) Fase A: água + $1 \%$ de $A C N+$ $0,1 \%$ de ácido fórmico $+2 \mathrm{mM}$ de acetato de amônio/Fase B: $\mathrm{ACN}+$ $1 \%$ de água $+0,1 \%$ de ácido fórmico $+2 \mathrm{mM}$ de acetato de amônio; (c) Fase A: água $+1 \%$ de $\mathrm{ACN}+0,1 \%$ de ácido fórmico $+2 \mathrm{mM}$ de acetato de amônio/Fase B: ACN. Análises realizadas no modo $\mathrm{ESI}(+)$ e com injeção de $10 \mu \mathrm{L}$ da solução mista de padrões $\left(50 \mathrm{ng} \mathrm{mL}^{-1}\right)$.

A FIG. 24 mostra que as fases móveis do ensaio a (Fase A: água + $0,1 \%$ de ácido fórmico (Fase B: ACN) foram mais eficientes para $89 \%$ dos compostos analisados com fonte de $\mathrm{ESI}(+)$.

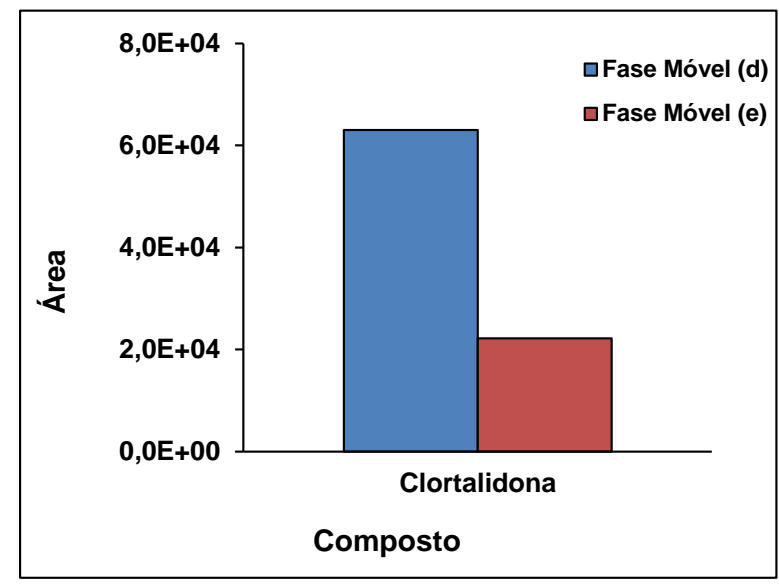

FIGURA 25. Área do pico da clortalidona na separação cromatográfica utilizando duas fases móveis: (d) Fase A: água $+5 \mathrm{mM}$ de acetato de amônio/Fase B: $A C N$; (e) Fase A: água + $1 \%$ de $A C N+0,1 \%$ de ácido fórmico $+2 \mathrm{mM}$ de acetato de amônio/Fase B: $\mathrm{ACN}+1 \%$ de água + $0,1 \%$ de ácido fórmico $+2 \mathrm{mM}$ de acetato de amônio. Análises realizadas no modo ESI(-) e com injeção de $10 \mu \mathrm{L}$ da solução mista de padrões $\left(50 \mathrm{ng} \mathrm{mL}^{-1}\right)$. 
Os resultados (FIG. 25) demonstraram que a sensibilidade da clortalidona é maior no ensaio $\underline{\mathrm{d}}$ (Fase: A água+5 mM acetato de amônio/Fase $\mathrm{B}$ : $A C N)$. As condições cromatográficas otimizadas dos compostos em estudo são apresentadas de forma resumidas na TAB. 23.

TABELA 23. Condições cromatográficas estabelecidas para a separação simultânea dos compostos selecionados para estudo.

\begin{tabular}{|c|c|c|c|c|c|}
\hline Coluna & \multicolumn{5}{|c|}{ Zorbax Eclipse XDB-C18 4,6x50 mm 1,8 $\mu \mathrm{m}$} \\
\hline \multirow{2}{*}{$\mathrm{ESI}(+)$} & \multirow{2}{*}{ Fase móvel } & A & \multicolumn{3}{|c|}{$99,9 \%$ água $+0,1 \%$ ácido fórmico } \\
\hline & & B & \multicolumn{3}{|c|}{$100 \%$ acetonitrila } \\
\hline \multirow{2}{*}{ ESI(-) } & \multirow{2}{*}{ Fase móvel } & A & \multirow{2}{*}{\multicolumn{3}{|c|}{$\begin{array}{l}95 \% \text { água }+5 \text { mM Acetato de Amônic } \\
100 \% \text { acetonitrila }\end{array}$}} \\
\hline & & B & & & \\
\hline Temperatura & $25^{\circ} \mathrm{C}$ & & & & \\
\hline Volume de injeção & $10 \mu \mathrm{L}$ & & & & \\
\hline \multirow{9}{*}{ Gradiente de eluiçãc } & Etapas & Tempo & Vazão & 0 & $\circ \mathrm{R}$ \\
\hline & & (min.) & $\left(\mu \mathrm{L} \mathrm{mim}^{-1}\right)$ & $70 A$ & $\% \mathrm{~B}$ \\
\hline & 1 & 1 & 700 & 95 & 5 \\
\hline & 2 & 0 & 700 & 95 & 5 \\
\hline & 3 & 0.5 & 700 & 95 & 5 \\
\hline & 4 & 5 & 700 & 5 & 95 \\
\hline & 5 & 6 & 700 & 5 & 95 \\
\hline & 6 & 6.1 & 700 & 95 & 5 \\
\hline & 7 & 8 & 700 & 95 & 5 \\
\hline
\end{tabular}

\subsection{Validação da Metodologia}

\subsubsection{Seletividade e efeito matriz}

A LC-MS/MS apresenta a vantagem de não necessitar de um alto fator de separação entre os picos. Nas FIG. 26 e 27 observam-se os cromatogramas de separação de uma solução de calibração e de uma amostra obtidos nas análises LC-ESI(+)-MS/MS, respectivamente. O cromatograma dos compostos de interesse extraídos individualmente está apresentado no Apêndice A. 


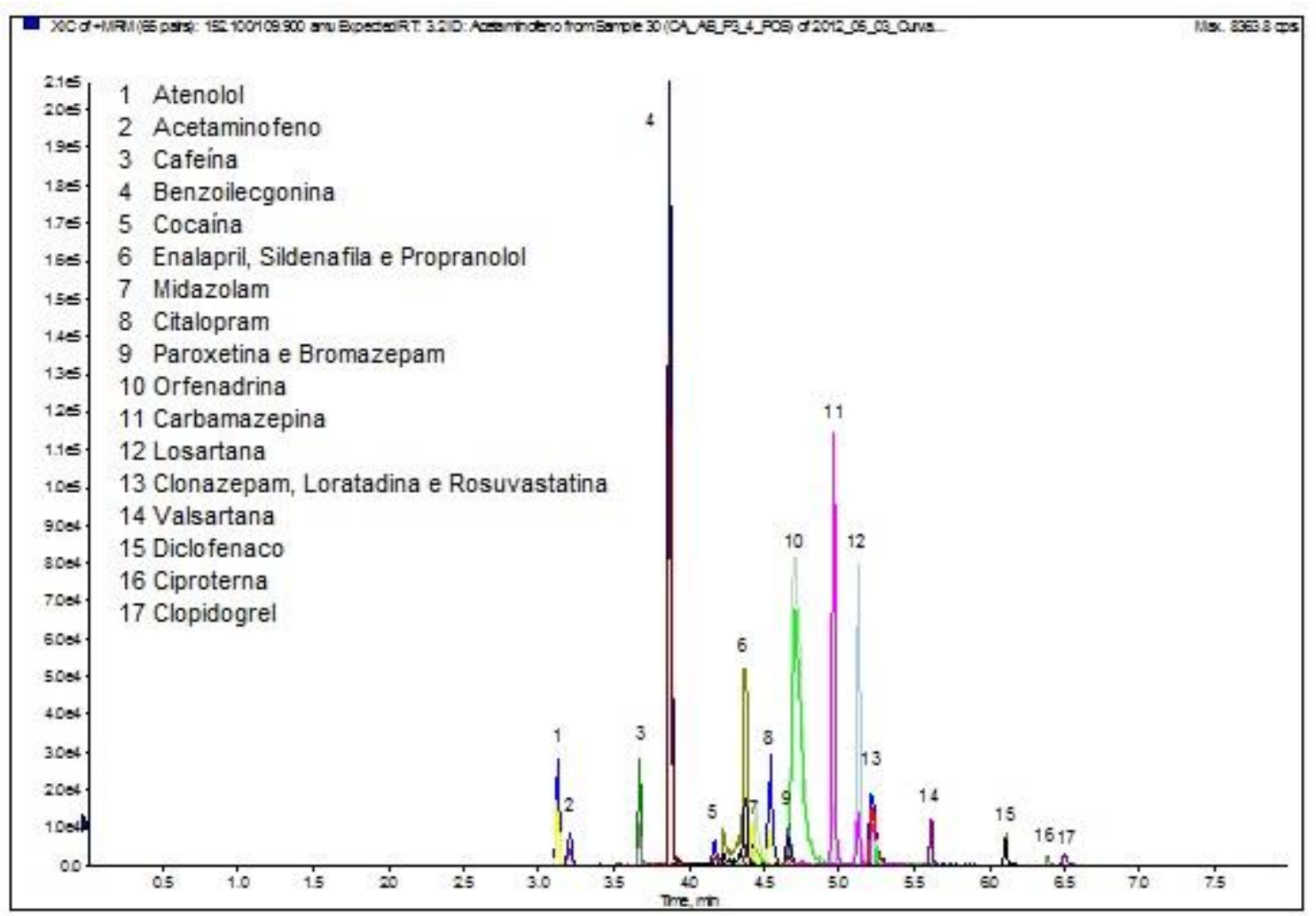

FIGURA 26. Cromatograma da solução de calibração (P3) para os compostos em estudo analisados no LC-ESI(+)-MS/MS no modo MRM.

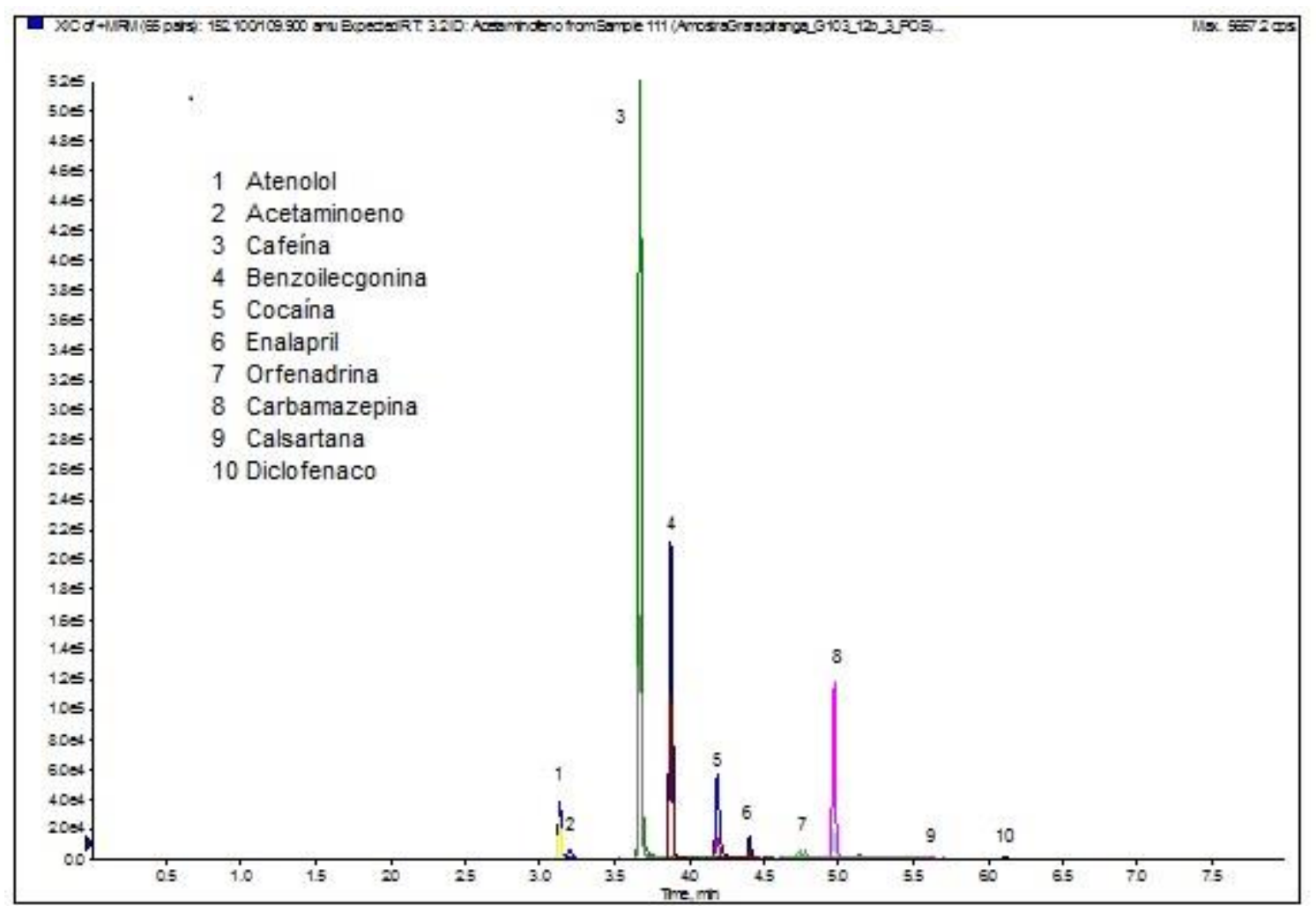

FIGURA 27. Cromatograma de uma amostra analisada no LC-ESI(-)-MS/MS no modo MRM. 
A alta seletividade conferida ao método confirmatório, utilizado neste trabalho, pode ser constatada pela comparação dos valores da razão de intensidade dos íons produtos e tempos de retenção dos compostos obtidos na amostra e solução de calibração com matriz ou na solução de calibração com matriz e solução de calibração com solvente (TAB. 24).

Os valores da TAB. 24 demonstram que as percentagens de variações das razões das intensidades e do tempo de retenção dos íons produtos na solução de calibração com matriz e na amostra foram iguais ou inferiores a $7 \mathrm{e}$ 0,8\%, respectivamente (Exemplo no Apendice A). Portanto, a detecção por espectrometria de massas foi altamente seletiva sem identificação falsa dos compostos estudados, uma vez que é recomendada uma variação de $20 \%$ para a razão de intensidade e de $2 \%$ para o tempo de retenção (GARCIA-GALÁN, et al., 2010; PETROVIC, et al., 2010). 
TABELA 24. Pontos de identificação (PI) adotados para a confirmação da presença dos compostos de interesse.

\begin{tabular}{|c|c|c|c|c|c|c|c|c|}
\hline \multirow{4}{*}{$\begin{array}{c}\text { Composto } \\
\text { Acetaminofeno }\end{array}$} & \multirow{3}{*}{\multicolumn{2}{|c|}{$\begin{array}{c}\text { Íon } \\
\begin{array}{c}\text { Precursor Produto } \\
(\mathrm{m} / \mathrm{z})\end{array}\end{array}$}} & \multirow{3}{*}{\multicolumn{2}{|c|}{$\begin{array}{c}\text { Razão } \\
\text { Intensidade } \\
\text { Padrão Amostra }\end{array}$}} & \multirow{2}{*}{\multicolumn{2}{|c|}{ TR }} & \multicolumn{2}{|c|}{ \% Variação } \\
\hline & & & & & & & Razão & $\overline{T R}$ \\
\hline & & & Padrão & & Padrão & Amostra & Intensidade & $e^{\ln }$ \\
\hline & 152,1 & $\begin{array}{c}109,9 \\
93,1\end{array}$ & 2,88 & 2,86 & 3,20 & 3,21 & 0,7 & 0,3 \\
\hline Atenolol & 267,3 & $\begin{array}{l}145,2 \\
190,3\end{array}$ & 1,55 & 1,55 & 3,12 & 3,13 & 0,0 & 0,3 \\
\hline Benzoilecgonina & 290,2 & $\begin{array}{l}168,2 \\
105,1\end{array}$ & 1,72 & 1,76 & 3,87 & 3,88 & 2 & 0,3 \\
\hline Bromazepam & 316 & $\begin{array}{l}182,2 \\
209,2\end{array}$ & 1,19 & 1,18 & 4,67 & 4,66 & 0,8 & 0,2 \\
\hline Cafeína & 195,2 & $\begin{array}{l}138,3 \\
110,1\end{array}$ & 3,39 & 3,34 & 3,67 & 3,67 & 2 & 0,0 \\
\hline Carbamazepina & 237,1 & $\begin{array}{l}194,2 \\
179,1\end{array}$ & 6,75 & 6,48 & 4,97 & 4,98 & 4 & 0,2 \\
\hline Ciproterona & 417,3 & $\begin{array}{l}357,2 \\
279,3\end{array}$ & 1,16 & 1,14 & 6,39 & 6,39 & 2 & 0,0 \\
\hline Citalopram & 325,2 & $\begin{array}{l}109,2 \\
262,1\end{array}$ & 3,54 & 3,43 & 4,54 & 4,57 & 3 & 0,7 \\
\hline Clonazepam & 316,1 & $\begin{array}{l}270,0 \\
241,2\end{array}$ & 1,46 & 1,44 & 5,23 & 5,23 & 1 & 0,0 \\
\hline Clopidogrel & 322,2 & $\begin{array}{l}212,2 \\
155,0\end{array}$ & 1,15 & 1,15 & 6,50 & 6,51 & 0,0 & 0,2 \\
\hline Clortalidona & 336,9 & $\begin{array}{l}189,9 \\
146,2\end{array}$ & 1,18 & 1,18 & 4,34 & 4,35 & 0,0 & 0,2 \\
\hline Cocaína & 304,2 & $\begin{array}{l}182,2 \\
105,1\end{array}$ & 3,53 & 3,58 & 4,17 & 4,17 & 1 & 0,0 \\
\hline Diclofenaco & 296,1 & $\begin{array}{l}214,1 \\
250,0\end{array}$ & 1,15 & 1,15 & 6,11 & 6,11 & 0,0 & 0,0 \\
\hline Enalapril & 377,3 & $\begin{array}{l}234,2 \\
303,2\end{array}$ & 2,44 & 2,40 & 4,38 & 4,41 & 2 & 0,7 \\
\hline Loratadina & 383,3 & $\begin{array}{l}337,3 \\
267,1\end{array}$ & 1,25 & 1,34 & 5,21 & 5,22 & 7 & 0,2 \\
\hline Losartana & 432,2 & $\begin{array}{l}207,2 \\
405,2\end{array}$ & 5,16 & 5,28 & 5,13 & 5,13 & 2 & 0,0 \\
\hline Midazolam & 326,1 & $\begin{array}{l}291,2 \\
249,1\end{array}$ & 2,32 & 2,25 & 4,46 & 4,49 & 3 & 0,7 \\
\hline Orfenadrina & 270,2 & $\begin{array}{l}181,1 \\
165,0\end{array}$ & 1,24 & 1,25 & 4,71 & 4,73 & 0,8 & 0,4 \\
\hline Paroxetina & 330,2 & $\begin{array}{l}135,1 \\
192,2\end{array}$ & 1,09 & 0,91 & 4,56 & 4,58 & 1 & 0,4 \\
\hline Propranolol & 260,2 & $\begin{array}{l}116,0 \\
183,0\end{array}$ & 1,08 & 1,15 & 4,39 & 4,41 & 6 & 0,5 \\
\hline Rosuvastatina & 482,2 & $\begin{array}{l}258,2 \\
270,2\end{array}$ & 1,72 & 1,78 & 5,24 & 5,28 & 3 & 0,8 \\
\hline Sildenafila & 475,3 & $\begin{array}{l}283,2 \\
100,0\end{array}$ & 1,17 & 1,23 & 4,42 & 4,41 & 5 & 0,2 \\
\hline Valsartan & 436,3 & $\begin{array}{l}207,1 \\
235,1\end{array}$ & 1,24 & 1,23 & 5,61 & 5,62 & 0,9 & 0,2 \\
\hline
\end{tabular}

TR = tempo de retenção 
A avaliação da seletividade utilizando os cálculos estatísticos do teste $F$ (Snedecor) para estudar a homogeneidade das variâncias, bem como, o teste $\mathrm{t}$ (Student) para estudar a significância das diferenças das médias dos conjuntos de amostras estão apresentados nas TAB. 25 a 29.

TABELA 25. Valores de $F_{\text {calc }}$ e $t_{\text {calc }}$ do acetaminofeno, atenolol, benzoilecgonina e bromazepam para o estudo da seletividade com a solução de calibração com solvente e com matriz considerando $F_{\operatorname{tab}(6,95 \%)}=4,28$ e $t_{\operatorname{tab}(12,95 \%)}=2,179$.

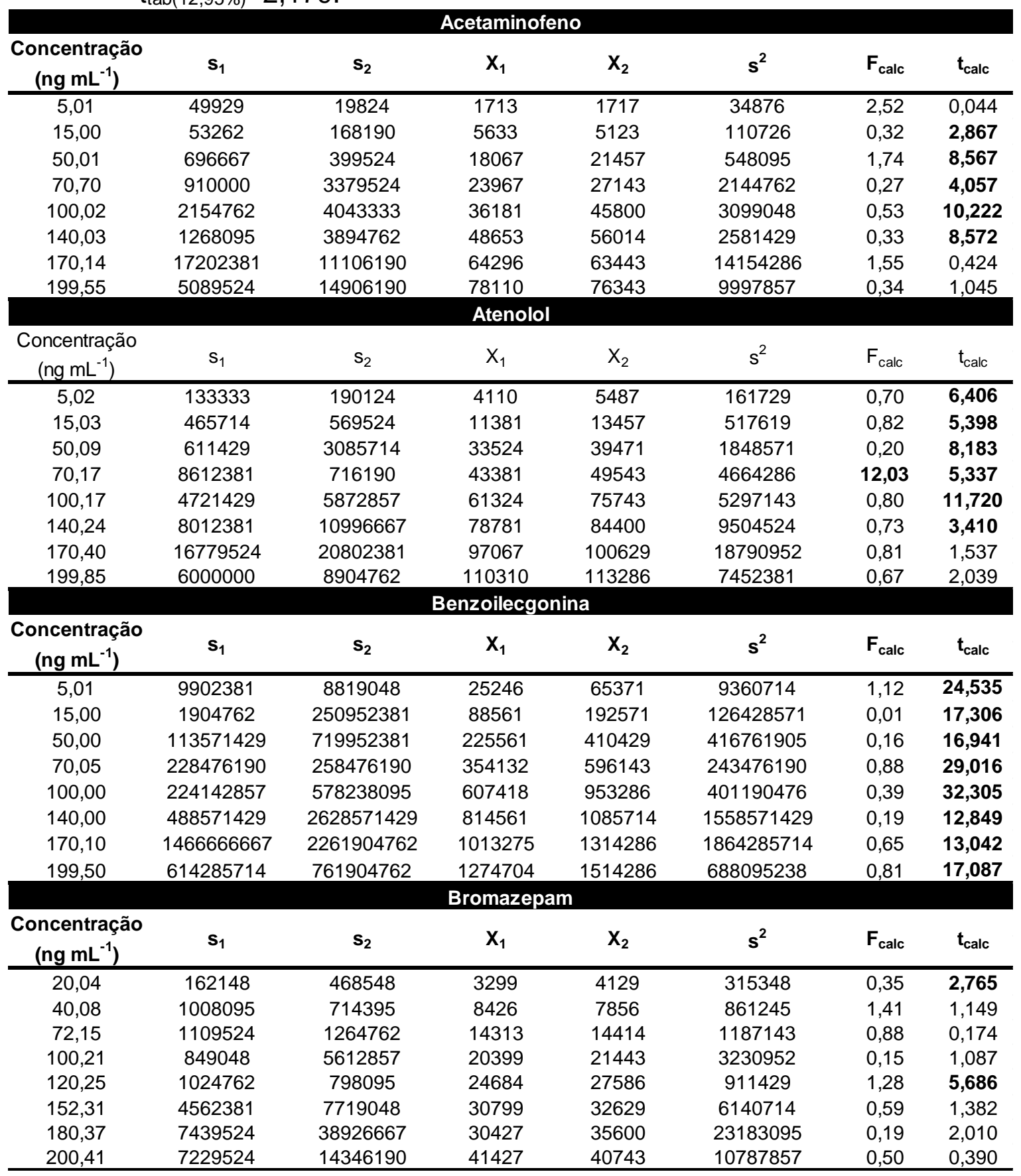


TABELA 26. Valores de $F_{\text {calc }}$ e $t_{\text {calc }}$ da cafeína carbamazpina, ciproterona, citalopram e clonazepam para o estudo da seletividade com a solução de calibração com solvente e com matriz considerando $F_{\operatorname{tab}(6,95 \%)}=4,28$ e $t_{\operatorname{tab}(12,95 \%)}=2,179$.

\begin{tabular}{|c|c|c|c|c|c|c|c|}
\hline \multicolumn{8}{|c|}{ Cafeína } \\
\hline $\begin{array}{c}\text { Concentração } \\
\left(\mathrm{ng} \mathrm{mL}^{-1}\right)\end{array}$ & $\mathbf{s}_{1}$ & $\mathrm{~s}_{2}$ & $x_{1}$ & $X_{2}$ & $s^{2}$ & $F_{\text {calc }}$ & $t_{\text {calc }}$ \\
\hline 5,00 & 271614 & 103962 & 2305 & 4026 & 187788 & 2,61 & 7,428 \\
\hline 19,90 & 990000 & 1672381 & 11567 & 16071 & 1331190 & 0,59 & 7,304 \\
\hline 49,64 & 2471429 & 13349524 & 29081 & 41043 & 7910476 & 0,19 & 7,957 \\
\hline 99,18 & 21745714 & 40979048 & 57738 & 78029 & 31362381 & 0,53 & 6,778 \\
\hline 198,56 & 34904762 & 129904762 & 124052 & 181714 & 82404762 & 0,27 & 11,884 \\
\hline 297,84 & 64000000 & 206000000 & 171767 & 230000 & 135000000 & 0,31 & 9,376 \\
\hline 396,13 & 222571429 & 228952381 & 228052 & 295571 & 225761905 & 0,97 & 8,407 \\
\hline 496,80 & 52333333 & 421238095 & 296767 & 354286 & 236785714 & 0,12 & 6,993 \\
\hline \multicolumn{8}{|c|}{ Carbamazepina } \\
\hline $\begin{array}{c}\text { Concentração } \\
\left(\mathrm{ng} \mathrm{mL}^{-1}\right)\end{array}$ & $\mathbf{s}_{1}$ & $\mathbf{s}_{2}$ & $\mathrm{X}_{1}$ & $x_{2}$ & $s^{2}$ & $F_{\text {calc }}$ & $t_{\text {calc }}$ \\
\hline 5,01 & 31502857 & 26394762 & 26924 & 90286 & 28948810 & 1,19 & 22,032 \\
\hline 10,02 & 18809524 & 44142857 & 53524 & 154143 & 31476190 & 0,43 & 33,552 \\
\hline 18,04 & 39333333 & 74476190 & 84667 & 241143 & 56904762 & 0,53 & 38,807 \\
\hline 25,06 & 71142857 & 310619048 & 130524 & 306429 & 190880952 & 0,23 & 23,819 \\
\hline 30,07 & 17571429 & 1387952381 & 152952 & 400429 & 702761905 & 0,01 & 17,465 \\
\hline 38,09 & 228333333 & 449571429 & 199667 & 404714 & 338952381 & 0,51 & 20,836 \\
\hline 45,10 & 195809524 & 672238095 & 222810 & 455286 & 434023810 & 0,29 & 20,876 \\
\hline 50,11 & 119476190 & 687285714 & 252810 & 483429 & 403380952 & 0,17 & 21,482 \\
\hline \multicolumn{8}{|c|}{ Ciproterona } \\
\hline $\begin{array}{c}\text { Concentração } \\
\left(\mathrm{ng} \mathrm{mL}^{-1}\right)\end{array}$ & $s_{1}$ & $\mathbf{s}_{2}$ & $\mathrm{X}_{1}$ & $X_{2}$ & $s^{2}$ & $F_{\text {calc }}$ & $t_{\text {calc }}$ \\
\hline 5,01 & 13814 & 2192 & 1076 & 267 & 8003 & 6,30 & 16,932 \\
\hline 10,01 & 17581 & 6404 & 2239 & 594 & 11992 & 2,75 & 28,109 \\
\hline 18,02 & 19333 & 4990 & 3478 & 1333 & 12162 & 3,87 & 36,385 \\
\hline 25,03 & 70314 & 17995 & 5109 & 1864 & 44155 & 3,91 & 28,889 \\
\hline 30,03 & 60295 & 20181 & 6022 & 2291 & 40238 & 2,99 & 34,792 \\
\hline 38,04 & 506048 & 27081 & 7519 & 2699 & 266564 & 18,69 & 17,467 \\
\hline 45,05 & 402324 & 37214 & 8805 & 3441 & 219769 & 10,81 & 21,404 \\
\hline 50,05 & 158095 & 45895 & 11272 & 2996 & 101995 & 3,44 & 48,482 \\
\hline \multicolumn{8}{|c|}{ Citalopram } \\
\hline $\begin{array}{c}\text { Concentração } \\
\left(\mathrm{ng} \mathrm{mL}^{-1}\right)\end{array}$ & $s_{1}$ & $\mathbf{s}_{2}$ & $X_{1}$ & $X_{2}$ & $s^{2}$ & $F_{\text {calc }}$ & $t_{\text {calc }}$ \\
\hline 5,00 & 758095 & 8962857 & 17444 & 64157 & 4860476 & 0,08 & 39,640 \\
\hline 10,01 & 5399048 & 11809524 & 36387 & 117857 & 8604286 & 0,46 & 51,961 \\
\hline 18,01 & 4792381 & 174809524 & 54729 & 160143 & 89800952 & 0,03 & 20,811 \\
\hline 25,02 & 10932381 & 393476190 & 81787 & 291143 & 202204286 & 0,03 & 27,544 \\
\hline 30,02 & 21928095 & 388238095 & 99672 & 333714 & 205083095 & 0,06 & 30,575 \\
\hline 38,02 & 36142857 & 669619048 & 131415 & 361571 & 352880952 & 0,05 & 22,921 \\
\hline 45,03 & 23476190 & 216571429 & 151701 & 445286 & 120023810 & 0,11 & 50,134 \\
\hline 50,03 & 14952381 & 1796904762 & 173987 & 487714 & 905928571 & 0,01 & 19,500 \\
\hline \multicolumn{8}{|c|}{ Clonazepam } \\
\hline $\begin{array}{c}\text { Concentração } \\
\left(\mathrm{ng} \mathrm{mL}^{-1}\right)\end{array}$ & $s_{1}$ & $s_{2}$ & $x_{1}$ & $x_{2}$ & $s^{2}$ & $F_{\text {calc }}$ & $t_{\text {calc }}$ \\
\hline 10,00 & 55590 & 2229114 & 5969 & 9301 & 1142352 & 0,02 & 5,833 \\
\hline 20,00 & 382381 & 742857 & 12670 & 16357 & 562619 & 0,51 & 9,196 \\
\hline 36,00 & 822857 & 32151429 & 19899 & 31086 & 16487143 & 0,03 & 5,154 \\
\hline 50,00 & 922857 & 5304762 & 28485 & 42414 & 3113810 & 0,17 & 14,768 \\
\hline 60,00 & 9832381 & 13556190 & 36370 & 57843 & 11694286 & 0,73 & 11,747 \\
\hline 76,00 & 59826667 & 37638095 & 42442 & 63186 & 48732381 & 1,59 & 5,559 \\
\hline 90,00 & 2194762 & 6895714 & 40656 & 67171 & 4545238 & 0,32 & 23,268 \\
\hline 100,00 & 5412381 & 9883333 & 47313 & 66100 & 7647857 & 0,55 & 12,709 \\
\hline
\end{tabular}


TABELA 27. Valores de $F_{\text {calc }}$ e $t_{\text {calc }}$ do clopidogrel, clortalidona, cocaína, diclofenaco e enalapril para o estudo da seletividade com a solução de calibração com solvente e com matriz considerando $F_{\operatorname{tab}(6,95 \%)}=4,28$ e $t_{\operatorname{tab}(12,95 \%)}=2,179$.

\begin{tabular}{|c|c|c|c|c|c|c|c|}
\hline \multicolumn{8}{|c|}{ Clopidogrel } \\
\hline $\begin{array}{c}\text { Concentração } \\
\left(\text { (ng mL }^{-1}\right)\end{array}$ & $s_{1}$ & $\mathbf{s}_{2}$ & $X_{1}$ & $X_{2}$ & $s^{2}$ & $\mathbf{F}_{\text {calc }}$ & $t_{\text {calc }}$ \\
\hline 0,20 & 27362 & 2995 & 1951 & 3646 & 15179 & 9,14 & 25,732 \\
\hline 0,40 & 37081 & 110124 & 4018 & 7497 & 73602 & 0,34 & 23,989 \\
\hline 0,72 & 110429 & 241429 & 6503 & 11586 & 175929 & 0,46 & 22,672 \\
\hline 1,00 & 83700 & 189048 & 9417 & 19529 & 136374 & 0,44 & 51,226 \\
\hline 1,20 & 59524 & 254762 & 11704 & 26514 & 157143 & 0,23 & 69,895 \\
\hline 1,52 & 231429 & 316190 & 14833 & 29743 & 273810 & 0,73 & 53,308 \\
\hline 1,80 & 636667 & 806667 & 17447 & 35200 & 721667 & 0,79 & 39,097 \\
\hline 2,00 & 199048 & 1009524 & 20375 & 34943 & 604286 & 0,20 & 35,059 \\
\hline \multicolumn{8}{|c|}{ Clortalidona } \\
\hline $\begin{array}{c}\text { Concentração } \\
\left(\text { (ng mL } L^{-1}\right)\end{array}$ & $\mathbf{s}_{1}$ & $\mathbf{s}_{2}$ & $X_{1}$ & $X_{2}$ & $s^{2}$ & $\mathbf{F}_{\text {calc }}$ & $t_{\text {calc }}$ \\
\hline 5,00 & 56062 & 52729 & 1088 & 1906 & 54395 & 1,06 & 6,562 \\
\hline 10,00 & 45433 & 87348 & 2443 & 3601 & 66390 & 0,52 & 8,409 \\
\hline 18,01 & 51462 & 236233 & 4118 & 6340 & 143848 & 0,22 & 10,962 \\
\hline 25,01 & 81624 & 383190 & 5870 & 8683 & 232407 & 0,21 & 10,914 \\
\hline 30,01 & 91448 & 681429 & 7312 & 12186 & 386438 & 0,13 & 14,668 \\
\hline 38,01 & 422381 & 405714 & 9895 & 13671 & 414048 & 1,04 & 10,980 \\
\hline 45,02 & 226190 & 309048 & 10966 & 14629 & 267619 & 0,73 & 13,245 \\
\hline 50,02 & 414762 & 359524 & 12609 & 16157 & 387143 & 1,15 & 10,668 \\
\hline \multicolumn{8}{|c|}{ Cocaína } \\
\hline $\begin{array}{c}\text { Concentração } \\
\left.\text { (ng mL } \text { mL }^{-1}\right)\end{array}$ & $\mathbf{s}_{1}$ & $\mathbf{s}_{2}$ & $X_{1}$ & $X_{2}$ & $s^{2}$ & $\mathbf{F}_{\text {calc }}$ & $t_{\text {calc }}$ \\
\hline 5,04 & 139990 & 141129 & 1496 & 3156 & 140560 & 0,99 & 8,281 \\
\hline 20,04 & 593490 & 1255714 & 6156 & 12371 & 924602 & 0,47 & 12,092 \\
\hline 50,00 & 406190 & 4164762 & 14030 & 32114 & 2285476 & 0,10 & 22,379 \\
\hline 99,90 & 1844762 & 4911429 & 26988 & 62886 & 3378095 & 0,38 & 36,540 \\
\hline 200,00 & 5244762 & 54476190 & 56988 & 144143 & 29860476 & 0,10 & 29,839 \\
\hline 300,00 & 2469048 & 272571429 & 82202 & 181286 & 137520238 & 0,01 & 15,807 \\
\hline 399,00 & 6571429 & 38142857 & 110759 & 238857 & 22357143 & 0,17 & 50,684 \\
\hline 500,40 & 13000000 & 196619048 & 137473 & 298571 & 104809524 & 0,07 & 29,439 \\
\hline \multicolumn{8}{|c|}{ Diclofenaco } \\
\hline $\begin{array}{c}\text { Concentração } \\
\left(\mathrm{ng} \mathrm{mL}^{-1}\right)\end{array}$ & $s_{1}$ & $\mathbf{s}_{2}$ & $\mathrm{x}_{1}$ & $X_{2}$ & $s^{2}$ & $\mathbf{F}_{\text {calc }}$ & $t_{\text {calc }}$ \\
\hline 5,00 & 74762 & 115348 & 3247 & 5339 & 95055 & 0,65 & 12,689 \\
\hline 10,00 & 71448 & 276624 & 6830 & 8063 & 174036 & 0,26 & 5,528 \\
\hline 17,99 & 198095 & 724762 & 11097 & 17714 & 461429 & 0,27 & 18,224 \\
\hline 24,99 & 528095 & 2054762 & 16126 & 26714 & 1291429 & 0,26 & 17,431 \\
\hline 29,99 & 688095 & 3989524 & 19397 & 30643 & 2338810 & 0,17 & 13,757 \\
\hline 37,99 & 4868095 & 2241429 & 24597 & 36214 & 3554762 & 2,17 & 11,527 \\
\hline 44,98 & 1439524 & 895714 & 27869 & 35329 & 1167619 & 1,61 & 12,915 \\
\hline 49,98 & 579048 & 1509048 & 34183 & 35071 & 1044048 & 0,38 & 1,626 \\
\hline \multicolumn{8}{|c|}{ Enalapril } \\
\hline $\begin{array}{c}\text { Concentração } \\
\left.\text { (ng mL } \mathbf{~ L}^{-1}\right)\end{array}$ & $\mathbf{s}_{1}$ & $\mathbf{s}_{2}$ & $X_{1}$ & $X_{2}$ & $s^{2}$ & $\mathbf{F}_{\text {calc }}$ & $t_{\text {calc }}$ \\
\hline 5,01 & 38386667 & 50975714 & 37614 & 24271 & 44681190 & 0,75 & 3,734 \\
\hline 10,02 & 151136190 & 96064762 & 74071 & 46614 & 123600476 & 1,57 & 4,620 \\
\hline 18,03 & 117956190 & 67143333 & 102771 & 64800 & 92549762 & 1,76 & 7,384 \\
\hline 25,04 & 305666667 & 654476190 & 160814 & 135143 & 480071429 & 0,47 & 2,192 \\
\hline 30,05 & 154666667 & 888476190 & 183814 & 160143 & 521571429 & 0,17 & 1,939 \\
\hline 38,06 & 718285714 & 1338619048 & 239386 & 167429 & 1028452381 & 0,54 & 4,198 \\
\hline 45,07 & 2651809524 & 2048904762 & 284957 & 235286 & 2350357143 & 1,29 & 1,917 \\
\hline 50,08 & 1236285714 & 1286666667 & 316243 & 237000 & 1261476190 & 0,96 & 4,174 \\
\hline
\end{tabular}


TABELA 28. Valores de $F_{\text {calc }}$ e $t_{\text {calc }}$ da loratadina, losartana, midazolam, orfenadrina e paroxetina para o estudo da seletividade com a solução de calibração com solvente e com matriz considerando $F_{\text {tab(6,95\%) }}=4,28$ e $\operatorname{tab}_{\operatorname{tab}(12.95 \%)}=2,179$.

\begin{tabular}{|c|c|c|c|c|c|c|c|}
\hline \multicolumn{8}{|c|}{ Loratadina } \\
\hline $\begin{array}{c}\text { Concentração } \\
\left(\mathrm{ng} \mathrm{mL}^{-1}\right)\end{array}$ & $s_{1}$ & $s_{2}$ & $\mathrm{X}_{1}$ & $X_{2}$ & $s^{2}$ & $F_{\text {calc }}$ & $t_{\text {calc }}$ \\
\hline 10,02 & 828095 & 5164762 & 18623 & 31086 & 2996429 & 0,16 & 13,469 \\
\hline 20,05 & 2436190 & 4119048 & 39981 & 51471 & 3277619 & 0,59 & 11,874 \\
\hline 36,09 & 4559048 & 16792857 & 59209 & 52143 & 10675952 & 0,27 & 4,046 \\
\hline 50,12 & 9545714 & 33952381 & 82166 & 155429 & 21749048 & 0,28 & 29,390 \\
\hline 60,15 & 27784762 & 12000000 & 102123 & 120000 & 19892381 & 2,32 & 7,499 \\
\hline 76,19 & 52809524 & 25904762 & 131495 & 148714 & 39357143 & 2,04 & 5,135 \\
\hline 90,22 & 29333333 & 105809524 & 134638 & 273143 & 67571429 & 0,28 & 31,522 \\
\hline 100,25 & 13619048 & 99904762 & 164209 & 280286 & 56761905 & 0,14 & 28,824 \\
\hline \multicolumn{8}{|c|}{ Losartana } \\
\hline $\begin{array}{c}\text { Concentração } \\
\left(\mathrm{ng} \mathrm{mL}^{-1}\right)\end{array}$ & $s_{1}$ & $s_{2}$ & $x_{1}$ & $X_{2}$ & $s^{2}$ & $F_{\text {calc }}$ & $t_{\text {calc }}$ \\
\hline 5,02 & 252381 & 1016990 & 9972 & 10923 & 634686 & 0,25 & 2,233 \\
\hline 15,03 & 1166190 & 2592381 & 26786 & 27629 & 1879286 & 0,45 & 1,150 \\
\hline 50,09 & 3333333 & 30809524 & 94743 & 111143 & 17071429 & 0,11 & 7,426 \\
\hline 70,18 & 35619048 & 95619048 & 131315 & 161571 & 65619048 & 0,37 & 6,988 \\
\hline 100,19 & 100285714 & 140666667 & 186172 & 251000 & 120476190 & 0,71 & 11,050 \\
\hline 140,26 & 292000000 & 64476190 & 250743 & 317857 & 178238095 & 4,53 & 9,405 \\
\hline 170,42 & 232142857 & 269238095 & 302600 & 350714 & 250690476 & 0,86 & 5,685 \\
\hline 199,87 & 215904762 & 747619048 & 368029 & 390571 & 481761905 & 0,29 & 1,921 \\
\hline \multicolumn{8}{|c|}{ Midazolam } \\
\hline $\begin{array}{c}\text { Concentração } \\
\left(\mathrm{ng} \mathrm{mL}^{-1}\right)\end{array}$ & $s_{1}$ & $s_{2}$ & $X_{1}$ & $X_{2}$ & $s^{2}$ & $F_{\text {calc }}$ & $t_{\text {calc }}$ \\
\hline 5,00 & 274762 & 3772381 & 10613 & 24029 & 2023571 & 0,07 & 17,643 \\
\hline 10,01 & 326667 & 28108095 & 23027 & 45786 & 14217381 & 0,01 & 11,292 \\
\hline 18,01 & 2289524 & 14391429 & 37784 & 66014 & 8340476 & 0,16 & 18,287 \\
\hline 25,02 & 1115714 & 22595714 & 56556 & 100471 & 11855714 & 0,05 & 23,861 \\
\hline 30,02 & 4074762 & 101238095 & 67542 & 127714 & 52656429 & 0,04 & 15,513 \\
\hline 38,02 & 17179524 & 57952381 & 86184 & 137571 & 37565952 & 0,30 & 15,685 \\
\hline 45,03 & 10926667 & 38571429 & 97627 & 160286 & 24749048 & 0,28 & 23,563 \\
\hline 50,03 & 18619048 & 80285714 & 111399 & 167571 & 49452381 & 0,23 & 14,944 \\
\hline \multicolumn{8}{|c|}{ Orfenadrina } \\
\hline $\begin{array}{c}\text { Concentração } \\
\left(\mathrm{ng} \mathrm{mL}^{-1}\right)\end{array}$ & $s_{1}$ & $s_{2}$ & $X_{1}$ & $X_{2}$ & $s^{2}$ & $F_{\text {calc }}$ & $t_{\text {calc }}$ \\
\hline 5,01 & 4778095 & 18156667 & 38371 & 87100 & 11467381 & 0,26 & 26,921 \\
\hline 14,99 & 10952381 & 236571429 & 115328 & 249286 & 123761905 & 0,05 & 22,527 \\
\hline 49,98 & 60952381 & 951904762 & 363328 & 681286 & 506428571 & 0,06 & 26,433 \\
\hline 70,02 & 442571429 & 1528904762 & 477471 & 1053286 & 985738095 & 0,29 & 34,311 \\
\hline 99,96 & 144904762 & 1790476190 & 713471 & 1372857 & 967690476 & 0,08 & 39,656 \\
\hline 139,94 & 803952381 & 780952381 & 917328 & 1591429 & 792452381 & 1,03 & 44,799 \\
\hline 170,03 & 1664142857 & 2400000000 & 1015614 & 2010000 & 2032071429 & 0,69 & 41,269 \\
\hline 199,42 & 647619048 & 3828571429 & 1145328 & 2245714 & 2238095238 & 0,17 & 43,515 \\
\hline \multicolumn{8}{|c|}{ Paroxetina } \\
\hline $\begin{array}{c}\text { Concentração } \\
\left(\mathrm{ng} \mathrm{mL}^{-1}\right)\end{array}$ & $\mathbf{s}_{1}$ & $\mathbf{s}_{2}$ & $\mathrm{X}_{1}$ & $X_{2}$ & $s^{2}$ & $F_{\text {calc }}$ & $t_{\text {calc }}$ \\
\hline 20,00 & 235114 & 521181 & 5361 & 8201 & 378148 & 0,45 & 8,642 \\
\hline 39,99 & 519048 & 3105714 & 13441 & 15071 & 1812381 & 0,17 & 2,266 \\
\hline 71,99 & 885714 & 2301429 & 19298 & 23386 & 1593571 & 0,38 & 6,058 \\
\hline 99,99 & 1388095 & 10901429 & 26955 & 36214 & 6144762 & 0,13 & 6,988 \\
\hline 119,98 & 3962857 & 8554762 & 35926 & 41186 & 6258810 & 0,46 & 3,933 \\
\hline 151,98 & 16229048 & 11048095 & 48141 & 49014 & 13638571 & 1,47 & 0,443 \\
\hline 179,97 & 3478095 & 24844762 & 47584 & 57314 & 14161429 & 0,14 & 4,838 \\
\hline 199,97 & 5832381 & 4548095 & 58098 & 59086 & 5190238 & 1,28 & 0,811 \\
\hline
\end{tabular}


TABELA 29. Valores de $F_{\text {calc }}$ e $t_{c a l c}$ do propranolol, rosuvastatina, sildenafila e valsartana para o estudo da seletividade com a solução de calibração com solvente e com matriz considerando $\mathrm{F}_{\mathrm{tab}(6,95 \%)}=4,28$ e $t_{\mathrm{tab}(12,95 \%)}=2,179$.

\begin{tabular}{|c|c|c|c|c|c|c|c|}
\hline \multicolumn{8}{|c|}{ Propranolol } \\
\hline $\begin{array}{c}\text { Concentração } \\
\left(\mathrm{ng} \mathrm{mL}^{-1}\right)\end{array}$ & $s_{1}$ & $\mathbf{s}_{2}$ & $X_{1}$ & $X_{2}$ & $s^{2}$ & $F_{\text {calc }}$ & $t_{\text {calc }}$ \\
\hline 5,00 & 106614 & 1833829 & 3623 & 9786 & 970221 & 0,06 & 11,705 \\
\hline 10,00 & 161714 & 5205714 & 6783 & 17729 & 2683714 & 0,03 & 12,500 \\
\hline 17,99 & 999048 & 7430000 & 10933 & 27300 & 4214524 & 0,13 & 14,915 \\
\hline 24,99 & 678095 & 6932381 & 16276 & 37971 & 3805238 & 0,10 & 20,807 \\
\hline 29,99 & 1846190 & 57528095 & 19419 & 49986 & 29687143 & 0,03 & 10,495 \\
\hline 37,99 & 1601429 & 14139524 & 25747 & 53543 & 7870476 & 0,11 & 18,536 \\
\hline 44,98 & 2729524 & 7765714 & 28005 & 58929 & 5247619 & 0,35 & 25,255 \\
\hline 49,98 & 2102857 & 4432381 & 31505 & 65929 & 3267619 & 0,47 & 35,627 \\
\hline \multicolumn{8}{|c|}{ Rosuvastatina } \\
\hline $\begin{array}{c}\text { Concentração } \\
\left(\mathrm{ng} \mathrm{mL}^{-1}\right)\end{array}$ & $s_{1}$ & $\mathbf{s}_{2}$ & $\mathrm{X}_{1}$ & $X_{2}$ & $s^{2}$ & $F_{\text {calc }}$ & $t_{\text {calc }}$ \\
\hline 5,00 & 34590 & 64924 & 2780 & 1867 & 49757 & 0,53 & 7,653 \\
\hline 10,00 & 280181 & 131095 & 5945 & 3514 & 205638 & 2,14 & 10,029 \\
\hline 18,01 & 221567 & 1971695 & 8917 & 9234 & 1096631 & 0,11 & 0,567 \\
\hline 25,01 & 78095 & 1311433 & 13741 & 9950 & 694764 & 0,06 & 8,509 \\
\hline 30,01 & 748095 & 1336190 & 16441 & 15357 & 1042143 & 0,56 & 1,986 \\
\hline 38,01 & 2281429 & 251429 & 20812 & 18114 & 1266429 & 9,07 & 4,486 \\
\hline 45,01 & 1046190 & 994762 & 24184 & 19714 & 1020476 & 1,05 & 8,278 \\
\hline 50,01 & 972857 & 1158095 & 29084 & 21714 & 1065476 & 0,84 & 13,357 \\
\hline \multicolumn{8}{|c|}{ Sildenafila } \\
\hline $\begin{array}{c}\text { Concentração } \\
\left(\mathrm{ng} \mathrm{mL}^{-1}\right)\end{array}$ & $s_{1}$ & $\mathbf{s}_{2}$ & $X_{1}$ & $X_{2}$ & $s^{2}$ & $F_{\text {calc }}$ & $t_{\text {calc }}$ \\
\hline 30,00 & 150262 & 1978062 & 4228 & 5276 & 1064162 & 0,08 & 1,901 \\
\hline 60,00 & 167124 & 1386357 & 8695 & 9513 & 776740 & 0,12 & 1,736 \\
\hline 107,99 & 406190 & 536148 & 14319 & 9859 & 471169 & 0,76 & 12,157 \\
\hline 149,99 & 238095 & 786667 & 20276 & 30900 & 512381 & 0,30 & 27,766 \\
\hline 179,99 & 296667 & 1918095 & 26262 & 22286 & 1107381 & 0,15 & 7,069 \\
\hline 227,99 & 1721429 & 10228095 & 33876 & 30186 & 5974762 & 0,17 & 2,825 \\
\hline 269,98 & 1552857 & 2892381 & 37605 & 52971 & 2222619 & 0,54 & 19,283 \\
\hline 299,98 & 1878095 & 20881429 & 44948 & 55514 & 11379762 & 0,09 & 5,860 \\
\hline \multicolumn{8}{|c|}{ Valsartana } \\
\hline $\begin{array}{c}\text { Concentração } \\
\left(\mathrm{ng} \mathrm{mL}^{-1}\right)\end{array}$ & $s_{1}$ & $s_{2}$ & $X_{1}$ & $X_{2}$ & $s^{2}$ & $F_{\text {calc }}$ & $t_{\text {calc }}$ \\
\hline 5,00 & 210329 & 11730 & 4176 & 738 & 111029 & 17,93 & 19,303 \\
\hline 10,00 & 166429 & 48762 & 8436 & 1436 & 107595 & 3,41 & 39,924 \\
\hline 18,00 & 299048 & 108257 & 13731 & 5523 & 203652 & 2,76 & 34,030 \\
\hline 25,00 & 3342857 & 365500 & 20017 & 5040 & 1854179 & 9,15 & 20,577 \\
\hline 29,99 & 936190 & 3304929 & 23603 & 10576 & 2120560 & 0,28 & 16,736 \\
\hline 37,99 & 6142857 & 1529524 & 29703 & 12157 & 3836190 & 4,02 & 16,759 \\
\hline 44,99 & 1042381 & 369524 & 35631 & 10757 & 705952 & 2,82 & 55,386 \\
\hline 49,99 & 2722381 & 258095 & 42131 & 11986 & 1490238 & 10,55 & 46,199 \\
\hline
\end{tabular}

A análise dos valores do teste $F$ indica que 0 efeito matriz para a maioria dos compostos não é significativo $\left(F_{\text {calc }}<F_{t a b}\right)$, apenas para as soluções de calibração do atenolol, ciproterona, clopidogrel, losartana, rosuvastatina e valsartana, $\mathrm{o}$ efeito se apresentaram significativos. Entretanto, $\mathrm{o}$ teste $\mathrm{t}$ 
demonstrou que a matriz tem efeito significativo na maioria dos níveis de concentração dos compostos estudados ( $t_{\text {calc }}>t_{\text {tab}}$ ). Os valores com efeito significativo estão apresentados em negrito nas TAB. 25 a 29.

O efeito matriz pode ser visualizado nas FIG. 28 a 30, onde são apresentados os gráficos de área pela concentração para a solução de calibração com matriz e com solvente dos compostos em estudo.

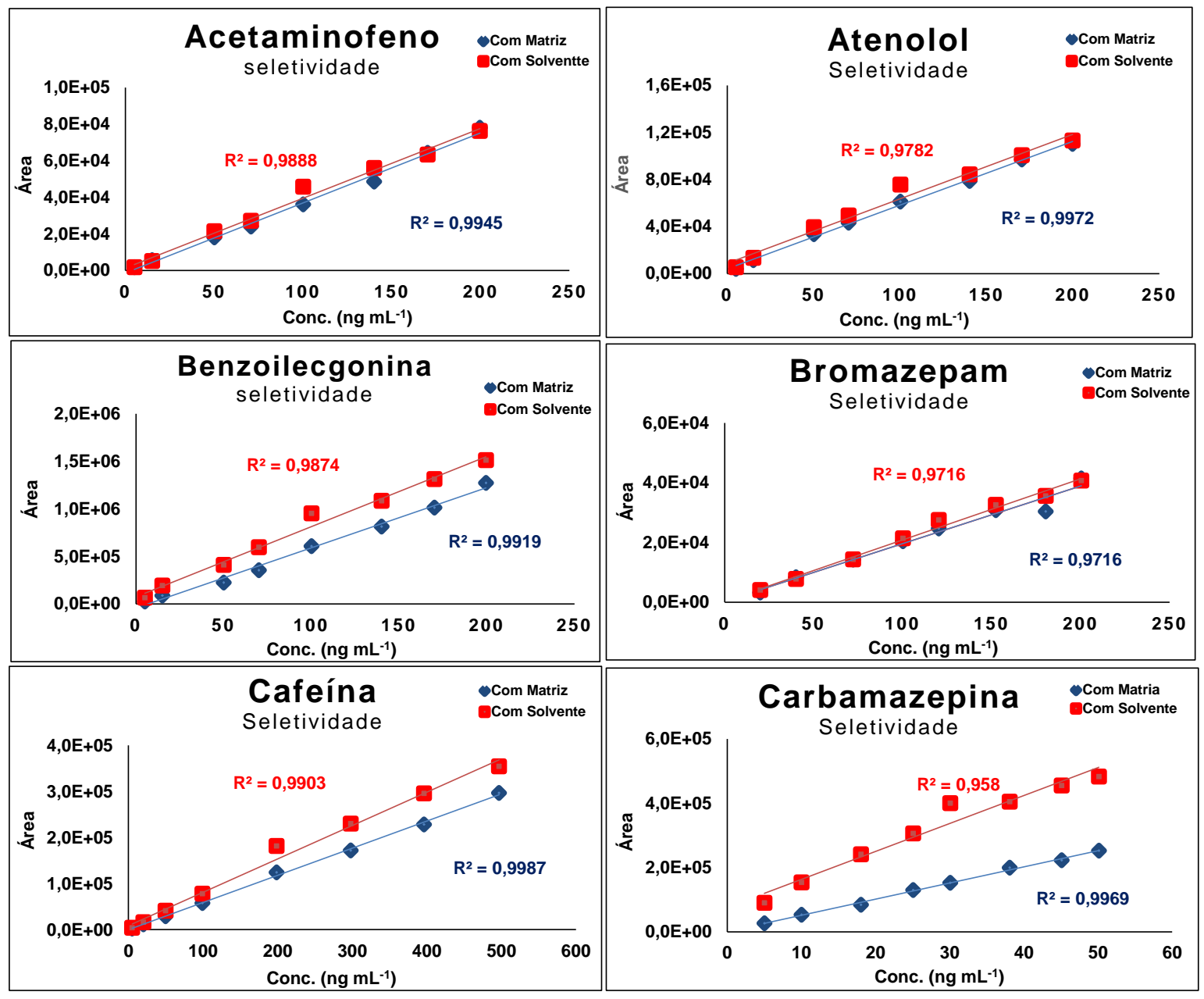

FIGURA 28. Estudo do efeito da matriz na quantificação do acetaminofeno, atenolol, benzoilecgonina, bromazepam, cafeína e carbamazepina, utilizando padronização externa. 


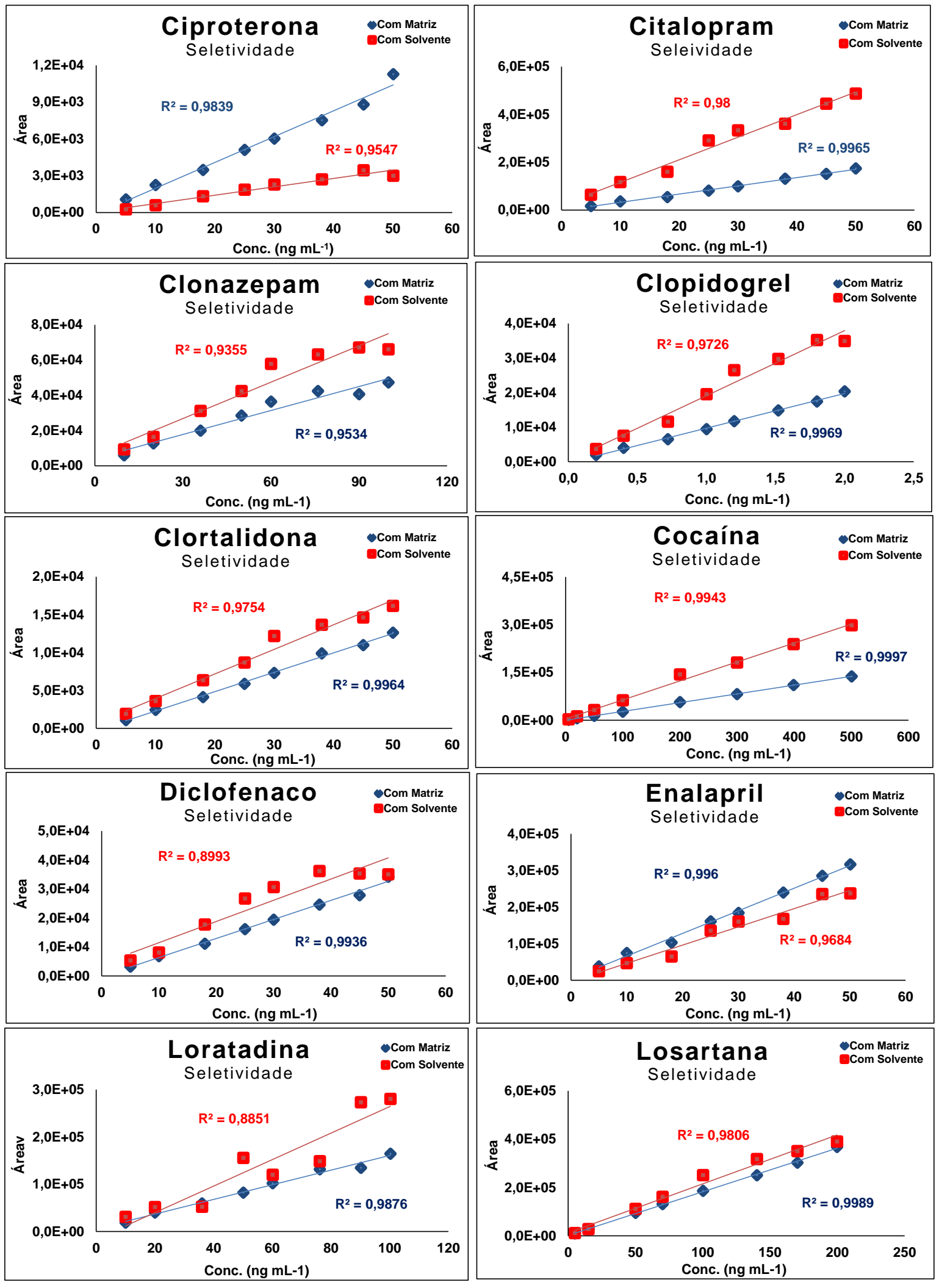

FIGURA 29. Estudo do efeito da matriz na quantificação da ciproterona, citalopram, clonazepam, clopidogrel, clortalidona, cocaína, diclofenaco, enalapril, loratadina e losartana, utilizando padronização externa. 

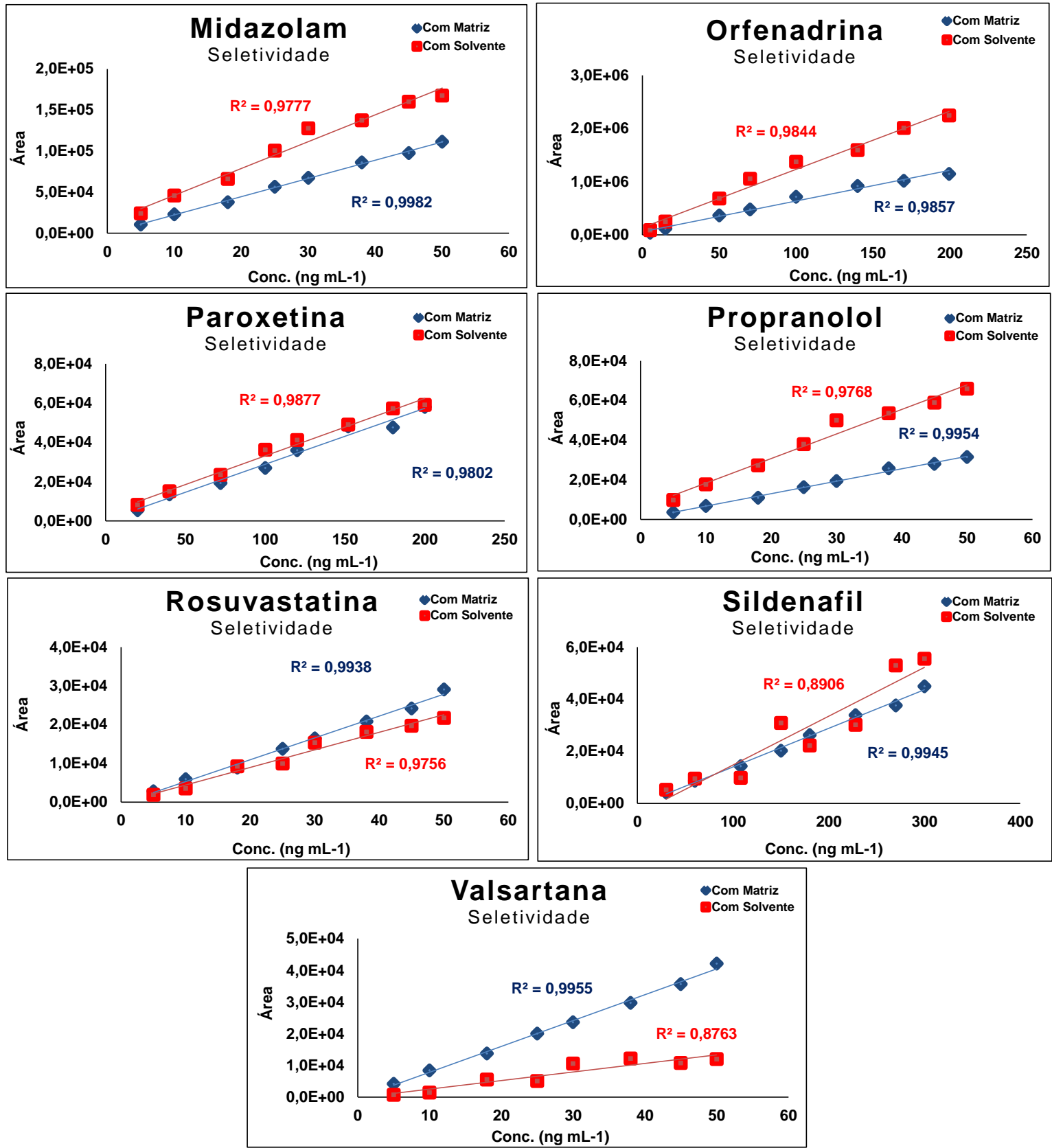

FIGURA 30. Estudo do efeito da matriz na quantificação da midazolam, orfenadrina, paroxetina, propranolol, rosuvastatina, sildenafila $e$ valsartana utilizando padronização externa.

As FIG. 28 a 30 mostraram que o efeito matriz para acetaminofeno, atenolol, bromazepam, losartana e paroxetina não é significativo e a aplicação do teste $F$ também revelou que o efeito matriz não é significativo para a maioria dos compostos $\left(F_{\text {calc }}<F_{\text {tab }}\right)$. A exceção foram atenolol, ciproterona, clopidogrel, losartana, rosuvastatina e valsartana que apresentaram valores de $F_{\text {calc }}>F_{\text {tab }}$ em alguns níveis de concentrações. Entretanto o teste t demostrou que o efeito matriz 
é significativo para todos os compostos em estudo ( $\left.t_{\text {calc }}>t_{\text {tab}}\right)$. Portanto, nesse trabalho, optou-se em utilizar a curva analítica com matriz na quantificação dos 23 compostos em estudo.

Para a maioria dos compostos em estudo, a presença da matriz acarretou uma supressão de sinal, com exceção para ciproterona, enalapril, rosuvastatina e valsartana que demonstraram um aumento de sinal.

\subsubsection{Linearidade}

A TAB. 30 apresentada a faixa de trabalho, as equações das retas e os coeficientes de determinação $\left(r^{2}\right)$ obtidos das 8 (oito) soluções de calibração com matriz em concentrações crescentes dos compostos em estudo. 
TABELA 30. Faixa de trabalho, equação da reta e coeficiente de determinação $\left(r^{2}\right)$ para os compostos de estudo obtidos das 8 (oito) soluções de calibração com matriz.

\begin{tabular}{|c|c|c|c|}
\hline Composto & $\begin{array}{c}\text { Faixa de Trabalho } \\
\left.\text { (ng mL }{ }^{-1}\right)\end{array}$ & Equaçâo da reta & $r^{2}$ \\
\hline Acetam & $5,01-199,55$ & $y=3$ & 0,9999 \\
\hline Atenolol & $5,02-199,85$ & $y=547,97 x+2137,4$ & 0,9999 \\
\hline Benzoilecgonina & $5,01-199,50$ & $y=6247,3 x-7054$ & 0,9996 \\
\hline Bromazepam & $20,04-200,41$ & $y=2 c$ & 1,0000 \\
\hline afeína & 491,83 & $y=5$ & 1,0000 \\
\hline Carbame & 11 & $y=5$ & 1,0000 \\
\hline ipre & 05 & $y=1$ & 98 \\
\hline ital & 3 & $y=3$ & 1,0000 \\
\hline Clor & 0,00 & $y=4$ & 0,9987 \\
\hline Clop & O & $y=$ & 999 \\
\hline Clorta & 50,02 & $y=2$ & 1,0000 \\
\hline Cocaína & $5,04-500,4$ & $y=2$ & 1,0000 \\
\hline Diclof & $5,00-49,98$ & $y=6$ & 0,9996 \\
\hline Enalapril & $5,01-50,08$ & $y=6$ & 1,0000 \\
\hline Loratadina & $10,02-100,25$ & $y=1$ & 1,0000 \\
\hline Losartana & $5,02-199,87$ & $y=1838,3 x+1$ & 1,0000 \\
\hline Midazolam & $5,00-50,03$ & $y=2306,2 x-352,81$ & 1,0000 \\
\hline Orfenadrina & $5,01-199,42$ & $y=5753,1 x+29870$ & 0,9987 \\
\hline Paroxetina & $20,00-199,97$ & $y=281,43 x-869,14$ & 0,9996 \\
\hline Propranolol & $5,00-49,98$ & $y=621,8 x+826,07$ & 0,9999 \\
\hline Rosuvastatina & $4,95-50,01$ & $y=579,81 x-280,23$ & 0,9998 \\
\hline Sildenafila & $30,00-299,98$ & $y=150,59 x-344,68$ & 1,0000 \\
\hline Valsartana & $5,00-49,99$ & $y=810,48 x+218,95$ & 0,9996 \\
\hline
\end{tabular}

Os valores de coeficiente de determinação $\left(r^{2}\right)$ obtidos demonstram linearidade para as regressões de todos os compostos. Os valores obtidos foram superiores ao valor recomendado pelo INMETRO (2003), que orienta coeficiente de correlação linear acima de 0,90. 
A análise de resíduo utilizando o teste t foi realizada para avaliar se os pontos pertencem à curva e se há linearidade na faixa de trabalho, por meio da comparação dos valores de $t$ calculado ( $t_{\text {calc }}$ ) com o valor de $t$ tabelado ( $\left.t_{\text {tab }}\right)$. Neste estudo, o valor de tab é 2,356 (7 graus de liberdade (n-1) e 95\% de nível de confiança). Quando o valor de $t_{\text {calc }}<t_{\text {tab }}$ é indicativo de que o ponto pertence à curva analítica. Os valores de tcalc dos pontos das curvas analíticas dos compostos estudados estão nas TAB. 31 a 33.

TABELA 31. Valores de tcalc para a análise de resíduo das soluções de calibração com matriz do acetaminofeno, atenolol, benzoilecgonina, bromazepam, cafeína, carbamazepina, ciproterona e citalopram, considerando $t_{\text {tab }(7 ; 95 \%)}=2,356$.

\begin{tabular}{|c|c|c|c|c|c|c|c|c|}
\hline & & & Acetar & nofeno & & & & \\
\hline Conc. (ng mL $\mathrm{m}^{-1}$ ) & 5,01 & 15,00 & 50,01 & 70,70 & 100,02 & 140,03 & 170,14 & 199,55 \\
\hline$t_{\text {calc }}$ & 1,637 & 1,761 & 0,391 & 2,424 & 1,077 & 5,051 & 0,625 & 4,139 \\
\hline & & & Ate & plol & & & & \\
\hline Conc. (ng mL $\mathrm{m}^{-1}$ ) & 5,02 & 15,03 & 50,09 & 70,17 & 100,17 & 140,24 & 170,40 & 199,85 \\
\hline$t_{\text {calc }}$ & 3,850 & 1,312 & 3,034 & 1,662 & 4,008 & 1,755 & 0,942 & 2,730 \\
\hline & & & Benzoi & gonina & & & & \\
\hline Conc. (ng mL $\mathrm{m}^{-1}$ ) & 5,01 & 15,00 & 50,00 & 70,05 & 100,00 & 140,00 & 170,10 & 199,50 \\
\hline$t_{\text {calc }}$ & 2,529 & 2,532 & 3,332 & 3,221 & 1,187 & 2,011 & 1,450 & 3,764 \\
\hline & & & Brom & epam & & & & \\
\hline Conc. (ng mL $\mathrm{m}^{-1}$ ) & 20,04 & 40,08 & 72,15 & 100,21 & 120,25 & 152,31 & 180,37 & 200,41 \\
\hline$t_{\text {calc }}$ & 1,257 & 0,417 & 0,032 & 0,931 & 1,492 & 1,409 & 6,234 & 3,210 \\
\hline & & & & & & & & \\
\hline Conc. (ng mL $\mathrm{m}^{-1}$ ) & 5,00 & 19,90 & 49,64 & 99,18 & 198,56 & 297,84 & 396,13 & 496,80 \\
\hline$t_{\text {calc }}$ & 0,475 & 0,131 & 0,140 & 0,525 & 5,012 & 2,702 & 3,874 & 2,835 \\
\hline & & & Carbar & zepina & & & & \\
\hline Conc. (ng mL $\mathrm{m}^{-1}$ ) & 5,01 & 10,02 & 18,04 & 25,06 & 30,07 & 38,09 & 45,10 & 50,11 \\
\hline$t_{\text {calc }}$ & 0,221 & 1,111 & 4,604 & 2,025 & 0,312 & 4,349 & 3,219 & 0,195 \\
\hline & & & Cipre & rona & & & & \\
\hline Conc. (ng mL $\mathrm{m}^{-1}$ ) & 5,01 & 10,01 & 18,02 & 25,03 & 30,03 & 38,04 & 45,05 & 50,05 \\
\hline$t_{\text {calc }}$ & 0,955 & 1,678 & 1,206 & 0,188 & 1,085 & 2,294 & 3,515 & 5,656 \\
\hline & & & Cita & ram & & & & \\
\hline Conc. (ng mL ${ }^{-1}$ ) & 5,00 & 10,01 & 18,01 & 25,02 & 30,02 & 38,02 & 45,03 & 50,03 \\
\hline$t_{\text {calc }}$ & 1,906 & 3,306 & 4,569 & 2,155 & 1,632 & 1,839 & 1,471 & 2,777 \\
\hline
\end{tabular}


TABELA 32. Valores de tcalc para a análise de resíduo das soluções de calibração com matriz da clonazepam, clopidogrel, clortalidona, cocaína, diclofenaco, enalapril, loratadina, losartana, midazolam, orfenadrina, paroxetina e propranolol considerando $\mathrm{t}_{\operatorname{tab}(7 ; 99 \%)}=2,356$.

\begin{tabular}{|c|c|c|c|c|c|c|c|c|}
\hline \multicolumn{9}{|c|}{ Clonazepam } \\
\hline Conc. (ng mL ${ }^{-1}$ ) & 10,00 & 20,00 & 36,00 & 50,00 & 60,00 & 76,00 & 90,00 & 100,00 \\
\hline$t_{\text {calc }}$ & 2,381 & 0,495 & 0,519 & 1,428 & 4,346 & 3,313 & 3,770 & 1,923 \\
\hline \multicolumn{9}{|c|}{ Clopidogrel } \\
\hline Conc. (ng mL ${ }^{-1}$ ) & 0,20 & 0,40 & 0,72 & 1,00 & 1,20 & 1,52 & 1,80 & 2,00 \\
\hline$t_{\text {calc }}$ & 2,042 & 2,497 & 3,218 & 2,422 & 0,244 & 0,916 & 2,468 & 4,731 \\
\hline \multicolumn{9}{|c|}{ Clortalidona } \\
\hline Conc. (ng mL ${ }^{-1}$ ) & 5,00 & 10,00 & 18,01 & 25,01 & 30,01 & 38,01 & 45,02 & 50,02 \\
\hline$t_{\text {calc }}$ & 0,975 & 1,852 & 2,378 & 2,804 & 0,942 & 5,178 & 3,019 & 1,137 \\
\hline \multicolumn{9}{|c|}{ Cocaína } \\
\hline Conc. (ng mL ${ }^{-1}$ ) & 5,04 & 20,04 & 50,00 & 99,90 & 200,00 & 300,00 & 399,00 & 500,40 \\
\hline$t_{\text {calc }}$ & 0,942 & 0,914 & 0,359 & 3,029 & 5,543 & 2,419 & 2,190 & 1,898 \\
\hline \multicolumn{9}{|c|}{ Diclofenaco } \\
\hline Conc. (ng mL ${ }^{-1}$ ) & 5,00 & 10,00 & 17,99 & 24,99 & 29,99 & 37,99 & 44,98 & 49,98 \\
\hline$t_{\text {calc }}$ & 0,632 & 1,618 & 1,643 & 0,223 & 0,271 & 0,455 & 4,824 & 5,166 \\
\hline \multicolumn{9}{|c|}{ Enalapril } \\
\hline Conc. (ng mL $\mathrm{L}^{-1}$ ) & 5,01 & 10,02 & 18,03 & 25,04 & 30,05 & 38,06 & 45,07 & 50,08 \\
\hline$t_{\text {calc }}$ & 1,210 & 3,647 & 5,568 & 0,933 & 2,594 & 0,085 & 1,074 & 1,213 \\
\hline \multicolumn{9}{|c|}{ Loratadina } \\
\hline Conc. (ng mL ${ }^{-1}$ ) & 10,02 & 20,05 & 36,09 & 50,12 & 60,15 & 76,19 & 90,22 & 100,25 \\
\hline$t_{\text {calc }}$ & 1,330 & 1,589 & 1,230 & 0,618 & 1,598 & 3,869 & 5,458 & 1,580 \\
\hline \multicolumn{9}{|c|}{ Losartana } \\
\hline Conc. (ng mL ${ }^{-1}$ ) & 5,02 & 15,03 & 50,09 & 70,18 & 100,19 & 140,26 & 170,42 & 199,87 \\
\hline$t_{\text {calc }}$ & 0,692 & 1,519 & 1,623 & 1,846 & 2,331 & 2,799 & 4,493 & 3,704 \\
\hline \multicolumn{9}{|c|}{ Midazolam } \\
\hline Conc. (ng mL ${ }^{-1}$ ) & 5,00 & 10,01 & 18,01 & 25,02 & 30,02 & 38,02 & 45,03 & 50,03 \\
\hline$t_{\text {calc }}$ & 0,799 & 1,598 & 4,007 & 1,925 & 1,701 & 3,316 & 4,335 & 0,602 \\
\hline \multicolumn{9}{|c|}{ Orfenadrina } \\
\hline Conc. (ng mL $\left.{ }^{-1}\right)$ & 5,01 & 14,99 & 49,98 & 70,02 & 99,96 & 139,94 & 170,03 & 199,42 \\
\hline$t_{\text {calc }}$ & 2,775 & 1,667 & 0,971 & 0,889 & 4,505 & 2,980 & 1,316 & 3,588 \\
\hline \multicolumn{9}{|c|}{ Paroxetina } \\
\hline Conc. (ng mL ${ }^{-1}$ ) & 20,00 & 39,99 & 71,99 & 99,99 & 119,98 & 151,98 & 179,97 & 199,97 \\
\hline$t_{\text {calc }}$ & 0,729 & 1,828 & 1,690 & 2,046 & 1,471 & 4,792 & 4,400 & 0,774 \\
\hline \multicolumn{9}{|c|}{ Propranolol } \\
\hline Conc. (ng mL ${ }^{-1}$ ) & 5,00 & 10,00 & 17,99 & 24,99 & 29,99 & 37,99 & 44,98 & 49,98 \\
\hline$t_{\text {calc }}$ & 0,238 & 0,310 & 3,271 & 0,571 & 0,565 & 5,859 & 2,860 & 1,412 \\
\hline
\end{tabular}


TABELA 33. Valores de tcalc para a análise de resíduo das soluções de calibração com matriz da rosuvastatina, sildenafila e valsartana considerando $t_{\text {tab }(7 ; 95 \%)}=2,356$.

\begin{tabular}{|c|c|c|c|c|c|c|c|c|}
\hline \multicolumn{9}{|c|}{ Rosuvastatina } \\
\hline Conc. (ng mL $\left.{ }^{-1}\right)$ & 5,00 & 10,00 & 18,01 & 25,01 & 30,01 & 38,01 & 45,01 & 50,01 \\
\hline $\mathrm{t}_{\text {calc }}$ (c/Matriz) & 1,180 & 2,534 & 3,505 & 0,073 & 0,539 & 1,085 & 3,338 & 4,825 \\
\hline $\mathrm{t}_{\text {calc }}$ (c/Solvente) & 0,716 & 2,185 & 2,758 & 3,058 & 4,362 & 2,303 & 1,416 & 2,048 \\
\hline \multicolumn{9}{|c|}{ Sildenafila } \\
\hline Conc. (ng mL ${ }^{-1}$ ) & 30,00 & 60,00 & 107,99 & 149,99 & 179,99 & 227,99 & 269,98 & 299,98 \\
\hline $\mathrm{t}_{\text {calc }}$ (c/Matriz) & 1,466 & 1,532 & 2,394 & 3,089 & 0,993 & 2,333 & 4,258 & 3,416 \\
\hline$t_{\text {calc }}$ (c/Solvente) & 1,527 & 0,948 & 2,679 & 2,847 & 3,124 & 3,582 & 2,677 & 1,386 \\
\hline \multicolumn{9}{|c|}{ Valsartana } \\
\hline Conc. (ng mL ${ }^{-1}$ ) & 5,00 & 10,00 & 18,00 & 25,00 & 29,99 & 37,99 & 44,99 & 49,99 \\
\hline $\mathrm{t}_{\text {calc }}$ (c/Matriz) & 1,402 & 1,991 & 1,916 & 0,081 & 1,620 & 2,974 & 2,262 & 5,460 \\
\hline $\mathrm{t}_{\text {calc }}$ (c/Solvente) & 0,688 & 1,793 & 1,437 & 2,569 & 4,471 & 3,483 & 2,064 & 2,277 \\
\hline
\end{tabular}

Os valores de tcalc (TAB. 31 a 33) para algumas soluções de calibração com matriz estão acima do valor do $t_{\text {tab }}$, indicando que esses pontos não pertencem à reta de regressão da curva analítica. No entanto, a TAB. 30 mostra que os coeficientes de determinação dessas regressões foram superiores ou iguais a 0,99 para todos os compostos.

A avaliação da linearidade por meio dos gráficos de resíduo absoluto e normalizado dos fármacos nas soluções de calibrações com matriz pode ser observada na FIG. 31 a 34. 


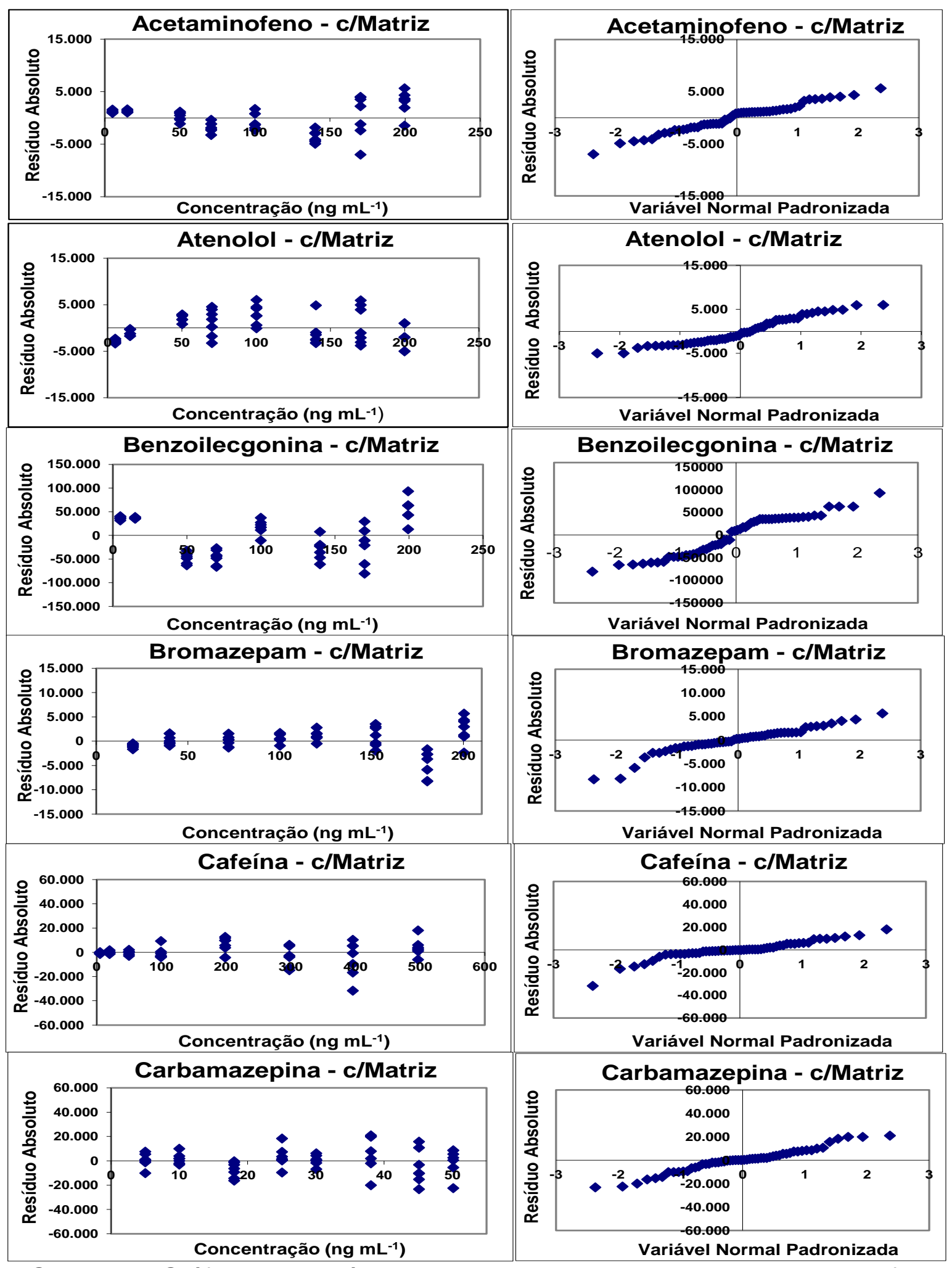

FIGURA 31. Gráficos de resíduo absoluto e normalizado para acetaminofeno. Atenolol, benzoilecgonina, bromazepam, cafeína e carbamazepina nas soluções de calibração com matriz. 


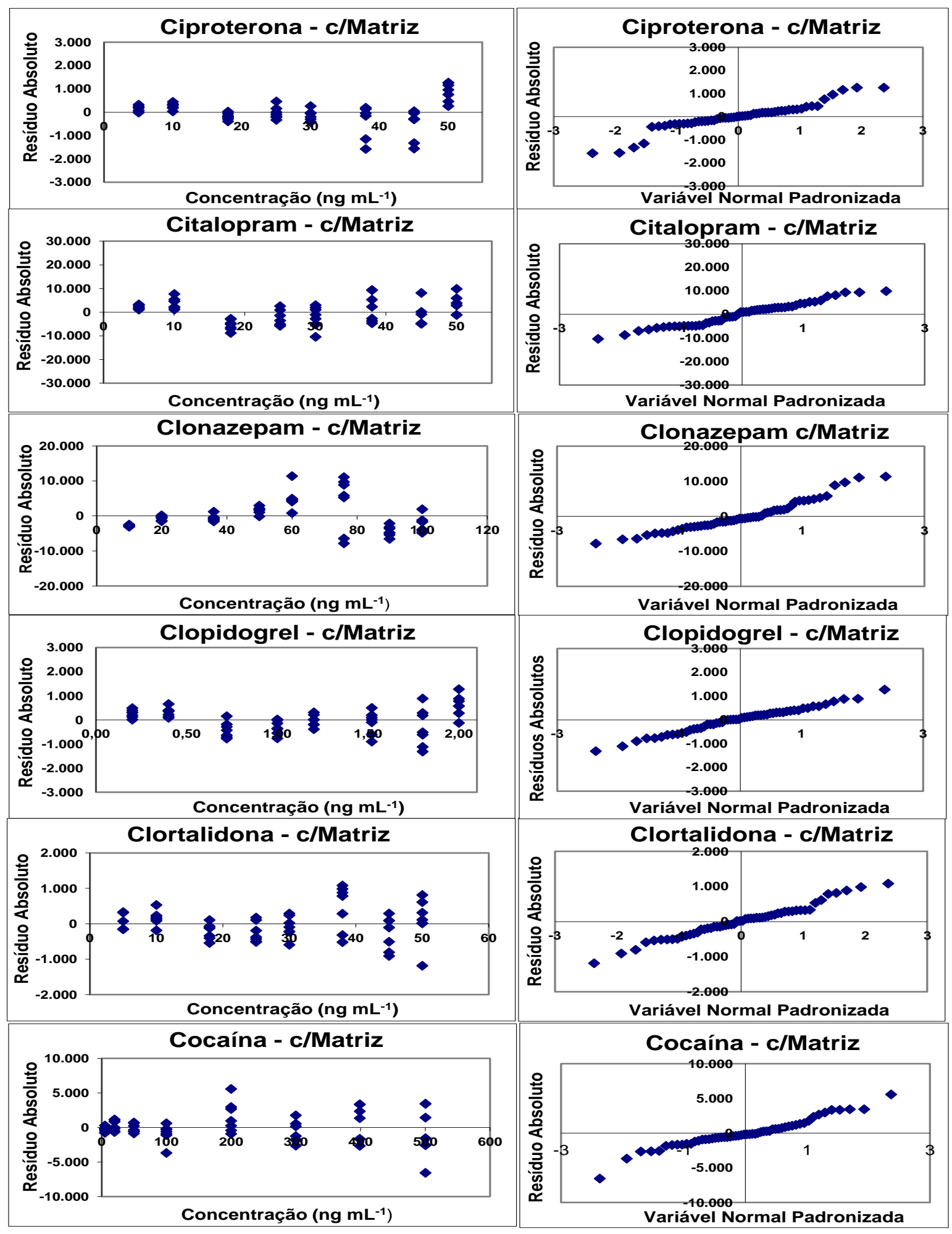

FIGURA 32. Gráficos de resíduo absoluto e normalizado para ciproterona, citalopram, clonazepam, clopidogrel, clortalidona e cocaína nas soluções de calibração com matriz. 


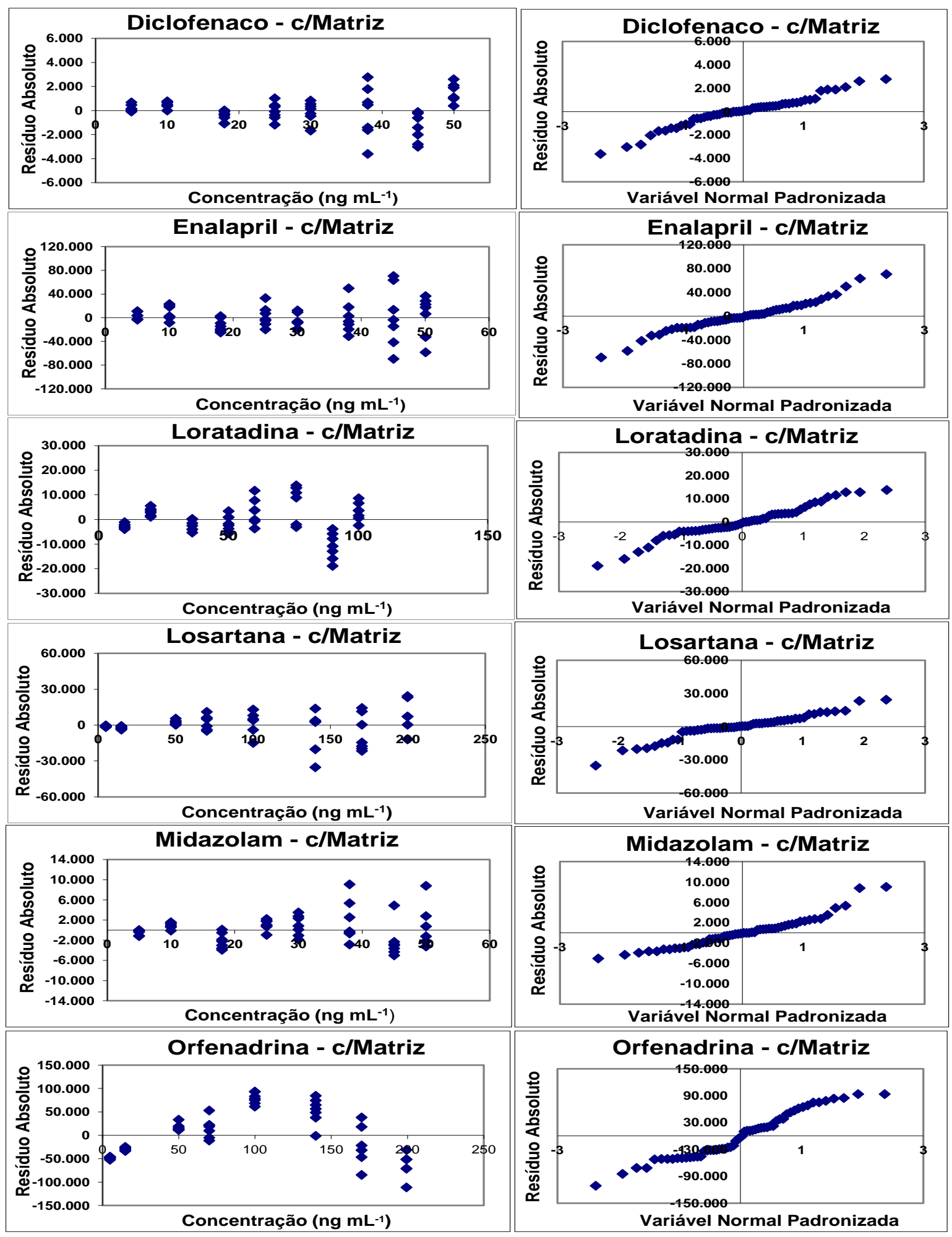

FIGURA 33. Gráficos de resíduo absoluto e normalizado para diclofenaco, enalapril, loratadina, losartana, midazolam e orfenadrina nas soluções de calibração com matriz. 


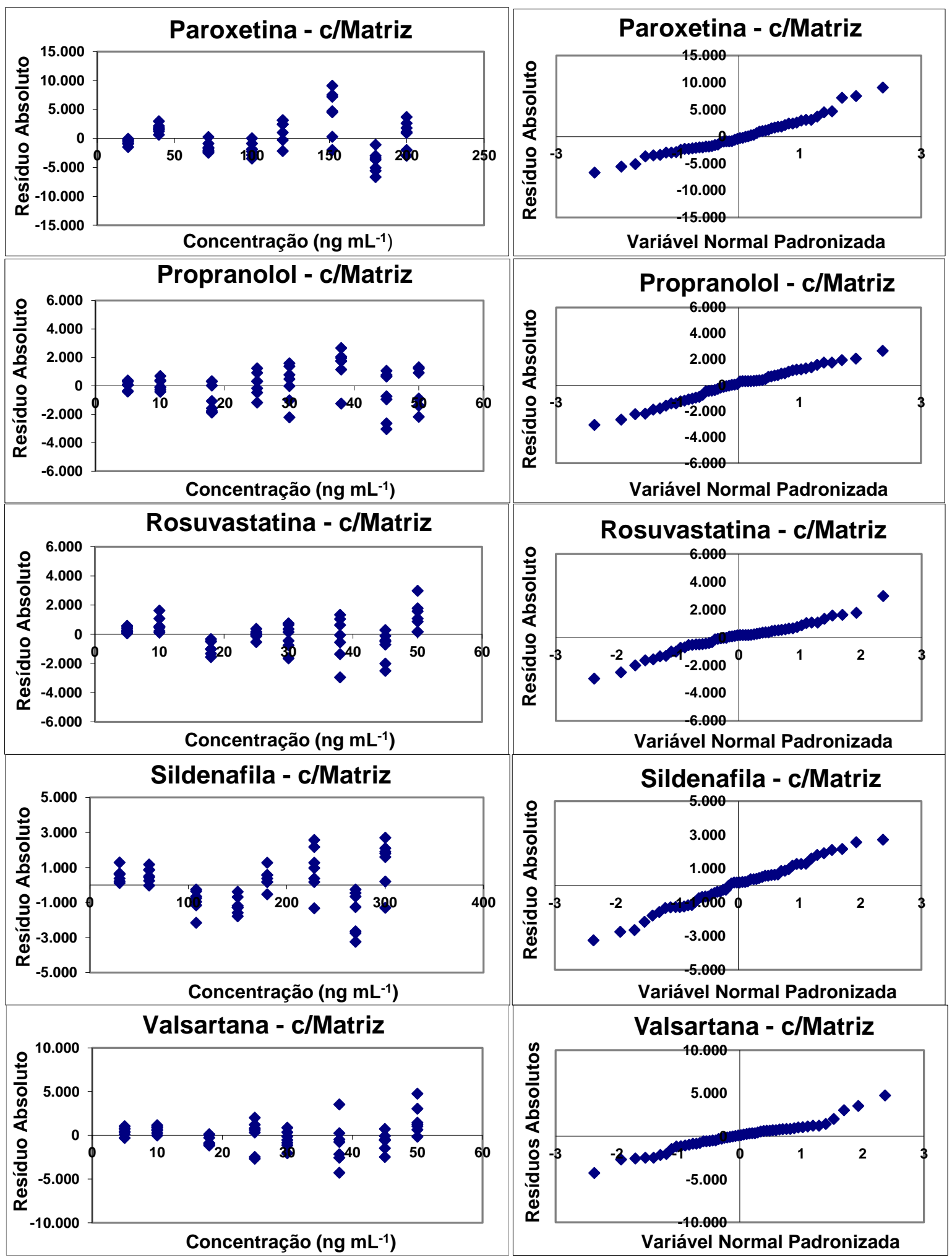

FIGURA 34. Gráficos de resíduo absoluto e normalizado para paroxetina, propranolol, rosuvastatina, sildenafila e valsartana nas soluções de calibração com matriz. 
Observando-se os gráficos de resíduo absoluto para as soluções de calibração com matriz (FIG. 31 a 34) foi possível verificar que existem flutuações nos resultados em cada nível de concentração. Entretanto, quando se analisa os gráficos de resíduo absoluto versus normalizado, nas mesmas soluções, verificase que, os pontos estão distribuídos dentro da faixa de desvio padrão \pm 2 (95\% de confiança) e sem grandes tendências que depreciam o comportamento linear.

Portanto, a quantificação dos compostos em estudo foi realizada com a curva analítica obtida com 5 (cinco) soluções de calibração com matriz.

\subsubsection{Limites de detecção (LD) e quantificação (LQ)}

Na TAB. 34 são apresentados o LD e o LQ obtidos por meio das Eq. 6 e 7, respectivamente.

TABELA 34. Limites de detecção (LD) e quantificação (LQ) do método com matriz.

\begin{tabular}{lcc}
\hline \multirow{2}{*}{ Composto } & \multicolumn{2}{c}{ Limite do Método } \\
\cline { 2 - 3 } & $\begin{array}{c}\text { LD } \\
\text { (ng L') }\end{array}$ & $\begin{array}{c}\text { LQ } \\
\text { (ng L') }\end{array}$ \\
\hline Acetaminofeno & 1,4 & 8,4 \\
Atenolol & 1,6 & 6,9 \\
Benzoilecgonina & 1,2 & 7,7 \\
Bromazepam & 5 & 28 \\
Cafeína & 2,2 & 8,5 \\
Carbamazepina & 3 & 10 \\
Ciproterona & 1,5 & 7,5 \\
Citalopram & 0,6 & 5,9 \\
Clonazepam & 1,3 & 10,0 \\
Clopidogrel & 0,04 & 0,28 \\
Clortalidona & 2,3 & 8,8 \\
Cocaína & 3 & 12 \\
Diclofenaco & 1,0 & 7,4 \\
Enalapril & 3 & 9 \\
Loratadina & 1,4 & 12,6 \\
Losartana & 0,7 & 6,1 \\
Midazolam & 0,6 & 5,9 \\
Orfenadrina & 1,4 & 17,7 \\
Paroxetina & 4 & 31 \\
Propanolol & 1,3 & 7,2 \\
Rosuvastatina & 0,8 & 6,9 \\
Sildenafila & 6 & 43 \\
Valsartana & 1,4 & 7,7 \\
\hline
\end{tabular}




\subsubsection{Precisão}

A precisão do método (CV\%) e os limites de repetibilidade $(r)$ e reprodutibilidade $(R)$ calculados pelas Eq. 8, 9 e 10, respectivamente, são apresentados na TAB. 35.

TABELA 35. Coeficiente de variação (CV\%), limites de repetibilidade $(r)$ e reprodutibilidade $(R)$ e seus respectivos desvios padrão $\left(S_{r}\right.$ e $\left.S_{R}\right)$ obtidos em três níveis de concentrações da curva analítica com matriz para os compostos em estudo.

\begin{tabular}{|c|c|c|c|c|c|c|}
\hline Composto & $\begin{array}{c}\text { Conc. } \\
\left.\text { (ng mL }{ }^{-1}\right)\end{array}$ & CV (\%) & $\mathrm{S}_{\mathrm{r}}$ & $r$ & $\mathrm{~S}_{\mathrm{R}}$ & $\mathrm{R}$ \\
\hline & 15,00 & 4 & 0,6 & 1,7 & 0,2 & 0,5 \\
\hline \multirow[t]{2}{*}{ Acetaminofeno } & 100,00 & 4 & 4 & 11 & 2 & 6 \\
\hline & 199,55 & 3 & 6 & 16 & 3 & 9 \\
\hline & 50,09 & 2 & 1 & 4 & 0,3 & 0,8 \\
\hline \multirow[t]{2}{*}{ Atenolol } & 100,17 & 4 & 4 & 11 & 1 & 3 \\
\hline & 199,85 & 2 & 4 & 13 & 2 & 5 \\
\hline \multirow{4}{*}{ Benzoilecgonina } & 15,00 & 1 & 0,2 & 0,6 & 0,1 & 0,3 \\
\hline & 100,00 & 2 & 2 & 7 & 1 & 3 \\
\hline & 199,50 & 2 & 4 & 11 & 1 & 4 \\
\hline & 40,08 & 11 & 5 & 13 & 2 & 6 \\
\hline \multirow[t]{2}{*}{ Bromazepam } & 120,25 & 4 & 5 & 14 & 2 & 6 \\
\hline & 200,41 & 6 & 13 & 36 & 6 & 18 \\
\hline \multirow{3}{*}{ Cafeína } & 198,56 & 5 & 10 & 28 & 3 & 9 \\
\hline & 297,84 & 5 & 14 & 38 & 5 & 14 \\
\hline & 496,80 & 2 & 12 & 34 & 7 & 21 \\
\hline \multirow{3}{*}{ Carbamazepina } & 30,07 & 3 & 0,8 & 2,3 & 0,3 & 0,9 \\
\hline & 45,10 & 7 & 3 & 8 & 1 & 4 \\
\hline & 50,11 & 4 & 2 & 6 & 0,7 & 1,9 \\
\hline \multirow{3}{*}{ Ciproterona } & 18,02 & 4 & 0,7 & 2,0 & 0,5 & 1,3 \\
\hline & 30,03 & 4 & 1 & 4 & 0,6 & 1,6 \\
\hline & 50,05 & 4 & 2 & 6 & 0,8 & 2,2 \\
\hline \multirow{3}{*}{ Citalopram } & 18,01 & 4 & 0,6 & 1,8 & 0,2 & 0,4 \\
\hline & 45,03 & 3 & 1 & 4 & 0,4 & 1,1 \\
\hline & 50,03 & 2 & 1 & 3 & 0,7 & 1,9 \\
\hline \multirow{3}{*}{ Clonazepam } & 10,00 & 7 & 0,5 & 1,5 & 0,2 & 0,6 \\
\hline & 50,00 & 4 & 2 & 6 & 1 & 4 \\
\hline & 90,00 & 4 & 3 & 9 & 1 & 3 \\
\hline \multirow{3}{*}{ Clopidogrel } & 0,40 & 5 & 0,02 & 0,05 & 0,01 & 0,02 \\
\hline & 1,20 & 2 & 0,02 & 0,07 & 0,01 & 0,03 \\
\hline & 2,00 & 2 & 0,04 & 0,12 & 0,02 & 0,06 \\
\hline \multirow{3}{*}{ Clortalidona } & 10,00 & 9 & 0,9 & 2,4 & 0,5 & 1,4 \\
\hline & 30,01 & 4 & 1 & 3 & 0,8 & 2,3 \\
\hline & 45,02 & 4 & 2 & 5 & 0,5 & 1,4 \\
\hline
\end{tabular}


Cont. TABELA 35.

\begin{tabular}{|c|c|c|c|c|c|c|}
\hline Composto & $\begin{array}{c}\text { Conc. } \\
\left(\mathrm{ng} \mathrm{mL}^{-1}\right)\end{array}$ & CV (\%) & $\mathrm{S}_{\mathrm{r}}$ & $r$ & $\mathrm{~S}_{\mathrm{R}}$ & $\mathrm{R}$ \\
\hline & 50,00 & 5 & 2 & 6 & 1 & 4 \\
\hline \multirow{3}{*}{ Cocaína } & 200,00 & 4 & 8 & 23 & 3 & 8 \\
\hline & 500,40 & 3 & 13 & 37 & 4 & 11 \\
\hline & 10,00 & 4 & 0,4 & 1,1 & 0,2 & 0,5 \\
\hline \multirow[t]{3}{*}{ Diclofenaco } & 17,99 & 4 & 0,7 & 1,8 & 0,2 & 0,7 \\
\hline & 49,98 & 2 & 1 & 3 & 0,4 & 1,1 \\
\hline & 18,03 & 12 & 2 & 5 & 2 & 5 \\
\hline \multirow{3}{*}{ Enalapril } & 25,04 & 12 & 3 & 8 & 2 & 4 \\
\hline & 30,05 & 7 & 2 & 6 & 3 & 9 \\
\hline & 36,09 & 4 & 1 & 4 & 0,7 & 2,0 \\
\hline \multirow{3}{*}{ Loratadina } & 50,12 & 4 & 2 & 5 & 1 & 3 \\
\hline & 100,25 & 2 & 2 & 6 & 2 & 4 \\
\hline & 15,03 & 4 & 0,6 & 1,6 & 0,3 & 0,7 \\
\hline \multirow{3}{*}{ Losartana } & 50,09 & 2 & 1 & 3 & 0,3 & 0,9 \\
\hline & 199,87 & 4 & 8 & 22 & 3 & 8 \\
\hline & 10,01 & 2 & 0,2 & 0,7 & 0,07 & 0,20 \\
\hline \multirow{3}{*}{ Midazolam } & 25,02 & 2 & 0,5 & 1,3 & 0,2 & 0,5 \\
\hline & 30,02 & 3 & 0,9 & 2,5 & 0,3 & 1,0 \\
\hline & 49,98 & 3 & 1 & 4 & 0,6 & 1,5 \\
\hline \multirow[t]{3}{*}{ Orfenadrina } & 99,96 & 2 & 2 & 6 & 1 & 3 \\
\hline & 199,42 & 2 & 4 & 12 & 2 & 5 \\
\hline & 99,99 & 4 & 4 & 12 & 2 & 5 \\
\hline \multirow[t]{3}{*}{ Paroxetina } & 179,97 & 4 & 7 & 18 & 2 & 5 \\
\hline & 199,97 & 4 & 8 & 24 & 6 & 15 \\
\hline & 10,00 & 7 & 0,7 & 1,8 & 0,3 & 0,8 \\
\hline \multirow[t]{3}{*}{ Propanolol } & 24,99 & 5 & 1 & 4 & 0,9 & 2,4 \\
\hline & 49,98 & 5 & 2 & 7 & 0,6 & 1,8 \\
\hline & 5,00 & 6 & 0,3 & 0,9 & 0,2 & 0,6 \\
\hline \multirow[t]{3}{*}{ Rosuvastatina } & 25,01 & 2 & 0,5 & 1,3 & 0,1 & 0,2 \\
\hline & 50,01 & 3 & 2 & 5 & 0,4 & 1,1 \\
\hline & 60,00 & 5 & 3 & 8 & 1 & 3 \\
\hline \multirow{3}{*}{ Sildenafila } & 179,99 & 2 & 4 & 10 & 2 & 6 \\
\hline & 299,98 & 3 & 9 & 25 & 4 & 10 \\
\hline & 10,00 & 5 & 0,5 & 1,4 & 0,2 & 0,6 \\
\hline \multirow[t]{2}{*}{ Valsartana } & 29,99 & 4 & 1 & 3 & 0,4 & 1,0 \\
\hline & 49,99 & 4 & 2 & 6 & 1 & 3 \\
\hline
\end{tabular}

Os coeficientes de variação (CV\%) obtidos foram iguais ou inferiores a $7 \%$ para a maioria dos compostos, sendo superior apenas para o Enalapril $(12 \%$ para as concentrações baixa e média) e bromazepam (11\% para a concentração mais baixa). De acordo com Horwitz \& Albert (2006), um método é considerado ideal para análises de traços quando se obtém valores de precisão inferior a $20 \%$, portanto o método proposto foi considerado preciso para todos os compostos estudados. 
Segundo Chui et al. (2009), para que a metodologia apresente repetitividade e reprodutibilidade, os valores de $r$ e $R$ devem ser superiores à diferença entre as replicatas. Portanto, verifica-se na TAB. 35, que a metodologia proposta é precisa, uma vez que todos os valores de $r$ e $R$ são superiores aos seus respectivos desvios padrão.

\subsubsection{Exatidão}

A exatidão (Z) do método para os 23 compostos em estudo foi calculado pela Eq. 11 e os resultados estão apresentados na TAB. 36.

TABELA 36. Valores de $Z$ obtidos para os 23 compostos nas soluções de calibração com matriz.

\begin{tabular}{lc}
\hline \multicolumn{1}{c}{ Composto } & Z-score \\
\hline Acetaminofeno & 0,8 \\
Atenolol & 0,4 \\
Benzoilecgonina & 0,3 \\
Bromazepam & 0,6 \\
Cafeína & 0,1 \\
Carbamazepina & 0,3 \\
Ciproterona & 0,9 \\
Citalopram & 0,2 \\
Clonazepam & 1,5 \\
Clopidogrel & 0,1 \\
Clortalidona & 1,0 \\
Cocaína & 0,1 \\
Diclofenaco & 1,0 \\
Enalapril & 0,9 \\
Loratadina & 0,4 \\
Losartana & 1,0 \\
Midazolam & 0,5 \\
Orfenadrina & 0,2 \\
Paroxetina & 0,1 \\
Propanolol & 0,5 \\
Rosuvastatina & 0,6 \\
Sildenafila & 0,1 \\
Valsartana & 0,2 \\
\hline
\end{tabular}


Os valores de $Z$ obtidos (TAB. 36) estão dentro do intervalo satisfatório de exatidão para todos os compostos nas soluções de calibração com matriz.

\subsubsection{Recuperação}

O estudo da recuperação foi realizado para as concentrações referentes às soluções de calibração P2, P4 e P7 (TAB. 18) com matriz. Os valores da média de 3 (três) ensaios de recuperação, em 3 (três) níveis de concentração obtidos para os 23 compostos, na solução de análise, são apresentados na TAB. 37.

TABELA 37. Recuperação, referente à média de 3 ensaios, em 3 níveis de concentrações dos 23 compostos selecionados

\begin{tabular}{|c|c|c|c|c|c|c|}
\hline Composto & $\begin{array}{l}\text { Conc. } \\
\left(\mu \mathrm{g} \mathrm{L}^{-1}\right)\end{array}$ & $\begin{array}{c}\text { Recuperação } \\
(\%)\end{array}$ & $\begin{array}{l}\text { Conc. } \\
\left(\mu \mathrm{g} \mathrm{L}^{-1}\right)\end{array}$ & $\begin{array}{c}\text { Recuperação } \\
(\%)\end{array}$ & $\begin{array}{l}\text { Conc. } \\
\left(\mu \mathrm{g} \mathrm{L}^{-1}\right)\end{array}$ & $\begin{array}{c}\text { Recuperação } \\
(\%)\end{array}$ \\
\hline Acetaminofeno & 15,00 & 38 & 70,07 & 33 & 170,14 & 32 \\
\hline Atenolol & 15,03 & 85 & 70,17 & 96 & 170,40 & 97 \\
\hline Benzoilecgonina & 15,00 & 82 & 70,05 & 73 & 170,10 & 92 \\
\hline Bromazepam & 40,08 & 95 & 100,21 & 97 & 180,37 & 97 \\
\hline Cafeína & 19,90 & 73 & 99,18 & 88 & 396,13 & 92 \\
\hline Carbamazepina & 10,02 & 99 & 25,06 & 90 & 45,10 & 95 \\
\hline Ciproteroma & 10,01 & 97 & 25,03 & 89 & 45,05 & 91 \\
\hline Citalopram & 10,01 & 91 & 25,02 & 86 & 45,03 & 94 \\
\hline Clonazepam & 20,00 & 99 & 50,00 & 94 & 90,00 & 99 \\
\hline Clopidogrel & 0,40 & 82 & 1,00 & 87 & 1,80 & 98 \\
\hline Clortalidona & 10,00 & 90 & 25,01 & 76 & 45,02 & 78 \\
\hline Cocaína & 20,04 & 102 & 99,90 & 83 & 399,00 & 77 \\
\hline Diclofenaco & 10,00 & 67 & 24,99 & 71 & 44,98 & 66 \\
\hline Enlapril & 10,02 & 91 & 25,04 & 88 & 45,07 & 75 \\
\hline Loratadina & 20,05 & 97 & 50,12 & 94 & 90,22 & 103 \\
\hline Losartana & 15,03 & 72 & 70,18 & 77 & 170,42 & 79 \\
\hline Midazolam & 10,01 & 75 & 25,02 & 81 & 45,03 & 80 \\
\hline Orfenadrina & 49,98 & 55 & 70,02 & 78 & 170,03 & 82 \\
\hline Paroxetina & 39,99 & 12 & 99,99 & 34 & 179,97 & 31 \\
\hline Propranolol & 10,00 & 104 & 24,99 & 101 & 44,98 & 101 \\
\hline Rosuvastatina & 10,00 & 96 & 25,01 & 97 & 45,01 & 96 \\
\hline Sildenafila & 60,00 & 90 & 149,99 & 78 & 269,98 & 84 \\
\hline Valsartana & 10,00 & 83 & 25,00 & 81 & 44,99 & 82 \\
\hline
\end{tabular}


Os intervalos aceitáveis de recuperação para análise de traços são de 70 a $120 \%$, com precisão de até $\pm 20 \%$. Porém, dependendo da complexidade analítica e da amostra, este valor pode ser de 50 a $120 \%$, com precisão de até \pm 15\% (RIBANI, et al., 2004).

Os valores de recuperação obtidos encontraram-se na faixa de $55 \%$ a 104\%, para 21 (vinte e um) compostos, indicando uma adequada recuperação do método desenvolvido. Apenas para acetaminofeno e paroxetina, os valores de recuperações em todos os níveis de concentração ficaram abaixo dos valores recomendados. Segundo GROS et al. (2006), quando outros parâmetros de desempenho como o LD, LQ, precisão e exatidão estiverem dentro do intervalo satisfatório, os compostos com baixa taxa de recuperação podem ser quantificados. Portanto, a acetaminofeno e a paroxetina foram quantificadas pela metodologia desenvolvida neste trabalho.

\subsubsection{Robustez}

A robustez do método desenvolvido foi avaliada por meio de 8 (oito) ensaios distintos, descritos no item 5.5.7 desse trabalho.

O resultado dos ensaios é apresentado nas FIG. 35 a 37, onde se pode avaliar melhor as influências dos 7 (sete) parâmetros selecionados, do método desenvolvido, para a quantificação dos 23 compostos em estudo. 


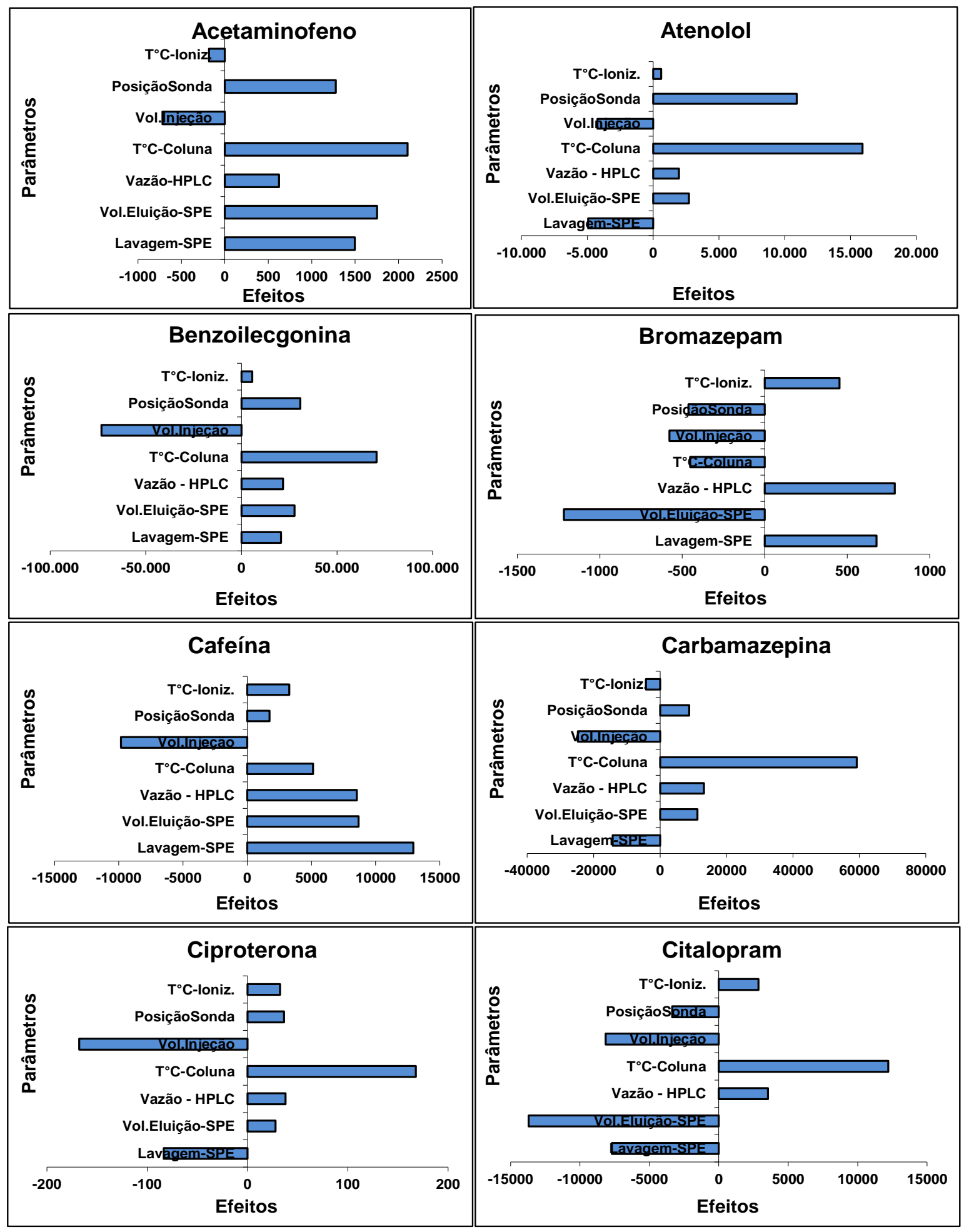

FIGURA 35. Efeitos dos parâmetros selecionados para avaliar a robustez do método na quantificação do acetaminofeno, atenolol, benzoilecgonina, bromazepam, cafeína, carbamazepina, ciproterona e citalopram, em amostra com adição de solução mista de padrões. 


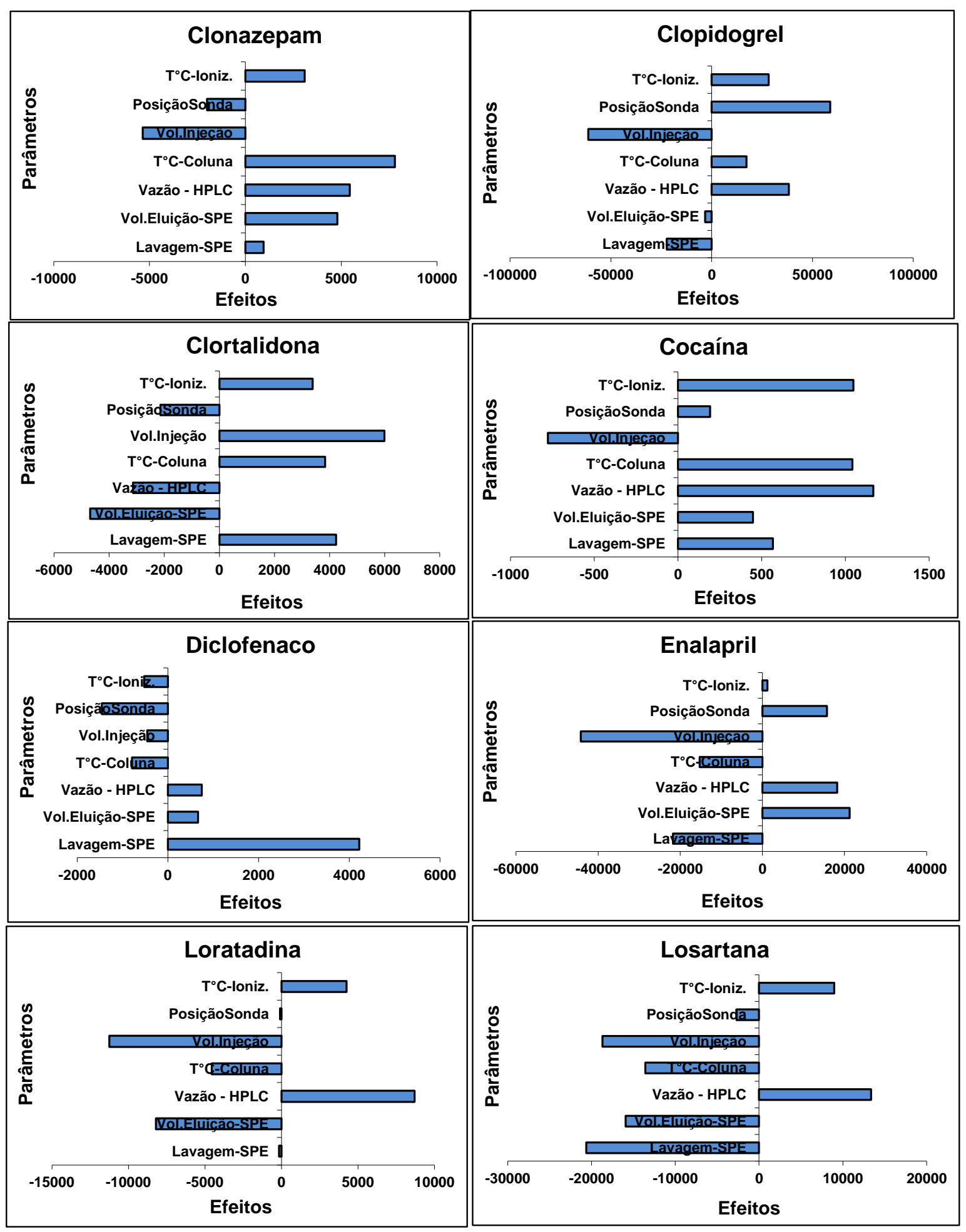

FIGURA 36. Efeitos dos parâmetros selecionados para avaliar a robustez do método de quantificação do clonazepam, clopidogrel, clortalidona, cocaína, diclofenaco, enalapril, loratadina e losartana, em amostra com adição de solução mistura de padrões. 

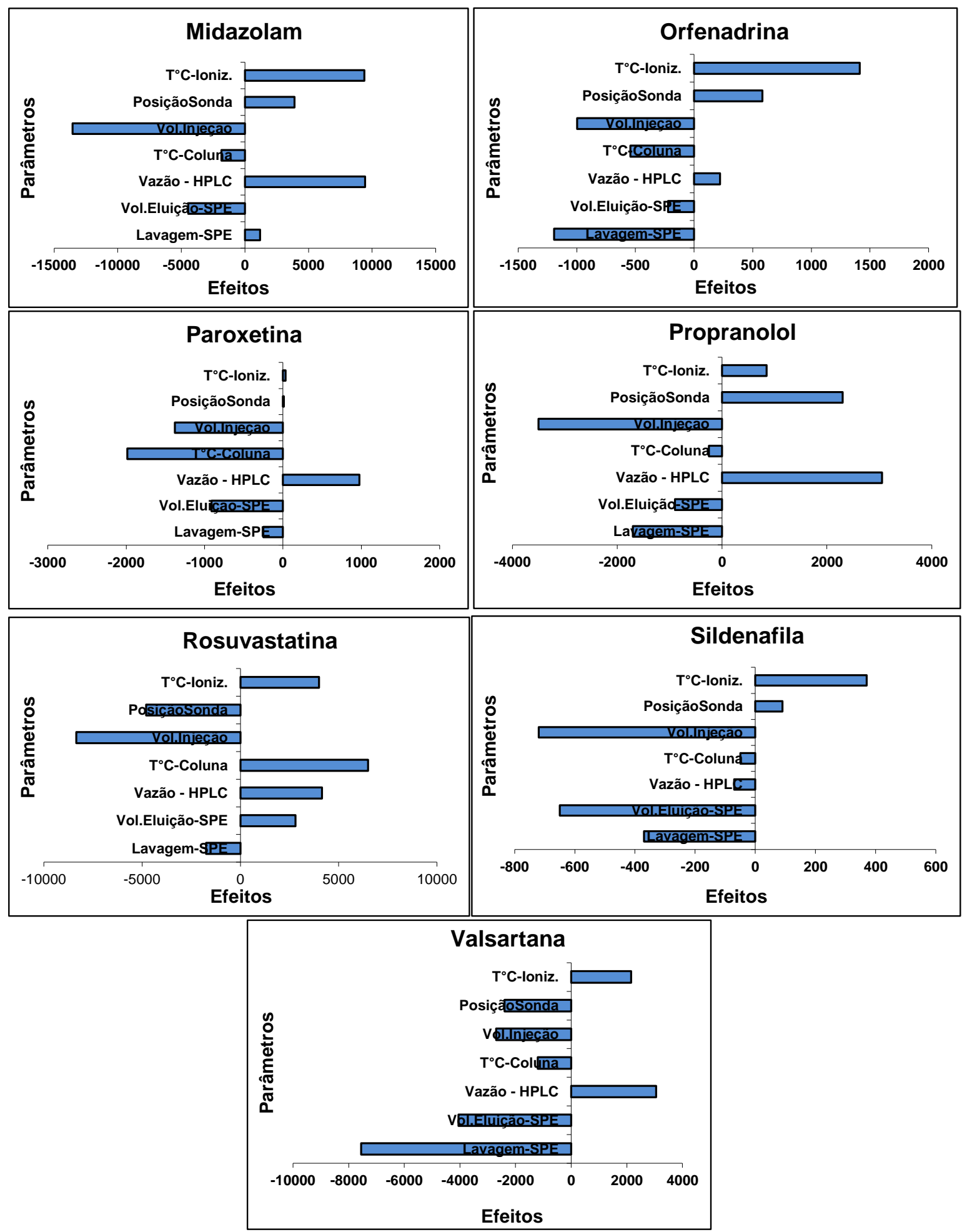

FIGURA 37. Efeitos dos parâmetros selecionados para avaliar a robustez do método de quantificação do midazolam, orfenadrina, paroxetina, propranolol, rosuvastatina, sildenafila e valsartana, em amostra com adição de solução mista de padrões.

Nas FIG. 35 a 37 observam-se que 87\%, 65\%, 7\%, 52\%, 87\%, 48\% e $39 \%$ dos compostos em estudo acusaram efeitos positivos no teste de robustez 
referente à mudança dos valores da temperatura de ionização, posição da sonda, volume de injeção das amostras, temperatura de coluna, vazão do HPLC, volume de eluição no SPE e volume de lavagem do SPE, respectivamente.

Os resultados mostraram que a vazão do HPLC e a temperatura de ionização foram os parâmetros com efeito positivo mais presente. Nesses casos, o estudo da robustez adotado sugere que, valores nominais dos parâmetros favorece a análise dos compostos de interesse. Alguns compostos apresentaram efeitos negativos acentuados, por exemplo, orfenadrina, sildenafila, propranolol, valsartana, losartana, citalopram e atenolol, para o parâmetro lavagem do SPE. Esse comportamento perante a mudança do valor nominal indica um favorecimento na determinação destes compostos em relação à alteração. Entretanto, em um estudo onde estão envolvidos 23 compostos é muito difícil encontrar um valor de consenso, onde todos os compostos são favorecidos da mesma forma e para todos os parâmetros. O importante é que se tenha um controle eficaz, ou seja, um cuidado maior em relação aos parâmetros que interferem na realização do método. Por meio do resultado do teste de robustez realizado, foi possível observar que os compostos têm robustez bem diferente em relação aos parâmetros avaliados. Por exemplo, o parâmetro temperatura de ionização é bem robusto para os compostos acetaminofeno, atenolol, benzoilecgonina, carbamazepina, diclofenaco, enalapril e paroxetina, fato este que pode ser observado nas representações gráficas das FIG. 35 a 37, por estarem bem próximas ao eixo. Para os compostos clortalidona, cocaína e orfenadrina, por exemplo, a temperatura de ionização é um parâmetro que requer muita atenção na determinação.

Para uma melhor avaliação dos efeitos resultantes da variação do valor dos parâmetros, construiu-se com os resultados obtidos gráfico de Rankit dos compostos em estudo (FIG. 38 a 40). Os gráficos demonstram que os efeitos das variações aplicadas não são significativos sobre os resultados, pois os valores obtidos para todos os 23 compostos encontram-se abaixo do limite mais crítico, ME ("Margin of Error") e SME ("Simultaneous Margin Error") (ZEAITER, et al., 2004; FURUSAWA, 2007). 

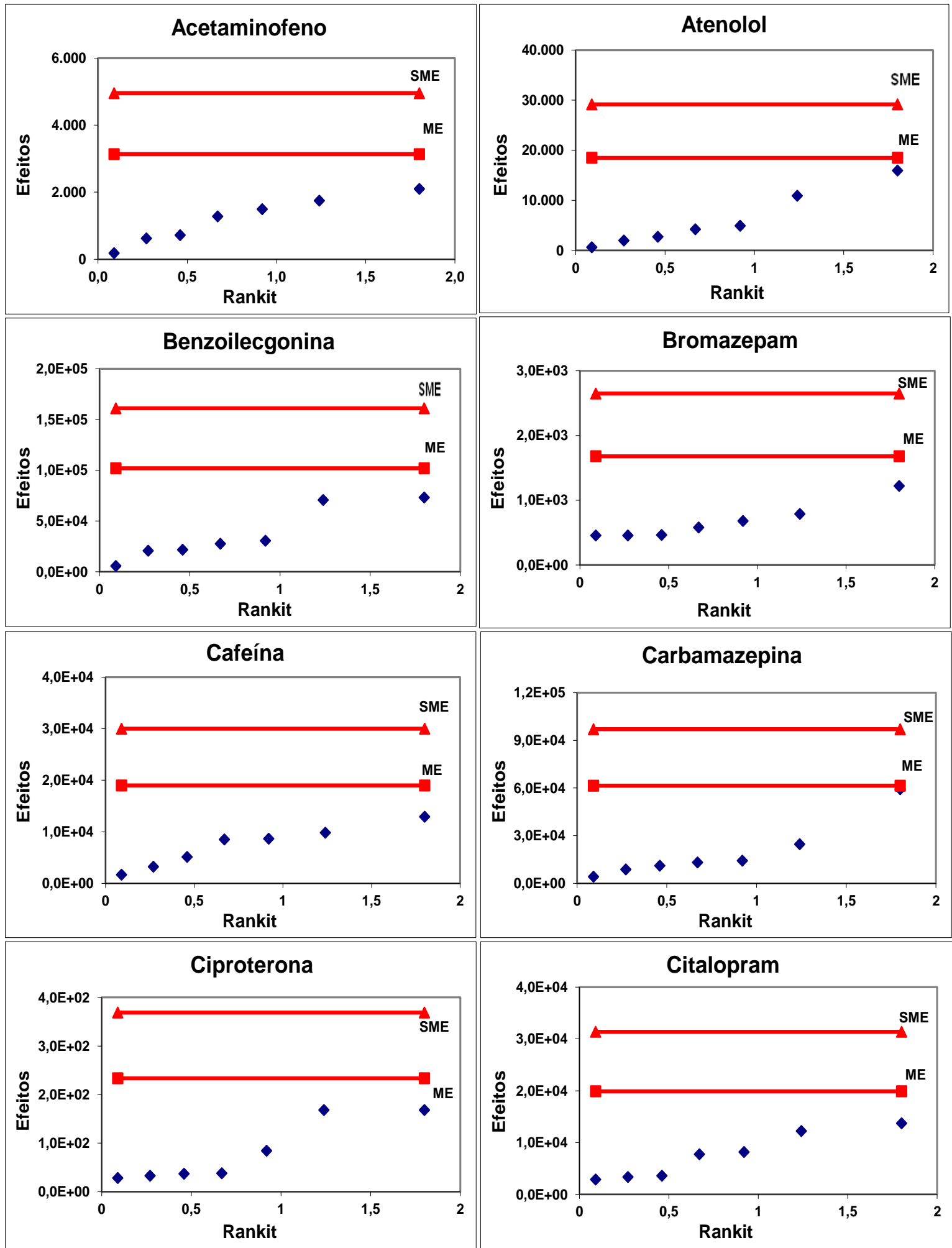

FIGURA 38. Gráficos de rankit para acetaminofeno, atenolol, benzoilecgonina, bromazepam, cafeína, carbamazepina, ciproterona e citalopram nas amostras com adição de solução mista de padrões. 

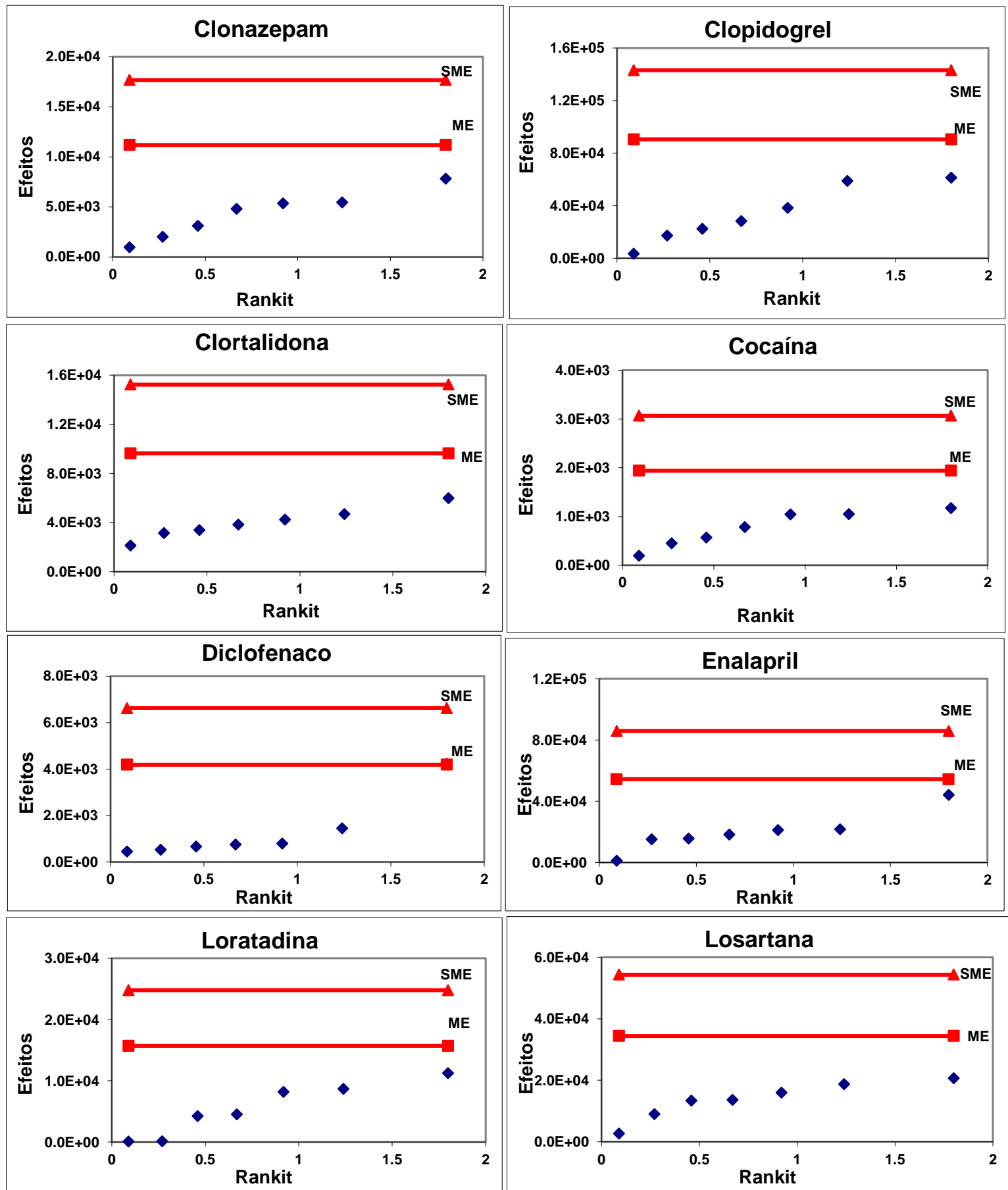

FIGURA 39. Gráficos de rankit para clonazepam, clopidogrel, clortalidona, cocaína, diclofenaco, enalapril, loratadina e losartana nas amostras com adição de solução mista de padrões. 

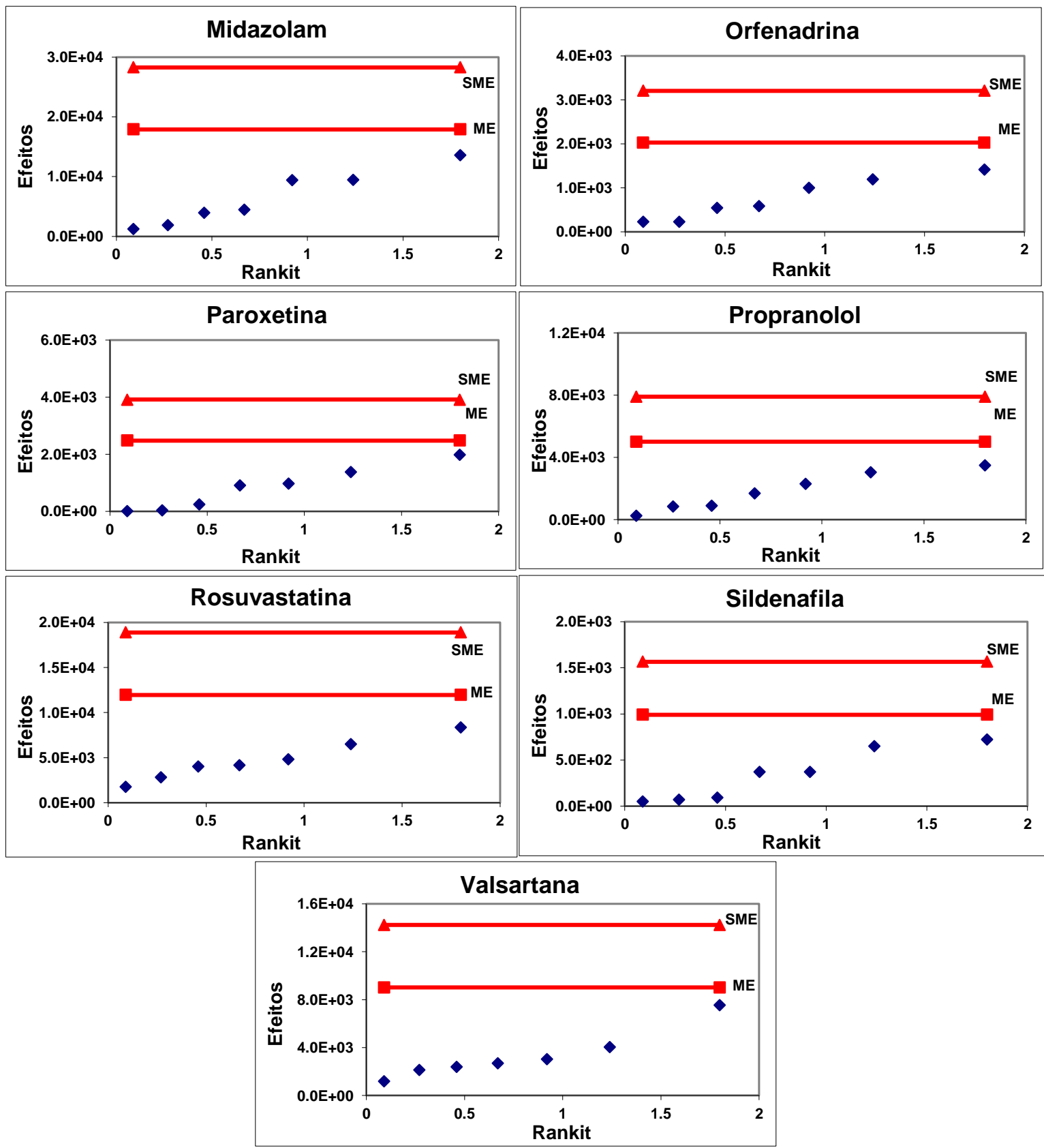

FIGURA 40. Gráficos de rankit para midazolam, orfenadrina, paroxetina, propranolol, rosuvastatina, sildenafila e valsartana nas amostras com adição de solução mista de padrões.

Os gráficos de probabilidade normal, que representam o comportamento da distribuição dos resultados obtidos nos ensaios da robustez (FIG. 41 a 43), revelaram que os dados têm distribuição normal, comportamento linear e estão distribuídos no intervalo entre $-2 \mathrm{e}+2$, indicando que provavelmente não há dados discrepantes. 


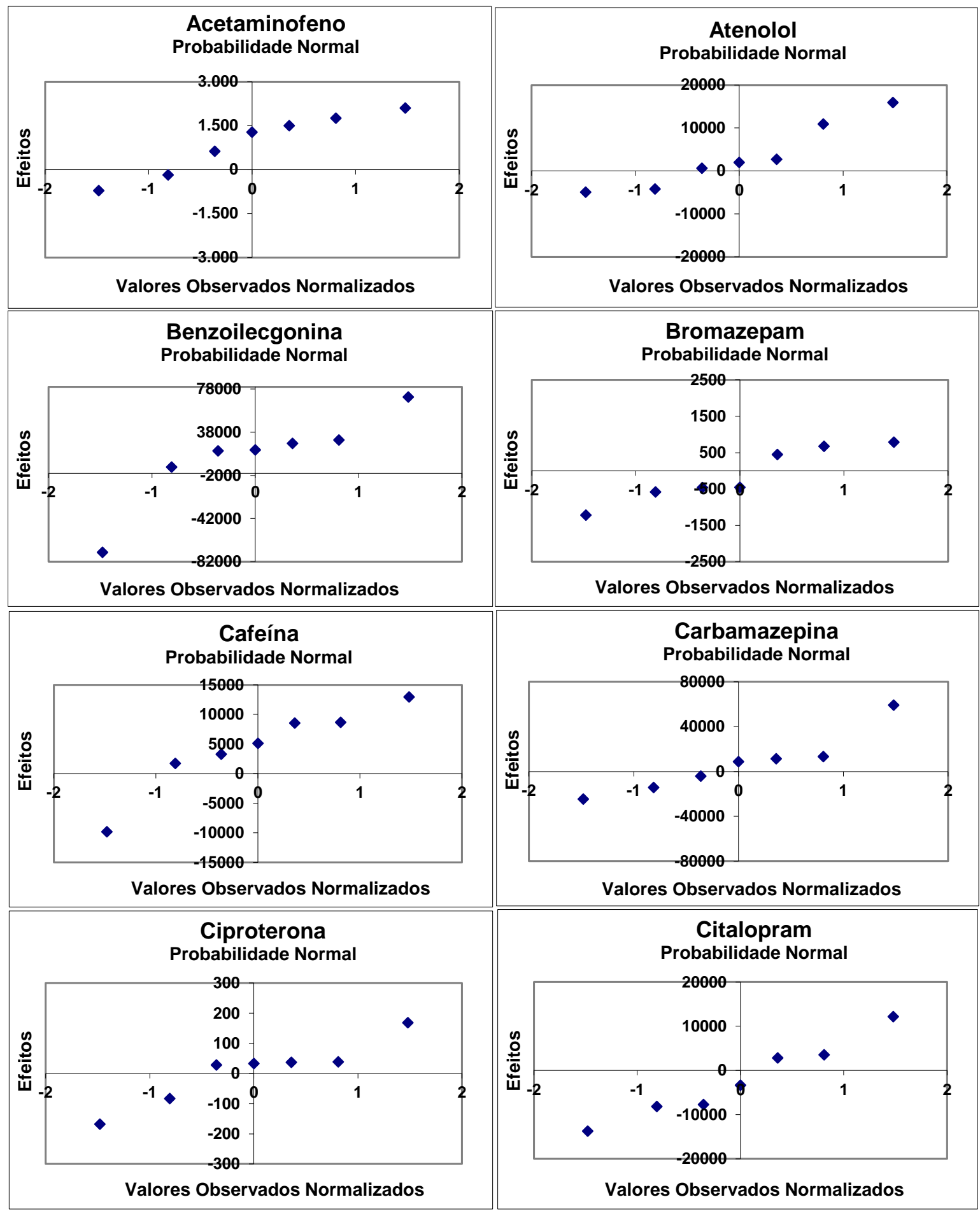

FIGURA 41. Gráficos de probabilidade normal para acetaminofeno, atenolol, benzoilecgonina, bromazepam, cafeína, carbamazepina, ciproterona, e citalopram nas amostras com adição de solução mista de padrões. 


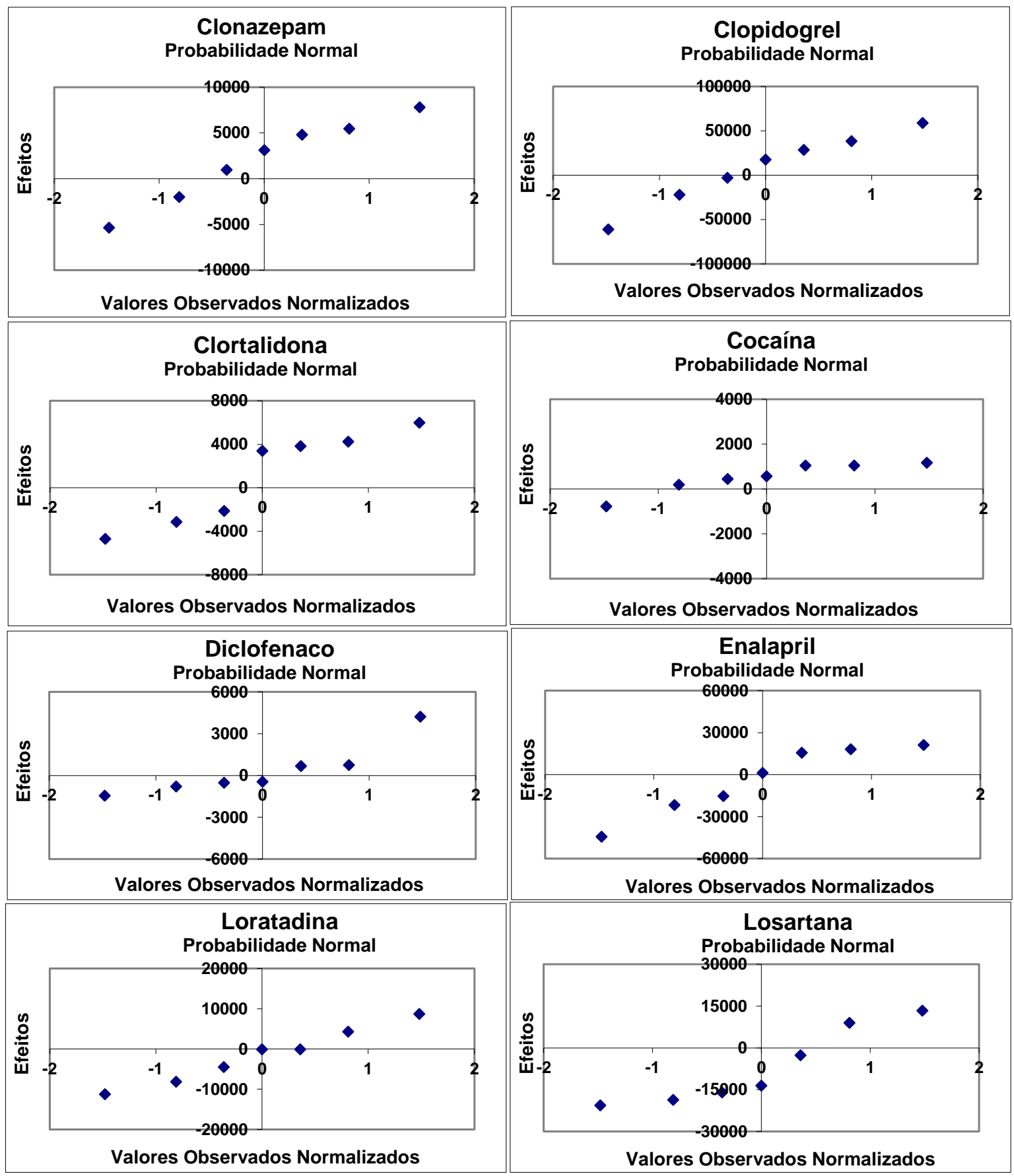

FIGURA 42. Gráficos de probabilidade normal para clonazepam, clopidogrel, clortalidona, cocaína, diclofenaco, enalapril, loratadina e losartana nas amostras com adição de solução mista de padrões. 

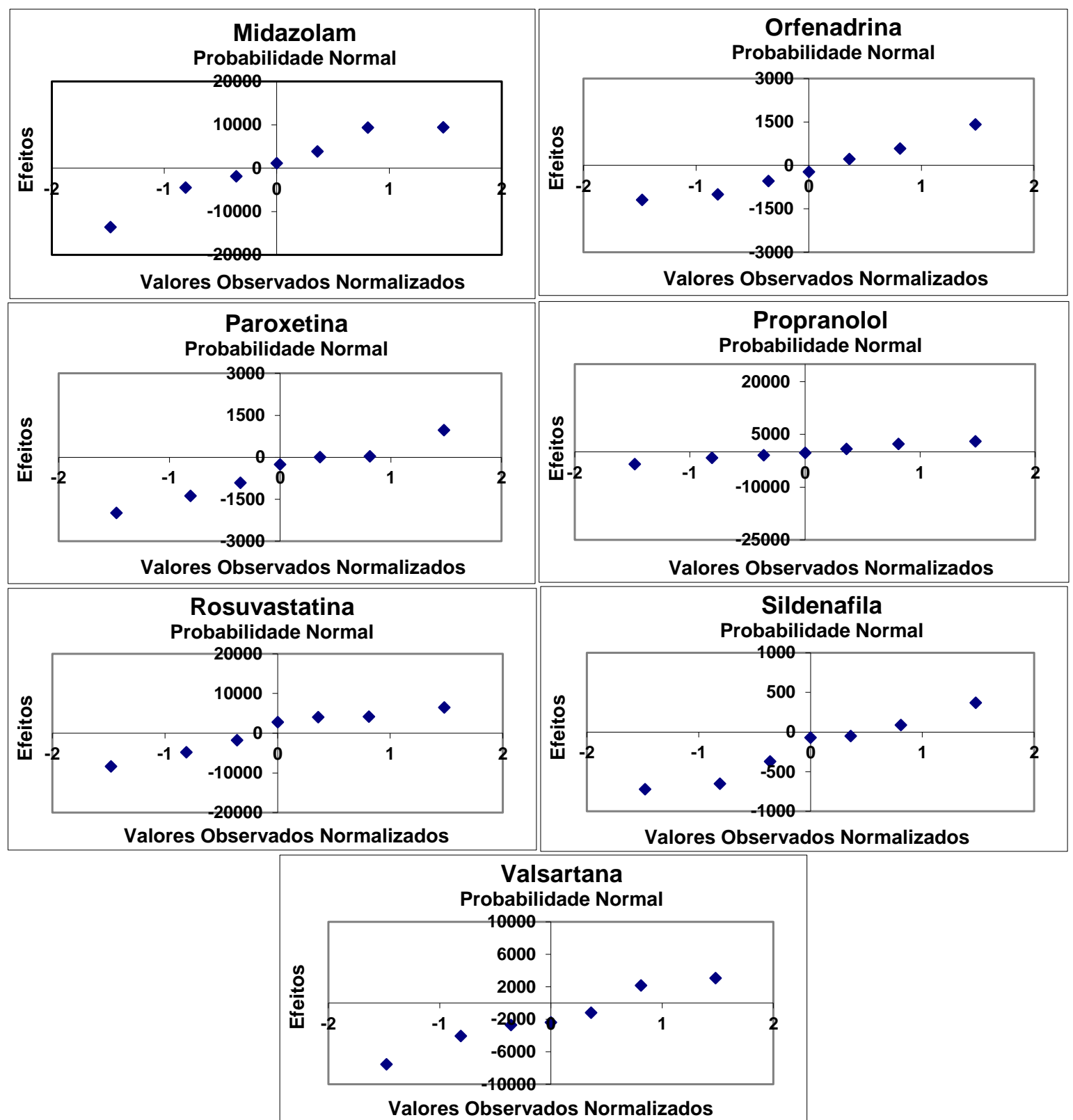

FIGURA 43. Gráficos de probabilidade normal para midazolam, orfenadrina, paroxetina, propranolol, rosuvastatina, sildenafila e valsartana nas amostras com adição de solução mista de padrões.

Assim, apesar do estudo de robustez sugerir possíveis mudanças no valor de alguns parâmetros, como por exemplo, volume de injeção e lavagem do SPE, para determinados compostos, os gráficos de Rankit e de probabilidade normal demonstram que o método é robusto. 


\subsection{Incerteza nas medições químicas}

A incerteza da medição foi estimada apenas para os compostos quantificados e, seguiu a descrição do item 5.6 desse trabalho. Apesar do baixo valor de recuperação obtido para o acetaminofeno, a incerteza foi estimada por ser detectada nas 3 (três) coletas

A incerteza expandida na faixa média de concentração da curva analítica dos compostos quantificados foi estimada entre 3 e $12 \%$ da concentração encontrada. Os resultados são apresentados na TAB. 38. A incerteza expandida para o composto foi calculada pela Eq. 25, admitindo um nível de confiança de $90 \%$ e indicando um fator de abrangência $\mathrm{K}$ igual a 2 . $\mathrm{Na}$ TAB. 38 são apresentadas as incertezas combinadas $(\mu)$ das contribuições das grandezas de entrada: concentração do composto encontrada na alíquota analisada $\left(\mathrm{C}_{0}\right)$; volume inicial $\left(\mathrm{V}_{\mathrm{i}}\right)$ e final $\left(\mathrm{V}_{\mathrm{f}}\right)$ da amostra; e a recuperação $(\mathrm{R})$ do composto no método, as quais foram calculadas pelas Eq. 14, 19 e 23, respectivamente. $\mathrm{O}$ valor de cada uma das incertezas envolvidas no cálculo da incerteza expandida dos compostos quantificados encontra-se no Apêndice $C$.

TABELA 38. Concentração, incertezas expandidas e as contribuições das grandezas de entrada envolvidas na quantificação dos compostos desse estudo.

\begin{tabular}{|c|c|c|c|c|c|c|c|}
\hline \multirow{2}{*}{ Composto } & \multirow{2}{*}{$\begin{array}{c}\text { Cocentração } \\
\text { (ng L-1) }\end{array}$} & \multicolumn{4}{|c|}{$\mu$} & \multicolumn{2}{|c|}{ Incerteza Expandida } \\
\hline & & $\left(C_{0}\right)$ & $\left(V_{f}\right)$ & (R) & $\left(V_{i}\right)$ & $\mathbf{U}$ & $\%$ \\
\hline Acetaminofeno & 98 & 0,0292 & 0,0082 & 0,0266 & 0,00015 & \pm 8 & 8 \\
\hline Atenolol & 74 & 0,0260 & 0,0082 & 0,0264 & 0,00017 & \pm 6 & 8 \\
\hline Benzoilecgonina & 99 & 0,0110 & 0,0082 & 0,0237 & 0,00015 & \pm 5 & 5 \\
\hline Cafeina & 107 & 0,0141 & 0,0082 & 0,0560 & 0,00015 & \pm 12 & 11 \\
\hline Carbamazepina & 29 & 0,0114 & 0,0082 & 0,0599 & 0,00015 & \pm 3 & 10 \\
\hline Clortalidona & 25 & 0,0274 & 0,0082 & 0,0231 & 0,00015 & \pm 2 & 8 \\
\hline Cocaina & 97 & 0,0100 & 0,0082 & 0,0086 & 0,00015 & \pm 3 & 3 \\
\hline Diclofenaco & 24 & 0,0161 & 0,0082 & 0,0406 & 0,00015 & \pm 2 & 8 \\
\hline Enalapril & 25 & 0,0457 & 0,0082 & 0,0448 & 0,00015 & \pm 3 & 12 \\
\hline Losartana & 74 & 0,0175 & 0,0042 & 0,0333 & 0,00017 & \pm 5 & 7 \\
\hline Valsartana & 25 & 0,0126 & 0,0082 & 0,0150 & 0,00015 & \pm 1 & 4 \\
\hline
\end{tabular}


As contribuições das incertezas combinadas na incerteza expandida para cada composto podem ser visualizadas nas FIG. 44 e 45 .

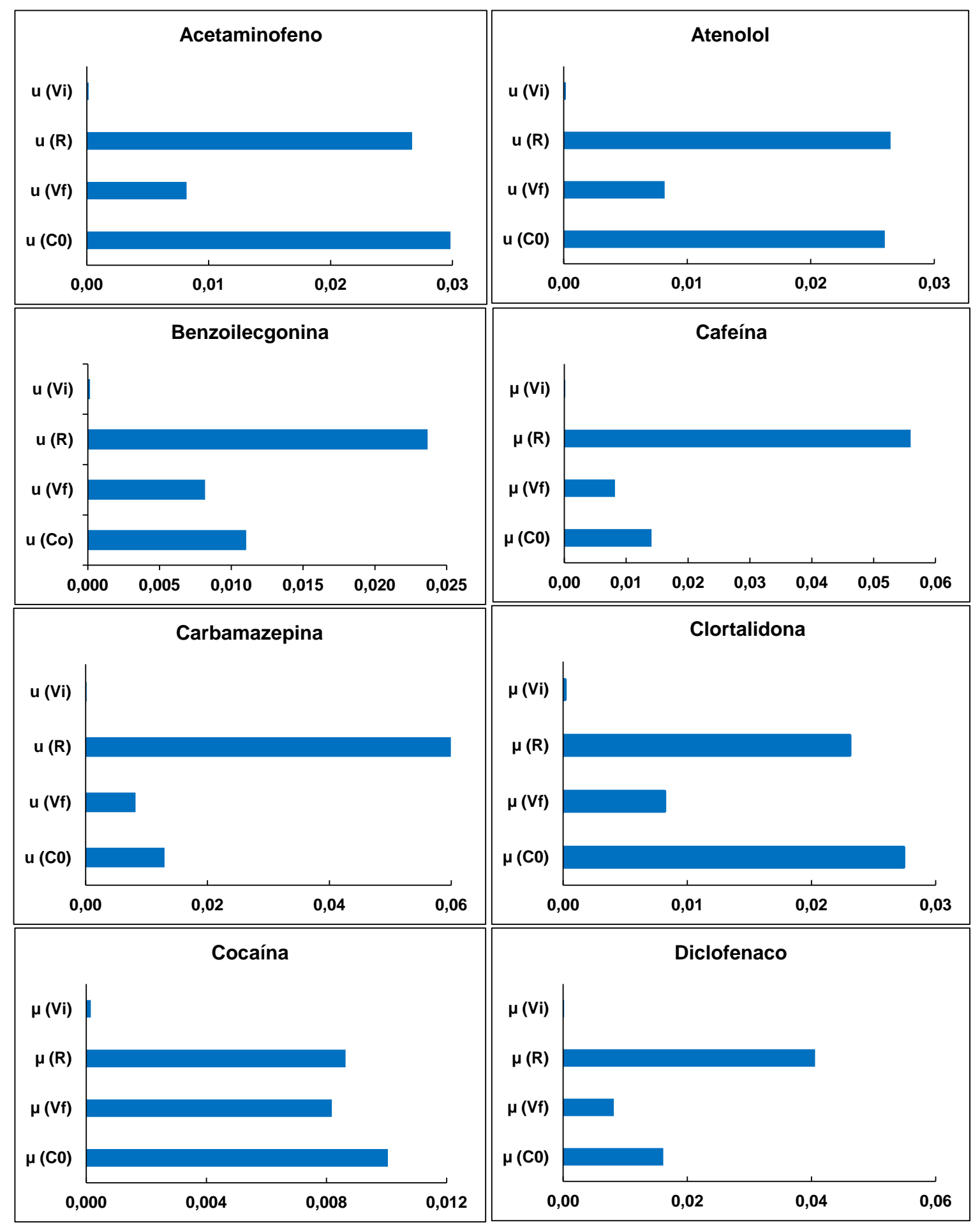

FIGURA 44. Contribuição das incertezas combinadas envolvidas na determinação da concentração do acetaminofeno, atenolol, benzoilecgonina, bromazepam, cafeína, carbamazepina, clortalidona, cocaína e diclofenaco pelo método desenvolvido. 


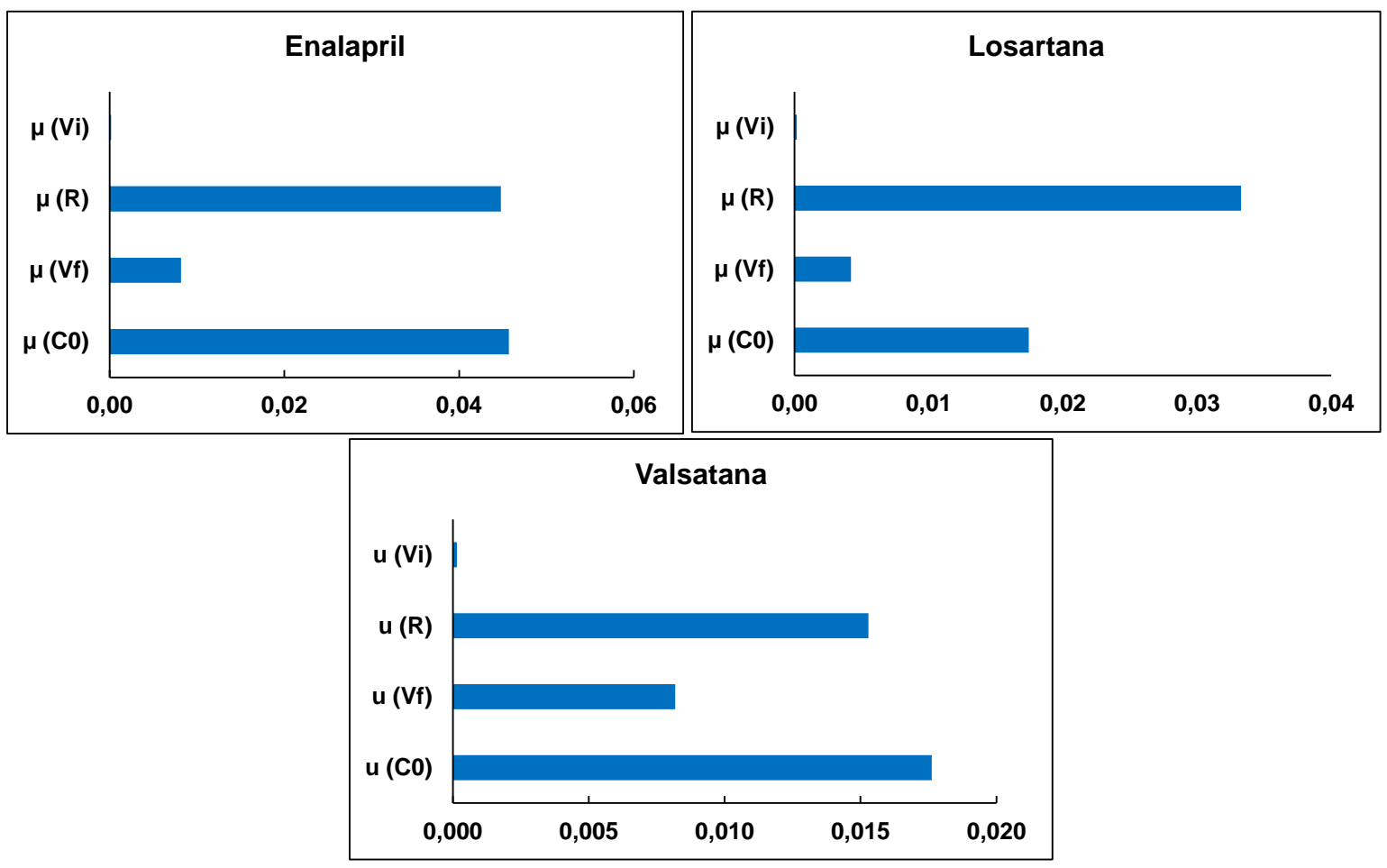

FIGURA 45. Contribuição das incertezas combinadas envolvidas na determinação da concentração do enalapril, losartana e valsartana pelo método desenvolvido.

Observa-se que as incertezas combinadas de maior influência na incerteza expandidas são a incerteza associada à curva analítica $\left(\mu\left(\mathrm{C}_{0}\right)\right)$ e a incerteza associada à recuperação $(\mu(R))$, o que é coerente, pois ambas estão relacionadas com as concentrações e a resposta do equipamento.

\subsection{Aplicação da metodologia nas águas da Represa Guarapiranga}

A avaliação dos parâmetros de validação da metodologia de SPE-LCMS/MS possibilitou a sua aplicação na identificação e quantificação dos compostos de interesse, nas amostras de água da Represa Guarapiranga.

Os locais e as coordenadas geográficas da coleta das amostras na Represa Guarapiranga encontram-se na FIG. 18 e TAB. 16, respectivamente. As amostras foram coletadas em 02, 03, 04 e 29/08/2011; 11/09/2012 e 04/04/2013 e, os resultados obtidos são apresentados nas TAB. 39 a 41, respectivamente. Os resultados referem-se às médias das concentrações de 3 (três) extrações das 
amostras por SPE, acompanhada do valor da incerteza expandida, que foi calculada seguindo as orientações da EURACHEM (2002; EURACHEM/CITAC, 2012) conforme descrito no item 5.6, considerando $\mathrm{k}=2$ e $90 \%$ de confiança. 
TABELA 39. Concentração média de 3 extrações e o valor da incerteza associada dos compostos detectados nas amostras coletadas da Represa Guarapiranga em Agosto de 2011.

\begin{tabular}{|c|c|c|c|c|c|c|c|c|c|c|c|c|c|c|}
\hline \multirow[b]{2}{*}{ Composto } & \multicolumn{14}{|c|}{ Ponto de Coleta } \\
\hline & $\begin{array}{c}\text { GU000_01 } \\
\left(\mathrm{ng} \mathrm{L}^{-1}\right)\end{array}$ & $\begin{array}{c}\text { GU000_02 } \\
\left(\mathrm{ng} \mathrm{L}^{-1}\right)\end{array}$ & $\begin{array}{c}\text { GU000_03 } \\
\left(\mathrm{ng} \mathrm{L}^{-1}\right)\end{array}$ & $\begin{array}{c}\text { GU106_04 } \\
\left(\mathrm{ng} \mathrm{L}^{-1}\right)\end{array}$ & $\begin{array}{c}\text { GU000_05 } \\
\left(\mathrm{ng} \mathrm{L}^{-1}\right)\end{array}$ & $\begin{array}{c}\text { GU107_06 } \\
\left(\mathrm{ng} \mathrm{L}^{-1}\right)\end{array}$ & $\begin{array}{c}\text { GU108_07 } \\
\left(\mathrm{ng} \mathrm{L}^{-1}\right)\end{array}$ & $\begin{array}{c}\text { GU000_08 } \\
\left(\mathrm{ng} \mathrm{L}^{-1}\right)\end{array}$ & $\begin{array}{c}\text { GU109_09 } \\
\left(\mathrm{ng} \mathrm{L}^{-1}\right)\end{array}$ & $\begin{array}{c}\text { GU105_10 } \\
\left(\mathrm{ng} \mathrm{L}^{-1}\right)\end{array}$ & $\begin{array}{c}\text { GU104_11 } \\
\left(\mathrm{ng} \mathrm{L}^{-1}\right)\end{array}$ & $\begin{array}{c}\text { GU103_12 } \\
\left(\mathrm{ng} \mathrm{L}^{-1}\right)\end{array}$ & $\begin{array}{c}\mathrm{GU102} 13 \\
\left(\mathrm{ng} \mathrm{L}^{-1}\right)\end{array}$ & $\begin{array}{c}\text { GU000_14 } \\
\left(\mathrm{ng} \mathrm{L}^{-1}\right)\end{array}$ \\
\hline Acetaminofeno & $190 \pm 15$ & $254 \pm 18$ & $45 \pm 3$ & $24 \pm 2$ & $59 \pm 4$ & $48 \pm 3$ & $109 \pm 8$ & $75 \pm 4$ & $29 \pm 2$ & $12,8 \pm 0,7$ & $46 \pm 3$ & $91 \pm 6$ & $192 \pm 16$ & $38 \pm 2$ \\
\hline Atenolol & $33 \pm 2$ & $34 \pm 2$ & $31 \pm 2$ & $34 \pm 2$ & $64 \pm 3$ & $115 \pm 8$ & $77 \pm 5$ & $76 \pm 5$ & $71 \pm 5$ & $107 \pm 6$ & $79 \pm 6$ & $116 \pm 9$ & $95 \pm 6$ & $73 \pm 6$ \\
\hline Benzoilecgonina & $11,9 \pm 0,8$ & $18,7 \pm 0,6$ & $21 \pm 2$ & $25 \pm 2$ & $38 \pm 2$ & $104 \pm 7$ & $41 \pm 2$ & $41 \pm 2$ & $36 \pm 2$ & $86 \pm 5$ & $35 \pm 2$ & $60 \pm 5$ & $67 \pm 4$ & $59 \pm 4$ \\
\hline Bromazepam & $<L D$ & $<L D$ & $<L D$ & $<L D$ & $<$ LD & $<L D$ & $<L D$ & $<L Q$ & $<$ LD & $<$ LD & $<L D$ & $<L D$ & $<L D$ & $<L D$ \\
\hline Cafeína & $381 \pm 12$ & $6017 \pm 33$ & $76 \pm 3$ & $27 \pm 2$ & $92 \pm 10$ & $6316 \pm 143$ & $239 \pm 27$ & $220 \pm 25$ & $72 \pm 8$ & $17416 \pm 90$ & $236 \pm 27$ & $12019 \pm 65$ & $7776 \pm 176$ & $253 \pm 28$ \\
\hline Carbamazepina & $13 \pm 1$ & $13 \pm 1$ & $16 \pm 1$ & $21 \pm 3$ & $27 \pm 3$ & $33 \pm 4$ & $33 \pm 4$ & $32 \pm 4$ & $32 \pm 4$ & $34 \pm 4$ & $34 \pm 4$ & $33 \pm 4$ & $37 \pm 4$ & $32 \pm 4$ \\
\hline Ciproterona & $<$ LD & $<L D$ & $<L D$ & $<L D$ & $<$ LD & $<L D$ & $<L D$ & $<L D$ & $<$ LD & $<L D$ & $<L D$ & $<L D$ & $<L D$ & $<L D$ \\
\hline Citalopram & $<L D$ & $<L D$ & $<$ LD & $<$ LD & $<$ LD & $<$ LD & $<$ LD & $<$ LD & $<L Q$ & $<$ LD & $<L D$ & $<$ LD & $<$ LD & $<$ LD \\
\hline Clonazepam & $<\mathrm{LD}$ & $<$ LD & $<\mathrm{LD}$ & $<L Q$ & $<$ LD & $<$ LD & $<L Q$ & $<$ LD & $<L Q$ & $<L Q$ & $<L D$ & $<L Q$ & $<L Q$ & $<L Q$ \\
\hline Clopidogrel & $<L D$ & $<$ LD & $<L D$ & $<$ LD & $<L D$ & $<$ LD & $<$ LD & $<$ LD & $<$ LD & $<$ LD & $<L D$ & $<$ LD & $<$ LD & $<$ LD \\
\hline Clortalidona & $<L Q$ & $9,4 \pm 0,5$ & $10,6 \pm 0,5$ & $13,3 \pm 0,9$ & $18,2 \pm 0,9$ & $34 \pm 2$ & $28 \pm 2$ & $27 \pm 2$ & $28 \pm 2$ & $29 \pm 2$ & $28 \pm 2$ & $33 \pm 2$ & $33 \pm 2$ & $32 \pm 2$ \\
\hline Cocaína & $97 \pm 5$ & $114 \pm 6$ & $73 \pm 3$ & $21 \pm 1$ & $112 \pm 4$ & $277 \pm 10$ & $137 \pm 4$ & $220 \pm 9$ & $125 \pm 4$ & $314 \pm 13$ & $104 \pm 4$ & $512 \pm 18$ & $257 \pm 8$ & $95 \pm 3$ \\
\hline Diclofenaco & $8 \pm 1$ & $<L Q$ & $<L Q$ & $<L Q$ & $<L Q$ & $8 \pm 1$ & $<L Q$ & $<L Q$ & $<L Q$ & $<L Q$ & $<L Q$ & $<L Q$ & $<L Q$ & $<$ LD \\
\hline Enalapril & $<L D$ & $<$ LD & $<L D$ & $<L D$ & $<L D$ & $<L Q$ & $<$ LD & $<$ LD & $<$ LD & $<L Q$ & $<L D$ & $<L Q$ & $<$ LD & $<$ LD \\
\hline Loratadina & $<L D$ & $<L D$ & $<L D$ & $<$ LD & $<$ LD & $<L D$ & $<L D$ & $<L D$ & $<L D$ & $<L D$ & $<L D$ & $<L D$ & $<L D$ & $<$ LD \\
\hline Losartana & $<L D$ & $<L D$ & $<L D$ & $<L D$ & $<L Q$ & $<L Q$ & $<L Q$ & $<L D$ & $<L Q$ & $11 \pm 2$ & $10 \pm 1$ & $12 \pm 1$ & $8 \pm 1$ & $11 \pm 1$ \\
\hline Midazolam & $<L D$ & $<L D$ & $<L D$ & $<L D$ & $<L D$ & $<L D$ & $<L D$ & $<L D$ & $<L D$ & $<L D$ & $<L D$ & $<L D$ & $<L D$ & $<L D$ \\
\hline Orfenadrina & $<$ LD & $<$ LD & $<$ LD & $<$ LD & $<L Q$ & $<L Q$ & $<L Q$ & $<L Q$ & $<L Q$ & $<L Q$ & $<L Q$ & $<L Q$ & $<L Q$ & $<L Q$ \\
\hline Paroxetina & $<L Q$ & $<L D$ & $<L Q$ & $<L Q$ & $<L Q$ & $<L Q$ & $<L Q$ & $<L Q$ & $<L Q$ & $<L Q$ & $<L Q$ & $<L Q$ & $<L Q$ & $<L D$ \\
\hline Propranolol & $<L D$ & $<$ LD & $<L Q$ & $<L D$ & $<L D$ & $<L D$ & $<$ LD & $<L D$ & $<L Q$ & $<L Q$ & $<\mathrm{LD}$ & $<L Q$ & $<L Q$ & $<L Q$ \\
\hline Rosuvastatina & $<$ LD & $<$ LD & $<L D$ & $<L D$ & $<L D$ & $<L D$ & $<$ LD & $<L D$ & $<L D$ & $<L D$ & $<\mathrm{LD}$ & $<L D$ & $<L D$ & $<L D$ \\
\hline Sildenafila & $<\mathrm{LD}$ & $<L D$ & $<L D$ & $<L D$ & $<\mathrm{LD}$ & $<L D$ & $<\mathrm{LD}$ & $<$ LD & $<L D$ & $<L D$ & $<\mathrm{LD}$ & $<L D$ & $<L D$ & $<L D$ \\
\hline Valsartana & $<\mathrm{LQ}$ & $<\mathrm{LQ}$ & $<\mathrm{LD}$ & $<\mathrm{LQ}$ & $<\mathrm{LQ}$ & $<L Q$ & $<\mathrm{LQ}$ & $<\mathrm{LQ}$ & $<\mathrm{LQ}$ & $<\mathrm{LQ}$ & $<\mathrm{LQ}$ & $<\mathrm{LQ}$ & $<\mathrm{LQ}$ & $<\mathrm{LQ}$ \\
\hline
\end{tabular}


TABELA 40. Concentração média de 3 extrações mais o valor da incerteza associada dos compostos detectados nas amostras coletadas da Represa Guarapiranga em setembro de 2012.

\begin{tabular}{|c|c|c|c|c|c|c|c|c|c|c|c|c|c|c|}
\hline \multirow[b]{2}{*}{ Composto } & \multicolumn{14}{|c|}{$\begin{array}{r}2^{\mathrm{a}} \text { Coleta - Setembro de } 2012 \\
\text { Ponto de Coleta }\end{array}$} \\
\hline & $\begin{array}{l}\text { GU000_01 } \\
\left(\mathrm{ng} \mathrm{L}^{-1}\right)\end{array}$ & $\begin{array}{c}\text { GU000_02 } \\
\left(\mathrm{ng} \mathrm{L}^{-1}\right)\end{array}$ & $\begin{array}{c}\text { GU000_03 } \\
\left(\mathrm{ng} \mathrm{L}^{-1}\right)\end{array}$ & $\begin{array}{c}\text { GU106_04 } \\
\left(n g L^{-1}\right)\end{array}$ & $\begin{array}{c}\text { GU000_05 } \\
\left(\mathrm{ng} \mathrm{L}^{-1}\right)\end{array}$ & $\begin{array}{l}\text { GU107_06 } \\
\left(\mathrm{ng} \mathrm{L}^{-1}\right)\end{array}$ & $\begin{array}{l}\text { GU108_07 } \\
\left(n g L^{-1}\right)\end{array}$ & $\begin{array}{l}\text { GU000_08 } \\
\left(\mathrm{ng} \mathrm{L}^{-1}\right)\end{array}$ & $\begin{array}{c}\text { GU109_09 } \\
\left(\mathrm{ng} \mathrm{L}^{-1}\right)\end{array}$ & $\begin{array}{l}\text { GU105_10 } \\
\left(\mathrm{ng} \mathrm{L}^{-1}\right)\end{array}$ & $\begin{array}{c}\text { GU104_11 } \\
\left(\mathrm{ng} \mathrm{L}^{-1}\right)\end{array}$ & $\begin{array}{c}\text { GU103_12 } \\
\left(\mathrm{ng} \mathrm{L}^{-1}\right)\end{array}$ & $\begin{array}{c}\text { GU102_13 } \\
\left(\mathrm{ng} \mathrm{L}^{-1}\right)\end{array}$ & $\begin{array}{c}\text { GU000_14 } \\
\left(\mathrm{ng} \mathrm{L}^{-1}\right)\end{array}$ \\
\hline Acetaminofeno & $<L Q$ & $19 \pm 1$ & $13 \pm 1$ & $<\mathrm{LQ}$ & $<\mathrm{LQ}$ & $13 \pm 1$ & $78 \pm 5$ & $13,1 \pm 0,7$ & $12 \pm 1$ & $12,0 \pm 0,8$ & $12,0 \pm 0,8$ & $<L Q$ & $9,6 \pm 0,7$ & $<L Q$ \\
\hline Atenolol & $23 \pm 1$ & $17,1 \pm 0,8$ & $22 \pm 1$ & $22 \pm 1$ & $22 \pm 1$ & $44 \pm 2$ & $52 \pm 2$ & $18 \pm 1$ & $23 \pm 1$ & $17,2 \pm 0,8$ & $14,3 \pm 0,6$ & $177 \pm 5$ & $15,2 \pm 0,7$ & $11,0 \pm 0,5$ \\
\hline Benzoilecgonina & $<\mathrm{LQ}$ & $8,7 \pm 0,3$ & $21,0 \pm 0,6$ & $26 \pm 1$ & $26,9 \pm 0,8$ & $58 \pm 3$ & $71 \pm 4$ & $42 \pm 1$ & $40 \pm 1$ & $53 \pm 3$ & $41 \pm 2$ & $139 \pm 7$ & $33 \pm 2$ & $31 \pm 1$ \\
\hline Bromazepam & $<$ LD & $<$ LD & $<$ LD & $<$ LD & $<L D$ & $<L D$ & $<L D$ & $<$ LD & $<L D$ & $<$ LD & $<L D$ & $<\mathrm{LD}$ & $<L D$ & $<$ LD \\
\hline Cafeína & $108 \pm 12$ & $223 \pm 25$ & $81 \pm 9$ & $44 \pm 3$ & $47 \pm 4$ & $80 \pm 9$ & $465 \pm 16$ & $85 \pm 10$ & $67 \pm 8$ & $200 \pm 23$ & $75 \pm 8$ & $313 \pm 35$ & $98 \pm 11$ & $107 \pm 12$ \\
\hline Carbamazepina & $<\mathrm{LQ}$ & $12 \pm 1$ & $29 \pm 3$ & $49 \pm 2$ & $45 \pm 2$ & $121 \pm 3$ & $140 \pm 3$ & $139 \pm 3$ & $149 \pm 4$ & $116 \pm 3$ & $148 \pm 4$ & $149 \pm 4$ & $152 \pm 4$ & $150 \pm 4$ \\
\hline Ciproterona & $<\mathrm{LD}$ & $<\mathrm{LD}$ & $<\mathrm{LD}$ & $<\mathrm{LD}$ & $<L D$ & $<\mathrm{LD}$ & $<\mathrm{LD}$ & $<L D$ & $<L D$ & $<\mathrm{LD}$ & $<\mathrm{LD}$ & $<\mathrm{LD}$ & $<L D$ & $<\mathrm{LD}$ \\
\hline Citalopram & $<\mathrm{LD}$ & $<\mathrm{LD}$ & $<\mathrm{LD}$ & $<\mathrm{LD}$ & $<\mathrm{LD}$ & $<\mathrm{LD}$ & $<L D$ & $<L D$ & $<\mathrm{LD}$ & $<L D$ & $<\mathrm{LD}$ & $<L D$ & $<L D$ & $<L D$ \\
\hline Clonazepam & $<\mathrm{LD}$ & $<\mathrm{LD}$ & $<\mathrm{LD}$ & $<\mathrm{LD}$ & $<\mathrm{LD}$ & $<\mathrm{LD}$ & $<L D$ & $<L D$ & $<\mathrm{LD}$ & $<L D$ & $<\mathrm{LD}$ & $<L D$ & $<L D$ & $<L D$ \\
\hline Clopidogrel & $<$ LD & $<\mathrm{LD}$ & $<\mathrm{LD}$ & $<\mathrm{LD}$ & $<L D$ & $<\mathrm{LD}$ & $<L D$ & $<L D$ & $<L D$ & $<L D$ & $<L D$ & $<L D$ & $<L D$ & $<L D$ \\
\hline Clortalidona & $<L Q$ & $<L Q$ & $9,5 \pm 0,8$ & $12,7 \pm 0,9$ & $13,9 \pm 0,8$ & $22 \pm 1$ & $22 \pm 1$ & $22 \pm 1$ & $19 \pm 1$ & $23 \pm 2$ & $16,5 \pm 0,9$ & $35 \pm 2$ & $21 \pm 1$ & $21 \pm 1$ \\
\hline Cocaína & $19 \pm 1$ & $41 \pm 3$ & $23 \pm 2$ & $<\mathrm{LQ}$ & $<\mathrm{LQ}$ & $94 \pm 8$ & $197 \pm 8$ & $74 \pm 5$ & $<\mathrm{LQ}$ & $<\mathrm{LQ}$ & $<\mathrm{LD}$ & $2650 \pm 28$ & $<\mathrm{LQ}$ & $<\mathrm{LQ}$ \\
\hline Diclofenaco & $<L Q$ & $<L Q$ & $<L Q$ & $<L Q$ & $<L Q$ & $<L Q$ & $<L Q$ & $<L Q$ & $<L Q$ & $<L Q$ & $<L Q$ & $35 \pm 3$ & $<L Q$ & $<L Q$ \\
\hline Enalapril & $<$ LD & $<$ LD & $<$ LD & $<$ LD & $<$ LD & $<$ LD & $<$ LD & $<L D$ & $<L D$ & $<$ LD & $<$ LD & $20 \pm 3$ & $<$ LD & $<$ LD \\
\hline Loratadina & $<$ LD & $<L D$ & $<$ LD & $<L D$ & $<$ LD & $<L D$ & $<L D$ & $<L D$ & $<L D$ & $<L D$ & $<L D$ & $<L D$ & $<L D$ & $<L D$ \\
\hline Losartana & $7,1 \pm 0,9$ & $10 \pm 1$ & $22 \pm 3$ & $34 \pm 4$ & $29 \pm 4$ & $62 \pm 8$ & $59 \pm 7$ & $34 \pm 4$ & $46 \pm 6$ & $24 \pm 3$ & $53 \pm 7$ & $114 \pm 8$ & $53 \pm 7$ & $45 \pm 5$ \\
\hline Midazolam & $<$ LD & $<L D$ & $<L D$ & $<L D$ & $<L D$ & $<L D$ & $<L D$ & $<L D$ & $<L D$ & $<L D$ & $<L D$ & $<$ LD & $<L D$ & $<L D$ \\
\hline Orfenadrina & $<$ LD & $<$ LD & $<\mathrm{LQ}$ & $<\mathrm{LQ}$ & $<\mathrm{LQ}$ & $<\mathrm{LQ}$ & $<\mathrm{LQ}$ & $<\mathrm{LQ}$ & $<\mathrm{LQ}$ & $<\mathrm{LQ}$ & $<\mathrm{LQ}$ & $<\mathrm{LQ}$ & $<\mathrm{LQ}$ & $<\mathrm{LQ}$ \\
\hline Paroxetina & $<L D$ & $<L D$ & $<L D$ & $<L D$ & $<L D$ & $<L D$ & $<L D$ & $<L D$ & $<L D$ & $<L D$ & $<L D$ & $<L D$ & $<L D$ & $<L D$ \\
\hline Propranolol & $<$ LD & $<$ LD & $<$ LD & $<$ LD & $<$ LD & $<$ LD & $<$ LD & $<L Q$ & $<L Q$ & $<L Q$ & $<L Q$ & $<L Q$ & $<$ LD & $<$ LD \\
\hline Rosuvastatina & $<L D$ & $<$ LD & $<L D$ & $<L D$ & $<L D$ & $<L D$ & $<$ LD & $<L D$ & $<L D$ & $<$ LD & $<$ LD & $<$ LD & $<L D$ & $<$ LD \\
\hline Sildenafil & $<L D$ & $<L D$ & $<L D$ & $<L D$ & $<L D$ & $<L D$ & $<L D$ & $<L D$ & $<L D$ & $<L D$ & $<L D$ & $<L D$ & $<L D$ & $<L D$ \\
\hline Valsartana & $<\mathrm{LQ}$ & $<\mathrm{LQ}$ & $<\mathrm{LQ}$ & $<\mathrm{LQ}$ & $<\mathrm{LQ}$ & $14,3 \pm 0,9$ & $15 \pm 1$ & $9,7 \pm 0,8$ & $11,3 \pm 0,8$ & $<\mathrm{LQ}$ & $10,2 \pm 0,6$ & $47 \pm 2$ & $11,1 \pm 0,6$ & $10,6 \pm 0,7$ \\
\hline
\end{tabular}

$L D=$ Limite de Detecção do Método

LQ = Limite de Quantificação do Método

$\mathrm{K}=2$ e $90 \%$ de confiança 
TABELA 41. Concentração média de 3 extrações mais o valor da incerteza associada dos compostos detectados nas amostras coletadas da Represa Guarapiranga em abril de 2013.

\begin{tabular}{|c|c|c|c|c|c|c|c|c|c|c|c|c|c|c|}
\hline \multirow[b]{2}{*}{ Composto } & \multicolumn{14}{|c|}{ Ponto de Coleta } \\
\hline & $\begin{array}{c}\text { GU000_01 } \\
\left(\mathrm{ng} \mathrm{L}^{-1}\right)\end{array}$ & $\begin{array}{c}\text { GU000_02 } \\
\left(\mathrm{ng} \mathrm{L}^{-1}\right)\end{array}$ & $\begin{array}{c}\text { GU000_03 } \\
\left(\mathrm{ng} \mathrm{L}^{-1}\right)\end{array}$ & $\begin{array}{c}\text { GU106_04 } \\
\left(\mathrm{ng} \mathrm{L}^{-1}\right)\end{array}$ & $\begin{array}{c}\text { GU000_05 } \\
\left(\mathrm{ng} \mathrm{L}^{-1}\right)\end{array}$ & $\begin{array}{c}\text { GU107_06 } \\
\left(\mathrm{ng} \mathrm{L}^{-1}\right)\end{array}$ & $\begin{array}{c}\text { GU108_07 } \\
\left(\mathrm{ng} \mathrm{L}^{-1}\right)\end{array}$ & $\begin{array}{c}\text { GU000_08 } \\
\left(\mathrm{ng} \mathrm{L}^{-1}\right)\end{array}$ & $\begin{array}{c}\text { GU109_09 } \\
\left(\mathrm{ng} \mathrm{L}^{-1}\right)\end{array}$ & $\begin{array}{c}\text { GU105_10 } \\
\left(\mathrm{ng} \mathrm{L}^{-1}\right)\end{array}$ & $\begin{array}{c}\text { GU104_11 } \\
\left(\mathrm{ng} \mathrm{L}^{-1}\right)\end{array}$ & $\begin{array}{c}\text { GU103_12 } \\
\left(\mathrm{ng} \mathrm{L}^{-1}\right)\end{array}$ & $\begin{array}{c}\text { GU102_13 } \\
\left(\mathrm{ng} \mathrm{L}^{-1}\right)\end{array}$ & $\begin{array}{c}\text { GU000_14 } \\
\left(\mathrm{ng} \mathrm{L}^{-1}\right)\end{array}$ \\
\hline Acetaminofeno & $<\mathrm{LQ}$ & $<\mathrm{LD}$ & $<\mathrm{LD}$ & $<L D$ & $<\mathrm{LQ}$ & $<L Q$ & $108 \pm 9$ & $16,0 \pm 0,9$ & $16 \pm 1$ & $33 \pm 3$ & $18 \pm 2$ & $73 \pm 7$ & $16 \pm 1$ & $15 \pm 2$ \\
\hline Atenolol & $<L Q$ & $8,5 \pm 0,4$ & $10,1 \pm 0,4$ & $9,8 \pm 0,6$ & $18,3 \pm 0,8$ & $30 \pm 1$ & $37 \pm 2$ & $22 \pm 1$ & $23 \pm 1$ & $28 \pm 1$ & $24 \pm 1$ & $70 \pm 3$ & $21 \pm 1$ & $24 \pm 1$ \\
\hline Benzoilecgonina & $<L Q$ & $<L Q$ & $7,9 \pm 0,3$ & $8,9 \pm 0,8$ & $16 \pm 1$ & $21 \pm 1$ & $29 \pm 2$ & $22 \pm 1$ & $15,4 \pm 0,9$ & $22 \pm 1$ & $18 \pm 1$ & $42 \pm 3$ & $16,7 \pm 0,8$ & $16,7 \pm 0,5$ \\
\hline Bromazepam & $<L D$ & $<\mathrm{LD}$ & $<L D$ & $<\mathrm{LD}$ & $<\mathrm{LD}$ & $<L D$ & $<L D$ & $<L D$ & $<L D$ & $<\mathrm{LD}$ & $<L D$ & $<\mathrm{LD}$ & $<\mathrm{LD}$ & $<\mathrm{LD}$ \\
\hline Cafeína & $71 \pm 8$ & $43 \pm 6$ & $36 \pm 4$ & $27 \pm 2$ & $59 \pm 5$ & $51 \pm 5$ & $423 \pm 18$ & $189 \pm 11$ & $265 \pm 14$ & $210 \pm 15$ & $248 \pm 15$ & $27386 \pm 142$ & $310 \pm 21$ & $302 \pm 18$ \\
\hline Carbamazepina & $<\mathrm{LQ}$ & $25 \pm 3$ & $28 \pm 4$ & $31 \pm 4$ & $164 \pm 15$ & $204 \pm 30$ & $305 \pm 41$ & $264 \pm 36$ & $296 \pm 38$ & $259 \pm 32$ & $314 \pm 39$ & $277 \pm 35$ & $358 \pm 44$ & $327 \pm 41$ \\
\hline Ciproterona & $<\mathrm{LD}$ & $<$ LD & $<\mathrm{LD}$ & $<$ LD & $<\mathrm{LD}$ & $<L D$ & $<L D$ & $<L D$ & $<L D$ & $<L D$ & $<L D$ & $<L D$ & $<L D$ & $<$ LD \\
\hline Citalopram & $<$ LD & $<$ LD & $<$ LD & $<$ LD & $<$ LD & $<$ LD & $<$ LD & $<$ LD & $<$ LD & $<$ LD & $<L D$ & $<$ LD & $<$ LD & $<$ LD \\
\hline Clonazepam & $<L D$ & $<L D$ & $<L D$ & $<L D$ & $<L D$ & $<L D$ & $<L D$ & $<L D$ & $<L D$ & $<L D$ & $<L D$ & $<L D$ & $<L D$ & $<L D$ \\
\hline Clopidogrel & $<$ LD & $<L D$ & $<L D$ & $<L D$ & $<L D$ & $<L D$ & $<L D$ & $<L D$ & $<L D$ & $<$ LD & $<L D$ & $<$ LD & $<L D$ & $<$ LD \\
\hline Clortalidona & $<L D$ & $<L Q$ & $<\mathrm{LQ}$ & $<L Q$ & $<\mathrm{LQ}$ & $10,6 \pm 0,5$ & $14,4 \pm 0,8$ & $11,6 \pm 0,6$ & $12,2 \pm 0,6$ & $12,0 \pm 0,6$ & $12,7 \pm 0,7$ & $14,7 \pm 0,7$ & $14,5 \pm 0,7$ & $14,2 \pm 0,9$ \\
\hline Cocaína & $26 \pm 2$ & $<L Q$ & $22 \pm 2$ & $<L Q$ & $35 \pm 3$ & $44 \pm 3$ & $70 \pm 3$ & $<L Q$ & $32 \pm 2$ & $25 \pm 2$ & $18 \pm 1$ & $261 \pm 8$ & $19 \pm 1$ & $12,8 \pm 0,8$ \\
\hline Diclofenaco & $<L D$ & $<L D$ & $<$ LD & $<$ LD & $<L Q$ & $<L D$ & $<L Q$ & $<L D$ & $<\mathrm{LD}$ & $<L D$ & $<\mathrm{LD}$ & $<L Q$ & $<$ LD & $<$ LD \\
\hline Enalapril & $<\mathrm{LD}$ & $<L D$ & $<$ LD & $<\mathrm{LD}$ & $<L Q$ & $<L D$ & $<L Q$ & $<L D$ & $<\mathrm{LD}$ & $<L D$ & $<\mathrm{LD}$ & $<L Q$ & $<\mathrm{LD}$ & $<L D$ \\
\hline Loratadina & $<$ LD & $<L D$ & $<$ LD & $<L D$ & $<L Q$ & $<L D$ & $<L Q$ & $<L D$ & $<L D$ & $<L D$ & $<\mathrm{LD}$ & $<L Q$ & $<$ LD & $<L D$ \\
\hline Losartana & $<\mathrm{LD}$ & $<L Q$ & $<L Q$ & $<L Q$ & $6,7 \pm 0,9$ & $13 \pm 2$ & $27 \pm 3$ & $13 \pm 2$ & $<\mathrm{LQ}$ & $21 \pm 3$ & $12 \pm 1$ & $24 \pm 3$ & $15 \pm 2$ & $21 \pm 3$ \\
\hline Midazolam & $<L D$ & $<L D$ & $<L D$ & $<\mathrm{LD}$ & $<L Q$ & $<L D$ & $<L Q$ & $<\mathrm{LD}$ & $<\mathrm{LD}$ & $<\mathrm{LD}$ & $<\mathrm{LD}$ & $<L Q$ & $<L D$ & $<\mathrm{LD}$ \\
\hline Orfenadrina & $<L D$ & $<L D$ & $<$ LD & $<L D$ & $<L Q$ & $<L Q$ & $<$ LD & $<L D$ & $<L Q$ & $<L Q$ & $<L Q$ & $<L Q$ & $<L Q$ & $<L Q$ \\
\hline Paroxetina & $<\mathrm{LD}$ & $<L D$ & $<\mathrm{LD}$ & $<L D$ & $<\mathrm{LD}$ & $<L D$ & $<L Q$ & $<L D$ & $<\mathrm{LD}$ & $<\mathrm{LD}$ & $<\mathrm{LD}$ & $<L Q$ & $<L Q$ & $<\mathrm{LD}$ \\
\hline Propranolol & $<\mathrm{LD}$ & $<L D$ & $<\mathrm{LD}$ & $<L D$ & $<\mathrm{LD}$ & $<L D$ & $<\mathrm{LD}$ & $<L D$ & $<\mathrm{LD}$ & $<\mathrm{LQ}$ & $<\mathrm{LD}$ & $<\mathrm{LQ}$ & $<\mathrm{LD}$ & $<L Q$ \\
\hline Rosuvastatina & $<$ LD & $<L D$ & $<\mathrm{LD}$ & $<L D$ & $<L D$ & $<L D$ & $<L D$ & $<L D$ & $<\mathrm{LD}$ & $<L D$ & $<\mathrm{LD}$ & $<L D$ & $<\mathrm{LD}$ & $<L D$ \\
\hline Sildenafil & $<\mathrm{LD}$ & $<L D$ & $<\mathrm{LD}$ & $<L D$ & $<\mathrm{LD}$ & $<L D$ & $<\mathrm{LD}$ & $<L D$ & $<\mathrm{LD}$ & $<L D$ & $<\mathrm{LD}$ & $<\mathrm{LD}$ & $<\mathrm{LD}$ & $<\mathrm{LD}$ \\
\hline Valsartana & $<\mathrm{LD}$ & $<L D$ & $<\mathrm{LD}$ & $<L D$ & $<\mathrm{LD}$ & $<L D$ & $<\mathrm{LD}$ & $<L D$ & $<\mathrm{LD}$ & $<L D$ & $<\mathrm{LD}$ & $<\mathrm{LD}$ & $<\mathrm{LD}$ & $<\mathrm{LD}$ \\
\hline
\end{tabular}

$\mathrm{LD}=$ Limite de Detecção do Método

LQ= Limite de Quantificação do Método

$\mathrm{K}=2$ e $90 \%$ de confiança 
A cafeína foi detectada em $100 \%$ das amostragens, realizadas nas três campanhas de coletas (ago./2011, set./2012 e abr./2013), seguida pelo atenolol em $98 \%$, carbamazepina em $95 \%$, benzoilecgonina em $93 \%$, clortalidona em $83 \%$, cocaína em $76 \%$, acetaminofeno em $74 \%$, losartana em $67 \%$, valsartana em $19 \%$, diclofenaco em 7\%, e enalapril em 2\% (FIG. 46). Bromazepam, ciproterona, citalopram, clonazepam, clopidogrel, loratadina, midazolam, orfenadrina, paroxetina, propranolol, rosuvastatina e sildenafila foram detectados abaixo do LD ou entre o LD e LQ em todas as coletas.

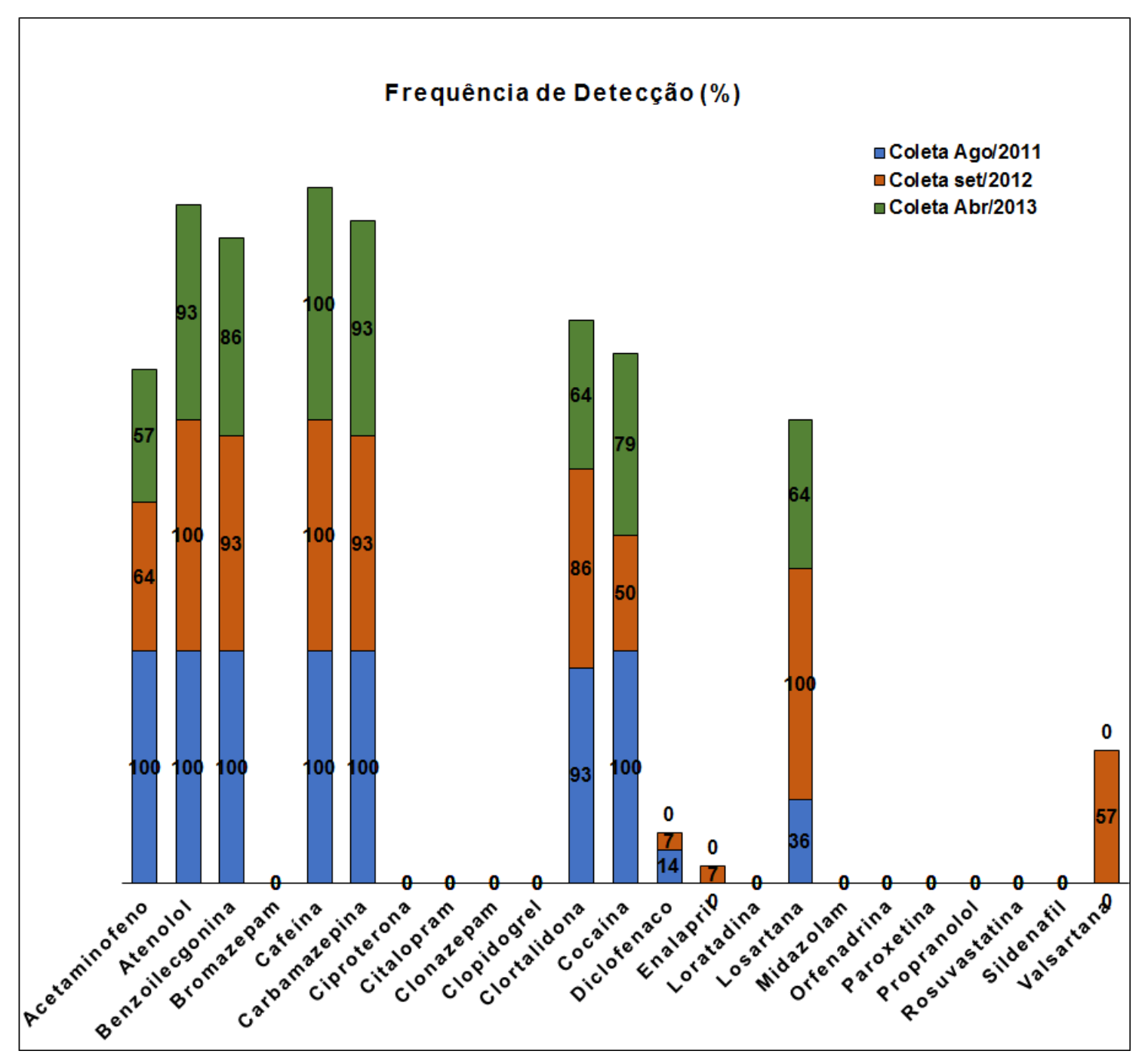

FIGURA 46. Visualização gráfica da frequência de detecção dos compostos de interesse nas amostras de água da represa Guarapiranga. 
Nas FIG. 47 a 54 são apresentados os gráficos tipo Box-plot para melhor visualização da distribuição dos compostos detectados nas 3 (três) campanhas de coleta, ao longo da represa Guarapiranga.

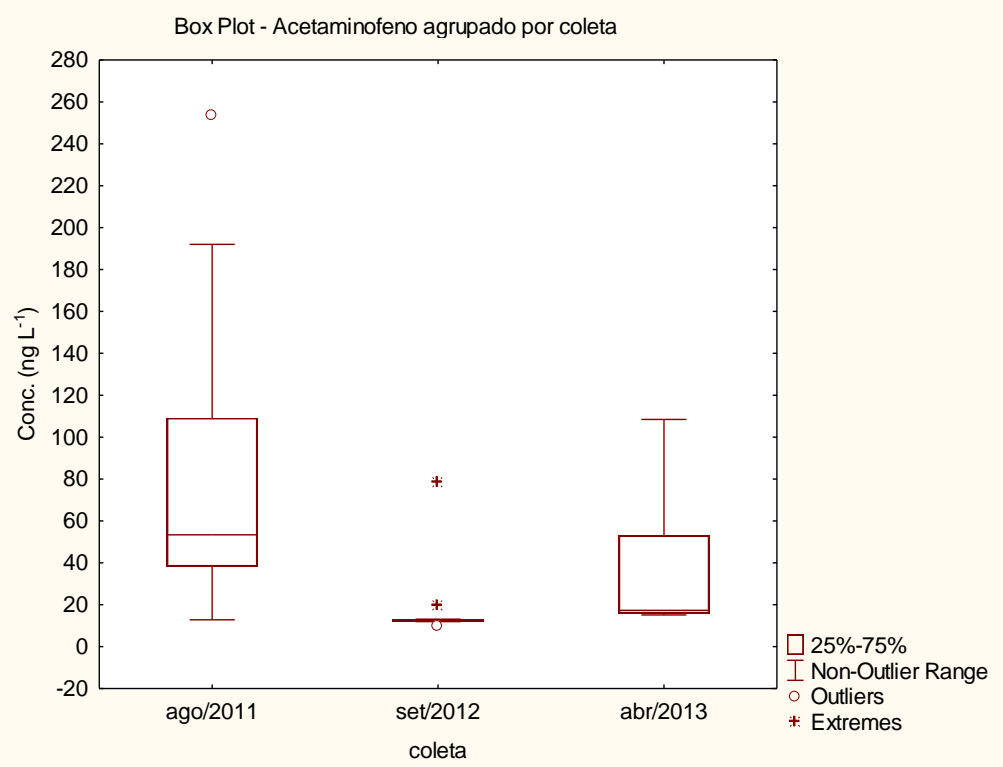

FIGURA 47. Distribuição do acetaminofeno nas águas da represa Guarapiranga durante as coletas realizadas em ago./2011, set./2012 e abr./2013.

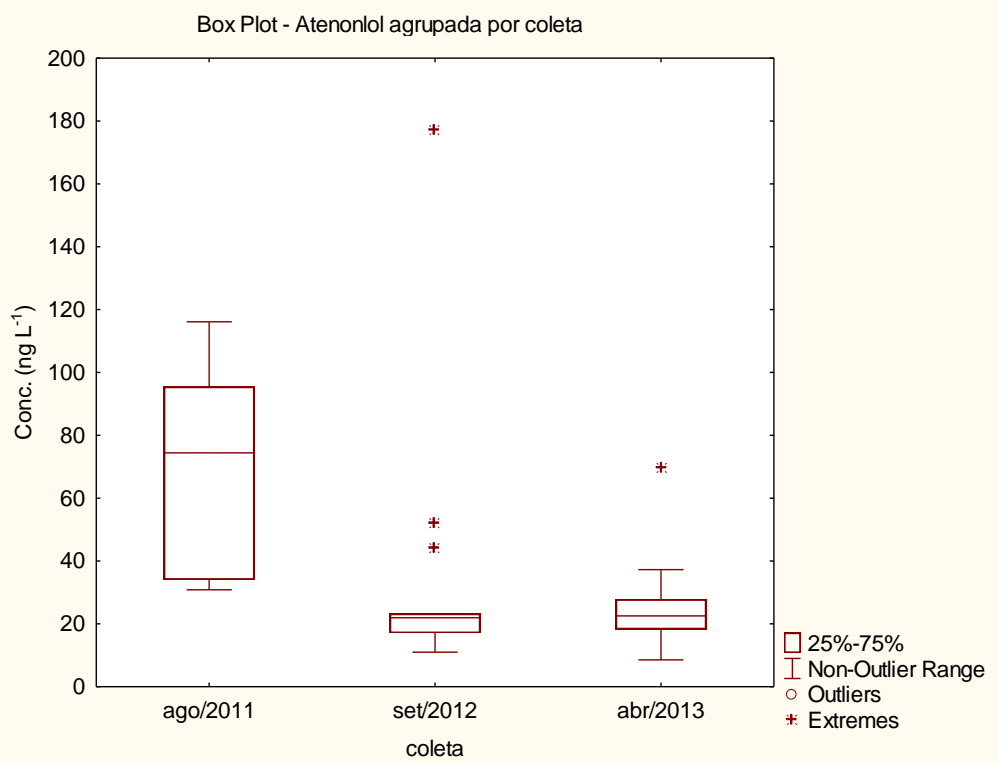

FIGURA 48. Distribuição do atenolol nas águas da represa Guarapiranga durante as coletas realizadas em ago./2011, set./2012 e abr./2013. 


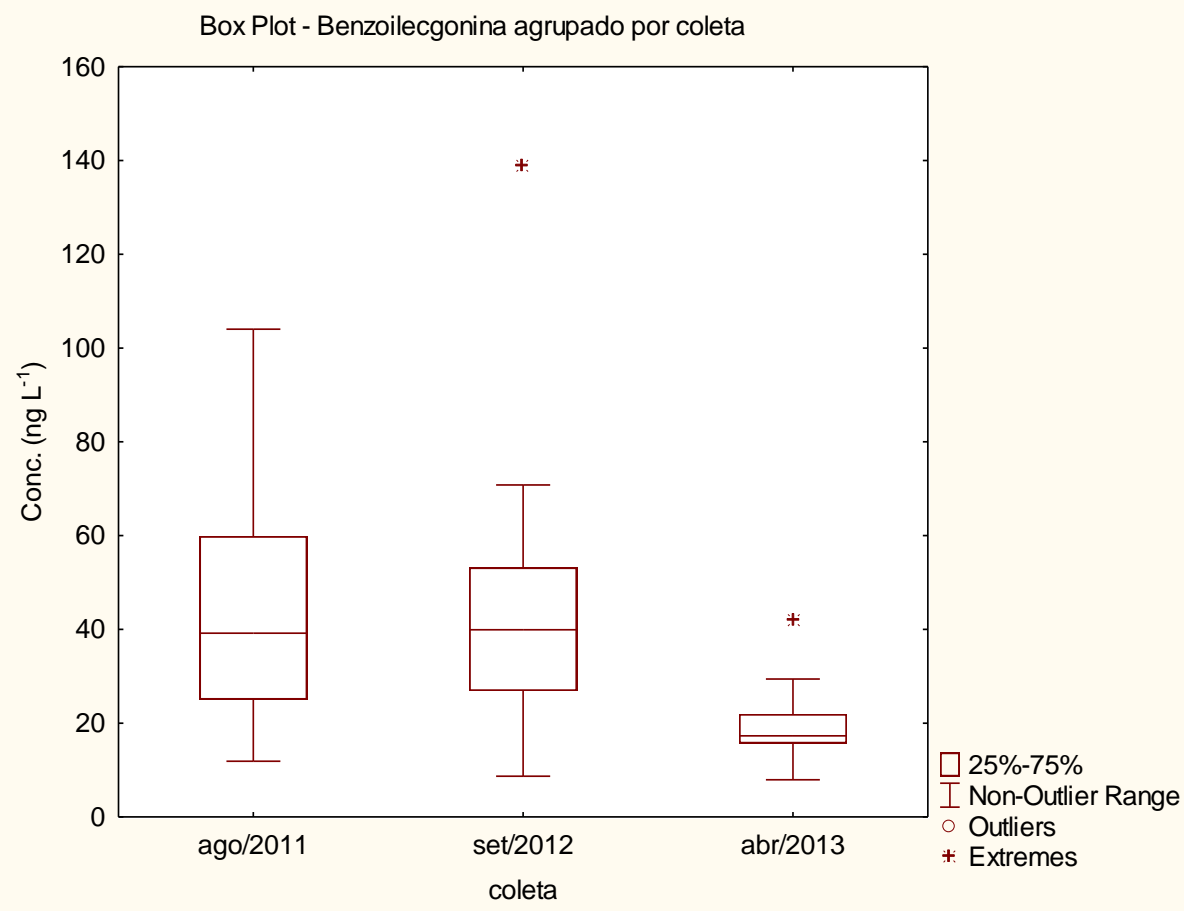

FIGURA 49. Distribuição do benzoilecgonina nas águas da represa Guarapiranga durante as coletas realizadas em ago./2011, set./2012 e abr./2013.

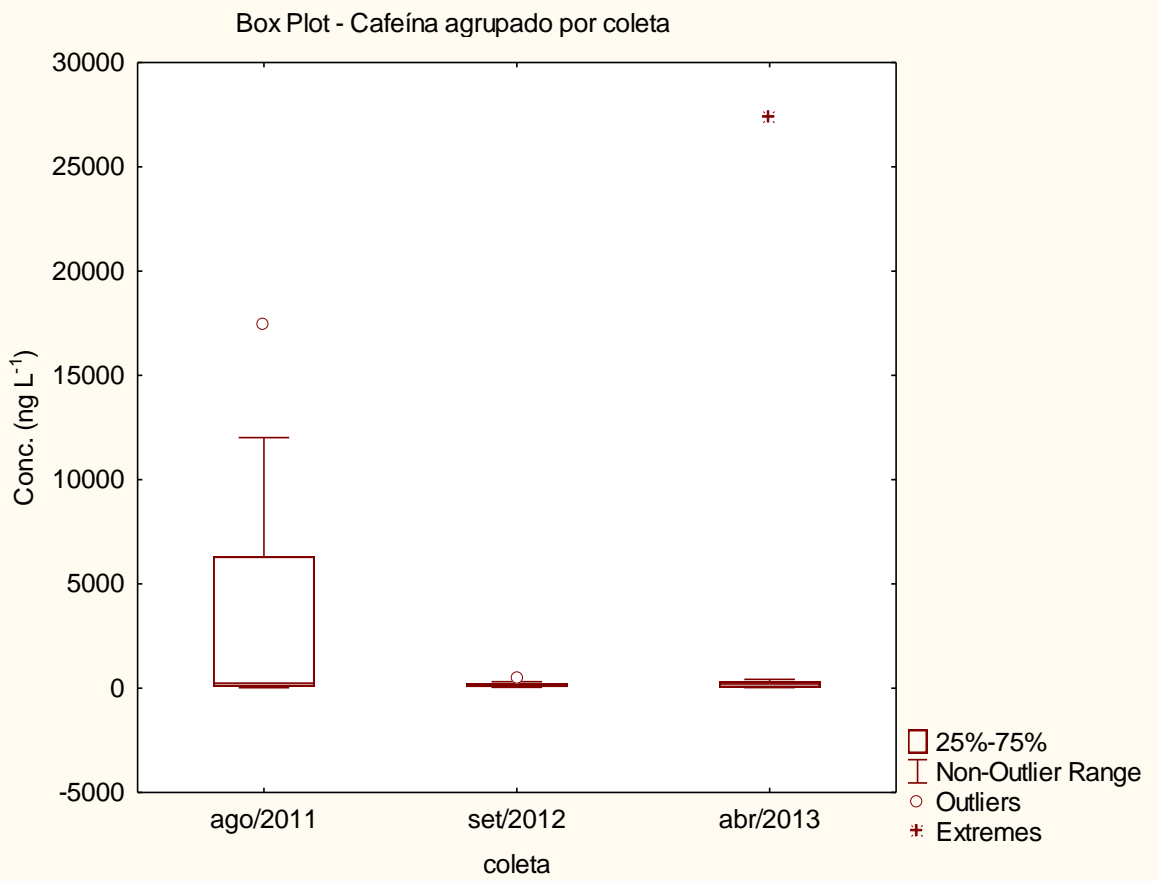

FIGURA 50. Distribuição da cafeína nas águas da represa Guarapiranga durante as coletas realizadas em ago./2011, set./2012 e abr./2013. 


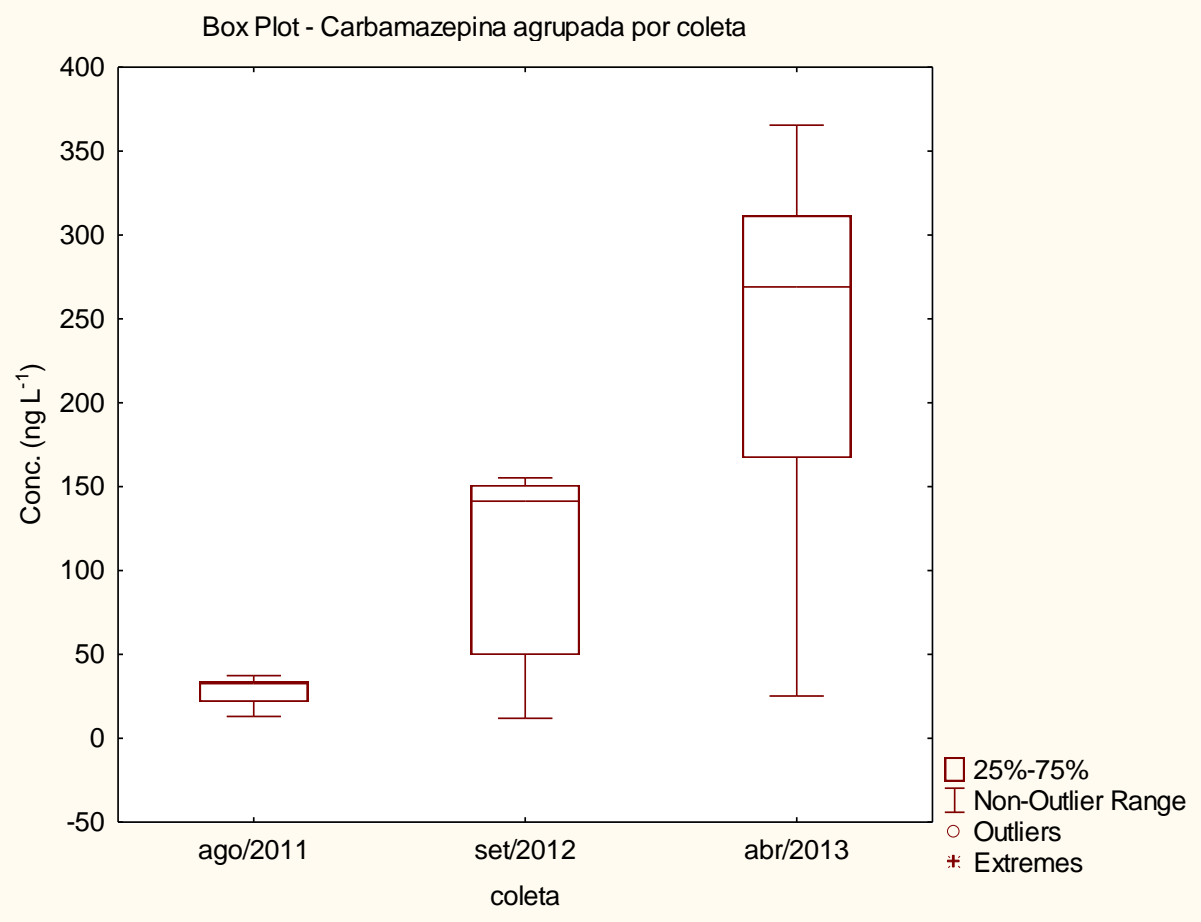

FIGURA 51. Distribuição da carbamazepina nas águas da represa Guarapiranga durante as coletas realizadas em ago./2011, set./2012 e abr./2013.

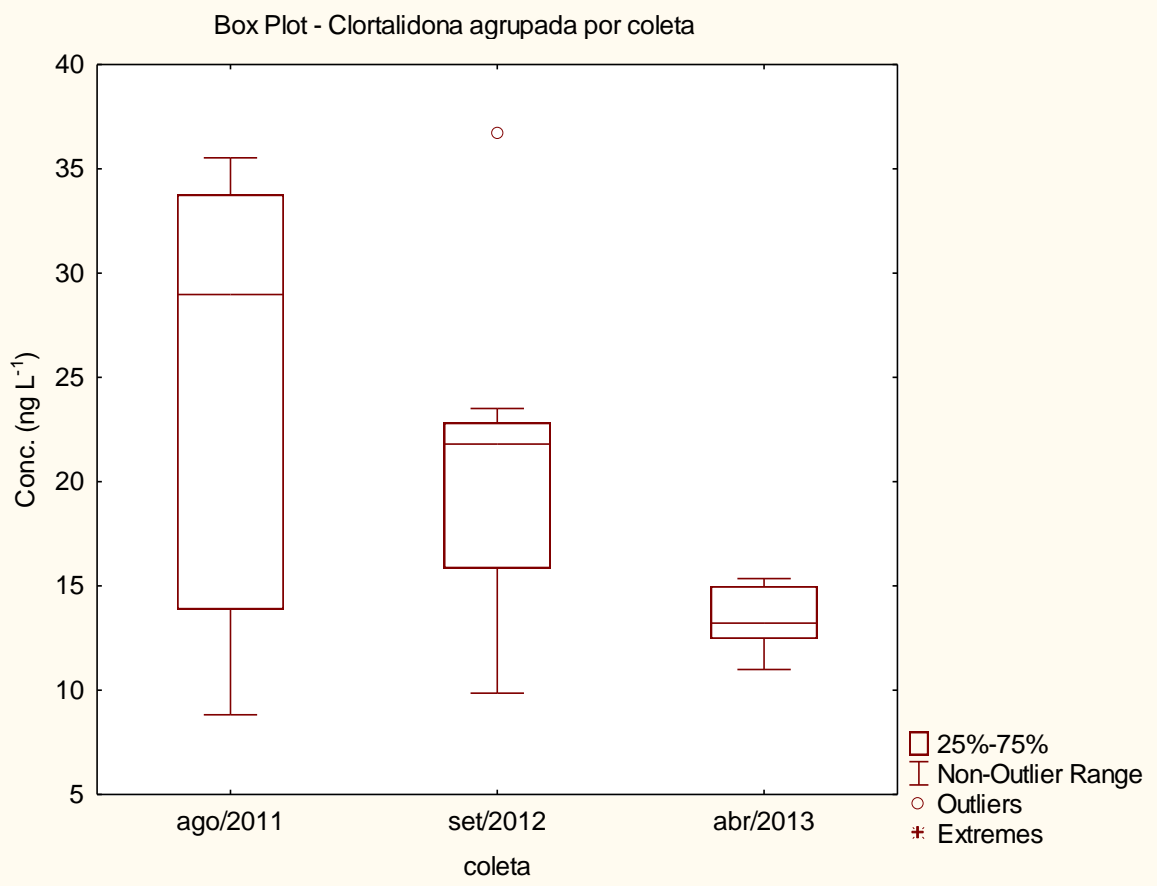

FIGURA 52. Distribuição da clortalidona nas águas da represa Guarapiranga durante as coletas realizadas em ago./2011, set./2012 e abr./2013. 


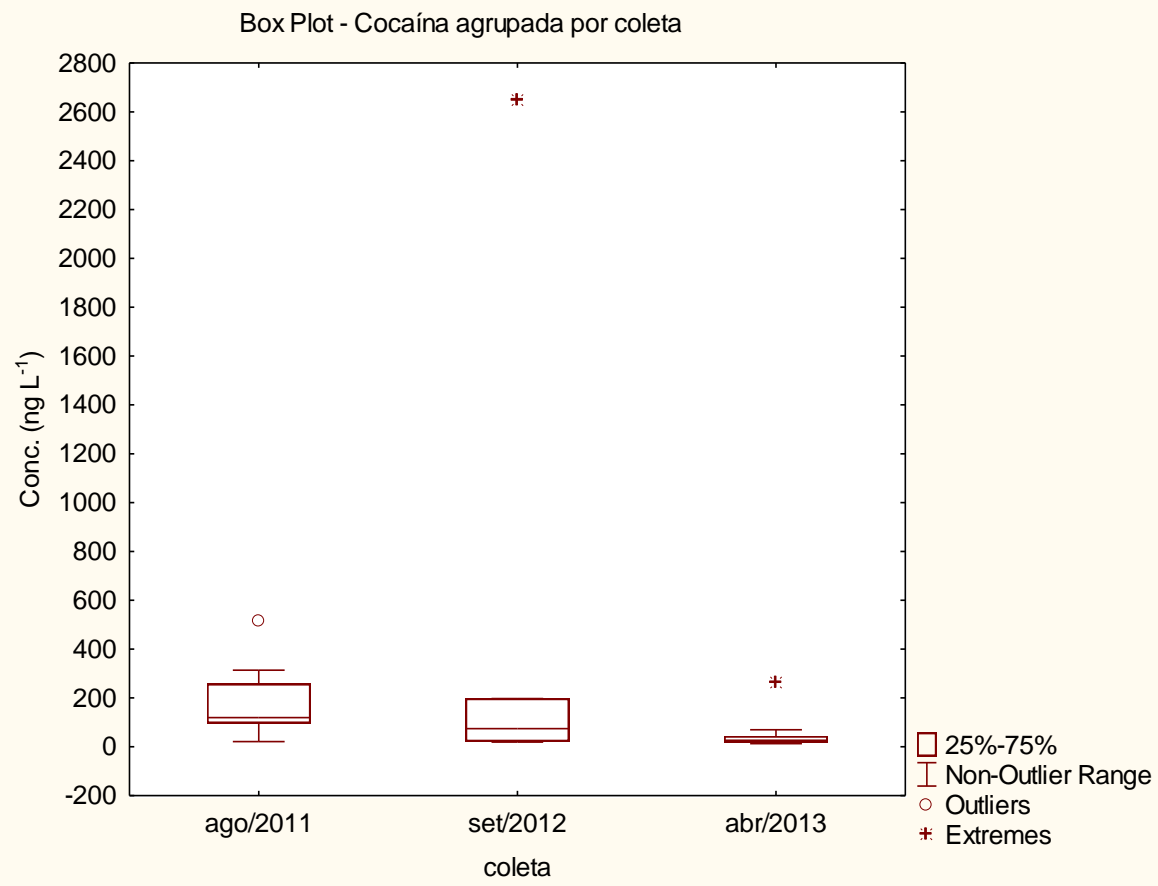

FIGURA 53. Distribuição da cocaína nas águas da represa Guarapiranga durante as coletas realizadas em ago./2011, set./2012 e abr./2013.

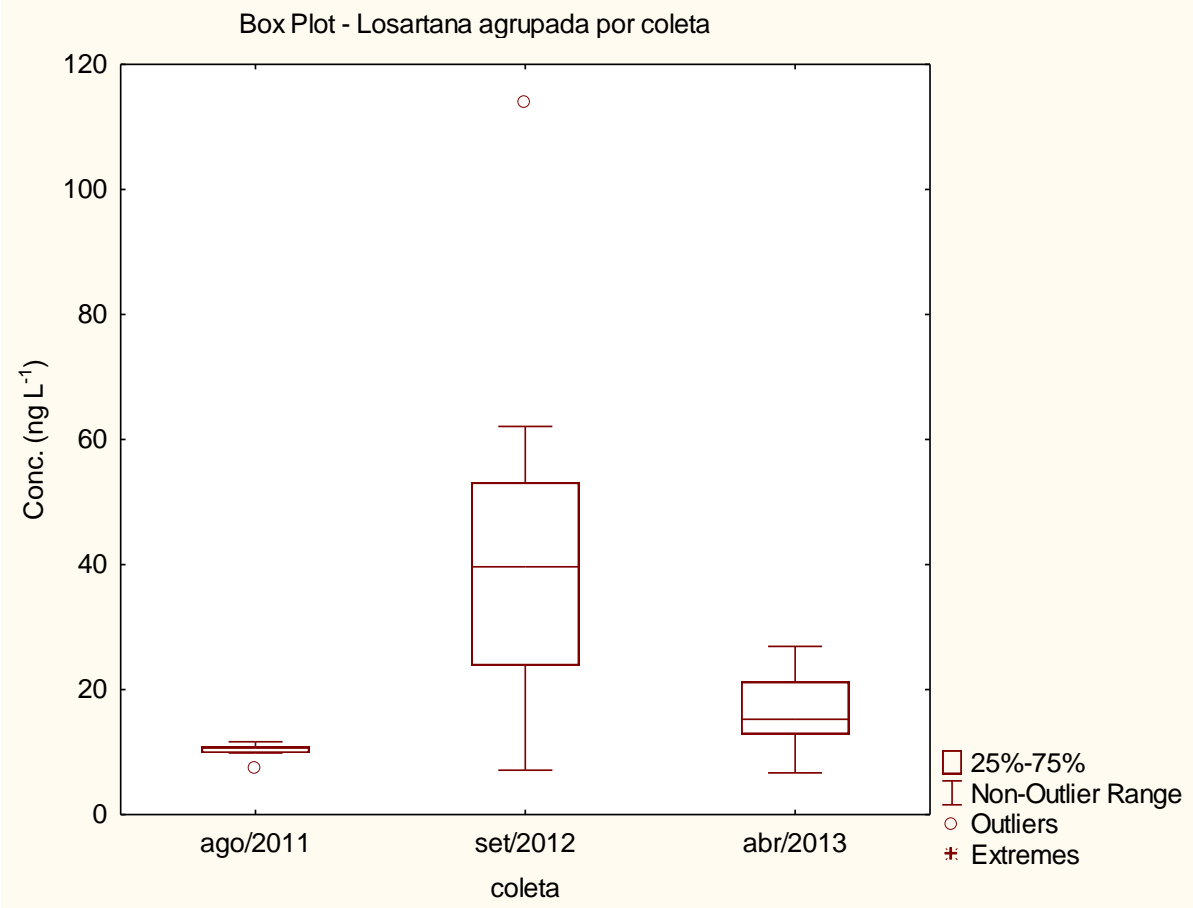

FIGURA 54. Distribuição da losartana nas águas da represa Guarapiranga durante as coletas realizadas em ago./2011, set./2012 e abr./2013. 
Na coleta de ago./2011, as concentrações obtidas foram mais elevadas para a maioria dos compostos, que podem estar relacionadas com o volume de água armazenada no período da coleta. Na FIG. 55, observa-se que o volume de água armazenado, na represa Guarapiranga, durante a coleta de ago./2011 foi menor do que nas coletas de set./2012 e abr./2013, indicando que pode ter ocorrido a concentração dos contaminantes orgânicos em ago./2011 e diluição nas outras duas campanhas de coleta. A exceção foram a carbamazepina e a losartana, para as quais foram obtidas concentrações menores em ago./2011, que pode estar relacionado com o consumo do medicamento.

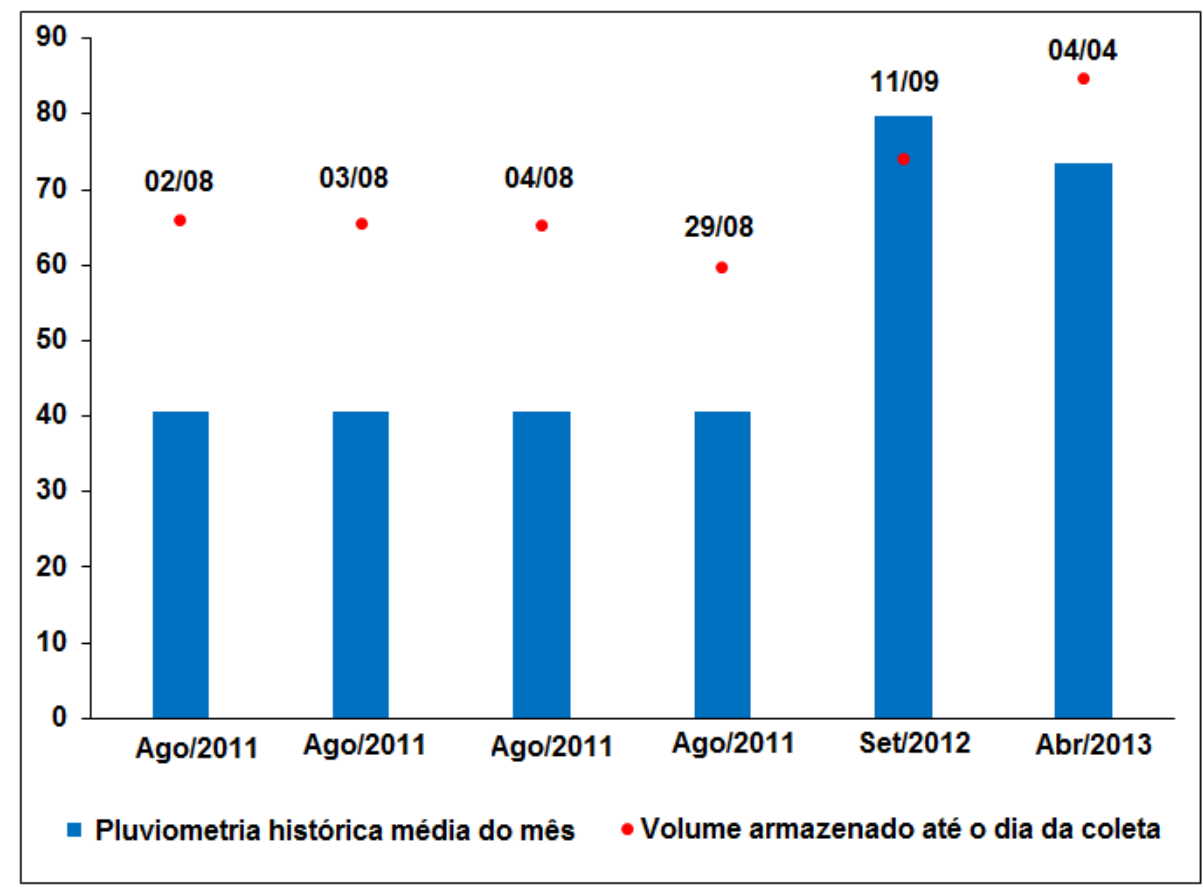

FIGURA 55. Pluviometria histórica média do mês e volume armazenado até o dia da coleta na represa Guarapiranga (SABESP).

Estudos mostram que água residual urbanas é a principal via de contaminação de ambiente aquático por resíduos de fármacos. Como vias secundárias podem ser citadas os descartes industriais e dos medicamentos vencidos. Além disso, não devem ser esquecidas as ETEs com procedimento convencional, que são incapazes de remover de modo eficiente a maioria dos contaminantes orgânicos, 
permitindo a sua presença nas águas superficiais e consequentemente na água potável (Gross et al., 2009; Loss et al., 2010; Valcárcel et al., 2011).

Um marcador antropogênico quantitativo apropriado para indicar a contaminação das águas superficiais por aguas residuais é a cafeína, uma vez que tem como origem uma fonte específica, que é o esgoto doméstico (BUERGE, et al., 2003; KOSTOPOULOU \& NIKOLAOU, 2008; DANESHVAR, et al., 2012).

A carbamazepina é também indicada como um marcador antropogênico por ter a mesma origem da cafeína. Apesar de estar presente em concentração mais baixa, apresenta a vantagem de ser mais persistente e resistente à degradação e adsorção, durante os processos nas ETEs, permitindo confirmar a contaminação por águas residuais (CLARA, et al., 2004).

Neste trabalho, a ocorrência da cafeína e da carbamazepina foi constatada em praticamente todos os locais de coleta, durante as três campanhas realizadas.

A cafeína foi detectada nas faixas de 27 a $17416 \mathrm{ng} \mathrm{L}^{-1}, 44$ a $465 \mathrm{ng} \mathrm{L}^{-1} \mathrm{e}$ 27 a $27386 \mathrm{ng} \mathrm{L}^{-1}$ nas coletas de ago./2011, set./2012 e abr./2013, respectivamente (FIG. 56A). Enquanto que, a carbamazepina foi encontrada nas faixas de 13 a $37 \mathrm{ng} \mathrm{L}^{-1}, 12$ a $152 \mathrm{ng} \mathrm{L}^{-1}$ e 25 a $358 \mathrm{ng} \mathrm{L}^{-1}$ nas coletas de ago./2011, set./2012 e abr./2013, respectivamente (FIG. 56B). 

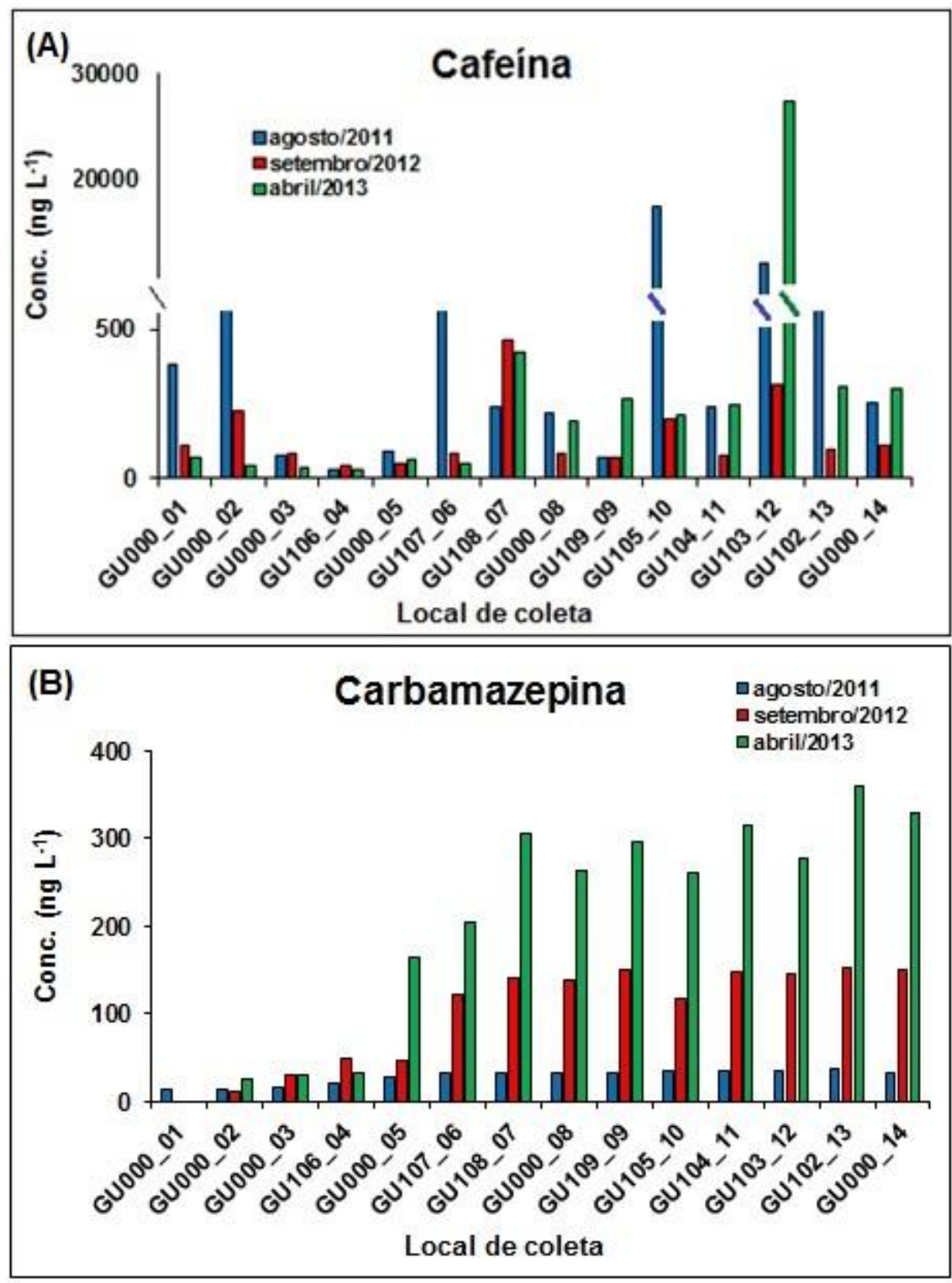

FIGURA 56. Ocorrência da cafeína (A) e carbamazepina (B) em ago./2011, set./2012 e abr./2013 nas águas da represa Guarapiranga.

A cafeína foi o composto detectado com as concentrações mais elevadas, provavelmente devido ao alto consumo de bebidas contendo cafeína como o café e o chá. (SUI, et al., 2010). Entretanto, a cafeína é rapidamente biodegradada por reações bioquímicas, durante o processo de remoção da matéria orgânica nas ETE's, com taxa 
de remoção de 72 a 98\% (BENDZ, et al., 2005; GÓMEZ, et al., 2007; LIN, et al., 2009; SUI, et al., 2010; BUENO, et al., 2011). No entanto, a presença da cafeína está sendo detectada em águas superficiais da Alemanha, no rio Leine, com concentração de $101 \mathrm{ng} \mathrm{L}^{-1}$ (NÓDLER, et al., 2010); da Coréia do Sul, no rio Han na faixa de 50 a $59 \mathrm{ng} \mathrm{L}^{-1}$ (YOON, et al., 2010); da Espanha, na região de Almeria, na faixa de 475 a $515 \mathrm{ng} \mathrm{L}^{-1}$ (BUENO, et al., 2011); dos Estados Unidos com concentração de $6000 \mathrm{ng} \mathrm{L}^{-1}$ (KOLPIN, et al., 2002) e da União Europeia, na faixa de 1467 a $39813 \mathrm{ng} \mathrm{L}^{-1}($ LOSS, et al., 2009; 2010). Segundo SILVA et al (2014), uma porção significativa do esgoto coletado é liberada sem tratamento nas águas superficiais. Em seus estudos realizados nos rios da região norte e centro de Portugal foram detectados cafeína em concentração algumas vezes maior ou próxima do efluente da ETE (<100 a $9000 \mathrm{ng} \mathrm{L}^{-1}$ ), caracterizando o ocorrido. A ocorrência da cafeína também foi observada em efluente de Estação de Tratamento de Água de Portugal na faixa de concentração de 170 a $920 \mathrm{ng} \mathrm{L}^{-1}$ (SILVA, et al., 2014).

No Brasil, a cafeína foi encontrada nas águas da Represa Billings com concentrações médias de 0,35 a 28,3 ng L-1 (ALMEIDA \& WEBER, 2005) e nas águas do rio Atibaia na faixa de 6000,04 a 32000,4 $\mathrm{ng} \mathrm{L}^{-1}$ (SODRÉ, et al., 2007).

Os resultados de cafeína (27 a $27386 \mathrm{ng} \mathrm{L}^{-1}$ ) encontrados nas águas da Represa Guarapiranga demonstram como nos estudos relatado acima, que a região apresenta um sistema de esgotamento sanitário precário, propiciando o descarte direto ou parcial de águas residuais nas águas da represa.

A carbamazepina é um importante fármaco empregado no tratamento de grande variedade de distúrbios como a epilepsia e esquizofrenia e um dos fármacos mais importantes do ponto de vista ambiental (PETROVIC, et al., 2005; JURATO, et al., 2014). 
A carbamazepina é pouco removida durante os processos de tratamento das ETE's atuais com taxa de remoção de apenas 4 a 32 \% (BENDZ, et al., 2005; VIENO, et al., 2006; GÓMEZ, et al., 2007; GROS, et al., 2009; LIN, et al., 2009; SUI, et al., 2010).

A vantagem da carbamazepina de ser resistente e indicada como indicador antropogênico representa, por outro lado, um fator de risco potencial para as águas de reservatório de abastecimento público pela possibilidade da sua presença na água potável de distribuição, devido a sua baixa taxa de remoção (CLARA, et al., 2004).

A carbamazepina foi detectada nas águas superficiais da Alemanha na faixa de 265 a 1101 ng L-1 (TERNES, 1998; NÓDLER, et al., 2010); da Coréia do Sul na faixa de 8,4 a $68 \mathrm{ng} \mathrm{L}^{-1}$ (YOON, et al., 2010), da Espanha na faixa de 1 a $60 \mathrm{ng} \mathrm{L}^{-1}$ (LÓPEZ-SERNA, et al., 2011), dos Estados Unidos na faixa de $<0,5$ a $5,1 \mathrm{ng} \mathrm{L}^{-1}$ (TRENHOLM, et al., 2009); da União Europeia na faixa de 66 a $11561 \mathrm{ng} \mathrm{L}^{-1}$ (LOSS, et al., 2009; 2010); da Finlândia na faixa de $<1,4$ a $66 \mathrm{ng} \mathrm{L}^{-1}$ (VIENO, et al., 2006) e da Romênia na faixa de 30 a $75,1 \mathrm{ng} \mathrm{L}^{-1}$ (MOLDOVAN, 2006).

A carbamazepina foi também detectada em outros ambientes aquáticos por GROS et al (2012) como: em águas de reservatórios (7 $\left.\mathrm{ng} \mathrm{L}^{-1}\right)$, água de torneira (2 $\left.\mathrm{ng} \mathrm{L}^{-1}\right)$, água do mar (8 $\left.\mathrm{ng} \mathrm{L}^{-1}\right)$, afluente de ETE's (46 a $95 \mathrm{ng} \mathrm{L}^{-1}$ ) e efluente de ETE's (13 a 158 ng L-1 $^{-1}$ ) da região da Catalonia, Espanha.

Os resultados da carbamazepina (12 a $358 \mathrm{ng} \mathrm{L}^{-1}$ ) encontrados nas águas da Represa Guarapiranga estão acima da concentração encontrada por GROS et al. (2012) nas águas de reservatórios, mas no mesmo nível de concentração encontrado em águas de rios.

Entre os produtos farmacêuticos frequentemente detectados no ambiente aquático estão os $\beta$-bloqueadores (atenolol e propranolol) e anti-hipertensivos 
(enalapril, losartana e valsartana), indicados no tratamento cardiovascular como hipertensão, arritmia e insuficiência cardíaca (GROS, et al., 2008). A hipertensão é a doença crônica de maior incidência entre as pessoas com mais de 60 anos de idade. $O$ envelhecimento populacional é hoje um fenômeno universal, característico tanto dos países desenvolvidos como, de modo crescente, do Terceiro Mundo. No Brasil, entre as pessoas que declaram ter alguma doença crônica, 53,3\% são hipertensas (IBGE, 2010).

Propranolol não foi quantificado em nenhuma das amostragens das águas da Represa Guarapiranga. No entanto, propranolol foi detectado na faixa de 0,02 a $39,17 \mathrm{ng} \mathrm{L}^{-1}$ no Reino Unido (HILTON \& THOMAS, 2003) e na Espanha, Catalonia, Bacia do Rio Ebro (GROS, et al., 2009; LÓPEZ-SERNA, et al., 2011). As concentrações de propranolol foram maiores na Alemanha, $590 \mathrm{ng} \mathrm{L}^{-1}$ (TERNES, 1998) e na Inglaterra propranolol, 35 a 107 ng L $^{-1}$ (ROBERTS\&THOMAS, 2006).

GROS et al. (2012) detectou propranolol em águas superficiais (12 $\mathrm{ng} \mathrm{L}^{-1}$ ), afluente (172 $\left.\mathrm{ng} \mathrm{L}^{-1}\right)$ e efluente $\left(97 \mathrm{ng} \mathrm{L}^{-1}\right)$ de ETE e não detectou em água de reservatório, água de torneira e água do mar, da região da Catalonia, Espanha.

Enalapril foi quantificado apenas durante a coleta de setembro/2012 no local GU103-12 com $20 \mathrm{ng} \mathrm{L}^{-1}$, valor este acima dos encontrados por Gross et al. (2009) e LÓPEZ-SERNA et al. (2011) na Espanha, na Bacia do Rio Ebro $(<0,09$ a 6,84 ng L-1) e por CALAMARI et al. (2003) na Itália, (0,05 a 0,54 ng L-1). Entretanto, o valor de enalapril encontrado no presente trabalho é muito abaixo dos valores encontrados nos afluentes (293 a $1268 \mathrm{ng} \mathrm{L-1}$ ) e efluentes (0.3 a $1041 \mathrm{ng} \mathrm{L-1})$ de Estação de Tratamento de Esgoto (ETE) por GROS et al. (2009) e LÓPEZ-SERNA et al. (2011).

A ocorrência do atenolol e da losartana nas águas da Represa Guarapiranga, nas coletas de ago./2011, set./2012 e abr./2013 são apresentadas na FIG. 56. As faixas de concentração do atenolol foram de 31 a $116 \mathrm{ng} \mathrm{L}^{-1}, 11$ a 
$177 \mathrm{ng} \mathrm{L}^{-1}$ e 8,5 a $70 \mathrm{ng} \mathrm{L}^{-1}$ (FIG. 57A), enquanto que da losartana foram de 8 a $12 \mathrm{ng} \mathrm{L}^{-1}, 7,1$ a $114 \mathrm{ng} \mathrm{L}^{-1}$ e 6,7 a $27 \mathrm{ng} \mathrm{L}^{-1}$ (FIG. 57B) nas coletas respectivas.
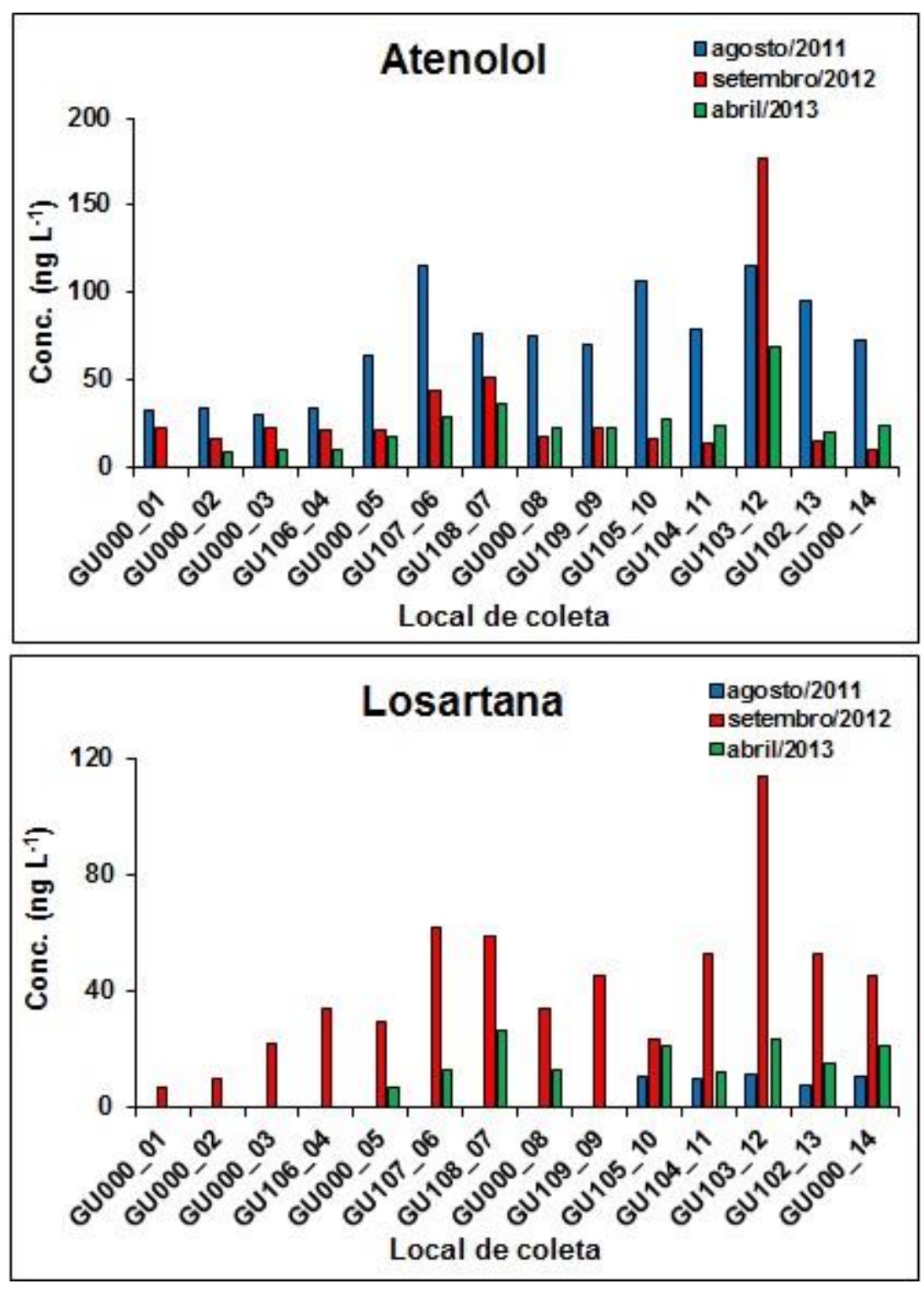

FIGURA 57. Perfil de ocorrência do atenolol (A) e losartana (B) nas águas da represa Guarapiranga coletadas em ago./2011; set./2012 e abr./2013.

O composto losartana (34 $\mathrm{ng} \mathrm{L}^{-1}$ ) foi detectado na mesma faixa de concentração deste trabalho em água superficial da região da Catalonia, Espanha (GROS, et al., 2012). Concentrações maiores de losartana foram detectadas em 
afluente e efluente de ETE's, 135 a $366 \mathrm{ng} \mathrm{L}^{-1}$ e 42 a $75 \mathrm{ng} \mathrm{L}^{-1}$, respectivamente, da mesma região. Concentrações mais baixas de losartana $\left(<7,3 \mathrm{ng} \mathrm{L}^{-1}\right)$ foram detectadas nas águas de reservatório da região da Catalonia, Espanha (GROS, et al., 2012). Em água de torneira, da mesma região a losartana foi detectada com $5 \mathrm{ng} \mathrm{L}^{-1}$

A mesma faixa de concentração de atenolol obtida neste trabalho foram detectadas por CALAMARI et al. (2003) ao analisarem as águas do Rio Po, Lambro, Itália e por YOON et al. (2010) ao estudarem as águas do Rio Han, Coréia do sul. Faixas menores de concentração de atenolol $\left(0,9\right.$ a $\left.66 \mathrm{ng} \mathrm{L}^{-1}\right)$ foram relatadas por ALMEIDA \& WEBER (2005) nas águas da Represa Billings; TRENHOLM et al. (2009) nas águas do rio Colorado, Texas, Estados Unidos; VIENO et al. (2006) na Finlândia; NÓDLER et al. (2010) nas águas do rio Leine, Göttingen, Alemanha e por GROS et al. (2009; 2012) nas águas da Bacia Ebro, Espanha. No entanto, estudo realizado por LÓPEZ-SERNA et al. (2011) em 13 amostras de águas do rio Ebro e 13 amostras de águas de tributários do rio Ebro detectaram concentrações mais elevadas de $1238 \mathrm{ng} \mathrm{L}^{-1}$ e $11020 \mathrm{ng} \mathrm{L}^{-1}$ de atenolol, respectivamente.

Valsartana esteve presente nas águas da Represa Guarapiranga apenas na coleta de set./2012 com faixa de concentração de 9,7 a 47 ng L $^{-1}$ (FIG. 58). 


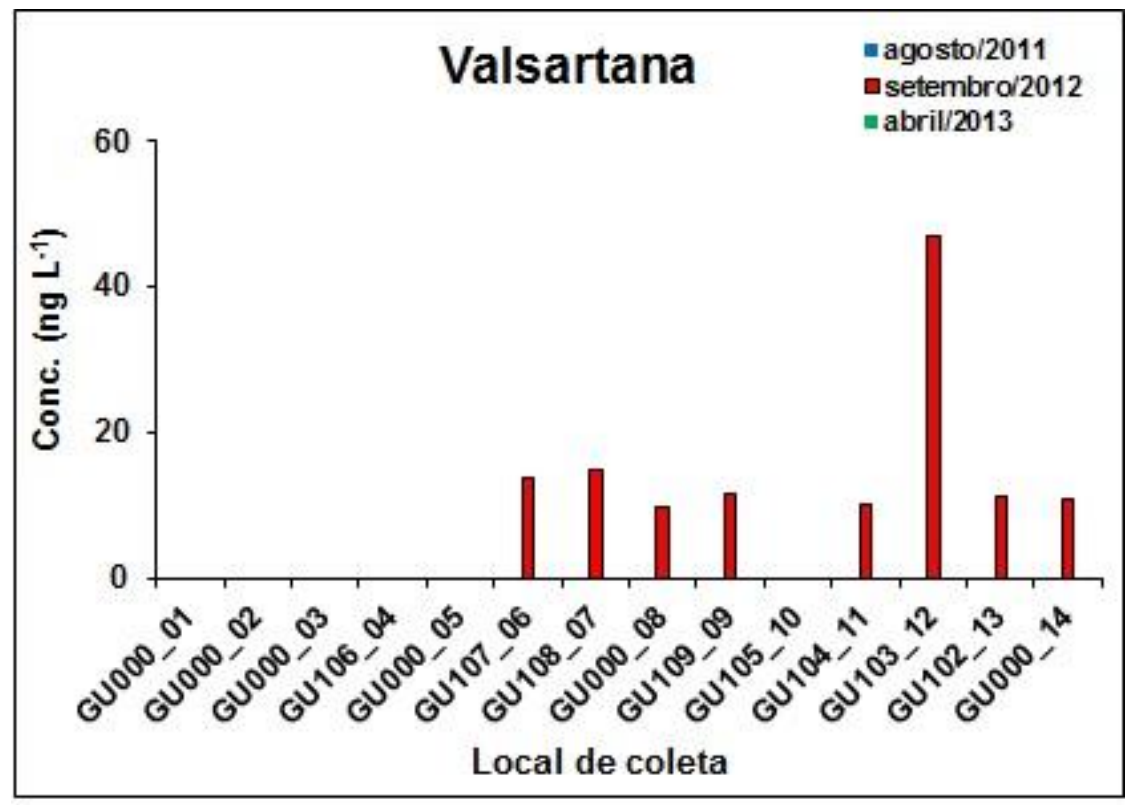

FIGURA 58. Perfil de ocorrência da valsartana nas águas da represa Guarapiranga coletada em ago./2011; set./2012 e abr./2013.

Os valores de valsartana obtidos, neste trabalho, foram maiores quando comparados com obtido por GROS et al. (2012) em água de reservatório $\left(11 \mathrm{ng} \mathrm{L}^{-1}\right) \mathrm{da}$ região da Catalonia, Espanha. Entretanto, foram da mesma ordem dos valores encontrados por KLOSTERHAUS et al. (2013) na baia de São Francisco, CA, EUA (18 a 92,1 ng L-1). O composto valsartana também foi detectado em água de torneira, água do mar, água superficial, afluente e efluente de ETE's da região de Catalonia, Espanha, com concentração de $13 \mathrm{ng} \mathrm{L} \mathrm{L}^{-1}, 29 \mathrm{ng} \mathrm{L}^{-1}, 734 \mathrm{ng} \mathrm{L}^{-1}, 1076$ a $3696 \mathrm{ng} \mathrm{L}^{-1} \mathrm{e}$ 58 a $574 \mathrm{ng} \mathrm{L}^{-1}$, respectivamente.

A presença de $\beta$-bloqueadores e anti-hipertensivos em águas superficiais é uma consequência da liberação direta do esgoto e da baixa taxa de remoção das ETE's. GROS et al. (2009) analisaram amostras de afluentes e efluentes de três ETE's localizadas na Catalonia, Espanha e obtiveram taxas de remoção de 11\% para atenolol e 18\% para enalapril. Taxas elevadas de remoção para atenolol foram encontradas nas ETE's de Taiwan, China (76\%) por LIN et al. (2009); da Finlândia (45\%) por VIENO et al. (2006) e de Barcelona, Espanha (49\%) por GROS et al. (2008). 
Para propranolol, a concentração nos efluentes das ETE's foi maior do que nos afluentes. Estes resultados também foram obtidos para propranolol por ROBERTS\& THOMAS (2006) nas ETE's da Inglaterra e para enalapril por BENDZ et al. (2005) nas ETE's da Suécia. Segundo HEBERER (2002), esse aumento pode ser devido à clivagem de metabólitos formados por conjugação, permitindo assim a liberação do fármaco pai e, consequentemente aumentando a concentração do fármaco original no efluente. PETROVIC et al. (2005) sugere também que pode ocorrer uma supressão de sinal no detector MS/MS, ocasionada pelas altas concentrações de matérias orgânicas no esgoto bruto, que resulta em concentração menor que a do real no afluente.

Clortalidona é um diurético que aumenta moderadamente a eliminação de urina, e como age também como vasodilatador sanguíneo é indicado também como anti-hipertensivo. Nesse trabalho, a clortalidona foi quantificada na faixa de concentração 9,4 a $34 \mathrm{ng} \mathrm{L}^{-1}, 9,5$ a $35 \mathrm{ng} \mathrm{L}^{-1}$ e 10,6 a 14,7 $\mathrm{ng} \mathrm{L}^{-1}$ durante as amostragens de ago./2011, set./2012 e abr./2013, respectivamente (FIG. 59).

Relatos de ocorrência de clortalidona não foram encontrados na literatura. 


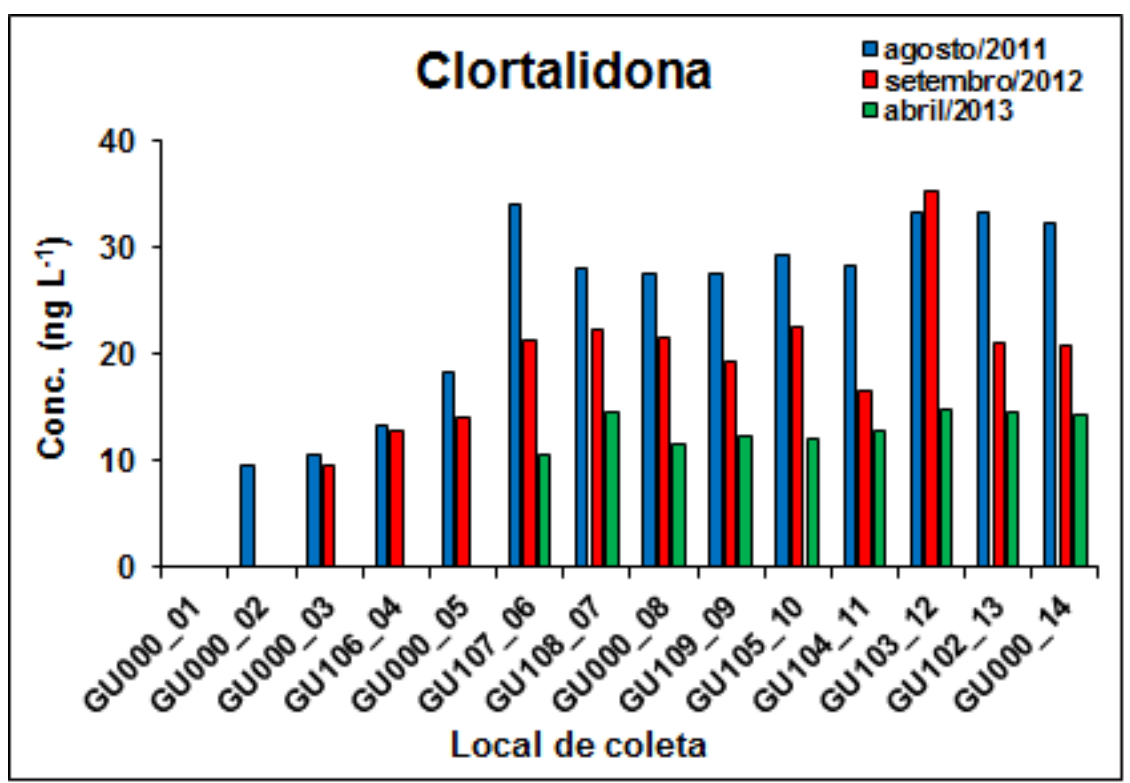

FIGURA 59. Perfil de ocorrência da clortalidona nas águas da represa Guarapiranga coletada em ago./2011; set./2012 e abr./2013.

Os anti-inflamatórios não esteroides (ANEs) são considerados, do ponto de vista ambiental, o grupo mais relevante de substâncias farmacologicamente ativas, por ser altamente consumido e de aquisição sem prescrição médica (GÓMEZ, et al., 2007).

A presença de acetaminofeno e diclofenaco em águas superficiais, afluentes e efluentes de ETE's é largamente documentada e com concentrações elevadas. Em águas superficiais, as concentrações mais elevadas de acetaminofeno e diclofenaco foram encontradas na Alemanha (TERNES, 1998; NÓDLER, et al., 2010), Espanha (GROS, et al., 2009; LÓPEZ-SERNA, et al., 2011; VALCÁRCEL, et al., 2011), Estados Unidos (KOLPIN, et al., 2002) e União Europeia (LOSS, et al., 2009; LOSS, et al., 2010) na faixa de concentração de $<2,46$ a $10000 \mathrm{ng} \mathrm{L}^{-1}$ para acetaminofeno e $<0,30$ a $3363 \mathrm{ng} \mathrm{L}^{-1}$ para diclofenaco.

No Brasil SODRÉ et al. (2007) também detectou em águas superficiais da Região Metropolitana de Campinas, SP, $840 \mathrm{ng} \mathrm{L}^{-1}$ de acetaminofeno e ALMEIDA \& 
WEBER (2005) encontrou diclofenaco na faixa de concentração de 8,1 a 394,5 ng L-1 nas águas da Represa Billings .

Neste estudo, acetaminofeno, diclofenaco e orfenadrina, três dos mais comumente consumidos no Brasil foram investigados nas águas da Represa Guarapiranga. O acetaminofeno foi encontrado na faixa de concentração de 12,8 a $254 \mathrm{ng} \mathrm{L}^{-1}, 9,6$ a $78 \mathrm{ng} \mathrm{L^{-1 }}$ e 16 a $108 \mathrm{ng} \mathrm{L}^{-1}$ durante a amostragem de agosto/2011, setembro/2012 e abril/2013, respectivamente (FIG. 60A), enquanto diclofenaco foi quantificado, na coleta de ago./2011, apenas em 2 locais (G000-01 e G107-06) com $8 \mathrm{ng} \mathrm{L}^{-1}$; na coleta de set./2012 somente em um local (G103-12) com 35 ng $\mathrm{L}^{-1}$ e não esteve presente na coleta de abr./2013 (FIG. 60B). A orfenadrina não foi quantificada em nenhuma campanha de coleta, mas foi observada em $71 \%$ e $29 \%$ das amostras coletadas abaixo do LQ e LD, respectivamente. 

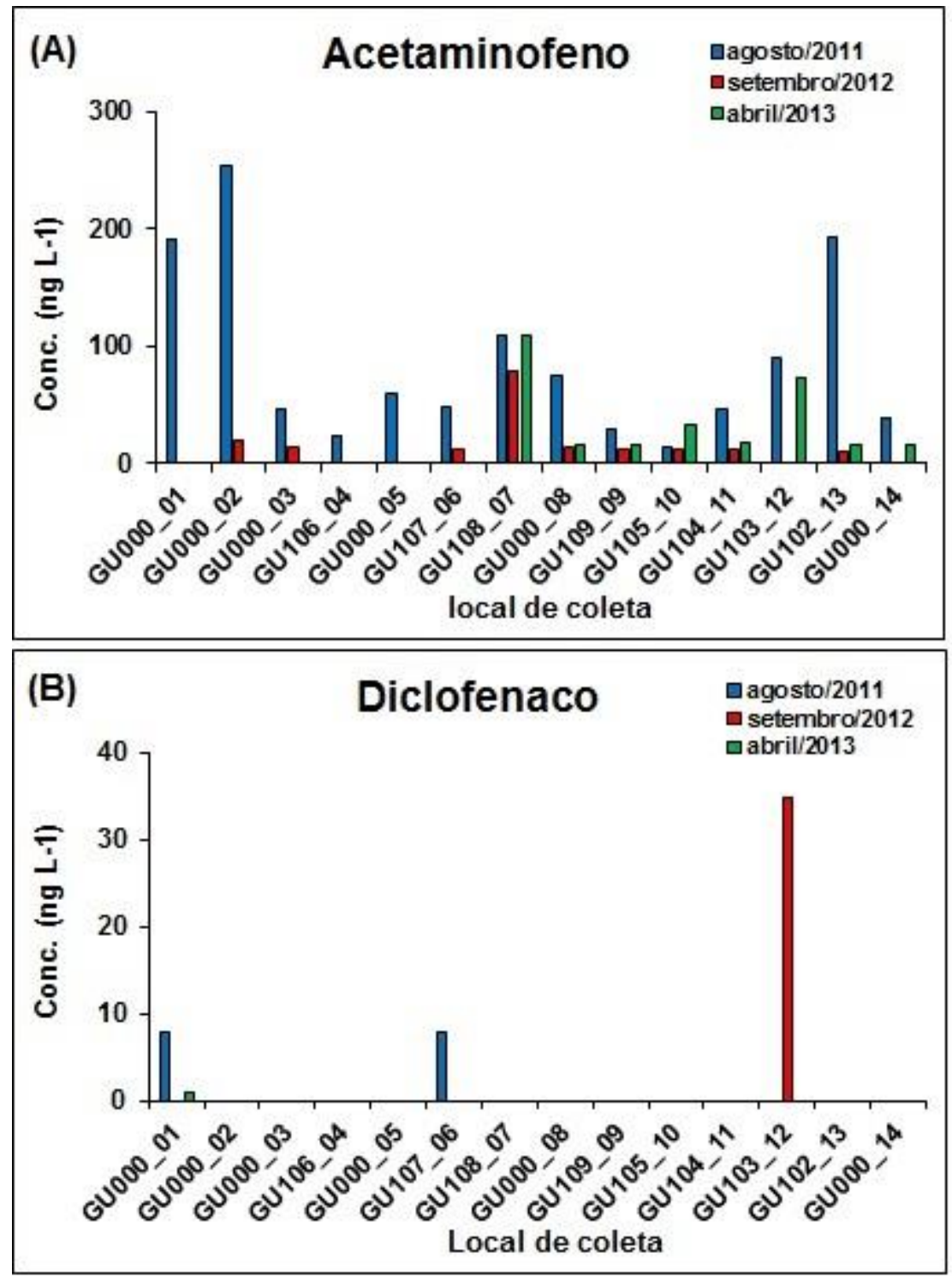

FIGURA 60. Perfil de ocorrência do acetaminofeno (A) e diclofenaco (B) nas águas da represa Guarapiranga coletadas em ago./2011; set./2012 e abr./2013.

Estudos mostram que acetaminofeno é encontrado no afluente de ETE's em concentração $\left(4,16\right.$ a $\left.246 \mu \mathrm{g} \mathrm{L}^{-1}\right)$ significativamente mais alta do que outros fármacos (TAB. 5 a 11). No entanto, a elevada eficiência de remoção, 93 a 100\%, alcançada durante os processos de tratamento da ETE permite uma eliminação ou redução drástica do nível de concentração no efluente de ETE's, e consequentemente nas 
águas superficiais (ROBERTS\&THOMAS, 2006; GÓMEZ, et al., 2007; GROS, et al., 2009; VALCÁRCEL, et al., 2011; GROS, et al., 2012).

Diclofenaco está presente no afluente e efluente de ETE's em concentração menor que acetaminofeno. Entretanto, a presença de diclofenaco mesmo em baixas concentrações deve ser monitorada, uma vez que foi encontrada uma correlação direta entre o diclofenaco e a insuficiência renal, que provocou o declínio da população de urubu na Índia e Paquistão (FENT, et al., 2006).

Os processos de tratamento das ETE's atuais conseguem taxa de remoção para o diclofenaco de apenas 25 a 77\% (BENDZ, et al., 2005; ROBERTS\&THOMAS, 2006; GÓMEZ, et al., 2007; GROS, et al., 2009; LIN, et al., 2009; SUI, et al., 2010; LÓPEZ-SERNA, et al., 2011).

Os valores de acetaminofeno e diclofenaco obtidos nesse estudo foram maiores quando comparados com os de GROS et al. (2012), que detectaram $21 \mathrm{ng} \mathrm{L}^{-1}$ de acetaminofeno e não detectaram diclofenaco nas águas de reservatório da região da Catalonia, Espanha.

Os valores de ocorrência de orfenadrina não foram encontrados na literatura.

A cocaína é um estimulante potente do sistema nervoso central e a benzoilecgonina o seu principal metabólito. No Brasil, o consumo de cocaína tem sido crescente nas últimas décadas e com demonstração de consequências socioeconômicas significativas na saúde e na incidência criminal (SENAD, 2009).

Os resíduos de drogas ilícitas e seus metabólitos de uso humano estão sendo detectados em ambiente aquático, de modo similar aos produtos farmacêuticos, após a excreção pela urina. A quantidade de produção da cocaína tem levado a 
classificação de contaminante ambiental emergente pela sua presença no ambiente aquático (BAKER \& KRASPRZYK-HORDERN, 2011).

Nesse trabalho, a cocaína foi encontrada nas águas da represa Guarapiranga com concentração nas faixas de 21 a $512 \mathrm{ng} \mathrm{L}^{-1}, 19$ a $2650 \mathrm{ng} \mathrm{L}^{-1} \mathrm{e}$ 12,8 a $261 \mathrm{ng} \mathrm{L}^{-1}$ durante as coletas de ago./2011, set./2012 e abr./2013, respectivamente (FIG. 61A), enquanto a benzoilecgonina nas faixas de 11,9 a $104 \mathrm{ng} \mathrm{L}^{-1}, 8,7$ a $139 \mathrm{ng} \mathrm{L}^{-1}$ e 7,9 a $42 \mathrm{ng} \mathrm{L}^{-1}$ durante os mesmos períodos de coletas (FIG. 61B). 

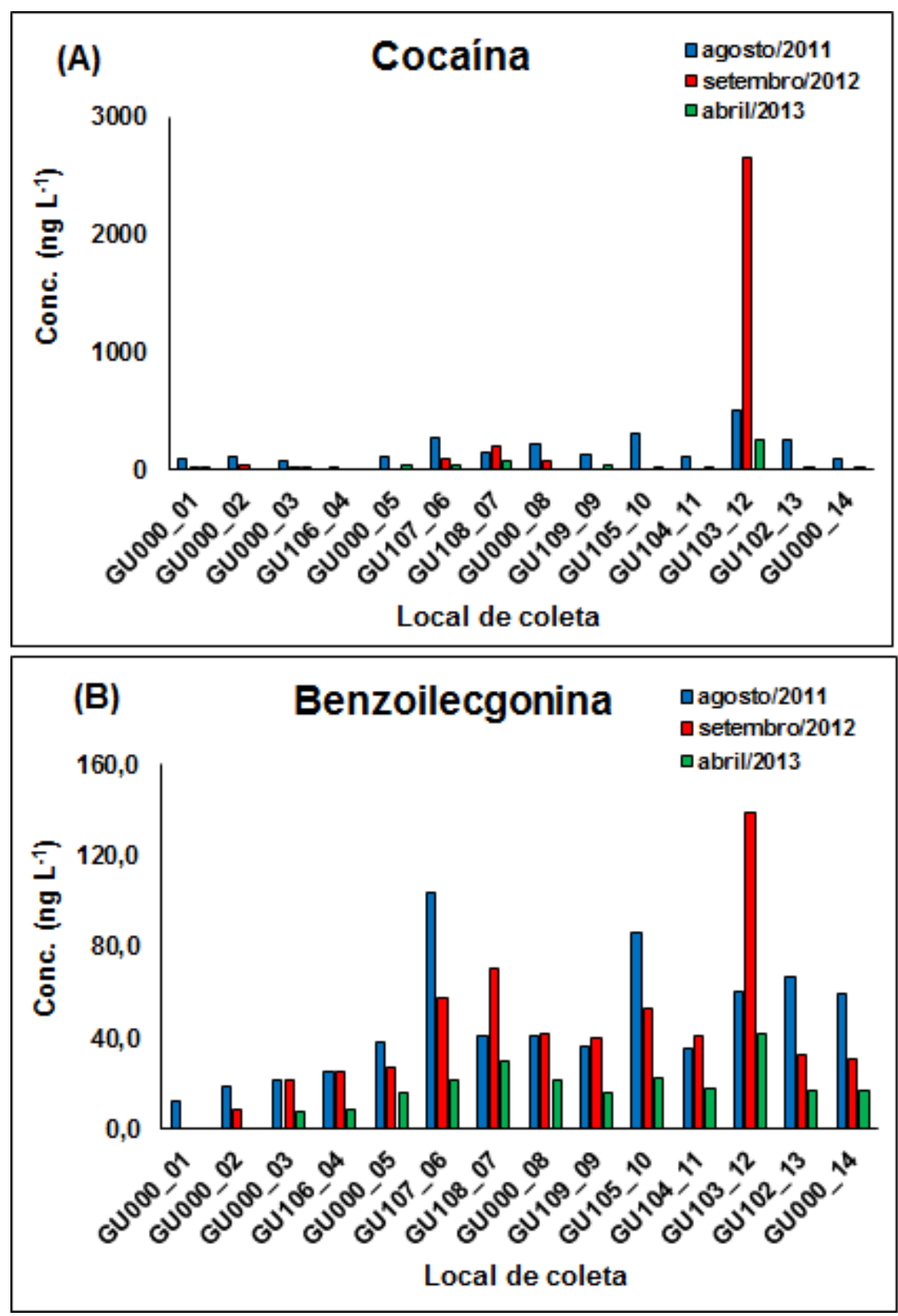

FIGURA 61. Perfil de ocorrência da cocaína (A) e benzoilecgonina (B) nas águas da represa Guarapiranga coletadas em ago./2011; set./2012 e abr./2013.

Os valores de cocaína obtidos neste trabalho, 12,8 a $2650 \mathrm{ng} \mathrm{L}^{-1}$, foram maiores que os encontrados nas águas superficiais da China (LIN, et al., 2010), Espanha (BUENO, et al., 2011), Inglaterra, Itália (ZUCCATO, et al., 2008), Irlanda (BONES, et al., 2007) e do Reino Unido (BAKER \& KRASPRZYK-HORDERN, 2011), 
que foram na faixa de 0,13 a $530 \mathrm{ng} \mathrm{L}^{-1}$. Entretanto, os valores de cocaína podem ser concordantes, uma vez que a mediana dos valores obtidos nas 3 (três) campanhas de coleta foi de $84 \mathrm{ng} \mathrm{L}^{-1} \mathrm{e}$ o valor máximo de cocaína $\left(2650 \mathrm{ng} \mathrm{L}^{-1}\right)$ foi detectado apenas em GU103-12, durante a coleta de set./2012.

As concentrações de benzoilecgonina obtidas neste trabalho, 7,9 a $139 \mathrm{ng} \mathrm{L}^{-1}$, estão dentro da faixa de concentração, 0,5 a $530 \mathrm{ng} \mathrm{L}^{-1}$, encontrada nas águas superficiais citadas para a cocaína.

Nesses mesmos países foram constatada a presença de altas concentrações de cocaína (1 a $652 \mathrm{ng} \mathrm{L}^{-1}$ ) e benzoilecgonina $\left(3,4\right.$ a $\left.2933 \mathrm{ng} \mathrm{L}^{-1}\right)$ nos efluentes de ETEs, decorrente da ineficiência e instabilidade dos processos de tratamento convencionais, os quais proporcionaram larga taxa de remoção para cocaína (40 a $93 \%$ ) e para benzoilecgonina (12 a 92\%).

A metodologia desenvolvida, neste trabalho, quando aplicada em amostras de águas residuais pode fornecer os níveis de cocaína e benzoilecgonina, que com o valor da vazão das águas residuais, o consumo da cocaína em g/dia ou dose/dia pode ser estimada nessa comunidade (NUIJS, A. L. N. van, et al., 2011; SILVA, 2012). Esse método permite estimar o consumo da cocaína de um modo mais rápida e seguro, além de fornecer dados de modo anônimo, o que evita os conflitos de privacidade. Enquanto que o método convencional para estimar o consumo de drogas baseia-se nos dados de entrevistas ao consumidor, registros médicos, estatísticas de criminalidade (por exemplo, número de prisões e detenções), produção de drogas, taxas de apreensão, assim como, as informações de testes pessoais realizados durante o monitoramento de abstinência e estudos toxicológicos nas amostras de plasma, soro, urina, saliva, suor e cabelo (BONES, et al., 2007).

Com a aplicação do conceito da metodologia deste trabalho, é possível obter dados de uma comunidade em tempo real, para permitir adoção imediata de medidas 
adequadas por parte das autoridades responsáveis, quando necessárias. Esses dados podem auxiliar as políticas públicas no conhecimento do nível de uso, locais de utilização e distribuição para subsidiar projetos de campanhas de prevenção e estratégias de execução (CNPq, 2011).

Os dendogramas da distribuição de atenolol e cocaína nas águas da represa Guarapiranga apresentados nas FIG. 62 e 63 demonstram que GU103-12 foi o local com as maiores concentrações nas três campanhas de amostragens (ago./2011, set./2012 e abril2013). Os compostos foram quantificados em pelo menos $65 \%$ das amostragens nas concentrações de 116, 177 e $70 \mathrm{ng} \mathrm{L}^{-1}$ de atenolol e 512, 2650 e 261 ng L $\mathrm{L}^{-1}$ de cocaína.

Os dendogramas individuais da distribuição da benzoilecgonina, cafeína, carbamazepina, clortalidona e acetaminofeno nas águas da represa Guarapiranga coletadas em ago./2011, set./2012 e abr./2013 encontram-se no Apêndice C.

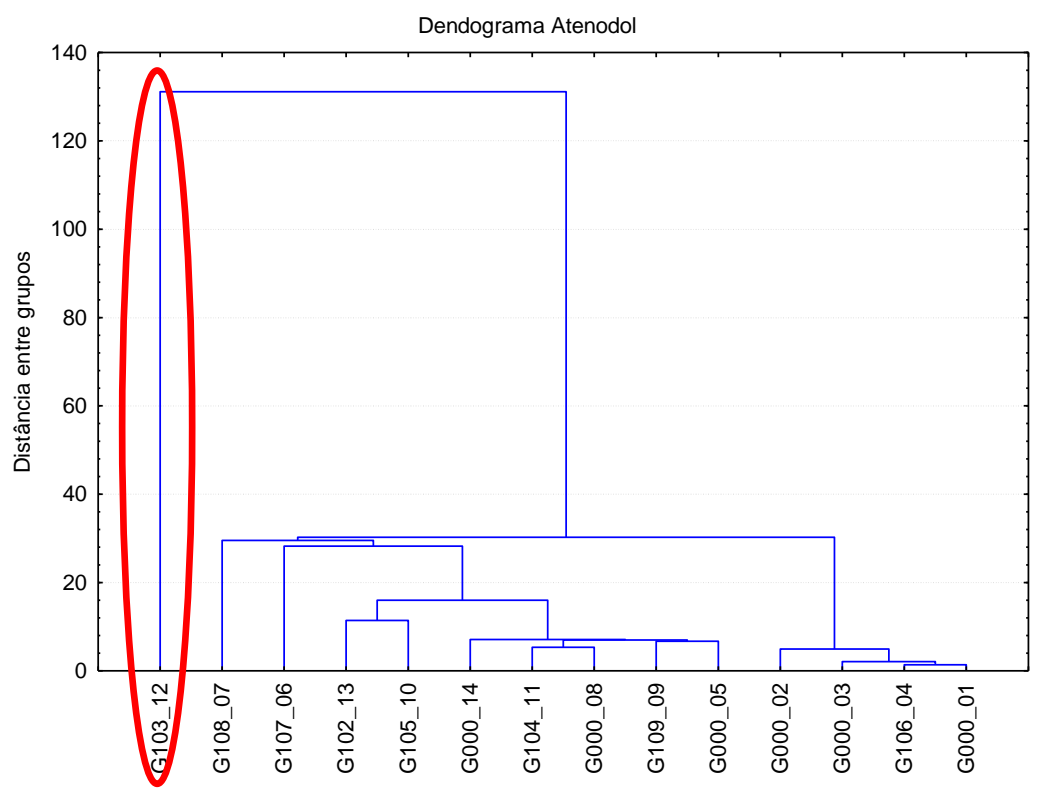

FIGURA 62. Dendograma da distribuição do atenolol nas águas da represa Guarapiranga coletadas em ago./2011, set./2012 e abr./2013. 


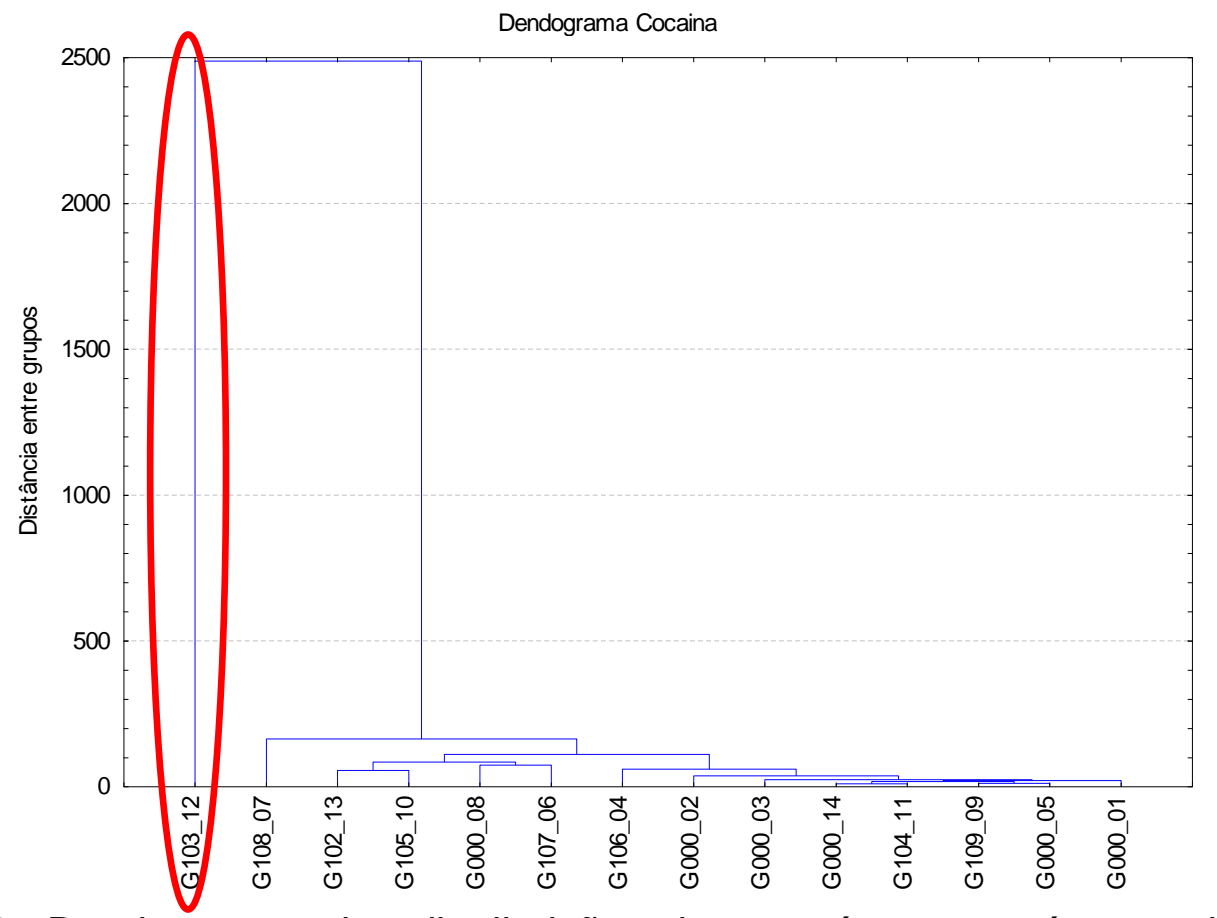

FIGURA 63. Dendograma da distribuição da cocaína nas águas da represa Guarapiranga coletadas em ago./2011, set./2012 e abr./2013.

Os dendogramas das FIG. 62 e 63 mostram que o local de amostragem denominado GU103-12 foi também o local de maiores concentrações, na coleta de set./2012, para benzoilecgonina (139 $\mathrm{ng} \mathrm{\textrm {L } ^ { - 1 }}$ ), cafeína (313 $\mathrm{ng} \mathrm{L}^{-1}$ ), clortalidona (37 $\left.n g \mathrm{~L}^{-1}\right)$, losartana $\left(114 \mathrm{ng} \mathrm{L}^{-1}\right)$ e valsartana $\left(49 \mathrm{ng} \mathrm{L}^{-1}\right)$.

$\mathrm{Na}$ coleta de abr./2013, os fármacos de concentrações mais elevadas em GU103-12 foram o benzoilecgonina (42 $\left.\mathrm{ng} \mathrm{L}^{-1}\right)$, cafeína (27386 $\mathrm{ng} \mathrm{L^{-1 }}$ ) e clortalidona (261 ng L-1).

O dendograma das concentrações da cafeína (Apêndice C) mostra que no local GU105-10 foram também detectadas concentrações altas de cafeína nas 3 três campanhas de amostragens.

As concentrações mais elevadas nos pontos amostrados em GU103-12 e GU105-10 são provavelmente consequências de uma área densamente urbanizada, 
com diferentes padrões urbanístico e próximo ao aporte dos córregos Itupu e Guavirutuba, sendo este último, região de baixo padrão urbanístico e uma rede de esgotamento com baixa eficiência (SÃO PAULO, 2013). Na FIG.64 pode-se observar a ocupação da região do local de coleta G103-12 e a presença da tela submersa para a contenção de lixo.

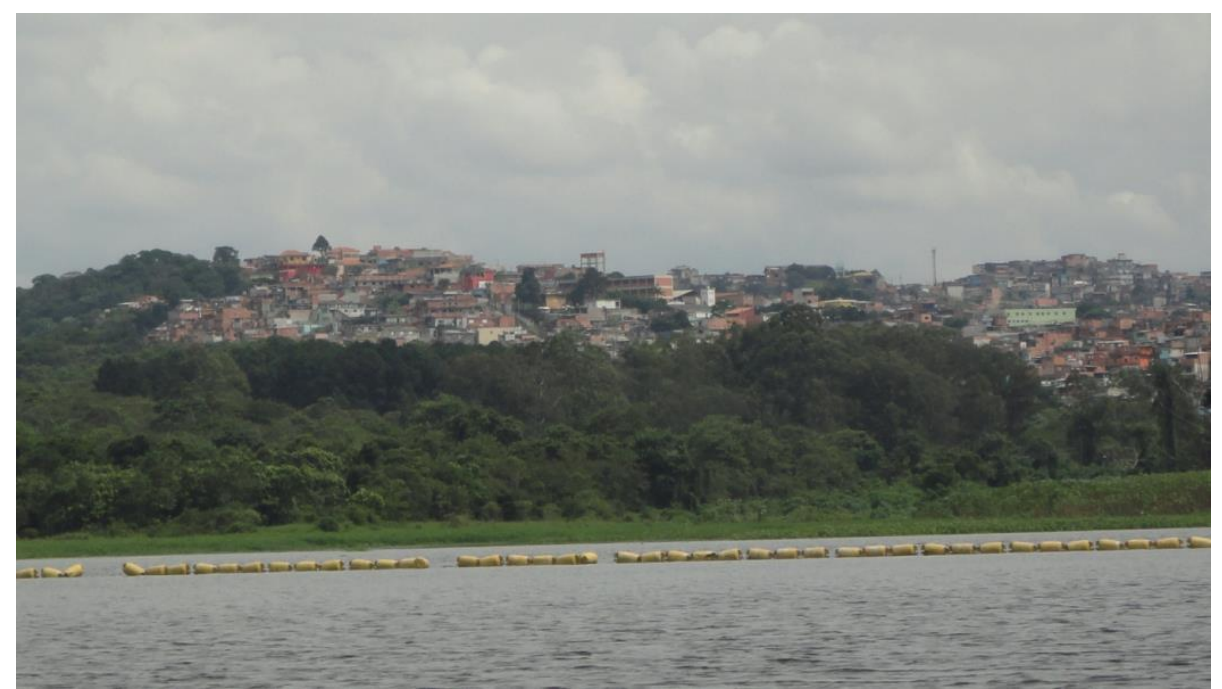

FIGURA 64. Imagem fotográfica da região de coleta G103-12 mostrando a ocupação e a rede de contenção de lixo (Foto de Shihomatsu, H. M. em 4/abril/2013).

GU107-06 foi o local com as concentrações mais elevadas para benzoilecgonina (104 $\mathrm{ng} \mathrm{L}^{-1}$ ) e clortalidona (36 $\left.\mathrm{ng} \mathrm{L}^{-1}\right)$, durante a coleta de agosto/2011 Esta é uma área que recebe o aporte das águas do rio Parelheiros e ribeirão Itaim, caracterizado por área de uso misto, com núcleos urbanos circundados por áreas de chácaras de lazer, atividades agrícolas e remanescentes de vegetação natural (FIG. 65A). Provavelmente, o maior aporte de contaminantes dessa área é proveniente da transferência das águas da Represa Billings para as águas da Represa Guarapiranga por meio do braço Taquacetuba. Atualmente a Represa Billings se encontra altamente impactada pela falta de saneamento básico na região e por influência das águas do Rio Pinheiros (ALMEIDA \& WEBER, 2005; WHATELY \& CUNHA, 2006). 


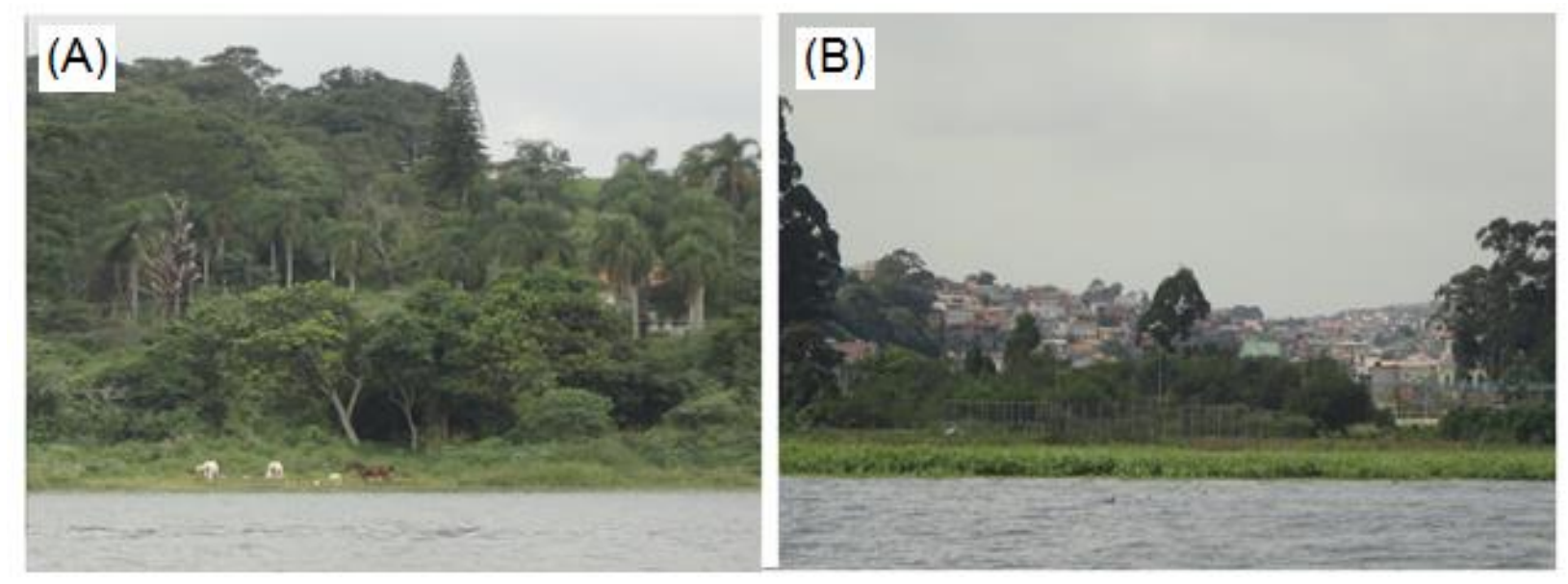

FIGURA 65. Imagem fotográfica da região de coleta GU107-06 (A) e GU108-07 (B) (Foto de Shihomatsu, H. M. em 4/abril/2013).

GU108-07 foi o local com as concentrações mais elevadas para acetaminofeno (108 $\left.\mathrm{ng} \mathrm{L}^{-1}\right)$ e losartana $\left(26,9 \mathrm{ng} \mathrm{L}^{-1}\right)$ durante a coleta de abr./2013. Esta é também uma área densamente urbanizada, com diferentes padrões urbanísticos e parcialmente provida de sistema de coleta e exportação de esgoto (SÃO PAULO, 2013) (FIG. 65B).

As concentrações mais elevadas encontradas nos locais de amostragem GU107-06 e GU108-07 podem também estar relacionadas com o baixo volume de água (profundidade) nesses locais em relação aos demais locais de amostragem (TAB. 16)

Em GU000-01 e GU000-02 foram obtidas as concentrações mais elevadas para acetaminofeno durante a coleta de agosto/2011 (254 ng L-1). GU000-01 recebe o aporte das águas do Rio Embu-Guaçu, o maior dos tributários, que drena uma área de $272 \mathrm{~km}^{2}$ abrangendo o município de Embu-Guaçu, o extremo sul dos municípios de São Paulo e Itapecerica da Serra, além de uma pequena parcela de Juquitiba e São Lourenço da Serra, com usos variados como áreas urbanas consolidadas e em expansão, chácaras de lazer, agrícolas e preservadas (SÃO PAULO, 2013). GU000-02 recebe as águas do córrego Mombaça. A FIG. 66 mostra uma região mais preservada 
e de ocupação na região de coleta GU000-01 (A) e GU000-02 (B), respectivamente, e a proliferação de algas devido à presença de matéria orgânica. Nesses locais, as maiores concentrações foram obtidas apenas para acetaminofeno, enquanto para outras substâncias esta foi a área de menor concentração.
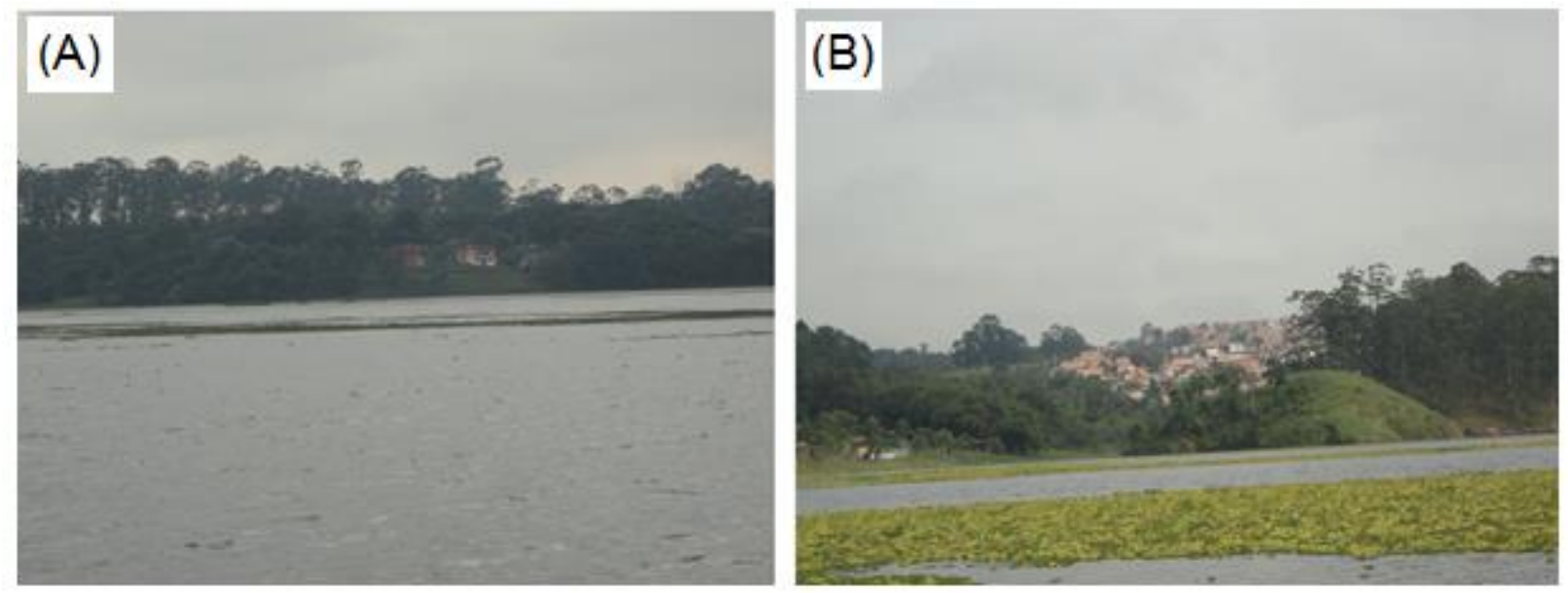

FIGURA 66. Imagem fotográfica da região de coleta GU100-01 (A) e GU100-02 (B) (Foto de Shihomatsu, H. M. em 4/abril/2013).

Ao considerarmos todos os resultados obtidos para acetaminofeno, atenolol, cocaína, cafeína, carbamazepina, clortalidona e benzoilecgonina nas 3 (três) campanhas de amostragens, o dendograma dessas concentrações (FIG. 67) mostra que GU103-12 e GU105-10 são os locais que apresentaram maior interferência de águas residuais. 


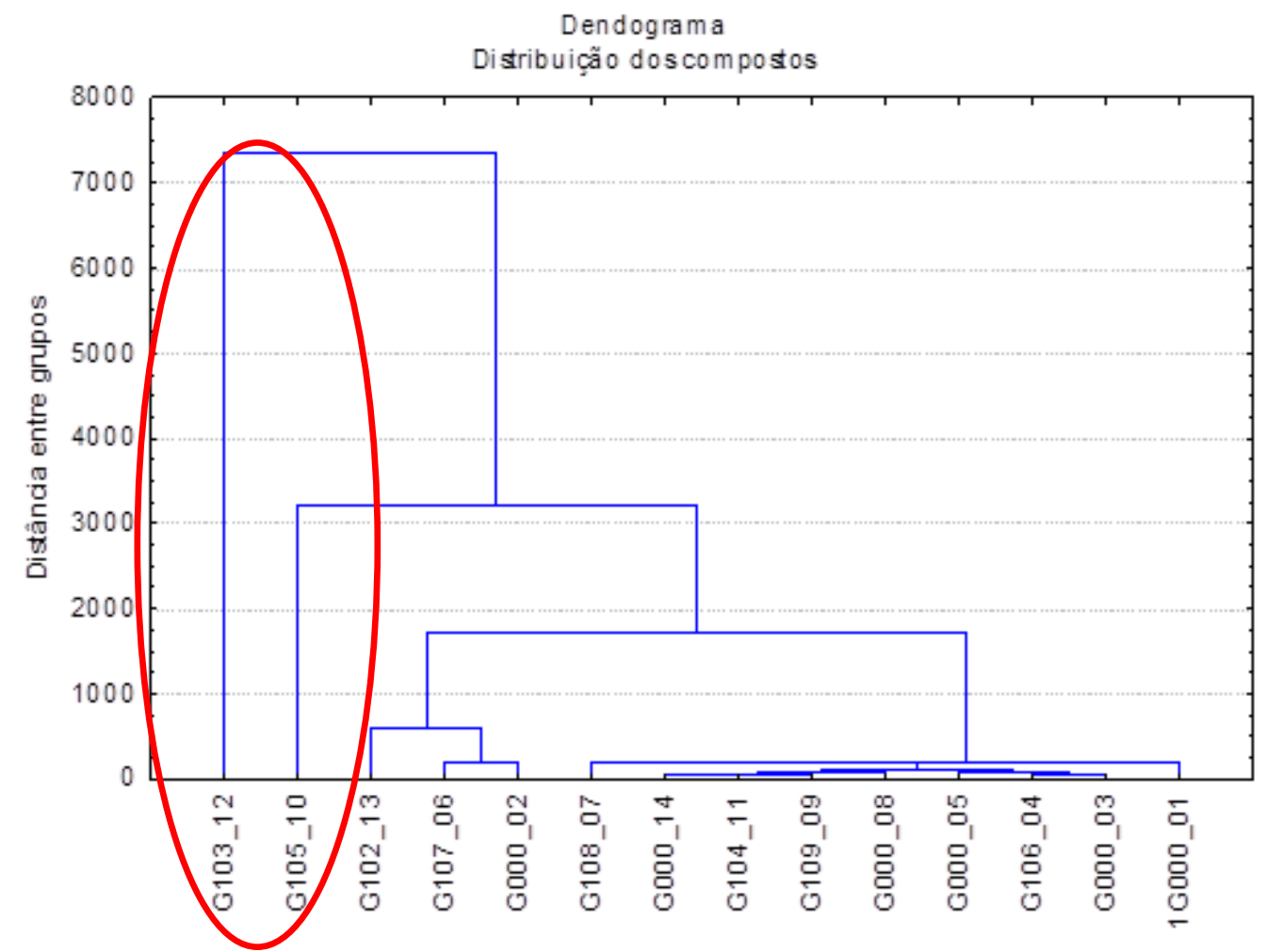

FIGURA 67. Dendograma da distribuição do acetaminofeno, atenolol, cocaína, cafeína, carbamazepina, clortalidona e benzoilecgonina nas águas da represa Guarapiranga coletadas em ago./2011, set./2012 e abr./2013.

O GU00014 é o local de amostragem mais próximo do local de capitação de água da ETA-ABV. Em GU00-14, as concentrações de acetaminofeno atenolol, benzoilecgonina, cafeína, cocaína, losartana e valsartana foram menores, apesar da proximidade com o local GU103-12, onde foram detectadas as concentrações mais elevadas desses compostos. As concentrações menores detectadas em GU000-14 provavelmente foram devido ao importante fator de diluição, comprovado pelo maior volume de água (profundidade) desse local (TAB 16).

\subsubsection{Avaliação de risco integrado (IRICAP) nas águas da Represa Guarapiranga}

Os homens assim como os organismos vivos de um ambiente aquático estão constantemente expostos a uma mistura de contaminantes químicos orgânicos e 
não a uma só substância. Assim, para avaliar o risco da exposição combinada de um conjunto de poluentes orgânicos associados usamos o índice de risco integrado de poluição química aquática ("Integrated Risk Index of Chemical Aquatic Pollution IRICAP") desenvolvido por FÀBREGA et al. (2013). Esse índice considera as propriedades de persistência, bioacumulação e toxicidade, assim como as concentrações de todos os compostos. Na TAB.42 são apresentados os IRICAP para cada local de coleta realizada em ago./2011, set./2012 e abr./2013 e, os detalhes do cálculo se encontram no Apêndice D.

TABELA 42. Índice integrado de risco de poluição química aquática (IRICAP) nos locais de coletas das amostragens de ago./2011, set./2012 e abr./2013.

\begin{tabular}{lccc}
\hline \multirow{2}{*}{ Local de coleta } & \multicolumn{3}{c}{ IRICAP } \\
\cline { 2 - 4 } & ago/2011 & set/2012 & abr/2013 \\
\hline G000_01 & 0,742 & 0,173 & 0,071 \\
G000_02 & 0,452 & 0,208 & 0,001 \\
G000_03 & 0,205 & 0,183 & 0,043 \\
G106_04 & 0,347 & 0,473 & 0,042 \\
G000_05 & 0,598 & 0,341 & 0,408 \\
G107_06 & 1,381 & 0,674 & 0,667 \\
G108_07 & 0,847 & 1,115 & 1,364 \\
G000_08 & 0,850 & 0,604 & 0,691 \\
G109_09 & 0,697 & 0,686 & 0,556 \\
G105_10 & 1,816 & 0,644 & 0,848 \\
G104_11 & 0,922 & 0,698 & 0,628 \\
G103_12 & 1,756 & 2,118 & 1,851 \\
G102_13 & 1,341 & 0,833 & 0,739 \\
G000_14 & 1,006 & 0,931 & 1,174 \\
\hline
\end{tabular}

Na FIG. 68 pode-se observar que o IRICAP é mais significativo a partir do GU106-06 até GU000-14 com destaque para G103-12. 


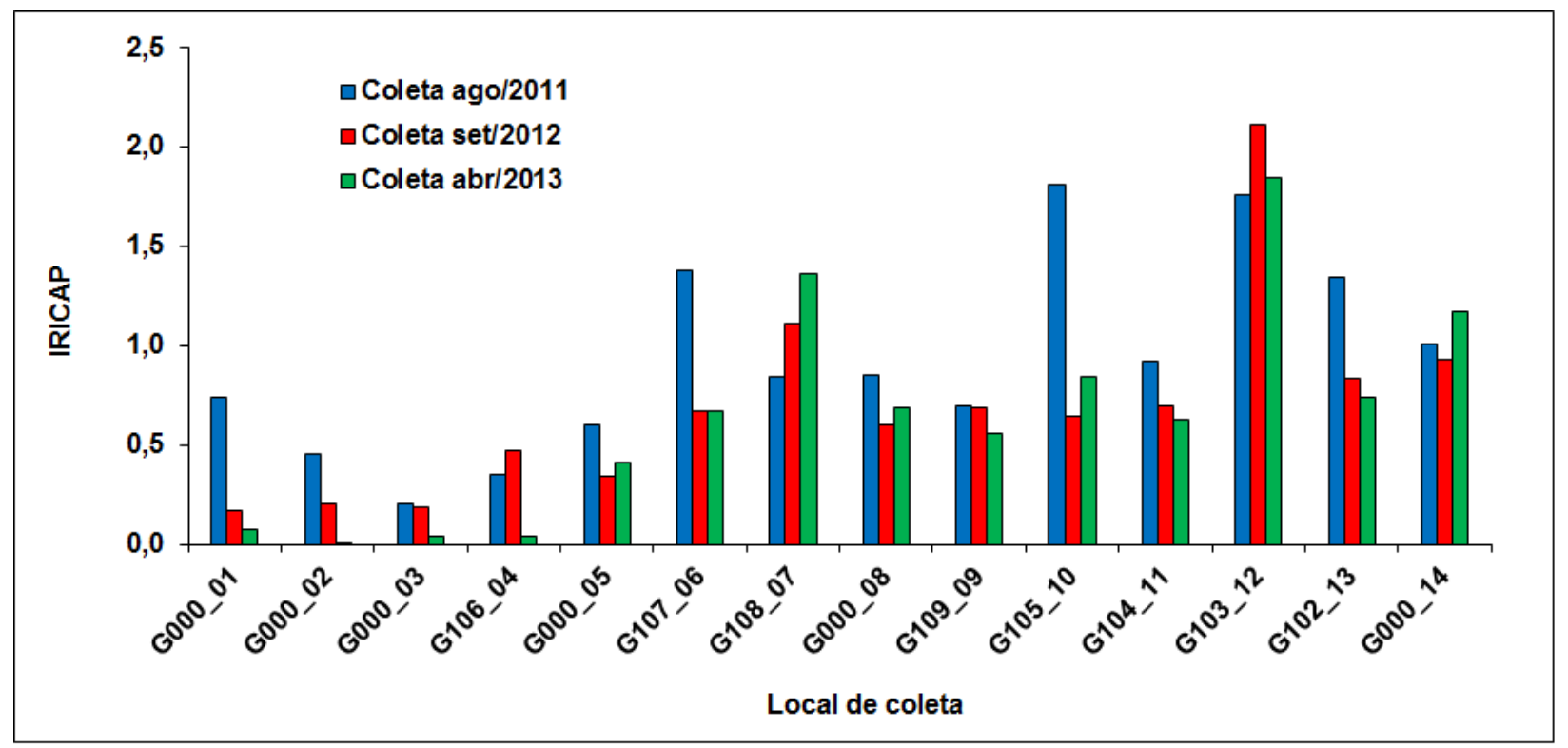

FIGURA 68. Índice de riscos integrado da poluição química aquática ao longo da represa Guarapiranga durante as coletas de ago./2011, set./2012 e abr./2013.

As concentrações obtidas para os compostos monitorados em GU000-14 (captação da ETA) foram menores do em GU103-12, que não significa a ausência desses compostos na água potável. Segundo STACKELBERG et al. (2007), a taxa de remoção em uma ETA convencional (clarificação/filtração/cloração) é de $98 \%$, 88\% e $85 \%$ para o acetaminofeno, cafeína e carbamazepina, respectivamente.

No estudo de avaliação de risco à saúde humana, GIBS et al. (2007)(citado em MOMPELAT (2009) mostraram que acetaminofeno $\left(5 \mu \mathrm{g} \mathrm{L}^{-1}\right)$ adicionado na água de consumo com cloro livre $\left(1,2 \mathrm{mg} \mathrm{L}^{-1}\right)$ reage totalmente em apenas 1 (um) dia, enquanto que os compostos mais persistentes como a cafeína e a carbamazepina eram detectados mesmo após 10 dias, que é o tempo de residência em uma ETA convencional. Esses compostos estão entre os de maior frequência de detecção nesse estudo.

Produtos farmacêuticos como a carbamazepina (2 $\mathrm{ng} \mathrm{L} \mathrm{L}^{-1}$ ), losartana (5 $\left.\mathrm{ng} \mathrm{L}^{-1}\right)$ e valsartana (13 $\left.\mathrm{ng} \mathrm{L}^{-1}\right)$ também foram detectados em água de consumo 
humano na Espanha (GROS, et al., 2012). Na França, TOGOLA \& BUDZINSKI (2008) encontraram cafeína, carbamazepina, diclofenaco e acetaminofeno, em água de consumo da região da cidade de Marseilles, na concentração máxima de $22,9 \mathrm{ng} \mathrm{L}^{-1}$, $43,2 \mathrm{ng} \mathrm{L}^{-1}, 2,5 \mathrm{ng} \mathrm{L}^{-1}$ e $210,1 \mathrm{ng} \mathrm{L}^{-1}$, respectivamente.

Assim, os poluentes emergentes como os produtos farmacêuticos constituem-se em uma fonte importante de preocupação por estarem presentes nos esgotos domésticos, que diferentemente dos efluentes industriais não apresentam uma concentração elevada de determinado composto, mas sim concentrações menores de diferentes compostos, o que torna o seu tratamento e entendimento ainda mais complexo. Tendo em vista a complexidade deste grupo de poluentes e o fato de a maioria dos compostos serem resistentes aos processos convencionais de tratamento, pesquisas que busquem tratamentos alternativos fazem-se extremamente necessárias. Uma alternativa a estes métodos convencionais que têm obtido bons resultados são os Processos Oxidativos Avançados (POA) (CLARA, et al., 2004; MELO, et al., 2009).

\subsection{Aplicação da metodologia nas águas das represas das UGRH 5 e 6 do Estado de São Paulo}

A metodologia SPE-LC-MS/MS foi também aplicada para determinar fármacos nas amostras de água das represas localizadas na URGHI 5: Atibainha (AT), Cachoeira (CA), Salto Grande (SG), Ribeirão do Pinhal (RP) e na URGHI 6: Paiva Castro (PC), Tanque Grande (TG) e Cabuçu (CA).

Os resultados obtidos são apresentados na TAB. 43 e se referem à média das concentrações de 3 (três) extrações das amostras por SPE acompanhadas do valor da incerteza expandida, calculada seguindo as orientações da EURACHEM (EURACHEM/CITAC, 2002; 2012) e considerando $\mathrm{k}=2$ e $90 \%$ de confiança. 
TABELA 43. Valores de fármacos em ng $\mathrm{L}^{-1}$ encontrados nas represas Cachoeira (CA), Paiva Castro (PC), Ribeirão do Pinhal (RP), Atibainha (AT), Salto Grande (SG), Cabuçu (CB) e Tanque Grande (TG).

\begin{tabular}{|c|c|c|c|c|c|c|c|c|c|c|c|}
\hline \multirow{3}{*}{ Composto } & \multicolumn{2}{|c|}{$\mathrm{CA}$} & \multicolumn{2}{|c|}{$\mathrm{PC}$} & \multirow{2}{*}{$\frac{\mathrm{RP}}{\mathrm{RP} 3}$} & \multicolumn{2}{|c|}{ AT } & \multicolumn{2}{|c|}{ SG } & \multirow{2}{*}{$\begin{array}{c}\mathrm{CB} \\
\mathrm{CB} 1\end{array}$} & \multirow{3}{*}{$\begin{array}{c}\mathrm{TG} \\
\mathrm{TG} 1 \\
\text { Conc. }\left(\mathrm{ng} \mathrm{L}^{-1}\right)\end{array}$} \\
\hline & CA 3 & CA 4 & PC 2 & PC 4 & & AT 3 & AT 6 & SG 1 & SG 3 & & \\
\hline & Conc. $\left(\mathrm{ng} \mathrm{L}^{-1}\right)$ & Conc. $\left(\mathrm{ng} \mathrm{L}^{-1}\right)$ & Conc. $\left(\mathrm{ng} \mathrm{L}^{-1}\right)$ & Conc. $\left(\mathrm{ng} \mathrm{L}^{-1}\right)$ & Conc. $\left(\mathrm{ng} \mathrm{L}^{-1}\right)$ & Conc. $\left(\mathrm{ng} \mathrm{L}^{-1}\right)$ & Conc. $\left(\mathrm{ng} \mathrm{L}^{-1}\right)$ & Conc. $\left(\mathrm{ng} \mathrm{L}^{-1}\right)$ & Conc. $\left(\mathrm{ng} \mathrm{L}^{-1}\right)$ & Conc. $\left(\mathrm{ng} \mathrm{L}^{-1}\right)$ & \\
\hline Acetaminofeno & $<\mathrm{LD}$ & $<\mathrm{LD}$ & $<L Q$ & $<\mathrm{LQ}$ & $<\mathrm{LD}$ & $<L Q$ & $<\mathrm{LD}$ & $<\mathrm{LQ}$ & $<L Q$ & $<\mathrm{LQ}$ & $<L Q$ \\
\hline Atenolol & $<L Q$ & $<\mathrm{LQ}$ & $9,9 \pm 10,5$ & $9,5 \pm 0,5$ & $<$ LDM & $<L Q$ & $<\mathrm{LD}$ & $133 \pm 6$ & $126 \pm 6$ & $<\mathrm{LD}$ & $<L D$ \\
\hline Benzoilecgonina & $<L D$ & $<\mathrm{LD}$ & $<L Q$ & $<\mathrm{LQ}$ & $<\mathrm{LD}$ & $<\mathrm{LD}$ & $<\mathrm{LD}$ & $23 \pm 1$ & $24,08 \pm 0,8$ & $<\mathrm{LD}$ & $<L Q$ \\
\hline Bromazepam & $<\mathrm{LD}$ & $<\mathrm{LD}$ & $<\mathrm{LD}$ & $<\mathrm{LD}$ & $<\mathrm{LD}$ & $<L D$ & $<\mathrm{LD}$ & $<L D$ & $<L D$ & $<\mathrm{LD}$ & $<L D$ \\
\hline Cafeína & $14 \pm 2$ & $13 \pm 2$ & $76 \pm 9$ & $54 \pm 6$ & $23 \pm 2$ & $12 \pm 2$ & $12 \pm 1$ & $24 \pm 2$ & $12 \pm 1$ & $16 \pm 1$ & $51 \pm 4$ \\
\hline Carbamazepina & $<\mathrm{LD}$ & $<\mathrm{LD}$ & $<L D$ & $<\mathrm{LD}$ & $<\mathrm{LD}$ & $<L D$ & $<\mathrm{LD}$ & $27 \pm 3$ & $29 \pm 4$ & $<\mathrm{LD}$ & $<L D$ \\
\hline Ciproterona & $<\mathrm{LD}$ & $<\mathrm{LD}$ & $<L D$ & $<\mathrm{LD}$ & $<\mathrm{LD}$ & $<\mathrm{LD}$ & $<\mathrm{LD}$ & $<\mathrm{LD}$ & $<\mathrm{LD}$ & $<\mathrm{LD}$ & $<\mathrm{LD}$ \\
\hline Citalopram & $<\mathrm{LD}$ & $<\mathrm{LD}$ & $<L D$ & $<\mathrm{LD}$ & $<\mathrm{LD}$ & $<\mathrm{LD}$ & $<\mathrm{LD}$ & $<L D$ & $<\mathrm{LD}$ & $<\mathrm{LD}$ & $<L D$ \\
\hline Clonazepam & $<\mathrm{LD}$ & $<\mathrm{LD}$ & $<L D$ & $<\mathrm{LD}$ & $<L Q$ & $<\mathrm{LQ}$ & $<\mathrm{LQ}$ & $<L Q$ & $<\mathrm{LQ}$ & $<\mathrm{LD}$ & $<L D$ \\
\hline Clopidogrel & $<\mathrm{LD}$ & $<\mathrm{LD}$ & $<L D$ & $<\mathrm{LD}$ & $<\mathrm{LD}$ & $<\mathrm{LD}$ & $<\mathrm{LD}$ & $<\mathrm{LQ}$ & $<\mathrm{LQ}$ & $<\mathrm{LD}$ & $<L D$ \\
\hline Clortalidona & $<\mathrm{LD}$ & $<\mathrm{LD}$ & $<L D$ & $<\mathrm{LD}$ & $<\mathrm{LD}$ & $<\mathrm{LD}$ & $<\mathrm{LD}$ & $29 \pm 4$ & $29 \pm 2$ & $<\mathrm{LD}$ & $<L D$ \\
\hline Cocaína & $14 \pm 1$ & $16 \pm 1$ & $22 \pm 2$ & $16 \pm 1$ & $<L Q$ & $<\mathrm{LQ}$ & $12 \pm 2$ & $21 \pm 3$ & $27 \pm 2$ & $<\mathrm{LQ}$ & $24 \pm 2$ \\
\hline Diclofenaco & $<\mathrm{LD}$ & $<\mathrm{LD}$ & $<L D$ & $<\mathrm{LD}$ & $<L D$ & $<\mathrm{LD}$ & $<\mathrm{LD}$ & $<L Q$ & $<\mathrm{LQ}$ & $<\mathrm{LD}$ & $<L D$ \\
\hline Enalapril & $<\mathrm{LD}$ & $<\mathrm{LD}$ & $<L D$ & $<\mathrm{LD}$ & $<\mathrm{LD}$ & $<\mathrm{LD}$ & $<\mathrm{LD}$ & $<L D$ & $<\mathrm{LD}$ & $<\mathrm{LD}$ & $<L D$ \\
\hline Loratadina & $<\mathrm{LD}$ & $<\mathrm{LD}$ & $<L D$ & $<\mathrm{LD}$ & $<\mathrm{LD}$ & $<\mathrm{LD}$ & $<\mathrm{LD}$ & $<L D$ & $<\mathrm{LD}$ & $<\mathrm{LD}$ & $<L D$ \\
\hline Losartana & $<L Q$ & $<\mathrm{LQ}$ & $<\mathrm{LQ}$ & $<\mathrm{LQ}$ & $<\mathrm{LD}$ & $<\mathrm{LD}$ & $<\mathrm{LQ}$ & $180 \pm 48$ & $222 \pm 59$ & $<\mathrm{LD}$ & $<L D$ \\
\hline Midazolam & $<\mathrm{LD}$ & $<\mathrm{LD}$ & $<L D$ & $<\mathrm{LD}$ & $<\mathrm{LD}$ & $<L D$ & $<\mathrm{LD}$ & $<L D$ & $<L D$ & $<\mathrm{LD}$ & $<L D$ \\
\hline Orfenadrina & $<\mathrm{LD}$ & $<\mathrm{LD}$ & $<L D$ & $<\mathrm{LD}$ & $<\mathrm{LD}$ & $<\mathrm{LD}$ & $<\mathrm{LD}$ & $<L Q$ & $<L Q$ & $<\mathrm{LD}$ & $<L D$ \\
\hline Paroxetina & $<\mathrm{LD}$ & $<\mathrm{LD}$ & $<L D$ & $<\mathrm{LD}$ & $<\mathrm{LD}$ & $<\mathrm{LD}$ & $<\mathrm{LD}$ & $<L D$ & $<\mathrm{LD}$ & $<L D$ & $<L D$ \\
\hline Propranolol & $<\mathrm{LD}$ & $<\mathrm{LD}$ & $<L D$ & $<\mathrm{LD}$ & $<\mathrm{LD}$ & $<\mathrm{LD}$ & $<\mathrm{LD}$ & $<\mathrm{LQ}$ & $<L Q$ & $<\mathrm{LD}$ & $<L D$ \\
\hline Rosuvastatina & $<L D$ & $<\mathrm{LD}$ & $<L D$ & $<\mathrm{LD}$ & $<L D$ & $<L D$ & $<\mathrm{LD}$ & $<\mathrm{LD}$ & $<L D$ & $<\mathrm{LD}$ & $<L D$ \\
\hline Sildenafil & $<\mathrm{LD}$ & $<\mathrm{LD}$ & $<\mathrm{LD}$ & $<\mathrm{LD}$ & $<\mathrm{LD}$ & $<\mathrm{LD}$ & $<\mathrm{LD}$ & $<\mathrm{LD}$ & $<L D$ & $<\mathrm{LD}$ & $<L D$ \\
\hline Valsartana & $<L D$ & $<\mathrm{LD}$ & $<L D$ & $<L D$ & $<L D$ & $<L D$ & $<L D$ & $96 \pm 5$ & $66 \pm 4$ & $<\mathrm{LD}$ & $<L D$ \\
\hline
\end{tabular}

$\mathrm{LDM}=$ Limite de Detecção do Método

LQM = Limite de Quantificação do Método

$\mathrm{K}=2$ e $90 \%$ de confiança 
Os compostos detectados nessas represas foram: atenolol, benzoilecgonina, cafeína, carbamazepina, cocaína, losartana e valsartana. Acetaminofeno, diclofenaco, orfenadrina, propranolol, enalapril, paroxetina, citalopram, bromazepam, midazolam, clopidogrel, rosuvastatina, clonazepam, loratadina, ciproterona e sildenafila foram detectados abaixo do LD ou entre o LD e LQ nessas amostras.

Os resultados mostram que essas represas estão mais preservados que a represa Guarapiranga. A detecção de menor número de compostos e em concentrações mais baixas indica uma contribuição menor da descarga de aguas residuais e, consequentemente, melhor qualidade de água das represas.

A ocorrência dos fármacos quantificados nas represas acima relatadas está apresentada na FIG. 69.

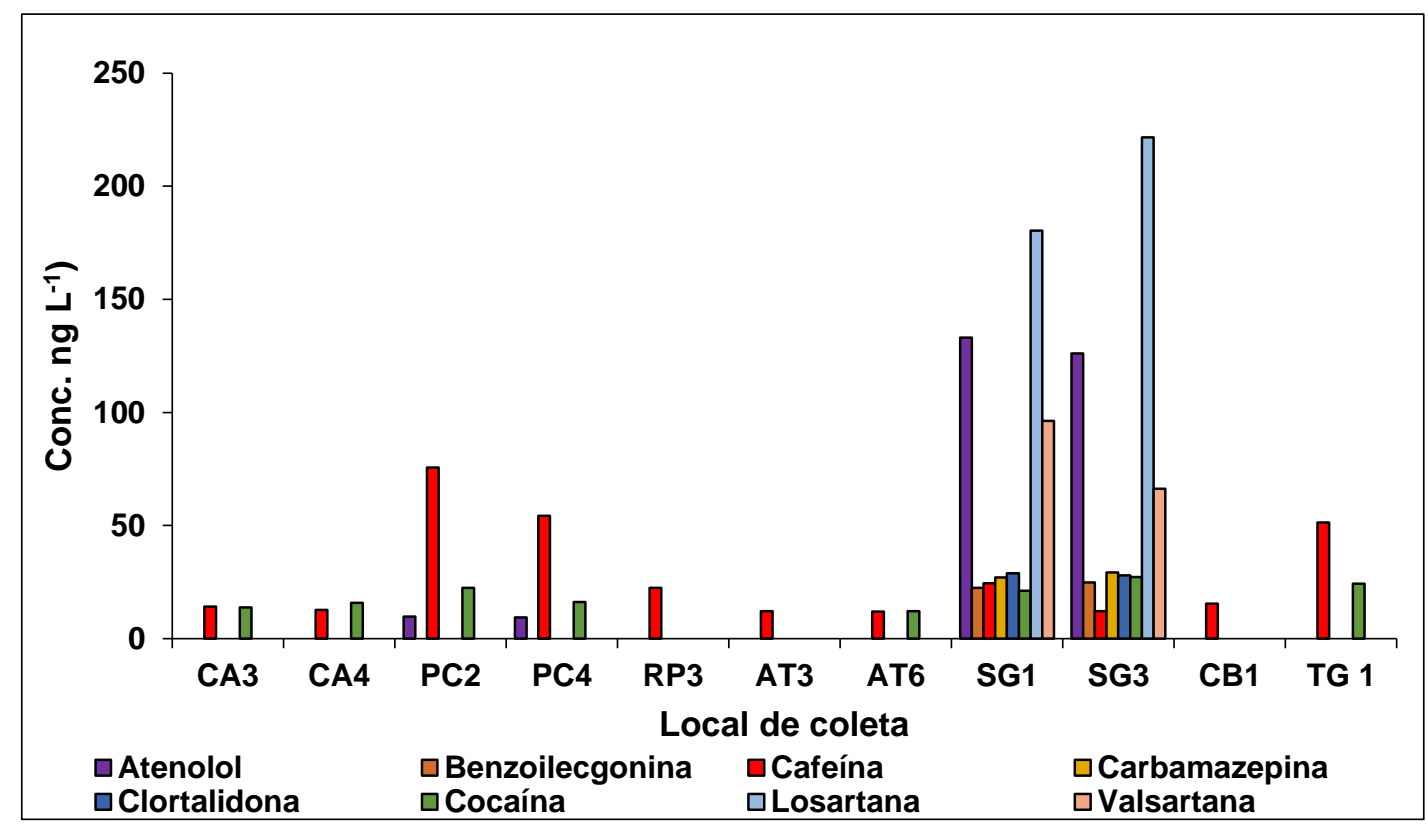

FIGURA 69. Ocorrência de atenolol, benzoilecgonina, cafeína, carbamazepina, clortalidona, cocaína, losartana e valsartana nas águas das represas: Cachoeira (CA), Paiva Castro (PC), Ribeirão do Pinhal (RP), Atibainha (AT), Salto Grande (SG), Cabuçu (CB) e Tanque Grande (TG).

A cafeína esteve presente em todas as represas, sendo que as concentrações mais elevadas foram detectadas na represa Paiva Castro nos pontos de coleta PC2 (76 ng L-1) e PC4 (54 ng L-1). Apesar da cafeína ser um 
indicador de influência antropogênica, na Represa Paiva Castro foram detectadas, além da cafeína apenas a cocaína (22 e $16 \mathrm{ng} \mathrm{L}^{-1}$ ) e o atenolol (9,9 e 9,5 ng L¹).

Um maior número de fármacos foi detectado na Represa de Salto Grande nos pontos SG1 e SG2. Os compostos determinados foram atenolol (133 e $126 \mathrm{ng} \mathrm{L}^{-1}$ ), cafeína (24 e $12 \mathrm{ng} \mathrm{L}^{-1}$ ) carbamazepina (27 e $29 \mathrm{ng} \mathrm{L}^{-1}$ ), clortalidona (29 e $28 \mathrm{ng} \mathrm{L}^{-1}$ ), losartana (180 e $222 \mathrm{ng} \mathrm{L}^{-1}$ ), valsartana (96 e $66 \mathrm{ng} \mathrm{L}^{-1}$ ), cocaína (21 e $27 \mathrm{ng} \mathrm{L}^{-1}$ ) e benzoilecgonina ( 23 e $24,8 \mathrm{ng} \mathrm{L}^{-1}$ ).

Nas amostras de água das represas Cachoeira, Tanque Grande e Atibainha foram detectadas além da cafeína, a cocaína com concentração de $14 \mathrm{ng} \mathrm{L}^{-1}, 16 \mathrm{ng} \mathrm{L}^{-1}, 24 \mathrm{ng} \mathrm{L}^{-1}$ e $12 \mathrm{ng} \mathrm{L}^{-1}$ nos pontos de coleta denominados de CA3, CA4, TG e AT6, respectivamente.

As represas com a presença somente da cafeína foram a Ribeirão do Pinhal em RP3 (23 ng L-1), Atibainha em AT3 (12 ng L-1) e Cabuçu (16 ng L L $)$.

Esses resultados mostram que as águas da Represa de Salto Grande se encontram mais impactadas pela presença dos compostos de interesse, em comparação com as outras represas estudadas. A ocorrência em concentrações mais elevadas dos compostos em estudo é decorrente do reservatório de Salto Grande estar inserido no município de Americana (IRRIGART, 2006), e apesar de ser ocupada predominantemente por uso agrícola na margem direita, na margem esquerda prevalece uma ocupação urbana com chácaras, casas de veraneio, condomínios de alto padrão e bairros de classe média baixa (FIG. 70). 


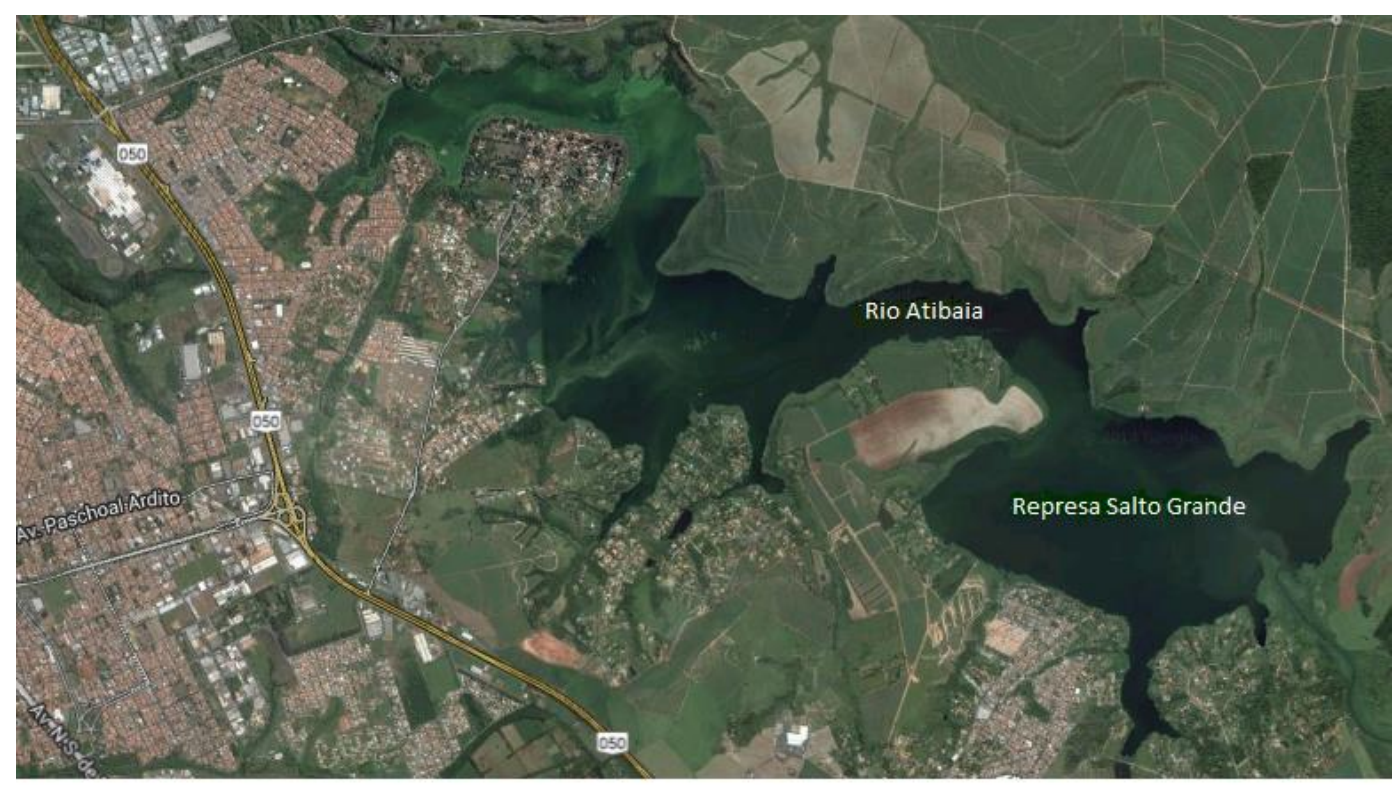

FIGURA 70. Reservatório de Salto Grande com ocupação predominantemente urbana na margem esquerda e agrícola na margem direita. (https://www.google.com.br/maps/@-22.7290256,-47.2911566,8873m/data=!3m1!1e3?hl=pt$\mathrm{BR})$, visualizado em jan.2015. 


\section{CONCLUSÃO}

O método de SPE desenvolvido e otimizado permitiu a extração dos 23 compostos em uma única etapa sem a necessidade de ajuste de $\mathrm{pH}$.

O método cromatográfico desenvolvido para o modo de ionização ESI(+) e ESI(-) permitiu que a quantificação, por LC-MS/MS, de 22 compostos fosse realizada em pouco tempo de análise (8 minutos).

O desenvolvimento da metodologia de SPE-LC-MS/MS proposta, mostrou-se, com base no processo de validação, adequado para a determinação simultânea de 21 (vinte e um) fármacos, 1 (uma) droga de abuso e seu principal metabólito em amostras de águas superficiais, na faixa de concentração de ng $\mathrm{L}^{-1}$.

O processo de validação demonstrou que a metodologia é linear na faixa de trabalho proposta, ou seja, a área obtida foi diretamente proporcional à concentração do composto, e com variação dentro do intervalo estatisticamente aceitável.

A seletividade, sensibilidade e a robustez da metodologia conferiram $L D$ e $L Q$ na faixa de $n g L^{-1}$, com precisão e exatidão dentro do intervalo satisfatório para todos os compostos estudados.

Os valores de recuperação obtidos em 3 (três) níveis de concentração, para os compostos estudados, situam-se dentro da faixa recomendada pela literatura, exceto para acetaminofeno e paroxetina, cujos valores ficaram abaixo dos recomendados.

A estimativa de incerteza das medições obtidas pela metodologia proposta foi estimada no intervalo de 3 a $12 \%$, destacando que as fontes de incerteza mais influentes são as associadas às curvas analíticas e à recuperação do método. 
A metodologia proposta demonstrou ser uma ferramenta importante para a verificação de ocorrência de fármacos em ambientes aquáticos. A ferramenta permitiu quantificar 11 compostos (acetaminofeno, atenolol, benzoilegonina, cafeína, carbamazepina, cocaína, clortalidona, diclofenaco, enalapril, losartana e valsartana) e verificar que a represa Guarapiranga apresenta alterações na qualidade da água e, que esta qualidade está diretamente relacionada com o uso e ocupação do solo.

As concentrações de carbamazepina, valsartana e diclofenaco determinadas, neste trabalho, estão acima das concentrações detectadas nas águas de reservatório relatadas na literatura, mas estão, como os outros compostos, dentro da faixa de concentração encontrada por pesquisadores de vários países em águas superficiais (rios).

Este trabalho forneceu também dados de losartana, valsartana, clortalidona e orfenadrina, que são escassos ou inexistem na literatura. Todos esses compostos foram quantificados, com exceção da orfenadrina, que foi detectada abaixo do LQ.

Os níveis de concentração dos compostos quantificados destacam a região do ponto de coleta GU103-12 e GU105-10 com os níveis mais elevados, seguido das regiões dos pontos GU107-06 e GU108-07. Os níveis de concentração foram menores para a região entre os pontos de coleta GU0001 a GU000-5.

O IRICAP ("Integrated Risk Index of Chemical Aquatic Pollution") indica que na represa Guarapiranga o risco integrado de exposição à mistura dos compostos detectados é mais significativo na área dos pontos de coleta GU107-06 a GU000-14 com destaque para o ponto GU103-12.

A verificação de ocorrência realizada nas aguas das represas de Paiva Castro, Ribeirão do Pinhal, Salto Grande, Atibainha, Cachoeira, Tanque Grande e Cabuçu, referente à presença dos 23 (vinte e três) compostos mostrou que as 
águas da represa do Salto Grande são mais impactadas do que as outras represas, porém menos impactada que a represa Guarapiranga.

A metodologia contribuiu na formação de um primeiro banco de dados de contaminantes emergente orgânicos presentes em águas de reservatórios.

Os resultados deste estudo apresentaram evidencias de que a qualidade das águas de reservatório está sendo influenciada significativamente pela atividade urbana ao seu redor. Uma contribuição a ser destacada é a liberação irregular de águas residuais nas águas de reservatórios, confirmada pela presença de fármacos, cada vez mais frequente nessas águas. 


\section{CONSIDERAÇÕES GERAIS}

Espera-se que os dados obtidos, nesta pesquisa, possam auxiliar no desenvolvimento de políticas públicas, mostrando a necessidade de:

- Fiscalizar o uso e ocupação do solo e o descarte irregular de resíduos e de esgoto doméstico no entorno das bacias;

- Melhorar o sistema de coleta e tratamento de esgoto e evitar a liberação direta de esgoto nas águas de represas e rios, principalmente em reservatórios urbanos destinados ao abastecimento público; e

- Dar subsídios aos órgãos governamentais para oferecer incentivos aos estudos relacionados com a melhoria nos procedimentos de tratamento atualmente adotado nas ETEs e reavaliar a legislação vigente.

Como sugestão de trabalho futuro recomenda-se:

- Aplicação da metodologia desenvolvida e otimizada no efluente e afluente de Estações de Tratamento de Esgoto do Brasil para avaliar a taxa de remoção dos compostos estudados.

- Diagnóstico das águas de distribuição quanto à presença dos fármacos estudados.

- Estudar um método cromatográfico para monitorar outros compostos não incluídos nesse trabalho. 


\section{APÊNDICE A}

Na FIG. A1 é apresentado o cromatograma do acetaminofeno, na solução padrão $\left(1 \mu \mathrm{g} \mathrm{mL}^{-1}\right)$, no modo de análise MS para identificação do íon precursor (a) e MS/MS para seleção dos 2 (dois) íons produtos mais intensos, com fluxo contínuo de $10 \mu \mathrm{L} \mathrm{min}{ }^{-1}$ (b) e na solução calibração com matriz (P4) no modo de análise MRM para quantificação do acetaminofeno (c). Apresenta-se também o espectro de massas confirmando os 2 (dois) íons produto mais intensos (d).

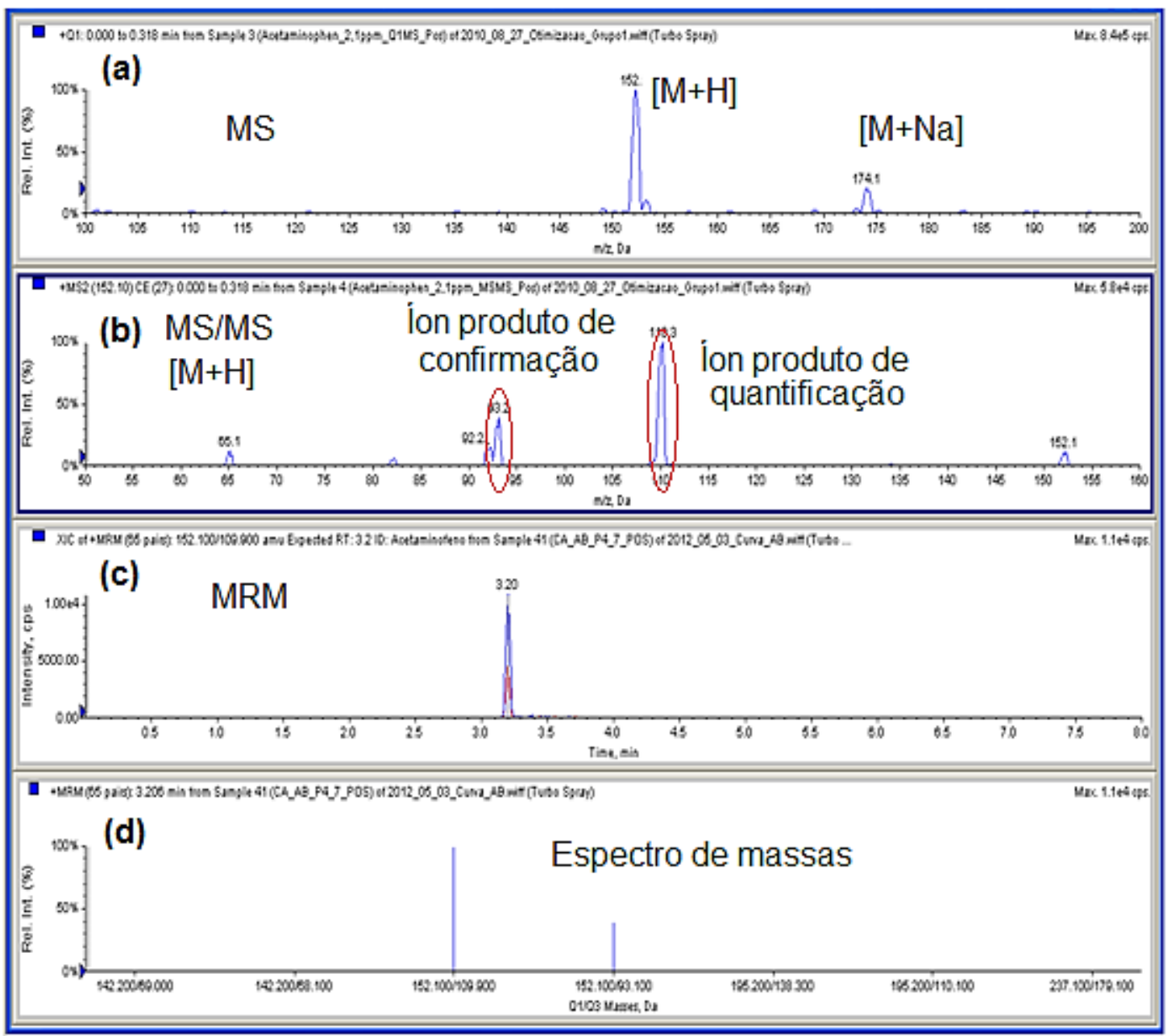

FIGURA A 1. Cromatogramas do acetaminofeno no modo de análise MS (a), dos íons produtos do acetaminofeno mais intensos no modo de análise MS/MS (b) e no modo de análise MRM (c) e o espectro de massas dos íons produto mais intensos (d). 
Na FIG. A2 observam-se os cromatogramas com o tempo de retenção dos compostos de interesse na solução de calibração com matriz (P3) no modo de análise $\mathrm{ESI}(+)-\mathrm{MRM}$.

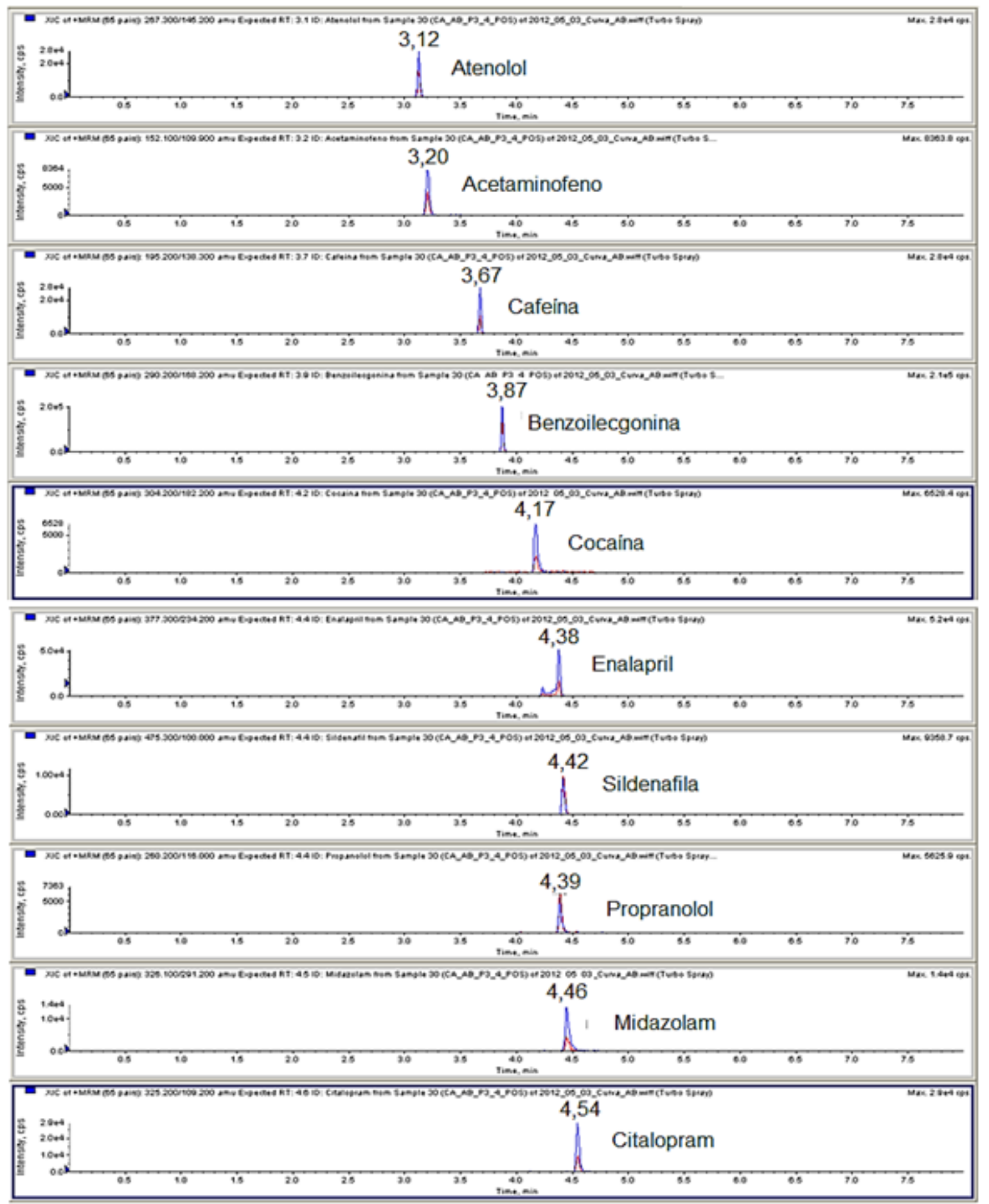

FIGURA A 2. Cromatogramas dos compostos de interesse na solução de calibração com matriz (P3) no modo de análise ESI(+)-MRM. 


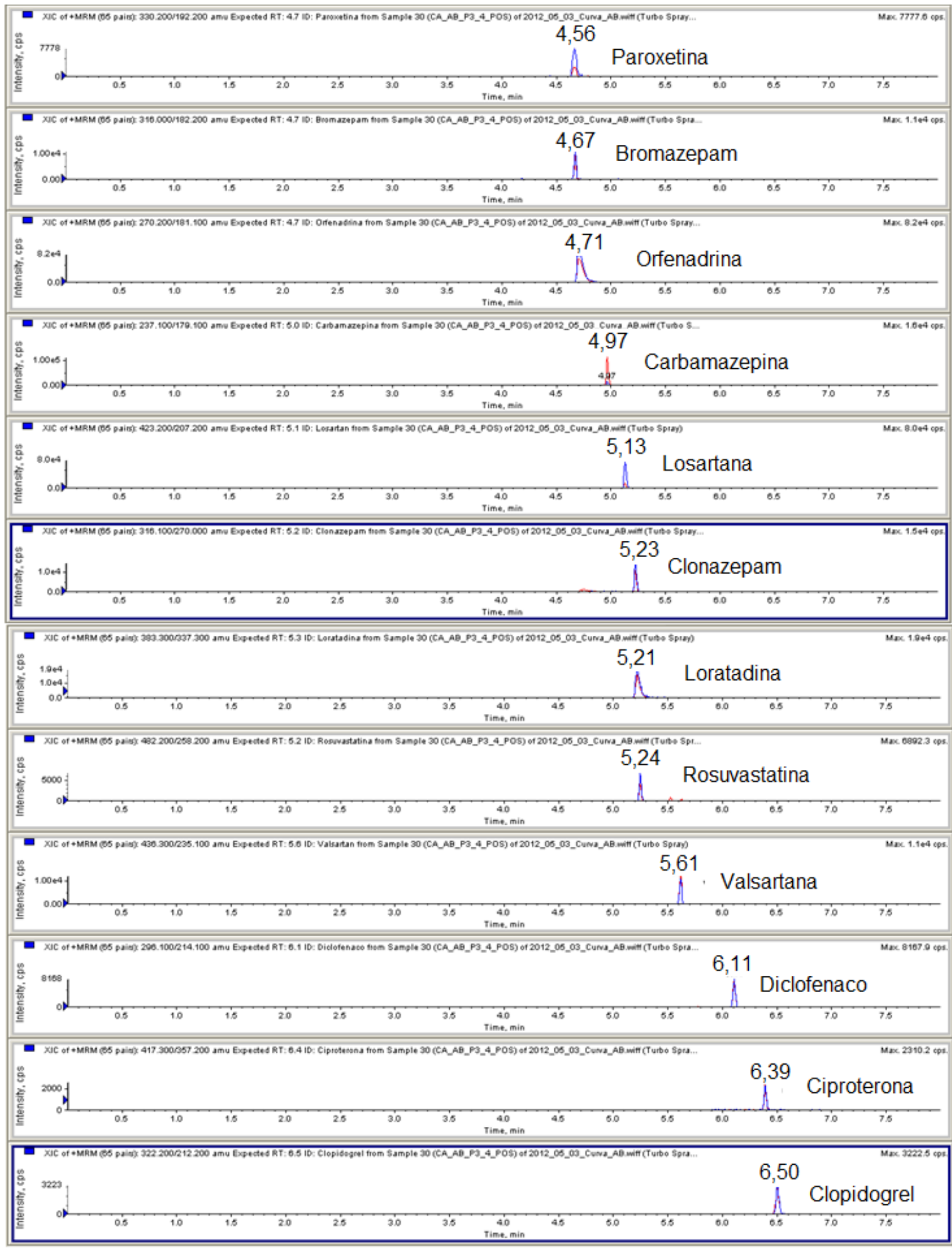

Continuação da FIGURA A2. Cromatogramas dos compostos de interesse na solução de calibração com matriz (P3) no modo de análise $\mathrm{ESI}(+)$ MRM. 
Na FIG. A3 é apresentado o cromatograma com o tempo de retenção da clortalidona na solução de calibração com matriz (P3) no modo de análise ESI(+)-MRM.

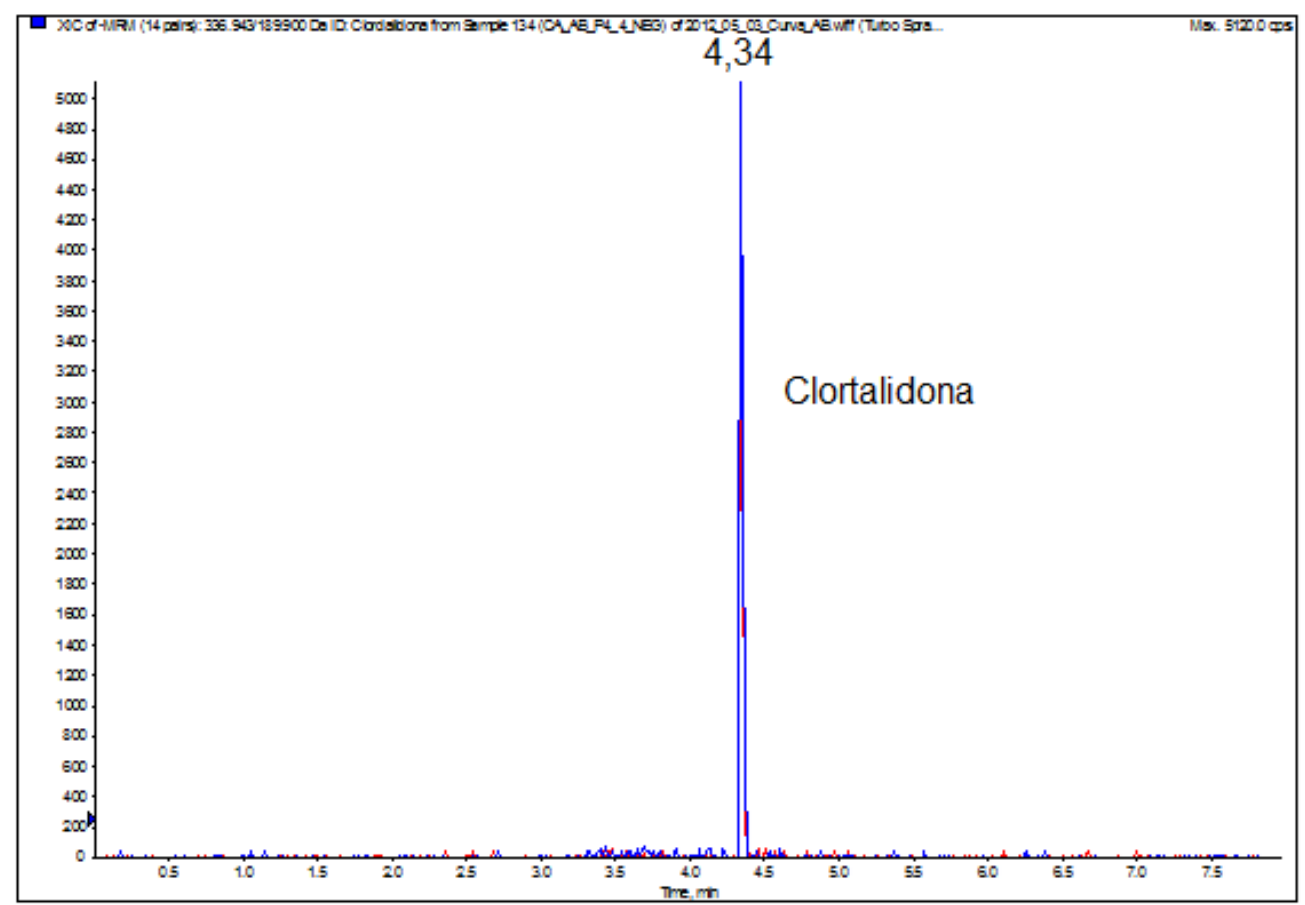

FIGURA A3. Cromatograma da clortalidona na solução de calibração com matriz (P3) no modo de análise ESI(-)-MRM

Na FIG. A4 são apresentados os cromatogramas dos 2 (dois) íons produtos mais intensos da cocaína na solução de calibração com matriz (P4) e na amostra GU103-12, com as respectivas razão de intensidade.

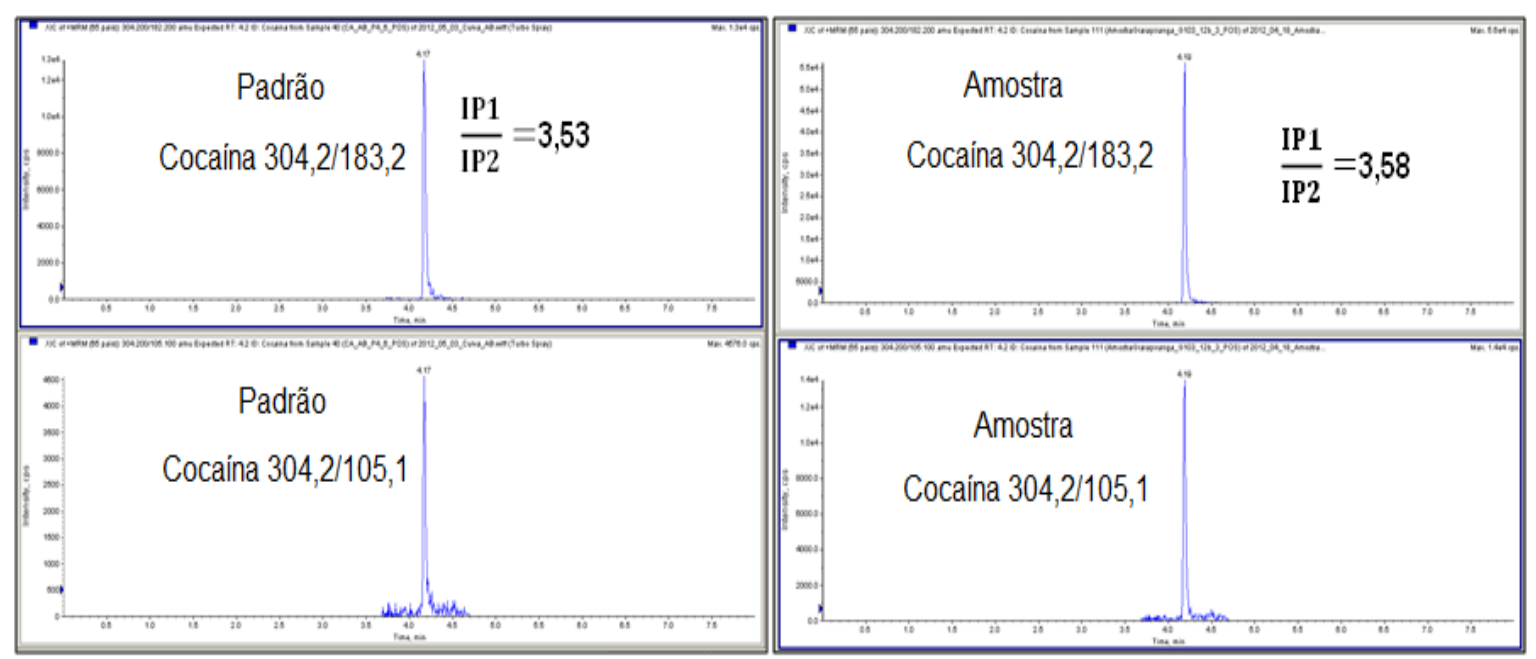

FIGURA A4. Cromatogramas dos íons produtos da cocaína na solução de calibração com matriz e na amostra com as respectivas razões de intensidade. 


\section{APÊNDICE B}

Cálculo da estimativa da incerteza para os compostos quantificados.

\section{B1. Incerteza da preparação da solução estoque individual de padrão}

\section{B1.1.Padrão Sólido}

Grandezas de entrada: Massa e pureza do padrão e volume final da solução estoque. Individual do padrão.

$\mathrm{Na}$ TAB. B1 são apresentados os componentes das incertezas $u$ (mpadrão) e $\mathrm{u}\left(\mathrm{V}_{\text {Sol.Estoq. }}\right)$, a incerteza combinada da solução estoque $\left(\mathrm{u}\left(\mathrm{C}_{\text {sol.Estog. }}\right)\right)$ calculados pelas Eq. 18, 19 e 17, respectivamente, assim como a respectiva concentração da solução estoque.

TABELA B1. Incerteza combinada da solução estoque com seus respectivos componentes de incertezas e a concentração da solução estoque para acetaminofeno, atenolol, cafeína, carbamazepina, clortalidona, diclofenaco, enalapril, losartana e valsartana.

\begin{tabular}{lccccc}
\hline \multirow{2}{*}{ Composto } & \multirow{2}{*}{$\mathrm{u}(\mathrm{P})$} & $\mathrm{u}\left(\mathrm{m}_{\text {Padrão }}\right)$ & $\mathrm{u}\left(\mathrm{V}_{\text {sol.Estoq. }}\right)$ & $\mathrm{u}\left(\mathrm{C}_{\text {sol.Estoq. }}\right)$ & $\mathrm{C}_{\text {sol.Estoq. }}$ \\
\cline { 3 - 6 } & & $\mathrm{mg}$ & $\mathrm{mL}$ & $\mathrm{mg} \mathrm{mL}^{-1}$ & $\mathrm{mg} \mathrm{mL}^{-1}$ \\
\hline Acetaminofeno & $1,5 \mathrm{E}-03$ & $8,1 \mathrm{E}-05$ & $2,2 \mathrm{E}-04$ & $1,5 \mathrm{E}-03$ & 0,253 \\
Atenolol & $3,4 \mathrm{E}-03$ & $8,0 \mathrm{E}-05$ & $2,6 \mathrm{E}-04$ & $3,4 \mathrm{E}-03$ & 0,290 \\
Cafeína & $1,3 \mathrm{E}-03$ & $8,1 \mathrm{E}-05$ & $1,9 \mathrm{E}-04$ & $1,3 \mathrm{E}-03$ & 0,217 \\
Carbamazepina & $1,3 \mathrm{E}-03$ & $8,1 \mathrm{E}-05$ & $2,0 \mathrm{E}-04$ & $1,4 \mathrm{E}-03$ & 0,2297 \\
Clortalidona & $2,4 \mathrm{E}-03$ & $8,0 \mathrm{E}-05$ & $1,8 \mathrm{E}-04$ & $2,4 \mathrm{E}-03$ & 0,208 \\
Diclofenaco & $2,8 \mathrm{E}-03$ & $8,0 \mathrm{E}-05$ & $2,8 \mathrm{E}-04$ & $2,8 \mathrm{E}-03$ & 0,320 \\
Enalapril & $3,2 \mathrm{E}-03$ & $8,0 \mathrm{E}-05$ & $2,4 \mathrm{E}-04$ & $3,2 \mathrm{E}-03$ & 0,270 \\
Losartana & $6,4 \mathrm{E}-04$ & $8,1 \mathrm{E}-05$ & $3,8 \mathrm{E}-04$ & $7,5 \mathrm{E}-04$ & 0,3131 \\
Valsartana & $1,8 \mathrm{E}-03$ & $8,0 \mathrm{E}-05$ & $1,3 \mathrm{E}-04$ & $1,8 \mathrm{E}-03$ & 0,1494 \\
\hline
\end{tabular}




\section{B1.2.Padrão Líquido}

Grandezas de entrada: Volume e pureza do padrão e volume final da solução estoque individual.

$\mathrm{Na}$ TAB. B2 são apresentados os componentes das incertezas $u\left(P_{\text {padrão }}\right)$ e $\mathrm{u}\left(\mathrm{V}_{\text {Sol.Estog. }}\right)$, a incerteza combinada da solução estoque individual ( $\left.\mathrm{u}\left(\mathrm{C}_{\text {Sol.Estoq. }}\right)\right)$ calculados pelas Eq. 18, 19 e 17, respectivamente, assim como a respectiva concentração da solução estoque individual.

TABELA B2. Incerteza combinada da solução estoque individual, seus respectivos componentes de incertezas e a concentração da solução estoque individual de benzoilecgonina e cocaína.

\begin{tabular}{lcccccc}
\hline \multirow{2}{*}{ Composto } & \multirow{2}{*}{$\mathrm{u}(\mathrm{P})$} & $\mathrm{u}\left(\mathrm{C}_{\text {sol.Padrão }}\right)$ & $\mathrm{u}\left(\mathrm{V}_{\text {sol.Padrão }}\right)$ & $\mathrm{u}\left(\mathrm{V}_{\text {sol.estoque }}\right)$ & $\mathrm{u}\left(\mathrm{C}_{\text {sol.estoque }}\right)$ & $\mathrm{C}_{\text {sol.estoque }}$ \\
\cline { 3 - 7 } & & $\mu \mathrm{g} \mathrm{mL} \mathrm{mL}^{-1}$ & $\mathrm{ml}$ & $\mathrm{ml}$ & $\mu \mathrm{mL}^{-1}$ & $\mu \mathrm{mL}^{-1}$ \\
\hline Benzoilecgonina & $1,7 \mathrm{E}-03$ & $2,4 \mathrm{E}-03$ & $2,5 \mathrm{E}-03$ & $2,5 \mathrm{E}-03$ & $2,3 \mathrm{E}-01$ & 49,9 \\
Cocaína & $3,5 \mathrm{E}-03$ & $2,4 \mathrm{E}-06$ & $4,3 \mathrm{E}-04$ & $2,5 \mathrm{E}-03$ & $2,1 \mathrm{E}-01$ & 49,7 \\
\hline
\end{tabular}

\section{B2. Incerteza da preparação da solução de trabalho mista de padrões}

Grandezas de entrada: incerteza das soluções estoque individual dos padrões, dos volumes pipetados das soluções estoque individual dos padrões e do volume finaL da solução de trabalho mista de padrões.

Os componentes da incerteza da solução de trabalho mista de padrões, $u\left(V_{\text {Sol.Estoq. }}\right)$ e $u\left(V_{\text {Sol.Trab. }}\right)$ foram calculados pela Eq. 19. A incerteza combinada da preparação da solução de trabalho mista de padrões (u( $\left.\mathrm{C}_{\text {sol.Trab. }}\right)$ ) foi obtida pela equação 20 e a concentração da solução de trabalho mista de padrões (C sol.Trab. $_{\text {. }}$ pela Eq. 21. Os valores obtidos estão na TAB. B3. 
TABELA B 3. Incerteza combinada da solução de trabalho mista de padrões com seus respectivos componentes de incertezas e a concentração da solução de trabalho para os compostos quantificados nesse trabalho.

\begin{tabular}{|c|c|c|c|c|c|c|c|c|c|}
\hline Composto & $x$ & valor $(x)$ & Calibração & Repe & $\Delta \mathrm{t}$ & $u(x)$ & $u(x) / x$ & $\frac{\mathrm{u}\left(\mathrm{C}_{\text {sol.trab. }}\right)}{\mu \mathrm{g} \mathrm{mL}^{-1}}$ & $\frac{\mathrm{C}_{\text {sol.Trab. }}}{\mu \mathrm{g} \mathrm{mL}^{-1}}$ \\
\hline & $\mathrm{V}_{\text {Sol.Estoque }}(\mathrm{mL})$ & 0,0592 & $1,2 \mathrm{E}-05$ & $2,6 \mathrm{E}-06$ & 7,2E-06 & $1,4 \mathrm{E}-05$ & 2,4E-04 & & \\
\hline \multirow[t]{3}{*}{ Acetaminofeno } & $\mathrm{V}_{\text {Sol.Trab. }}(\mathrm{mL})$ & 10 & $8,2 \mathrm{E}-03$ & $3,2 \mathrm{E}-03$ & 1,2E-03 & 8,8E-03 & $8,8 \mathrm{E}-04$ & $9,0 \mathrm{E}-03$ & 1,500 \\
\hline & $\mathrm{C}_{\text {sol.Estoque }}\left(\mu \mathrm{g} \mathrm{mL}^{-1}\right)$ & 253 & 1 & 1 & 1 & 1,5 & $5,9 \mathrm{E}-03$ & & \\
\hline & $\mathrm{V}_{\text {Sol.Estoque }}(\mathrm{mL})$ & 0,0518 & $1,1 \mathrm{E}-05$ & $2,3 E-06$ & 6,3E-06 & 1,3E-05 & 2,4E-04 & & \\
\hline \multirow[t]{3}{*}{ Atenolol } & $\mathrm{V}_{\text {Sol.Trab. }}(\mathrm{mL})$ & 10 & $8,2 \mathrm{E}-03$ & $3,2 \mathrm{E}-03$ & $1,2 \mathrm{E}-03$ & 8,8E-03 & $8,8 \mathrm{E}-04$ & 1,7E-03 & 1,503 \\
\hline & $\mathrm{C}_{\text {sol.Estoque }}\left(\mu \mathrm{g} \mathrm{mL}^{-1}\right)$ & 290 & 1 & 1 & 1 & 3,4 & $6,1 \mathrm{E}-04$ & & \\
\hline & $\mathrm{V}_{\text {Sol.Estoque }}$ & 0,30 & $2,0 \mathrm{E}-03$ & $3,1 \mathrm{E}-05$ & $3,6 \mathrm{E}-05$ & $2,0 \mathrm{E}-03$ & $6,8 \mathrm{E}-03$ & & \\
\hline \multirow[t]{3}{*}{ Benzoilecgonina } & $\mathrm{V}_{\text {Sol.Trab. }}$ & 10 & $8,2 \mathrm{E}-03$ & $3,2 \mathrm{E}-03$ & $1,2 \mathrm{E}-03$ & $8,8 \mathrm{E}-03$ & $8,8 \mathrm{E}-04$ & $1,2 \mathrm{E}-02$ & 1,50 \\
\hline & $\mathrm{C}_{\text {sol.Estoque }}\left(\mu \mathrm{g} \mathrm{mL}^{-1}\right)$ & 49,85 & 1 & 1 & 1 & 0,02 & 4,6E-03 & & \\
\hline & $\mathrm{V}_{\text {Sol.Estoque }}$ & 0,068 & $2,8 \mathrm{E}-05$ & 4,4E-06 & 8,2E-06 & 2,9E-05 & 4,3E-04 & & \\
\hline \multirow[t]{3}{*}{ Cafeína } & $\mathrm{V}_{\text {Sol.Trab. }}$ & 5 & $2,4 \mathrm{E}-03$ & $2,7 \mathrm{E}-04$ & 6,1E-04 & $2,5 \mathrm{E}-03$ & $5,1 \mathrm{E}-04$ & $1,8 \mathrm{E}-02$ & 2,95 \\
\hline & $\mathrm{C}_{\text {sol.Estoque }}\left(\mu \mathrm{g} \mathrm{mL}^{-1}\right)$ & 217 & 1 & 1 & 1 & 1,30 & 5,9E-06 & & \\
\hline & $\mathrm{V}_{\text {Sol.Estoque }}$ & 0,108 & 4,4E-05 & $7,0 \mathrm{E}-06$ & 1,3E-05 & 4,7E-05 & 4,3E-04 & & \\
\hline \multirow[t]{3}{*}{ Carbamazepina } & $\mathrm{V}_{\text {Sol.Trab. }}$ & 50 & 4,1E-03 & $2,8 \mathrm{E}-03$ & $6,1 \mathrm{E}-03$ & $7,8 \mathrm{E}-03$ & $1,6 \mathrm{E}-04$ & $2,9 \mathrm{E}-03$ & 0,496 \\
\hline & $\mathrm{C}_{\text {sol.Estoque }}\left(\mu \mathrm{g} \mathrm{mL}^{-1}\right)$ & 230 & 1 & 1 & 1 & 1,36 & $5,9 \mathrm{E}-03$ & & \\
\hline & $\mathrm{V}_{\text {Sol.Estoque }}$ & 0,119 & $2,4 \mathrm{E}-04$ & $1,2 \mathrm{E}-05$ & 1,4E-05 & 2,4E-04 & $2,0 \mathrm{E}-03$ & & \\
\hline \multirow[t]{3}{*}{ Clortalidona } & V $_{\text {Sol.Trab. }}$ & 50 & 4,1E-03 & $1,6 \mathrm{E}-01$ & 6,1E-03 & $1,6 \mathrm{E}-01$ & 3,3E-03 & $6,1 \mathrm{E}-03$ & 0,490 \\
\hline & $\mathrm{C}_{\text {sol.Estoque }}\left(\mu \mathrm{g} \mathrm{mL}^{-1}\right)$ & 206 & 1 & 1 & 1 & 2,43 & 1,2E-02 & & \\
\hline & $\mathrm{V}_{\text {Sol.Estoque }}$ & 0,3 & $2,0 \mathrm{E}-03$ & $3,1 \mathrm{E}-05$ & 3,6E-05 & $2,0 \mathrm{E}-03$ & $6,8 \mathrm{E}-03$ & & \\
\hline \multirow[t]{3}{*}{ Cocaína } & $\mathrm{V}_{\text {Sol.Trab. }}$ & 5 & $2,4 \mathrm{E}-03$ & 2,7E-04 & 6,1E-04 & 2,5E-03 & 5,1E-04 & 2,4E-02 & 2,98 \\
\hline & $\mathrm{C}_{\text {sol.Estoque }}\left(\mu \mathrm{g} \mathrm{mL}^{-1}\right)$ & 49,7 & 1 & 1 & 1 & 0,21 & 4,3E-03 & & \\
\hline & $\mathrm{V}_{\text {Sol.Estoque }}$ & 0,0768 & $3,1 \mathrm{E}-05$ & $5,0 \mathrm{E}-06$ & 9,3E-06 & 3,3E-05 & 4,3E-04 & & \\
\hline \multirow[t]{3}{*}{ Diclofenaco } & $\mathrm{V}_{\text {Sol.Trab. }}$ & 50 & $4,1 \mathrm{E}-03$ & $2,8 \mathrm{E}-03$ & 6,1E-03 & $7,8 \mathrm{E}-03$ & $1,6 \mathrm{E}-04$ & 4,4E-03 & 0,492 \\
\hline & $\mathrm{C}_{\text {sol.Estoque }}\left(\mu \mathrm{g} \mathrm{mL}^{-1}\right)$ & 320 & 1 & 1 & 1 & 2,83 & $8,8 \mathrm{E}-03$ & & \\
\hline & $\mathrm{V}_{\text {Sol.Estoque }}$ & 0,0926 & $3,8 \mathrm{E}-05$ & $6,0 \mathrm{E}-06$ & 1,1E-05 & 4,0E-05 & 4,3E-04 & & \\
\hline \multirow[t]{3}{*}{ Enalapril } & $\mathrm{V}_{\text {Sol.Trab. }}$ & 50 & 4,1E-03 & $2,8 \mathrm{E}-03$ & $6,1 \mathrm{E}-03$ & $7,8 \mathrm{E}-03$ & $1,6 \mathrm{E}-04$ & 5,9E-03 & 0,501 \\
\hline & $\mathrm{C}_{\text {sol.Estoque }}\left(\mu \mathrm{g} \mathrm{mL}^{-1}\right)$ & 270 & 1 & 1 & 1 & 3,20 & $1,2 \mathrm{E}-02$ & & \\
\hline & $\mathrm{V}_{\text {Sol.Estoque }}$ & 0,05 & $9,8 \mathrm{E}-06$ & $2,1 \mathrm{E}-06$ & $5,8 \mathrm{E}-06$ & $1,2 \mathrm{E}-05$ & 2,4E-04 & & \\
\hline \multirow[t]{3}{*}{ Losartana } & $\mathrm{V}_{\text {Sol.Trab. }}$ & 10 & $8,2 \mathrm{E}-03$ & $3,2 \mathrm{E}-03$ & 1,2E-03 & $8,8 \mathrm{E}-03$ & $8,8 \mathrm{E}-04$ & $4,0 \mathrm{E}-03$ & 1,503 \\
\hline & $\mathrm{C}_{\text {sol.Estoque }}\left(\mu \mathrm{g} \mathrm{mL}^{-1}\right)$ & 313 & 1 & 1 & 1 & 0,75 & 2,4E-06 & & \\
\hline & $\mathrm{V}_{\text {Sol.Estoque }}$ & 0,16 & 6,7E-05 & $1,1 \mathrm{E}-05$ & $2,0 \mathrm{E}-05$ & 7,1E-05 & 4,3E-04 & & \\
\hline \multirow[t]{2}{*}{ Valsartana } & $\mathrm{V}_{\text {Sol.Trab. }}$ & 50 & $4,1 \mathrm{E}-03$ & $1,6 \mathrm{E}-01$ & $6,1 \mathrm{E}-03$ & 1,6E-01 & 3,3E-03 & $6,0 \mathrm{E}-03$ & 0,490 \\
\hline & $\mathrm{C}_{\text {sol.Estoque }}\left(\mu \mathrm{g} \mathrm{mL}^{-1}\right)$ & 149 & 1 & 1 & 1 & 1,77 & 1,2E-02 & & \\
\hline
\end{tabular}

\section{B3. Incerteza da preparação da solução de calibração para a curva analítica}

Grandezas de entrada: incerteza das soluções de trabalho mista de padrões, dos volumes pipetados das soluções de trabalho mista de padrões e dos volumes dos balões utilizados para diluição das soluções. 
Os componentes da incerteza da solução de calibração, $u\left(V_{\text {Sol.Trab. }}\right)$ e $\mathrm{u}\left(\mathrm{V}_{\text {Sol.Calib. }}\right)$ foram calculados pela Eq. 19. A incerteza combinada da preparação da solução de calibração ( $u\left(\mathrm{C}_{\text {sol.calib. }}\right)$ ) foi obtida pela Eq. 20 e a concentração da solução de trabalho mista de padrões (Csol.Calib.) pela Eq. 21. Os valores obtidos estão nas TAB. B4 a B6.

TABELA B4. Incerteza combinada da solução de calibração com seus respectivos componentes de incertezas e a concentração da solução de calibração para acetaminofeno, atenolol, benzoilecgonina e cafeína.

\begin{tabular}{|c|c|c|c|c|c|c|c|c|c|}
\hline Composto & $x$ & Valor (x) & Calibração & Repe & $\Delta \mathrm{t}$ & $u(x)$ & $u(x) / x$ & $\frac{\mathrm{u}\left(\mathrm{C}_{\text {sol.Calb. }}\right)}{\mu \mathrm{g} \mathrm{mL}^{-1}}$ & $\frac{C_{\text {sol.Calb. }}}{\mu \mathrm{g} \mathrm{mL}^{-1}}$ \\
\hline \multirow{10}{*}{ Acetaminofeno } & $\mathrm{V}_{\text {Sol.Trab. }}(\mathrm{mL})$ & 0,033 & $6,8 \mathrm{E}-06$ & $1,5 \mathrm{E}-06$ & $4,0 \mathrm{E}-06$ & $8,1 \mathrm{E}-06$ & $2,4 \mathrm{E}-04$ & \multirow{2}{*}{$3,0 E-05$} & \multirow{2}{*}{0,00501} \\
\hline & $\mathrm{V}_{\text {Sol.Calb.1 }}(\mathrm{mL})$ & 10 & $8,2 \mathrm{E}-03$ & $3,2 \mathrm{E}-03$ & 1,2E-03 & 8,8E-03 & 8,8E-04 & & \\
\hline & $\mathrm{V}_{\text {Sol.Trab. }}(\mathrm{mL})$ & 0,100 & 4,1E-05 & $6,5 \mathrm{E}-06$ & 1,2E-05 & 4,3E-05 & 4,3E-04 & \multirow{2}{*}{$9,1 \mathrm{E}-05$} & \multirow{2}{*}{0,01500} \\
\hline & $\mathrm{V}_{\text {Sol.Calb.2 }}(\mathrm{mL})$ & 10 & $8,2 \mathrm{E}-03$ & $3,2 \mathrm{E}-03$ & 1,2E-03 & $8,8 \mathrm{E}-03$ & $8,8 \mathrm{E}-04$ & & \\
\hline & $\mathrm{V}_{\text {Sol.Trab. }}(\mathrm{mL})$ & 0,100 & 4,1E-05 & $6,5 \mathrm{E}-06$ & 1,2E-05 & $4,3 E-05$ & 4,3E-04 & \multirow{2}{*}{$3,0 E-04$} & \multirow{2}{*}{0,0500} \\
\hline & $\mathrm{V}_{\text {Sol.Calb.3 }}(\mathrm{mL})$ & 3 & $2,4 \mathrm{E}-03$ & 2,7E-04 & 3,6E-04 & 2,5E-03 & 8,3E-04 & & \\
\hline & $\mathrm{V}_{\text {Sol.Trab. }}(\mathrm{mL})$ & 0,200 & $9,8 \mathrm{E}-05$ & 2,7E-05 & 2,4E-05 & $1,0 \mathrm{E}-04$ & 5,2E-04 & \multirow{2}{*}{$6,1 \mathrm{E}-04$} & \multirow{2}{*}{0,1000} \\
\hline & $\mathrm{V}_{\text {Sol.Calb.4 }}(\mathrm{mL})$ & 3 & 2,4E-03 & 2,7E-04 & $3,6 \mathrm{E}-04$ & $2,5 \mathrm{E}-03$ & $8,3 E-04$ & & \\
\hline & $\mathrm{V}_{\text {Sol.Trab. }}(\mathrm{mL})$ & 1,330 & 2,7E-03 & 1,4E-04 & 1,6E-04 & 2,7E-03 & 2,0E-03 & \multirow{2}{*}{$1,3 E-03$} & \multirow{2}{*}{0,200} \\
\hline & $\mathrm{V}_{\text {Sol.Calb.5 }}(\mathrm{mL})$ & 10 & $8,2 \mathrm{E}-03$ & $3,2 \mathrm{E}-03$ & 1,2E-03 & $8,8 \mathrm{E}-03$ & $8,8 \mathrm{E}-04$ & & \\
\hline \multirow{10}{*}{ Atenolol } & $\mathrm{V}_{\text {Sol.Trab. }}(\mathrm{mL})$ & 0,033 & $6,8 \mathrm{E}-06$ & 1,5E-06 & 4,0E-06 & 8,1E-06 & $2,4 \mathrm{E}-04$ & \multirow{2}{*}{ 7,2E-06 } & \multirow{2}{*}{0,005019} \\
\hline & $\mathrm{V}_{\text {Sol.Calb.1 }}(\mathrm{mL})$ & 10 & $8,2 \mathrm{E}-03$ & 3,2E-03 & 1,2E-03 & $8,8 \mathrm{E}-03$ & $8,8 \mathrm{E}-04$ & & \\
\hline & $\mathrm{V}_{\text {Sol.Trab. }}(\mathrm{mL})$ & 0,100 & 4,1E-05 & $6,5 E-06$ & 1,2E-05 & 4,3E-05 & 4,3E-04 & \multirow{2}{*}{$2,2 \mathrm{E}-05$} & \multirow{2}{*}{0,01503} \\
\hline & $\mathrm{V}_{\text {Sol.Calb.2 }}(\mathrm{mL})$ & 10 & $8,2 \mathrm{E}-03$ & $3,2 \mathrm{E}-03$ & 1,2E-03 & 8,8E-03 & 8,8E-04 & & \\
\hline & $\mathrm{V}_{\text {Sol.Trab. }}(\mathrm{mL})$ & 0,280 & 5,7E-04 & 3,7E-05 & 3,4E-05 & 5,7E-04 & 2,0E-03 & \multirow{2}{*}{$3,5 E-04$} & \multirow{2}{*}{0,1402} \\
\hline & $\mathrm{V}_{\text {Sol.Calb.3 }}(\mathrm{mL})$ & 3 & 2,4E-03 & 2,7E-04 & 3,6E-04 & 2,5E-03 & 8,3E-04 & & \\
\hline & $\mathrm{V}_{\text {Sol.Trab. }}(\mathrm{mL})$ & 0,134 & 2,3E-03 & $1,2 \mathrm{E}-04$ & $1,4 \mathrm{E}-04$ & $2,3 E-03$ & $2,0 \mathrm{E}-03$ & \multirow{2}{*}{$4,2 \mathrm{E}-04$} & \multirow{2}{*}{0,1704} \\
\hline & $\mathrm{V}_{\text {Sol.Calb.4 }}(\mathrm{mL})$ & 10 & $8,2 \mathrm{E}-03$ & $3,2 \mathrm{E}-03$ & 1,2E-03 & 8,8E-03 & 8,8E-04 & & \\
\hline & $\mathrm{V}_{\text {Sol.Trab. }}(\mathrm{mL})$ & 1,330 & 2,7E-03 & 1,4E-04 & $1,6 \mathrm{E}-04$ & 2,7E-03 & $2,0 E-03$ & \multirow{2}{*}{$5,0 E-04$} & \multirow{2}{*}{0,1998} \\
\hline & $\mathrm{V}_{\text {Sol.Calb.5 }}(\mathrm{mL})$ & 10 & $8,2 \mathrm{E}-03$ & 3,2E-03 & 1,2E-03 & $8,8 \mathrm{E}-03$ & $8,8 \mathrm{E}-04$ & & \\
\hline \multirow{10}{*}{ Benzoilecgonina } & $\mathrm{V}_{\text {Sol.Trab. }}(\mathrm{mL})$ & 0,033 & $6,8 \mathrm{E}-06$ & $1,5 \mathrm{E}-06$ & $4,0 \mathrm{E}-06$ & 8,1E-06 & $2,4 \mathrm{E}-04$ & & \\
\hline & $\mathrm{V}_{\text {Sol.Calb.1 }}(\mathrm{mL})$ & 10 & $8,2 \mathrm{E}-03$ & $3,2 \mathrm{E}-03$ & 1,2E-03 & 8,8E-03 & $8,8 \mathrm{E}-04$ & $3,5 \mathrm{E}-05$ & 0,00499 \\
\hline & $\mathrm{V}_{\text {Sol.Trab. }}(\mathrm{mL})$ & 0,100 & 4,1E-05 & $6,5 \mathrm{E}-06$ & $1,2 \mathrm{E}-05$ & 4,3E-05 & 4,3E-04 & \multirow{2}{*}{$1,0 \mathrm{E}-04$} & 0.01 \\
\hline & $\mathrm{V}_{\text {Sol.Calb.2 }}(\mathrm{mL})$ & 10 & $8,2 \mathrm{E}-03$ & 3,2E-03 & 1,2E-03 & $8,8 \mathrm{E}-03$ & $8,8 \mathrm{E}-04$ & & ( \\
\hline & $\mathrm{V}_{\text {Sol.Trab. }}(\mathrm{mL})$ & 0,200 & $9,8 \mathrm{E}-05$ & 2,7E-05 & 2,4E-05 & $1,0 \mathrm{E}-04$ & $5,2 \mathrm{E}-04$ & & 00 \\
\hline & $\mathrm{V}_{\text {Sol.Calb.3 }}(\mathrm{mL})$ & 3 & $2,4 \mathrm{E}-03$ & 2,7E-04 & $3,6 \mathrm{E}-04$ & $2,5 E-03$ & $8,3 E-04$ & $0,95-04$ & 0,0 \\
\hline & $\mathrm{V}_{\text {Sol.Trab. }}(\mathrm{mL})$ & 1,134 & 2,3E-03 & $1,2 \mathrm{E}-04$ & 1,4E-04 & 2,3E-03 & $2,0 \mathrm{E}-03$ & 3 & 0,170 \\
\hline & $\mathrm{V}_{\text {Sol.Calb.4 }}(\mathrm{mL})$ & 10 & $8,2 \mathrm{E}-03$ & $3,2 \mathrm{E}-03$ & 1,2E-03 & 8,8E-03 & $8,8 \mathrm{E}-04$ & 3 & $0,1 / 0$ \\
\hline & $\mathrm{V}_{\text {Sol.Trab. }}(\mathrm{mL})$ & 1,330 & 3,3E-03 & $3,5 \mathrm{E}-04$ & 1,6E-04 & 3,3E-03 & $2,5 \mathrm{E}-03$ & $15 \mathrm{~F}-03$ & 0199 \\
\hline & $\mathrm{V}_{\text {Sol.Calb.5 }}(\mathrm{mL})$ & 10 & $8,2 \mathrm{E}-03$ & 3,2E-03 & 1,2E-03 & $8,8 \mathrm{E}-03$ & $8,8 E-04$ & 3, & 0,199 \\
\hline & $\mathrm{V}_{\text {Sol.Trab. }}(\mathrm{mL})$ & 0,0168 & 1,4E-06 & $8,9 \mathrm{E}-07$ & $2,0 \mathrm{E}-06$ & 2,6E-06 & $1,6 \mathrm{E}-04$ & $3.0 E-05$ & 0.00495 \\
\hline & $\mathrm{V}_{\text {Sol.Calb.1 }}(\mathrm{mL})$ & 10 & 8,2E-03 & $3,2 \mathrm{E}-03$ & $1,2 \mathrm{E}-03$ & 8,8E-03 & $8,8 \mathrm{E}-04$ & & \\
\hline & $\mathrm{V}_{\text {Sol.Trab. }}(\mathrm{mL})$ & 0,0668 & $1,4 \mathrm{E}-05$ & 2,9E-06 & 8,1E-06 & 1,6E-05 & $2,4 \mathrm{E}-04$ & & \\
\hline & $\mathrm{V}_{\text {Sol.Calb.2 }}(\mathrm{mL})$ & 10 & 8,2E-03 & $3,2 \mathrm{E}-03$ & $1,2 \mathrm{E}-03$ & 8,8E-03 & $8,8 \mathrm{E}-04$ & 4 & , 0 \\
\hline & $\mathrm{V}_{\text {Sol.Trab. }}(\mathrm{mL})$ & 0,05 & $1,0 \mathrm{E}-05$ & 2,2E-06 & 6,1E-06 & 1,2E-05 & 2,4E-04 & 0 E-04 & $0<-2>$ \\
\hline Calenta & $\mathrm{V}_{\text {Sol.Calb.3 }}(\mathrm{mL})$ & 3 & 2,4E-03 & 2,7E-04 & $3,6 \mathrm{E}-04$ & 2,5E-03 & $8,3 E-04$ &, $0 €-04$ & 0,04 \\
\hline & $\mathrm{V}_{\text {Sol.Trab. }}(\mathrm{mL})$ & 0,333 & $6,8 \mathrm{E}-04$ & $3,5 \mathrm{E}-05$ & 4,0E-05 & $6,8 \mathrm{E}-04$ & 2,0E-03 & & \\
\hline & $\mathrm{V}_{\text {Sol.Calb.4 }}(\mathrm{mL})$ & 10 & 8,2E-03 & $3,2 \mathrm{E}-03$ & $1,2 \mathrm{E}-03$ & 8,8E-03 & $8,8 \mathrm{E}-04$ & 4 & 32 \\
\hline & $\mathrm{V}_{\text {Sol.Trab. }}(\mathrm{mL})$ & 1,668 & $3,4 \mathrm{E}-03$ & 1,7E-04 & 2,0E-04 & $3,4 \mathrm{E}-03$ & $2,0 \mathrm{E}-03$ & & \\
\hline & $\mathrm{V}_{\text {Sol.Calb.5 }}(\mathrm{mL})$ & 10 & $8,2 \mathrm{E}-03$ & $3,2 \mathrm{E}-03$ & $1,2 \mathrm{E}-03$ & 8,8E-03 & $8,8 \mathrm{E}-04$ & & , \\
\hline
\end{tabular}


TABELA B5. Incerteza combinada da solução de calibração com seus respectivos componentes de incertezas e a concentração da solução de calibração para carbamazepina, clortalidona, cocaína e diclofenaco.

\begin{tabular}{|c|c|c|c|c|c|c|c|c|c|}
\hline Composto & $x$ & Valor (x) & Calibração & Repe & $\Delta \mathrm{t}$ & $u(x)$ & $u(x) / x$ & $\frac{\mathrm{u}\left(\mathrm{C}_{\text {sol.Call. }}\right)}{\mu \mathrm{g} \mathrm{mL}^{-1}}$ & $\begin{array}{l}\mathrm{C}_{\text {sol.Callb. }} \\
\mu \mathrm{gL}^{-1}\end{array}$ \\
\hline \multirow{10}{*}{ Carbamazepina } & $\mathrm{V}_{\text {Sol.Trab. }}(\mathrm{mL})$ & 0,1 & $4,1 \mathrm{E}-05$ & $6,5 \mathrm{E}-06$ & $1,2 \mathrm{E}-05$ & $4,3 E-05$ & $4,3 \mathrm{E}-04$ & \multirow{2}{*}{ 3,0E-05 } & \multirow{2}{*}{0,00496} \\
\hline & $\mathrm{V}_{\text {Sol.Calb.1 }}(\mathrm{mL})$ & 10 & $8,2 \mathrm{E}-03$ & $3,2 \mathrm{E}-03$ & $1,2 \mathrm{E}-03$ & $8,8 \mathrm{E}-03$ & $8,8 \mathrm{E}-04$ & & \\
\hline & $\mathrm{V}_{\text {Sol. Trab. }}(\mathrm{mL})$ & 0,2 & $9,8 \mathrm{E}-05$ & 2,7E-05 & $2,4 \mathrm{E}-05$ & $1,0 \mathrm{E}-04$ & $5,2 \mathrm{E}-04$ & \multirow{2}{*}{$6,0 \mathrm{E}-05$} & \multirow{2}{*}{0,00992} \\
\hline & $\mathrm{V}_{\text {Sol.Calb.2 }}(\mathrm{mL})$ & 10 & $8,2 \mathrm{E}-03$ & $3,2 \mathrm{E}-03$ & $1,2 \mathrm{E}-03$ & $8,8 \mathrm{E}-03$ & $8,8 \mathrm{E}-04$ & & \\
\hline & $\mathrm{V}_{\text {Sol.Trab. }}(\mathrm{mL})$ & 0,5 & $1,0 \mathrm{E}-03$ & $5,2 \mathrm{E}-05$ & $6,1 \mathrm{E}-05$ & $1,0 \mathrm{E}-03$ & $2,0 \mathrm{E}-03$ & \multirow{2}{*}{$1,6 \mathrm{E}-04$} & \multirow{2}{*}{0,0248} \\
\hline & $\mathrm{V}_{\text {Sol.Calb.3 }}(\mathrm{mL})$ & 10 & $8,2 \mathrm{E}-03$ & $3,2 \mathrm{E}-03$ & $1,2 \mathrm{E}-03$ & $8,8 \mathrm{E}-03$ & $8,8 \mathrm{E}-04$ & & \\
\hline & $\mathrm{V}_{\text {Sol.Trab. }}(\mathrm{mL})$ & 0,18 & $8,8 \mathrm{E}-05$ & $2,4 \mathrm{E}-05$ & 2,2E-05 & $9,4 \mathrm{E}-05$ & $5,2 \mathrm{E}-04$ & \multirow{2}{*}{$1,8 \mathrm{E}-04$} & \multirow{2}{*}{0,2977} \\
\hline & $\mathrm{V}_{\text {Sol.Calb4 } 4}(\mathrm{~mL})$ & 3 & $2,4 \mathrm{E}-03$ & 2,7E-04 & $3,6 \mathrm{E}-04$ & $2,5 \mathrm{E}-03$ & $8,3 E-04$ & & \\
\hline & $\mathrm{V}_{\text {Sol. Trab. }}(\mathrm{mL})$ & 1 & $2,4 \mathrm{E}-03$ & 2,7E-04 & $1,2 \mathrm{E}-04$ & $2,5 \mathrm{E}-03$ & 2,5E-03 & \multirow{2}{*}{$3,2 \mathrm{E}-04$} & \multirow{2}{*}{0,0496} \\
\hline & $\mathrm{V}_{\text {Sol.Calb.5 }}(\mathrm{mL})$ & 10 & $8,2 \mathrm{E}-03$ & 3,2E-03 & $1,2 \mathrm{E}-03$ & $8,8 \mathrm{E}-03$ & 8,8E-04 & & \\
\hline \multirow{10}{*}{ Clortalidona } & $\mathrm{V}_{\text {Sol. Trab. }}(\mathrm{mL})$ & 0,1 & $4,1 \mathrm{E}-05$ & $6,5 \mathrm{E}-06$ & $1,2 \mathrm{E}-05$ & $4,3 \mathrm{E}-05$ & 4,3E-04 & \multirow{2}{*}{$6,1 \mathrm{E}-05$} & \multirow{2}{*}{0,00490} \\
\hline & $\mathrm{V}_{\text {Sol.Calb.1 }}(\mathrm{mL})$ & 10 & $8,2 \mathrm{E}-03$ & $3,2 \mathrm{E}-03$ & $1,2 \mathrm{E}-03$ & $8,8 \mathrm{E}-03$ & $8,8 \mathrm{E}-04$ & & \\
\hline & $\mathrm{V}_{\text {Sol.Trab. }}(\mathrm{mL})$ & 0,2 & $9,8 \mathrm{E}-05$ & 2,7E-05 & $2,4 \mathrm{E}-05$ & $1,0 \mathrm{E}-04$ & $5,2 \mathrm{E}-04$ & \multirow{2}{*}{$1,2 \mathrm{E}-04$} & \multirow{2}{*}{0,0098} \\
\hline & $\mathrm{V}_{\text {Sol.Calb.2. }}(\mathrm{mL})$ & 10 & $8,2 \mathrm{E}-03$ & $3,2 \mathrm{E}-03$ & $1,2 \mathrm{E}-03$ & $8,8 \mathrm{E}-03$ & $8,8 \mathrm{E}-04$ & & \\
\hline & $\mathrm{V}_{\text {Sol. Trab. }}(\mathrm{mL})$ & 0,18 & $8,8 \mathrm{E}-05$ & $2,4 \mathrm{E}-05$ & 2,2E-05 & $9,4 \mathrm{E}-05$ & $5,2 \mathrm{E}-04$ & \multirow{2}{*}{$3,7 \mathrm{E}-04$} & \multirow{2}{*}{0,0294} \\
\hline & $\mathrm{V}_{\text {Sol.Calb.3. }}(\mathrm{mL})$ & 3 & $2,4 \mathrm{E}-03$ & 2,7E-04 & $3,6 \mathrm{E}-04$ & $2,5 \mathrm{E}-03$ & $8,3 \mathrm{E}-04$ & & \\
\hline & $\mathrm{V}_{\text {Sol. Trab. }}(\mathrm{mL})$ & 0,9 & $2,2 \mathrm{E}-03$ & $2,4 \mathrm{E}-04$ & $1,1 \mathrm{E}-04$ & $2,2 \mathrm{E}-03$ & $2,5 \mathrm{E}-03$ & \multirow{2}{*}{$5,6 \mathrm{E}-04$} & \multirow{2}{*}{0,0441} \\
\hline & $\mathrm{V}_{\text {Sol.Calb.4 }}(\mathrm{mL})$ & 10 & $8,2 \mathrm{E}-03$ & $3,2 \mathrm{E}-03$ & $1,2 \mathrm{E}-03$ & $8,8 \mathrm{E}-03$ & $8,8 \mathrm{E}-04$ & & \\
\hline & $\mathrm{V}_{\text {Sol. Trab. }}(\mathrm{mL})$ & 1 & $2,4 \mathrm{E}-03$ & 2,7E-04 & $1,2 \mathrm{E}-04$ & $2,5 \mathrm{E}-03$ & $2,5 \mathrm{E}-03$ & \multirow{2}{*}{$6,2 \mathrm{E}-04$} & \multirow{2}{*}{0,0490} \\
\hline & $\mathrm{V}_{\text {Sol.Calb.5 }}(\mathrm{mL})$ & 10 & $8,2 \mathrm{E}-03$ & $3,2 \mathrm{E}-03$ & $1,2 \mathrm{E}-03$ & $8,8 \mathrm{E}-03$ & $8,8 \mathrm{E}-04$ & & \\
\hline \multirow{10}{*}{ Cocaína } & $\mathrm{V}_{\text {Sol. Trab. }}(\mathrm{mL})$ & 0,0168 & $1,4 \mathrm{E}-06$ & $8,9 \mathrm{E}-07$ & $2,0 \mathrm{E}-06$ & $2,6 \mathrm{E}-06$ & $1,6 \mathrm{E}-04$ & \multirow{2}{*}{$4,1 \mathrm{E}-05$} & 0 \\
\hline & $\mathrm{V}_{\text {Sol.Calb.1 }}(\mathrm{mL})$ & 10 & $8,2 \mathrm{E}-03$ & $3,2 \mathrm{E}-03$ & $1,2 \mathrm{E}-03$ & $8,8 \mathrm{E}-03$ & $8,8 \mathrm{E}-04$ & & \\
\hline & $\mathrm{V}_{\text {Sol.Trab. }}(\mathrm{mL})$ & 0,333 & $6,8 \mathrm{E}-04$ & 3,5E-05 & $4,0 \mathrm{E}-05$ & $6,8 \mathrm{E}-04$ & $2,0 \mathrm{E}-03$ & $83 \mathrm{E}-04$ & 0.0993 \\
\hline & $\mathrm{V}_{\text {Sol.Calb.2. }}(\mathrm{mL})$ & 10 & $8,2 \mathrm{E}-03$ & $3,2 \mathrm{E}-03$ & $1,2 \mathrm{E}-03$ & $8,8 \mathrm{E}-03$ & $8,8 \mathrm{E}-04$ & & \\
\hline & $\mathrm{V}_{\text {Sol.Trab. }}(\mathrm{mL})$ & 0,3 & $6,1 \mathrm{E}-04$ & 3,1E-05 & $3,6 \mathrm{E}-05$ & $6,1 \mathrm{E}-04$ & $2,0 \mathrm{E}-03$ & $25 \mathrm{~F}-03$ & 0298 \\
\hline & $\mathrm{V}_{\text {Sol.Calb.3 }}(\mathrm{mL})$ & 10 & $2,4 \mathrm{E}-03$ & 2,7E-04 & $3,6 \mathrm{E}-04$ & $2,5 \mathrm{E}-03$ & 8,3E-04 & $2, O L-60$ &,$<\mathrm{JO}$ \\
\hline & $\mathrm{V}_{\text {Sol. Trab. }}(\mathrm{mL})$ & 1,33 & $2,7 \mathrm{E}-03$ & $1,4 \mathrm{E}-04$ & $1,6 \mathrm{E}-04$ & $2,7 \mathrm{E}-03$ & $2,0 \mathrm{E}-03$ & $33 \mathrm{~F}-03$ & 0.397 \\
\hline & $\mathrm{V}_{\text {Sol.Calb.4 }}(\mathrm{mL})$ & 10 & $8,2 \mathrm{E}-03$ & $3,2 \mathrm{E}-03$ & $1,2 \mathrm{E}-03$ & $8,8 \mathrm{E}-03$ & $8,8 \mathrm{E}-04$ & & \\
\hline & $\mathrm{V}_{\text {Sol.Trab. }}(\mathrm{mL})$ & 1,668 & $4,1 \mathrm{E}-03$ & 4,4E-04 & $2,0 \mathrm{E}-04$ & $4,1 \mathrm{E}-03$ & $2,5 \mathrm{E}-03$ & , $2 \mathrm{E}-03$ & 0,497 \\
\hline & $\mathrm{V}_{\text {Sol.Calb.5 }}(\mathrm{mL})$ & 10 & $8,2 \mathrm{E}-03$ & $3,2 \mathrm{E}-03$ & $1,2 \mathrm{E}-03$ & $8,8 \mathrm{E}-03$ & $8,8 \mathrm{E}-04$ & & \\
\hline & $\mathrm{V}_{\text {Sol. Trab. }}(\mathrm{mL})$ & 0,1 & $4,1 \mathrm{E}-05$ & $6,5 \mathrm{E}-06$ & $1,2 \mathrm{E}-05$ & $4,3 \mathrm{E}-05$ & 4,3E-04 & $4.4 \mathrm{E}-05$ & 0.00492 \\
\hline & $\mathrm{V}_{\text {Sol.Calb.1 }}(\mathrm{mL})$ & 10 & $8,2 \mathrm{E}-03$ & $3,2 \mathrm{E}-03$ & $1,2 \mathrm{E}-03$ & $8,8 \mathrm{E}-03$ & $8,8 \mathrm{E}-04$ & & \\
\hline & $\mathrm{V}_{\text {Sol.Trab. }}(\mathrm{mL})$ & 0,2 & $9,8 \mathrm{E}-05$ & 2,7E-05 & $2,4 \mathrm{E}-05$ & $1,0 \mathrm{E}-04$ & $5,2 \mathrm{E}-04$ & $8,8 \mathrm{E}-05$ & 0,00983 \\
\hline & $\mathrm{V}_{\text {Sol.Calb.2. }}(\mathrm{mL})$ & 10 & $8,2 \mathrm{E}-03$ & $3,2 \mathrm{E}-03$ & $1,2 \mathrm{E}-03$ & $8,8 \mathrm{E}-03$ & $8,8 \mathrm{E}-04$ & & \\
\hline Diclofenz & $\mathrm{V}_{\text {Sol.Trab. }}(\mathrm{mL})$ & 0,108 & $4,4 \mathrm{E}-05$ & $7,0 \mathrm{E}-06$ & $1,3 \mathrm{E}-05$ & $4,7 \mathrm{E}-05$ & 4,3E-04 & $1,6 \mathrm{E}-04$ & 0.0177 \\
\hline & $\mathrm{V}_{\text {Sol.Calb. } 3}(\mathrm{~mL})$ & 3 & $2,4 \mathrm{E}-03$ & 2,7E-04 & $3,6 \mathrm{E}-04$ & $2,5 \mathrm{E}-03$ & 8,3E-04 & & \\
\hline & $\mathrm{V}_{\text {Sol. Trab. }}(\mathrm{mL})$ & 0,18 & $8,8 \mathrm{E}-05$ & $2,4 \mathrm{E}-05$ & $2,2 \mathrm{E}-05$ & $9,4 \mathrm{E}-05$ & $5,2 \mathrm{E}-04$ & $2.6 \mathrm{E}-04$ & 0.0295 \\
\hline & $\mathrm{V}_{\text {Sol.Calb.4 }}(\mathrm{mL})$ & 3 & $2,4 \mathrm{E}-03$ & 2,7E-04 & $3,6 \mathrm{E}-04$ & $2,5 \mathrm{E}-03$ & $8,3 \mathrm{E}-04$ & & \\
\hline & $\mathrm{V}_{\text {Sol. Trab. }}(\mathrm{mL})$ & 1 & $2,4 \mathrm{E}-03$ & $2,7 \mathrm{E}-04$ & $1,2 \mathrm{E}-04$ & $2,5 \mathrm{E}-03$ & $2,5 \mathrm{E}-03$ & $5 \mathrm{E}-04$ & 0.0492 \\
\hline & $\mathrm{V}_{\text {Sol.Calb.5 }}(\mathrm{mL})$ & 10 & $8,2 \mathrm{E}-03$ & $3,2 \mathrm{E}-03$ & $1,2 \mathrm{E}-03$ & $8,8 \mathrm{E}-03$ & $8,8 \mathrm{E}-04$ & & \\
\hline
\end{tabular}


TABELA B6. Incerteza combinada da solução de calibração com seus respectivos componentes de incertezas e a concentração da solução de calibração para enalapril, losartana e valsartana.

\begin{tabular}{|c|c|c|c|c|c|c|c|c|c|}
\hline Composto & $x$ & Valor (x) & Calibração & Repe & $\Delta \mathrm{t}$ & $u(x)$ & $u(x) / x$ & $\frac{\mathrm{u}\left(\mathrm{C}_{\text {sol.Calb. }}\right)}{\mu \mathrm{gLL}^{-1}}$ & $\begin{array}{l}\mathrm{C}_{\text {sol.Calb. }} \\
\mu \mathrm{gL}^{-1}\end{array}$ \\
\hline \multirow{10}{*}{ Enalapril } & $\mathrm{V}_{\text {Sol. Trab. }}(\mathrm{mL})$ & 0,1 & $4,1 \mathrm{E}-05$ & $6,5 \mathrm{E}-06$ & $1,2 \mathrm{E}-05$ & $4,3 \mathrm{E}-05$ & $4,3 \mathrm{E}-04$ & \multirow{2}{*}{$5,9 \mathrm{E}-05$} & \multirow{2}{*}{0,00501} \\
\hline & $\mathrm{V}_{\text {Sol.Calb.1 }}(\mathrm{mL})$ & 10 & $8,2 \mathrm{E}-03$ & $3,2 \mathrm{E}-03$ & $1,2 \mathrm{E}-03$ & $8,8 \mathrm{E}-03$ & $8,8 \mathrm{E}-04$ & & \\
\hline & $\mathrm{V}_{\text {Sol. Trab. }}(\mathrm{mL})$ & 0,5 & $1,0 \mathrm{E}-03$ & $5,2 \mathrm{E}-05$ & $6,1 \mathrm{E}-05$ & $1,0 \mathrm{E}-03$ & $2,0 \mathrm{E}-03$ & \multirow{2}{*}{$3,0 \mathrm{E}-04$} & \multirow{2}{*}{0,0250} \\
\hline & $\mathrm{V}_{\text {Sol.Calb. } 2}(\mathrm{~mL})$ & 10 & $8,2 \mathrm{E}-03$ & $3,2 \mathrm{E}-03$ & $1,2 \mathrm{E}-03$ & $8,8 \mathrm{E}-03$ & $8,8 \mathrm{E}-04$ & & \\
\hline & $\mathrm{V}_{\text {Sol. Trab. }}(\mathrm{mL})$ & 0,228 & 4,7E-04 & $2,4 \mathrm{E}-05$ & $2,8 \mathrm{E}-05$ & $4,7 \mathrm{E}-04$ & $2,0 \mathrm{E}-03$ & \multirow{2}{*}{ 4,6E-04 } & \multirow{2}{*}{0,0381} \\
\hline & $\mathrm{V}_{\text {Sol.Calb.3 }}(\mathrm{mL})$ & 3 & $2,4 \mathrm{E}-03$ & 2,7E-04 & $3,6 \mathrm{E}-04$ & $2,5 \mathrm{E}-03$ & 8,3E-04 & & \\
\hline & $\mathrm{V}_{\text {Sol.Trab. }}(\mathrm{mL})$ & 0,9 & $2,2 \mathrm{E}-03$ & 2,4E-04 & $1,1 \mathrm{E}-04$ & $2,2 \mathrm{E}-03$ & $2,5 \mathrm{E}-03$ & \multirow{2}{*}{$5,5 \mathrm{E}-04$} & \multirow{2}{*}{0,0451} \\
\hline & $\mathrm{V}_{\text {Sol.Calb.4}}(\mathrm{mL})$ & 10 & $8,2 \mathrm{E}-03$ & $3,2 \mathrm{E}-03$ & $1,2 \mathrm{E}-03$ & $8,8 \mathrm{E}-03$ & $8,8 \mathrm{E}-04$ & & \\
\hline & $\mathrm{V}_{\text {Sol.Trab. }}(\mathrm{mL})$ & 1 & $2,4 \mathrm{E}-03$ & 2,7E-04 & $1,2 \mathrm{E}-04$ & $2,5 \mathrm{E}-03$ & $2,5 \mathrm{E}-03$ & \multirow{2}{*}{$6,1 \mathrm{E}-04$} & \multirow{2}{*}{0,0501} \\
\hline & $\mathrm{V}_{\text {Sol.Calb.5}}(\mathrm{mL})$ & 10 & $8,2 \mathrm{E}-03$ & 3,2E-03 & $1,2 \mathrm{E}-03$ & $8,8 \mathrm{E}-03$ & 8,8E-04 & & \\
\hline \multirow{10}{*}{ Losartana } & $\mathrm{V}_{\text {Sol. Trab. }}(\mathrm{mL})$ & 0,0334 & $6,8 \mathrm{E}-06$ & $1,5 \mathrm{E}-06$ & $4,0 \mathrm{E}-06$ & $8,1 \mathrm{E}-06$ & $2,4 \mathrm{E}-04$ & \multirow{2}{*}{$1,4 \mathrm{E}-05$} & \multirow{2}{*}{0,00502} \\
\hline & $\mathrm{V}_{\text {Sol.Calb.1 }}(\mathrm{mL})$ & 10 & $8,2 \mathrm{E}-03$ & $3,2 \mathrm{E}-03$ & $1,2 \mathrm{E}-03$ & $8,8 \mathrm{E}-03$ & $8,8 \mathrm{E}-04$ & & \\
\hline & $\mathrm{V}_{\text {Sol. Trab. }}(\mathrm{mL})$ & 0,1 & $4,1 \mathrm{E}-05$ & $6,5 \mathrm{E}-06$ & $1,2 \mathrm{E}-05$ & $4,3 \mathrm{E}-05$ & 4,3E-04 & \multirow{2}{*}{$4,1 \mathrm{E}-05$} & \multirow{2}{*}{0,01503} \\
\hline & $\mathrm{V}_{\text {Sol.Calb.2. }}(\mathrm{mL})$ & 10 & $8,2 \mathrm{E}-03$ & $3,2 \mathrm{E}-03$ & $1,2 \mathrm{E}-03$ & $8,8 \mathrm{E}-03$ & 8,8E-04 & & \\
\hline & $\mathrm{V}_{\text {Sol. Trab. }}(\mathrm{mL})$ & 0,467 & $9,5 \mathrm{E}-04$ & 4,8E-05 & 5,7E-05 & $9,6 \mathrm{E}-04$ & $2,0 \mathrm{E}-03$ & \multirow{2}{*}{ 2,4E-04 } & \multirow{2}{*}{0,0702} \\
\hline & $\mathrm{V}_{\text {Sol.Calb.3 }}(\mathrm{mL})$ & 10 & $8,2 \mathrm{E}-03$ & $3,2 \mathrm{E}-03$ & $1,2 \mathrm{E}-03$ & $8,8 \mathrm{E}-03$ & $8,8 \mathrm{E}-04$ & & \\
\hline & $\mathrm{V}_{\text {Sol.Trab. }}(\mathrm{mL})$ & 0,280 & $5,7 \mathrm{E}-04$ & 2,9E-05 & $3,4 \mathrm{E}-05$ & $5,7 \mathrm{E}-04$ & $2,0 \mathrm{E}-03$ & \multirow{2}{*}{ 4,7E-04 } & \multirow{2}{*}{0,1403} \\
\hline & $\mathrm{V}_{\text {Sol.Calb.4 }}(\mathrm{mL})$ & 3 & $2,4 \mathrm{E}-03$ & 2,7E-04 & $3,6 \mathrm{E}-04$ & $2,5 \mathrm{E}-03$ & 8,3E-04 & & \\
\hline & $\mathrm{V}_{\text {Sol.Trab. }}(\mathrm{mL})$ & 1,33 & $2,7 \mathrm{E}-03$ & $1,4 \mathrm{E}-04$ & $1,6 \mathrm{E}-04$ & $2,7 \mathrm{E}-03$ & $2,0 \mathrm{E}-03$ & \multirow{2}{*}{ 6,8E-04 } & \multirow{2}{*}{0,1999} \\
\hline & $\mathrm{V}_{\text {Sol.Calb.5 }}(\mathrm{mL})$ & 10 & $8,2 \mathrm{E}-03$ & $3,2 \mathrm{E}-03$ & $1,2 \mathrm{E}-03$ & $8,8 \mathrm{E}-03$ & $8,8 \mathrm{E}-04$ & & \\
\hline \multirow{10}{*}{ Valsartana } & $\mathrm{V}_{\text {Sol. Trab. }}(\mathrm{mL})$ & 0,1 & $4,1 \mathrm{E}-05$ & $6,5 \mathrm{E}-06$ & $1,2 \mathrm{E}-05$ & $4,3 \mathrm{E}-05$ & $4,3 \mathrm{E}-04$ & \multirow{2}{*}{$6,0 \mathrm{E}-05$} & \multirow{2}{*}{0,00495} \\
\hline & $\mathrm{V}_{\text {Sol.Calb.1 }}(\mathrm{mL})$ & 10 & $8,2 \mathrm{E}-03$ & $3,2 \mathrm{E}-03$ & $1,2 \mathrm{E}-03$ & $8,8 \mathrm{E}-03$ & $8,8 \mathrm{E}-04$ & & \\
\hline & $\mathrm{V}_{\text {Sol. Trab. }}(\mathrm{mL})$ & 0,2 & $9,8 \mathrm{E}-05$ & 2,7E-05 & $2,4 \mathrm{E}-05$ & $1,0 \mathrm{E}-04$ & $5,2 \mathrm{E}-04$ & \multirow{2}{*}{$1,2 \mathrm{E}-04$} & \multirow{2}{*}{0,0098} \\
\hline & $\mathrm{V}_{\text {Sol.Calb.2 }}(\mathrm{mL})$ & 10 & $8,2 \mathrm{E}-03$ & $3,2 \mathrm{E}-03$ & $1,2 \mathrm{E}-03$ & $8,8 \mathrm{E}-03$ & $8,8 \mathrm{E}-04$ & & \\
\hline & $\mathrm{V}_{\text {Sol. Trab. }}(\mathrm{mL})$ & 0,5 & $1,0 \mathrm{E}-03$ & $5,2 \mathrm{E}-05$ & $6,1 \mathrm{E}-05$ & $1,0 \mathrm{E}-03$ & $2,0 \mathrm{E}-03$ & \multirow{2}{*}{ 3,1E-04 } & \multirow{2}{*}{0,0245} \\
\hline & $\mathrm{V}_{\text {Sol.Call.3. }}(\mathrm{mL})$ & 10 & $8,2 \mathrm{E}-03$ & $3,2 \mathrm{E}-03$ & $1,2 \mathrm{E}-03$ & $8,8 \mathrm{E}-03$ & $8,8 \mathrm{E}-04$ & & \\
\hline & $\mathrm{V}_{\text {Sol. Trab. }}(\mathrm{mL})$ & 0,18 & $8,8 \mathrm{E}-05$ & $2,4 \mathrm{E}-05$ & $2,2 \mathrm{E}-05$ & $9,4 \mathrm{E}-05$ & $5,2 \mathrm{E}-04$ & $6 \mathrm{~F}-04$ & 0 \\
\hline & $\mathrm{V}_{\text {Sol.Calb.4 }}(\mathrm{mL})$ & 3 & $2,4 \mathrm{E}-03$ & 2,7E-04 & $3,6 \mathrm{E}-04$ & $2,5 \mathrm{E}-03$ & $8,3 \mathrm{E}-04$ & & \\
\hline & $\mathrm{V}_{\text {Sol. Trab. }}(\mathrm{mL})$ & 1 & $2,4 \mathrm{E}-03$ & 2,7E-04 & $1,2 \mathrm{E}-04$ & $2,5 \mathrm{E}-03$ & $2,5 \mathrm{E}-03$ & $62 \mathrm{~F}-04$ & 0 \\
\hline & $\mathrm{V}_{\text {Sol.Calb.5 }}(\mathrm{mL})$ & 10 & $8,2 \mathrm{E}-03$ & $3,2 \mathrm{E}-03$ & $1,2 \mathrm{E}-03$ & $8,8 \mathrm{E}-03$ & $8,8 \mathrm{E}-04$ & $0, \angle L-U 4$ & 0,0450 \\
\hline
\end{tabular}

\section{B4. Incerteza da curva analítica}

Grandezas de entrada: área dos picos dos cromatogramas das amostras, área dos picos dos brancos das amostras, incertezas das soluções da curva ( 1 1 a C5), áreas dos picos dos cromatogramas referentes às soluções da curva.

A incerteza da curva analítica foi calculada por meio das Eq. 14, $15 \mathrm{e}$ 16 e foi estimada na concentração média da curva analítica de cada composto. Os valores obtidos estão na TAB. B7. 
TABELA B7. Incerteza da curva analítica na concentração média da curva analítica de acetaminofeno, atenolol, benzoilecgonina, cafeína, carbamazepina, clortalidona, cocaína, diclofenaco, enalapril, losartana e valsartana.

\begin{tabular}{lccc}
\hline \multirow{2}{*}{ Composto } & $\mathrm{C}_{0}$ & $\mathrm{u}\left(\mathrm{C}_{0}\right)$ & $\mathrm{u}\left(\mathrm{C}_{0}\right) / \mathrm{C}_{0}$ \\
\cline { 2 - 4 } & $\mu \mathrm{g} \mathrm{mL}^{-1}$ & $\mu \mathrm{gL}^{-1}$ & 0,03 \\
\hline Acetaminofeno & 0,0976 & 0,0029 & 0,036 \\
Atenolol & 0,0741 & 0,0019 & 0,026 \\
Benzoilecgonina & 0,0988 & 0,0011 & 0,011 \\
Cafeína & 0,094 & 0,001 & 0,0154 \\
Carbamazepina & 0,0252 & 0,0003 & 0,0129 \\
Clortalidona & 0,0240 & 0,0007 & 0,0292 \\
Cocaína & 0,0972 & 0,0010 & 0,0105 \\
Diclofenaco & 0,0241 & 0,0005 & 0,0187 \\
Enalapril & 0,025 & 0,001 & 0,0468 \\
Losartana & 0,074 & 0,001 & 0,0176 \\
Valsartana & 0,0249 & 0,0004 & 0,0176 \\
\hline
\end{tabular}

\section{B5. Incerteza da recuperação}

Grandezas de entrada: concentração da solução de calibração com solvente e resultado da concentração encontrada.

A incerteza da recuperação foi calculada por meio da Eq. 23 e foi estimada na concentração média da curva analítica de cada composto. Os valores obtidos estão na TAB. B8. 
TABELA B8. Incerteza da recuperação na concentração média da curva analítica de acetaminofeno, atenolol, benzoilecgonina, cafeína, carbamazepina, clortalidona, cocaína, diclofenaco, enalapril, losartana e valsartana.

\begin{tabular}{|c|c|c|c|c|c|}
\hline & \multirow{2}{*}{$x$} & Valor $(\mathrm{x})$ & $u(x)$ & \multirow{2}{*}{$u(x) / x$} & \multirow{2}{*}{$\mathrm{u}(\mathrm{R}$} \\
\hline & & $\mu \mathrm{g} \mathrm{mL}^{-1}$ & $\mu \mathrm{g} \mathrm{mL}^{-1}$ & & \\
\hline \multirow{3}{*}{ Acetaminofeno } & $\mathrm{C}_{\text {real }}\left(\mu \mathrm{gL}^{-1}\right)$ & 0,0701 & $1,1 \mathrm{E}-04$ & $1,6 \mathrm{E}-03$ & \\
\hline & $\mathrm{C}_{\text {encontrada }}(\mu \mathrm{g} \mathrm{mL}-1)$ & 0,0233 & $6,2 \mathrm{E}-04$ & 2,7E-02 & 0,01 \\
\hline & $\mathrm{R}$ & 0,33 & 1 & 1 & \\
\hline \multirow{3}{*}{ Atenolol } & $\mathrm{C}_{\text {real }}\left(\mu \mathrm{gL}^{-1}\right)$ & 0,0702 & $4,4 \mathrm{E}-05$ & $6,2 \mathrm{E}-04$ & \\
\hline & $\mathrm{C}_{\text {encontrada }}(\mu \mathrm{g} \mathrm{mL}-1)$ & 0,0677 & 1,8E-03 & $2,6 \mathrm{E}-02$ & 0,03 \\
\hline & $\mathrm{R}$ & 0,96 & l & / & \\
\hline \multirow{3}{*}{ Benzoilecgonina } & $\mathrm{C}_{\text {real }}\left(\mu \mathrm{g} \mathrm{mL} \mathrm{L}^{-1}\right)$ & 0,0698 & $1,3 \mathrm{E}-04$ & $1,8 \mathrm{E}-03$ & \\
\hline & $\mathrm{C}_{\text {encontrada }}(\mu \mathrm{g} \mathrm{mL}-1)$ & 0,0508 & $1,2 \mathrm{E}-03$ & $2,4 \mathrm{E}-02$ & 0,02 \\
\hline & $\mathrm{R}$ & 0,73 & I & I & \\
\hline \multirow{3}{*}{ Cafeína } & $\mathrm{C}_{\text {real }}\left(\mu \mathrm{g} \mathrm{mL}^{-1}\right)$ & 0,0982 & $1,6 \mathrm{E}-04$ & $1,6 \mathrm{E}-02$ & \\
\hline & $\mathrm{C}_{\text {encontrada }}(\mu \mathrm{g} \mathrm{mL}-1)$ & 0,0863 & 4,8E-03 & $5,6 \mathrm{E}-02$ & 0,05 \\
\hline & $\mathrm{R}$ & 0,88 & I & I & \\
\hline \multirow{3}{*}{ Carbamazepina } & $\mathrm{C}_{\text {real }}\left(\mu \mathrm{gL}^{-1}\right)$ & 0,0248 & 3,9E-05 & $1,6 \mathrm{E}-03$ & \\
\hline & $\mathrm{C}_{\text {encontrada }}(\mu \mathrm{g} \mathrm{mL}-1)$ & 0,0223 & 1,3E-03 & $6,0 \mathrm{E}-02$ & 0,05 \\
\hline & $\mathrm{R}$ & 0,90 & I & I & \\
\hline \multirow{3}{*}{ Clortalidona } & $\mathrm{C}_{\text {real }}\left(\mu \mathrm{g} \mathrm{mL}^{-1}\right)$ & 0,0245 & 7,7E-05 & $3,2 \mathrm{E}-03$ & \\
\hline & $\mathrm{C}_{\text {encontrada }}(\mu \mathrm{g} \mathrm{mL}-1)$ & 0,0185 & 4,3E-04 & 2,3E-02 & 0,02 \\
\hline & $\mathrm{R}$ & 0,76 & l & 1 & \\
\hline \multirow{3}{*}{ Cocaína } & $\mathrm{C}_{\text {real }}\left(\mu \mathrm{gL}^{-1}\right)$ & 0,0993 & $2,1 \mathrm{E}-04$ & $2,1 \mathrm{E}-03$ & \\
\hline & $\mathrm{C}_{\text {encontrada }}(\mu \mathrm{g} \mathrm{mL}-1)$ & 0,0827 & $7,0 \mathrm{E}-04$ & $8,4 \mathrm{E}-03$ & 0,01 \\
\hline & $\mathrm{R}$ & 0,83 & I & 1 & \\
\hline \multirow{3}{*}{ Diclofenaco } & $\mathrm{C}_{\text {real }}\left(\mu \mathrm{gL}^{-1}\right)$ & 0,0246 & $5,6 \mathrm{E}-05$ & $2,3 \mathrm{E}-03$ & \\
\hline & $\mathrm{C}_{\text {encontrada }}(\mu \mathrm{g} \mathrm{mL}-1)$ & 0,0176 & 7,1E-04 & $4,1 \mathrm{E}-02$ & 0,03 \\
\hline & $\mathrm{R}$ & 0,71 & l & 1 & \\
\hline \multirow{3}{*}{ Enalapril } & $\mathrm{C}_{\text {real }}\left(\mu \mathrm{g} \mathrm{mL}^{-1}\right)$ & 0,0251 & $7,5 \mathrm{E}-05$ & 3,0E-03 & \\
\hline & $\mathrm{C}_{\text {encontrada }}(\mu \mathrm{g} \mathrm{mL}-1)$ & 0,0222 & 9,9E-04 & $4,5 \mathrm{E}-02$ & 0,04 \\
\hline & $\mathrm{R}$ & 0,88 & l & l & \\
\hline \multirow{3}{*}{ Losartana } & $\mathrm{C}_{\text {real }}\left(\mu \mathrm{g} \mathrm{mL}^{-1}\right)$ & 0,0702 & $6,0 \mathrm{E}-05$ & $8,5 \mathrm{E}-04$ & \\
\hline & $\mathrm{C}_{\text {encontrada }}(\mu \mathrm{g} \mathrm{mL}-1)$ & 0,0543 & $1,8 \mathrm{E}-03$ & 3,3E-02 & 0,03 \\
\hline & $\mathrm{R}$ & 0,77 & I & 1 & \\
\hline \multirow{3}{*}{ Valsartana } & $\mathrm{C}_{\text {real }}\left(\mu \mathrm{gL} \mathrm{m}^{-1}\right)$ & 0,0245 & $7,6 \mathrm{E}-05$ & $3,1 \mathrm{E}-03$ & \\
\hline & $\mathrm{C}_{\text {encontrada }}(\mu \mathrm{g} \mathrm{mL}-1)$ & 0,0200 & $3,0 \mathrm{E}-04$ & $1,5 \mathrm{E}-02$ & 0,01 \\
\hline & $\mathrm{R}$ & 0,81 & I & I & \\
\hline
\end{tabular}




\section{APÊNDICE C}

\section{Dendogramas}

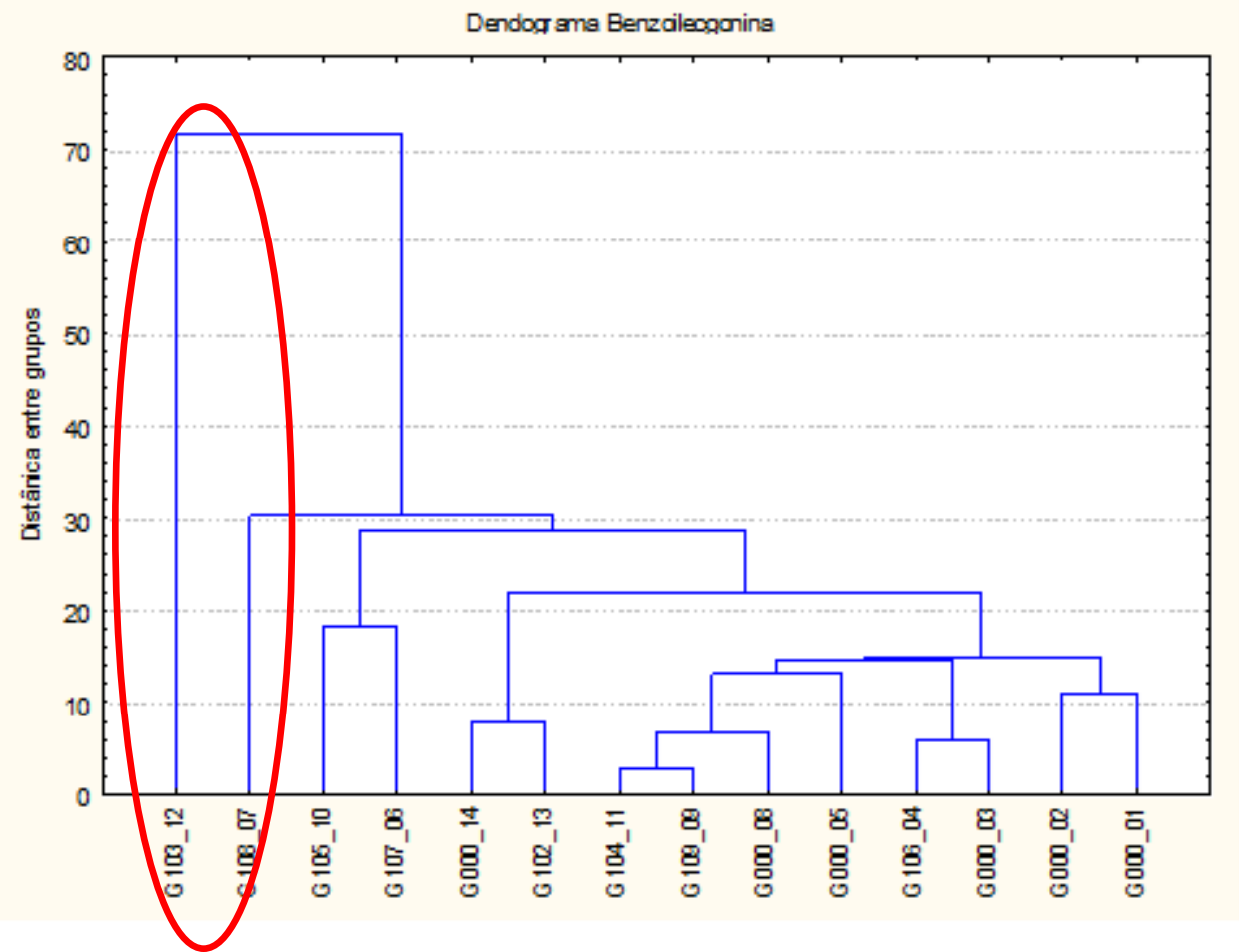

FIGURA C 1. Dendograma da distribuição da benzoilecgonina nas águas da represa Guarapiranga coletadas em ago./2011, set./2012 e abr./2013. 


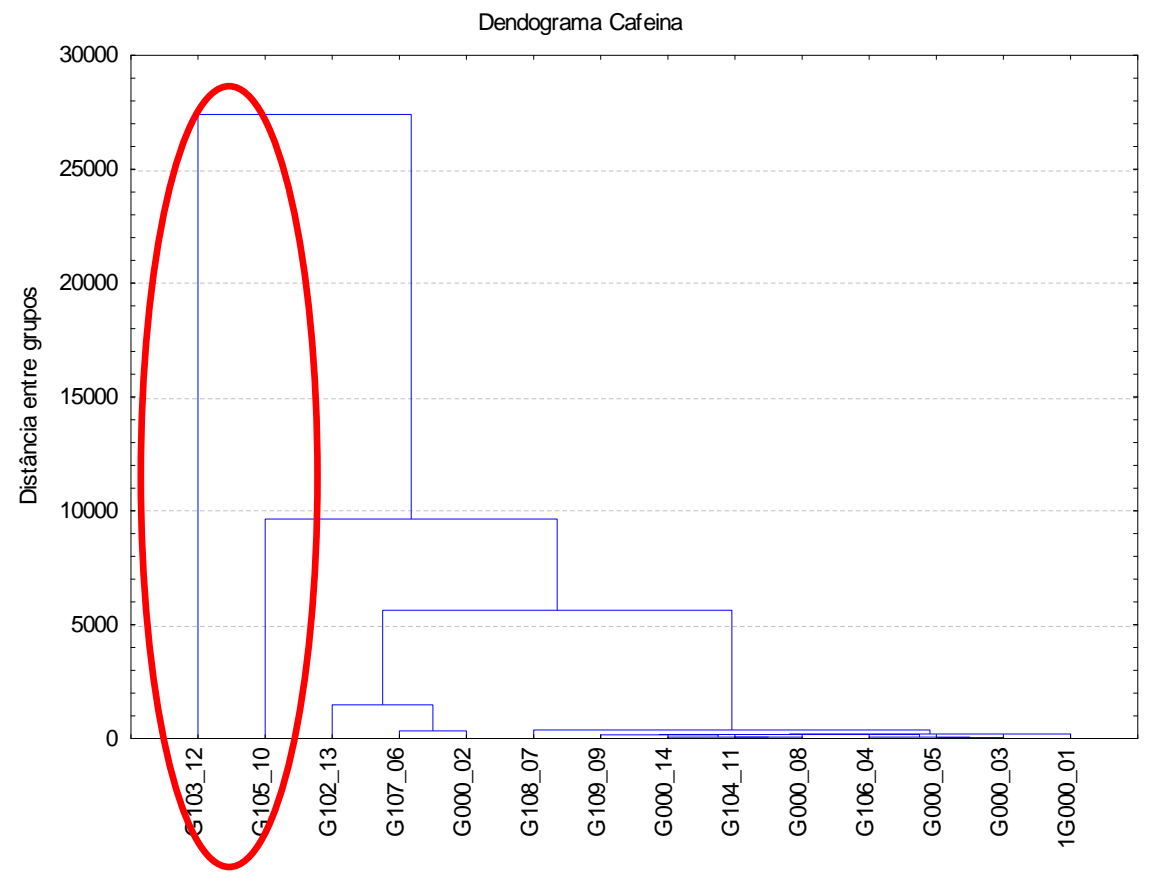

FIGURA C 2. Dendograma da distribuição da cafeína nas águas da represa Guarapiranga coletadas em ago./2011, set./2012 e abr./2013.

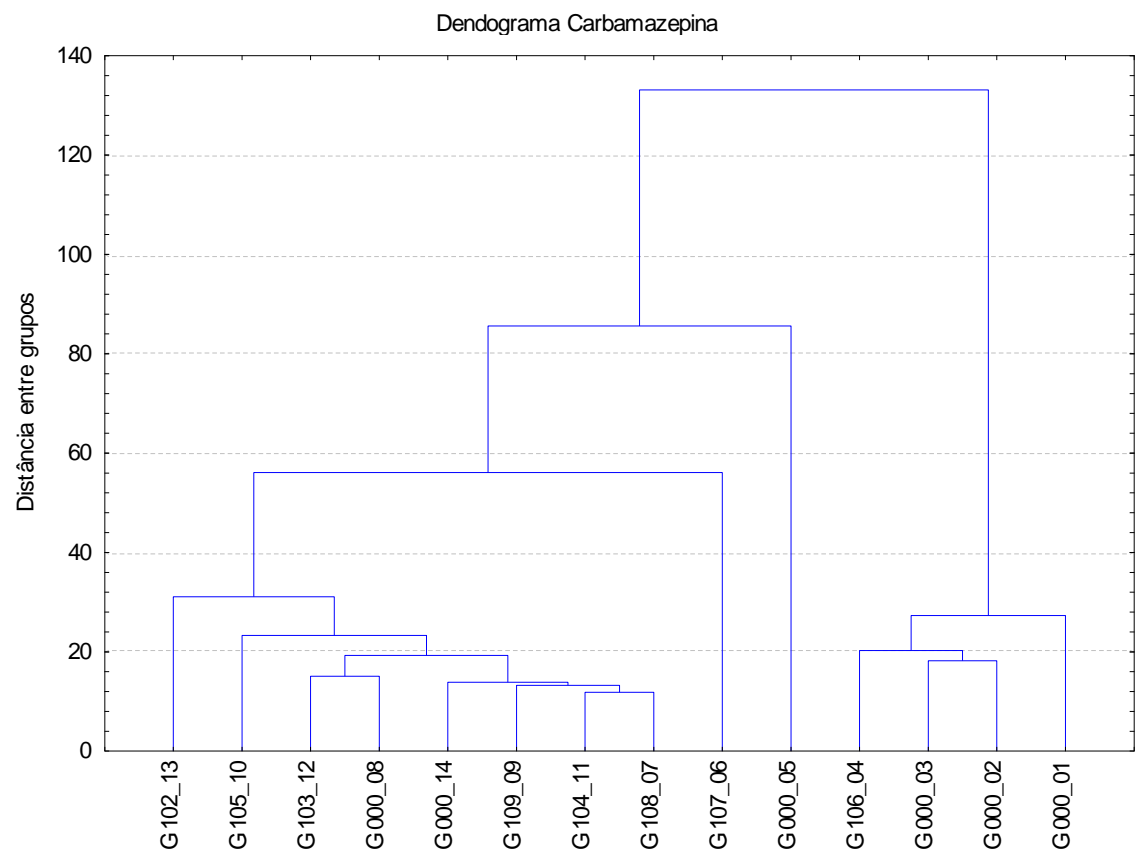

FIGURA C 3. Dendograma da distribuição da carbamazepina nas águas da represa Guarapiranga coletadas em ago./2011, set./2012 e abr./2013. 


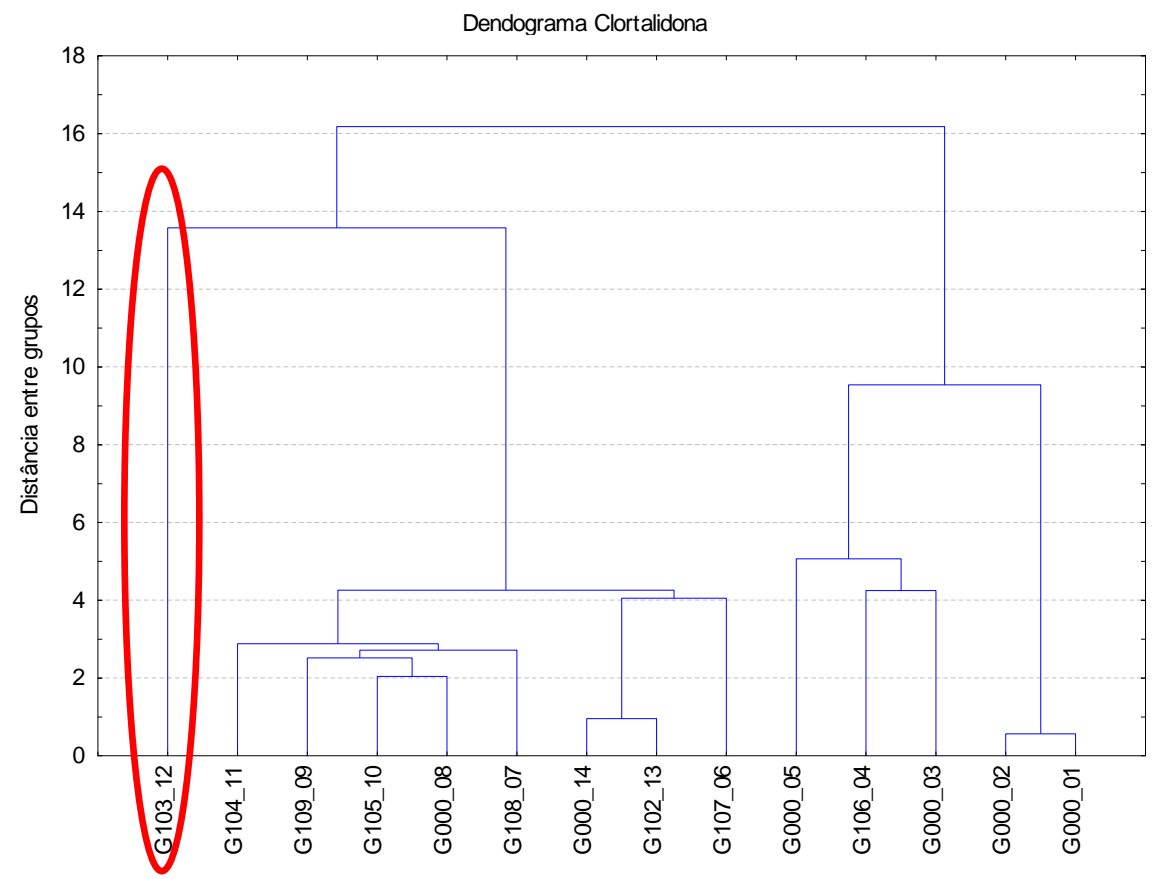

FIGURA C 4. Dendograma da distribuição da clortalidona nas águas da represa Guarapiranga coletadas em ago./2011, set./2012 e abr./2013.

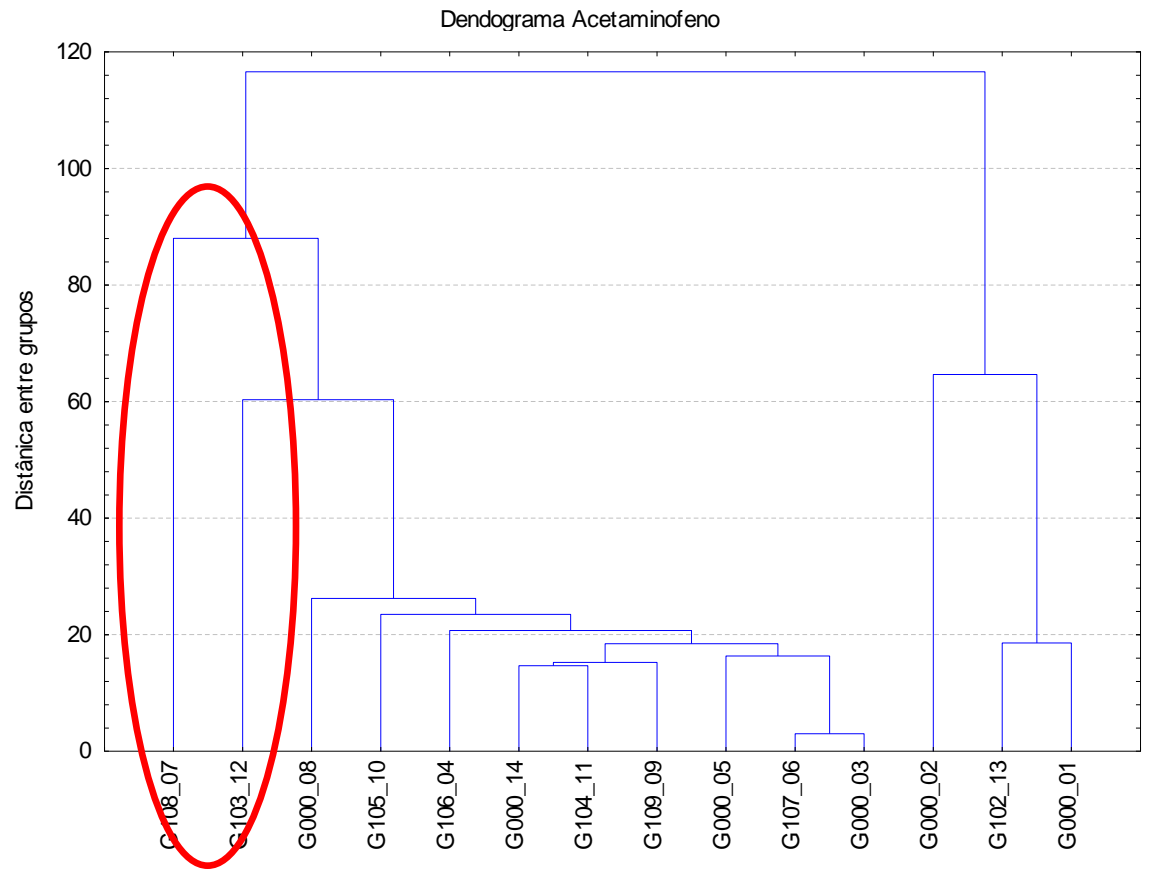

FIGURA C 5. Dendograma da distribuição do acetaminofeno nas águas da represa Guarapiranga coletadas em ago./2011, set./2012 e abr./2013. 


\section{APENDICE D}

Cálculo do índice de riscos integrado de poluição química aquática (“Integrated Risk Index of Chemical Aquatic Pollution - IRICAP").

O IRICAP foi calculado pela Eq. C1:

$\boldsymbol{I R I C A P}=\frac{\sum\left(H I_{i} \times C_{i N}\right)+\left(H_{j} \times C_{j N}\right)+\cdots\left(H I_{n} \times C_{n N}\right)}{\text { Número de Composto Químico }} \quad$ Equação C1

Onde:

$C_{i N}=$ concentração normalizada do composto i de um dado local de amostragem e, $\mathrm{HI}=$ índice de perigo ("Hazard index")

A $C_{i N}$ foi obtida pela Eq. C2:

$$
C_{i N}=\frac{C_{i}-C_{\min }}{C_{\operatorname{má} x}-C_{\min }} \quad \text { Equação C 2 }
$$

Onde;

$C_{i}=$ concentração do composto i num dado local da amostragem,

$C_{\text {min }}=$ concentração mínima do composto i obtida num dado local da amostragem, e

$C_{\text {máx }}=$ concentração máxima do composto i obtida num dado local da amostragem. 
Os valores de $\mathrm{HI}$ adotados neste trabalho, TAB. D1, foram calculados por FÀBREGA et al. (2013) com base nos Mapas Auto Organizáveis ("SelfOrganizing Maps, SOM'), uma rede neural artificial (RNA), amplamente utilizados na análise de dados capazes de visualizar grande quantidade de informações para priorizar os compostos conforme as propriedades de persistência, bioacumulação e toxicidade.

No presente cálculo, apenas o composto clortalidona foi excluído por não dispor do valor HI.

TABELA D1. Índice de perigo (HI) calculado com base no SOM por FÁBREGA (2013)

\begin{tabular}{lc}
\hline \multicolumn{1}{c}{ Compoto } & $\mathrm{HI}$ \\
\hline Acetamiofeno & 1,53 \\
Atenolol & 1,64 \\
Benzoilegonina & 1,24 \\
Cafeína & 1,53 \\
Carbamazepia & 3,02 \\
Cocaína & 2,55 \\
Diclofenaco & 2,12 \\
Enalapril & 1,76 \\
Losatana & 3,32 \\
Valsartana & 2,21 \\
\hline
\end{tabular}

Na TAB. D2 a D4 são apresentadas as concentrações normalizadas, dos fármacos quantificados nas coletas de ago./2011, set./2012 e abr./2013, conforme a Eq. C2. 
TABELA D2. Concentração normalizada de acetaminofeno, atenolol, benzoilecgonina, cafeína, carbamazepina, cocaína e losartana quantificada na coleta de ago./2011.

\begin{tabular}{|c|c|c|c|c|c|c|c|c|}
\hline \multirow{2}{*}{$\begin{array}{l}\text { Local de } \\
\text { Coleta }\end{array}$} & \multicolumn{8}{|c|}{ Concnetração Normalizada - ng L L-1 - Coleta ago/2011 } \\
\hline & Acetaminofeno & Atenolol & Benzoilecgonina & Cafeína & Carbamazepina & Cocaína & Diclofenaco & Losartana \\
\hline G000_01 & 0,736 & 0,024 & 0,000 & 0,020 & 0,000 & 0,154 & 1,000 & $<L D$ \\
\hline G000_02 & 1,000 & 0,032 & 0,074 & 0,344 & 0,009 & 0,189 & $<L Q$ & $<L D$ \\
\hline G000 03 & 0,134 & 0,000 & 0,104 & 0,003 & 0,138 & 0,106 & $<L Q$ & $<L D$ \\
\hline G106_04 & 0,046 & 0,038 & 0,142 & 0,000 & 0,356 & 0,000 & $<L Q$ & $<L D$ \\
\hline G000_05 & 0,190 & 0,393 & 0,281 & 0,004 & 0,604 & 0,186 & $<L Q$ & $<L Q$ \\
\hline G107_06 & 0,147 & 0,990 & 1,000 & 0,362 & 0,852 & 0,522 & 1,000 & $<L Q$ \\
\hline G108_07 & 0,400 & 0,545 & 0,318 & 0,012 & 0,850 & 0,235 & $<L Q$ & $<L Q$ \\
\hline G000_08 & 0,257 & 0,525 & 0,311 & 0,011 & 0,798 & 0,406 & $<Q Q$ & $<L D$ \\
\hline G109_09 & 0,067 & 0,470 & 0,265 & 0,003 & 0,807 & 0,211 & $<L Q$ & $<L Q$ \\
\hline G105_10 & 0,000 & 0,889 & 0,808 & 1,000 & 0,890 & 0,597 & $<Q Q$ & 0,812 \\
\hline G104_11 & 0,138 & 0,570 & 0,251 & 0,012 & 0,887 & 0,169 & $<L Q$ & 0,564 \\
\hline G103_12 & 0,323 & 1,000 & 0,521 & 0,690 & 0,856 & 1,000 & $<L Q$ & 1,000 \\
\hline G102_13 & 0,743 & 0,757 & 0,597 & 0,446 & 1,000 & 0,482 & $<L Q$ & 0,000 \\
\hline G000_14 & 0,106 & 0,496 & 0,515 & 0,013 & 0,829 & 0,150 & $<L d$ & 0,760 \\
\hline
\end{tabular}

$\mathrm{LD}=$ Limite de Deteç̧ão do Método; $\mathrm{LQ}=$ Limite de Quantificaçãao do Método

TABELA D3. Concentração normalizada de acetaminofeno, atenolol, benzoilecgonina, cafeína, carbamazepina, cocaína, losartana e valsartana quantificada na coleta de set./2012.

\begin{tabular}{|c|c|c|c|c|c|c|c|c|c|}
\hline \multirow{2}{*}{$\begin{array}{l}\text { Local de } \\
\text { Coleta }\end{array}$} & \multicolumn{9}{|c|}{ Concnetração Normalizada - ng L ${ }^{-1}$ - Coleta set2012 } \\
\hline & Acetaminofeno & Atenolol & Benzoilecgoni & Caféína & Carbamazepina & Cocaína & Diclofenaco & Losartana & Valsartana \\
\hline G000_01 & $<L Q$ & 0,070 & $<L Q$ & 0,151 & $<L Q$ & 0,000 & $<L Q$ & 0,000 & $<L Q$ \\
\hline G000_02 & 0,144 & 0,037 & 0,000 & 0,426 & 0,000 & 0,008 & $<L$ & 0,026 & $<L Q$ \\
\hline 000003 & 0,050 & 0,068 & 0,095 & 0,088 & 0,125 & 0,001 & $<L Q$ & 0,139 & $<L Q$ \\
\hline 10604 & $<L Q$ & 0,066 & 0,130 & 0,000 & 0,263 & $<L Q$ & $<L Q$ & 0,250 & $<L Q$ \\
\hline 1000_05 & $<L Q$ & 0,065 & 0,140 & 0,007 & 0,238 & $<L Q$ & $<L Q$ & 0,209 & $<L Q$ \\
\hline 107 o6 & 0,044 & 0,199 & 0,378 & 0,086 & 0,776 & 0,028 & $<L Q$ & 0,515 & 0,124 \\
\hline G108_07 & 1,000 & 0,247 & 0,477 & 1,000 & 0,912 & 0,068 & $<L Q$ & 0,488 & 0,142 \\
\hline $000 \_08$ & 0,051 & 0,042 & 0,253 & 0,097 & 0,903 & 0,021 & $<L Q$ & 0,252 & 0,000 \\
\hline 109 & 0,034 & 0,073 & 0,240 & 0,053 & 0,977 & $<L Q$ & $<L Q$ & 0,362 & 0,044 \\
\hline G105_10 & 0,034 & 0,037 & 0,342 & 0,371 & 0,741 & $<L Q$ & $<L Q$ & 0,157 & $<L Q$ \\
\hline 104_11 & 0,035 & 0,020 & 0,246 & 0,073 & 0,970 & $<L D$ & $<L Q$ & 0,429 & 0,013 \\
\hline 103 & $<\mathrm{LQ}$ & 1,000 & 1,000 & 0,639 & 0,955 & 1,000 & 1,000 & 1,000 & 1,000 \\
\hline 3102_13 & 0,000 & 0,025 & 0,185 & 0,128 & 1,000 & $<L Q$ & $<L Q$ & 0,431 & 0,037 \\
\hline G000_14 & $<L Q$ & 0,000 & 0,172 & 0,149 & 0,983 & $<L Q$ & $<Q Q$ & 0,357 & 0,026 \\
\hline
\end{tabular}


TABELA D4. Concentração normalizada de acetaminofeno, atenolol, benzoilecgonina, cafeína, carbamazepina, cocaína e losartana quantificada na coleta de abr./2013.

\begin{tabular}{|c|c|c|c|c|c|c|c|}
\hline \multirow{2}{*}{$\begin{array}{c}\text { Local de } \\
\text { Coleta }\end{array}$} & \multicolumn{7}{|c|}{ Concnetração Normalizada - ng L ${ }^{-1}$ - Coleta abr/2013 } \\
\hline & Acetaminofeno & Atenolol & Benzoilecgonina & Cafeína & Carbamazepina & Cocaína & Losartana \\
\hline G000_01 & $<L Q$ & $<L Q$ & $<\mathrm{LQ}$ & 0,002 & $<L Q$ & 0,054 & $<L D$ \\
\hline GO00_02 & $<L D$ & 0,000 & $<\mathrm{LQ}$ & 0,001 & 0,000 & $<L Q$ & $<L Q$ \\
\hline G000_03 & $<L D$ & 0,026 & 0,000 & 0,000 & 0,011 & 0,037 & $<L Q$ \\
\hline G106_04 & $<L D$ & 0,021 & 0,028 & 0,000 & 0,018 & $<L Q$ & $<L Q$ \\
\hline G000_05 & $<L Q$ & 0,160 & 0,233 & 0,001 & 0,417 & 0,089 & 0,000 \\
\hline G107_06 & $<L Q$ & 0,345 & 0,386 & 0,001 & 0,536 & 0,124 & 0,307 \\
\hline G108_07 & 1,000 & 0,471 & 0,630 & 0,014 & 0,842 & 0,229 & 1,000 \\
\hline G000_08 & 0,009 & 0,226 & 0,401 & 0,006 & 0,716 & $<L Q$ & 0,328 \\
\hline G109_09 & 0,012 & 0,229 & 0,221 & 0,009 & 0,813 & 0,078 & $<L Q$ \\
\hline G105_10 & 0,195 & 0,315 & 0,421 & 0,007 & 0,704 & 0,048 & 0,704 \\
\hline G104_11 & 0,035 & 0,253 & 0,292 & 0,008 & 0,867 & 0,023 & 0,263 \\
\hline G103_12 & 0,617 & 1,000 & 1,000 & 1,000 & 0,756 & 1,000 & 0,834 \\
\hline G102_13 & 0,007 & 0,201 & 0,257 & 0,010 & 1,000 & 0,026 & 0,424 \\
\hline G000 14 & 0,000 & 0,246 & 0,258 & 0,010 & 0,908 & 0,000 & 0,720 \\
\hline
\end{tabular}




\section{REFEÊNCIAS BIBLIOGRÁFICAS}

ABQUIM - Associação Brasileira da Insustria Química. O desempenho da industria química em 2013. Disponível em:

$<$ http://www.abiquim.org.br/pdf/Livro Desempenho da Industria Quimica.pdf > Acesso em: nov de 2014.

ALMEIDA, G. A.; WEBER, R. R. Fármacos na Represa Billings. Revista Saúde e Ambient/Health and Environ. J. v. 6, n. 2, p. 7-13,2005.

AL-ODAINI, N. A.; ZAKARIA, M. P.; YAZIZ, M. I.; SURIF, S. Multi-residue analytical methods for human pharmaceuticals and synthetic hormones in river water and sewage efluents by solid-phase extraction and liquid chromatographytandem mass spectrometry. J. Chromatogr. A., v. 1217,.p. 6791-6806, 2010.

ANDRADE, A. A. S. Análise da eficiência da Várzea do Ribeirão Parelheiros na melhoria da qualidade das águas que afluem à Represa Guarapiranga, São Paulo. 2005. Dissertação (Mestrado). Universidade de São Paulo, São Carlos.

ANDRADE, M. R. M. Planejamento Ambiental da APA Cabuçu-Tanque Grande, Guarulhos, SP. Tese (Doutorado). Faculdade de Filosofia, Letras e Ciências Sociais da Universidade de São Paulo, 2009

ANUMOL, T.; SNYDER, S. A. Rapid analysis of trace organic compounds in water by automated online soli-phase extraction coupled to liquid chromatographytandem mass spectrometry. Talanta, v. 132, p. 77-86, 2015.

ANVISA - Agência Nacional de Vigilância Sanitária. Guia para validação de métodos analíticos e bioanalíticos. RE-899. Brasília, 29 de Maio de 2003.

ARDREY R. E. Liquid chromatography-mass spectrometry: An introduction. Wiley: Huddersfield, 2003.

BAKER, D. R.; KRASPRZYK-HORDERN, B. Multi-residue analysis of drugs of abuse in wastewater and surface water by solid-phase extraction and liquid chromatography-positive electrospray ionisation tandem mass spectrometry. J. Chromatogr. A., v. 1218, p. 1620-1631, 2011.

BARREK, S.; CREN-OLIVÉ, C.; WIEST, L.; BAUDOT, R. Multi-residue analysis and ultra-trace quantitation of 36 priority substances from the European Water Directive by GC-MS and LC-FLD-MS/MS in surface waters. Talanta, v. 79, p. 712-722, 2009. 
BENDZ, D.; PAXÉUS, A.; GINN, T. R.; LOGE, F. J. Occurrence and fate of harmaceutically active compounds in the envrironment, a case study: Höje River in Sweden. J. Hazard. Mater., v. 122, p. 195-204, 2005.

BENIJTS, T.; DAMS, R.; LAMBERT, W.; DE LEENHEER, A. Countering matrix effects in environmental liquid chromatography-electrospray ionization tandem mass spectrometry water analysis for endocrine disrupting chemicals. J. Cromatogr. A., v. 1029, p. 153-159, 2004.

BENOTTI, M. J.; VANDERFORD, A. J.; VANDERFORD, B. J.; HOLADY, J. C.; STANFORD, B. D.; SNYDER, S. A. Pharmaceuticals and endocrine disrupting compounds in U.S. Drinking water. Environ. Sci. Technol., v. 43, p. 597-603, 2009.

BEYRUTH, Z. Periodic disturbances, trophic gradient and phytoplankton characterisics related to cyanobacterial growth in Guarapiranga reservoir, São Paulo State, Brazil. Hydrobiologia, v. 424, p. 51-65, 2000.

BILA, D. M.; DEZOTTI, M. Fármacos no meio ambiente. Química Nova, v. 26, p. 523-530, 2003.

BONES, J.; THOMAS, K. V.; PAULL, B. Using environmental analytical data to estimate levels of community consumption of illicit drugs and abused pharmaceuticals. J. Environ. Monit., v. 9, p. 701-707, 2007.

BRASIL Ministério do desenvolvimento urbano e meio ambiente. Conselho nacional do meio ambiente (CONAMA). Resolução n. 430, D. O. U. de 13/05/2011. Brasília, 2011.

BRASIL Ministério do desenvolvimento urbano e meio ambiente. Conselho nacional do meio ambiente (CONAMA). Resoluçao n. 357, D.O.U. de 17/03/05. Brasília, 2005.

BRITO C. F. Desenvolvimento e validação de metodologia analítica para determinação de hidrocarbonetos policíclicos aromáticos (HPAs) em sedimentos. Avaliação da represa do Parque Pedroso, Santo André. Dissertação (Mestrado).2009: Instituto de Pesquisas Energéticas e Nucleares/Universidade de São Paulo, São Paulo.

BUENO, M. J. M.; UCLÉS, S.; HERNANDO, M. D.; FERNÁNDEZ-ALBA, A. R. Development of a solvent-free method for the simultaneous identification/quatification of drugs of abuse and their metabolites in environmental water by LC-MS/MS. Talanta, v. 85, p. 157-166, 2011. .

BUERGE, I J.; POIGER, T.; MÜLLER, M. D.; BUSE, H-R Caffeine, an anthropogenic maarker for wastewater contaminantion of surface waters.

Environ. Sci. Technol., v. 37, n. 4, p. 691-700, 2003. 
CALAMARI, D.; ZUCCATO, E.; CASTIGLIONI, S.; BAGNATI, R.; FANELLI, R. Strategic survey of therapeutic drugs in the rivers Po and Lambro in northern Italy. Environ. Sci. Technol., v. 37, p. 1241-1248, 2003.

CARVALHO M. C. Comunidade ftoplanctônica como instrumento de biomonitoramento de reservatórios do Estado de São Paulo. 2003. Tese (Doutorado). Universidade de Aão Paulo.

CASTIGLIONE, S.; BAGNATI, R.; CALAMARI, D.; FANELLI, R.; ZUCCATO, E. A multireside analytical method using solid-phase extraction and high-pressure liquid chromatography tandem mass spectrometry to measure pharmaceuticals of different therapeutic classes in urban wastewaters. J. Chromatogr. A, v. 1092, p. 206-215, 2005.

CELLE-JEANTON, H.; SCHEMBERG, D.; MOHAMMED, N.; HUNEAU, F.; BERTRAND, G.; LAVASTRE, V.; LE COUSTUMER, P. Evaluation of pharmaceuticals in surface water: Reliability of PECs compared to MECs. Environ. Int., v. 73, p. 10-21, 2014.

CETESB - Companhia de Tecnologia de Saneamento Ambiental. Relatório de qualidade de águas interiores do Estado de São Paulo. São Paulo, 2007.

CHIARADIA, M. C.; COLLINS, C. H.; JARDINS, I. C. S. F. O estado da arte da cromatografia associada à espectrometria de massas acoplada à espectrometria de massas na análise de compostos tóxicos em alimentos. Quim. Nova, v. 31, n. 3, p. 623-636, 2008.

CHUI, Q. S. H.; BARROS, C. B.; SILVA, T. D. Parâmetros r e R obtidos de programa interlaboratorial - como usa-los. Quím. Nova, v. 32, n. 8, p. 2209 2213, 2009.

CLARA M.; STRENN, B.; KREUZINGER, N. Carbamazepine as a possible anthropogenic marker in the aquatic environment: investigation on the behavoir of carbamazepine in wastewater treatment and during groundwater infiltration. Water Res., v. 38. p. 947-954, 2004.

CLEUVERS M. Aquatic ecotocixiy of pharmaceuticals including the assessment of combination effects. Toxicol. Lett., v. 142, p. 185-194, 2003.

CLEUVERS M. Initial risk assessment for three $\beta$-blockers found in the aquatic environment. Chemosphere, v. 59, p. 199-205, 2005.

CNPq - Conselho Nacional de desenvolvimento Científico e Tecnológico. Análise de esgoto permite mapear áreas de consumo e refino de drogas. Disponível em: $<$ http://www.bv.fapesp.br/namidia/noticia/44873/analise-esgoto-permite-mapearareas > Acesso em: 12 de jan de 2012. 
COLBORN, T.; DUMANOSK, D.; MIYERS, J. P. O futuro roubado. 2002.

Tradução Claudia Buchweltz, Editora L\&PM, Porto Alegre, RS.

COSTA, C. R.; OLIVI, P.; BOTTA, C. M. R.; ESPINDOLA, E. L. G. A toxicidade em ambientes aquáticos: discussão e métodos de avaliação. Quim. Nova, v. 31, n. 7, p. 1820-1830, 2008.

CUNNINGHAM, V. L.; C., CONSTABLE D. J.; HANNAH, R. E. Environmental risk assessment of paroxetine. Environ. Sci. Technol., v. 38, p. 3351-3359, 2004.

DANESHVAR, A.; ABOULFADL, K.; VIGLINO, L.; BROSÉUS, R.; SAUVÉ, S.; MADOUX-HUMERY, A.-S.; WEYHENMEYER, G. A.; PRÉVOST, M. Evaluating pharmaceuticals and caffeine as indicators of fecal contamination in drinking water sources of the Greater Montreal region. Chemosphere, v. 88, p. 131-139, 2012.

DIAZ-CRUZ, M. S.; BARCELÓ, D. LC-MS2 trace analysis of antimicrobials in water, sediment and soil. Trac-Trends in Anal. Chem., v. 24, n. 7, p. 645-657, 2005.

DOLE, M.; MACK , L. L.; HINES, R. L.; MOBLEY, R. C.; FERGUNSON, L. D.; ALICE, M.B. Molecular beams of macroions. J. Chem. Phys., v. 49, p. 22401249, 1968.

DRUGBANK DrugBank version 4.1 [Online] // Disponível em: <http://www.drugbank.ca>. - Acesso em: 27 de Out de 2014.

EMEA - European Medicines Agency. Guideline on the environmental risk assessment of medicinal products for human use. Commitee for Medicinal Products for Human Use. EMEA/CHMP/SWP/4447/00. 2006.

EMEA - Europen Medicines Agency. Note for the Guidance: Environmental risk assessment for veterinary medicinal products other than GMO-containing and innumological products. Veterinary Medicines Evaluation Unit.

EMEA/CVMP/055/96-FINAL. - 1998.

EURACHEM/CITAC Determinando a incertza na medição analítica. 2 ed. Vesão Brasileira. 2002.

EURACHEM/CITAC Qunatifying Uncertainty in Analytical Measurement. 3 rd Edition. 2012.

EUROPEAN COMMISSION Commission decision 2002/657/EC of 12 August 2002 Implementing council directive 96/23/EC concerning the performance of analytical methods and the interpretation of results. Official Journal European Communities. p.L221/8. - 2002. 
FÀBREGA, F.; MARQUÈS, M.; GINEBREDA, A.; KUZMANOVIC, M.; BARCELÓ, D.; SCHUHMACHER, M.; DOMINGO, J.; NADAL, M. Integrated risk index of chemical aquatic pollution (IRICAP): Case studies in lberian rivers. J. Hazard. Mat., v. 263P, p. 187-196, 2013.

FARRÉ M.; PÉREZ S.; KANTIANI L.; BARCELÓ D. Fate and toxicity of emerging pollutants, their metabolites and transformation products in the aquatic environment. Anal. Chem., v. 27, n. 11, p. 991-1007, 2008.

FDA - Food and Drugs Administration. Guidance for Industry: Environmental assessment of human drug and biologics applications. CMC 6, Revision 1. 1998.

FENT, K.; WESTON, A. A.; CAMINADA, D. Ecotoxicology of human pharmaceuticals. Aquatic Toxicol., v. 76, n. 2, p. 122-159, 2006.

FIGUEREDO F. As perspectivas futuras da indústria química // 7º Fórum ABRAFATI. 21 de agosto de 2012. Disponível em:<http://www.abrafati.com.br/wp-content/uploads/2013/06/competitividade-daindustria.pdf $>$ Acesso em nov. de 2014.

FREDHOLM, B. B.; BÄTTIG, K.; HOLMÉN, J.; NEHLIG, A.; ZVARTAU, E. E. Actions of cafeine in the brain with special reference of factors that contribute to its widespread use. Pharmacol. Rev., v. 51, n. 1, p. 83-133, 1999.

FURUSAWA H. A. Validação de Ensaios Químicos. São Paulo, IPEN-CNEN/SP (adaptação eletrônica baseada no documento DOQ-CGCRE-008 de 01/03/2003 do INMETRO). 2007.

G1.GLOBO Cantareira, Alto Tiete e Guarapiranga têm nova queda nesta segunda. 10 de 11 de 2014. Disponível em: <http://g1.globo.com/saopaulo/noticia/2014/11/cantareira-alto-tiete-e-guarapiranga-tem-nova-quedanesta-segunda.html> Acesso em: 25 de nov de 2014.

GARCIA-GALÁN, M. J.; DÍAZ-CRUZ, M. S.; BARCELÓ, D. Determination of 19 sulfonamides in water samples by automated on-line solid-phase extraction-liquid chromatography-tandem mass spectrometry (SPE-LC-MS/MS). Talanta, v. 81, p. 355-366, 2010.

GIBS, J.; STACKELBERG, P. E.; FURLONG, E. T.; MEYER, M.; ZAUGG, S. D.; LIPPINCOTT, R. L. Persistence of pharmaceuticals and other organic compounds in chlorinated drinking water as a function of time. Sci. Total Environ., v. 373, p. 240-249, 2007. 
GILTROW, E.; ECCLES, P. D.; WINTER, M. J.; MCCORMACK, P. J.; RANDWEAVER, M.; HUTCHINSON, T. H.; SUMPTER, J. P. Chronic effects assessment and plasma concentrations of the $\beta$-blocker propranolol in fathead minnows (Pimephales promelas). Aquat. Toxicol., v. 95, p. 195-202, 2009.

GÓMEZ, , M. J.; PETROVIC, M.; FERNÁNDEZ, A. R.; BARCELÓ, D. Determination of Pharmaceuticals of various therapeutic class by solid-phase extration and liquid chromatography-tandem mass spectrometry analysis in hospital effluent wastewaters. Chromatgr. A, v. 1114, p. 224-233, 2006.

GÓMEZ, M. J.; BUENO, M. J. M.; LACORTE, S.; FERNÁNDEZ-ALBA, A. R.; AGÜERA, A. Pilot suvey monitoring pharmaceuticals and related compounds in a sewage treatment plant located on the Meditaerranean coast. Chemosphere, v. 66, p. 993-1002, 2007.

GONSCHOROWSKI, G. P. C. Caracterização química de hormônios sexuais em águas de poço da região da USP via cromatografia a gás acoplada a espectrometria de massas. Dissertação (Mestrado). Instituto de Pesquisas Energéticas e Nucleares/Universidade de São Paulo, São Paulo. 2013.

GROS, M.; PETROVIC, M.; BARCELÓ, D. Multi-residue analytical methods using LC-tandem MS for the determination of pharmaceuticals in environmental and wastewater samples: a review. Anal. Bioanal. Chem., v. 386, p. 941-952, 2006.

GROS, M.; PIZZOLATO, T.M.; PETROVIC, M.; ALDA, M. J. L.; BARCELÓ, D. Trace level determination of $\beta$-blockers in waste waters by highly selective moleculary imprinted polymers extraction followed by liquid chromatographyquadrupole-linear ion trap mass spectrometry. J. Chromatogr. A, v. 1189, p. 374-384, 2008.

GROS, M.; PETROCIC, M.; BARCELÓ, D. Tracing pharmaceutical residues of different therapeutic classes in environmental waters by using liquid chromatography/quadrupole-linear ion trap mass spectrometry and automated library searching. Anal. Chem., v. 81, p. 898-912, 2009.

GROS, M.; RODRÍGUEZ-MOZAZ, S.; BARCELÓ, D. Fast and comprehensive multi-residue analysis of a broad rang human and veterinary pharmaceuticals and some of their metabolites in surface and treated waters by ultrai-highperformance liquid chromatograhy coupled to quadrupole-linear ion trap tandem mass. J. Chromatog. A, v. 1248, p. 104-121, 2012.

GUERRA A. E. Qualidade e eficiência dos serviços de saneamento. In: Atlas de saneamento 2011. IBGE, Rio de Janeiro, p.27-44, 2011.

HEBERER T. Occurrence, fate, and removal of pharmaceutical residues in the aquatic environmental: a review of recent research data. Toxicol. Lett., v. 131, p. $5-17,2002$. 
HIGDON, J. V.; BALZ, F. Coffe and health: a review of recent human research. Crit. Rev.in Food Sci., v. 46, p. 101-123, 2006.

HILTON, M. J.; THOMAS, K. V. Determination of selected human pharmaceutical compounds in effluent and surface water samples by high-performance liquid chromatography-electrospray tandem mass spectrometry. J. Chromatogr. A, v. 1015. p. 129-141, 2003.

HOEGER, B.; KÖLLNER, B.; DIETRICH, D. R.; HITZFELD, B. Water-bone diclofenac affects kidney and gill integrity and selected immune parameters in brown trout (Salmo trutta f. fario). Aquat. Taoxiclol., v. 75, p. 53-64, 2006.

HORWITZ, W.; ALBERT, R. The Horwitz ratio (HorRat): a useful index of method performance with respect to precision. J. AOAC Int., v. 89, n. 4, p. 1095-1109, 2006.

IBANEZ, M.; SANCHO, J. V.; POZO, O. J.; NIESSEN, W.; HERNANDEZ, F. Use of quadrupole time-of-flight mass spectrometry in the elucidation of unknown compounds present in environmental water. Rapid Commun. Mass Spectrom., v. 19, n. 2, p. 169-178, 2005.

IBGE - Instituto Brasileiro de Geografia e Estatística. Sintese de Indicadores Sociais. Uma análise das condições de vida da população brasileira. 2010, 317p.

IBGE - Instituto Brasileira de Geografia e Estatística. Brasil avança rumo ao desenvolvimento sustentável, mas ainda tem muitos desafios a enfrentar. - IDS 2012, 18 de junho de 2012. Disponível em:

$<$ http://www.ibge.gov.br/home/presidencia/noticias/noticia visualiza.php?id notic ia=2161\&id pagina $=1>$ acesso em: outubro de 2012>.

INMETRO - Instituto Nacional de Metrologia, Normalização e Qualidade Industrial. Orientação sobre validação de métodos de ensaios químicos. Rio de Janeiro. DOQ-CGCRE-008. Revisao 01. Mar. de 2003.

INMETRO - Instituto Nacional de Metrologia, Normalização e Qualidade Industrial. Orientação sobre validação de métodos de ensaios químicos. Rio de Janeiro. DOQ-CGCRE-008. Revisão 02. Jun. de 2007.

INMETRO - Instiuto Nacional de Mtrologia, Normalização e Qualidade Industrial. Vocabulário Internacional de Metrologia: Concentitos fundamentais e gerais e termos associados (VIM2008). Rio de Janeiro. Primeira Edição Bras. 2009.

INMETRO - Instituto Nacioanl de Metrologia, Normalização e Qualidade Industrial. Orientação sobre validação de métodos de ensaios químicos. Rio de Janeiro. DOQ-CGCRE-008. Revisão 03. Fev de 2010. 
INMETRO - Instituto Nacional de Metrologia, Normalização e Qualidade Industrial. Orientação sobre validação de métodos de ensaios químicos. Rio de Janeiro. DOQ-CGCRE-008. Revisão 04. Jul. de 2011.

IRIBANI, J. V.; THOMASON, B.A. On the evaporation of small ions from charged droplets. J. Chem. Phys., v. 64, n. 6, p. 2287-2294, 1976.

IRRIGART - Engenharia e Consultoria em Recursos Hídricos e Meio Ambiente Ltda. Plano de gerenciamento integrado para remediação e proteção dos recursos hídricos da sub-bacia do Atibaia com ênfase ao reservatório de Salto Grande - Americana - SP. Piracicaba. 2006. Disponível em: www.comitepci.sp.gov/download/PGISaltoGrande Relatório.pdf Acesso em: 28/01/2015.

JARDIM, I. C. S. F. Extração em fase sólida: fundamentos teóricos e novas estratégias para preparação de fases sólidas. Sci. Chromatogr., v. 2, n. 1, p. 1325, 2010.

JELIC, A.; PETROVIC, M.; BARCELÓ, D. Multi-residue mehod for trace level deermination of harmaceuticals in solid samples using pressurized liquid extraction followed by liquid chromatography/quadrupole-Inear ion trap spectrometry. Talanta, v. 80, p. 363-371, 2009.

JJEMBA P. K. Excretion and ecotocixity of pharmaceutical and personal care products in the environment. Ecotoxicol. Environ. Safety, v. 63, p. 113-130, 2006.

JURATO, A.; LÓPEZ-SERNA, R.; VÁZQUEZ-SUNÉ, E.; CARRERA, J.; PUJADES, E.; PETROVIC, M.; BARCELÓ, D. Occurrence of carbamazepine and five metabolites in an urban aquifer. Chemosphere, v. 115, p. 47-53, 2014.

KAROLAK, S.; NEFAU, T.; BAILLY, E.; SOLGADI, A.; LEVI, Y. Estimation of illicit drugs consumption by wastewater analysis in Paris area (France). Forensic Sci. Int., v. 200, p. 153-160, 2010.

KIM, Y.; CHOI, K.; JUNG, J.; PARK, S.; KIM, P.-G; PARK, J. Aquatic toxicity of acetaminophen, carbamazepine, cimetidine, diltiazem and six major sulfonamides, and their potential ecological risks in Korea. Environ. Int., v. 33, p. 370-375, 2007.

KLOEPFER, A.; QUINTANA, J. B.; REMTSMA, T. Operational options to reduce matrix effects in liquid crhomatography-electrospray ionization-mass spectrometry analysis of aqueous environmetal samples. J. Chromatogr. A, v. 1067, p. 153-160, 2005. 
KLOSTERHAUS, S. L.; GRACE, R.; HAMILTON, M.C.; YEE, D. Method validation and reconnaissance of pharmaceuticals, personal care products, and alkylphenols in surface water, sediments, and mussels in an urban estuary. Environ. Int., v. 54, p. 92-99, 2013.

KÓLAR, M.; URBANEK, K.; LÁTAL, T. Antibiotic selective pressure and development of bacterial resitance. Inter. J. Antimicrob. Agents., v. 17, p. 357363, 2001.

KOLPIN, D. W.; FURLONG, E. T.; MEYER, M. T.; M., THURMAN E.; ZAUGG, S. D.; BARBER, L. B.; BUXTON, H. T. Pharmaceuticals, hormones, and others organic wastewater contaminants in U. S. streams, 1999=2000: a national reconnaissance. Environ. Sci. Technol., v. 36, p. 1202-1211, 2002.

KOSTOPOULOU, M.; NIKOLAOU, A. Analytical problems and the need for sample preparation in the determination of pharmaceuticals and their metabolites in aqueous environmental matrices. Trends in Anal. Chem., v. 27, n 11, p. 1023-1035, 2008.

LAJEUNESSE, A.; GAGNON, C.; SAUVÉ, S. Determination of basic antidepressants and their $n$-desmethyl metabolites in raw sewage and wastewater using solid-phase extraction and liquid chromatography-tandem mass spectrometry. Anal.Chem., v. 80, p. 5325-5333, 2008.

LANÇAS F. M. Extração em fase sólida (SPE). RIMA. São Carlos, 2004.

LEITE, I. Nível da Guarapiranga tem queda de 25,5 pontos percentuais em um ano. G1.Globo.com. 12 de set de 2014. Disponível em: <http://g1.globo.com/saopaulo/noticia/2014/09/nivel-da-guarapiranga-tem-queda-de-255-pontospercentuais-em-um-ano.html>. Acesso em: 13 de set de 2014.

LIMEIRA Prefeitura Municipal de Limeira Disponível em :

http://www.limeira.sp.gov.br/municipio/04.htm, Acesso em: 12 de fev. de 2015.

LIN, A.Y.-C.; YU, T. -H.; LATEEF, S. K. Removal of pharmaceuticals in secondary wastewater treatment processes in Taiwan. J. Hazard. Mater., v. 167, p. 11631169, 2009.

LIN, A. Y.-C.; WANG, X.-H.; LIN, C.-F. Impact of wastewaters and hospital effluents on the occurrence of coontroled substances in surface waters. Chemosphere, v. 81, p. 562-570, 2010.

LÓPEZ-SERNA, R.; PETROVIC, M.; BARCELÓ, D. Development of fast instrumental method for the analysis of pharmaceuticals in enveronmental and wastewaters based on ultra high performance liquid chromatography (UhPLC)tandem mass spectrometry (MS/MS). Chemosphere, v. 85, p. 1390-1399, 2011. 
LOSS, R.; GAWLIK, B. M..; LOCORO, G.; RIMSVICIUTE, E.; CONTINI, S.; BIDOGLIO, G. EU-wide survey of polar organic persistent pollutants in European river waters. Environ. Poll., v. 157, p. 561-568, 2009.

LOSS, R.; LOCORO, G.; CONTINI, S. Occurrence of polar organic contaminants in the dissolved water phase of the Danubio River and its major tributaries using SPE-LC-MS2 analysis. Water Res., v. 44, p. 2325-2335, 2010.

MARTINS JUNIOR, H. A.; BUSTILLOS, O. V.; PIRES, M. A. F. Determinação de resíduos de cloranfenicol em amostras de leite e mel industrializados utilizando a técnica de espectrometria de massas em "tandem"(CLAE-EM/EM). Quim. Nova, v. 29, n, 3, p. 586-592, 2006.

MATEUS, R. S. Modelo hidrográfico da bacia hidrográfica da represa Guarapiranga - São Paulo (SP). Dissertação (Mestrado). Faculdade de Filosofia e Ciências Humanas. Universidade de São Paulo, São Paulo. 2006.

MATSUMURA-TUNDISI, T.; TUNDISI, J. G. Checklist dos Copepoda Calanoida de água doce do Estado de São Paulo. Biota Neotrop., v. 11, n. 1, p. 551-557, 2011.

MATSUZAKI M. Transposição das águas do braço Taquacetuba da represa Billings para a represa Guarapiranga: aspectros relacionados à qualidade de água para abastecimento. Dissertação (Mestrado). Faculdade de Saúde Pública; Universidade de São Paulo. São Paulo. 2007.

MELO, S. A. S.; TROVÓ, A. G.;BAUTITZ, I. R.; NOGUEIRA, R. F. P. Degradação de fármacos residuais por processos oxidativos avançados. Quim. Nova, v.32, n. 1, p 188-197, 2009.

MELLO-DA-SILVA, C.; FRUCHTENGARTEN, L. Riscos químicos ambientias à saúde da criança. J. de Pediatria, v. 81, n. 5, p. S205-S211, 2005.

MODA, T. L. Desenvolvimento de modelo in silico de propriedades de ADME para a triagem de novos candidatos a novos fármacos. Dissertação (Mestrado). Universidade de São Paulo, São Carlos. 2007.

MOLDOVAN, Z. Occurrences of pharmaceutical and personal care products as micropollutants in rivers from Romania. Chemosphere, v. 64, p. 1808-1817, 2006.

MOMPELAT, S.; LE BOT, B.; THOMAS, O. Occurrence and fate of pharmaceutical product and by-products, from resource to drinking water. Environ. Int., v. 35, p. 803-814, 2009. 
MORAES, M. C.; LAGO, C. L. Espectrometria de massas com ionização por "'electrospray" aplicada ao estudo de espécies inorgânicas e organometálicas. Quim. Nova, v. 26, n. 4, p. 556-563, 2003.

MOZETO, A. A.; SILVERIO, P. F.; SOARES, A. Estimates of benthic fluxes of nutrients across the sediment-water interface (Guarapiranga reservoir, São Paulo, Brazil). Sci. Total Environ., v. 266, n. 1-3, p. 135 -142, 2001.

MULROY, A. Monitoring and analysis of water wastes. Water Environ. Technol., v. 13, p. 32-36, 2001.

NIESSEN, W. M. A. Liquid Chromatography Mass Spectrometry In:

Chromatographic Science Series. Ed. Group Taylor \& Trancis. CRC Press. Third Eddition, 2006.

NÓDLER, K.; LICHA, T.; BESTER, K.; SAUTER, M. Development of a multiresidue analytical method, based on liquid chromatography-tandem mass spectrometry, for the simultaneous determination of 46 micro-contaminants in aqueous samples. J. Chromatogr. A, v. 1217, p. 6511-6521, 2010.

NUIJS, A. L. N. van; PECCEU, B.; THEUNIS, L.; DUBOIS, N.; CHARLIER, C.; JORENS, G.; BERVOETS, L.; BLUST, R.; NEELS, H.; COVACI, A. Cocaine and metabolites in waste and surface water across Belgium. Environ. Poll., v. 157, p. 123-129, 2009.

NUIJS, A. L. N. van; CASTIGLIONI, S.; TARCOMNICU, I.; POSTIGO, C.; ALDA, M. L. DE; NEELS, H.; ZUCCATO, E.; BARCELO, DAMIA; COVACI, A. Illicit deug consumption estimations derived from wastewater analysis: a critical review. Sci. Total Environ.,v. 409, p. 3564-3577. 2011.

OLIVEIRA, C. L. Esteróis como marcadores químicos em águas destinadas ao abastecimento público na região do Rio Paraíba do Sul, SP. Desenvolvimento e validação de metodologia analítica. Dissertação (Mestrado). Instituto de Pesquisas Energéticas e Nucleares/Univerdidade de São Paulo, São Paulo, 2012.

OTOMO, J. I. Desenvolvimento e validação de metodologia analítica para determinação de hormônios, considerados disruptores endócrinos, nas águas destinadas ao abastecimento público na região do Rio Paraíba do Sul, SP. Dissertação (Mestrado). Instituo de Pesquisas Energéticas e Nucleares/Uiversidade de São Paulo, São Paulo, 2010.

PAILLER, J.-Y.; KREIN, A.; HOFFMANN, L.; GUIGNARD, C. Solid phase extraction coupled to liquid chromatography-tandem mass spectrometry analysis of sulfonamides, tetracyclines, analgesics ad hormones in surface water and wastewater in Luxembourg. Sci. Total Environ., v. 407, p. 4736-4743, 2009. 
PASCHOAL, J. A. R.; AIROLD, F. P. DA S.; AIROLD, F. P.da S.; REYES, G. R. Validação de métodos cromatográficos para a determinação de resíduos de medicametos veterinários em alimentos. Quim. Nova, v. 31, n. 5, p. 1190 - 1198, 2008.

PATRICK, G. Medical Chemistry In Instant Notes Serius. BIOS Scientific Publishers Itd, 2001.

PETROVIC, M.; HERNANDO, M. D.; DIAZ-CRUZ, M. S.; BARCELÓ, D. Liquid chromatography-tandem mass spectrometry for the analysis of pharmaceutical residues in environmental samples: a review. J. Chromatogr. A, v. 1067, p. 114, 2005.

PETROVIC, M.; FARRÉ, M.; ALDA, M. L.; PEREZ, S.; POSTIGO, C.; KOCK, M.; RADJENOVIC, J.; GROS, M.; BARCELÓ, D. Recent trends in the liquid chromatography-mass spectrometry analysis of organic contaminants in environmental samples. J. Chromatogr. A, v. 1217, p. 4004-4017, 2010.

PNUMA - Programa das Nações Unidas para o Meio Ambiente. Disponível em: <http://www.pnuma.org.br/interna.php?id=52> Acesso em: 25 de nov de 2014.

POSTIGO, C.; ALDA, M. J. L.; BARCELÓ, C. Fully automated determination in the low nanogram per liter level of different classes of drugs of abuse in sewage water by on-line solid-phase extraction-liquid chromatography-electrospraytandem mass spectrometry. Anal. Chem., v. 80, p. 3123-3134, 2008.

PRAMANIK, B. N.; GANGULY, A. K.; GROSS, M. L. Applied Electrospray Mass Spectrometry. CRC Press, 2008.

QUEIROZ, F. B. Desenvolvimento e validação de metodologia para determinação de fármacos e pertubadores endócrinos em amostras de esgoto utilizando extração em fase sólida e cromatografia líquida acoplada à espectrometria de massas. Dissertação (Mestrado). Universidade Federal de Ouro Preto, Minas Gerais, 2011.

QUINN, B.; GAGNÉ, F.; BLAISE, C. An investigation into the acute and chronic toxicity of eleven pharmaceuticals (and their solvents) found in wastewater effluent on the cnidarian, Hydra attenuata. Sci. Total Eviron., v.389, 306-314, 2008.

QUINN, B.; SCHMIDT, W.; O'ROURKE, K.; HERMAN, R. Effecs of the pharmaceuticals gemfibrozil and diclofenac on biomarker expression in the zebra mussel (dreissena polymorpha) and their comparison with standardised toxicity tests. Chemosphere, v. 84, p. 657-663, 2011.

RANG, H. P.; DALE, M. M.; RITTER, J. M. Farmacologia. Editora Guanabara Koogan S.A. Rio de Janeiro, RJ , 1997. 
RIBANI, M.; BOTTOLI, C. B. G.; COLLINS, C.H.; JARDIM, I. C. S. F.; MELO, L. F. C. Validação em métodos cromatográficos e eletroforéticos. Quím. Nova, v. 27, n.5, p. 771 - 780, 2004.

RIBEIRO, F. A. L.; FERREIR, M. M. M.; MORANO, S. C.; SILVA, L. R.; SCHNEIDER, R. P. Planilha de validação: uma nova ferramenta para estimar figuras de mérito na validação de métodos analíticos univariados. Quim. Nova, v. 31, n.1, p. 164-171, 2008.

RIBEIRO, W. C. Oferta e estresse hídrico na Região Meropolitana de São Paulo. Estudos Avançados. v. 25, n. 71, p. 119-133, 2011.

RICHARDSON, S. D.; TERNES, T.A. Water analysis: Emerging contaminants and current issues. Anal. Chem., v. 77, n. 12, p. 3807-3838, 2005.

RICHTER, E, M.; FORNARO, A.; LAGO, C. L. do; ANGNES, L. Evalution of the chemical composition of the Guarapiranga water system: case study (2002 and 2003). Quim. Nova, v. 30, n. 5, p. 1147-1152, 2007.

ROBERTS, P. H.; THOMAS, K. V. The occurrence of selected pharmaceuticals in wastewater effluent and surface waters of lower Tyne catchment. Sci. Total Environ., v. 356, p. 143-153, 2006.

RODGERS-GRAY, T. P.; JOBLING, S.; KELLY, C.; MORRIS, S.; BRIGHTY, G.; WALDOCK, M. J.; SUMPTER, J. P.; TYLER, C. R. Exposure of Juvenile Roach (Rutilus rutilus) to Treated Sewage Effluent Induces Dose-Dependent and Persistent Disruption in Gonadal Duct Development. Environ.Sci.Technol., v. 35, p. 462-470, 2001.

RODRIGUEZ-MOZAZ, S.; ALDA, M. J. L.; BARCELÓ, D. Advantages and limitations of on-line solid phase extraction coupled to liquid chromatographymass spectrometry technologies versus bio sensors for monitoring of emerging contaminants in water. J. Chromatogr. A, v. 1152, p. 97-115, 2007.

RUSSEL, A. D. Bioside usage and antibiotic resistance: the relevance of laboratory findings to clinical and environmental situations. Lancet Infec. Dis., v. 3, p. 794-803, 2003.

SABESP - Companhia de Saneamento Básico do Estado de São Paulo.

Disponível em < www.sabesp.com.br>. - Acesso em: 03 de Nov de 2014.

SACHER, F.; LANG, F.T.; BRAUCH, H. J.; BLANKENHORN, I. Pharmaceuticals in groundwaters analytical methods and results of a monitoring program in Baden-Wurttemberg, Germany. Journal Chromatogr. A, v. 938, n. 2, p. 199210, 2001. 
SANTOS, L. H. M. L.M.; ARAÚJO, A. N.; FACHINI, A.; PENA, A.; DELERUEMATOS, C.; MONTENEGRO, M. C. B. S. M. Ecotoxicological aspects related to the presence of pharmaceuticals in the aquatic environment. J.Hazard. Mater., v. 175, p. $45-95,2010$.

SANTOS NETO, A. J. DOS Cromatografia líquida multidimensional e espectrometria de massas em tandem para análise direta de fármacos em fluidos biológicos: da escala convencional à miniaturizada. Tese (Doutorado). Instituto de Química de são Carlos, Universidade de São Paulo, São Carlos, 2007

SÃO PAULO Governo do Estado de São Paulo. Secretaria do Meio Ambiente. Coordenadoria de Educação ambiental. Caderno Ambiental Guarapiranga. São Paulo: SMA/CEA, 2008.

SÃO PAULO Governo do Estado de São Paulo. Secretaria do Meio Ambiente. Coordenadoria de Planejamento Ambiental Estratégico e Educação Ambiental. Compania Brasileira de Projetos e Empreendimentos. 14 de 03 de 2013. Disponível em: <http://www.ambiente.sp.gov.br/cpla/2013/03/14/aprm-area-deprotecao-e-recuperacao-de-mananciais/>.Acesso em: 13 de out. de 2014..

SCHMIDT, W.; O'ROURKE, K.; HERMAN, R.; QUINN, B. Effects of the pharmaceuticals gemfibrozil and diclofenac on the marine mussel (mytilus spp) and their comparison with standardized toxiity tests. Mar. Poll. Bull., v. 62, p. 1389-1395, 2011.

SEADE Fundação Sistema Estadual de Análise de DadoDsiponível em: $<$ http://produtos.seade.gov.br/produtos/perfil regional/index.php $>$. Acesso em: 25 de nov de 2014.

SENAD Secretaria Nacional de Políticas sobre Drogas. Relat. Brasileiro sobre drogas. Brasília, 2009.

SILVA, C. P.; LIMA, D. L. D.; SCHNEIDER, R. J.; OTERO, M.; ESTEVES, V. I. Evaluation of the anthropogenic input of caffeine in surface waters of the north and center of Portugal by ELISA. Sci. Total Environ., v. 479-480, p. 227-232, 2014.

SILVA, M. H. Modelo de procedimentos para elaboração de Medotologia de Valorização Econômica de Impactos Ambientais em Bacia Hidrográfica: Estudo de caso - Guarapiranga - aplicação da função dose-resposta. Dissertação ( Mestrado). Escola Politécnica da Universidade de São Paulo. São Paulo, 2008.

SILVA, R. C. Métodos individual e multirresidual para determinação de pesticidas em grãos e derivados por GC-PFPD, GC-ITD-MS e LC-MS/MS. Tese (Doutorado). Universidade Federal de Santa Maria. Santa Maria, R. S., 2011. 
SILVA, R. T.; FOLEGATTI, M.V.; VEIGA NETO, F. C. Novas perspectivas de gestão de recursos hídricos nos comitês PCJ - a Cobrança pelo uso da água e a aplicação de Pagamentos por Serviços Ambientais ao setor rural. XVII Simpósio Brasileiro de Recursos Hídricos, $8^{\circ}$ simpósio de Hidráulica e Recursos Hídricos dos Países de Língua Oficial Portuguesa, São Paulo, 25 a 29 de novembro de 2007.

SILVA, R. F. Determinação de cocaína e benzoilecgonina em amostras de esgoto bruto do distrito federal como suporte à realização de estimativas de consumo. Dissertação (Mestrado). Unversidade de Brasília. Brasília, 2012.

SMS Secretaria Municipal da Saúde. Disponível em:

$<$ http://www.prefeitura.sp.gov.br/cidade/secretarias/upload/saude/arquivos/assist enciafarmaceutica/clopidogrel.pdf>. Acesso em:02 de agosto de 2014.

SNSA - Sistema Nacional de Saneamento Ambiental - Sistema Nacional de Informação sobre Saneamento: Diagnóstico dos Seviços de Água e Esgotos-2011. Brasília: MCIDADES.SNSA., 2013.

SODRÉ, F. F.; MONTAGNER, C. C.; LOCATELLI, M. A. F.; JARDIM, W. F. Ocorrência de interferentes endócrinos e produtos farmacêuticos em águas superficiais da região de Campinas (SP, Brasil). J. Braz. Soc. Ecotoxicol., v. 2, p. 187-196, 2007.

SOLOMOSNS, T. W. G. Organic Chemistry. New York, EUA: 4 ed. Willey, 1968.

SOUZA, L. M. Aplicações da espectrometria de massas e da cromatografia líquida na caracterização estrutural de biomoléculas de baixa massa molecular. Tese (Doutorado). Universidade Federal do Paraná, Curitiba, 2008.

SOUZA, R. R. Desenvolvimento e validação de metodologia analítica para determinação de disruptores endócrinos resultantes de atividades antrópicas nas águas da região do Rio Paraíba do Sul, SP. Dissertação (Mestrado). Instituto de Pesquisas Energéticas e Nucleares/Universidade de São Paulo, São Paulo, 2011.

STACKELBERG, P. E.; GIBS, J.; FURLONG, E. T.; MEYER, M. T.; ZUGG; ZAUGG, S.D.; LIPPINCOTT, R.L. Efficiency of conventional drinking-watertreatment processes in removal of pharmaceuticals and other organic compounds. Sci. Total Environ., v. 377, p. 255-272, 2007.

STUMPF, M., TERNES, T. A., WILKEN, R.-D., RODRIGUES, S. V., BAUMANN, W. Polar drug residue in sewage and natural waters in the state of Rio de Janeiro, Brazil. Sci. Total Environ., v. 225, p. 135-141, 1999. 
SUI, Q.; HUANG, J.; DENG, S.; YU, G.; FAN, Q. Occurrence and removal of pharmaceuticals, caffeine and DEET in wastewater treatment plants of Beijing, China. Wat. Res., v. 44, p. 417-426, 2010.

TERNES, T. A. Occurrence of drugs in Germany sewage treatment plants and rivers. Wat. Res., v. 32, n. 11, p. 3245-3260, 1998.

THOMPSOM, M.; ELLISON, S. L. R.; WOOD, R. Harmonized guidelines for single-laboratory validation of methods of analysis. Pure Appl. Chem., v. 74, n. 5, p. 835 - 855, 2002.,

TOGOLA, A.; BUDZINSKI, H. Multi-residue analysis of pharmaceutical compounds in aqueous samples. J. Chromatogr. A, v. 1177, p. 150-158, 2008.

TRENHOLM, R. A.; VANDERFORD, B. J.; SNYDER, S. A. On-line solid phase extraction LC-MS/MS anlysis of pharmaceuticals indicators in water: A green alternative to conventional methods. Talanta. v 79, p. 1425-1432, 2009.

TRIEBSKORN, R.; CASPERS, H.; SCHEIL, V.; J., SCHWAIGER Ultastructural effects of pharmaceuticals (carbamazepine, clofibric acid, metoprolol, diclofenac) in rainbow trout (Oncorhynchus mykiss) and common carp (Cyprinus carpio). Anal. Bioanal. Chem., v. 387, p. 1405-1416, 2007.

TUNDISI, J. G. Recursos hídricos no futuro: problemas e soluções. Estudos Avançados, v. 22, n. 63, p. 7-16, 2008.

USEPA - Agência de Proteção Ambiental dos Estads Unidos. Method 1684: Pharmaceuticals and Personal Care Products in Water, Soil Sediment, and Biosolids by HPLC/MS/MS. Washigton, 2007.

VALCÁRCEL, Y.; ALONSO, S. G.; RODRÍGUEZ-GIL, J. L.; MAROTO, R. R.; GIL, A.; CATALÁ, M. Analysis of the presence of cardiovascular and analgesic/antiinflammatory/antipyretic pharmaceuticals in river-and drinking-water of the Madrid Region of Spain. Chemosphere, v. 82, p. 1062-1071, 2011.

VALCÁRCEL, Y.; MARTINEZ, F.; GONZÁLEZ-ALONSO, S.; SEGURA, Y.; CATALÁ, M.; MOLINA, R.; MONTERO-RUBIO, J. C.; MASTROIANNI, N.; LÓPEZ DE ALDA, M.; BARCELÓ, D. Drugs of abuse in surface and tap waters of the tagus river basin: heterogeneous photo-Fenton process is effective in their degradation. Env. Int., v. 41, p. 35-43, 2012.

VAN DE STEENE, J. C.; LAMBERT, W. E. Comparison oF matriz effects in HPLCMS/MS and UPLC-MS/MS analysis of nine baisc pharmaceuticals in surface water. Am. Soc. Mass Spectrom., v. 19, p. 713-718, 2008. 
VAN DEN BRANDHOF, E.-J.; MONTFORTS, M. Fish embryo toxicity of carbamazepine, diclofenac and metoprolol. Ecotoxicol. Environ. Safety, v. 73, p. 1862-1866, 2010.

VANDER HEYDEN, Y.; NIJHUIS, A.; SMEYERS-VERBEKE, J.; ANDEGINSTE, B. G. M.; MASSART, D. L. Guidance for robustness/ruggedness ttest in method validation. J. Pharmaceut. Biomed. Anal., v. 24, p. 723-753, 2001.

VASSKOG, T.; BERGER, U.; SAMUELSEN, P. -J.; KALLERNBORN, R.; JENSEN, E. Selective serotonin reuptake inhibitors in sewage influents and effluents from Tromso, Norway. J. Chromatogr. A, v. 1115, p. 187-195, 2006.

VEJA/SP Sete vezes menor, Guarapiranga quase iguala captação do Cantareira. 18/12/2014. Disponível em: <http://veja.abril.com.br/noticia/brasil/sete-vezesmenor-guarapiranga-quase-iguala-captacao-do-cantareira> Acesso em: 20/01/2015.

VIENO, N. M.; TUHKANEN, T.; KRONBERG, L. Analysis of neutral and basic pharmaceuticals in sewage treatment plants and in recipient rivers using solid phase extraction and liquid chromatography-tandem mass spectrometry detection. J. Chromagr. A, v. 1134, p. 101-111, 2006.

WANG, C.; SHI, H.; ADAMS, C. D.; GAMAGEDARA, S.; STAYTON, I.; TIMMONS, T.; MA, Y. Investigation of pharmaceuticals in Missouri natural and drinking water using high performace liquid chromatography-tandem mass spectrometry. Water Res., v. 4, p. 1818-1828, 2011.

WEIGEL, S.; KALLENBORN, R.; HÜHNERFUSS, H. Simultaneous solid-phase extraction of acid, neutral and basic pharmaceuticals from aqueous samples at ambient (neutral) $\mathrm{pH}$ and their determintion by gas chromatograhy-mass spectrometry. J. Chromatogr. A, v. 1032, p. 183-195, 2004.

WHATELY, M.; CUNHA, P. M. Guarapiranga 2005 Como e porque São Paulo está perdendo este manancial: resultados do diagnóstico socioambiental participativo da Bacia Hidrográfico do Guarapiranga. Instituto Socioambiental, 2006.

WHATELY, M.; CUNHA, P. M. Proposição de ações prioritárias para garantir água de boa qualidade para abastecimento. Seminário Guarapiranga 2006. Instituo Socioambiental. ISBN 85-85994-41-X. São Paulo, 2006.

WHATELY, M.; CUNHA, P. Cantareira 2006: um olhar sobre o maior manancial de água da Região Metropolitana de São Paulo. Instituo Socioambiental, 2007 
WINKLER, M.; LAWRENCE, J. R.; NEU, T. R. Selective degradation of ibuprofen and clofibric acid in two model river biofilm system. Water Res., v. 35, p. 31973205, 2001.

WINTER, M. J.; LILLICRAP, A. D.; CAUNTER, J. E.; SCHAFFNER, C.; ALDER, A.C.; RAMIL, M.; TERNES, T. A.; GILTROW, E.; SUMPTER, J. P.;

HUTCHINSON, T. H. Defining the chronic impacts of atenolol on embryo-larval development and reproduction in the fathead minnow (Pimephales promelas). Aquat. Toxicol., v 86, p. 361-369, 2008.

WU, J.; QIAN, X.; YANG, Z.; ZHANG, L. Study on the matrix effect in the determination of selected pharmaceutical residues in seawater by soli-phase extraction and ultra-high-performance liquid chromatography-electrospray ionization low-energy collision-induced dissociation tandem mass spectro. J. Chromatogr. A, v. 1217, p. 1471-1475, 2010.

YAMASHITA, M.; FENN, J. B. Electrospray ion source. Another variation on the free-jet theme. J. Phys. Chem., v. 88, p. 4451-4459, 1984.

YOON, Y.; RYU, J.; OH, J.; CHOI, B.-G.; SNYDER, S. A. Occurrence of endocrine dirupting compounds, pharmaceuticals, and personal care products in the Han river (Seoul, South Korea). Sci. Total Environ., v. 408, p. 636-643, 2010.

ZAGATTO, P. A.; BERTOLETTI, E. Ecotoxicologia aquática. Rima, 2008.

ZEAITER, M.; ROGER, J. M.; BELLON-MAUREL, V.; RUTLEDGE, D. N. Robustness of models developed by multivariate calibration. Part I: The assessment of sobustness. Trends Anal. Chem., v. 23, n. 2, p. 157-170, 2004.

ZUCCATO, E,; CASTIGLIONI, S.; CHIABRANDO, C.; GRASSI, P.; FANELLI, R. Illicit drugs, a novel group of environmental contaminants. Wat. Res., v. 42, p. 961-968, 2008. 